Portland State University

PDXScholar

Fall 11-15-2012

\title{
Inventory and Initiation Zone Characterization of \\ Debris Flows on Mount St. Helens, Washington Initiated during a Major Storm Event in November, 2006
}

Keith Vinton Olson

Portland State University

Follow this and additional works at: https://pdxscholar.library.pdx.edu/open_access_etds

Part of the Geology Commons, and the Soil Science Commons Let us know how access to this document benefits you.

\section{Recommended Citation}

Olson, Keith Vinton, "Inventory and Initiation Zone Characterization of Debris Flows on Mount St. Helens, Washington Initiated during a Major Storm Event in November, 2006" (2012). Dissertations and Theses. Paper 929.

https://doi.org/10.15760/etd.929

This Thesis is brought to you for free and open access. It has been accepted for inclusion in Dissertations and Theses by an authorized administrator of PDXScholar. Please contact us if we can make this document more accessible: pdxscholar@pdx.edu. 
Inventory and Initiation Zone Characterization of Debris Flows

on Mount St. Helens, Washington

Initiated during a Major Storm Event in November, 2006

by

Keith Vinton Olson

A thesis submitted in partial fulfillment of the

requirements for the degree of

\author{
Master of Science \\ in \\ Geology
}

Thesis Committee:

Scott F. Burns, Chair

Christina L. Hulbe

Thomas C. Pierson

Portland State University

2012 


\begin{abstract}
The heavy precipitation event of November 3-8, 2006 dropped over $60 \mathrm{~cm}$ of rain onto the bare southern slopes of Mount St. Helens and generated debris flows in eight of the sixteen drainages outside the 1980 debris avalanche zone. Debris flows occurred on the upper catchments of the Muddy River, Shoestring Glacier, Pine Creek, June Lake, Butte Camp Dome, Blue Lake, Sheep Creek, and South Fork Toutle River. Debris flows were clustered on the west and south-east sides of the mountain. Of the eight debris flows, three were initiated by landslides, while five were initiated by headward or channel erosion. Six debris flows were initiated in deposits mapped as Holocene volcaniclastic deposits, while two were in 1980 pyroclastics on andesite flows. The largest $\left(\sim 975,000 \mathrm{~m}^{2}\right)$ and longest $(\sim 8,900 \mathrm{~m})$ debris flow was initiated by landslides in the upper South Fork Toutle River Drainage. The average debris flow initiation zone elevation was $1,750 \mathrm{~m}$, with clusters around $1,700 \mathrm{~m}$ and 2,000 $\mathrm{m}$ elevation. The lower cluster is associated with basins that host modern or historic glaciers, while the upper is possibly associated with recent pyroclastic deposits. Upper drainages with debris flows averaged $41 \%$ slopes steeper than 33 degrees, while those without debris flows averaged $34 \%$. The geology of upper basins with debris flows averaged $6 \%$ snow and ice cover, $21 \%$ consolidated bedrock, and $74 \%$ unconsolidated deposits. Geology of basins without debris flows averaged $3 \%$ snow and ice cover, $27 \%$ bedrock, and $67 \%$ unconsolidated deposits. Drainages with debris flows averaged an $89 \%$ loss of glacier area between 1998 and 2009, while those without debris flows lost 68\%. Further comparing glacier coverage during that period found that only five of ten glaciers still
\end{abstract}


existed in 2009. On average, the glaciers had reduced in area by $67 \%$, decreased in length by $36 \%$, and retreated by an average of $471 \mathrm{~m}$ during that period. Basin attributes were measured or calculated in order to construct a predictive debris flow model based on that of Pirot (2010) using multiple logistic regression. The most significant factors were the percentage of slopes steeper than 33 degrees, unconsolidated deposits in the upper basin, and average annual rainfall. These factors predicted the 2006 debris flows with an accuracy of $94 \%$ in a debris flow susceptibility map for Mount St. Helens. 


\section{ACKNOWLEDGEMENTS}

To begin, I would like to thank my family and friends for their continuing encouragement and support in my study of geology and of this thesis project. Special thanks to my brother, Craig Olson, and girlfriend, Melissa Carley, who both allowed themselves to be talked into spending very long days climbing on Mount St. Helens.

My thesis advisor, Scott Burns, deserves much thanks for his encouragement and direction, as well as his infectious enthusiasm for this field. Also, my many field assistants deserve recognition for their vital support and efforts while in the field. My assistants for 2010 included Jon Weatherford, Kent Stallings, Lina Ma, and Rachel Secrest. During the 2011 season, my field assistants included Harold Shields, Matt Gibson, Kent Stallings, Melissa Carley, and Craig Olson.

I would like to thank my committee members, Christina Hulbe and Thomas Pierson, for their time and energy spent to review and comment on early drafts of this thesis. Thanks also to Darrel Gusey at the U.S. Forest Service for initial maps and information, and Peter Frenzen the monument scientist at the U. S. Forest Service, Mount St. Helens National Volcanic Monument for access to restricted areas on the upper slopes of the mountain.

Finally, I would also like to thank Doug Anderson for allowing me the use of his excellent photos posted on flickr.com of roads and trails around Mount St. Helens taken between 1981 and 2009. 


\section{TABLE OF CONTENTS}

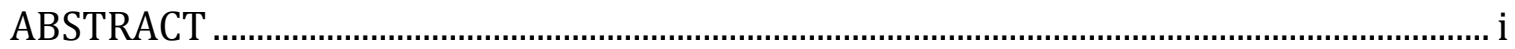

ACKNOWLEDGEMENTS ………….........................................................................................ii

LIST OF TABLES ……..........................................................................................................

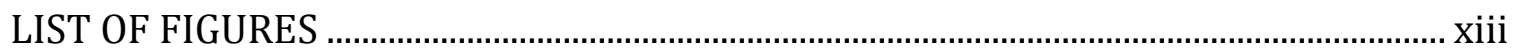

CHAPTER 1 - INTRODUCTION ........................................................................................ 1

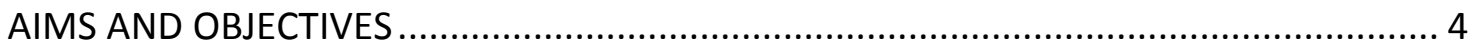

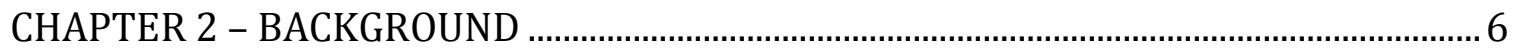

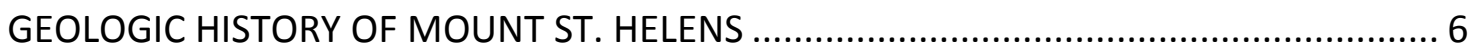

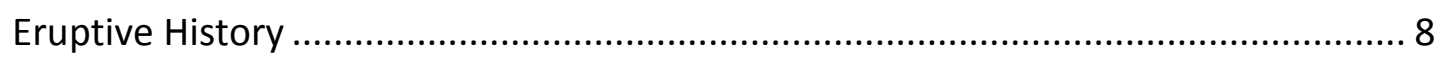

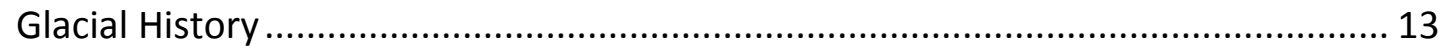

Debris Avalanche, Lahar, and Debris Flow History............................................... 17

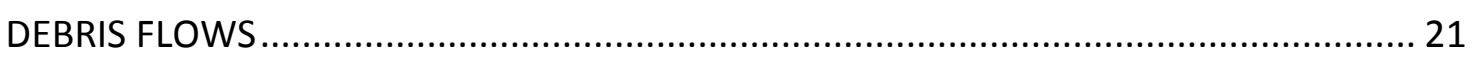

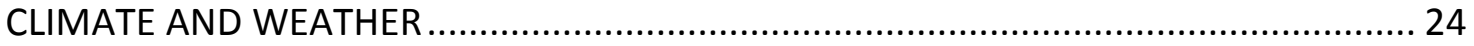

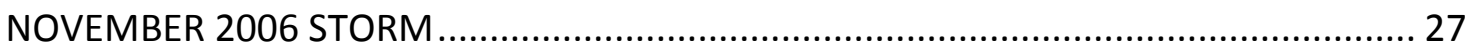

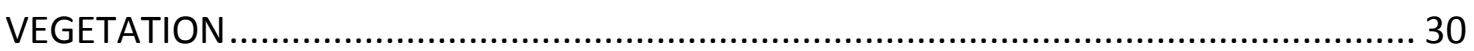

CHAPTER 3 - METHODS .................................................................................................. 34

FIELD METHODS

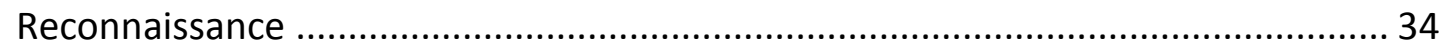

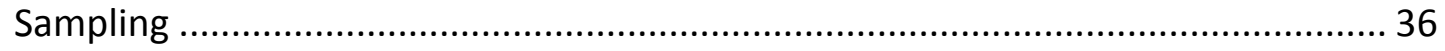

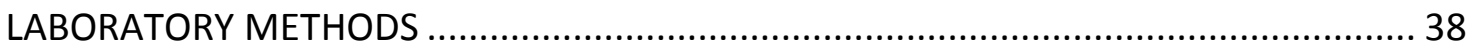

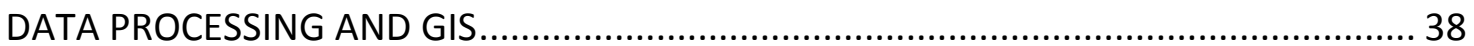

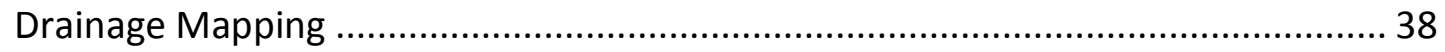

iv 


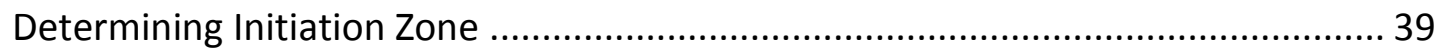

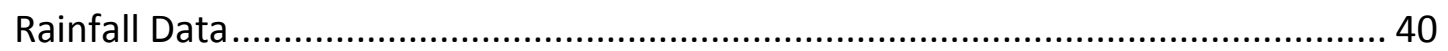

Collection of Basin Attributes ......................................................................... 41

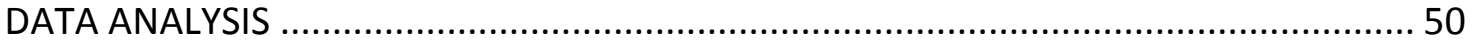

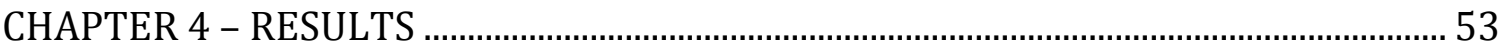

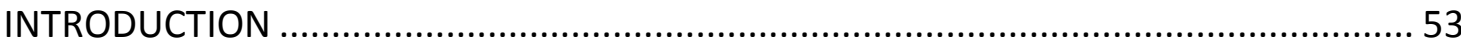

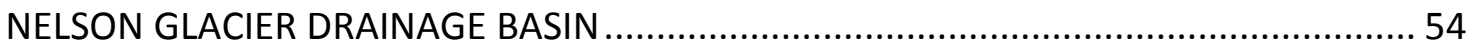

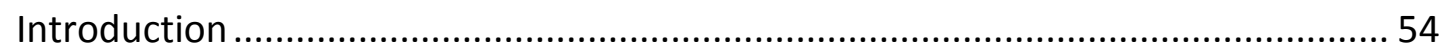

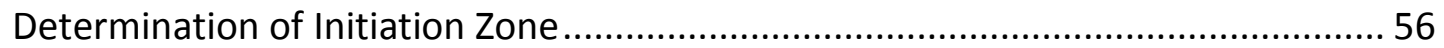

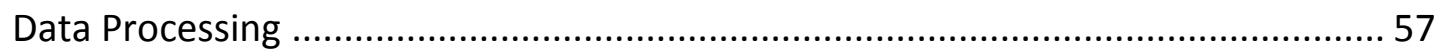

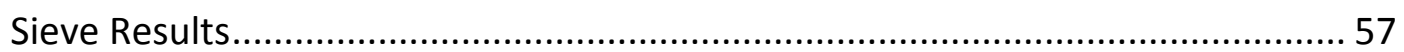

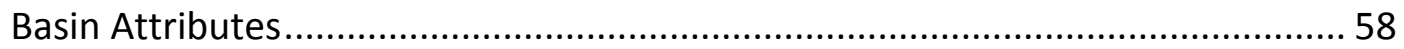

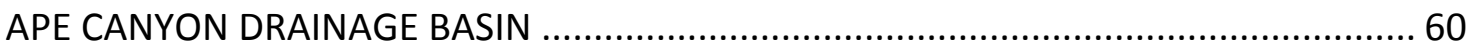

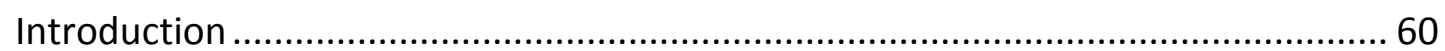

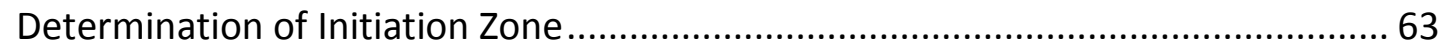

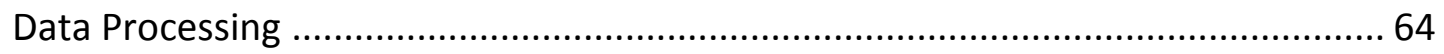

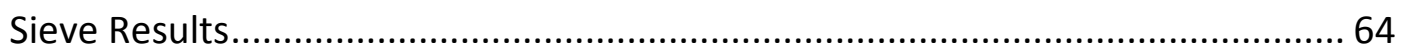

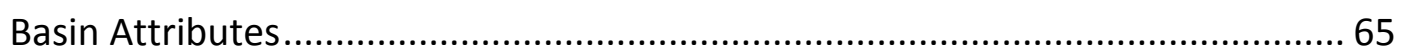

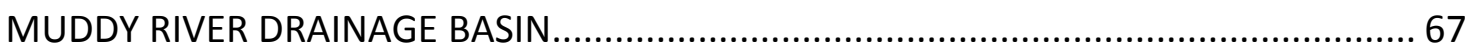

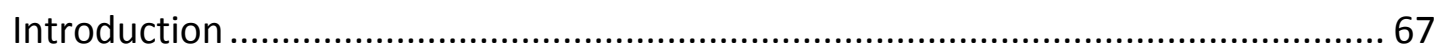

Determination of Initiation Zone ................................................................... 70

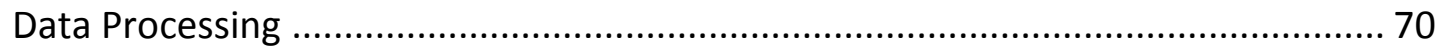

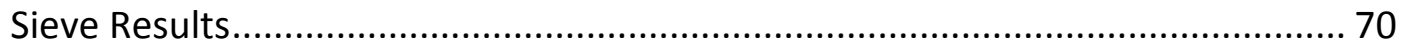

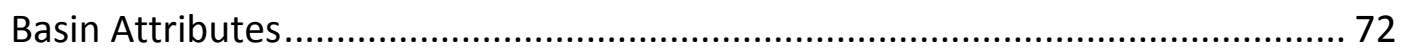

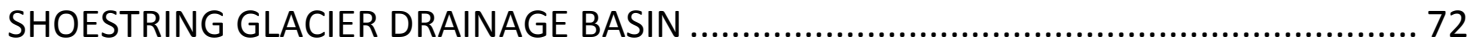

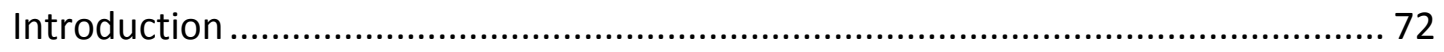

Determination of Initiation Zone ................................................................ 76

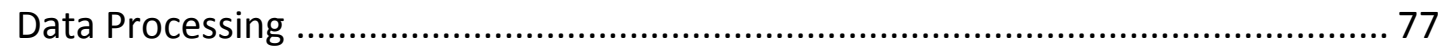

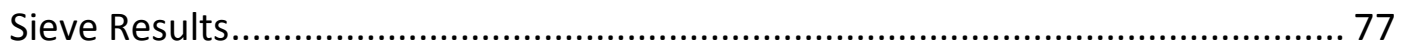

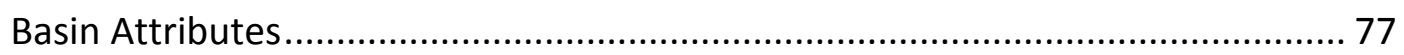

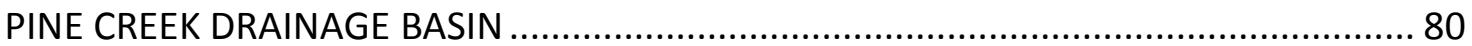




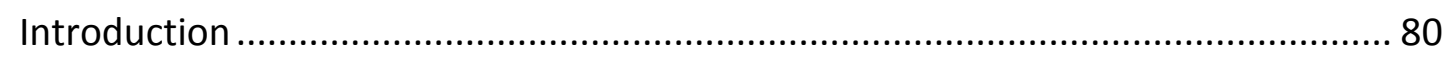

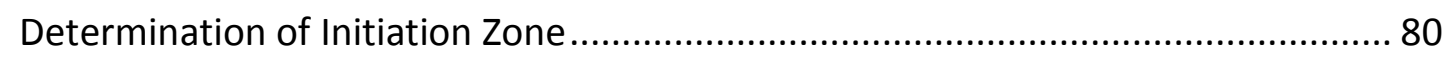

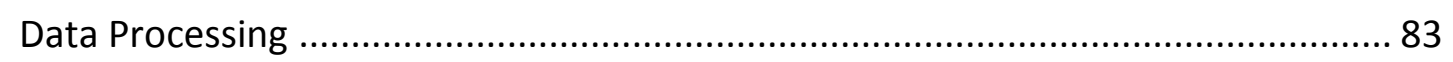

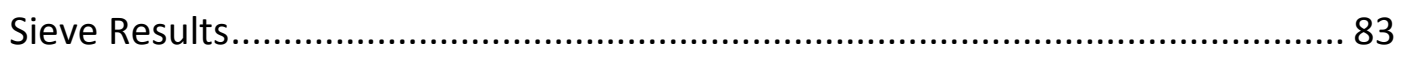

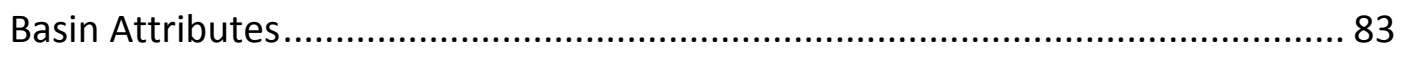

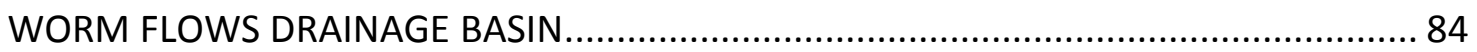

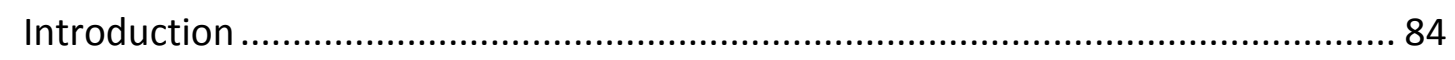

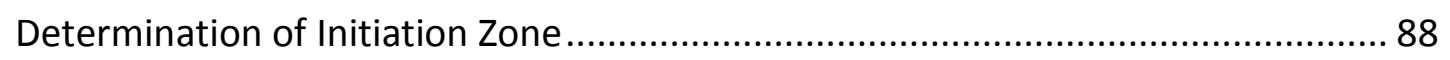

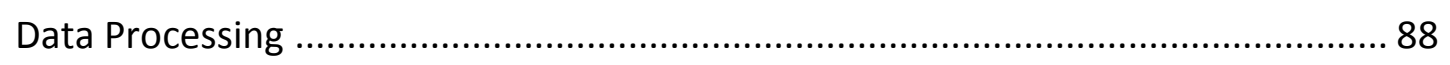

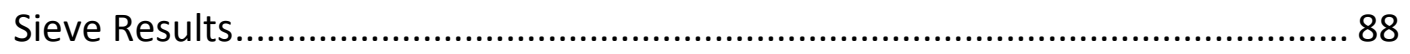

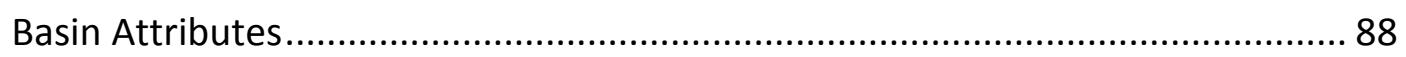

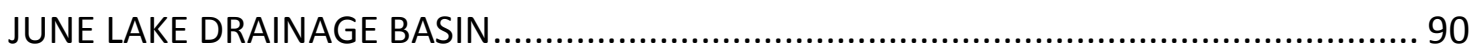

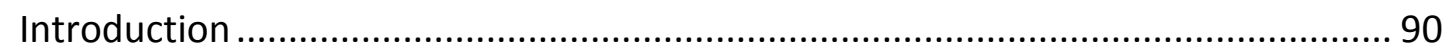

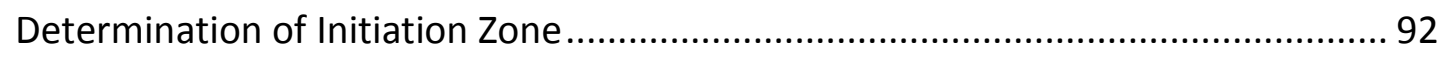

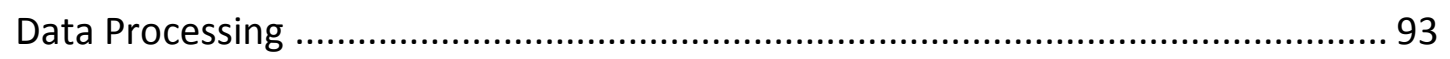

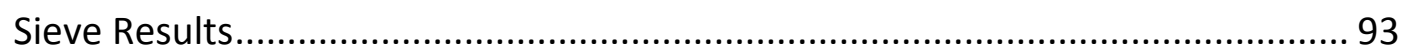

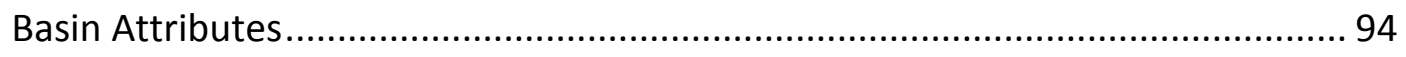

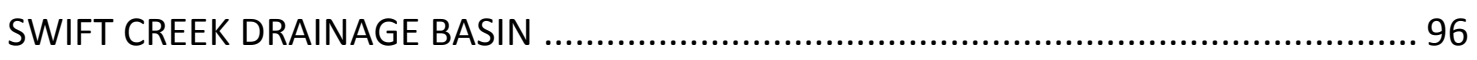

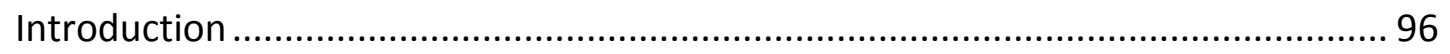

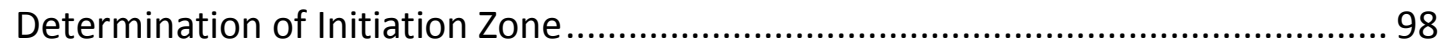

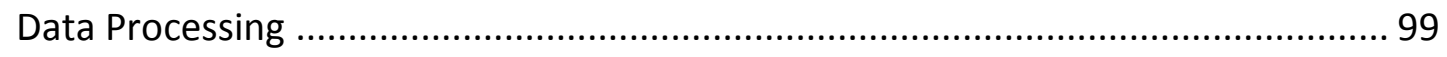

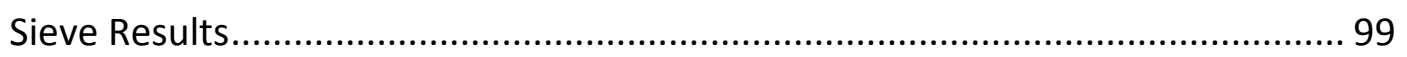

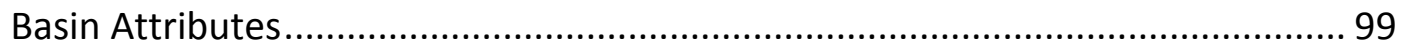

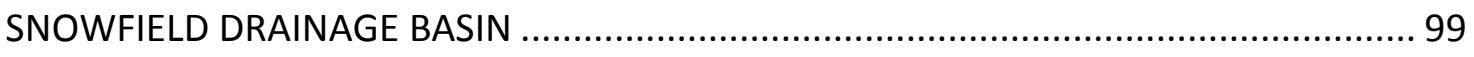

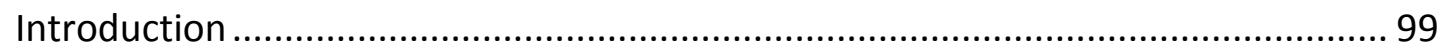

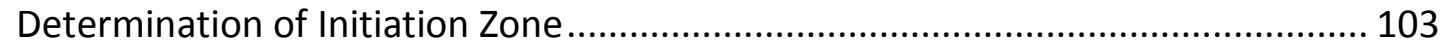

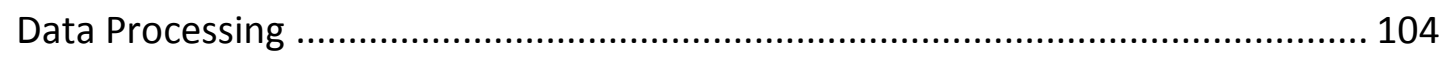

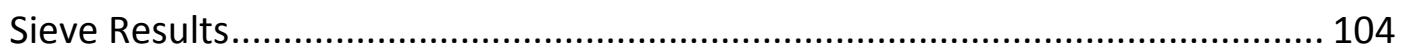

Basin Attributes..................................................................................... 104

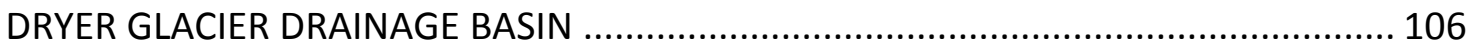

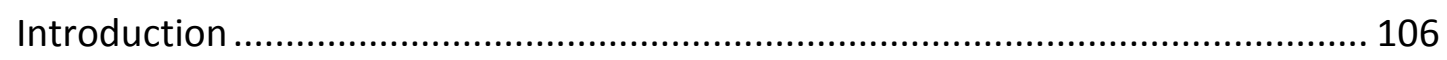

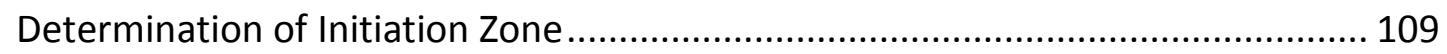

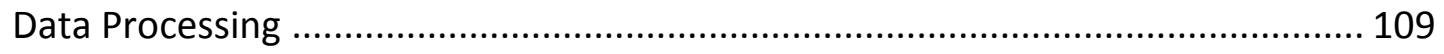

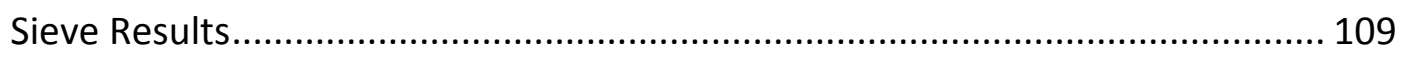


Basin Attributes 109

LITTLE KALAMA DRAINAGE BASIN............................................................... 111

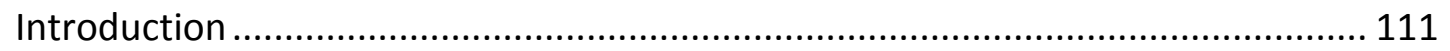

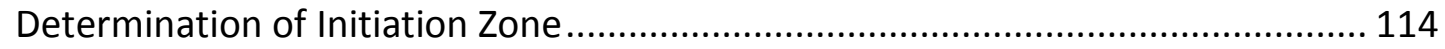

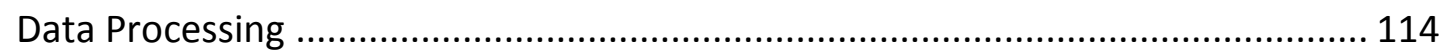

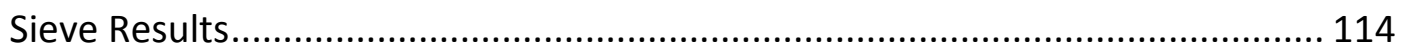

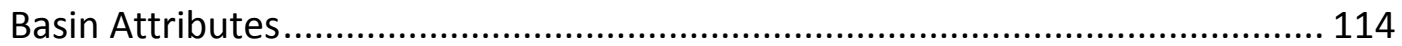

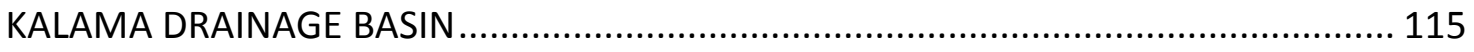

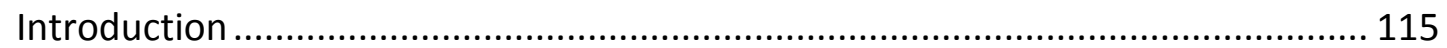

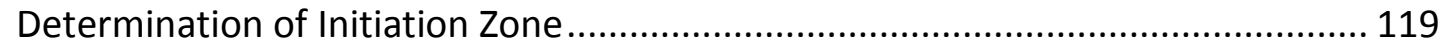

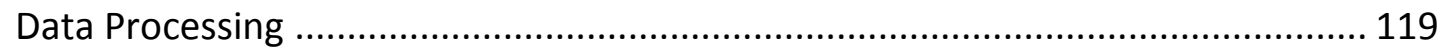

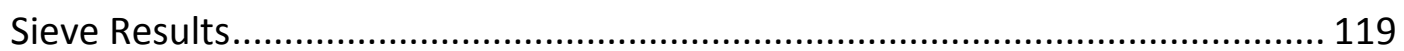

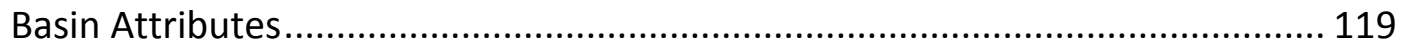

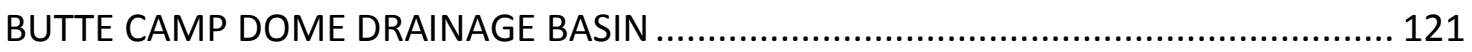

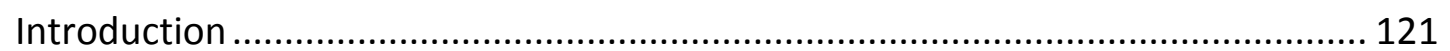

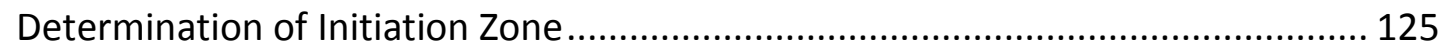

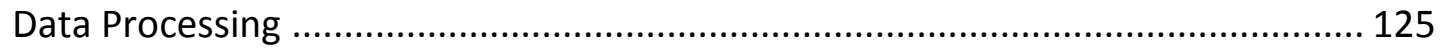

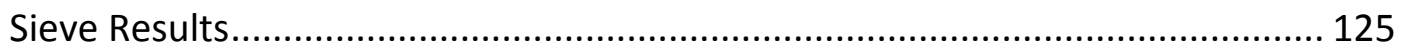

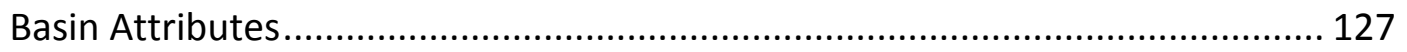

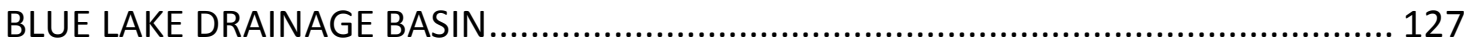

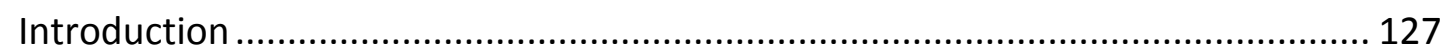

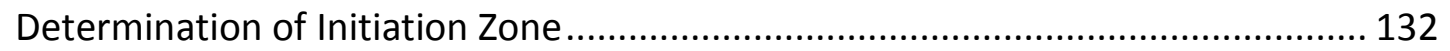

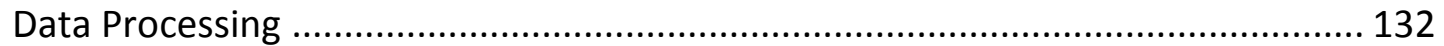

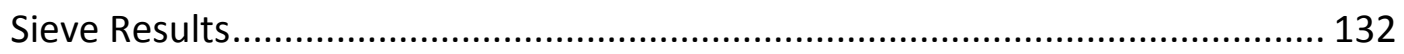

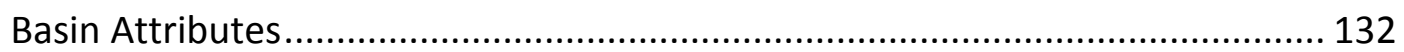

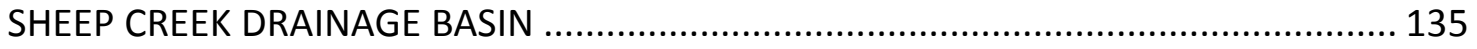

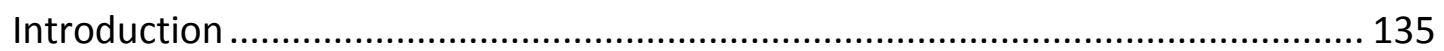

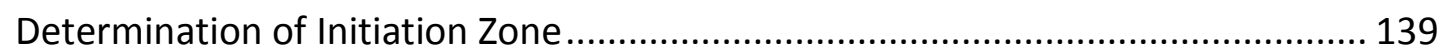

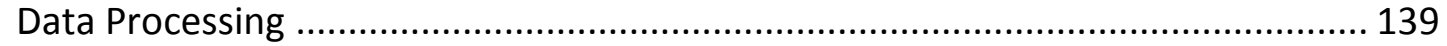

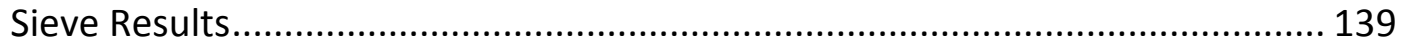

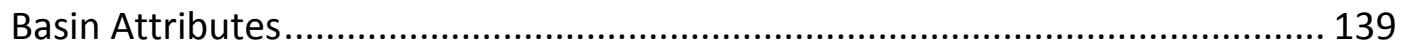

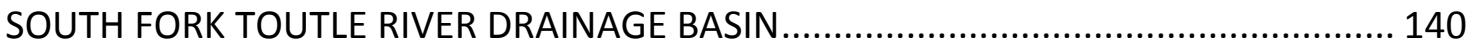

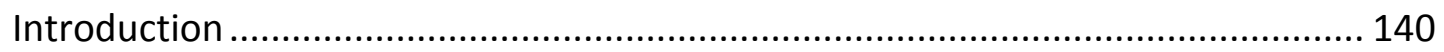




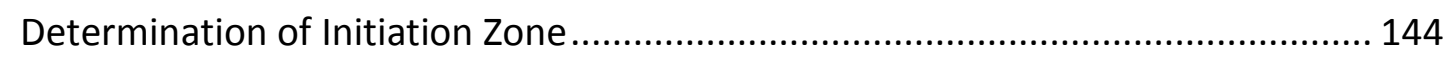

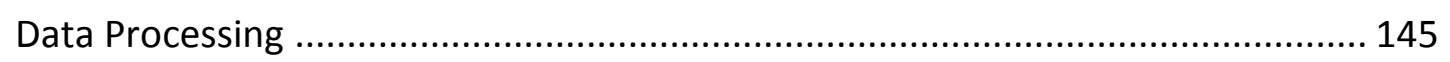

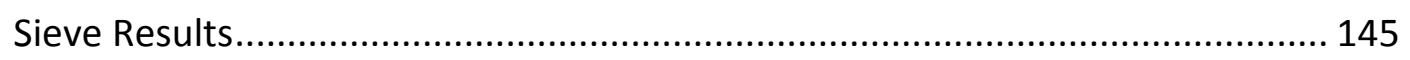

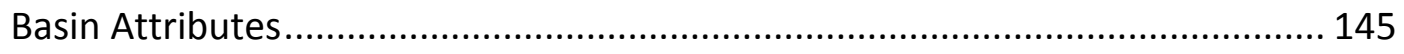

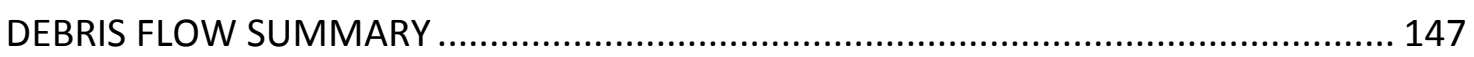

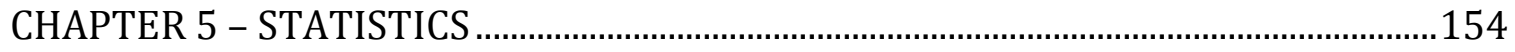

ANOVA AND MULTIPLE REGRESSION .......................................................... 154

MULTIPLE REGRESSION USING COMBINED DATA ............................................ 158

LIMITATIONS, ASSUMPTIONS, AND SOURCES OF ERROR .................................... 160

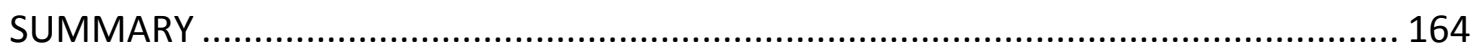

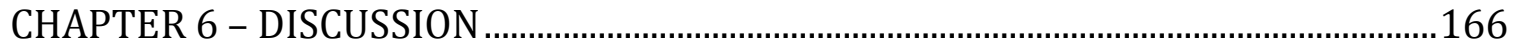

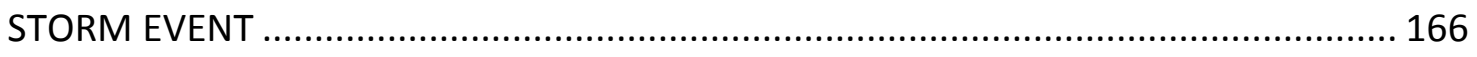

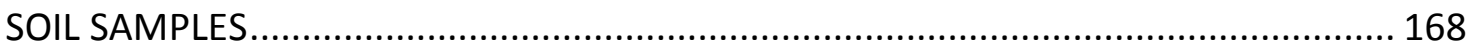

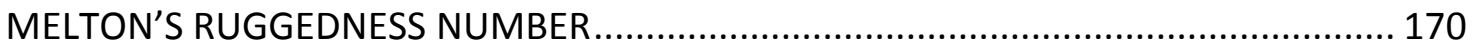

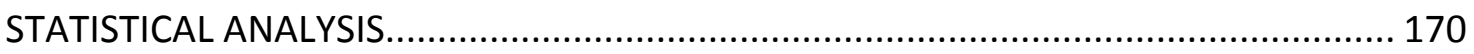

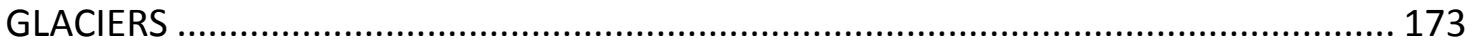

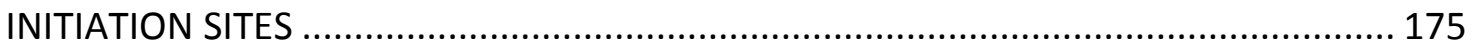

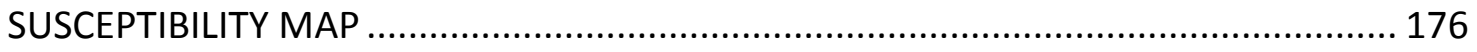

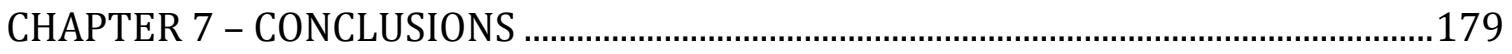

CHAPTER 8 - FUTURE WORK

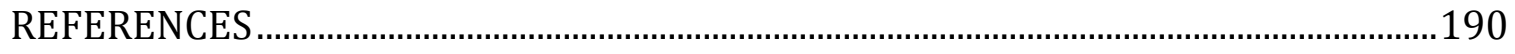

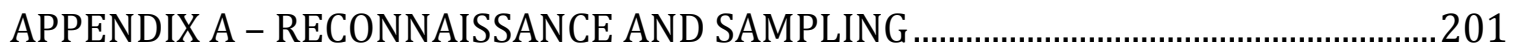




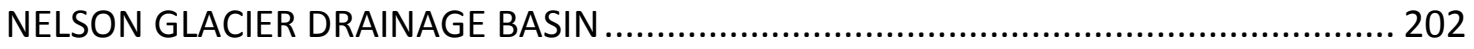

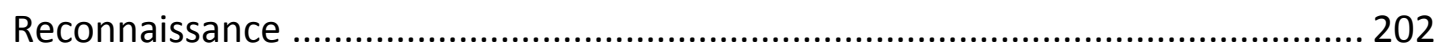

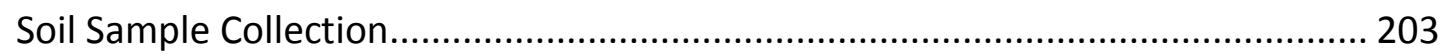

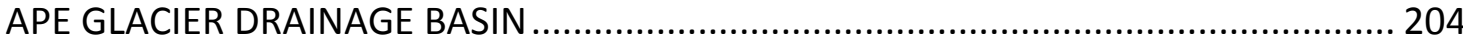

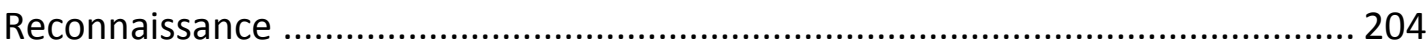

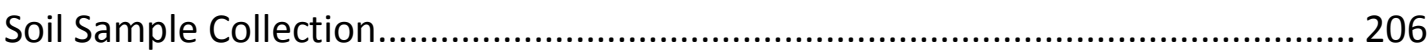

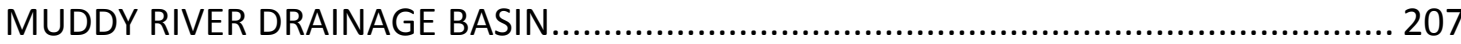

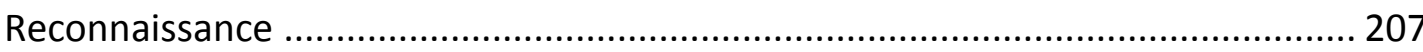

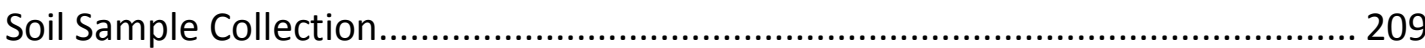

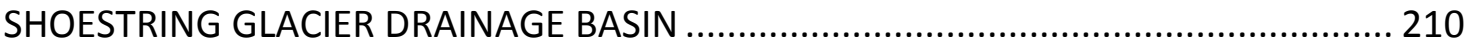

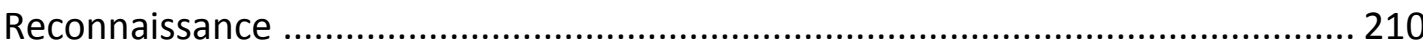

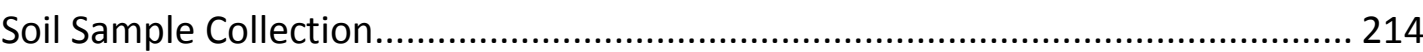

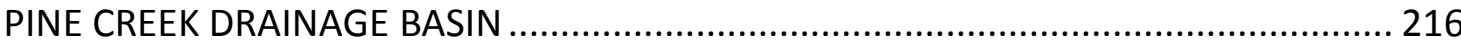

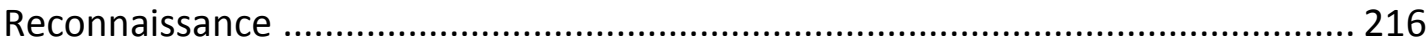

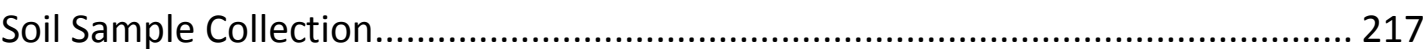

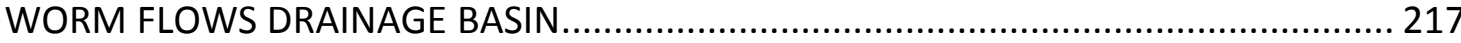

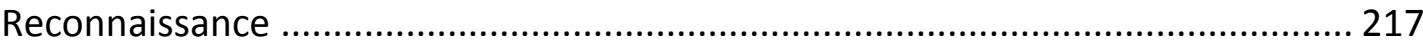

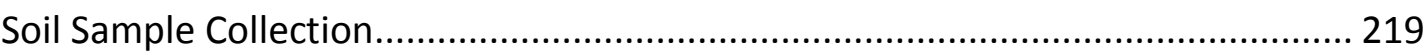

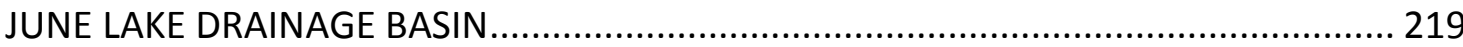

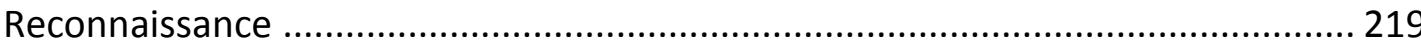

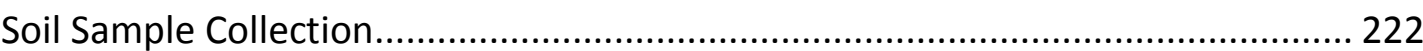

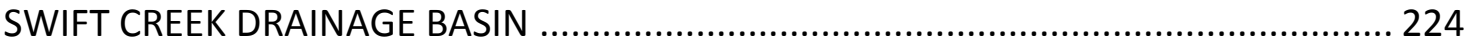

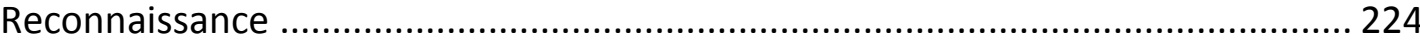

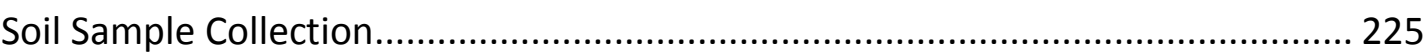

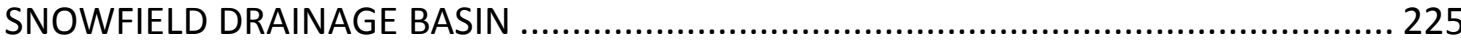

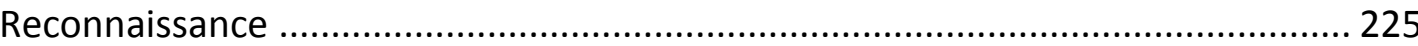

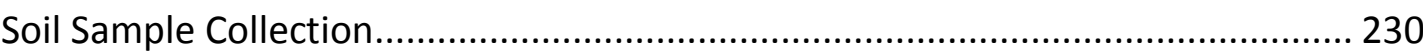

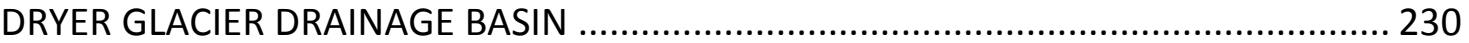

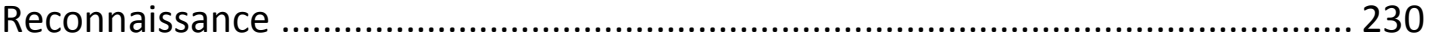

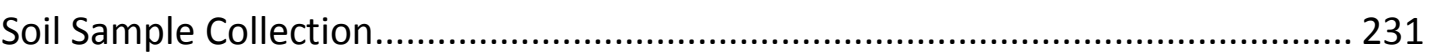




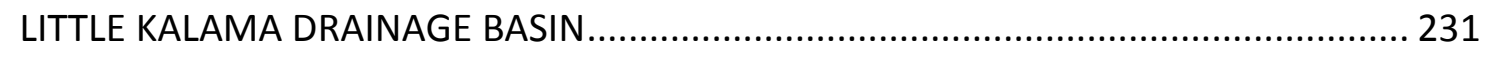

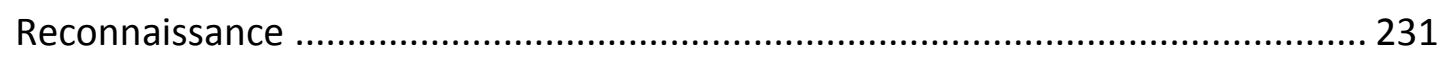

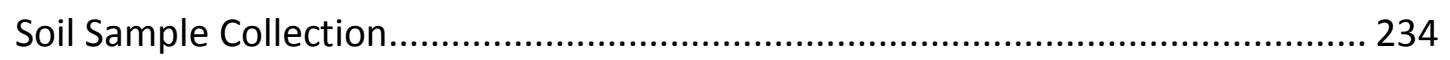

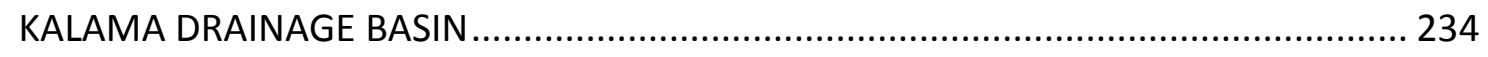

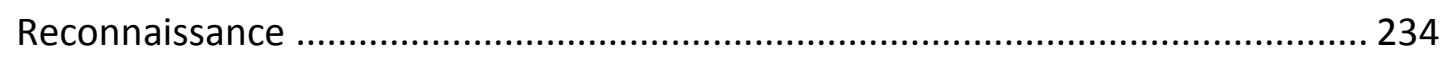

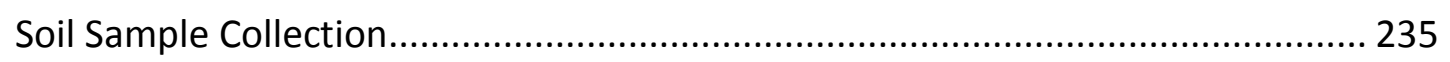

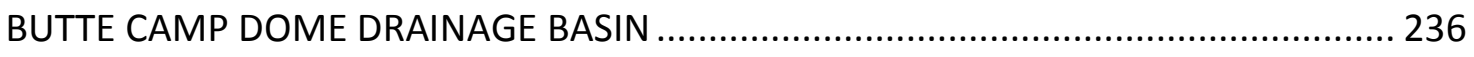

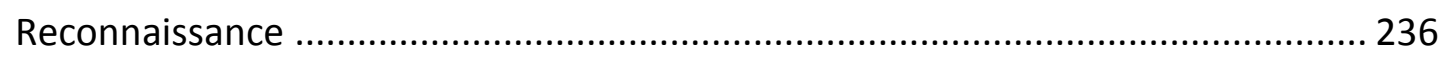

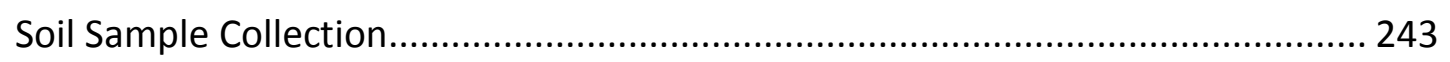

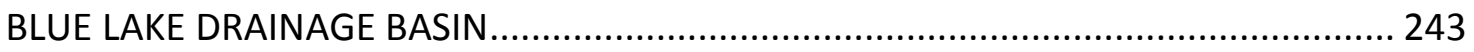

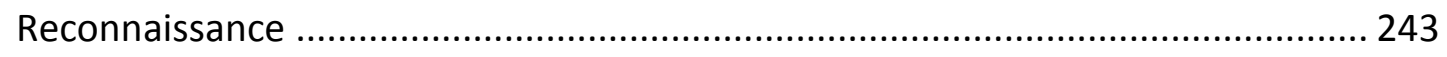

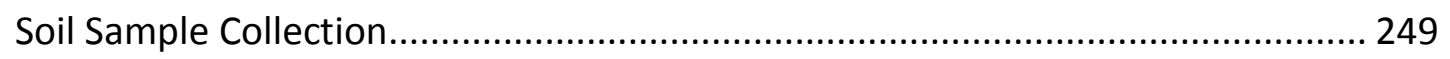

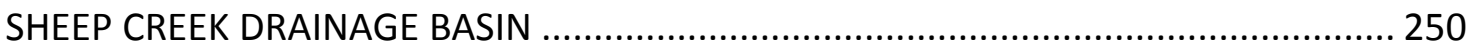

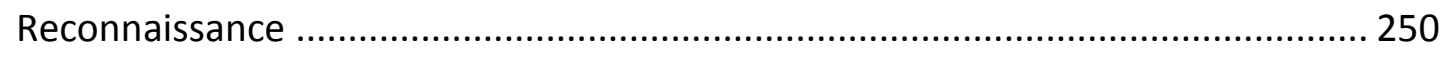

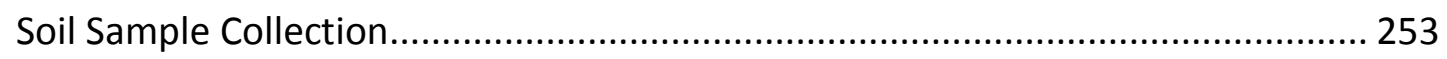

SOUTH FORK TOUTLE RIVER DRAINAGE BASIN................................................. 253

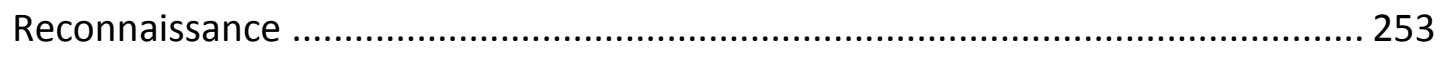

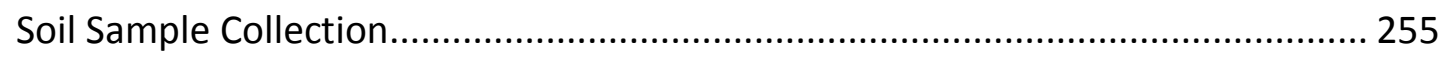

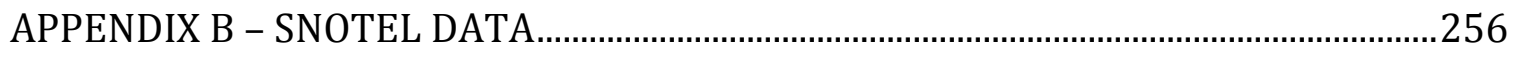

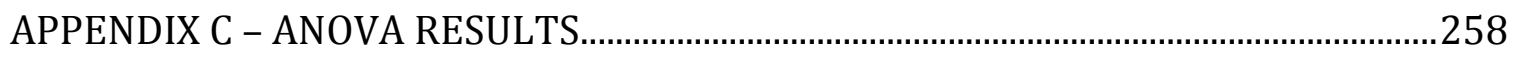

APPENDIX D - MULTIPLE REGRESSION FOR MOUNT ST. HELENS .............................2270

APPENDIX E - COMBINED MULTIPLE REGRESSION …..................................................275 


\section{LIST OF TABLES}

Table 1: Sieve analysis for the soil sample taken in the Nelson Glacier Drainage. The sample is over half coarse to medium sized sand.

Table 2: Nelson Glacier Drainage Basin attributes.

Table 3: Sieve analysis for the soil samples taken in the Ape Canyon drainage. The sample is almost half gavel and half sand of equally coarse, medium and fine grains 65

Table 4: Ape Canyon Drainage Basin attributes.

Table 5: Sieve analysis for the soil sample taken in the Muddy River Drainage. The sample is over half medium to fine sized sand .................................................. 70

Table 6: Muddy River Drainage Basin attributes. ..................................................... 73

Table 7: Sieve analysis for the soil samples taken in the Shoestring Glacier Drainage.

The sample is half sand of medium and fine sized grains. 78

Table 8: Shoestring Glacier Drainage Basin attributes. ................................................. 79

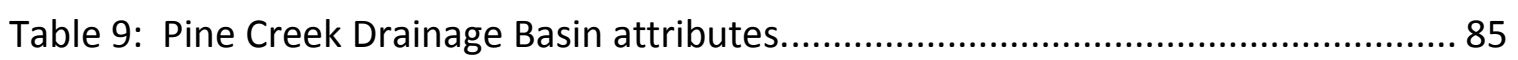

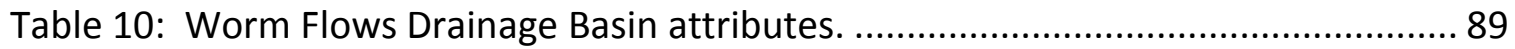

Table 11: Sieve analysis for the soil samples taken in the June Lake Drainage. The sample is over half sand of coarse and fine sized grains................................... 94

Table 12: June Lake Drainage Basin attributes.......................................................... 95

Table 13: Swift Creek Drainage Basin attributes. ....................................................... 100

Table 14: Snowfield Drainage Basin attributes........................................................ 105

Table 15: Dryer Glacier Drainage Basin attributes................................................... 110

Table 16: Little Kalama Drainage Basin attributes.................................................. 116

Table 17: Kalama Drainage Basin attributes............................................................ 120

Table 18: Sieve analysis for the soil samples taken on the South Channel in the Butte Camp Dome Drainage. The sample is half coarse to medium sized sand. ........ 126

Table 19: Sieve analysis for the soil samples taken on the North Channel in the Butte Camp Dome Drainage. The sample is half sand of coarse to medium sized grains.

Table 20: Butte Camp Dome Drainage Basin attributes.

Table 21: Sieve analysis for the soil samples taken in the Blue Lake Drainage. The sample is over half sand of predominately coarse-sized grains.

Table 22: Blue Lake Drainage Basin attributes. ....................................................... 136

Table 23: Sheep Creek Drainage Basin attributes..................................................... 141

Table 24: South Fork Toutle River Drainage Basin attributes................................... 148

Table 25: Summarized results from the ANOVA test between basin attributes in drainages with and without a 2006 debris flow. Percent steep slopes was the 
only factor determined to be significantly different. Units are also given for comparison.

Table 26: Selected basin attributes to be used in multiple logistic regression tests along with the variable name. All variables relate to upper basin attributes.

Table 27: Results of the predictive model described by Equation 7. Drainages in bold have $Y$ values $>0.50$. This model has $94 \%$ accuracy with no false positives and one false negative. 158

Table 28: Basin attributes to be used in multiple logistic regression model combining Mt. Hood (Pirot, 2010), Mt. Adams (Williams, 2011), and Mount St. Helens data. Variable name is also given. All variables relate to upper basin attributes. ..... 159

Table 29: Results for the combined predictive model described by Equation 8.

Drainages in bold have $Y$ values $>0.50$. Drainages in red are from Mount St. Helens with $Y$ values $>0.50$. This model has $69 \%$ accuracy with six false positives and eight false negatives. 161

Table 30: Average soil sample properties for eight sampled drainage basins on Mount St. Helens with and without a 2006 debris flow. 169

Table 31: Comparison of 1998 and 2009 glacier coverage on Mount St. Helens. Glaciers listed in red did not present a bergschrund in 2009 ortho imagery and therefore were not considered to be glaciers. Of the ten glaciers on the exterior slopes of Mount St. Helens in 1998, only five remained in 2009. PC is percent change. 174 Table 32: Comparison of the debris flow hazard level on the susceptibility map with the occurrence of a 2006 debris flow. 


\section{LIST OF FIGURES}

Figure 1: An aerial view of the southeastern quadrant of Mount St. Helens in late summer 2010 (courtesy of Kendra Williams).

Figure 2: Map showing the relative geographical location of Mount St. Helens to Portland, Oregon and Mt. Adams.

Figure 3: The Shoestring lahar deposit in the southeastern quadrant of Mount St. Helens, October 1980 (USGS). 6

Figure 4: Geologic map of the study area on Mount St. Helens (WaDNR, 2010).

Figure 5: Diagram of the eruptive history of Mount St. Helens showing eruptive stages and dormancy intervals, including major tephra units. Right block shows detail of the Spirit Lake Eruptive Stage (Clynne et al., 2005).

Figure 6: Channels impacted by major lahars caused by the May 18, 1980 Mount St. Helens eruption (Pierson, 1985). Lahars occurred on all drainages, with major lahars on the South Fork Toutle River, Sheep Creek, Swift Creek, Pine Creek, Shoestring Glacier, Muddy River, Ape Canyon, and Nelson Glacier.

Figure 7: Mount St. Helens edifice with the pre-May 18, 1980 eruption glacier distribution and extent. Glacier \#1 is the still existing June Lake Glacier. Glacier \#2 is the Snowfield Glacier, which today exists only as a permanent snowfield. Redrawn from Brugman and Post (1981).

Figure 8: Mount St. Helens edifice with post-May 18, 1980 eruption glacier distribution and extent. In existence as of 2009 are the glaciers: Nelson, Ape, Shoestring, June (\#1), and Swift. Glacier \#2 is the Snowfield Glacier, which today exists only as a permanent snowfield. Redrawn from Brugman and Post (1981). "New Glacier" was formally named Crater Glacier in 2006 (Walder et al., 2010). 18

Figure 9: Typical winter weather anomalies that precede heavy west coast precipitation events. Top panel occurs between 7-10 days before event, middle panel occurs 3-5 days before event, and bottom panel occurs during the precipitation event. From NOAA Climate Prediction Center/NCEP/NWS (NOAA-NWS, 2002).

Figure 10: Map showing the gridded PRISM average annual precipitation data for 2006 in hundredths of millimeters and as contours. Locations of nearby SNOTEL sites are also shown. The highest average rainfall values for this area are $430 \mathrm{~cm}$ (PRISM, 2007; USDA-NRCS, 2007).

Figure 11: Graph of rainfall measurements during the period of November 3-8 at the SNOTEL sites June Lake (1,049 m), Sheep Canyon (1,216 m), Lone Pine (1,198 m), Spensor Meadow (1,036 m), Spirit Lake (1,072 m), and Swift Creek (1,353 m) (USDA-NRCS, 2007). June Lake and Swift Creek, located in the southern quadrant of Mount St. Helens, experienced the greatest rainfall accumulation. 30 
Figure 12: Vegetation map of the study area around Mount St. Helens (USDA-FS, 2008b).

Data layer seems to be out-of-date in areas affected by 1980 lahars.

Figure 13: Map of the eleven soil sample locations around Mount St. Helens. Samples 1, 2, and 6 were taken in drainages without debris flows in 2006. Samples 3, 9, and 10 were taken from side-channels of the primary channel in drainages that experienced a debris flow in 2006. Trails shown include the Loowit Trail (216), $238 \mathrm{~A}$, and $216 \mathrm{H}$.

Figure 14: Example of a soil sample pit with sample bag. Photo of Site 8/Hole 2 in the Butte Camp Dome Drainage (UTM 10N 560779E 5115085N).

Figure 15: Drainage basin map showing boundaries defined for each major stream basin on Mount St. Helens south of the 1980 debris avalanche zone. High resolution area is the extent of LiDAR coverage on the southern slopes (USGS, 2004) ....... 53

Figure 16: Map of Nelson Glacier Drainage located in the northeastern quadrant of Mount St. Helens between Ape Canyon drainage and the 1980 debris avalanche zone. The upper basin includes a portion of Dogs Head, and the lower basin includes the northern portion of the Plains of Abraham. This drainage had no debris flow in 2006. Trails shown include the Loowit Trail (216) and 216D........ 55

Figure 17: Photographic mosaic of the upper and a portion of the total Nelson Glacier Drainage from the junction of trails 216 and 216D on the Plains of Abraham. View is to the west. Nelson Glacier wraps around the southern (left) side of Dogs Head.

Figure 18: A view of the upper portion of the bedrock barrier ridge running in a northeast orientation dividing the northern-most ravine of Nelson Glacier Basin from those to the south. On this portion are visible erosional scars (arrows). View is to the southeast.

Figure 19: Outcrop revealing over one meter of 1980 pumice in a fluvial channel near the lowest portion of the Nelson Glacier Basin. Original surface is visible below the pumice layer.

Figure 20: Map of Ape Canyon Drainage located in the eastern quadrant of Mount St. Helens between the Nelson Glacier and Muddy River drainages. The upper basin includes the Ape Glacier, and the lower basin includes the southern portion of the Plains of Abraham. This drainage had no debris flow in 2006. North is to the left.

Figure 21: Photographic mosaic of the Ape Canyon Basin from Trail 216 in the central Plains of Abraham. View is westward. The Ape Glacier is visible in the center of the peak with the left branch extending down to East Dome. To the right of Ape 
Glacier is an oblique view of Nelson Glacier and Dog's Head. The vertical gray line on East Dome is probably a zone of recent rock fall.

Figure 22: Photographic mosaic of the Ape Canyon Basin on the Plains of Abraham. The lower plains and breach are visible on the right. Pumice Butte is the peak right of center. The maze of channels crossing the Plains merge at the gap north of Pumice Butte, but a few channels can be seen to turn south toward the lower plain. View to the east from about 1,750 m on Mount St. Helens.

Figure 23: Photographic mosaic from the Plains of Abraham just north of Pumice Butte at the spillover into the lower Ape Canyon. Cobble-sized debris and vegetation are visible in the foreground, as well as fluvial reworking of the debris in the channel, and possible levees along the far channel bank. The channel at this point is about 20-30 m wide. View to the southwest.

Figure 24: View of the lower plain at the south end of the Plains of Abraham. The main channel (visible) is connected to the minor drainage that passes south of East Dome. Other channels to the right of this view are connected to Ape Glacier. View to the northwest. 64

Figure 25: Map of Muddy River Basin located in the southeastern quadrant of Mount St. Helens between the Ape Canyon and Shoestring Glacier Basins. The upper basin does not host a glacier, although the lower basin includes glacial till from the neighboring Shoestring Glacier. This drainage did experience a debris flow in 2006. North is to the left.

Figure 26: Comparison of 2006 debris flow deposition at the confluence of Muddy River and Shoestring Glacier in the southwestern quadrant of Mount St. Helens. Top picture is from August 2005, courtesy Doug Anderson. Bottom picture is from 2011. Smaller trees on the left and right are growing on the 1980 lahar terrace. View to the northwest.

Figure 27: Comparison of 2006 and 2009 ortho imagery showing the initiation site of the 2006 Muddy River Debris Flow (USDA-FSA, 2006; USDA-FSA, 2009). The channel walls retreat upslope (to the left) past the red dot, which is at the same spatial location in both images (UTM 10N 564943E 5115387N). North is up..... 71

Figure 28: The initiation site of the 2006 Muddy River Debris Flow (arrow) determined by comparison of ortho imagery taken in 2006 and 2009. View is looking due west from the north side of the Muddy River Channel. The channel leading from the initiation site to the main channel is obscured in the middle distance by ridges and rocky outcrops and enters the main channel upslope out of the image. Photo was taken on Sept 1, 2011. 
Figure 29: Map of Shoestring Glacier Drainage located in the southeastern quadrant of Mount St. Helens between the Muddy River and Pine Creek drainages. The upper basin hosts the Shoestring Glacier, although most of the glacial till in the lower basin is found in the neighboring Muddy River Drainage. This drainage did experience a debris flow in 2006. North is to the left.

Figure 30: View of the Shoestring Glacier upper basin taken from Road 83. The remains of the Shoestring Glacier are visible on the upper canyon floor. Arrowed is the side-channel that experienced extensive side wall erosion and small landslides in 2006. View is toward the northwest. 75

Figure 31: Comparison of 2006 (left) and 2009 (right) ortho imagery showing the initiation site of the 2006 Shoestring Glacier Debris Flow (USDA-FSA, 2006; USDA-FSA, 2009). The channel walls are observed to have eroded and experienced small landslides. The dots are in the same spatial location in both images (UTM 10N 564694E 5115390N). North is up.

Figure 32: Map of Pine Creek Drainage in the southeastern quadrant of Mount St. Helens between the Shoestring Glacier and Worm Flows drainages. The upper basin does not host a glacier. The main channel did not experience a debris flow in 2006; however, a side-channel neighboring Shoestring Glacier did unleash a small debris flow.

Figure 33: View of the Pine Creek upper basin taken from Road 83. The remains of the Shoestring Glacier are visible on the right. The basin is defined by the southern rim of the Shoestring Canyon on the north, and the levee of a lava flow (indicated in orange) to the south. View is toward the northwest.

Figure 34: View of the Pine Creek Channel from Road 83. Evidence of past debris flow activity is apparent, however, vegetation and shallow angled walls indicate it was not recent.

Figure 35: Comparison of 2006 (left) and 2009 (right) ortho imagery showing the initiation site of the 2006 Pine Creek Debris Flow (USDA-FSA, 2006; USDA-FSA, 2009). The channels show headward and bank erosion in multiple areas (blue and red dots). The dots are in the same spatial location in both images (UTM 10N 565575E 5514761N). North is up.

Figure 36: Map of Worm Flows Drainage located in the southeastern quadrant of Mount St. Helens between the Pine Creek and June Lake drainages. The upper basin does not host a glacier or extend to the crater rim, but there is a possible channel switching zone between the June Lake Glacier and this drainage. This drainage did not experience a debris flow in 2006. 
Figure 37: View of the Worm Flows Basin courtesy of Kendra Williams. The upper basin boundary is just downslope of the channel confluence. The red lines designate the total basin boundaries.

Figure 38: Map of June Lake Drainage located in the southern quadrant of Mount St. Helens between the Worm Flows and Swift Creek drainages. This drainage did experience a debris flow in 2006. The yellow area is beyond the range of LiDAR data.

Figure 39: View of a portion of the June Lake upper basin. The ridge on the left defines the western boundary, while the right boundary is more complex. The waterfall (arrowed) marks the lower extent of the channel switching zone. Soil samples were taken in the hollow below the ridge on the right flank of the waterfall..... 92

Figure 40: Comparison of 2006 (left) and 2009 (right) ortho imagery showing the initiation zone of the 2006 June Lake Debris Flow (USDA-FSA, 2006; USDA-FSA, 2009). There is some indication of a landslide on the east side of the channel below the waterfall (below the red dot). Snow cover on the western channel bank prevents age verification of landslide scarps found there during field observations. The dots are in the same spatial location in both images (UTM 10N563735E 5114126N). North is up

Figure 41: Map of the Swift Creek Drainage located in the southern quadrant of Mount St. Helens between the June Lake and Snowfield drainages. This drainage did not experience a debris flow in 2006. The yellow area is beyond the range of LiDAR data.

Figure 42: View of the Swift Creek upper basin from Trail 216 in an area of andesite flows. View is northward. The Swift Glacier (arrowed) is not visible as a distinct feature. The Monitor Ridge lava flow forms the boundary on the left horizon. The 1,823 $\mathrm{m}$ dome visible on the far left is unnamed on all maps.

Figure 43: Map of the Snowfield Drainage located in the southern quadrant of Mount St. Helens between the Swift Creek and Dryer Glacier drainages. This drainage did not experience a debris flow in 2006. The yellow area is beyond the range of LiDAR data. 101

Figure 44: View of the Snowfield upper basin taken in early August 2010 with snow remaining on the upper slopes. The Snowfield hollow is indicated by the large black arrow and the red line roughly defines the western boundary. The Monitor Ridge lava flow that dominates the horizon on the right defines the eastern boundary. The two channels can best be seen near the treeline (red arrows). View is to the northeast from Redrock Pass. 
Figure 45: Map of Dryer Glacier Drainage located in the southwestern quadrant of Mount St. Helens between Snowfield and the Little Kalama Drainage.

Figure 46: View of the Dryer Glacier upper basin taken in early August 2010 with snow remaining on the upper slopes. The main channel is seen on the left side of the image and extends upward through the snow packs. A large waterfall and erosional feature in the main channel is indicated by the arrow. The ridge on the right side of the image forms the southern boundary with the Snowfield Drainage Basin. View is to the northeast from Redrock Pass. 108

Figure 47: Map of the Little Kalama Drainage neighboring Kalama and Dryer Glacier in the southwestern quadrant of Mount St. Helens. The upper basin does not host a glacier, although a distinct channel was observed with past debris flow evidence. This drainage did not experience a debris flow in 2006.

Figure 48: View of the Little Kalama upper basin taken in early August 2010 with snow remaining on the upper slopes. The main channel for this basin is arrowed at approximate elevations: $1,400 \mathrm{~m}, 1,600 \mathrm{~m}$, and 2,200 $\mathrm{m}$. This is a relatively minor drainage with few large features observed. Much of the middle slope is a Quaternary andesite lava flow. The drainage boundary generally conforms to the channel. View is to the northeast from Redrock Pass.

Figure 49: Map of the Kalama Drainage neighboring Butte Camp Dome and Little Kalama in the southwestern quadrant of Mount St. Helens. The upper basin does not host a glacier or extend to the crater rim, however a small channel was observed with past debris flow evidence. This drainage did not experience a debris flow in 2006.

Figure 50: View of the Kalama upper basin taken in early August 2010 with snow remaining on the upper slopes. The main channel for this basin is arrowed at approximate elevations: $1,450 \mathrm{~m}, 1,830 \mathrm{~m}$, and 2,100 $\mathrm{m}$. This is a minor drainage with no large features observed. Much of the middle slope is a Quaternary andesite lava flow. The drainage boundary generally conforms to the channel. View is to the northeast from Redrock Pass.

Figure 51: Map of Butte Camp Dome Drainage located in the southwestern quadrant of Mount St. Helens between the Kalama and Blue Lake drainages. The upper basin does not host a glacier, but contains multiple converging and diverging channels and evidence of channel switching and past debris flows. The southern branch of this drainage did experience a debris flow in 2006. 122

Figure 52: View of the Butte Camp Dome upper basin area from the ridge separating the middle zone channels. The arrows designate the North, Central, and South 
Channels. The andesite and dacite intrusion is visible as the false peak. View is to the northeast.

Figure 53: View of the Butte Camp Dome intrusion and debris fan. An area of active erosion on the north side of Butte Camp Dome is visible, as is the North BCD channel at the extreme right. View is to the southwest, from the same location as in Figure 52.

Figure 54: Map of Blue Lake Drainage located in the western quadrant of Mount St. Helens between the Butte Camp Dome and Sheep Creek drainages. The upper basin does not host a glacier, although the basin features two large channels and possible glacial deposits. North is to the left.

Figure 55: View of the Blue Lake upper basin from Trail 216 on the northern rim of the North Channel. The rocky area in the center of the image is an exposed andesite flow which is more resistant to erosion and forms waterfalls on both channels. The black arrows indicate the North Channel, while the red arrows designate the South Channel. View is to the east. 130

Figure 56: View of the Blue Lake Debris Flow deposit (USDA-FS, 2007) covering about 350 meters of Road 8123 and all of the Blue Lake trailhead parking area by deposits of up to three meters thick.

Figure 57: Comparison of 2006 (top) with 2009 (bottom) ortho imagery showing a channel wall landslide at 1,565 m elevation that is one possible initiation site of the 2006 Blue Lake Debris Flow. The waterfall is to the right in the image. The contrast on the 2006 image is poor, but there is a definite change in the southern channel wall at the location of the blue dot. The dots are in the same spatial location in both images (UTM 10N 559843E 51155741N). North is up. 133

Figure 58: Comparison of 2006 (top) with 2009 (bottom) ortho imagery showing channel wall erosion (right) and a landslide (arrowed) at 1,720 m elevation that is one possible initiation site of the 2006 Blue Lake Debris Flow. The waterfall is to the left in the image. The dots are in the same spatial location in both images (UTM 10N 560207E 5115852N). North is up.

Figure 59: Comparison of 2006 (left) with 2009 (right) ortho imagery showing a channel wall landslide at 2,100 m elevation (red dot) that is one possible initiation site of the 2006 Blue Lake Debris Flow. The waterfall is to the distant left off the image. The dots are in the same spatial location in both images (UTM 10N 560917E $5116075 \mathrm{~N})$. North is up. 134

Figure 60: Map of Sheep Creek Drainage located in the western quadrant of Mount St. Helens between the Blue Lake and South Fork Toutle drainages. The upper basin 
no longer hosts a glacier, but the upper regions of the drainage contain large unconsolidated deposits. North is to the left.

Figure 61: View of the Sheep Creek upper basin area from Trail 240 on the south side of Sheep Canyon. The arrows designate the active channel. The bare feature to the left is Crescent Dome a Pleistocene andesite and dacite intrusion.

Considerable snow was present on the upper slopes of the mountain when this picture was taken in mid-August 2011. View is to the east.

Figure 62: Map of South Fork Toutle River Drainage located in the western quadrant of Mount St. Helens between the Sheep Creek Drainage and the 1980 debris avalanche zone. The upper basin includes the Toutle and Talus Glaciers which did not exhibit bergschrunds in 2009 orthophotos (USDA-FSA, 2009). North is to the left.

Figure 63: View of the northern channel of the South Fork Toutle River upper basin in August 2011. The southern channel is not visible, but is to the right of this image. The peak to the left is West Dome. The area to the right of that is the Toutle Glacier separated by a ridge from the Talus Glacier. View is the east from Trail 216. Photo credit to patskros.blogspot.com.

Figure 64: Comparison of 2006 (left) and 2009 (right) ortho imagery showing an initiation site of the 2006 South Fork Toutle River Debris Flow (USDA-FSA, 2006; USDA-FSA, 2009). The landslide scarp and toe are indicated by blue dots. A zone of channel wall erosion upslope from the landslide is also indicated. The dots (and stream line) are in the same spatial location in both images (the top of the landslide is at UTM 10N558740E 5117558N). North is up

Figure 65: Comparison of 2006 (top) and 2009 (bottom) ortho imagery showing the initiation zone of the 2006 South Fork Toutle River Debris Flow (USDA-FSA, 2006; USDA-FSA, 2009). The cliff face on the right has apparently retreated (red dot) about $30 \mathrm{~m}$. A landslide is also visible in the upper right corner (arrow). The dots (and stream line) are in the same spatial location in both images (UTM 10N560693E 5117576N). North is up. 146

Figure 66: Debris flow inventory map showing defined drainage outlines and 2006 event flow paths. Drainages with a 2006 debris flow are named. The largest and longest debris flow occurred in the South Fork Toutle River Drainage in the western quadrant.

Figure 67: Selection of particle size distribution graphs for active channels in the June Lake (A), Butte Camp Dome (B), Muddy River (C), and Blue Lake (D) Drainage Basins. All graphs have a similar curve in the sand-sized fraction, but Blue Lake has less larger particles. 169 
Figure 68: Debris flow susceptibility map for the non-blast zone drainages of Mount St. Helens developed using the basin attributes determined most significant by multiple logistic regression analysis. In this model there are three drainages of

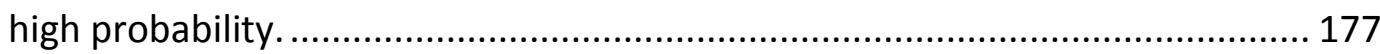




\section{CHAPTER 1 - INTRODUCTION}

Mount St. Helens (Figure 1) is a composite or strato- volcano located in southwestern Washington State, about $80 \mathrm{~km}$ northeast of Portland, Oregon and $50 \mathrm{~km}$ east of Mount Adams. This location westward of Mt Adams puts it outside the northsouth trend of the other major High Cascade volcanoes (Figure 2). Mount St. Helens is the youngest volcano in the High Cascades at around 300,000 years and has been erupting periodically since early 1980 (Pringle, 2002; Clynne et al., 2008). Since 1982, the volcano and surrounding area have been administered by the Mount St. Helens National Volcanic Monument which is part of the Gifford Pinchot National Forest (Pringle, 2002; USDA-FS, 2003).

The drainage basins around Mount St. Helens enter into the three primary river systems that drain the upper slopes of the volcano: the Lewis River, the Toutle River,

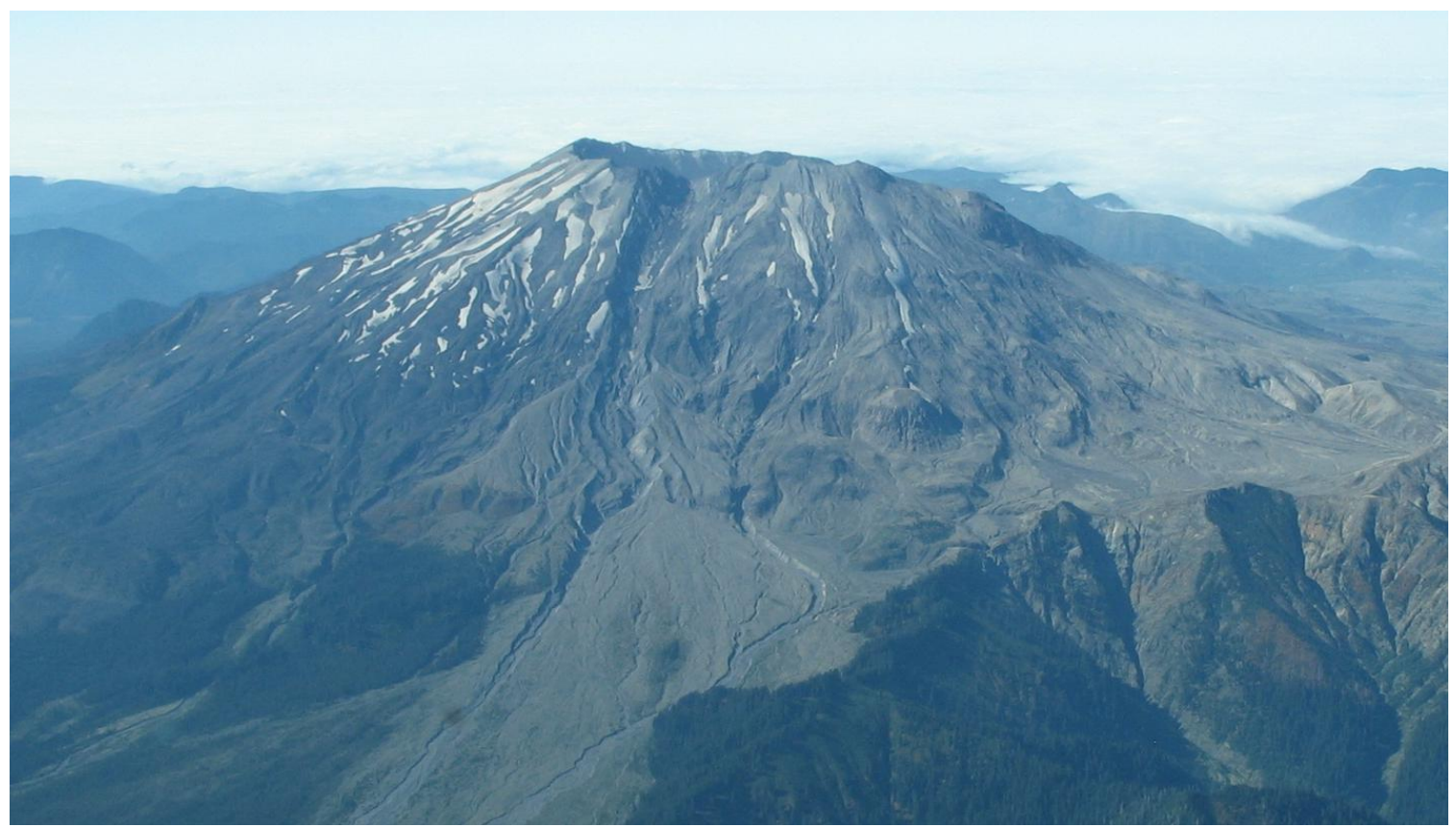

Figure 1: An aerial view of the southeastern quadrant of Mount St. Helens in late summer 2010 (courtesy of Kendra Williams). 
and the Kalama River (Pringle, 2002). The Lewis River system drains the Nelson Glacier, Ape Canyon, Muddy River, Shoestring Glacier, Pine Creek, June Lake, and Swift Creek Drainage Basins along the south and east sides of the mountain (USDA-FS, 2003). The North and South Fork Toutle River empty into the Cowlitz River and drain the north and west sides of the mountain (USDA-FS, 2003). The Kalama River drains the southwest

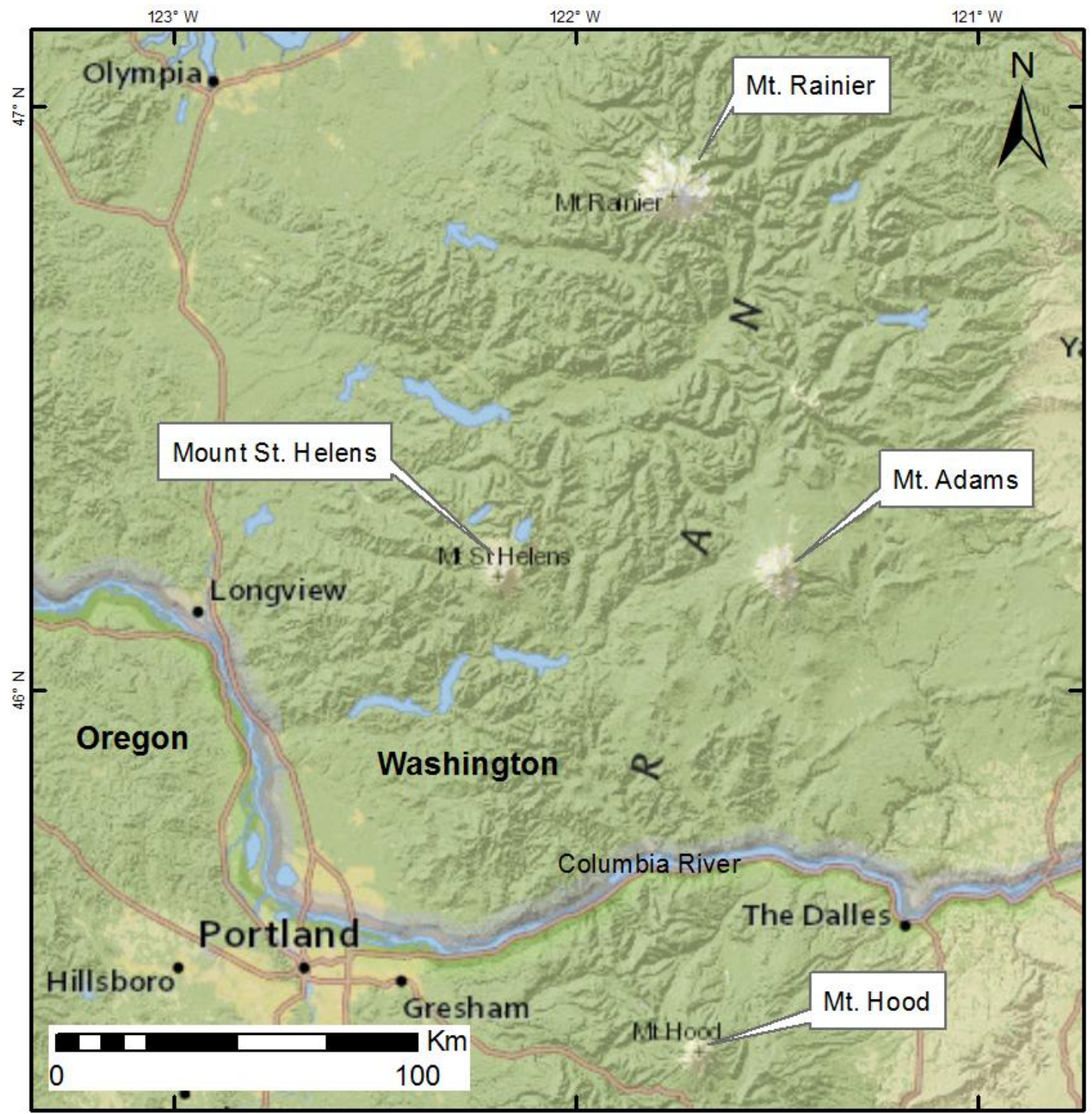

Figure 2: Map showing the relative geographical location of Mount St. Helens to Portland, Oregon and Mt. Adams. 
side of the volcano (USDA-FS, 2003). Eventually all these river systems empty into the Columbia River (Pringle, 2002).

During November 3-8, 2006 a large, warm precipitation event known as a "Pineapple Express" dropped over $60 \mathrm{~cm}$ of rain onto the bare slopes of the Pacific Northwest volcanoes (Burns et al., 2009). This precipitation event saturated the sediment deposits on the volcanic slopes and produced many debris flows on Mt. Rainier, Mt. St. Helens, Mt. Hood, Mt. Jefferson, and Mt. Adams (Burns et al., 2009). Geologic hazard studies and inventories of the debris flows have been published for Mt. Rainier, Mt. Hood, Mt. Jefferson, and Mt. Adams. During the 2006 storm event Mt. Rainier experienced debris flows in six drainages (Copeland, 2009), Mt. Hood had debris flows in seven of eleven drainages (Pirot, 2010), Mt. Jefferson experienced one rocky debris flow in the drainage basins of Milk and Pamelia Creeks (Sobieszczyk et al., 2008), and Mt. Adams experienced debris flows in seven of eighteen drainages (Williams, 2011).

Debris flows are mass movements of material transported by fluvial processes through steep mountain drainages (Ritter et al., 2011). They share similar processes with volcanic debris flows and lahars, except that the later originate during a volcanic eruption (Iverson, 1997). In either case, the transported material generally consists of sediments of a variety of grain sizes, organic debris, and varying amounts of water (Ritter et al., 2011). These flows are known for their high velocities and high impact forces (Ritter et al., 2011), and therefore represent a major geologic hazard for people and infrastructure in the affected drainages and depositional zones. 
On Mount St. Helens, the initial effect of the 2006 storm was thought to be minimal. Only one debris flow was previously known because it had damaged a forest road on the south side near the June Lake trailhead. However, field renaissance conducted during the summer of 2010 found that the storm damage was more extensive.

\section{AIMS AND OBJECTIVES}

The objective of this project is to characterize the debris flows on the southern flanks of Mount St. Helens that occurred during the November 2006 event. The study area is defined as all drainage basins except those on the northern flank of Mount St. Helens that empty into the North Fork Toutle River and Spirit Lake. Excluded drainages on the northern flank are well studied, and the recent deposits often generate debris flows.

The specific aims include:

- Investigate which drainages in the study area experienced a debris flow caused by the precipitation event in 2006 .

- Further investigate each debris flow to determine the initiation site, initiation method, and extent.

- Construct a debris flow inventory map for the November 2006 event on Mount St. Helens. 
- Use the multiple regression model developed by Pirot (2010) on Mt. Hood to analyze the characteristic features of each drainage basin and determine which are significant in determining the occurrence of a debris flow.

- Construct a debris flow hazard map of Mount St. Helens.

The finished project will give a complete picture of the effect this "Pineapple Express" rain event had on the central High Cascade volcanoes. The characterized drainage basins will also provide information on the southern flanks of the volcano useful in future scientific studies. Finally, the collected basin attributes will enable comparisons with the other central High Cascade volcanoes and further the development of a general debris flow hazard model. 


\section{CHAPTER 2 - BACKGROUND}

\section{GEOLOGIC HISTORY OF MOUNT ST. HELENS}

Mount St. Helens is the youngest member of the Cascade Volcanic Arc (Figure 3, Figure 4), having erupted sporadically for the last 300,000 years (Pringle, 2002; Clynne et al., 2008). The deposits that comprise Mount St. Helens vary in composition from mainly dacite and andesite to basalt (Pringle, 2002). The 2,950 m cone, as it existed in 1979, was largely constructed during the past 3,000 years (Pringle, 2002). The catastrophic eruption of May 18, 1980 reduced the peak to 2,550 m and excavated over $2.5 \mathrm{~km}^{3}$ of material (Pringle, 2002).

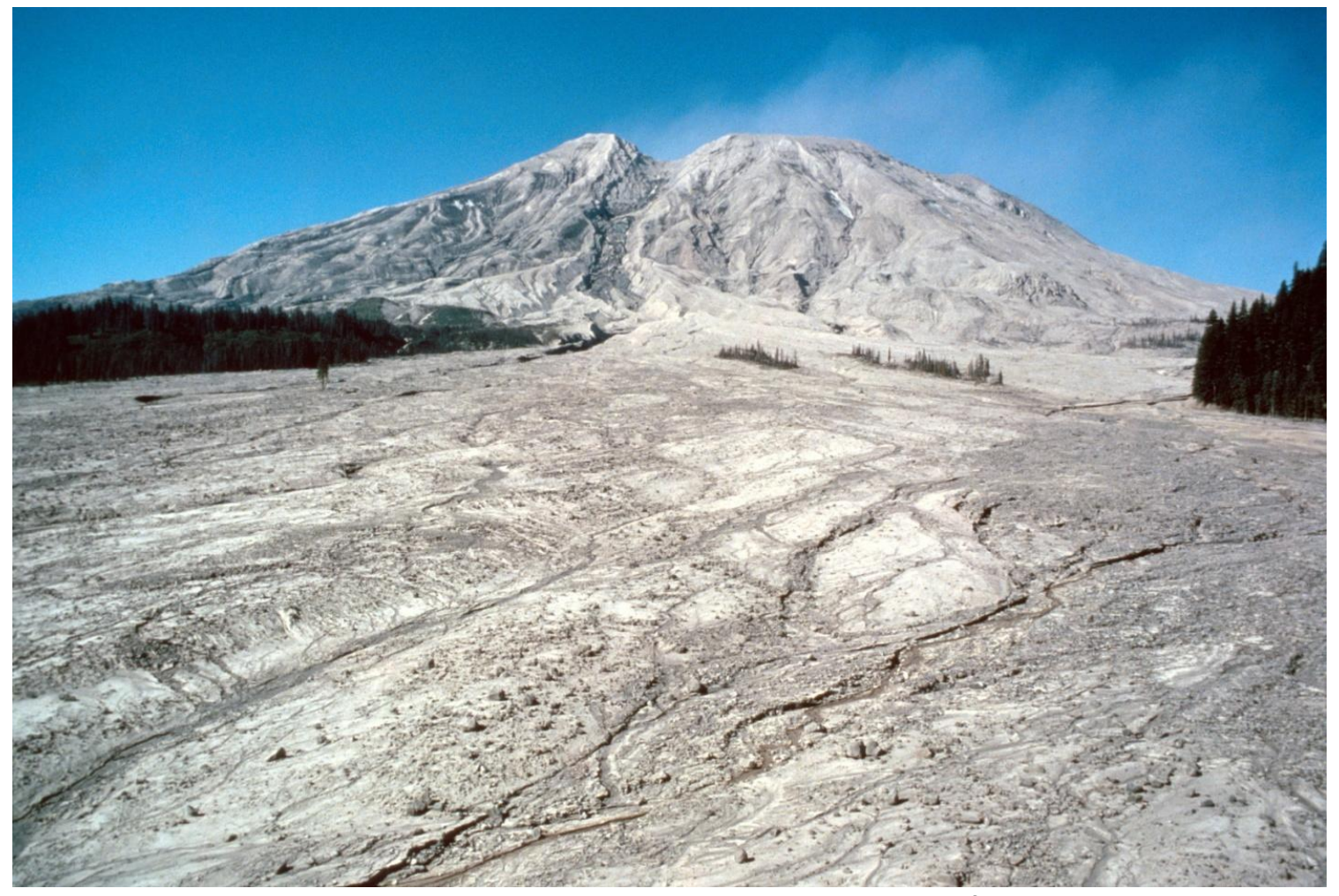

Figure 3: The Shoestring lahar deposit in the southeastern quadrant of Mount St. Helens, October 1980 (USGS). 
The first geologic description of Mount St. Helens was published by Carl Zapffe and included an overview of the geology of the St. Helens mining district, the "extinct" volcano, and local glacial features (Zapffe, 1912). A detailed survey of Mount St. Helens

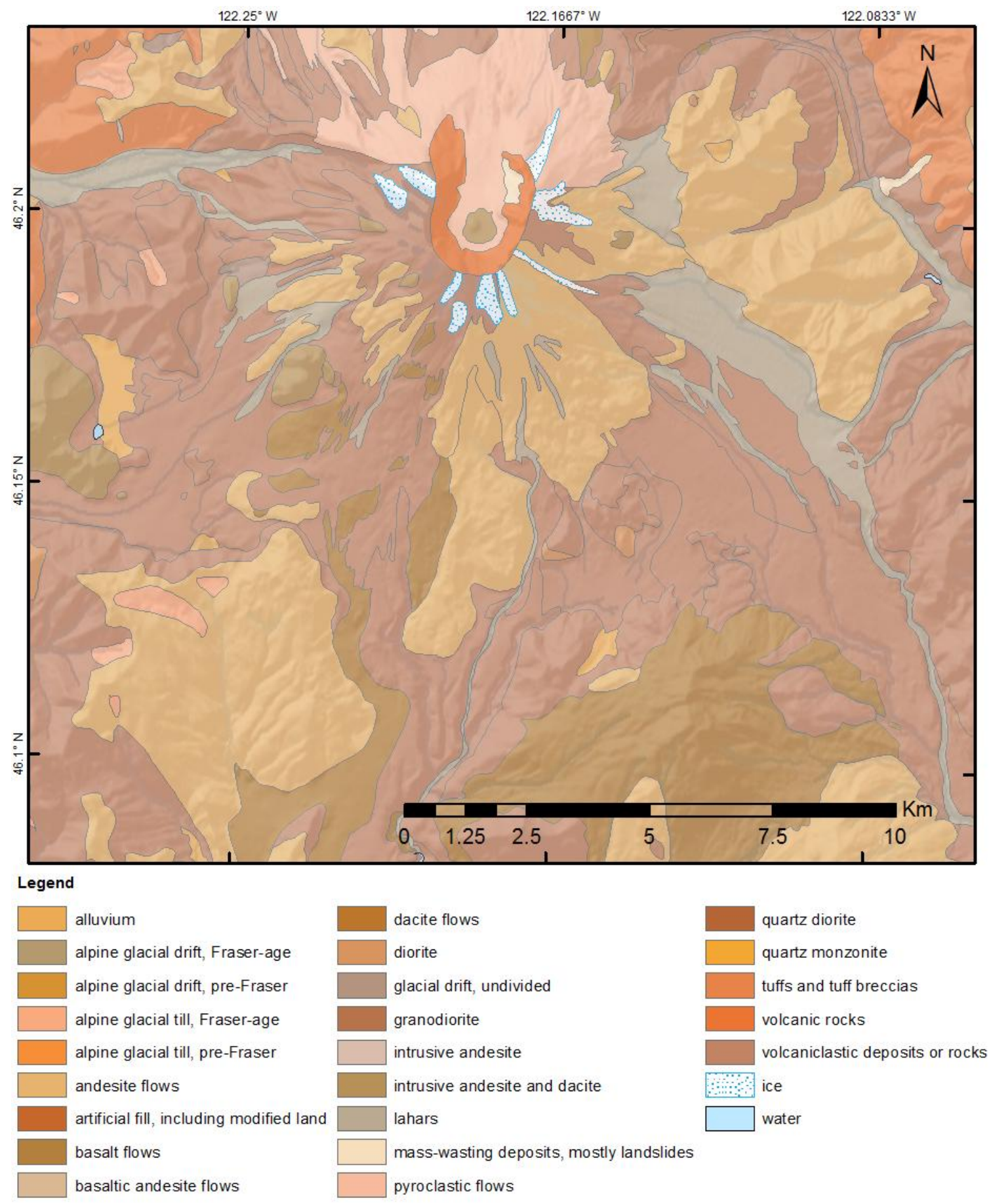

Figure 4: Geologic map of the study area on Mount St. Helens (WaDNR, 2010). 
was conducted in the 1950 s by Dwight R. Crandall and Donal R. Mullineaux of the USGS, and was finally published in 1978 (Hopson, 2008). They divided the mountain's history into four eruptive stages with intermittent periods of activity separated by thousands of years of dormancy (Crandall and Mullineaux, 1978).

Mount St. Helens is geologically a very young member of the Cascade Range, with the construction (and destruction) of the current edifice taking place within the last 3,000 years. It therefore is expected to host future dynamic geomorphologic and volcanic events in the geologically near future.

Eruptive History

The eruptive history of Mount St. Helens (Figure 5) began about 300,000 years ago with the Ape Canyon Eruptive Stage $(300,000$ to 36,000 c14 years B.P.) (Clynne et al., 2008). Lava domes erupted at Goat Mountain and Butte Camp Dome during two distinct periods during this stage separated by 125,000 years of dormancy (Clynne et al., 2005). Deposits of the period between 125,000 and $35,000 \mathrm{c} 14$ years B.P. include large volumes of pumice-rich dacite fallout tephra, pyroclastic flows, and lahars (Pringle, 2002; Clynne et al., 2005). Six distinct tephra layers have been observed with poorly developed soil between, suggesting as many as four eruptive periods (Pringle, 2002). This stage was followed by over 15,000 years of dormancy.

The Cougar Eruptive Stage (20,000 to 18,000 c14 years B.P.) began about 20,000 c14 years B.P. and continued for 2,000 years (Pringle, 2002). Deposits of this stage are found on the southeast, south, and west sides of the mountain and include multiple 


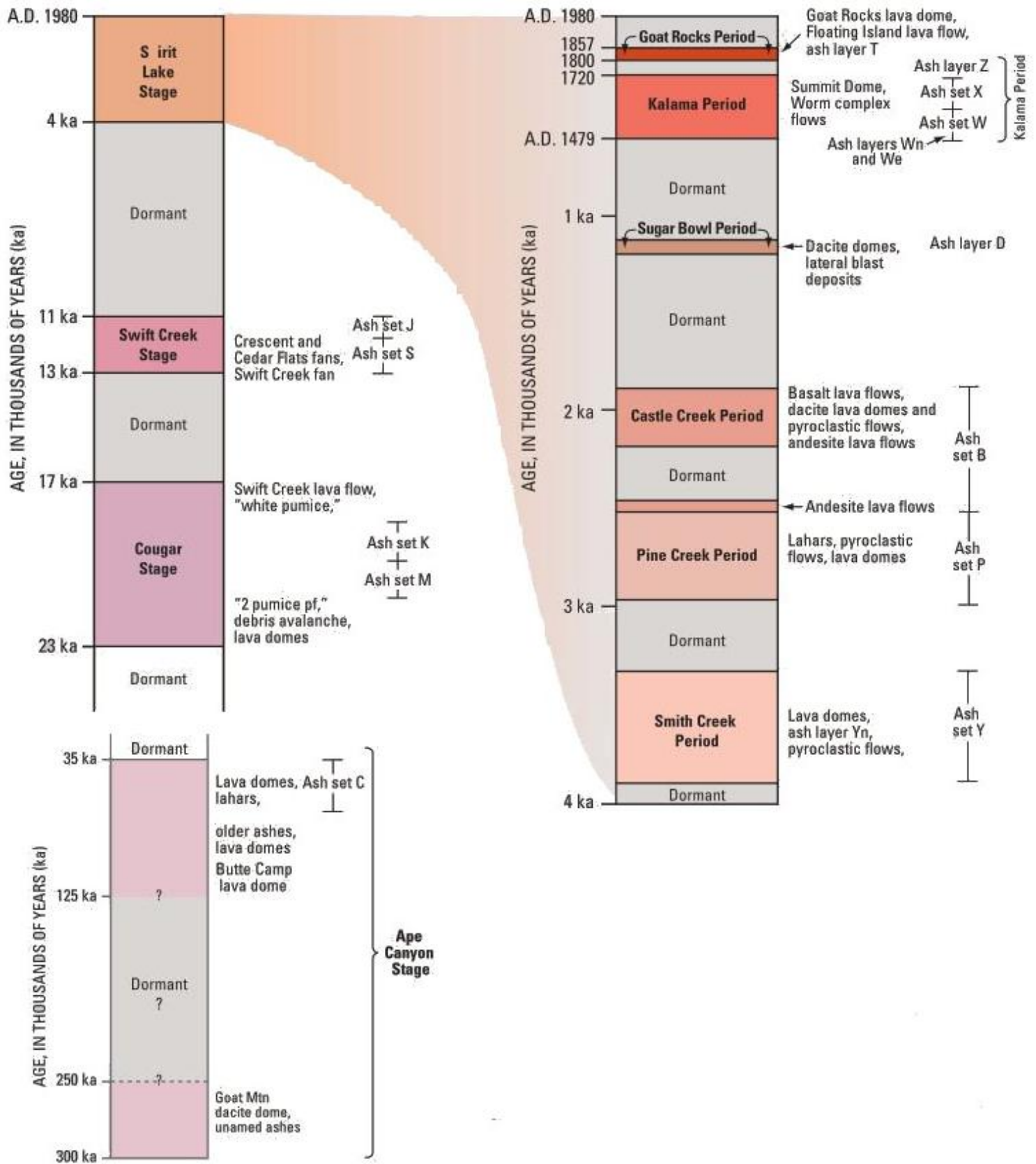

Figure 5: Diagram of the eruptive history of Mount St. Helens showing eruptive stages and dormancy intervals, including major tephra units. Right block shows detail of the Spirit Lake Eruptive Stage (Clynne et al., 2005).

lahars, a debris avalanche on the south flank of the volcano, pyroclastic flows, and dacite tephras (sets $M$ and $K$ ) (Pringle, 2002). An andesite lava flow from this stage is found on the southeast flank (Pringle, 2002). The debris avalanche filled the Lewis River 
Valley to a depth of more than $115 \mathrm{~m}$ and possibly extended to the Columbia River (Pringle, 2002). A dormancy period of roughly 5,000 years followed.

From 13,000 to 10,000 c14 years B.P., the Swift Creek Eruptive Stage deposited large volumes of tephra (sets $S$ and $J$ ) and pumiceous pyroclastic flows (Pringle, 2002). Multiple lithic-rich pyroclastic flows were deposited after tephra set $S$, possibly originating from lava dome collapses (Pringle, 2002). Thick lahar deposits from this period are found in the valleys of Pine Creek, Swift Creek, and the Lewis River on the southern flank of the mountain (Pringle, 2002).

After a dormancy period of over 5,000 years, the Spirit Lake Eruptive Stage began with seven eruptive periods including the most recent (Pringle, 2002). This Stage spans the last 3,900 radiocarbon or 4,500 calendar years (Pringle, 2002). The eruptive periods of this stage (from oldest to youngest) are the Smith Creek, Pine Creek, Castle Creek, Sugar Bowl, Kalama, Goat Rocks, and the modern period. The first three periods had eruptive deposits similar to prior stages, while the Castle Creek eruptions marked a change to deposits that alternate between silicic dacite to mafic basalt and andesite lavas (Pringle, 2002).

The Smith Creek Eruptive Period (3,900 to 3,300 c14 years B.P.) produced a massive and widespread layer of tephra (Set $Y n$ ) around 3,510 c14 years B.P (Pringle, 2002). This eruption produced about $4 \mathrm{~km}^{3}$ of pumice, ash, and rock, which is more than thirteen times the amount produced in 1980 and covers an area that stretches 900 $\mathrm{km}$ to the north-northeast (Carey et al., 1995). Most of the $Y$ tephras from this period can be identified by amphibole phenocrysts of cummingtonite (Pringle, 2002). Deposits 
of this age contain lithic pyroclastic flows which suggest lava dome formation was also occurring during this period (Pringle, 2002). Pyroclastic flows and lahar deposits are mainly found on the east and north sides of the mountain and extend some $50 \mathrm{~km}$ down the Toutle River Valley (Pringle, 2002).

From about 2,900 to 2,500 c14 years B.P. intermittent eruptions mark the Pine Creek Eruptive Period. Deposits from this period include thick lithic, pyroclastic flows on the southeast side and a small tephra layer (set $P$ ) (Pringle, 2002). Silver Lake was formed during this period (about 2,500 c14 years B.P.) by a large lahar that blocked Outlet Creek (Scott, 1988). The series of lava domes forming the core of the volcano were emplaced during this period (Clynne et al., 2005).

The Castle Creek Eruptive Period (2,200 to 1,600 c14 years B.P.) began after 300-years of dormancy and produced lava flows and domes, pyroclastic flows, and ash deposits (Clynne et al., 2005). Andesite lava flows that erupted from the summit were emplaced on all flanks (Clynne et al., 2005). This period ended with the eruption of fluid basalt lava flows that flowed down all flanks of the volcano and up to $12 \mathrm{~km}$ away (Clynne et al., 2005). The Cave Basalt that hosts Ape Cave was produced at about 1,900 c14 years B.P. (Pringle, 2002). The Dogs Head dacite dome was also probably erupted at this time (Pringle, 2002). By the end of this period the volcano had almost reached its pre-1980 profile and elevation (Pringle, 2002)

The next eruptive period has an uncertain age range, but the volcanism produced the Sugar Bowl dome and probably the East Dome (Pringle, 2002). The activity during this period included lahars, pyroclastic flows, and a small lateral blast to 
the northwest (Pringle, 2002). This blast has been dated to about 1,150 c14 years B.P. (Pringle, 2002).

The Kalama Eruptive Period (1480 to late 1700s A.D.) began with the eruption of the $W n$ tephra with a volume six times that of the 1980 eruption, and the We tephra in 1482 A.D. (Pringle, 2002). These eruptions were followed by pyroclastic flows, the construction of a lava dome in the 1490s, and an andesite eruption in 1500 that deposited the $X$ tephra (Pringle, 2002). During the mid-1500s, andesite lava and pyroclastic flows produced the Worm Complex Flows on the south and southeast flanks of the volcano (Pringle, 2002). After the mid-1600s the lavas increased in silica content, and the summit lava dome produced dacite pyroclastic flows (Pringle, 2002).

After only a few decades of dormancy, the Goat Rocks Eruptive Period (1800 to 1857 A.D.) began with the deposition of the $T$ tephra (Pringle, 2002). During this period the high-silica Floating Island Lava Flow was emplaced on the northwest flank (Pringle, 2002). The high silica Goat Rocks dacite dome was extruded from 1842 to 1857, before the volcano fell into a dormant period lasting 123 years (Pringle, 2002).

The Modern Eruptive Period began on March 20, 1980 with a series of earthquakes that preceded the first phreatic eruption on March 27. The catastrophic eruption of May 18, 1980, triggered by a magnitude 5.1 earthquake, initiated a massive debris avalanche that reduced the peak by $400 \mathrm{~m}$ to $2,551 \mathrm{~m}$ and excavated $2.5 \mathrm{~km}^{3}$ of material (Pringle, 2002). This material traveled both northward into Spirit Lake and over Johnston Ridge into the Coldwater Creek drainage, and westward $25 \mathrm{~km}$ down of the North Fork Toutle River (Pringle, 2002). The debris avalanche deposit was then 
immediately buried under overlapping pyroclastic flow deposits consisting of ash, pumice, and rocks up to $30 \mathrm{~m}$ thick (Pringle, 2002). This Pumice Plain extends eastward onto the high plateau of the Plains of Abraham and westward to the upper slopes of the South Fork Toutle River.

Throughout 1980 a series of lesser explosive eruptions occurred with accompanying pyroclastic flows and tephra (Pringle, 2002). From December 1980 to October 1986 the eruptive events turned to dome growth through inflation and minor lava flows, accompanied by minor explosions and lahars (Pringle, 2002). Dome growth then halted until late September 2004 when it renewed by inflation with minor steam and tephra eruptions until late January 2008 (Scott et al., 2008).

The effect of the 1980 and subsequent eruptions on the southern slopes of the volcano included tephra deposition, lahars, pyroclastic flows, and glacier mass loss. Major lahars flowed down many channels on the southwest flank, including in the Blue Lake and Butte Camp Dome drainages (Major and Voight, 1986). Major lahars also flowed down the South Fork Toutle River, Pine Creek, and Muddy River (Figure 6; Pierson, 1985; Janda et al., 1981). Smaller lahars flowed down channels on all sides of the mountain (Pierson, 1985; Major and Voight, 1986).

\section{Glacial History}

During the Late Pleistocene much of the Cascade Range and surrounding highlands were repeatedly covered with glaciers that coalesced into a single ice cap and spread down into the surrounding lowlands (Orr and Orr, 2002). This period includes 


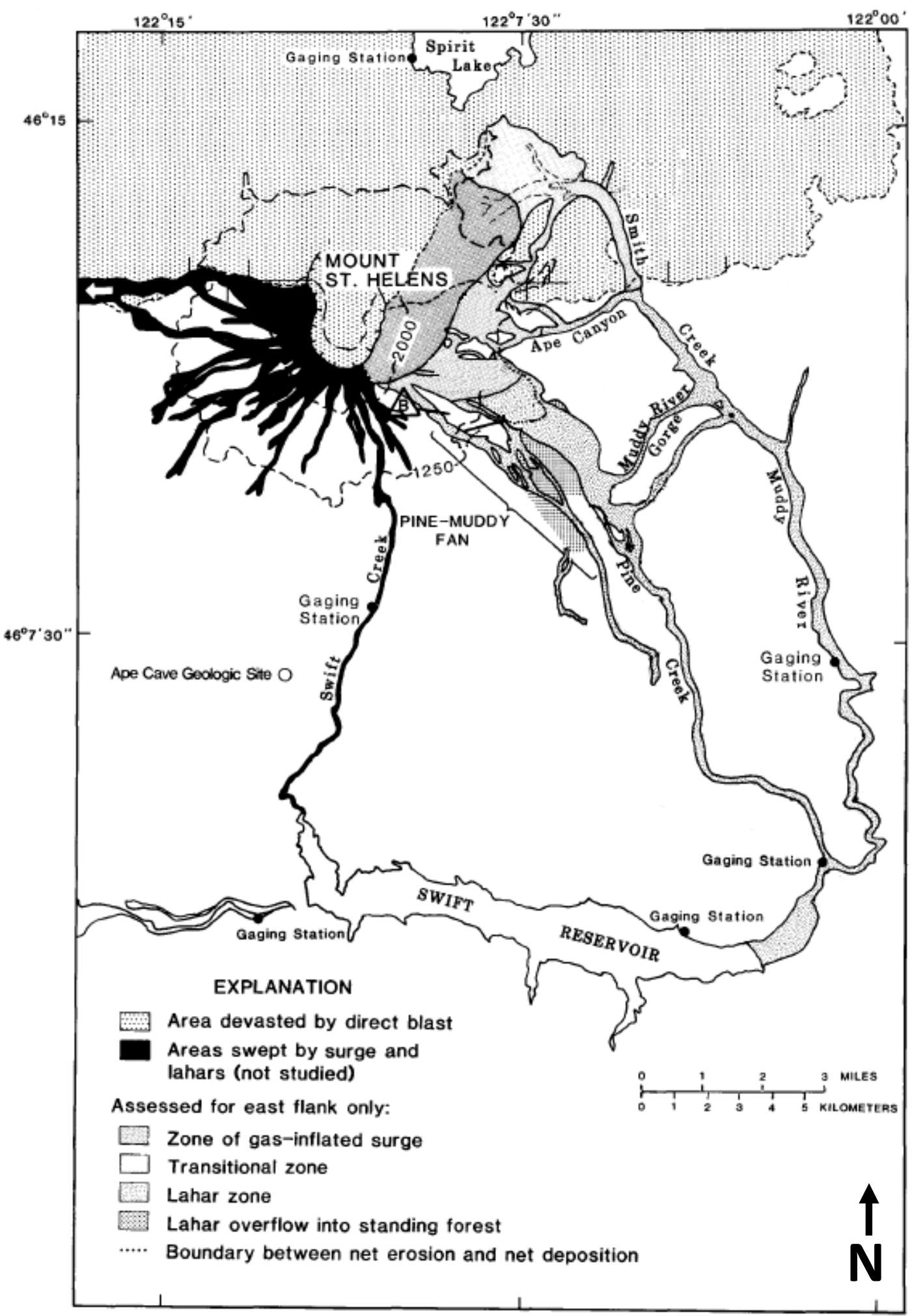

Figure 6: Channels impacted by major lahars caused by the May 18, 1980 Mount St. Helens eruption (Pierson, 1985). Lahars occurred on all drainages, with major lahars on the South Fork Toutle River, Sheep Creek, Swift Creek, Pine Creek, Shoestring Glacier, Muddy River, Ape Canyon, and Nelson Glacier. 
the ice cap glaciation of Hayden Creek about 140,000 c14 years B.P., and the alpine glaciation of Evans Creek between 22,000 to 11,000 c14 years B.P. (Pringle, 2002). These glaciers eroded the landscape, carved cirques, and created large U-shaped valleys which can be seen in the Clearwater, Smith-Muddy-Lewis, Toutle, and Green River drainages (Pringle, 2002). Hayden Creek age terminal moraine till deposits in the Toutle River Valley, that predate the formation of Mount St. Helens, contain granitic rocks from highlands north of Spirit Lake (Pringle, 2002).

The Mount St. Helens volcano, being relatively young, has experienced limited glaciation and glacial erosion (Orr and Orr, 2002). During the Ape Canyon Eruptive Stage, the major Hayden Creek and Evans Creek glacial advances occurred, followed by a minor neoglacial advance between 2,800 and 2,600 c14 years B.P. (Pringle, 2002; Clynne et al., 2008). The last glacial advance, known as the Little Ice Age, continued from 1250 A.D. until the mid-1800s and left moraines on the volcano nearly a kilometer down slope from pre-1980 glacial extents (Pringle, 2002).

The symmetrical cone hosted thirteen small alpine glaciers with a combined surface area of about $5 \mathrm{~km}^{2}$ prior to the May 18, 1980 eruption (Figure 7; Schilling, 2004). The eruption and pyroclastic flows removed about $70 \%$ of the ice volume contained in those glaciers, and the formation of the crater completely destroyed the Loowit and Leschi Glaciers, partly destroyed the Wishbone Glacier, and beheaded the Shoestring, Ape, Nelson, and Forsyth Glaciers (Schilling, 2004). Only two small glaciers on the south side in the June Lake and Swift Creek drainages suffered no volume loss during the eruption (Pringle, 2002). 


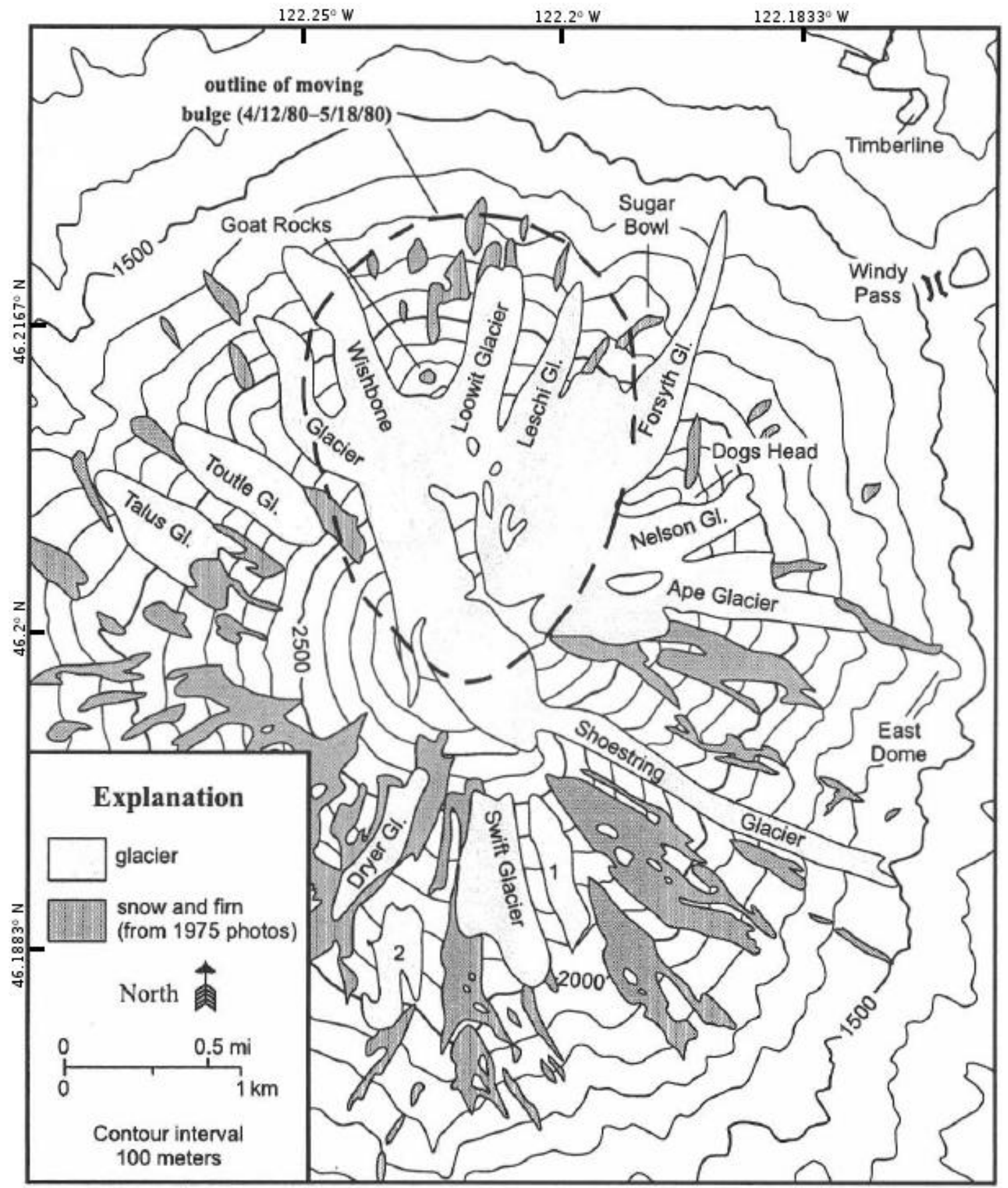

Figure 7: Mount St. Helens edifice with the pre-May 18, 1980 eruption glacier distribution and extent. Glacier \#1 is the still existing June Lake Glacier. Glacier \#2 is the Snowfield Glacier, which today exists only as a permanent snowfield. Redrawn from Brugman and Post (1981). 
The result of the eruption was the formation of a large, $2 \mathrm{~km}$ wide, northward facing crater with a steep headwall rising about $700 \mathrm{~m}$ above the crater floor (Schilling et al., 2004). This headwall is the source of frequent rockfall and snow avalanches which have contributed to the formation and growth of the Crater Glacier since about 1986 (Schilling et al., 2004). As of 2002, the glacial ice was estimated to be about $150 \mathrm{~m}$ thick and have a volume of more than $76,000 \mathrm{~km}^{3}$ (Pringle, 2002). Despite the renewed dome building activity during 2004-2008, the glacier continues to advance (Walder et al., 2010).

By summer of 2001, the remaining portions of the Shoestring, Nelson, Forsyth, and Dryer Glaciers had disappeared, while the Ape Glacier had significantly decreased in volume (Schilling et al., 2004). As of 2004 , only the Ape, Nelson, Toutle, Talus, June Lake, and Swift Glaciers exist outside the crater with a combined volume of $0.52 \mathrm{~km}^{2}$ (Figure 8; Schilling et al., 2004).

\section{Debris Avalanche, Lahar, and Debris Flow History}

Mount St. Helens is surrounded by an extensive debris apron of volcanic ash and rock fragments deposited by pyroclastic flows, lahars, debris flows, and debris avalanches (Clynne et al., 2005). Not much is known about these types of deposits from the Ape Canyon Eruptive Stage between 300,000 and 36,000 c14 years B.P. (Clynne et al., 2005; Pringle, 2002). However, the Cougar Eruptive Stage produced a devastating debris avalanche on the southern flank and a sequence of lahars around 20,000 c14 years B.P. (Clynne et al., 2005). The Cougar debris avalanche originated near Butte 


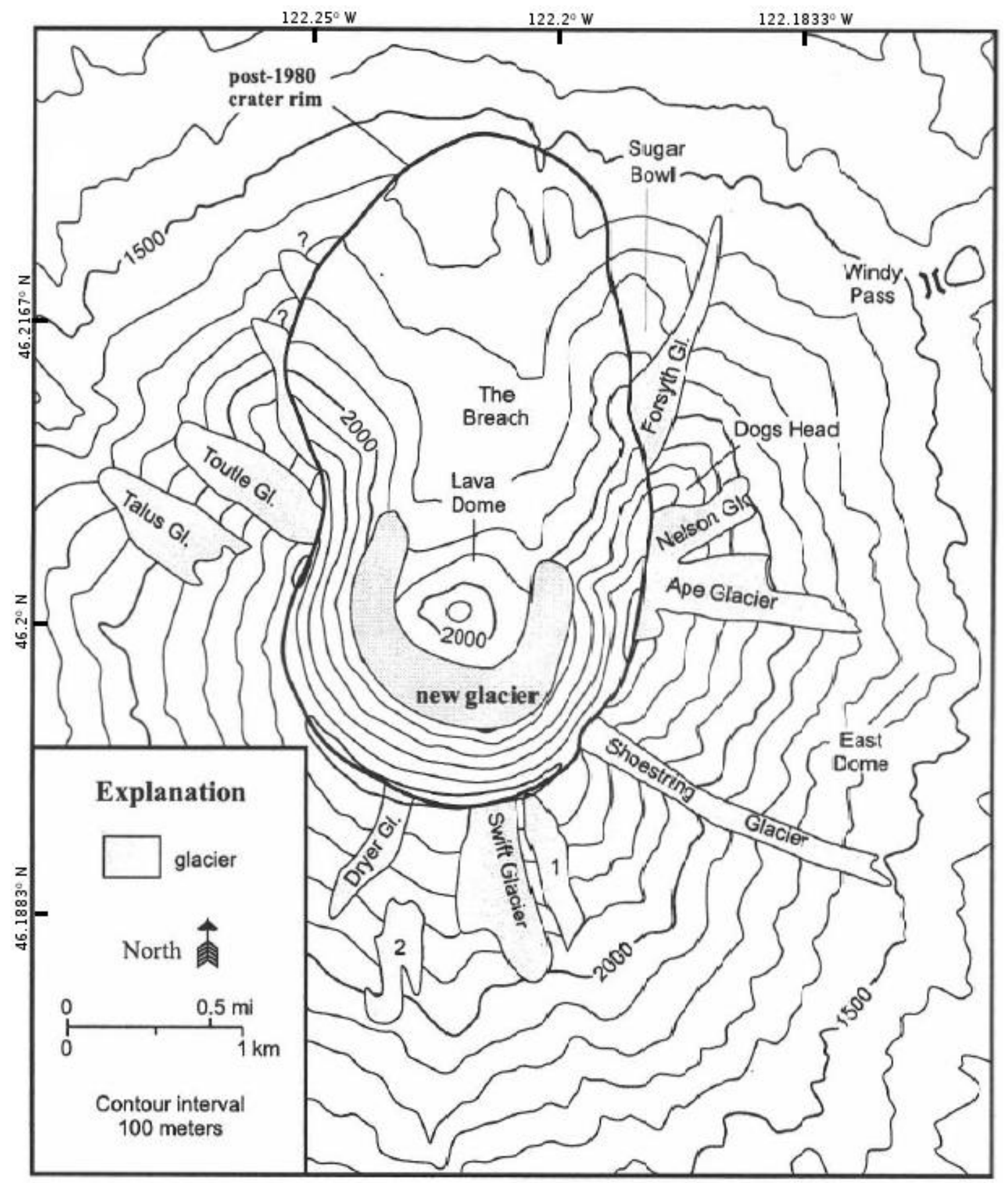

Figure 8: Mount St. Helens edifice with post-May 18, 1980 eruption glacier distribution and extent. In existence as of 2009 are the glaciers: Nelson, Ape, Shoestring, June (\#1), and Swift. Glacier \#2 is the Snowfield Glacier, which today exists only as a permanent snowfield. Redrawn from Brugman and Post (1981). "New Glacier" was formally named Crater Glacier in 2006 (Walder et al., 2010). 
Camp Dome and created a deposit 180-275 m thick and at least twice as large as the 1980 debris avalanche (Clynne et al., 2005). This deposit temporarily blocked the Lewis River creating a lake which burst, sending lahars down the Lower Lewis River Valley to the Columbia River and forming deposits at least 60 m thick (Clynne et al., 2005; Pringle, 2002).

During the Swift Creek Eruptive Stage, around 12,000 c14 years B.P., a debris fan dominated by lahar deposits was emplaced that filled the ancient Pine Creek drainage and buried the Lewis River Valley at Cedar Flats (east end of the Swift Reservoir) by a deposit 90 m thick (Clynne et al., 2005). The next notable lahar deposits were produced on the eastern and northern flanks during the late Smith Creek Eruptive Period of the Spirit Lake Stage about 3,500 c14 years B.P. (Clynne et al., 2005; Pringle, 2002). These huge lahars flowed down the Toutle River to form deposits as far away as $50 \mathrm{~km}$ (Pringle, 2002). Two small debris avalanches during the Pine Creek Period of the Spirit Lake Eruptive Stage about 2,900 to 2,500 c14 years B.P. may have created temporary dams which subsequently failed, sending huge lahars down the Toutle River drainage and forming Silver Lake (Pringle, 2002). Lahar deposits are also associated with the last three periods of the Spirit Lake Eruptive Stage (since 1,200 c14 years B.P.). Those during the Kalama Period from 1480 to 1700 formed extensive deposits on all flanks of the volcano (Clynne et al., 2005)

The Modern Eruptive Period, which began on March 20, 1980, has thus far produced a massive debris avalanche to the north and lahars in nearly all drainages of the volcano (Figure 6; Pringle, 2002; Janda et al., 1981). This debris avalanche, the 
largest landslide in modern history, redistributed about $2.5 \mathrm{~km}^{3}$ of volcanic material into deposits up to $180 \mathrm{~m}$ thick that stretch about $25 \mathrm{~km}$ westward down the Toutle River Valley (Pringle, 2002). Once the debris avalanche stopped moving it began dewatering and formed lahars which traveled at up to $12 \mathrm{~m} / \mathrm{s}$ down the North Fork Toutle River and deposited more than $35,000,000 \mathrm{~m}^{3}$ of sediment into the Columbia River (Pringle, 2002). Lahars in other drainages around the volcano were formed by the melting of debris covered ice and snow triggered by heat from pyroclastic flows (Janda et al., 1981). The largest of these lahars originated in the Muddy River/Pine Creek drainages and deposited more than $13,000,000 \mathrm{~m}^{3}$ of water and sediment into the Swift Reservoir (Janda et al., 1981).

Prior to 2006, episodes of debris flows had occurred around Mount St. Helens but were not well documented. In September 1997, two debris flows occurred in the Blue Lake area (USDA-FS, 1997). One deposited up to $1.2 \mathrm{~m}$ of debris over about $40 \mathrm{~m}$ of Road 8123 and the Blue Lake trailhead closing both (USDA-FS, 1997). The second debris flow did not reach the road, however, Trail 216, 237, and 238 were damaged (USDA-FS, 1997). Landsat data revealed debris flow activity in the Swift Creek Drainage during the winter of 1989-1990 (see Swift Creek Drainage Basin in the Results section). Also, ten small debris flows were observed in the Shoestring Canyon during August 1981 to October 1981, September 1982, and October 1983 (Pierson, 1986). 


\section{DEBRIS FLOWS}

Debris flows in the Pacific Northwest are a natural geomorphic process that deepen and widen steep, young valleys (Cornforth, 2005). Debris flows are a mixture of rock, sediment, organics, and water that can flow at high velocities in steep canyons and transport large boulders and trees causing catastrophic damage to life and infrastructure from both impact and burial (Pierson, 2005). They are distinguished from other related phenomena such as rock avalanches and floods by the interaction of solid and liquid components of the flow (Iverson, 1997). Therefore, geologic phenomena identified as mudflows, debris torrents, mudslides, hyperconcentrated flows, or lahars can be regarded as debris flows (Iverson, 1997). Debris flows can occur with little warning and travel long distances in channels with slight slopes, then emplace deposits over vast areas (Iverson, 1997).

Debris flow initiation sites generally occur in narrow ravines with slopes steeper than the angle of repose (Cornforth, 2005). Initiation sites can also occur in ravine hollows where runoff converges or where springs emerge (Cornforth, 2005). Debris flows can be initiated by landslides, rilling, intense stream erosion, dam breaks, or glacial outburst (Ritter et al., 2011; Godt and Coe, 2007; Benn and Evans, 2010). Rilling occurs when excessive overland flow on unprotected slopes mobilizes loose sediment which develops a network of coalescing gullies and can combine to form "headless" debris flows (Godt and Coe, 2007; Pirot, 2010). Concentrated stream flow through narrow, steep-sided channels can increase erosional scour and debris entrainment in a "firehose effect" which can also form debris flows (Godt and Coe, 2007). The 
catastrophic release of a supraglacial, subglacial, or moraine-dammed lake may produce a sudden increased stream flow and entrainment of sediment and debris orders of magnitude larger than normal discharges (Benn and Evans, 2010). As the flood progresses down the mountain, it incorporates bed sediment and bank debris and can transform into a debris flow (Walder and Driedger, 1994).

Slope failure is the dominant mechanism of debris flow initiation (Iverson, 1997). However, not all slope failures initiate a debris flow as mobilization requires sufficient water to saturate the mass and sufficient conversion of the gravitational potential energy of sliding to the kinetic energy of flowing (Iverson, 1997). Within the failed slope, the bulk friction angle and effective stress determine the resistance to continued motion (Iverson, 1997). Once a debris flow has been initiated it moves as an unsteady surge or a series of surges (Iverson, 1997).

Between initiation and deposition, debris flows can erode and aggregate the rocks and loose sediment of the channel bed and walls throughout the transportation zone in volume accumulation process termed "bulking" (Pierson et al., 1990). A dilution or "debulking" can also occur if enough additional water is added, and the debris flow is moving slow enough not to override the mixing zone (Pierson and Scott, 1985).

In the field, debris flow deposits can be distinguished from flood deposits by a unique set of features. Features of a debris flow deposit include boulder and debris levees; concentration of coarse clasts at the flow margins; convex surface relief; lobate margins; deposits that thicken toward the center of a channel; lack of dunes or ripples; sandy mud coatings on boulders, stream banks, and woody debris; local flow damming 
and redirection by log jams or boulder clusters; eroded splintered trees with embedded gravel; and splintered stumps with bark remaining only on the downstream side (Pierson, 2005). In contrast, flood deposits will contain longitudinal bars of coarse clasts; newly cut channels and scour depressions; accumulated flotsam along the flow margin; light debris caught in tree branches; dunes and ripples; and only light damage to tree bark and branches (Pierson, 2005).

Basins that produce debris flows can be either transport-limited or weatheringlimited (Bovis and Jakob, 1999). Transport-limited basins contain large amounts of available unconsolidated sediment with multiple channel incisions and generate a debris flow whenever a sufficient climatic event occurs (Bovis and Jakob, 1999). Weatheringlimited basins have a less readily available sediment supply that must be renewed by rock weathering and contain fewer and more stable channels (Bovis and Jakob, 1999). These categorizations, calculated from the debris contributing area, drainage density, and a terrain stability number, were used with a multiple regression model to predict the magnitude, frequency, and discharge for each group (Bovis and Jakob, 1999).

Debris flow hazard research began in 1965 with Melton, who attempted to predict debris flow occurrence with a ruggedness number developed by combining simple watershed morphometric characteristics. While examining alluvial fans, Jackson et al. (1987) determined that a Melton's Ruggedness Number (MRN) over 0.3 indicated a basin that is capable of producing a debris flow as opposed to be predominantly driven by fluvial processes. Willford et al. (2004), studying basins in British Columbia, determined that debris flood-prone drainages have MRN values over 0.3 , while debris 
flow-prone drainages have MRN values over 0.6. In 1999, multiple regression analysis was used by Bovis and Jakob to develop debris flow prediction equations using peak discharge, average magnitude, flow frequency, and an activity index. Multiple regression analysis was again used to estimate volumes of California debris flows using the basin attributes: basin area, average gradient, relief ratio, MRN, percent steep slopes greater than 30 and 50 percent, drainage density, and drainage bifurcation ratio (Cannon et al., 2007). Finally, multiple logistic regression was used by Pirot (2010) to determine factors significant to debris flows that occurred on Mt. Hood in 2006.

\section{CLIMATE AND WEATHER}

Mount St. Helens is located about $50 \mathrm{~km}$ directly to the east of Mt. Adams, within the north-south axis of the Cascade Range. The Cascade Range creates a climatic barrier that intercepts the moist west-blowing winds from the Pacific Ocean (Orr and Orr, 2002). These winds bring wet marine storms that deliver about $230 \mathrm{~cm}$ of annual rainfall west of the range (Hatton, 2005). During the winter this moisture accumulates as a thick snowpack that can remain through the early summer months (Orr and Orr, 2002).

Periodically this region of the Pacific Northwest (PNW) experiences extreme rainfall events produced by an intra-seasonal fluctuation in the tropical atmosphere called the Madden-Julian Oscillation (MJO). These anomalous rainfall events are colloquially referred to as "Pineapple Express" storms (Madden and Julian, 1971). The MJO can vary strongly from year-to-year, with strong activity followed by lengthy 
periods of a weak or absent oscillation (NOAA-NWS, 2002). There is evidence that this variability is linked to the El Niño/Southern Oscillation (ENSO) cycle (NOAA-NWS, 2002).

The weather anomalies preceding a MJO begin over a week prior to affecting the PNW (Figure 9), when heavy tropical rainfall in the far western Pacific migrates from the eastern Indian Ocean to the western tropical Pacific Ocean (NOAA-NWS, 2002). This moisture system continues northeastward toward the Hawaiian Islands in the central Pacific, while a strong high pressure zone in the Gulf of Alaska diverts the jet stream around its northern boundary (NOAA-NWS, 2002). A few days to a week before the storm event in the PNW, the tropical rainfall has moved northeast of the Hawaiian Islands, and the high pressure zone has weakened while shifting westward to divide the jet stream into northern and southern upper tropospheric westerly flows (NOAA-NWS, 2002). At this time the tropical and northern circulation patterns begin to synchronize which allows a mid-latitude trough to form which exploits the moisture plume extending from the tropics (NOAA-NWS, 2002). The tropical moisture continues to move northeastward into the mid-latitude trough located off the west coast of North America pushed by the strengthening southern upper tropospheric jet stream (NOAA-NWS, 2002). Finally, a deep low pressure zone near the PNW can cause up to a week of intense rain storms over the region fed from the mid-latitude trough (NOAA-NWS, 2002). 


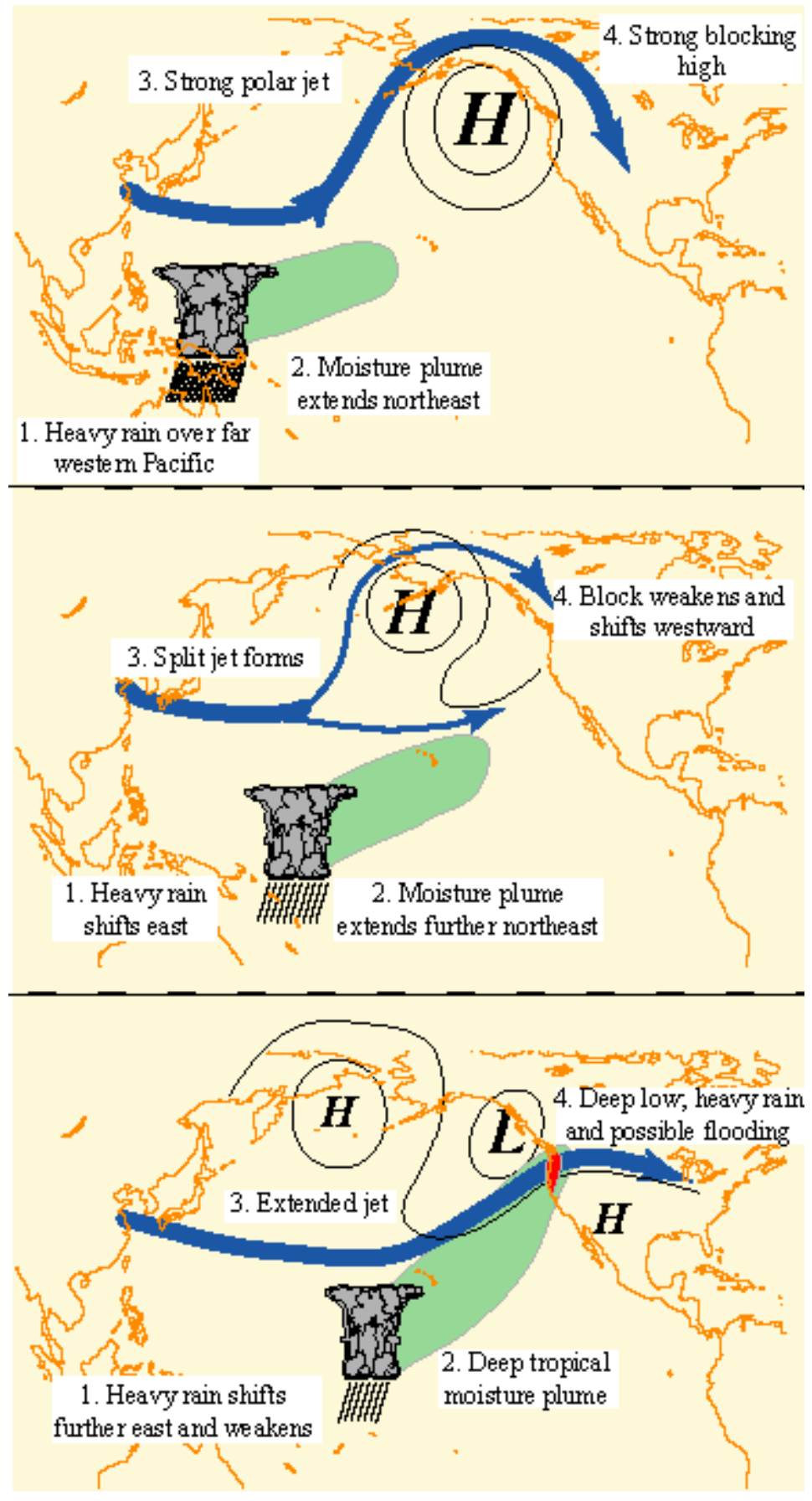

Figure 9: Typical winter weather anomalies that precede heavy west coast precipitation events. Top panel occurs between 7-10 days before event, middle panel occurs 3-5 days before event, and bottom panel occurs during the precipitation event. From NOAA Climate Prediction Center/NCEP/NWS (NOAA-NWS, 2002). 


\section{NOVEMBER 2006 STORM}

The November 2006 storm was an extreme precipitation event associated with

the MJO. The storm struck northern Oregon and Washington between the $3^{\text {rd }}$ and $8^{\text {th }}$ causing fifteen rivers in Washington State to break flood height records (USGS-WWSC, 2006), eleven counties to be declared federal disaster areas due to flooding, and monthly rainfall records to be broken in Vancouver $(33.8 \mathrm{~cm})$, Seattle $(39.7 \mathrm{~cm})$, and Olympia $(50.0 \mathrm{~cm})($ OWSC, 2006). Debris flows were observed in drainages sourced on all of the central Cascade volcanoes.

Mt. Rainier, located about $70 \mathrm{~km}$ southeast of Seattle, Washington, experienced debris flows in six drainages (Copeland, 2009). Initiation zones were not associated with landslide scarps or rockfall (Copeland, 2009). Instead, debris flows occurred in glacier fed drainages with steep-walled ravines of unconsolidated Quaternary sediments and little vegetation (Copeland, 2009). Debris flows initiated at an average of 2,180 m elevation and an average channel gradient of $39^{\circ}$ (Copeland, 2009).

Mt. Jefferson, located about $100 \mathrm{~km}$ east of Salem, Oregon, experienced a series of rocky debris flows in the Milk and Pamelia Creek drainages (Sobieszczyk et al., 2008). The debris flows initiated when the warmer than average air temperatures and heavy precipitation caused a portion of a talus-covered snowfield in the Milk Creek drainage to collapse (Sobieszczyk et al., 2008). As the material moved downslope, erosion and aggregation of existing weakly consolidated pyroclastic, debris flow, and glacial deposits bulked up the flow generating a final deposit of 100,000 to $240,000 \mathrm{~m}^{3}$ (Sobieszczyk et 
al., 2008). Peak rainfall in the area was measured at Marion Forks and Santiam Junction at $6.1-12.8 \mathrm{~cm}$ on November $7^{\text {th }}$ (Sobieszczyk et al., 2008).

Mt. Hood, located about $70 \mathrm{~km}$ east of Portland, Oregon, had debris flows in seven of eleven drainages (Pirot, 2010). Four of these were initiated by landslides, while the others initiated through coalescence of channel erosion and aggregation termed "headless debris flows" (Pirot, 2010). Initiation zones averaged 1,860 m in elevation and occurred in deposits that consisted of dominantly granular particles with a very low percentage of fines (Pirot, 2010).

Mt. Adams, located $50 \mathrm{~km}$ west of Mount St. Helens, experienced debris flows in seven of eighteen drainages (Williams, 2011). One was initiated by a landslide, three by channel erosion and channel wall failures, and three by coalescence of channel erosion and aggregation (Williams, 2011). All debris flows initiated in Quaternary glacial deposits (Williams, 2011). Debris flow initiation sites averaged 2,210 m in elevation and occurred in drainages with an average gradient of 0.38 (Williams, 2011). The daily peak rainfall during the storm was recorded on November $7^{\text {th }}$ at a SNOTEL site to the southwest of the mountain as $17.2 \mathrm{~cm}$ (Williams, 2011).

At Mount St. Helens, the six nearby SNOTEL stations (Figure 10) recorded the highest values of rainfall on November $7^{\text {th }}$ at June Lake station $(37.1 \mathrm{~cm})$ and Swift Creek station $(35.3 \mathrm{~cm}$ ) on the southern flank (Figure 11; USDA-NRCS, 2007). Sheep Creek experienced the next highest rainfall at $27.2 \mathrm{~cm}$ on the same day (USDA-NRCS, 2007). Highest total accumulated rainfall during the storm was recorded as $94.7 \mathrm{~cm}$ at June Lake. Swift Creek measured $89.9 \mathrm{~cm}$ and Sheep Canyon measured $68.6 \mathrm{~cm}$ during the 


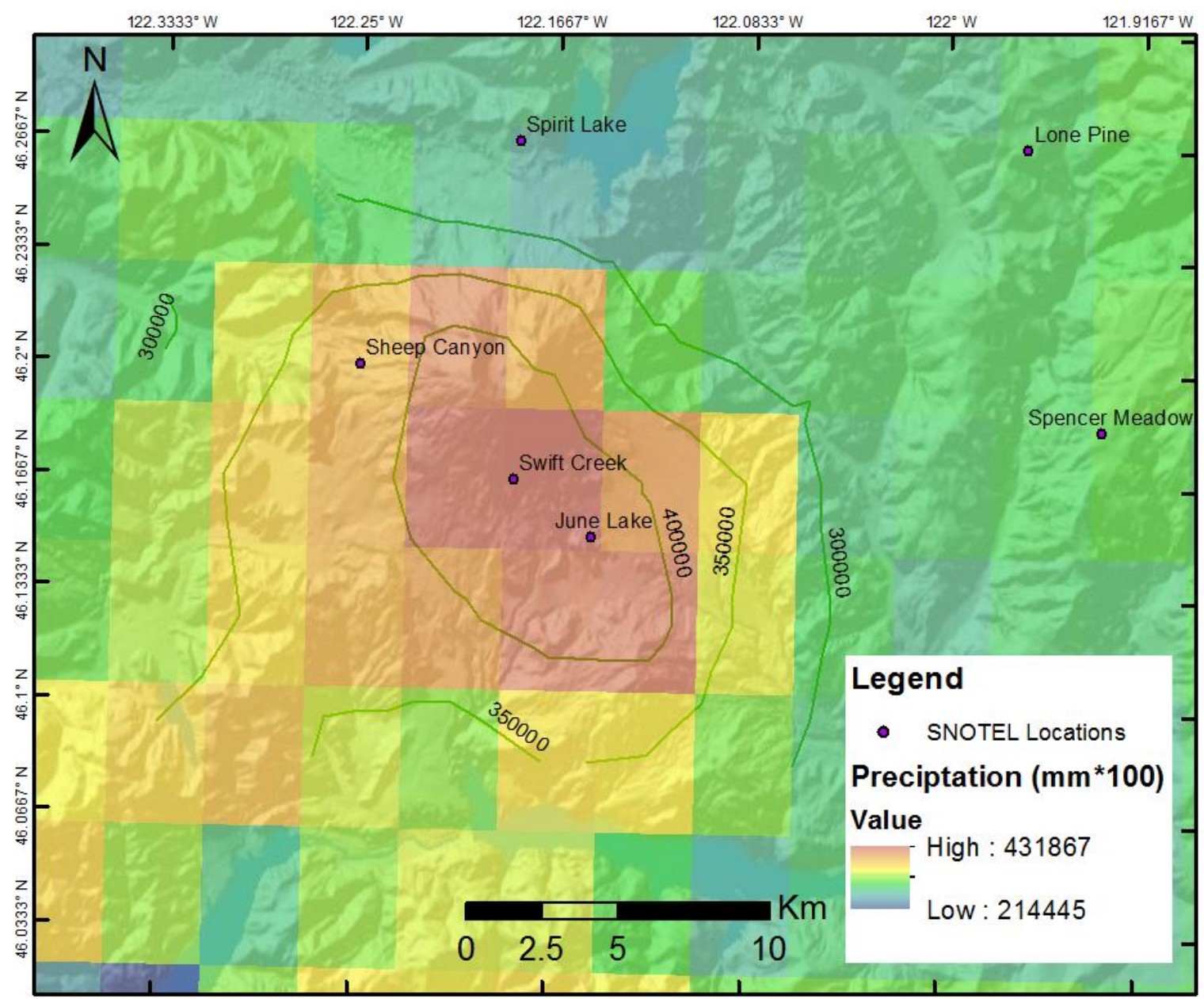

Figure 10: Map showing the gridded PRISM average annual precipitation data for 2006 in hundredths of millimeters and as contours. Locations of nearby SNOTEL sites are also shown. The highest average rainfall values for this area are $430 \mathrm{~cm}$ (PRISM, 2007; USDA-NRCS, 2007).

storm. The three other nearby SNOTEL stations are outside the study area. All sites reported no snow cover before the onset of the storm. See Table B.1 for SNOTEL precipitation data covering November 2006.

Damage to Gifford Pinchot National Forest was estimated to be greatest in the Mount St. Helens National Volcanic Monument and neighboring National Forest area (USDA-FS, 2006). The total damage to roads, trails, and campgrounds in Gifford Pinchot National Forest was estimated to be more than $\$ 17$ million (USDA-FS, 2006). Repairs to 
the flood damaged culvert at the Road 83 crossing of the June Lake stream were not completed until October 3, 2008 (USDA-FS, 2008a). The Blue Lake trailhead parking lot and nearby portions of Road 8123 were permanently closed by burial under debris flow deposits, while the surrounding trails were permanently redirected (USDA-FS, 2007).

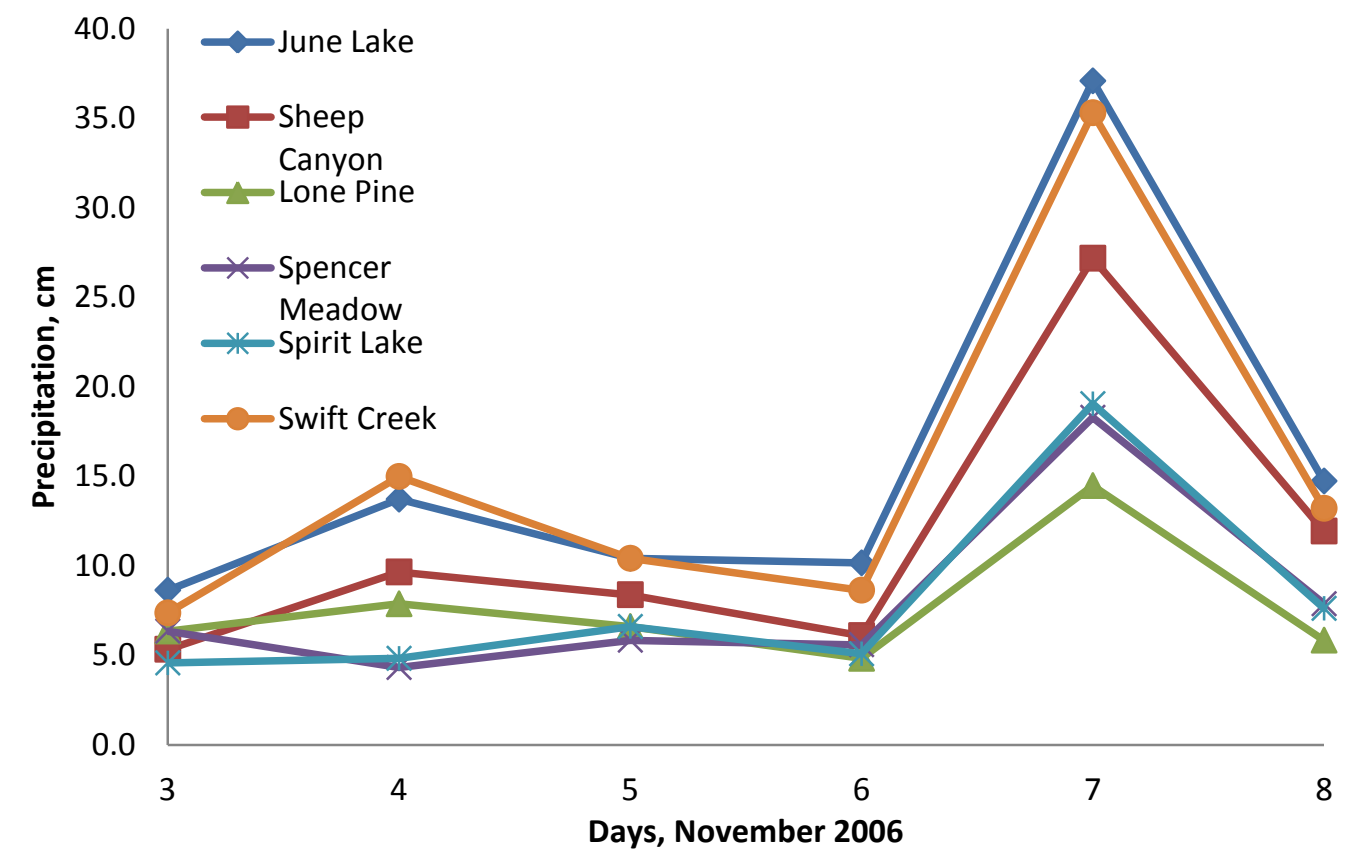

Figure 11: Graph of rainfall measurements during the period of November 3-8 at the SNOTEL sites June Lake (1,049 m), Sheep Canyon (1,216 m), Lone Pine (1,198 m), Spensor Meadow $(1,036 \mathrm{~m})$, Spirit Lake (1,072 m), and Swift Creek (1,353 m) (USDA-NRCS, 2007). June Lake and Swift Creek, located in the southern quadrant of Mount St. Helens, experienced the greatest rainfall accumulation.

\section{VEGETATION}

The upland and riparian vegetation (below about 1,000 m elevation) around Mount St. Helens outside the 1980 debris avalanche zone (Figure 12) consists of productive conifer forest primarily of Pseudotsuga menziesii (Douglas-fir), Abies amabilis (Pacific silver fir), Abies procera (noble fir), Tsuga heterophylla (western hemlock), and Thuja plicata (western red cedar) (McKee et al., 1987; Alaback et al., 1994). Also found 


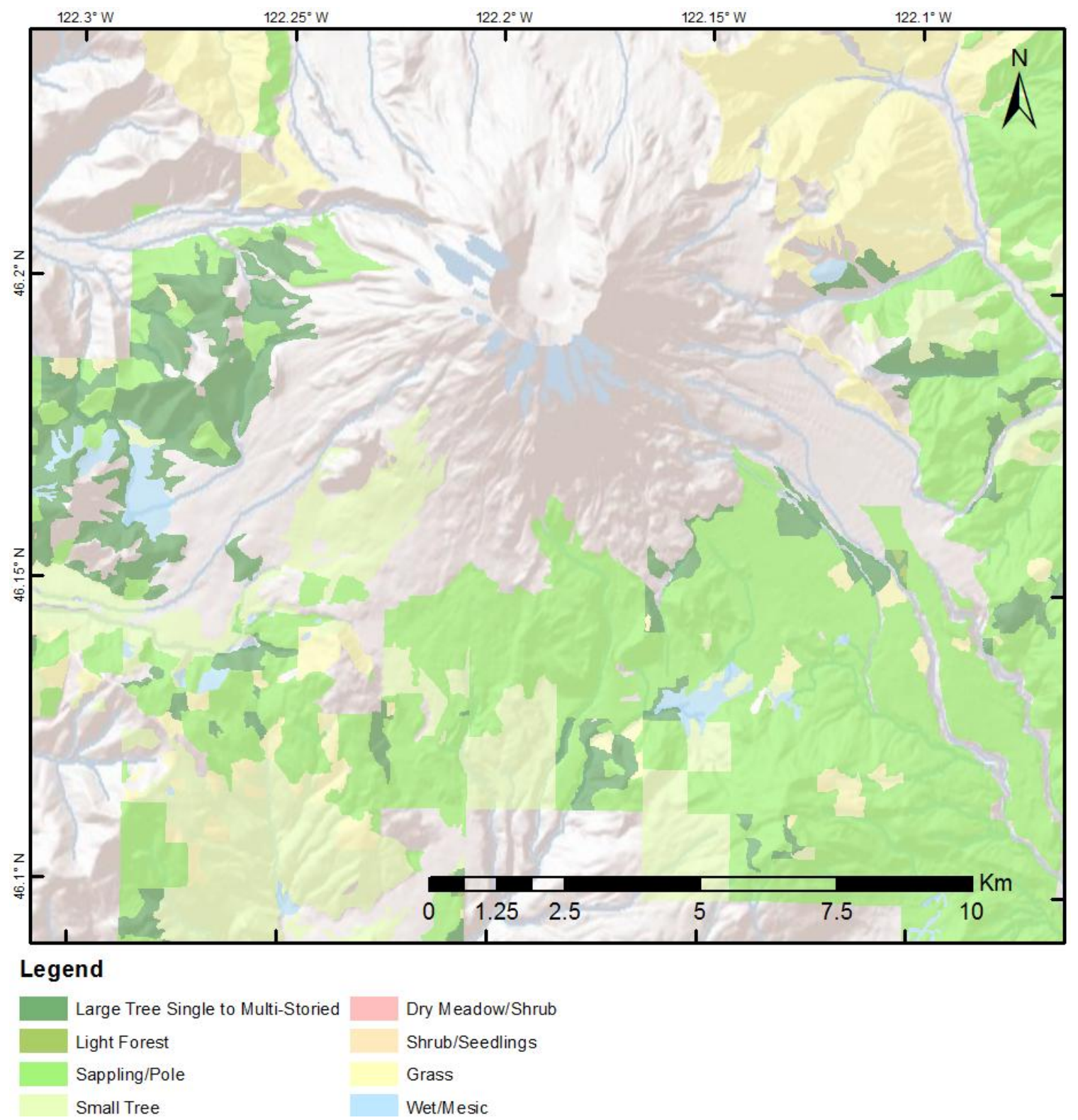

Figure 12: Vegetation map of the study area around Mount St. Helens (USDA-FS, 2008b). Data layer seems to be out-of-date in areas affected by 1980 lahars.

are Pinus monticola (western white pine), Alnus rubra (red alder), Acer circinatum (vine maple), and Acer glabrum (Rocky Mountain maple), and Populus trichocarpa (black cottonwood) (Shane, 1985; Alaback et al., 1994). The understory includes such plants as Vaccinium membranaceum (black huckleberry), Oplopanax horridum (devil's club), 
Arctostaphylos uva-ursi (bearberry), Ribes bracteosum (stink currant), Gaultheria shallon (salal), and Polystichum munitum (sword fern) (Shane, 1985; Alaback et al., 1994). The forests in the western and southern quadrants range in age from recently clear-cut to old-growth stands over 500 years old (McKee et al., 1987).

The tree line around Mount St. Helens is about $800 \mathrm{~m}$ lower than that found around nearby Mt. Adams; therefore, subalpine herbaceous vegetation occurs as low as 1,275 m elevation (Moral, 1983). The low treeline and bare slopes is attributed to a powerful eruption in 1482 (not 1842 as reported in St. John, 1976) which ejected large volumes of ash and pumice (Set $W n$ ) that layered the slopes up to a depth of nine meters (St. John, 1976; Clynne et al., 2005). The harsh subalpine environment is dominated by sparse forests of Pacific silver fir, Abies lasiocarpa (subalpine fir), Pinus contorta (lodgepole pine), and Tsuga mertensiana (mountain hemlock) (Shane, 1985; Alaback et al., 1994). The alpine and subalpine meadows are populated with Phyllodoce empetriformis (red mountain heath), Juniperus communis (common juniper), salal, and wide assortment of perennial wildflowers (Shane, 1985).

The sparse vegetation identified in alpine and subalpine lahar or debris-flowdevastated areas includes (but is not limited to) Achillea millefolium (yarrow), Agrostis spp. (bentgrass), Aster ledophyllus (tea-leaved aster), Anaphalis margaritacea (pearly everlasting), Calyptridium monadrum (pussy paws), Carex spp. (several species of sedges), Castilleja miniata (common red paintbrush), Collomia debilis (alpine collomia), Danthonia intermedia (timber oat-grass), Epilobium angustifolium (fireweed), Eriogonum pyrolifolium (alpine buckwheat, which is very common), Fragaria virginiana 
(wild strawberry), Hieracium gracile (white-flowered hawkweed), Juncus spp. (several species of rushes, including Juncus parryi or Parry's rush), Luetkea pectinata (partridgefoot, which is extremely common in alpine areas), Lupinus latifolius aka $L$. arcticus (arctic lupine), Lupinus lepidus (prairie lupine), Penstemon cardwellii (Cardwell's penstemon, which occurs in large patches around Mount St. Helens), Phlox diffusa (spreading phlox), Phyllodoce empetriformis (pink mountain-heather), Polygonum newberryi (Newberry's knotweed), Saxifraga tolmiei (Tolmie's saxifrage), Trisetum spicatum (spike of trisetum), and Xerophyllum tenax (bear-grass) (St. John, 1976; Moral, 1983; Moral and Clampitt, 1985; Alaback et al., 1994; Chapin, 1995). 


\section{CHAPTER 3 - METHODS}

Standard methods were used in each of the major phases of this thesis: field observations, laboratory analysis, and data processing and analysis. Although not entirely distinct, each major phase occurred during the following time frames. The field observations phase occurred during July, August and September of 2010 and 2011. Laboratory analysis occurred in October 2011. And the data processing and analysis phase began in November 2011 and continued into March 2012. Map production and report writing occurred sporadically until March 2012, at which point it began in earnest.

\section{FIELD METHODS}

\section{Reconnaissance}

Field reconnaissance involved two phases. The first occurred during the summer of 2010 and involved exploring the U. S. Forest Service roads and hiking Loowit Trail (Trail 216) around the southern flanks of the volcano guided by trail maps (USDA-FS, 2008b) and Google Earth research. Observations were recorded at stream channel intersections with roads and trails. Information was recorded on type and location of vegetation, damage to road or trail, channel size and shape, degree of channel erosion, presence of a continuous or ephemeral stream, existence of a debris flow levee or depositional fan, and existence of any other evidence of debris flow activity (Pirot, 2010; Williams, 2011; Pierson, 2005). At the end of the summer these observations were compiled into a database and analyzed to determine which channel locations had 
experienced a debris flow and to estimate the age. Of primary importance, was the determination of which channels had experienced a debris flow in 2006.

The second phase occurred during the summer of 2011 and focused on sampling and exploring the upper drainages of those basins determined, based on field and remote sensing evidence, to have experienced a debris flow in 2006. In this phase, a field expedition to a quadrant of the volcano first established a base camp above the tree line with access to water and a route into the upper basin. The next day or days involved hiking up the drainage taking observations, locating candidate initiation sites, and taking soil samples. Neighboring drainages were also explored by hiking across the upper basin. Due to the large field area, not every drainage basin was explored or sampled. Field expeditions were conducted into nine drainages: Blue Lake and Sheep Creek; Muddy River, with side expeditions into the Shoestring and Ape Glacier upper basins; June Lake; Nelson Glacier; Butte Camp Dome, with a side expedition into the Blue Lake upper basin.

Equipment used in both phases included Green Trails Maps No. 364 and 364S, a Gifford Pinchot National Forest map (USDA-FS, 2008b), binoculars, a Garmin eTrex Legend HCx GPS unit, and a Canon PowerShot SD1100 IS camera. Occasionally field assistants used personal equipment in the field to record images or location data and later shared this information. 


\section{Sampling}

Soil samples were taken in the upper drainage basins to determine the typical grain size and bulk density of soils involved in debris flow initiation. The sampling was conducted during the summer of 2011 in most of the drainages that experienced a debris flow in 2006 (Figure 13). Only the Pine Creek and South Fork Toutle River drainages were not sampled. Of drainages that did not experience a debris flow in 2006, only Nelson Glacier and Ape Glacier were sampled. At each site, groups of three

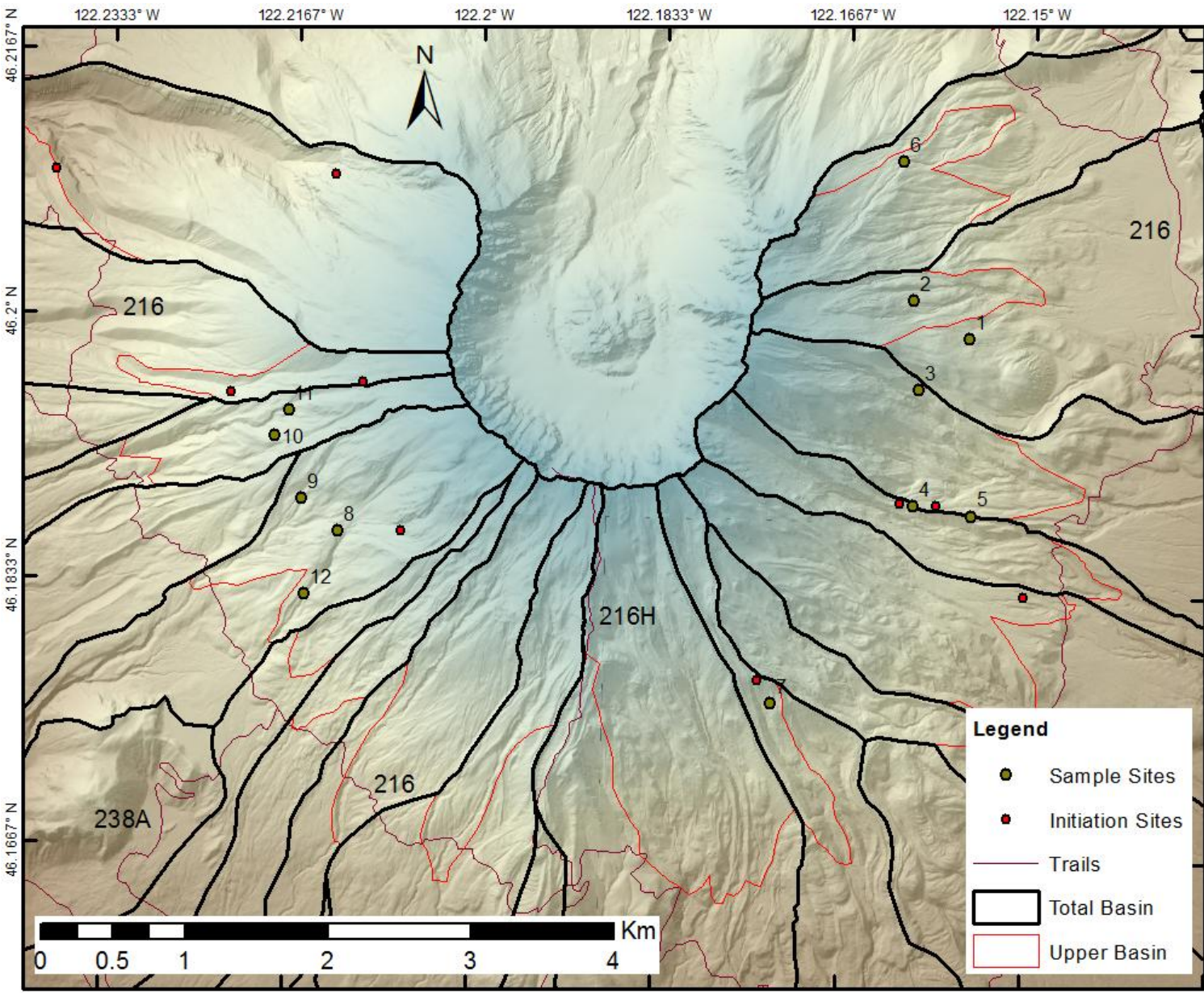

Figure 13: Map of the eleven soil sample locations around Mount St. Helens. Samples 1, 2, and 6 were taken in drainages without debris flows in 2006. Samples 3, 9, and 10 were taken from side-channels of the primary channel in drainages that experienced a debris flow in 2006. Trails shown include the Loowit Trail (216), 238A, and 216 H. 
soil samples were taken in deposits associated with landslide scarps or material representative of the initiation zone. Sample groups were generally triangular in configuration with individual sample pits located not further apart than three meters. Samples were taken with a small trowel used to dig a smooth walled hole (Figure 14). Removed soil was carefully stored in bags labeled with site number, drainage name, and date. Position of each sample pit was measured with the GPS unit. Sample volume was measured by lining the hole with a plastic bag, then pouring water from a $1000 \mathrm{~mL}$ graduated Nalgene bottle (modified from Pirot, 2010). Finally, the difference between the initial and final volumes in the Nalgene bottle is equal to the volume of the sample hole. Volume was later used to calculate dry bulk density. Samples taken had an average volume of $335 \pm 80 \mathrm{~mL}$

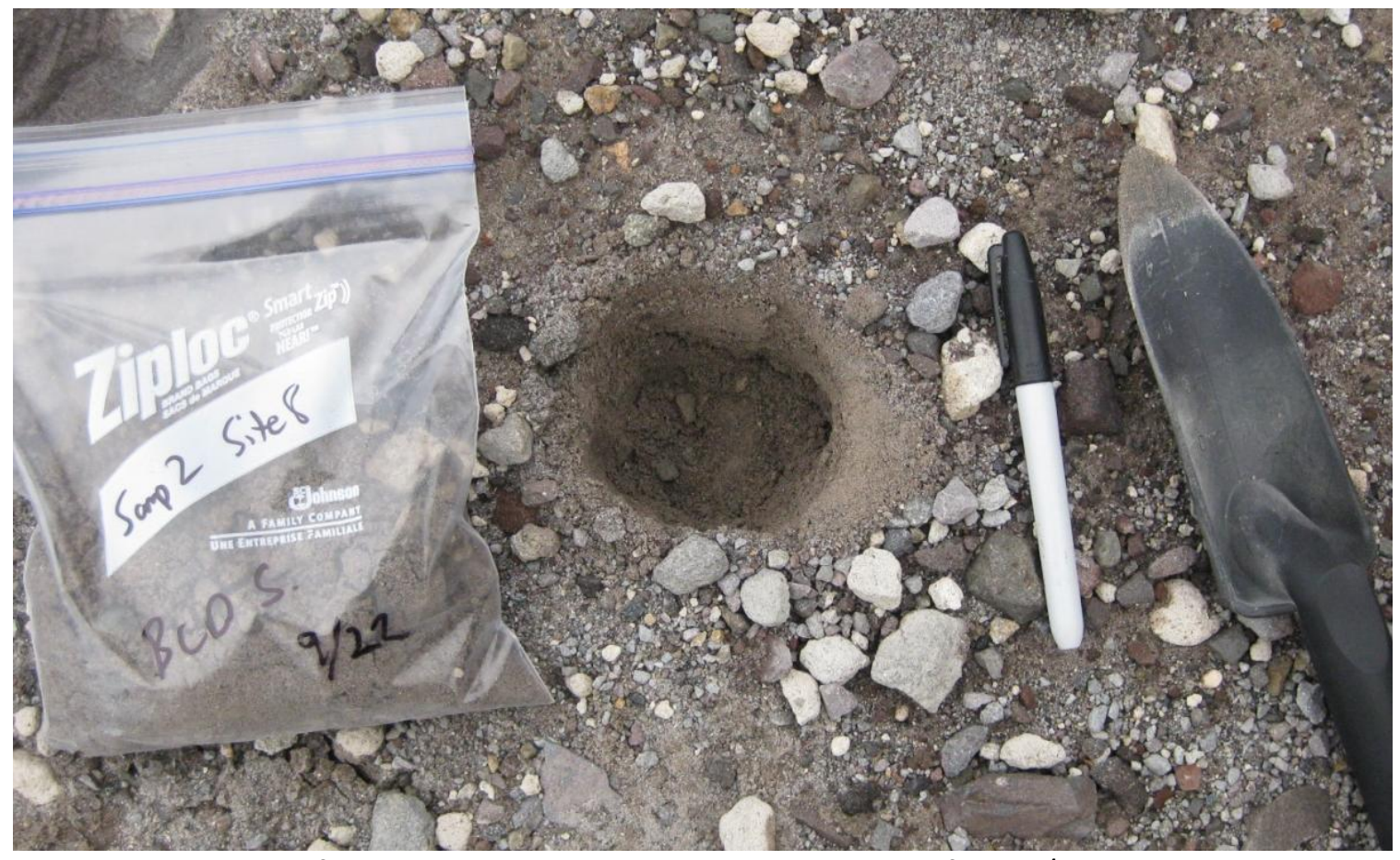

Figure 14: Example of a soil sample pit with sample bag. Photo of Site 8/Hole 2 in the Butte Camp Dome Drainage (UTM 10N 560779E 5115085N). 


\section{LABORATORY METHODS}

Soil samples were taken to the Van Atta Geology Lab at Portland State where the samples were sieved to determine the distribution into gravel, sand, and smaller sized particles (ASTM, 2007). The samples were first dried and then measured to determine the dry weight of each. Dry bulk density was then calculated as

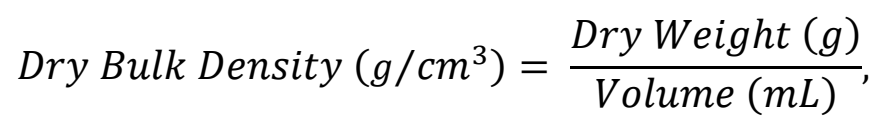

using the volume measured in the field. The dried samples were individually placed into a sieve stack that included sieves $10,20,40,100,140,200,230$, and a pan. Sieves were shaken for about ten minutes and then the retained samples were extracted and weighed. Grains were classified according to amounts of gravel, coarse sand, medium sand, fine sand, and silt and clay. The dry sieving process found an average of $7 \%$ silt and clay sized particles so analysis was not continued using a hydrometer.

\section{DATA PROCESSING AND GIS}

\section{Drainage Mapping}

After the initial field reconnaissance in 2010, during the compiling of the channel observations database, the boundary of each drainage basin around the mountain was determined. This required the use of a digital elevation map (DEM) with five meter resolution to determine the hydrologic boundaries of each basin. This DEM was also used extensively for map production and data analysis. The DEM was published by University of Washington using USGS LiDAR data collected between October 31 and 
November 2, 2002 with re-flights in 2003 (USGS, 2004). The primary goal of drainage mapping was the definition of the total basin boundaries and grouping of the 22 individual channels listed in the observational database into 16 drainage basins for the compiling of basin attributes. The debris flow transport and deposition zones were also digitally delineated using ortho imagery and LiDAR.

\section{Determining Initiation Zone}

Once field observations were complete, a final determination was made for the initiation site and method in all drainage basins with a 2006 debris flow. The initiation method was categorized as either a landslide, erosion of the channel, or rilling. Essential to this determination was the acquisition of two meter resolution ortho imagery produced by the Farm Service Agency of the USDA in 2006 and 2009 for all of Cowlitz and Skamania Counties, Washington (USDA-FSA, 2006; USDA-FSA, 2009). The 2006 data set was compiled from images taken in July 21, 23, 24 and August 5 and published in March 2007. The next available imagery set from 2009 was compiled from images taken in July 1, and August 1, 3, and 19 and published in March 2010.

To begin the procedure, the initiation site candidates observed in the field were located on 2009 ortho imagery. Then, comparing the located features against 2006 imagery either confirmed or disqualified that site as possibly created during the 2006 storm. Any confirmed sites were assumed to have been created during the 2006 storm event; although, they could have formed any time between the acquisition of ortho imagery in 2006 and 2009. Features found on both ortho imagery data sets could be 
considered to have formed before the 2006 event, and features not seen in either set formed after 2009. When evidence of the initiation site was not observed in the field, a determination was made based solely on evidence found in the ortho imagery.

The comparison process involved loading the orthoimagery into ArcMap and clipping the extent down to the study area. Then each drainage was compared from end to end at about 1:4,000 scale using the Swipe Layer tool in the Effects toolbar. Closer examinations were made at 1:2,000 scale. Major differences between the two images were spatially annotated on another data layer. In some cases the ortho imagery was not conclusive because of late snow cover in 2006, poor contrast, or shadows caused by low sun angle.

\section{Rainfall Data}

Precipitation amounts for the Mount St. Helens area during the November 2006 storm event were obtained indirectly from average annual precipitation data for 2006 (PRISM, 2007) and six nearby National Resources Conservation Service (NRCS) Snowpack Telemetry (SNOTEL) sites (Figure 10; USDA-NRCS, 2007). Three sites are located on the lower slopes of the volcano in the June Lake, Sheep Creek, and Swift Creek Drainage Basins. The June Lake station is located on the south side at $1,050 \mathrm{~m}$ elevation. The Sheep Canyon station is located on the west side at 1,215 m elevation. The Swift Creek station is located on the south side at an elevation of 1,350 m. Another site is located to the north at Spirit Lake at an elevation of 1,070 m. And the final two sites at Lone Pine (1,200 m elevation) and Spenser Meadow (1,035 m elevation) are about $25 \mathrm{~km}$ to the 
northeast and east. Sensors at each of these sites record precipitation, temperature, and snowpack data (USDA-NRCS, 2007). The standard site configuration includes a storage type precipitation gage and a sonic snow depth sensor (USDA-NRCS, 2009).

\section{Collection of Basin Attributes}

A variety of basin attribute data were collected for each drainage basin using ArcMap. Various digital data sets were used to measure attributes. The LiDAR based digital elevation map (DEM) was used most extensively (USGS, 2004). This list of vital basin attributes for the sixteen drainage basins on the southern slopes of Mount St. Helens is based on prior research into debris flows (Cannon et al, 2007) and the list compiled by Pirot (2010) and modified by Williams (2011). The first group of factors were used by both Pirot and Williams to analyze drainages. The factors and an explanation of how each was measured or calculated are listed below.

- Area of the Total Basin was calculated using ArcMap and a polygon data layer created to delineate each drainage basin. The boundary of each total basin was determined by following the topographic highs from the upper extent, which was usually the crater rim, and down along the ridge lines (Pirot, 2010). The lower boundary was determined by locating the confluence with another drainage basin either included in the study or outside the study area and closing the boundary just upstream of that convergence (Modified from Pirot, 2010). A 25 m contour line layer was created to assist with 
determining surface runoff flow lines. The area of each polygon was calculated in square meters.

- Height of the Total Basin was calculated using ArcMap and the LiDAR based digital elevation map (USGS, 2004). This factor was necessary to calculate Melton's Ruggedness Number and was found by subtracting the lowest elevation of the total basin from the highest elevation of the total basin (Williams, 2011).

- Elevation of the Initiation Zone was measured using ArcMap, the 2009 ortho imagery (USDA-FSA, 2009), and the LiDAR based digital elevation map (USGS, 2004). For drainage basins with a landslide initiation method, the upper edge of the scarp as seen on 2009 ortho imagery and measured using the DEM was chosen as the elevation (Pirot, 2010). For drainage basins with channel erosion type initiation methods, the highest evidence of channel erosion seen on 2009 ortho imagery was used as the elevation (Pirot, 2010). For drainages without a 2006 debris flow this factor was not measured. Field observations were also used as a guide when available. The elevation of each site was measured in meters.

- Area of the Upper Basin was calculated using ArcMap and a polygon data layer created to delineate the upper area of each drainage basin above the initiation zone. As with the total basin, the boundary of the upper basin follows the ridge lines down from the crater rim (Pirot, 2010). In this case, the lower boundary converges below the lowest extent of the initiation zone 
following the surface runoff flow lines down from the ridges (Pirot, 2010). This lower boundary is always within the transport zone and never within the depositional zone. For drainage basins without debris flows in 2006, the highest elevation of visible channel erosion was used an upper limit to the initiation zone and a natural constriction below that point chosen as the lower boundary of the upper basin (Modified from Pirot, 2010). The $25 \mathrm{~m}$ contour lines were also used here to assist with determining flow lines. The area of each polygon was calculated in square meters.

- WaDNR Geology of the Upper Basin was measured using ArcMap and the digital 1:100,000 scale geologic map of Washington State (WaDNR, 2010). The geologic map layer was clipped to the extent of each upper basin and the polygonal areas of the different geologic units summed. These sums were then divided by the total area of the upper basin to determine the percentage of each geologic unit in the upper basin (Williams, 2011).

- Measured Geology of the Upper Basin was found using ArcMap and the 2009 ortho imagery (USDA-FSA, 2009) to delineate the rough bedrock formations from ice and snowpack. The remaining areas were considered to be unconsolidated surficial deposits. This layer was then clipped to the extent of each upper basin and the polygonal areas of each type summed. These sums were then divided by the total area of the upper basin to determine the percentage of bedrock, ice and snowpack, and unconsolidated deposits in the upper basin. 
- Gradient of the Upper Basin was calculated by dividing the upper basin height by the upper basin length (Williams, 2011). This factor is dimensionless.

- Percent Vegetation in the Upper Basin was calculated using ArcMap and a polygon data layer created using the 2006 ortho imagery (USDA-FSA, 2006) delineating the zones with visible vegetation. Next, the vegetation layer was clipped to the extent of each upper basin. Finally, the vegetation polygon areas were summed and the sum divided by the total area of the upper basin to determine the percent vegetation (Williams, 2011).

- Percent Steep Slopes in the Upper Basin was calculated using the ArcMap Slope tool in the Spatial Analyst toolkit and the LiDAR based digital elevation map (USGS, 2004). Steep slopes are those with a gradient above 33 degrees (Williams, 2011). First, the Slope tool in ArcMap was used to produce an ArcGIS grid file with cells three meters square indicating slope steepness averaged over that nine square meter area. Then, all cells with gradients above 33 degrees were selected and counted. Finally, that number divided by the total number of cells in the upper basin gives the percent steep slopes.

- Melton's Ruggedness Number (MRN) for the Upper Basin was calculated as

$$
\text { Melton's Ruggedness Number }=\frac{H_{T}}{\sqrt{A_{T}}},
$$


where $H_{T}$ is the total basin height and $A_{T}$ is the total basin area (Melton, 1965). This attribute is dimensionless.

- Distance of Initiation Zone from Glacier was measured using Measure tool in ArcMap and the LiDAR based digital elevation map (USGS, 2004). The tool was used to measure between the upper extent of the initiation zone to the lowest extent of any glacier present in the drainage basin following existing stream channels (Modified from Pirot, 2010). If no glacier was present, then no data was indicated. The distance was measured in meters.

- Area of Glacier was calculated using ArcMap and a polygon data layer created by delineating the glacier and snowpack boundaries as observed from 2009 ortho imagery (USDA-FSA, 2009). Glaciers were differentiated from snow packs by a distinguishable crevasse or bergschrund observed on the surface. The area of each polygon was calculated in square meters.

- Direct Connection to Glacier was determined to exist if the initiation site was immediately downstream from a recognized glacier (Modified from Pirot, 2010). To be recognized, a glacier was required to display a crevasse or bergschrund in the 2009 ortho imagery (USDA-FSA, 2009). This factor was defined as either true or false.

The next group of factors include other basin attributes not used by Pirot (2010) or Williams (2011) that were measured or calculated for Mount St. Helens. Except for average annual precipitation, most were not used in the analysis phase. Some of these 
factors were found for comparative reasons, while others were found to complete the basin attribute database.

- Percent Change in Surface Area of Glacier was measured using ArcMap and a polygon data layer created by delineating the glacier and snowpack boundaries as observed from 2009 ortho imagery (USDA-FSA, 2009). Glaciers were differentiated from snow packs by a distinguishable crevasse or bergschrund observed on the surface. The polygonal areas of these 2009 glaciers were then compared to the polygonal areas of glaciers delineated from a digitized 1998 USGS topographic map (USGS, 2002). As thickness could not be measured, only area is compared and not volume. In drainage basins where the 2009 glacier did not present a crevasse or bergschrund, the largest remaining snowpack was used.

- Retreat Distance of Glacier was measured using ArcMap and a polygon data layer created to delineate the glacier and snowpack boundaries as observed from 2009 ortho imagery (USDA-FSA, 2009). Glaciers were differentiated from snow packs by a distinguishable crevasse or bergschrund observed on the surface. The distance in meters between the lower extent of the 2009 glacier was measured to the lower extent of the 1998 glacier along the channel path.

- Average Annual Precipitation was calculated using ArcMap and gridded 2006 average annual precipitation with $4 \mathrm{~km}$ resolution from the PRISM group (PRISM Climate Group, 2007). The gridded data was converted to contours 
of equal average annual precipitation using the ArcMap Contour tool in the Spatial Analysis toolkit. A contour interval of 50,000 hundredths of a millimeter was chosen for the most natural contour lines. Next, the contours were clipped to the extent of each upper basin boundary and the area above each contour measured. The average annual precipitation for each upper basin was then calculated as

$$
P=\frac{\left(\sum_{1}^{n} R_{n}+A_{n}\right)}{A_{T}},
$$

where $P$ is the average annual rainfall onto the upper basin, $R_{n}$ is the average annual precipitation at the $n$th contour line, $A_{n}$ is the area above the $n$th contour line in the upper basin, and $A_{T}$ is the total area of the upper basin (Williams, 2011).

- Melton's Ruggedness Number (MRN) for the Total Basin was calculated using Melton's Ruggedness Equation (Equation 2). This factor is dimensionless.

- WaDNR Geology of the Total Basin was calculated using ArcMap and the digital 1:100,000 scale geologic map of Washington State (WaDNR, 2010). The same procedure used to find the percentage of each geologic unit in the upper basin was used to find the percentage of each geologic unit in the total basin.

- Length of the Total Basin was calculated using the Measure tool in ArcMap and the LiDAR based digital elevation map (USGS, 2004). The distance in 
meters was measured from the highest to the lowest point in the basin following the path of the main drainage channel.

- Length of the Upper Basin was calculated using the Measure tool in ArcMap and the LiDAR based digital elevation map (USGS, 2004). The distance in meters was measured from the highest to the lowest point in the upper basin following the path of the main drainage channel (Williams, 2011).

- Gradient of the Total Basin was calculated by dividing the total basin height by the total basin length. This factor is dimensionless.

- Grain-Size Analysis percentages of gravel, sand, and fines were determined in the laboratory only for sampled drainages. Because of an incomplete data set, this factor could not be used in the analysis.

- Height of the Upper Basin was calculated using ArcMap and the LiDAR based digital elevation map (USGS, 2004). This factor was necessary to calculate Melton's Ruggedness Number and was found by subtracting the lowest elevation of the upper basin elevation from the highest elevation of the upper basin (Williams, 2011). The units are in meters.

- Highest Elevation of the Total Basin was measured using ArcMap and the LiDAR based digital elevation map (USGS, 2004). The DEM was clipped to the extent of the total basin and the highest value taken as the highest elevation in meters (Williams, 2011). 
- $\quad$ Highest Elevation of the Upper Basin was measured using ArcMap and the LiDAR based digital elevation map (USGS, 2004). The same procedure used to find the highest elevation in the total basin was used to find the highest elevation in the upper basin.

- Lowest Elevation of the Total Basin was measured using ArcMap and the LiDAR based digital elevation map (USGS, 2004). The DEM was clipped to the extent of the total basin and the lowest value taken as the lowest elevation in meters (Williams, 2011).

- Lowest Elevation of the Upper Basin was measured using ArcMap and the LiDAR based digital elevation map (USGS, 2004). The same procedure used to find the lowest elevation in the total basin was used to find the lowest elevation in the upper basin.

Of the sixteen drainage basin attributes compiled by Pirot (2010), not used here are the distance from glacier, glacier area, area above the initiation zone, and azimuth of upper basin. The glacier related features were not used in the analysis because only one glacier at June Lake was found to be directly associated with a 2006 debris flow. However, the effect of a glacier in a drainage basin will be analyzed in the Discussion section. The area above the initiation zone was not measured because it is roughly similar to the area of the upper basin, but is only valid for drainages that experienced a debris flow in 2006. And the azimuth of the upper basin, although geographically interesting, was not measured because it is related to both the average annual rainfall and the percent vegetation, which were included. 


\section{DATA ANALYSIS}

The statistical tests performed on these drainage basin attribute data included a one-way analysis of variance (ANOVA) between the two groups of drainage basins, and a multiple logistic regression used to construct a predictive model for debris flow occurrence on a Cascade volcano following the method used by Pirot (2010). The two groups of drainage basins are those that have evidence of a debris flow in 2006 and those that do not have evidence of a debris flow that year.

The one-way ANOVA test calculations were performed using the Analysis Toolkit in Excel 2007. The resulting ANOVA tables reveal which basin attributes have statistically different means between the groups. The groups are statistically different if the resulting $p$ value is less than the selected significance level of 0.05 (Davis, 2002). All basin attributes that were measured or calculated for each drainage basin were used in this analysis. Drainage attributes with incomplete data include the particle size analysis, area glacier in the upper basin, stream distance from glacier, glacier area lost, and percent glacier area lost. A one-way ANOVA test was also separately performed on the particle-size analysis results.

The logistic regression statistical test is used to develop a simple model to predict the outcome of individual cases using all predictor variables possibly related to the outcome (Agresti, 1996). The outcome or dependent variable is dichotomous with a value between 0 and 1 with an associated probability (Agresti, 1996). The predictor or independent variables can take any form, and are not required to be normally

distributed, linearly related, or of equal variance within each group (Agresti, 1996). The 
predictive model equation defines the relationship between predictor and outcome variables and is not a linear function, but a logit transformation

$$
Y=\frac{e^{\left(\alpha+\beta_{1} X_{1}+\beta_{2} X_{2}+\cdots+\beta_{n} X_{n}\right)}}{1+e^{\left(\alpha+\beta_{1} X_{1}+\beta_{2} X_{2}+\cdots+\beta_{n} X_{n}\right)}},
$$

where $Y$ is the outcome and variables $X_{i}$ are attribute variables with coefficients $B$ (Pirot, 2010; Agresti, 1996). The coefficients express the relative contributions of the individual variables to the outcome. In the Pirot (2010) model, the outcome, $Y$, is the occurrence of a debris flow in a drainage basin. The selected predictor variables, $X_{i}$, to be used in the method must be correlated across all drainage basins and not be represented within another attribute variable (Pirot, 2010). Once predictor variables are selected the different natural scales of the data must be normalized to allow comparison

$$
Z_{i}=\frac{x_{i}-x}{S}
$$

where $Z_{i}$ is the normalized value, $x_{i}$ is the natural value, $S$ is the standard deviation for the group of variables, and $x$ is the mean for the group of variables (Davis, 2002).

The logistic regression uses the Analysis Toolkit in Excel 2007 to calculate the coefficients. The first fit uses the full set of predictor variables (Davis, 2002; Pirot, 2010). Each calculated regression coefficient is then tested for goodness of fit using a squared z-statistic or Wald value

$$
W=z^{2}=\left(\frac{\beta}{S E_{\beta}}\right)^{2}
$$


where $W$ is the chi-square distribution or Wald value, $b$ is the value of a regression coefficient, and $S E_{6}$ is the standard error for the regression coefficient (Davis, 2002; Pirot, 2010). The results of the Wald test rank the regression coefficients by significance. Using backward stepwise elimination, the variable corresponding to the coefficient with the lowest Wald value is removed to produce a more refined model (Pirot, 2010; Agresti, 1996). The backward elimination of the least significant variables continues until the two most significant regression coefficients have been determined (Pirot, 2010; Agresti, 1996).

Once the logistic regression is completed the remaining most significant attribute variables and regression coefficients are written into the probability model equation (Equation 4). To verify the prediction accuracy of the probability model equation, the normalized values for the most significant variables are inserted into the equation and solved for each drainage basin. The resultant values of $Y$ range between 0 and 1 , with values closer to 1 indicating a higher probability of debris flow occurrence in that drainage basin (Hosmer and Lemshow, 1989). Values of $Y$ above 0.50 indicate a prediction of a debris flow in that drainage, while values below 0.50 indicate the prediction of no debris flow in that drainage (Pirot, 2010; Hosmer and Lemshow, 1989). Comparing the occurrence of predicted debris flows against actual debris flows will give an estimate of the accuracy of the model. 


\section{CHAPTER 4 - RESULTS}

\section{INTRODUCTION}

Using the methods described, sixteen drainage basins were defined for the slopes of Mount St. Helens outside the 1980 debris avalanche zone (Figure 15). Of the total drainage basins, eight experienced debris flows attributed to the November 2006 storm. There is a time-gap of three years between the 2006 event and the initiation of this research project in 2009. There is also a gap in resources as the most recent

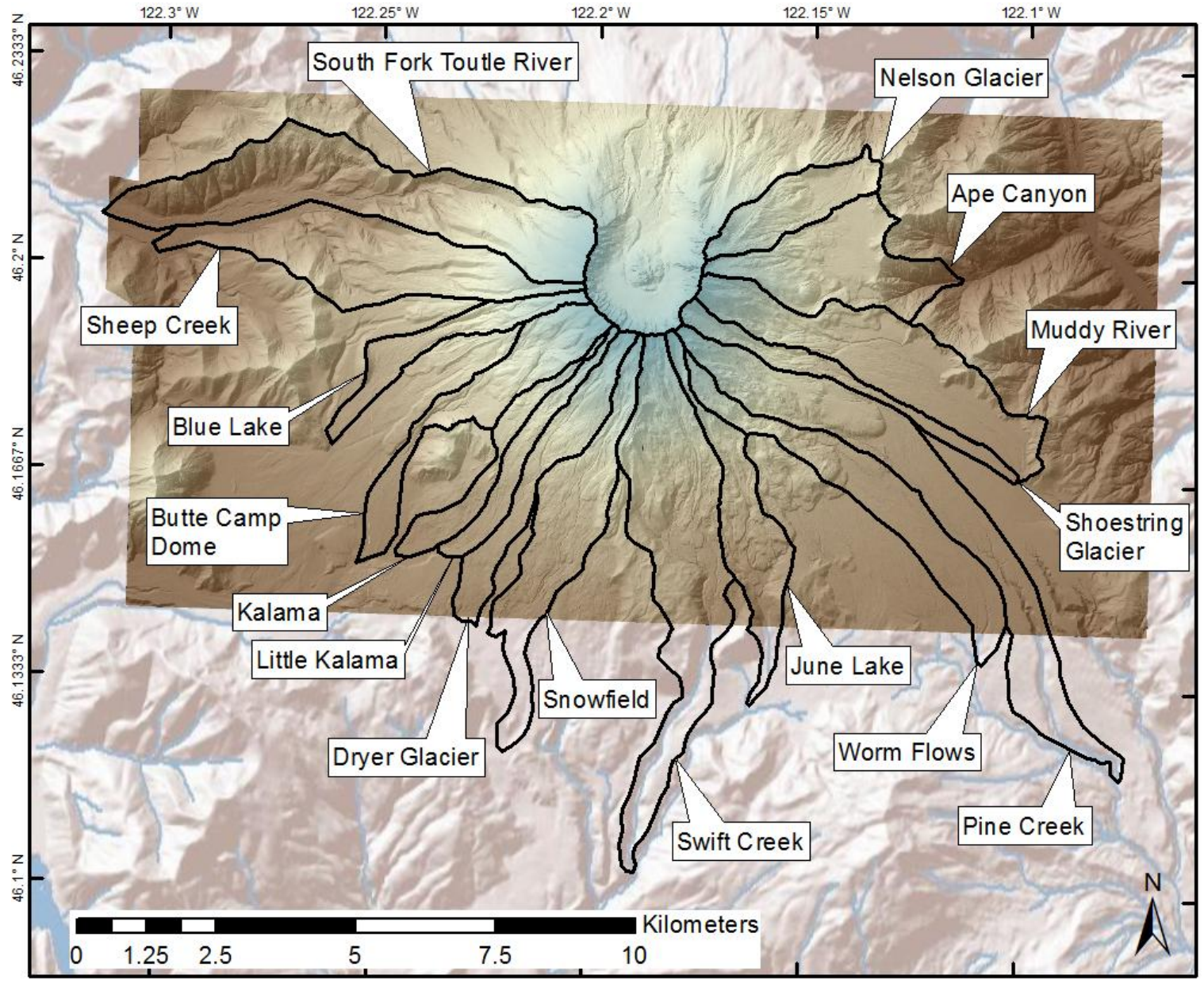

Figure 15: Drainage basin map showing boundaries defined for each major stream basin on Mount St. Helens south of the 1980 debris avalanche zone. High resolution area is the extent of LiDAR coverage on the southern slopes (USGS, 2004) 
remote-sensing data were orthophotographs taken during the summer of 2009 (USDAFSA, 2009). Of the eight drainages, all have supporting evidence that debris flows occurred in 2006. Also, there were no similar major rainfall events in the Mount St. Helens area or reports of damage to roads or trails during the intervening period.

The following sections will describe each drainage basin in detail starting with Nelson Glacier in the northeast and progressing clockwise around the mountain (Figure 15). Information provided for each will include basin description, location, basin attributes, sample description, description of debris flow initiation type and location (if any), and any details of historical debris flow evidence. Further details on field observations and sampling locations are provided in Appendix A. These types of data were also collected for Mt. Adams (Williams, 2011) and Mt. Hood (Pirot, 2010).

\section{NELSON GLACIER DRAINAGE BASIN}

\section{Introduction}

The Nelson Glacier Drainage Basin is located in the northeastern quadrant of Mount St. Helens between Ape Canyon drainage to the south and the 1980 debris avalanche zone to the north separated by Windy Ridge (Figure 15, Figure 16). The upper basin hosts the Nelson Glacier and drains through multiple channels to the northern end of a plateau known as the Plains of Abraham (Figure 17). Water from this drainage empties into Smith Creek, which merges with Muddy River above the Swift Reservoir. There are three large channels that drain the upper basin. The northern-most is oriented in a northeastern direction and empties onto the Plain close to Windy Pass. 


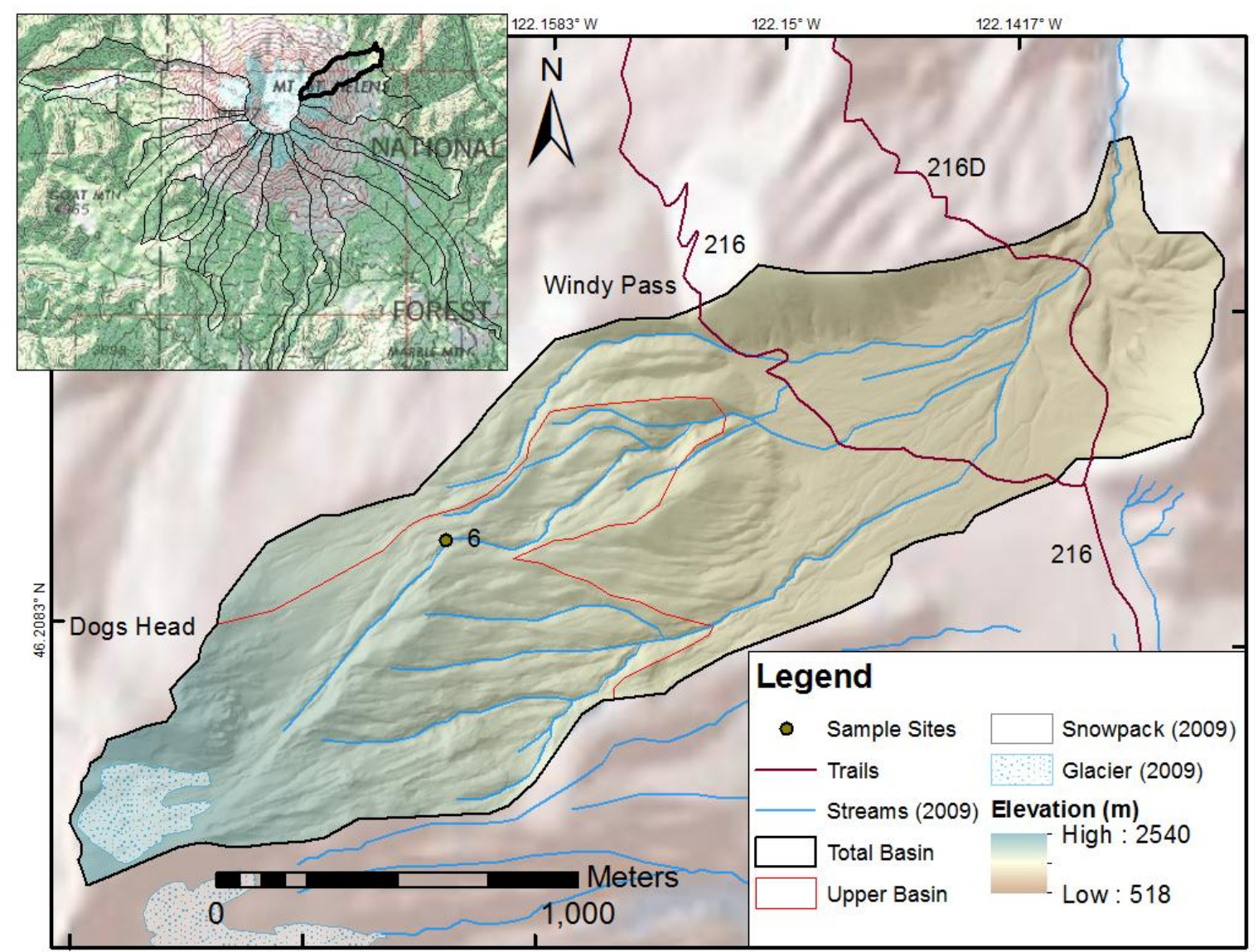

Figure 16: Map of Nelson Glacier Drainage located in the northeastern quadrant of Mount St. Helens between Ape Canyon drainage and the 1980 debris avalanche zone. The upper basin includes a portion of Dogs Head, and the lower basin includes the northern portion of the Plains of Abraham. This drainage had no debris flow in 2006. Trails shown include the Loowit Trail (216) and 216D.

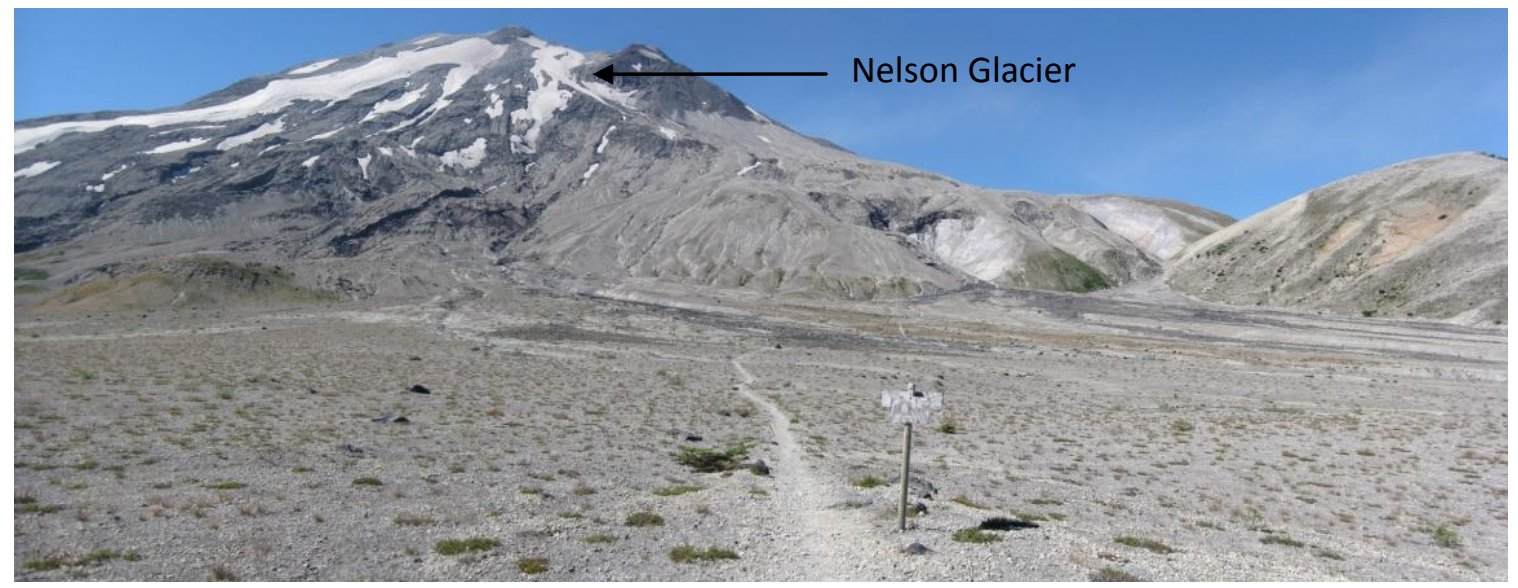

Figure 17: Photographic mosaic of the upper and a portion of the total Nelson Glacier Drainage from the junction of trails 216 and 216D on the Plains of Abraham. View is to the west. Nelson Glacier wraps around the southern (left) side of Dogs Head. 
The eastern bank of this channel forms a rocky barrier of exposed bedrock (Figure 18)

that is breached at the upper end and in at least three locations before passing around a bulge of unconsolidated deposits and also emptying onto the Plain. At each breach a minor to major channel is incised on the southern portion of the upper basin. These channels empty onto the Plains of Abraham south of the unconsolidated dome. The debris apron on the Plains of Abraham shows evidence of past debris flows exposed in channels that have eroded through a layer of 1980s pumice and ash that locally exceeds depths of one meter (Figure 19).

\section{Determination of Initiation Zone}

There was some evidence of debris flow levee deposits on the sides of one channel in the upper basin and channel wall erosion (Figure 18). However, comparison

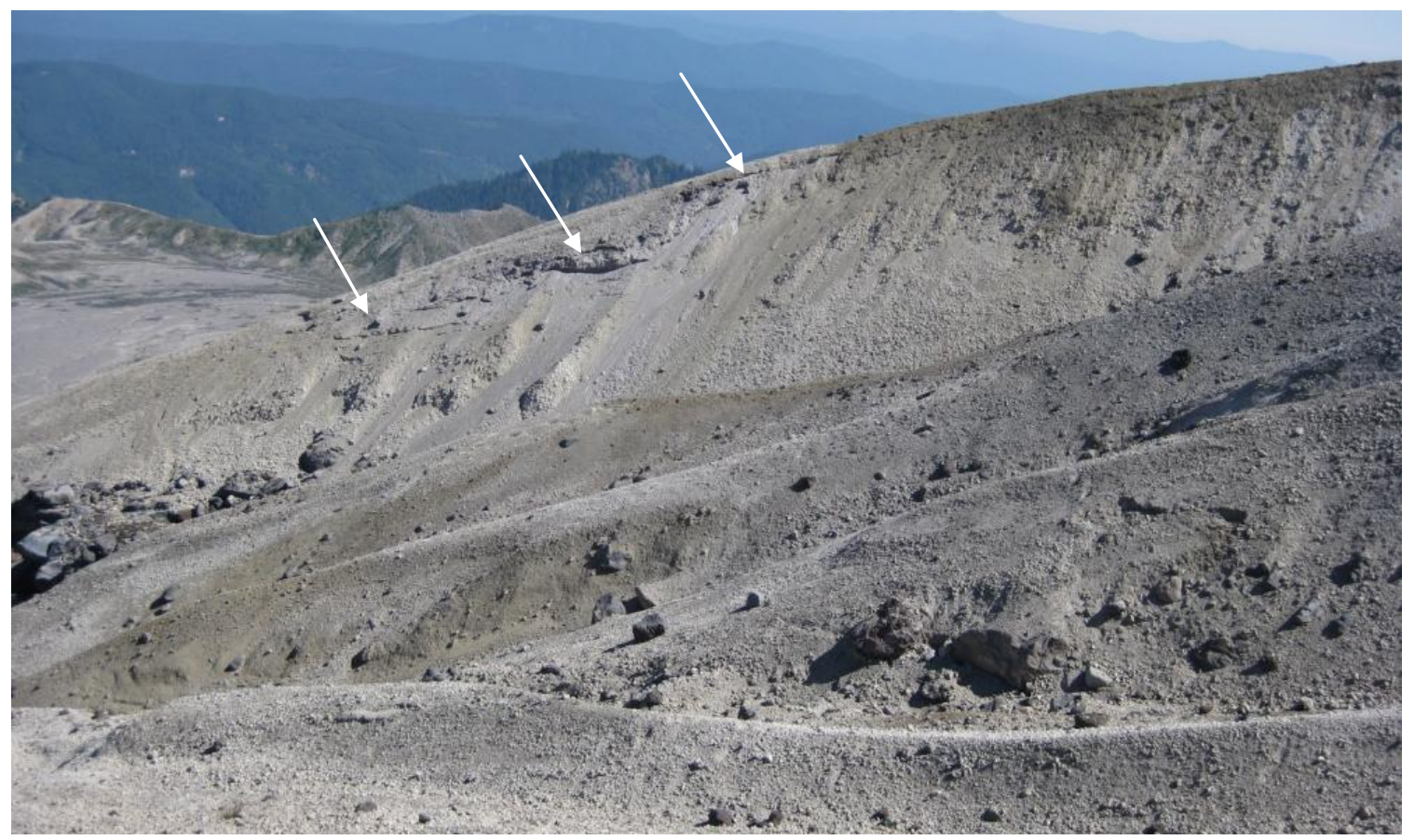

Figure 18: A view of the upper portion of the bedrock barrier ridge running in a northeast orientation dividing the northern-most ravine of Nelson Glacier Basin from those to the south. On this portion are visible erosional scars (arrows). View is to the southeast. 


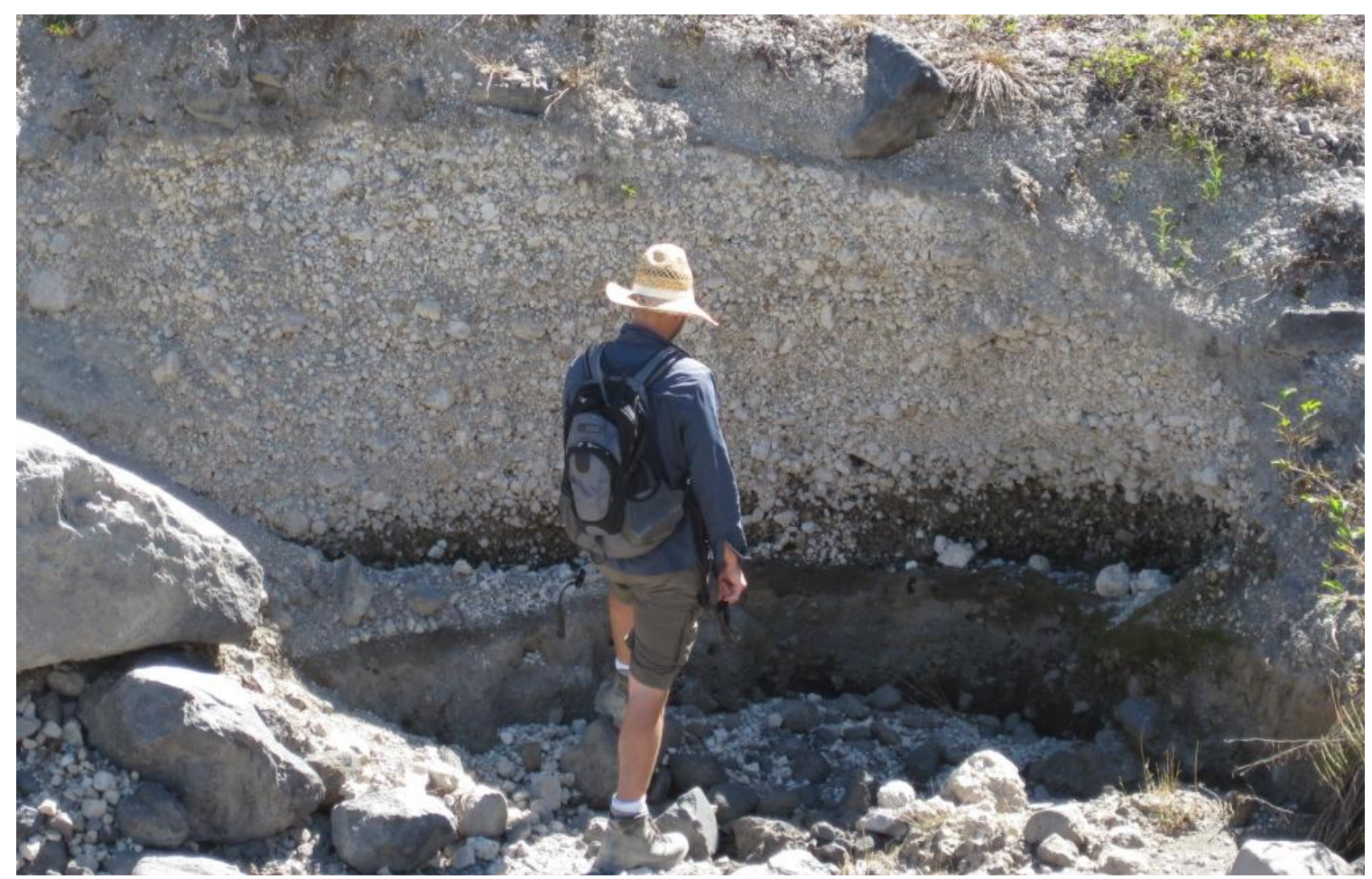

Figure 19: Outcrop revealing over one meter of 1980 pumice in a fluvial channel near the lowest portion of the Nelson Glacier Basin. Original surface is visible below the pumice layer.

of 2006 and 2009 ortho imagery did not reveal evidence of a recent debris flow initiation site or depositional fan. Therefore, because of the snow cover and lack of a distinguishable deposit at the debris fan, it was determined that this drainage did not have a debris flow in 2006.

\section{Data Processing}

\section{$\underline{\text { Sieve Results }}$}

Soil samples from the Nelson Glacier Drainage Basin are shown in Table 1 along with average values and standard deviation. The average bulk density was measured at $1.9 \mathrm{~g} / \mathrm{cm}^{3}$, and the average sample consisted of $36 \%$ gravel, $57 \%$ sand, and $8 \%$ silt and clay. 
Table 1: Sieve analysis for the soil sample taken in the Nelson Glacier Drainage. The sample is over half coarse to medium sized sand.

\begin{tabular}{|c|c|c|c|c|c|c|c|}
\hline \multirow[t]{2}{*}{ Sample \# } & \multirow{2}{*}{$\begin{array}{c}\text { Bulk } \\
\text { Density } \\
\left(\mathrm{g} / \mathrm{cm}^{3}\right)\end{array}$} & \multirow{2}{*}{$\begin{array}{c}\text { Gravel } \\
(>2.0 \\
\mathrm{mm})\end{array}$} & \multirow{2}{*}{$\begin{array}{l}\text { Sand } \\
(2.0 \text { to } \\
0.063 \\
\mathrm{~mm})\end{array}$} & \multirow{2}{*}{$\begin{array}{c}\text { Silt \& Clay } \\
(<0.063 \\
\mathrm{mm})\end{array}$} & \multicolumn{3}{|c|}{ Sand } \\
\hline & & & & & $\begin{array}{c}\text { Coarse } \\
(2.0 \text { to } \\
0.42 \\
\mathrm{~mm})\end{array}$ & $\begin{array}{c}\text { Medium } \\
\text { (0.42 to } \\
0.149 \\
\mathrm{~mm})\end{array}$ & $\begin{array}{c}\text { Fine } \\
\text { (0.149 to } \\
0.063 \\
\mathrm{~mm})\end{array}$ \\
\hline 6.1 & 1.6 & $35.5 \%$ & $57.2 \%$ & $7.4 \%$ & $32.3 \%$ & $38.8 \%$ & $29.0 \%$ \\
\hline 6.2 & 1.7 & $35.1 \%$ & $56.3 \%$ & $8.9 \%$ & $26.7 \%$ & $40.0 \%$ & $33.3 \%$ \\
\hline 6.3 & 2.3 & $37.2 \%$ & $56.3 \%$ & $6.4 \%$ & $43.7 \%$ & $32.3 \%$ & $24.0 \%$ \\
\hline Average & 1.9 & $35.9 \%$ & $56.6 \%$ & $7.6 \%$ & $34.2 \%$ & $37.0 \%$ & $28.8 \%$ \\
\hline Std. Dev. & 0.35 & $1.1 \%$ & $0.6 \%$ & $1.3 \%$ & $8.7 \%$ & $4.1 \%$ & $4.6 \%$ \\
\hline
\end{tabular}

\section{Basin Attributes}

There was no initiation zone found in the Nelson Glacier Drainage for a 2006 debris flow, so no data were recorded related to debris flows. A full summary of the basin attributes is listed in Table 2. In summary, the geologic units of the upper basin are $67 \%$ unconsolidated (volcaniclastics, alluvium, and colluvium), 18\% bedrock (volcanics, andesite, and basalt), and 15\% ice according to the geologic map (WaDNR, 2010). The measured extents of the upper basin geology are $6 \%$ snowpack and ice, $27 \%$ consolidated bedrock exposures, and 68\% unconsolidated deposits.

As of 2009 , the Nelson Glacier covered an area of $62,565 \mathrm{~m}^{2}$, or $6 \%$, of the upper basin (USDA-FSA, 2009). The glacier decreased in surface area between 1998 and 2009 by $58 \%$, and retreated upslope by 330 m (USGS, 2002; USDA-FSA, 2009). 
Table 2: Nelson Glacier Drainage Basin attributes.

\begin{tabular}{|c|c|c|c|c|}
\hline \multirow{2}{*}{$\begin{array}{l}\text { Basin Attributes } \\
\text { Total Basin }\end{array}$} & & \multirow[t]{2}{*}{ Geologic Units * } & \multicolumn{2}{|c|}{$\%$ Basin } \\
\hline & & & Total & Upper \\
\hline Area $\left(m^{2}\right)$ & $2,597,740$ & $\underline{\text { Water }}$ & & \\
\hline Comparative size rank & $12^{\text {th }}$ & ice & 6.5 & 15.3 \\
\hline Highest elevation (m) & 2,426 & $\underline{\text { Volcanics }}$ & & \\
\hline Lowest elevation (m) & 1,173 & Qv(sh) & 1.2 & 3.0 \\
\hline Height (m) & 1,254 & Andesite & & \\
\hline Length (m) & 3,874 & MOian & & \\
\hline Gradient & 0.32 & MOva(2) & 8.3 & \\
\hline \multirow[t]{2}{*}{ MRN } & 0.78 & Qiad(1) & & \\
\hline & & Qiad(2) & & \\
\hline Upper Basin & & QPLiad(g) & & \\
\hline Area $\left(m^{2}\right)$ & $1,100,060$ & Qva(1sh) & & \\
\hline Comparative size rank & $8^{\text {th }}$ & Qva(2sh) & 8.2 & 15.3 \\
\hline Highest elevation (m) & 2,426 & Basalt & & \\
\hline Lowest elevation (m) & 1,428 & Qvb(2sh) & & \\
\hline Height (m) & 998 & $\underline{\text { Volcaniclastics }}$ & & \\
\hline Length $(\mathrm{m})$ & 1,922 & MOvc(2) & 9.2 & \\
\hline Gradient & 0.52 & OEvc & & \\
\hline MRN & 0.95 & Qvc(1sh) & & \\
\hline Percent vegetation (\%) & 0.0 & Qvc(2sh) & 1.0 & 2.4 \\
\hline Percent steep slope (\%) & 32 & Qvc(sh) & & \\
\hline \multirow[t]{2}{*}{ Avg. annual precip. (m) } & 3.5 & Qvp(3sh) & 43.2 & 62.1 \\
\hline & & Ovt(1) & & \\
\hline Glacier & & Alluvium & & \\
\hline Area $\left(\mathrm{m}^{2}\right)$ & 62,565 & Qa & & \\
\hline Retreat distance $(\mathrm{m})$ & 330 & Qgu & & \\
\hline \multirow[t]{2}{*}{ Percent change in area (\%) } & -58 & Colluvium & & \\
\hline & & Qvl(3sh) & 22.5 & 2.0 \\
\hline \multicolumn{5}{|l|}{ Initiation } \\
\hline Elevation (m) & - & Summary & & \\
\hline Direct connection to glacier & - & Ice & 6.5 & 15.3 \\
\hline Distance from glacier $(\mathrm{m})$ & - & Bedrock & 17.8 & 18.3 \\
\hline \multirow[t]{5}{*}{ Type } & - & Unconsolidated & 75.8 & 66.6 \\
\hline & & Measured Extents ** & & \\
\hline & & Snowpack and Ice & & 5.7 \\
\hline & & Consolidated Bedrock & & 26.6 \\
\hline & & Unconsolidated & & 67.7 \\
\hline
\end{tabular}

* data from WaDNR, 2010.

** data from measured extents on 2009 ortho imagery (USDA-FSA, 2009). 


\section{APE CANYON DRAINAGE BASIN}

\section{Introduction}

The Ape Canyon Drainage Basin is located in the eastern quadrant of Mount St. Helens between Nelson Glacier to the north and Muddy River to the south (Figure 15, Figure 20). The upper basin contains the Ape Glacier from which melt water streams flow north of East Dome in three major channels which empty onto a debris fan on the Plains of Abraham (Figure 21). This fan is separated from that of Nelson Glacier by a rise and drains through two passes into Ape Canyon, which converges with Smith Creek before finally merging with Muddy River above the Swift Reservoir. The northern pass drops into Ape Canyon from an elevation of 1,313 m on the Plains of Abraham just north of Pumice Butte. The main branch of the drainage drops to a lower plain at the southern end of the Plains of Abraham and then passes through a narrow breach south of Pumice Butte. This channel drops down to Smith Creek via Ape Canyon, a vertical change in elevation of $685 \mathrm{~m}$ over about $4 \mathrm{~km}$.

In the upper basin, three channels emerge at the base of the glacier around $1,975 \mathrm{~m}$ and merge together at elevations of $1,700 \mathrm{~m}$ for the northern branch and 1,500 $m$ for the southern branch. The northern branch may switch channels at 1,700 m (UTM $10 N$ 564953E 5116976N) into two lower channels that empty into the central Plains of Abraham. The current bed of the northern channel is difficult to distinguish, even on 5 $m$ resolution LiDAR (USGS, 2004). This combined channel then passes through a large ravine and empties into a maze of channels on the Plains of Abraham (Figure 22). Many 


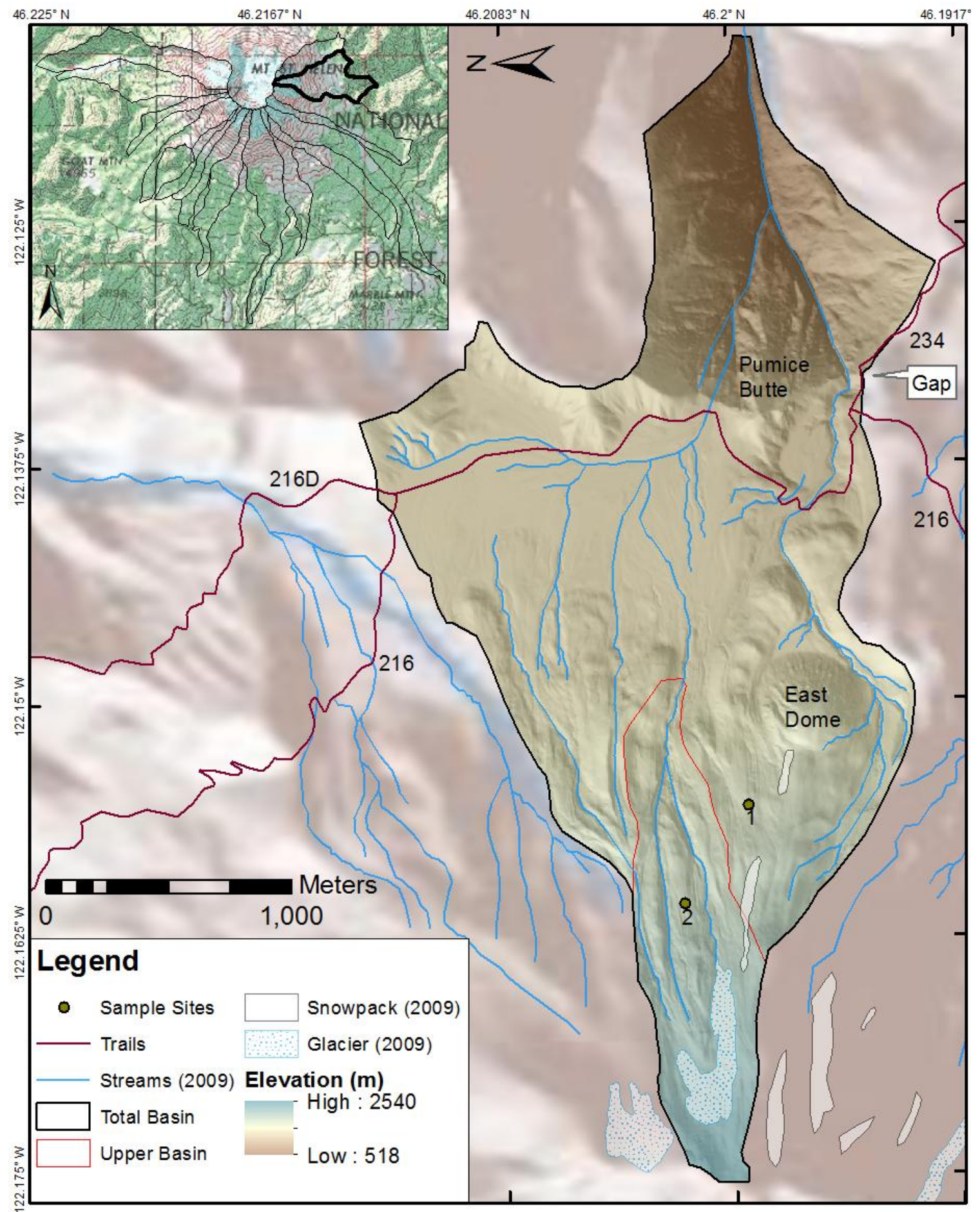

Figure 20: Map of Ape Canyon Drainage located in the eastern quadrant of Mount St. Helens between the Nelson Glacier and Muddy River drainages. The upper basin includes the Ape Glacier, and the lower basin includes the southern portion of the Plains of Abraham. This drainage had no debris flow in 2006. North is to the left. 


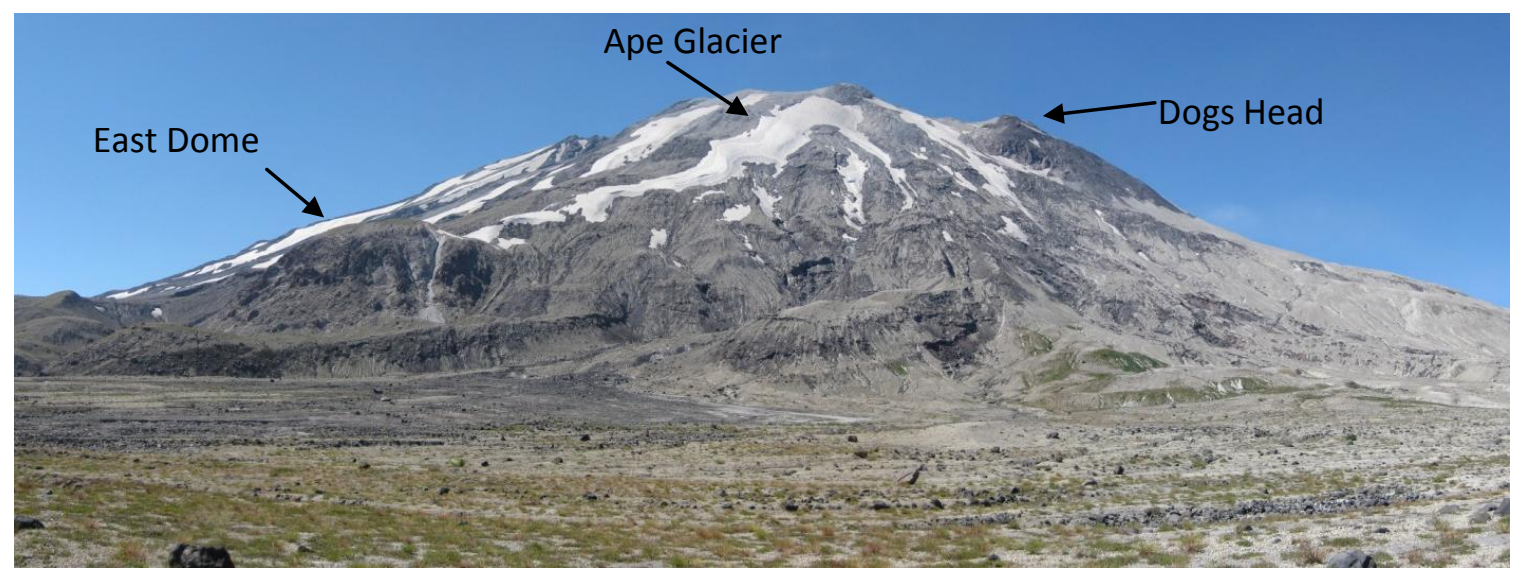

Figure 21: Photographic mosaic of the Ape Canyon Basin from Trail 216 in the central Plains of Abraham. View is westward. The Ape Glacier is visible in the center of the peak with the left branch extending down to East Dome. To the right of Ape Glacier is an oblique view of Nelson Glacier and Dog's Head. The vertical gray line on East Dome is probably a zone of recent rock fall.

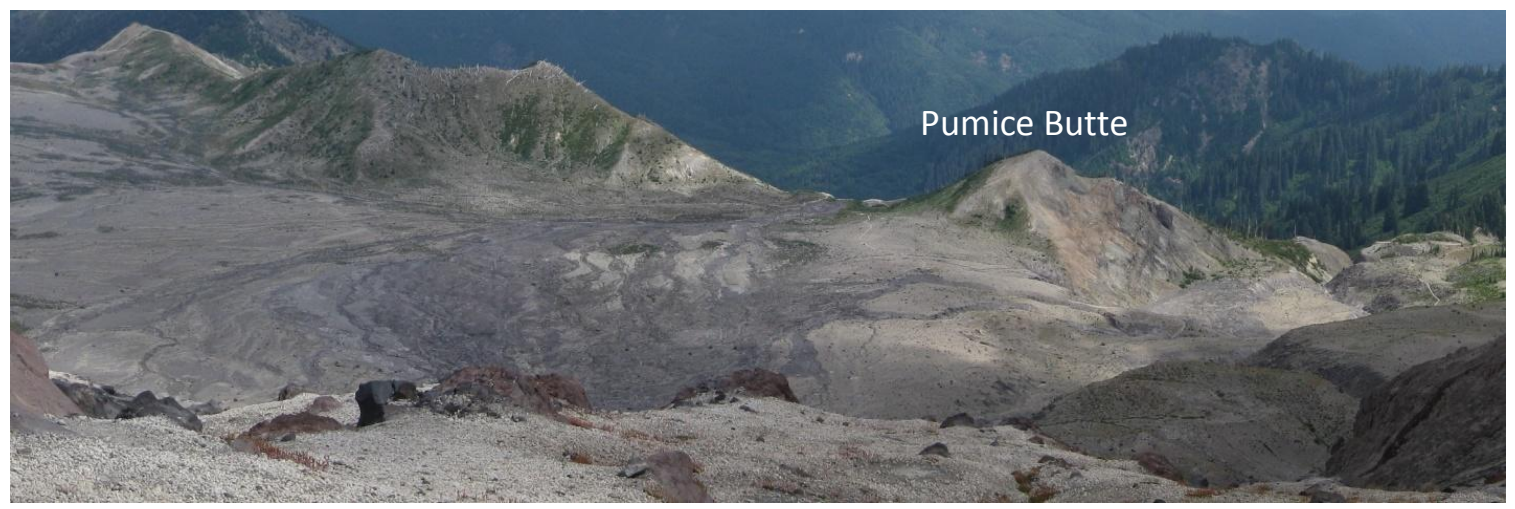

Figure 22: Photographic mosaic of the Ape Canyon Basin on the Plains of Abraham. The lower plains and breach are visible on the right. Pumice Butte is the peak right of center. The maze of channels crossing the Plains merge at the gap north of Pumice Butte, but a few channels can be seen to turn south toward the lower plain. View to the east from about 1,750 m on Mount St. Helens.

of these minor channels merge to pass north of Pumice Butte, but others merge to pass south through the narrow breach into lower Ape Canyon.

Like that of Nelson Glacier, the debris fan for Ape Canyon shows evidence of past debris flows exposed in channels eroded through layers of 1980s pumice and ash. Thick layers were observed from a distance near the base of the mountain slopes, but a thin pumice cover was observed near the trail (Figure 23). 


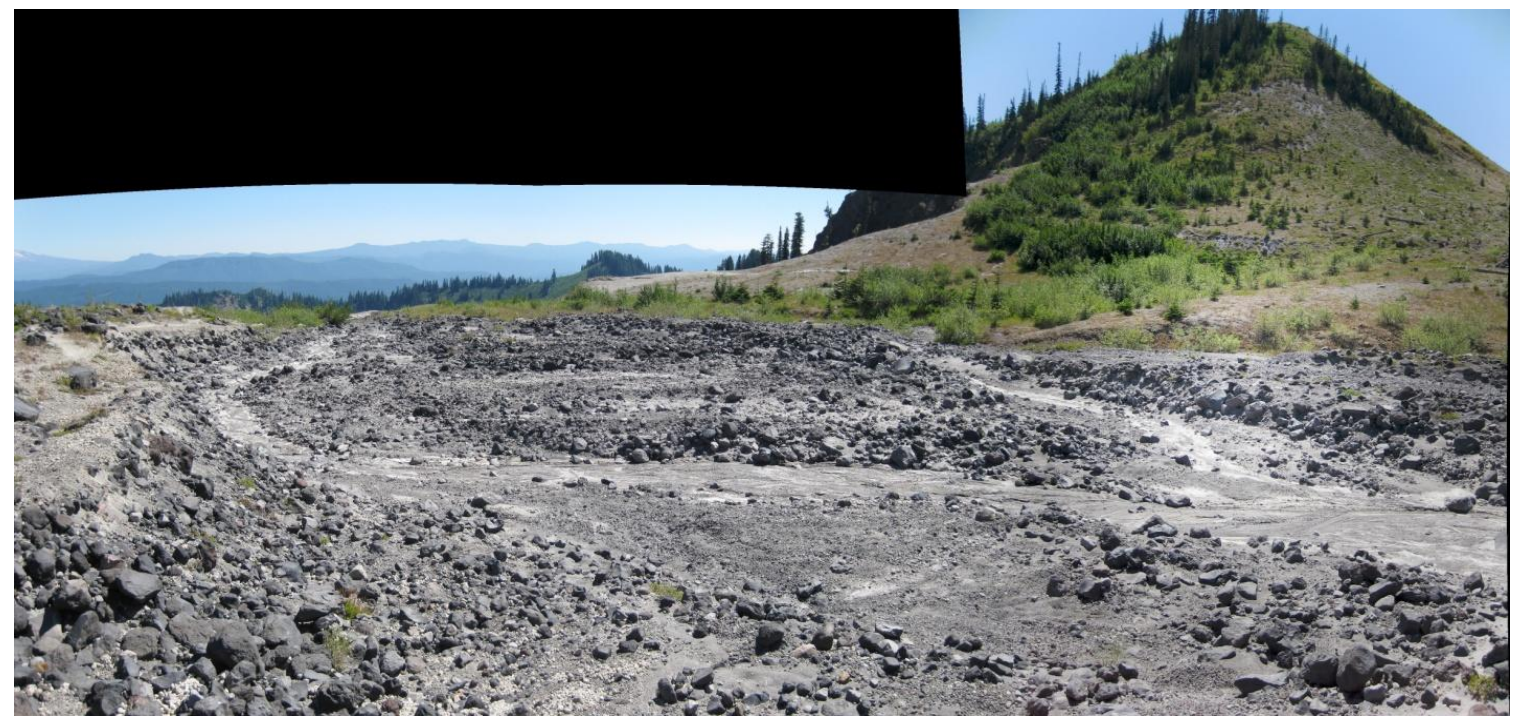

Figure 23: Photographic mosaic from the Plains of Abraham just north of Pumice Butte at the spillover into the lower Ape Canyon. Cobble-sized debris and vegetation are visible in the foreground, as well as fluvial reworking of the debris in the channel, and possible levees along the far channel bank. The channel at this point is about 20-30 m wide. View to the southwest.

Also included within the Ape Canyon Basin is a smaller drainage to the south of East Dome that empties an area above the dome to an elevation of about 1,900 m.

These channels pass to the south of the dome and eventually join with others that pass through the narrow breach into lower Ape Canyon (Figure 24). There is some evidence of past debris flow activity in the main channel which is filled with large boulders and debris.

\section{Determination of Initiation Zone}

Although there is evidence of past debris flow deposits on the Plains of Abraham, on the lower plain, and in the channel that cross the Plain, there is a lack of damage to trails or fresh evidence of levee and fan deposits. Also, comparison of 2006 and 2009 ortho imagery did not reveal evidence of a recent debris flow initiation site or 


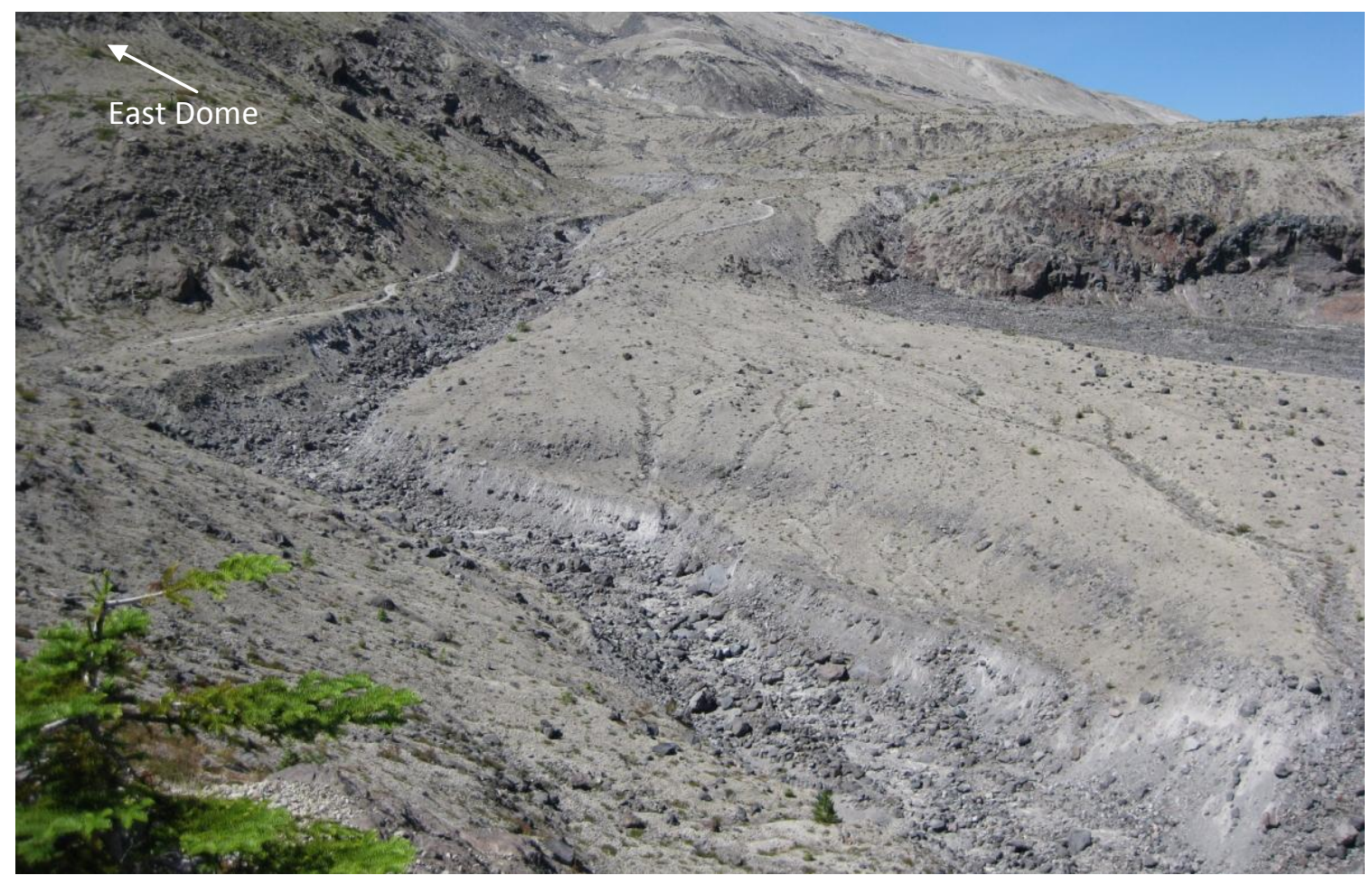

Figure 24: View of the lower plain at the south end of the Plains of Abraham. The main channel (visible) is connected to the minor drainage that passes south of East Dome. Other channels to the right of this view are connected to Ape Glacier. View to the northwest.

depositional fan. Therefore, it was determined that this drainage did not have a debris flow in 2006.

Data Processing

\section{Sieve Results}

Sieve results of the soil samples from the Ape Canyon Drainage Basin are shown in Table 3 along with average values and standard deviation. Total and site average values are also shown. The average bulk density was measured at $1.6 \mathrm{~g} / \mathrm{cm}^{3}$, and the average sample consisted of $37 \%$ gravel, $44 \%$ sand, and $9 \%$ silt and clay. 
Table 3: Sieve analysis for the soil samples taken in the Ape Canyon drainage. The sample is almost half gavel and half sand of equally coarse, medium and fine grains.

\begin{tabular}{|c|c|c|c|c|c|c|c|}
\hline \multirow[t]{2}{*}{ Sample \# } & \multirow{2}{*}{$\begin{array}{l}\text { Bulk } \\
\text { Density } \\
\left(\mathrm{g} / \mathrm{cm}^{3}\right)\end{array}$} & \multirow{2}{*}{$\begin{array}{c}\text { Gravel } \\
(>2.0 \\
\mathrm{mm})\end{array}$} & \multirow{2}{*}{$\begin{array}{c}\text { Sand } \\
(2.0 \text { to } \\
0.063 \\
\mathrm{~mm})\end{array}$} & \multirow{2}{*}{$\begin{array}{c}\text { Silt \& Clay } \\
\text { (<0.063 } \\
\text { mm })\end{array}$} & \multicolumn{3}{|c|}{ Sand } \\
\hline & & & & & $\begin{array}{c}\text { Coarse } \\
(2.0 \text { to } \\
0.42 \\
\mathrm{~mm})\end{array}$ & $\begin{array}{c}\text { Medium } \\
\text { (0.42 to } \\
0.149 \\
\mathrm{~mm})\end{array}$ & $\begin{array}{c}\text { Fine } \\
(0.149 \text { to } \\
0.063 \\
\mathrm{~mm})\end{array}$ \\
\hline 1.1 & 1.5 & $38.5 \%$ & $52.4 \%$ & $8.8 \%$ & $29.1 \%$ & $37.0 \%$ & $33.9 \%$ \\
\hline 1.2 & 1.7 & $5.9 \%$ & $78.9 \%$ & $15.0 \%$ & $22.7 \%$ & $39.2 \%$ & $38.1 \%$ \\
\hline 1.3 & 2.0 & $37.9 \%$ & $54.8 \%$ & $7.0 \%$ & $29.8 \%$ & $38.9 \%$ & $31.3 \%$ \\
\hline Site Avg. & 1.5 & $27.5 \%$ & $62.0 \%$ & $10.2 \%$ & $27.2 \%$ & $38.4 \%$ & $34.4 \%$ \\
\hline 2.1 & 2.0 & $30.0 \%$ & $61.6 \%$ & $8.0 \%$ & $29.9 \%$ & $33.4 \%$ & $36.7 \%$ \\
\hline 2.2 & 1.3 & $64.4 \%$ & $31.2 \%$ & $5.1 \%$ & $27.2 \%$ & $38.8 \%$ & $34.0 \%$ \\
\hline 2.3 & 1.9 & $45.1 \%$ & $40.4 \%$ & $13.9 \%$ & $32.4 \%$ & $27.6 \%$ & $40.0 \%$ \\
\hline Site Avg. & 1.7 & $46.5 \%$ & $44.4 \%$ & $9.0 \%$ & $29.8 \%$ & $33.3 \%$ & $36.9 \%$ \\
\hline Average & 1.6 & $37.0 \%$ & $53.2 \%$ & $9.6 \%$ & $28.5 \%$ & $35.8 \%$ & $35.7 \%$ \\
\hline Std. Dev. & 0.30 & $19.2 \%$ & $16.6 \%$ & $3.9 \%$ & $3.3 \%$ & $4.6 \%$ & $3.2 \%$ \\
\hline
\end{tabular}

\section{$\underline{\text { Basin Attributes }}$}

There was no initiation zone found in the Ape Canyon Drainage for a 2006 debris flow, therefore no data related to debris flows were recorded. A full summary of the basin attributes is listed in Table 4. In summary, the geologic units of the upper basin were mapped as $48 \%$ bedrock (volcanics, andesite, and basalt), $14 \%$ unconsolidated (volcaniclastics, alluvium, and colluvium), and 39\% ice according to the geologic map (WaDNR, 2010). The measured extents of the upper basin geology are $22 \%$ consolidated bedrock exposures, $67 \%$ unconsolidated deposits, and $12 \%$ snowpack and ice.

As measured on the 2009 orthophotographs, the Ape Glacier covered an area of $77,660 \mathrm{~m}^{2}$, or $11 \%$, of the upper basin (USDA-FSA, 2009). Between 1998 and 2009 the 
Table 4: Ape Canyon Drainage Basin attributes.

\begin{tabular}{|c|c|c|c|c|}
\hline \multirow{2}{*}{$\begin{array}{l}\text { Basin Attributes } \\
\text { Total Basin }\end{array}$} & & \multirow[t]{2}{*}{ Geologic Units* } & \multicolumn{2}{|c|}{$\%$ Basin } \\
\hline & & & Total & Upper \\
\hline Area $\left(m^{2}\right)$ & $4,973,660$ & Water & & \\
\hline Comparative size rank & $7^{\text {th }}$ & ice & 6.2 & 38.7 \\
\hline Highest elevation (m) & 2,471 & $\underline{\text { Volcanics }}$ & & \\
\hline Lowest elevation (m) & 705 & Qv(sh) & 0.1 & 0.9 \\
\hline Height (m) & 1,766 & $\underline{\text { Andesite }}$ & & \\
\hline Length $(\mathrm{m})$ & 4,981 & MOian & & \\
\hline Gradient & 0.35 & MOva(2) & 27.0 & \\
\hline \multirow[t]{2}{*}{ MRN } & 0.79 & Qiad(1) & & \\
\hline & & Qiad(2) & 2.4 & \\
\hline$\underline{\text { Upper Basin }}$ & & QPLiad(g) & & \\
\hline Area $\left(m^{2}\right)$ & 712,614 & Qva(1sh) & & \\
\hline Comparative size rank & $12^{\text {th }}$ & Qva(2sh) & 31.7 & 46.7 \\
\hline Highest elevation (m) & 2,471 & Basalt & & \\
\hline Lowest elevation (m) & 1,422 & Qvb(2sh) & & \\
\hline Height (m) & 1,049 & $\underline{\text { Volcaniclastics }}$ & & \\
\hline Length $(\mathrm{m})$ & 2,089 & $\operatorname{MOvc}(2)$ & 0.6 & \\
\hline Gradient & 0.50 & OEvc & & \\
\hline MRN & 1.24 & Qvc(1sh) & & \\
\hline Percent vegetation (\%) & 0.0 & Qvc(2sh) & 1.7 & 11.9 \\
\hline Percent steep slope (\%) & 39 & Qvc(sh) & & \\
\hline \multirow[t]{2}{*}{ Avg. annual precip. (m) } & 3.5 & Qvp(3sh) & & \\
\hline & & Ovt(1) & & \\
\hline Glacier & & $\underline{\text { Alluvium }}$ & & \\
\hline Area $\left(m^{2}\right)$ & 77,661 & Qa & & \\
\hline Retreat distance (m) & 236 & Qgu & & \\
\hline \multirow[t]{2}{*}{ Percent change in area (\%) } & -66 & $\underline{\text { Colluvium }}$ & & \\
\hline & & Qvl(3sh) & 30.4 & 1.8 \\
\hline \multicolumn{5}{|l|}{ Initiation } \\
\hline Elevation (m) & - & Summary & & \\
\hline Direct connection to glacier & - & Ice & 6.2 & 38.7 \\
\hline Distance from glacier (m) & - & Bedrock & 61.2 & 47.6 \\
\hline \multirow[t]{5}{*}{ Type } & - & Unconsolidated & 32.7 & 13.7 \\
\hline & & Measured Extents ** & & \\
\hline & & Snowpack and Ice & & 11.5 \\
\hline & & Consolidated Bedrock & & 21.6 \\
\hline & & Unconsolidated & & 66.9 \\
\hline
\end{tabular}

* data from WaDNR, 2010.

** data from measured extents on 2009 ortho imagery (USDA-FSA, 2009). 
glacier decreased in surface area by 66\%, and retreated upslope by 236 m (USGS, 2002; USDA-FSA, 2009).

\section{MUDDY RIVER DRAINAGE BASIN}

\section{Introduction}

The Muddy River Drainage Basin is located in the southeastern quadrant of Mount St. Helens between Shoestring Glacier Basin to the south and Ape Canyon Basin to the north (Figure 15, Figure 25). The upper basin does not host a glacier, although the upper basin does contain one large channel and the lower basin includes unconsolidated lahar and glacial deposits from the neighboring Shoestring Glacier. The lower end of the total basin extends toward Road 83, but merges with the Shoestring Glacier Basin at $930 \mathrm{~m}$ elevation, about $880 \mathrm{~m}$ north of the road. Water from this drainage enters Lava Canyon below Road 83 and flows eastward to merge with Smith and Clearwater creeks before turning south and entering the east end of Swift Reservoir in the same reach as Lewis River and Pine Creek.

A single large channel dominates this drainage. The channel begins near the crater rim on the north side of the upper basin, which is roughly divided into two halves by a ridge. The rocky southern side of the upper basin does not host a major channel. At the break in slope between the steeper upper basin and the beginning of the debris apron, there are many channels from the southern basin that merge with the major northern channel. One of these was discovered to have had a headward erosional 


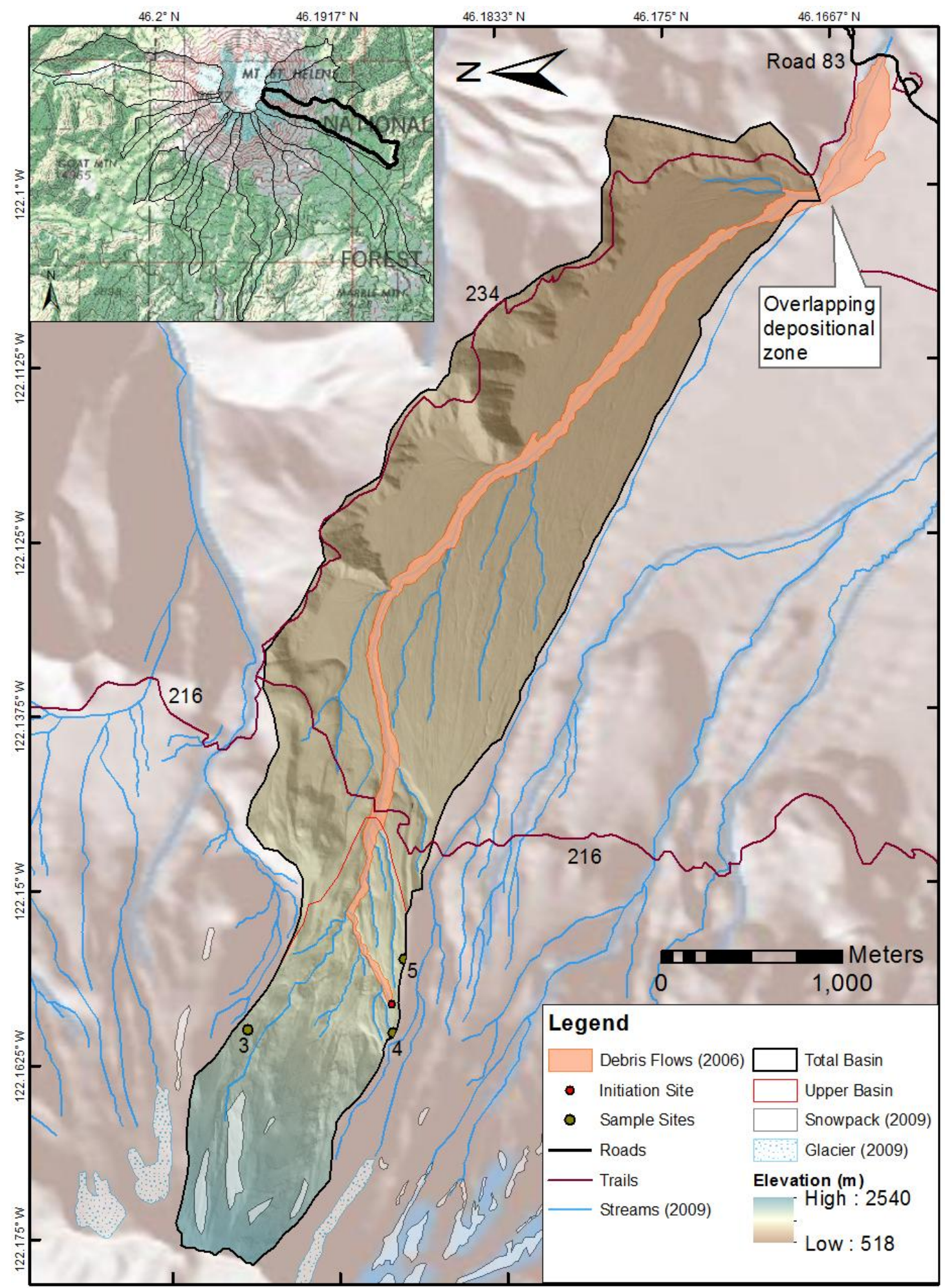

Figure 25: Map of Muddy River Basin located in the southeastern quadrant of Mount St. Helens between the Ape Canyon and Shoestring Glacier Basins. The upper basin does not host a glacier, although the lower basin includes glacial till from the neighboring Shoestring Glacier. This drainage did experience a debris flow in 2006. North is to the left. 
event between 2006 and 2009 that extended the channel by about 40 m upslope (USDA-FSA, 2006; USDA-FSA, 2009).

This channel and others merge with the main channel by 1,250 m elevation. From that point a single large channel passes through the 1980 lahar plain and joins with the Shoestring channel at an elevation of $930 \mathrm{~m}$. Around the $1,050 \mathrm{~m}$ elevation a large debris flow deposit of about $340,000 \mathrm{~m}^{2}$ fills and partially overflows the channel. A series of photographs show the changes in channel erosion and aggradation since the 1980 lahar and then after 2006 debris flow deposition (Figure 26).

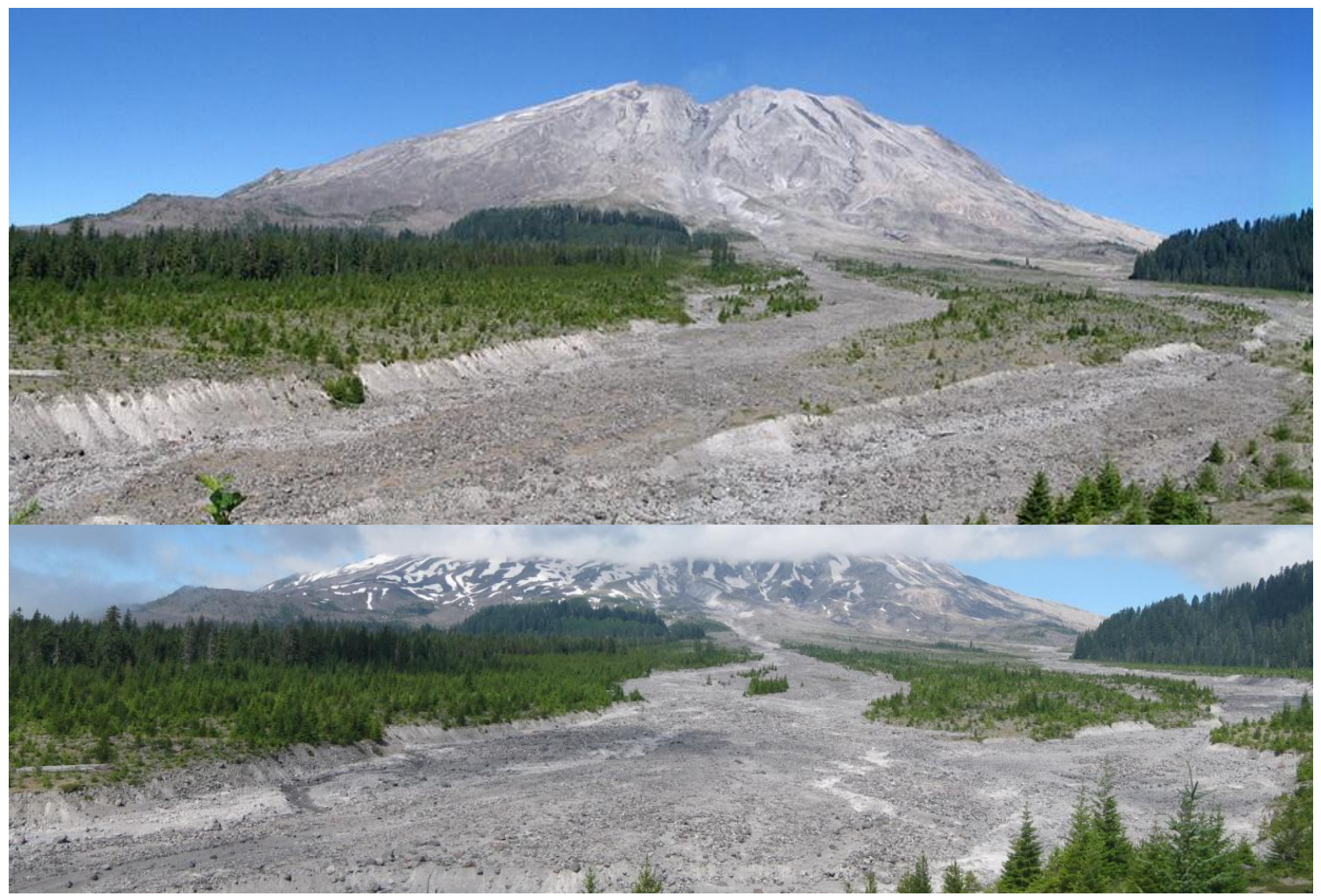

Figure 26: Comparison of 2006 debris flow deposition at the confluence of Muddy River and Shoestring Glacier in the southwestern quadrant of Mount St. Helens. Top picture is from August 2005, courtesy Doug Anderson. Bottom picture is from 2011. Smaller trees on the left and right are growing on the 1980 lahar terrace. View to the northwest. 


\section{Determination of Initiation Zone}

Field observations found evidence within the channel, but were unable to determine the source of the 2006 debris flow in the Muddy River Drainage. However, comparison of 2006 and 2009 ortho imagery discovered the site in lahar and glacial deposits at the base of the steep mountain slope at 1,605 m elevation (Figure 27). Field images that include this area show it to be filled with a snow bank during late August 2011 fieldwork (Figure 28). Therefore, based on the ortho imagery comparison it was determined that headward erosion in this channel was the initiation method of the Muddy River Debris Flow.

\section{Data Processing}

\section{$\underline{\text { Sieve Results }}$}

Sieve results of the soil samples from the Muddy River Drainage Basin are shown in Table 5 along with average values and standard deviation. The average bulk density

Table 5: Sieve analysis for the soil sample taken in the Muddy River Drainage. The sample is over half medium to fine sized sand

\begin{tabular}{|c|c|c|c|c|c|c|c|}
\hline \multirow[t]{2}{*}{ Sample \# } & \multirow{2}{*}{$\begin{array}{l}\text { Bulk } \\
\text { Density } \\
\left(\mathrm{g} / \mathrm{cm}^{3}\right)\end{array}$} & \multirow{2}{*}{$\begin{array}{c}\text { Gravel } \\
(>2.0 \\
\mathrm{mm})\end{array}$} & \multirow{2}{*}{$\begin{array}{c}\text { Sand } \\
(2.0 \text { to } \\
0.063 \\
\mathrm{~mm})\end{array}$} & \multirow{2}{*}{$\begin{array}{c}\text { Silt \& Clay } \\
(<0.063 \\
\text { mm })\end{array}$} & \multicolumn{3}{|c|}{ Sand } \\
\hline & & & & & $\begin{array}{c}\text { Coarse } \\
(2.0 \text { to } \\
0.42 \\
\mathrm{~mm})\end{array}$ & $\begin{array}{c}\text { Medium } \\
\text { (0.42 to } \\
0.149 \\
\mathrm{~mm})\end{array}$ & $\begin{array}{c}\text { Fine } \\
(0.149 \text { to } \\
0.063 \\
\mathrm{~mm})\end{array}$ \\
\hline 3.1 & 1.8 & $31.5 \%$ & $59.6 \%$ & $11.9 \%$ & $27.9 \%$ & $31.5 \%$ & $40.6 \%$ \\
\hline 3.2 & 1.7 & $34.1 \%$ & $56.9 \%$ & $8.6 \%$ & $34.0 \%$ & $40.2 \%$ & $25.8 \%$ \\
\hline 3.3 & 2.3 & $19.6 \%$ & $61.0 \%$ & $17.6 \%$ & $25.9 \%$ & $37.2 \%$ & $36.9 \%$ \\
\hline Average & 2.0 & $28.4 \%$ & $59.2 \%$ & $12.7 \%$ & $29.3 \%$ & $36.3 \%$ & $34.5 \%$ \\
\hline Std. Dev. & 0.33 & $7.7 \%$ & $2.1 \%$ & $4.6 \%$ & $4.2 \%$ & $4.4 \%$ & $7.7 \%$ \\
\hline
\end{tabular}


was measured at $2.0 \mathrm{~g} / \mathrm{cm}^{3}$, and the average sample consisted of $28 \%$ gravel, $59 \%$ sand, and $13 \%$ silt and clay.
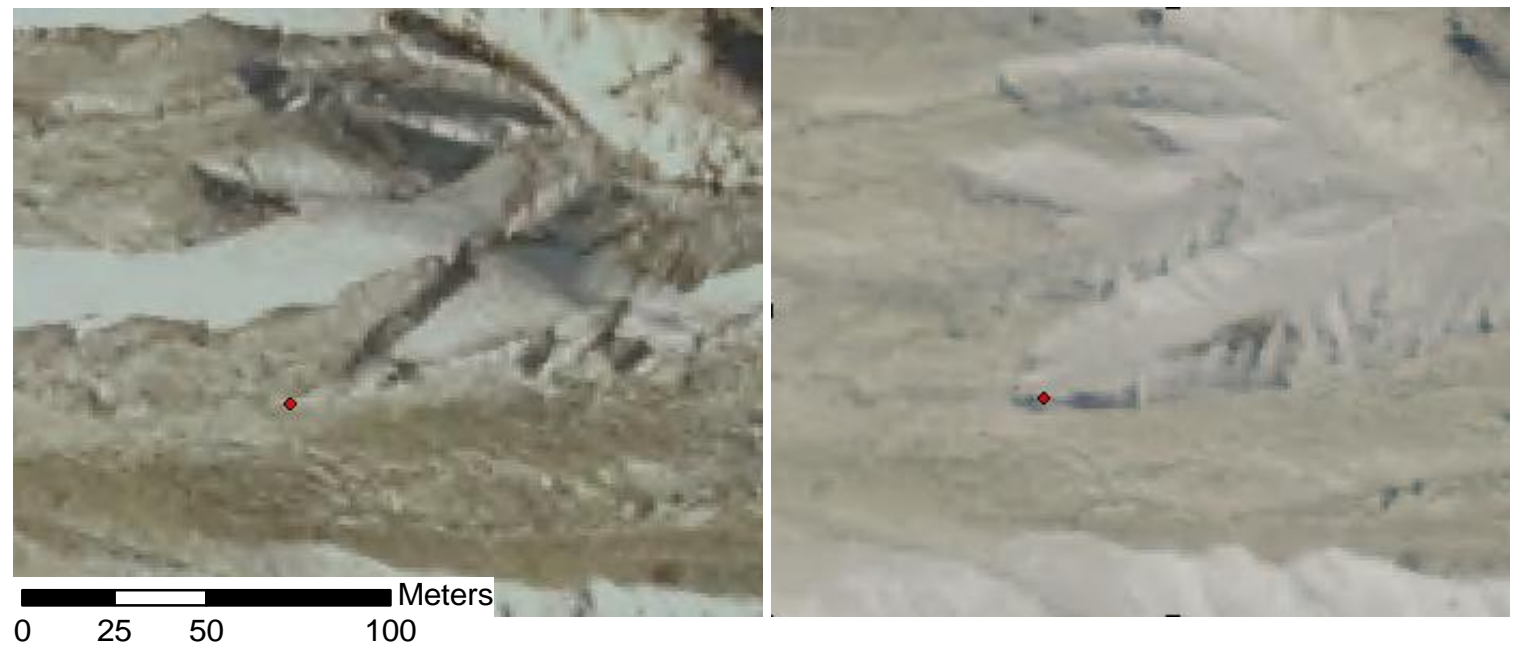

Figure 27: Comparison of 2006 and 2009 ortho imagery showing the initiation site of the 2006 Muddy River Debris Flow (USDA-FSA, 2006; USDA-FSA, 2009). The channel walls retreat upslope (to the left) past the red dot, which is at the same spatial location in both images (UTM 10N $564943 E 5115387 N$ ). North is up.

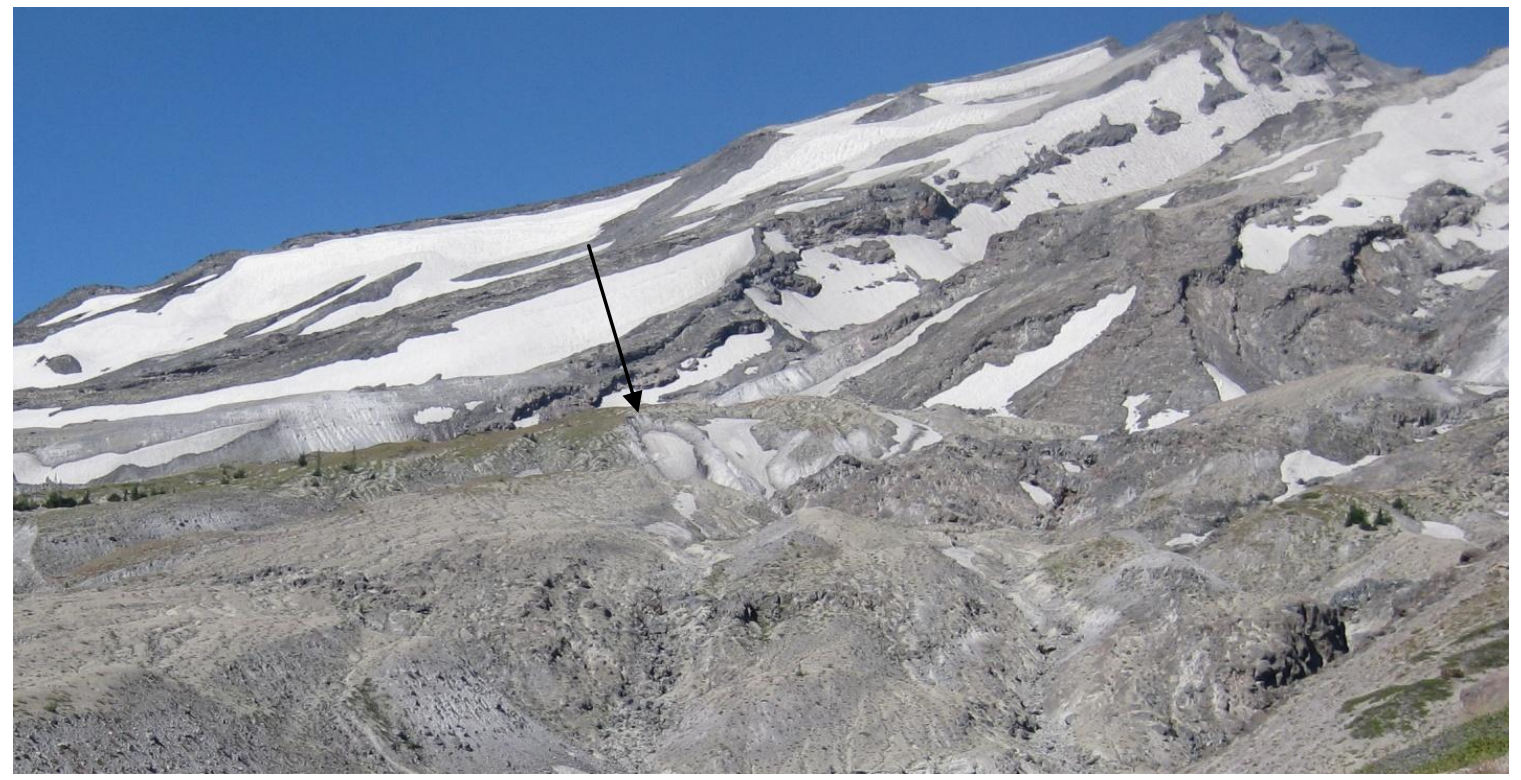

Figure 28: The initiation site of the 2006 Muddy River Debris Flow (arrow) determined by comparison of ortho imagery taken in 2006 and 2009. View is looking due west from the north side of the Muddy River Channel. The channel leading from the initiation site to the main channel is obscured in the middle distance by ridges and rocky outcrops and enters the main channel upslope out of the image. Photo was taken on Sept 1, 2011. 


\section{$\underline{\text { Basin Attributes }}$}

The initiation zone was found in the Muddy River Drainage at an elevation of 1,605 m, within an area mapped as volcaniclastic deposits and rocks (Qvc) (WaDNR, 2010). The geologic units of the upper basin are $44 \%$ unconsolidated (volcaniclastics, alluvium, and colluvium), 56\% bedrock (volcanics, andesite, and basalt), and $0 \%$ ice according to the geologic map (WaDNR, 2010). The measured extents of the upper basin geology are $5 \%$ snowpack and ice, $32 \%$ consolidated bedrock exposures, and $63 \%$ unconsolidated deposits. A full summary of the basin attributes is listed in Table 6 .

\section{SHOESTRING GLACIER DRAINAGE BASIN}

\section{Introduction}

The Shoestring Glacier Drainage Basin is located in the southeastern quadrant of Mount St. Helens between Muddy River to the north and Pine Creek to the south (Figure 15, Figure 29). The upper basin is defined by a 50 to $125 \mathrm{~m}$ deep canyon that extends upward to the 1980 crater rim and hosts the remnant of a glacier (Figure 30). The canyon is a steeper continuation of the channel that runs continuously from the top of the basin to the bottom. The total basin boundary tightly confines to this channel with the exterior lahar plain slopes angled away from the ravine. Therefore, surface runoff just beyond the north rim of the lower channel flows through numerous surface channels northward across the lahar plain into the neighboring Muddy River Drainage. The lowest point of the total basin extends toward Road 83, but merges with the Muddy River Basin at $930 \mathrm{~m}$ elevation, which is about $880 \mathrm{~m}$ from the road. Water from this 
Table 6: Muddy River Drainage Basin attributes.

\begin{tabular}{|c|c|c|c|c|}
\hline \multirow{2}{*}{$\begin{array}{l}\text { Basin Attributes } \\
\text { Total Basin }\end{array}$} & & \multirow[t]{2}{*}{ Geologic Units * } & \multicolumn{2}{|c|}{$\%$ Basin } \\
\hline & & & Total & Upper \\
\hline Area $\left(m^{2}\right)$ & $6,761,610$ & Water & & \\
\hline Comparative size rank & $4^{\text {th }}$ & ice & & \\
\hline Highest elevation (m) & 2,480 & $\underline{\text { Volcanics }}$ & & \\
\hline Lowest elevation (m) & 920 & Qv(sh) & 0.1 & 0.4 \\
\hline Height (m) & 1,560 & $\underline{\text { Andesite }}$ & & \\
\hline Length $(\mathrm{m})$ & 7,373 & MOian & & \\
\hline Gradient & 0.21 & MOva(2) & 14.3 & \\
\hline \multirow[t]{2}{*}{ MRN } & 0.60 & Qiad(1) & & \\
\hline & & Qiad(2) & & \\
\hline$\underline{\text { Upper Basin }}$ & & QPLiad(g) & & \\
\hline Area $\left(m^{2}\right)$ & $1,607,690$ & Qva(1sh) & & \\
\hline Comparative size rank & $5^{\text {th }}$ & Qva(2sh) & 22.2 & 55.9 \\
\hline Highest elevation (m) & 2,480 & Basalt & & \\
\hline Lowest elevation (m) & 1,316 & Qvb(2sh) & & \\
\hline Height (m) & 1,164 & $\underline{\text { Volcaniclastics }}$ & & \\
\hline Length $(\mathrm{m})$ & 2,739 & $\operatorname{MOvc}(2)$ & & \\
\hline Gradient & 0.42 & OEvc & & \\
\hline MRN & 0.92 & Qvc(1sh) & & \\
\hline Percent vegetation (\%) & 0.6 & Qvc(2sh) & 11.5 & 42.5 \\
\hline Percent steep slope (\%) & 44 & Qvc(sh) & & \\
\hline \multirow[t]{2}{*}{ Avg. annual precip. (m) } & 3.7 & Qvp(3sh) & & \\
\hline & & Ovt(1) & & \\
\hline Glacier & & $\underline{\text { Alluvium }}$ & & \\
\hline Area $\left(m^{2}\right)$ & - & Qa & & \\
\hline Retreat distance (m) & - & Qgu & & \\
\hline \multirow[t]{2}{*}{ Percent change in area (\%) } & - & $\underline{\text { Colluvium }}$ & & \\
\hline & & Qvl(3sh) & 52.0 & 1.3 \\
\hline \multicolumn{5}{|l|}{$\underline{\text { Initiation }}$} \\
\hline Elevation (m) & 1,605 & Summary & & \\
\hline Direct connection to glacier & - & Ice & 0.0 & 0.0 \\
\hline Distance from glacier (m) & - & Bedrock & 36.6 & 56.2 \\
\hline \multirow[t]{5}{*}{ Type } & Headless & Unconsolidated & 63.5 & 43.8 \\
\hline & & Measured Extents ** & & \\
\hline & & Snowpack and Ice & & 5.3 \\
\hline & & Consolidated Bedrock & & 32.0 \\
\hline & & Unconsolidated & & 62.8 \\
\hline
\end{tabular}

* data from WaDNR, 2010.

** data from measured extents on 2009 ortho imagery (USDA-FSA, 2009). 


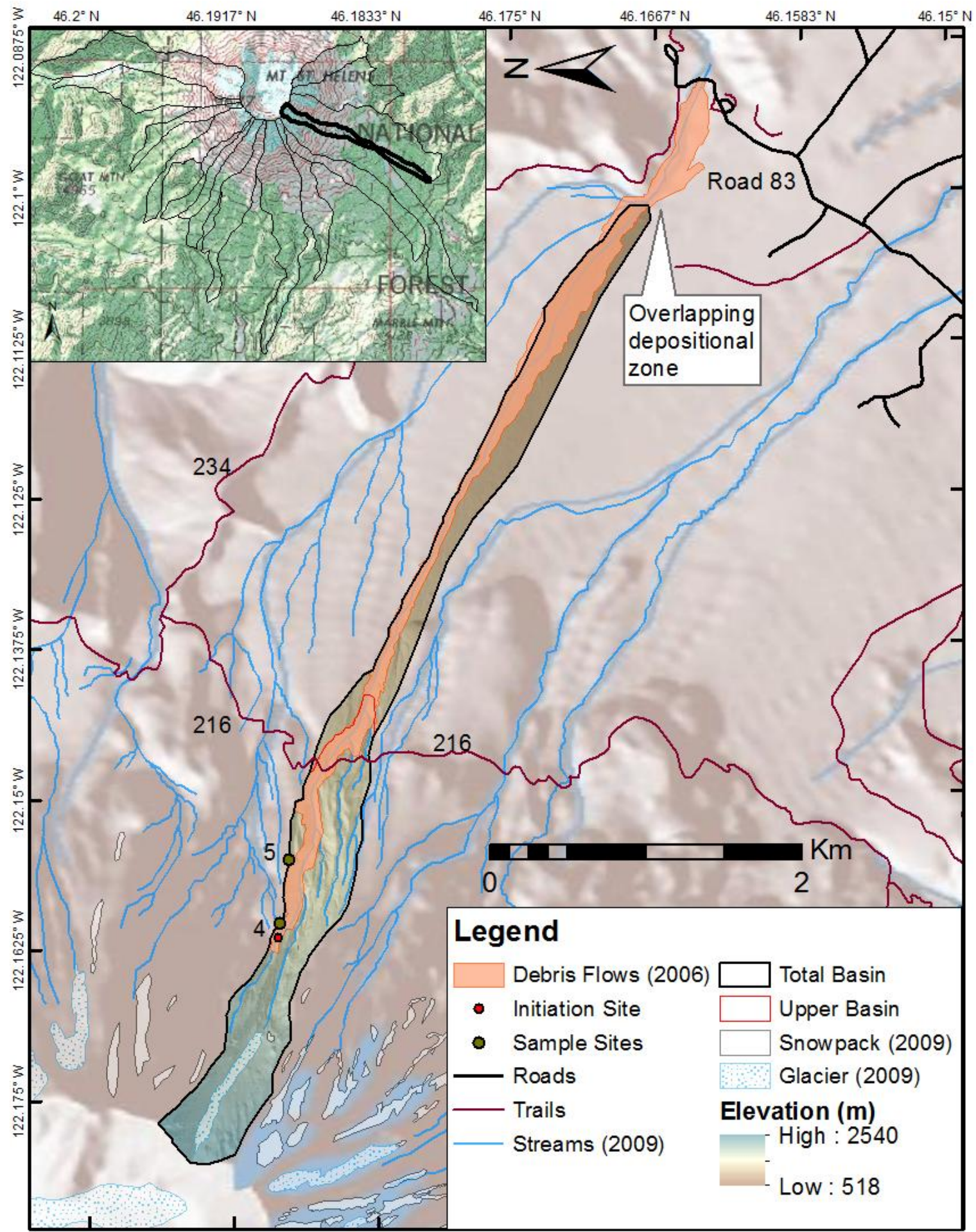

Figure 29: Map of Shoestring Glacier Drainage located in the southeastern quadrant of Mount St. Helens between the Muddy River and Pine Creek drainages. The upper basin hosts the Shoestring Glacier, although most of the glacial till in the lower basin is found in the neighboring Muddy River Drainage. This drainage did experience a debris flow in 2006. North is to the left. 


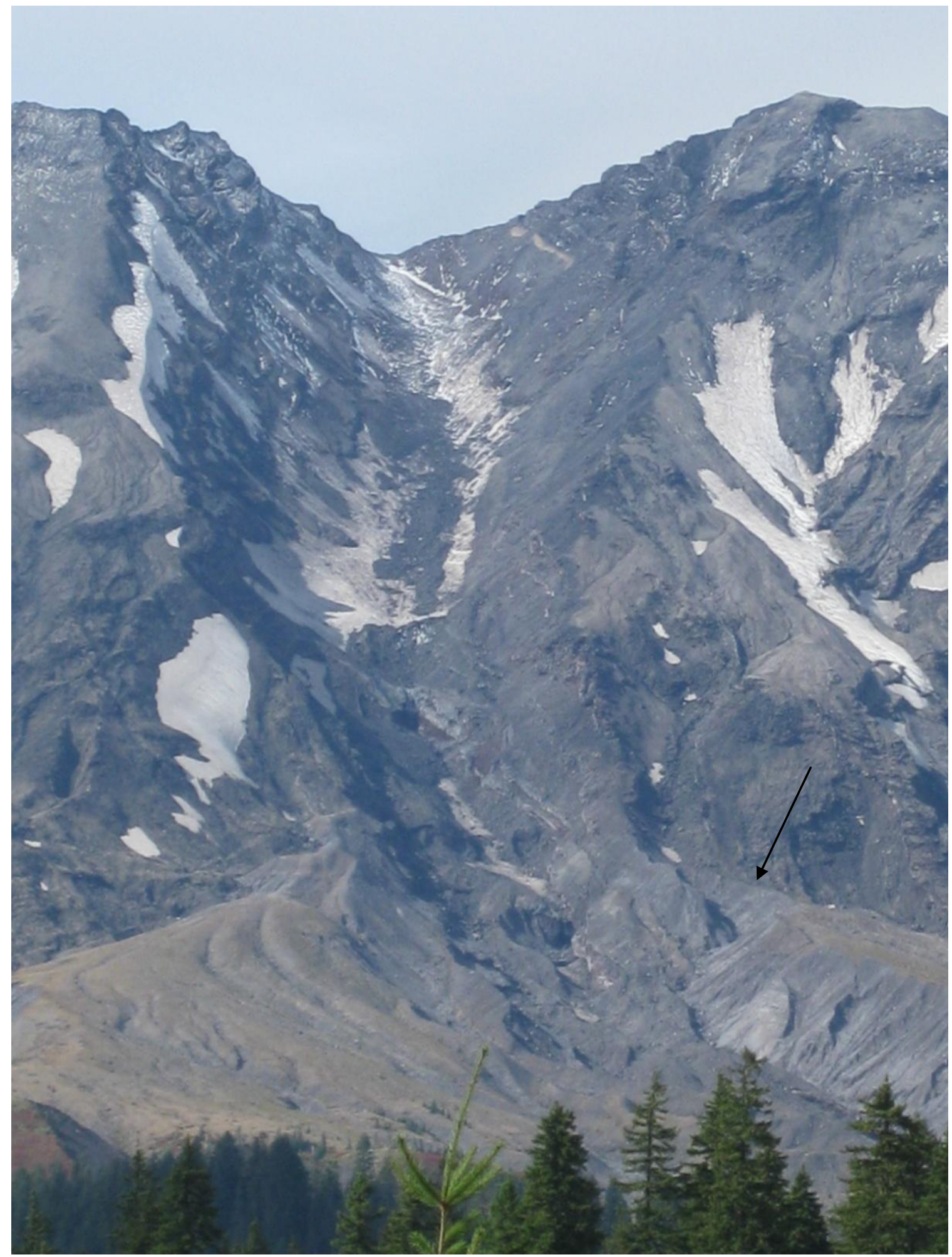

Figure 30: View of the Shoestring Glacier upper basin taken from Road 83. The remains of the Shoestring Glacier are visible on the upper canyon floor. Arrowed is the side-channel that experienced extensive side wall erosion and small landslides in 2006. View is toward the northwest. 
drainage merges with the Muddy River at that point and eventually reaches the Swift Reservoir.

Although the drainage basin is dominated by one large, deep channel there are numerous ravines that merge into the main channel on the south side between $1,300 \mathrm{~m}$ and 1,650 m elevation. One side-channel does exist on the north side beginning around 2,050 m (UTM 10N 564654E 5115390N) elevation and merging with the main channel near the break in slope between the steep upper basin and the lahar plain. It was this northern channel that was discovered to have extensive headward and sidewall erosion visible in comparative ortho imagery (USDA-FSA, 2006; USDA-FSA, 2009).

\section{Determination of Initiation Zone}

Field observations found much evidence of unstable slopes and possible landslide scarps along and within the channel, but were unable to determine the specific source of the 2006 debris flow in the Shoestring Glacier Drainage. Comparison of 2006 and 2009 ortho imagery discovered multiple areas of channel wall erosion and possible landslide scarps, the most promising of which is in the northern side-channel located above 1,640 m elevation (Figure 31). Therefore, it was determined that headward and channel wall erosion in this side-channel was the initiation site of the Shoestring Glacier Debris Flow in 2006. 

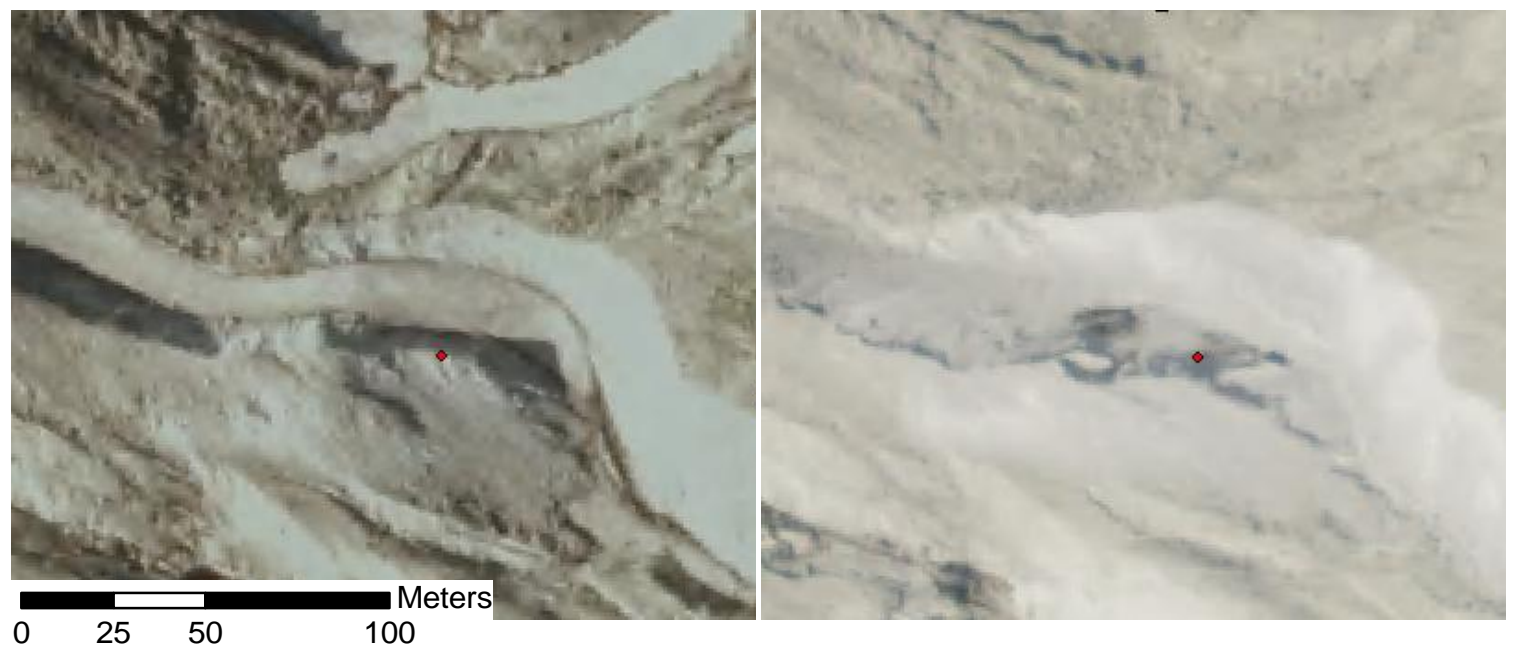

Figure 31: Comparison of 2006 (left) and 2009 (right) ortho imagery showing the initiation site of the 2006 Shoestring Glacier Debris Flow (USDA-FSA, 2006; USDA-FSA, 2009). The channel walls are observed to have eroded and experienced small landslides. The dots are in the same spatial location in both images (UTM 10N 564694E 5115390N). North is up.

\section{Data Processing}

\section{$\underline{\text { Sieve Results }}$}

Sieve results of the soil samples from the Shoestring Glacier Drainage Basin are shown in Table 7 along with average values and standard deviation. Total and site average values are also shown. The average bulk density was measured at $1.9 \mathrm{~g} / \mathrm{cm}^{3}$, and the average sample consisted of $40 \%$ gravel, $52 \%$ sand, and $8 \%$ silt and clay.

\section{Basin Attributes}

The initiation zone in the Shoestring Glacier Drainage was determined to be at an elevation of 1,674 m, within an area mapped as andesite flows (Qva) and volcaniclastic deposits and rocks (Qvc) (WaDNR, 2010). The geologic units of the upper basin were mapped as $36 \%$ bedrock (volcanics, andesite, and basalt), $46 \%$ unconsolidated (volcaniclastics, alluvium, and colluvium), and 5\% ice according to the 
Table 7: Sieve analysis for the soil samples taken in the Shoestring Glacier Drainage. The sample is half sand of medium and fine sized grains.

\begin{tabular}{|c|c|c|c|c|c|c|c|}
\hline \multirow[t]{2}{*}{ Sample \# } & \multirow{2}{*}{$\begin{array}{l}\text { Bulk } \\
\text { Density } \\
\left(\mathrm{g} / \mathrm{cm}^{3}\right)\end{array}$} & \multirow{2}{*}{$\begin{array}{c}\text { Gravel } \\
(>2.0 \\
\mathrm{mm})\end{array}$} & \multirow{2}{*}{$\begin{array}{c}\text { Sand } \\
(2.0 \text { to } \\
0.063 \\
\mathrm{~mm})\end{array}$} & \multirow{2}{*}{$\begin{array}{c}\text { Silt \& Clay } \\
(<0.063 \\
\text { mm })\end{array}$} & \multicolumn{3}{|c|}{ Sand } \\
\hline & & & & & $\begin{array}{c}\text { Coarse } \\
(2.0 \text { to } \\
0.42 \\
\mathrm{~mm})\end{array}$ & $\begin{array}{c}\text { Medium } \\
\text { (0.42 to } \\
0.149 \\
\mathrm{~mm})\end{array}$ & $\begin{array}{c}\text { Fine } \\
(0.149 \text { to } \\
0.063 \\
\mathrm{~mm})\end{array}$ \\
\hline 4.1 & 2.4 & $64.8 \%$ & $30.3 \%$ & $4.5 \%$ & $19.6 \%$ & $36.5 \%$ & $43.9 \%$ \\
\hline 4.2 & 1.6 & $46.0 \%$ & $48.3 \%$ & $6.1 \%$ & $39.2 \%$ & $38.8 \%$ & $22.0 \%$ \\
\hline 4.3 & 2.1 & $55.6 \%$ & $39.2 \%$ & $5.3 \%$ & $18.5 \%$ & $43.5 \%$ & $38.0 \%$ \\
\hline Site Avg. & 2.0 & $55.5 \%$ & $39.3 \%$ & $5.3 \%$ & $25.8 \%$ & $39.6 \%$ & $34.6 \%$ \\
\hline 5.1 & 1.6 & $22.7 \%$ & $69.0 \%$ & $8.3 \%$ & $32.6 \%$ & $32.4 \%$ & $35.0 \%$ \\
\hline 5.2 & 1.9 & $31.0 \%$ & $55.2 \%$ & $13.7 \%$ & $24.0 \%$ & $34.3 \%$ & $41.6 \%$ \\
\hline 5.3 & 1.8 & $16.7 \%$ & $72.6 \%$ & $11.0 \%$ & $30.6 \%$ & $34.0 \%$ & $35.4 \%$ \\
\hline Site Avg. & 1.7 & $23.5 \%$ & $65.6 \%$ & $11.0 \%$ & $29.1 \%$ & $33.6 \%$ & $37.3 \%$ \\
\hline Average & 1.9 & $39.5 \%$ & $52.4 \%$ & $8.1 \%$ & $27.4 \%$ & $36.6 \%$ & $36.0 \%$ \\
\hline Std. Dev. & 0.31 & $19.1 \%$ & $16.5 \%$ & $3.6 \%$ & $8.1 \%$ & $4.0 \%$ & $7.7 \%$ \\
\hline
\end{tabular}

geologic map (WaDNR, 2010). The measured extents of the upper basin geology are $23 \%$ consolidated bedrock exposures, $72 \%$ unconsolidated deposits, and $5 \%$ snowpack and ice. A full summary of the basin attributes is listed in Table 8.

As of 2009 , the Shoestring Glacier covered an area of $56,250 \mathrm{~m}^{2}$, or $5 \%$, of the upper basin (USDA-FSA, 2009). Between 1998 and 2009 the glacier decreased in surface area by $82 \%$, and retreated upslope by 1,340 m (USGS, 2002; USDA-FSA, 2009).

However, much debris was observed at the terminus and on the perimeter of the glacier obscuring boundaries and will affect these measurements. 
Table 8: Shoestring Glacier Drainage Basin attributes.

\begin{tabular}{|c|c|c|c|c|}
\hline \multirow{2}{*}{$\begin{array}{l}\text { Basin Attributes } \\
\underline{\text { Total Basin }}\end{array}$} & & \multirow[t]{2}{*}{ Geologic Units * } & \multicolumn{2}{|c|}{$\%$ Basin } \\
\hline & & & Total & Upper \\
\hline Area $\left(m^{2}\right)$ & $1,975,140$ & Water & & \\
\hline Comparative size rank & $14^{\text {th }}$ & ice & 10.7 & 18.6 \\
\hline Highest elevation (m) & 2,479 & $\underline{\text { Volcanics }}$ & & \\
\hline Lowest elevation (m) & 923 & Qv(sh) & 1.6 & 2.8 \\
\hline Height (m) & 1,556 & Andesite & & \\
\hline Length (m) & 6,975 & MOian & & \\
\hline Gradient & 0.22 & MOva(2) & & \\
\hline \multirow[t]{2}{*}{ MRN } & 1.11 & Qiad(1) & & \\
\hline & & Qiad(2) & & \\
\hline$\underline{\text { Upper Basin }}$ & & QPLiad(g) & & \\
\hline Area $\left(m^{2}\right)$ & $1,135,760$ & Qva(1sh) & & \\
\hline Comparative size rank & $7^{\text {th }}$ & Qva(2sh) & 18.9 & 32.8 \\
\hline Highest elevation (m) & 2,479 & Basalt & & \\
\hline Lowest elevation (m) & 1,247 & Qvb(2sh) & & \\
\hline Height (m) & 1,232 & $\underline{\text { Volcaniclastics }}$ & & \\
\hline Length (m) & 3,321 & $\operatorname{MOvc}(2)$ & & \\
\hline Gradient & 0.37 & OEvc & & \\
\hline MRN & 1.16 & Qvc(1sh) & & \\
\hline Percent vegetation (\%) & 0.7 & Qvc(2sh) & 24.1 & 41.8 \\
\hline Percent steep slope (\%) & 51 & Qvc(sh) & & \\
\hline \multirow[t]{2}{*}{ Avg. annual precip. (m) } & 3.8 & Qvp(3sh) & & \\
\hline & & Ovt(1) & & \\
\hline Glacier & & $\underline{\text { Alluvium }}$ & & \\
\hline Area $\left(m^{2}\right)$ & 56,249 & Qa & & \\
\hline Retreat distance $(\mathrm{m})$ & 1,340 & Qgu & & \\
\hline \multirow[t]{2}{*}{ Percent change in area (\%) } & -82 & $\underline{\text { Colluvium }}$ & & \\
\hline & & Qvl(3sh) & 44.9 & 4.1 \\
\hline \multicolumn{5}{|l|}{ Initiation } \\
\hline Elevation (m) & 1,674 & Summary & & \\
\hline Direct connection to glacier & - & Ice & 10.7 & 18.6 \\
\hline Distance from glacier (m) & - & Bedrock & 20.5 & 35.6 \\
\hline \multirow[t]{5}{*}{ Type } & Headless & Unconsolidated & 68.9 & 45.9 \\
\hline & & Measured Extents ** & & \\
\hline & & Snowpack and Ice & & 5.1 \\
\hline & & Consolidated Bedrock & & 23.4 \\
\hline & & Unconsolidated & & 71.5 \\
\hline
\end{tabular}

* data from WaDNR, 2010.

** data from measured extents on 2009 ortho imagery (USDA-FSA, 2009). 


\section{PINE CREEK DRAINAGE BASIN}

Introduction

The Pine Creek Drainage Basin is located in the southeastern quadrant of Mount

St. Helens between Shoestring Glacier to the north and Worm Flows to the south (Figure 15, Figure 32). The upper basin does not host a glacier, although it does include a large area of unconsolidated deposits above about 1,850 m. Below that elevation, the upper basin consists of the andesite lava flows known as the Worm Complex Flows. Many small channels are observed to cross this area. However, there are two major channels that run parallel along the northern edge of the drainage boundary before merging at an elevation of 1,300 $\mathrm{m}$ (Figure 33). Below the upper basin, this single channel runs about $4.5 \mathrm{~km}$ beyond Road 83 where it merges with streams draining the Marble Mountain area. Water from this drainage continues southward until entering the east end of Swift Reservoir in the same reach as the Lewis River and Muddy River.

The basin also includes a ridge of unconsolidated lahar and glacial deposits from the neighboring Shoestring Glacier along the northern boundary. The channels in this area currently drain into Pine Creek, but seem to have switched basin in the past at a spot around the 1,400 m elevation (UTM 10N565553E 5114847N). It was one or both of these side-channels that experienced a small debris flow in 2006.

\section{Determination of Initiation Zone}

There was evidence of past debris flows in the main channel at Road 83 (Figure 34) and the Trail 216 crossing. However, because of lack of damage to the trail and 


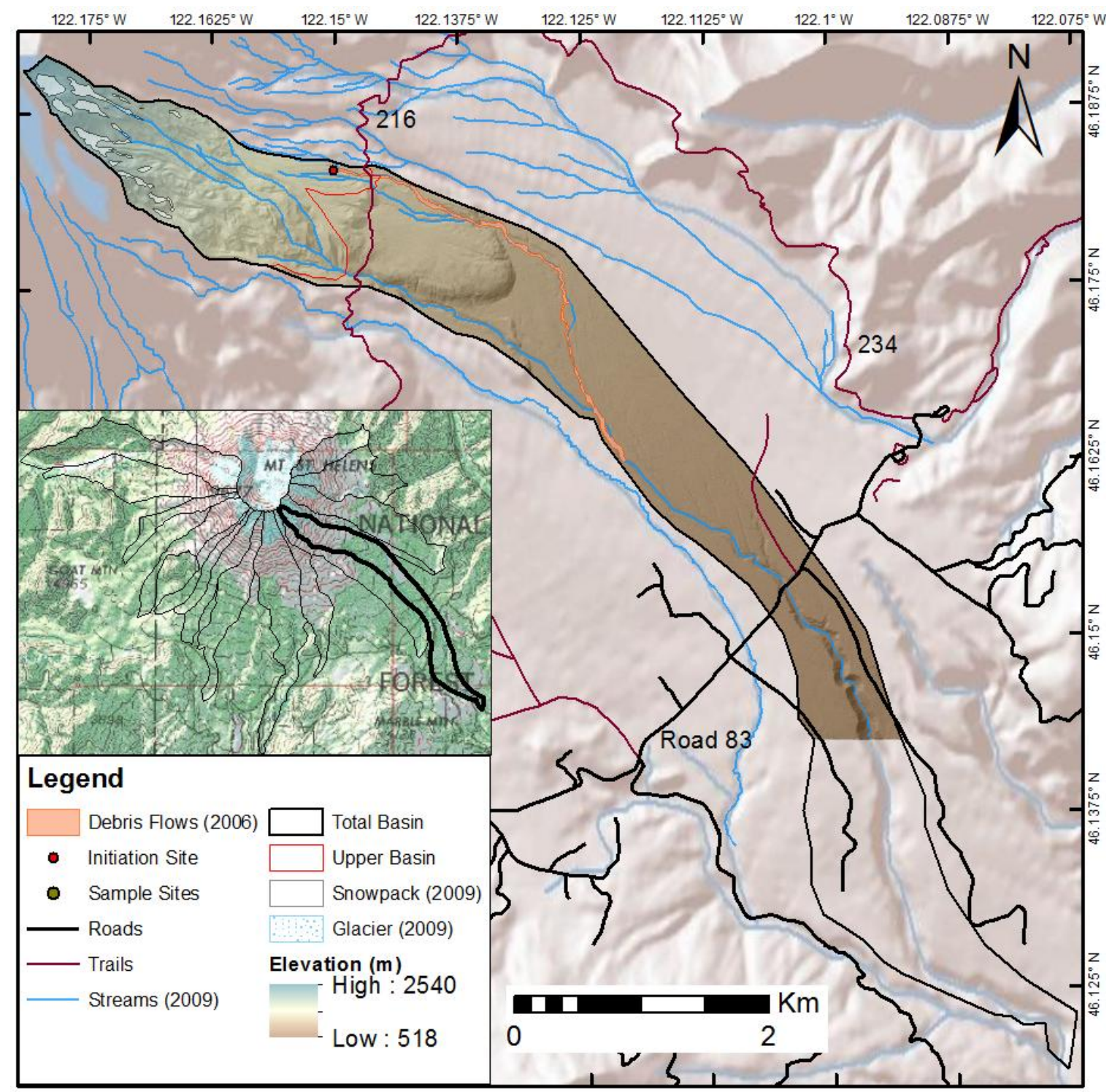

Figure 32: Map of Pine Creek Drainage in the southeastern quadrant of Mount St. Helens between the Shoestring Glacier and Worm Flows drainages. The upper basin does not host a glacier. The main channel did not experience a debris flow in 2006; however, a side-channel neighboring Shoestring Glacier did unleash a small debris flow.

road, vegetation in the channel, and amount of channel wall slumping, it was initially determined that this drainage did not have a debris flow in 2006. However, ortho imagery comparison between 2006 and 2009 found evidence of heavy channel erosion in a side-channel at 1,403 m elevation (Figure 35, USDA-FSA, 2006; USDA-FSA, 2009). 


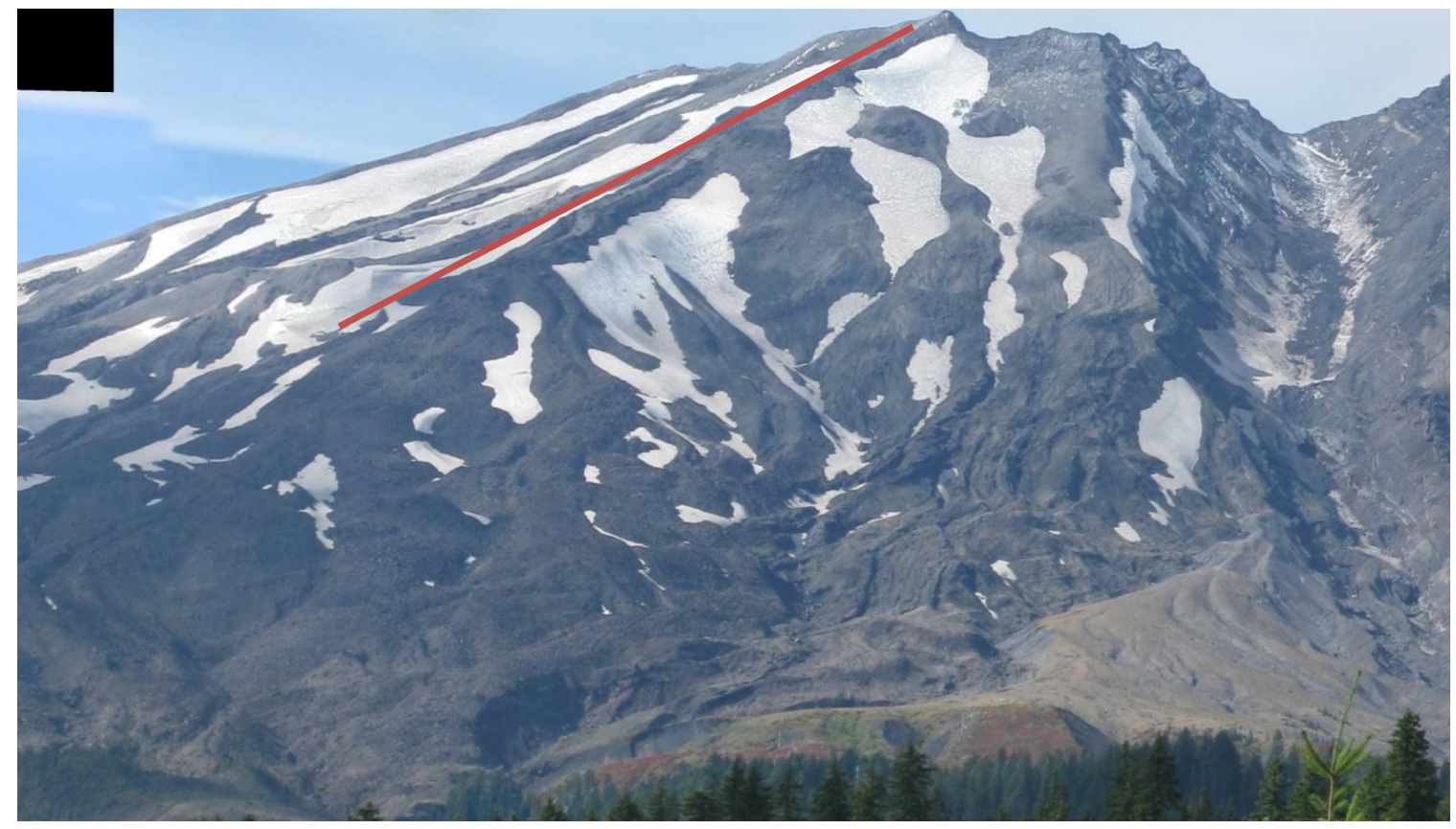

Figure 33: View of the Pine Creek upper basin taken from Road 83. The remains of the Shoestring Glacier are visible on the right. The basin is defined by the southern rim of the Shoestring Canyon on the north, and the levee of a lava flow (indicated in orange) to the south. View is toward the northwest.

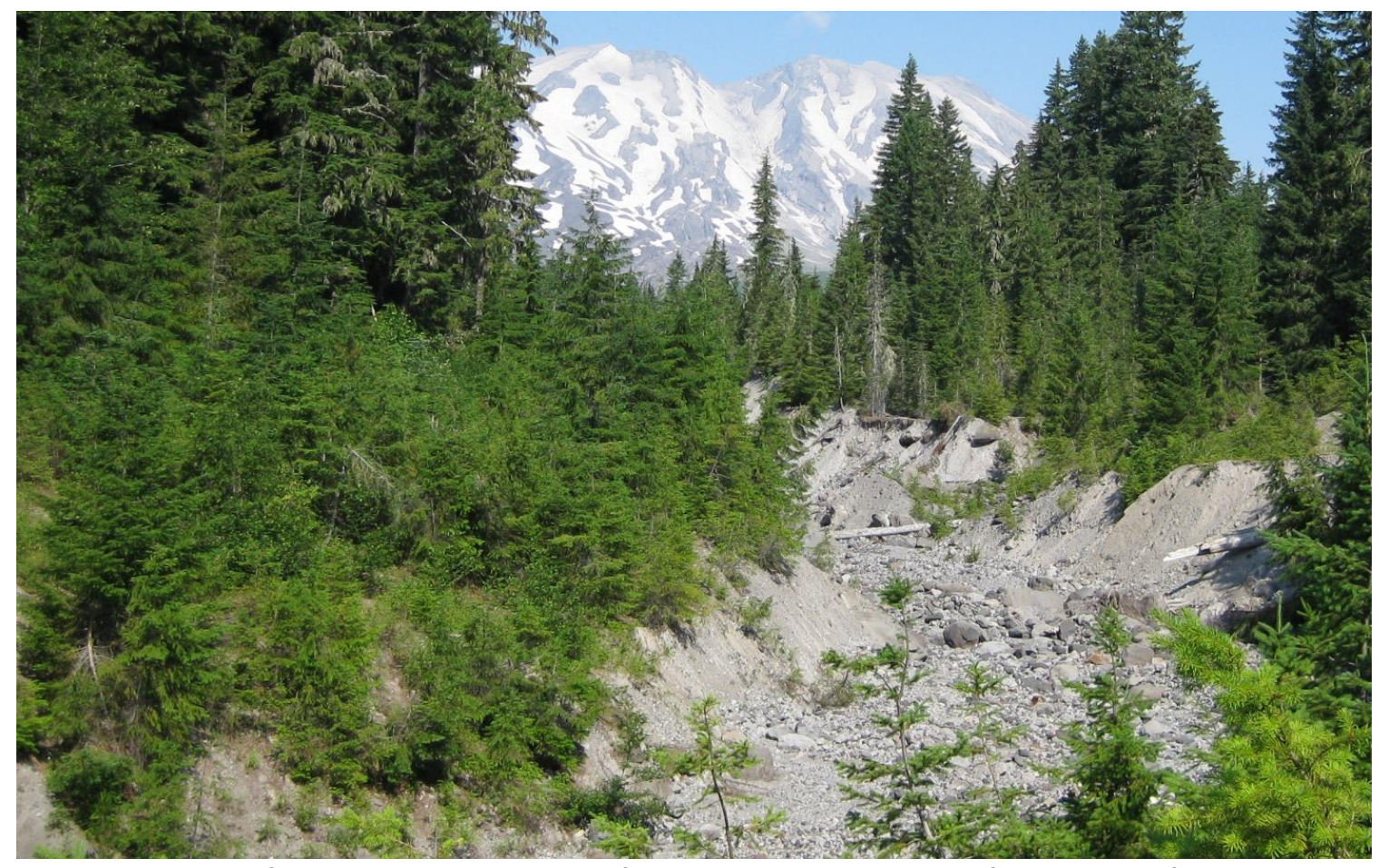

Figure 34: View of the Pine Creek Channel from Road 83. Evidence of past debris flow activity is apparent, however, vegetation and shallow angled walls indicate it was not recent. 

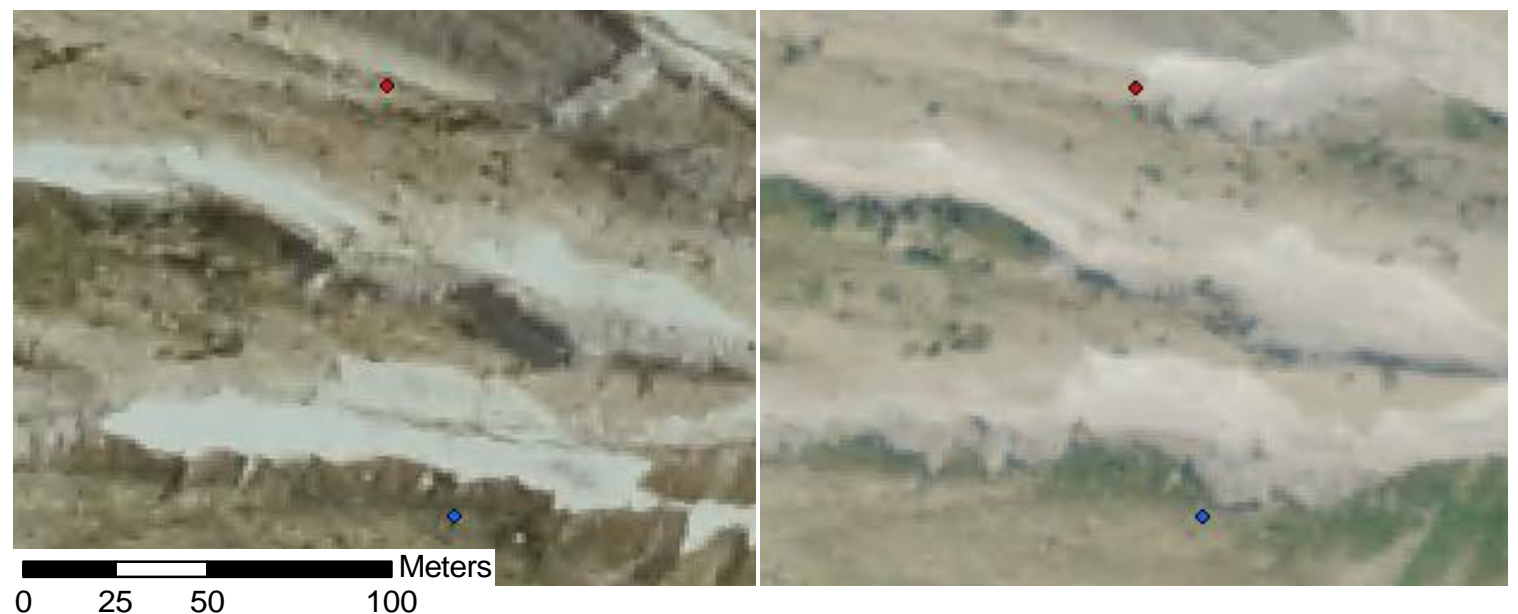

Figure 35: Comparison of 2006 (left) and 2009 (right) ortho imagery showing the initiation site of the 2006 Pine Creek Debris Flow (USDA-FSA, 2006; USDA-FSA, 2009). The channels show headward and bank erosion in multiple areas (blue and red dots). The dots are in the same spatial location in both images (UTM 10N 565575E 5514761N). North is up.

Orthophotographs indicate the debris flow probably reached the main channel, but do not show a depositional zone, therefore it is probable that the debris flow did not block the flow in the main channel or breach the channel walls.

\section{Data Processing}

\section{$\underline{\text { Sieve Results }}$}

No soil samples were taken from the Pine Creek Drainage Basin.

\section{Basin Attributes}

There was no 2006 debris flow initiation zone found in the main channel of the Pine Creek Drainage, however a side-channel did experience a debris flow. The elevation of the initiation zone was measured as $1,403 \mathrm{~m}$, within an area mapped as volcaniclastic deposits and rocks (Qvc) (WaDNR, 2010). The geologic units of the upper basin were mapped as $83 \%$ bedrock (volcanics, andesite, and basalt), $17 \%$ 
unconsolidated (volcaniclastics, alluvium, and colluvium), and less than $1 \%$ ice according to the geologic map (WaDNR, 2010). The measured extents of the upper basin geology are $39 \%$ consolidated bedrock exposures, $55 \%$ unconsolidated deposits, and $7 \%$ snowpack and ice. A full summary of the basin attributes is listed in Table 9.

\section{WORM FLOWS DRAINAGE BASIN}

\section{Introduction}

The Worm Flows Drainage Basin is located in the southeastern quadrant of Mount St. Helens between Pine Creek to the northeast and June Lake to the southwest (Figure 15, Figure 36). The upper basin does not connect to the crater rim or host a glacier, and contains andesitic lava flow terrain similar to neighboring Pine Creek. Found along the upper channel are pockets of lahar (Qvl) (WaDNR, 2010) and fluvial deposits. The lower boundary of the upper basin ends about $350 \mathrm{~m}$ above the channel junction with Trail 216. Below Trail 216, around 1,160 m elevation, the zone of overlapping andesite flows terminates to reveal a plain of unconsolidated volcaniclastic deposits and rocks related to those of Pine Creek. The total basin boundary ends about $1.2 \mathrm{~km}$ below Road 83 where the channel merges with streams draining the Marble Mountain area. Water from this drainage continues southward, joins with the flow from Pine Creek, and finally enters the east end of Swift Reservoir in the same reach as the Lewis River and Muddy River.

This basin is dominated by a single large channel that drains a hollow of snow fields in the upper basin. At about 1,500 m elevation, the channel merges with a 
Table 9: Pine Creek Drainage Basin attributes.

\begin{tabular}{|c|c|c|c|c|}
\hline \multirow{2}{*}{$\begin{array}{l}\text { Basin Attributes } \\
\underline{\text { Total Basin }}\end{array}$} & & \multirow[t]{2}{*}{ Geologic Units* } & \multicolumn{2}{|c|}{$\%$ Basin } \\
\hline & & & Total & Upper \\
\hline Area $\left(m^{2}\right)$ & $8,620,220$ & Water & & \\
\hline Comparative size rank & $3^{\text {rd }}$ & ice & 0.0 & 0.1 \\
\hline Highest elevation (m) & 2,487 & $\underline{\text { Volcanics }}$ & & \\
\hline Lowest elevation (m) & 646 & Qv(sh) & & \\
\hline Height (m) & 1,841 & $\underline{\text { Andesite }}$ & & \\
\hline Length ( $\mathrm{m})$ & 12,661 & MOian & & \\
\hline Gradient & 0.15 & MOva(2) & & \\
\hline \multirow[t]{2}{*}{ MRN } & 0.63 & Qiad(1) & & \\
\hline & & Qiad(2) & & \\
\hline$\underline{\text { Upper Basin }}$ & & QPLiad(g) & & \\
\hline Area $\left(m^{2}\right)$ & $1,987,150$ & Qva(1sh) & 2.2 & \\
\hline Comparative size rank & $3^{\text {rd }}$ & Qva(2sh) & 19.6 & 83.1 \\
\hline Highest elevation (m) & 2,487 & Basalt & & \\
\hline Lowest elevation (m) & 1,265 & Qvb(2sh) & & \\
\hline Height (m) & 1,222 & $\underline{\text { Volcaniclastics }}$ & & \\
\hline Length $(\mathrm{m})$ & 3,030 & $\operatorname{MOvc}(2)$ & & \\
\hline Gradient & 0.40 & OEvc & & \\
\hline MRN & 0.87 & Qvc(1sh) & 31.6 & \\
\hline Percent vegetation (\%) & 1.2 & Qvc(2sh) & 34.2 & 16.8 \\
\hline Percent steep slope (\%) & 34 & Qvc(sh) & & \\
\hline \multirow[t]{2}{*}{ Avg. annual precip. (m) } & 3.9 & Qvp(3sh) & & \\
\hline & & Ovt(1) & & \\
\hline$\underline{\text { Glacier }}$ & & $\underline{\text { Alluvium }}$ & & \\
\hline Area $\left(m^{2}\right)$ & - & Qa & & \\
\hline Retreat distance $(\mathrm{m})$ & - & Qgu & & \\
\hline \multirow[t]{2}{*}{ Percent change in area (\%) } & - & $\underline{\text { Colluvium }}$ & & \\
\hline & & Qvl(3sh) & 12.4 & 0.0 \\
\hline \multicolumn{5}{|l|}{ Initiation } \\
\hline Elevation (m) & 1,403 & Summary & & \\
\hline Direct connection to glacier & - & Ice & 0.0 & 0.1 \\
\hline Distance from glacier (m) & - & Bedrock & 21.8 & 83.1 \\
\hline \multirow[t]{5}{*}{ Type } & Headless & Unconsolidated & 78.2 & 16.8 \\
\hline & & Measured Extents ** & & \\
\hline & & Snowpack and Ice & & 6.8 \\
\hline & & Consolidated Bedrock & & 38.7 \\
\hline & & Unconsolidated & & 54.5 \\
\hline
\end{tabular}

* data from WaDNR, 2010.

** data from measured extents on 2009 ortho imagery (USDA-FSA, 2009). 


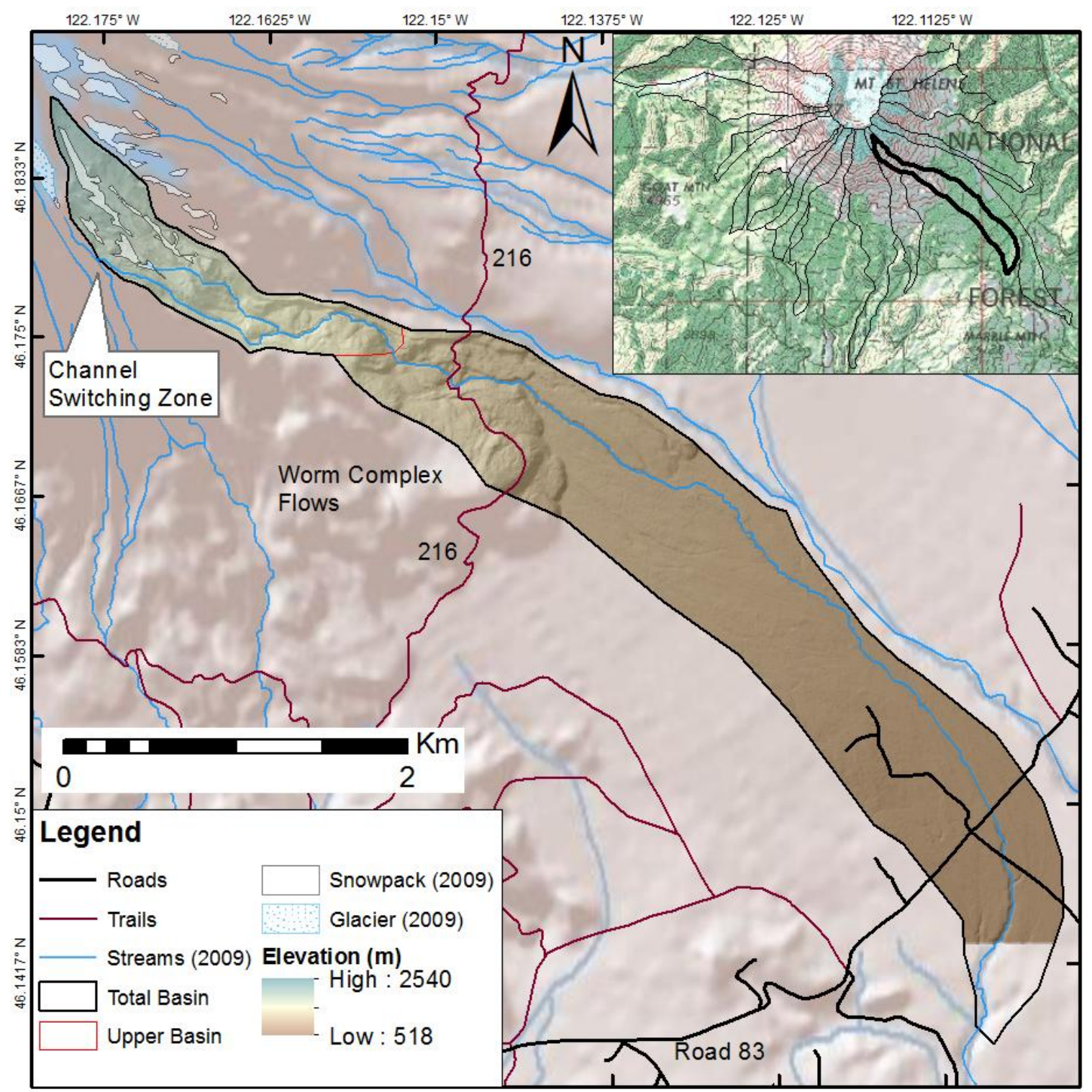

Figure 36: Map of Worm Flows Drainage located in the southeastern quadrant of Mount St. Helens between the Pine Creek and June Lake drainages. The upper basin does not host a glacier or extend to the crater rim, but there is a possible channel switching zone between the June Lake Glacier and this drainage. This drainage did not experience a debris flow in 2006.

secondary channel that follows a ridge forming the southern basin boundary. This ridge crosses the upper basin boundary at 1,890 m (UTM 10N563627E 5114275N) where there is evidence of past channel switching which diverts runoff from the June Lake Glacier into the Worm Flows Drainage Basin (Figure 37). This channel is apparently 


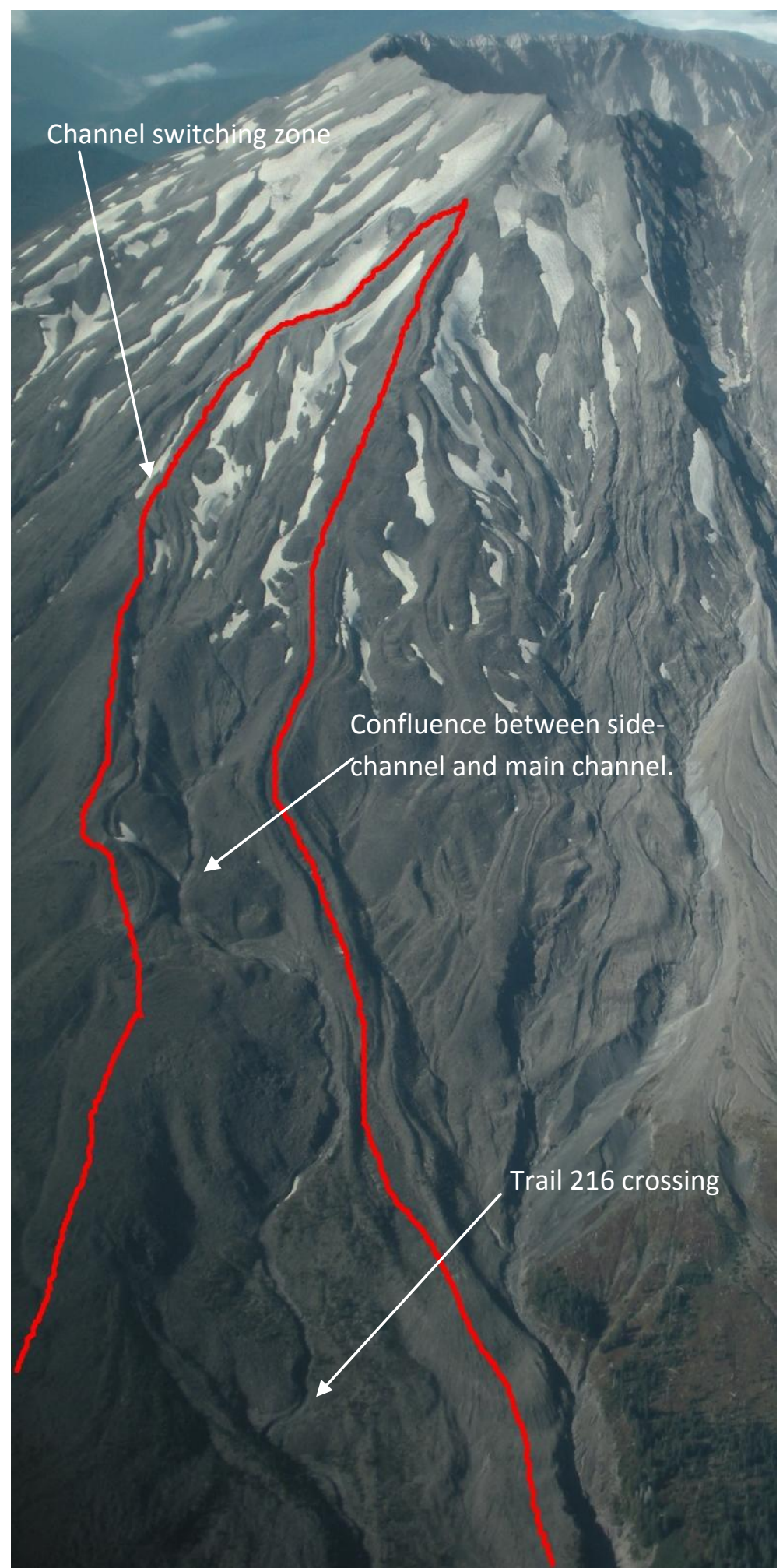

Figure 37: View of the Worm Flows Basin courtesy of Kendra Williams. The upper basin boundary is just downslope of the channel confluence. The red lines designate the total basin boundaries. 
abandoned or only active during times of high snow melt runoff.

Determination of Initiation Zone

Although evidence of past debris flows were observed along Trail 216, there was also minor vegetation observed in the channel and unraveling of the channel walls. Also, comparison of 2006 and 2009 ortho imagery did not reveal evidence of a recent debris flow initiation site or depositional fan. Therefore, it was determined that this drainage did not experience a debris flow in 2006.

\section{Data Processing}

\section{$\underline{\text { Sieve Results }}$}

No soil samples were taken from the Worm Flows Drainage.

\section{$\underline{\text { Basin Attributes }}$}

There was no initiation zone found in the Worm Flows Drainage for a 2006 debris flow, so no data were recorded related to debris flows. A full summary of the basin attributes is listed in Table 10. In summary, the geologic units of the upper basin are $88 \%$ unconsolidated (volcaniclastics, alluvium, and colluvium), 10\% bedrock (volcanics, andesite, and basalt), and over $1 \%$ snowpack and ice according to the geologic map (WaDNR, 2010). The measured extents of the upper basin geology are $8 \%$ snowpack and ice, 53\% consolidated bedrock exposures, and 39\% unconsolidated deposits. 
Table 10: Worm Flows Drainage Basin attributes.

\begin{tabular}{|c|c|c|c|c|}
\hline \multirow{2}{*}{$\begin{array}{l}\text { Basin Attributes } \\
\text { Total Basin }\end{array}$} & & \multirow[t]{2}{*}{ Geologic Units * } & \multicolumn{2}{|c|}{$\%$ Basin } \\
\hline & & & Total & Upper \\
\hline Area $\left(m^{2}\right)$ & $4,866,710$ & Water & & \\
\hline Comparative size rank & $8^{\text {th }}$ & ice & 0.2 & 1.3 \\
\hline Highest elevation (m) & 2,303 & $\underline{\text { Volcanics }}$ & & \\
\hline Lowest elevation (m) & 797 & Qv(sh) & & \\
\hline Height (m) & 1,506 & $\underline{\text { Andesite }}$ & & \\
\hline Length $(\mathrm{m})$ & 9,447 & MOian & & \\
\hline Gradient & 0.16 & MOva(2) & & \\
\hline \multirow[t]{2}{*}{ MRN } & 0.68 & Qiad(1) & & \\
\hline & & Qiad(2) & & \\
\hline$\underline{\text { Upper Basin }}$ & & QPLiad(g) & & \\
\hline Area $\left(m^{2}\right)$ & 852,581 & Qva(1sh) & & \\
\hline Comparative size rank & $11^{\text {th }}$ & Qva(2sh) & 30.0 & 88.4 \\
\hline Highest elevation (m) & 2,303 & Basalt & & \\
\hline Lowest elevation (m) & 1,300 & Qvb(2sh) & & \\
\hline Height (m) & 1,003 & $\underline{\text { Volcaniclastics }}$ & & \\
\hline Length $(\mathrm{m})$ & 2,980 & $\operatorname{MOvc}(2)$ & & \\
\hline Gradient & 0.34 & OEvc & & \\
\hline MRN & 1.09 & Qvc(1sh) & 34.7 & \\
\hline Percent vegetation (\%) & 0.4 & Qvc(2sh) & 30.6 & \\
\hline Percent steep slope (\%) & 33 & Qvc(sh) & & \\
\hline \multirow[t]{2}{*}{ Avg. annual precip. (m) } & 4.0 & Qvp(3sh) & & \\
\hline & & Ovt(1) & & \\
\hline Glacier & & $\underline{\text { Alluvium }}$ & & \\
\hline Area $\left(m^{2}\right)$ & - & Qa & & \\
\hline Retreat distance $(\mathrm{m})$ & - & Qgu & & \\
\hline \multirow[t]{2}{*}{ Percent change in area (\%) } & - & Colluvium & & \\
\hline & & Qvl(3sh) & 4.5 & 10.4 \\
\hline \multicolumn{5}{|l|}{ Initiation } \\
\hline Elevation (m) & - & Summary & & \\
\hline Direct connection to glacier & - & Ice & 0.2 & 1.3 \\
\hline Distance from glacier (m) & - & Bedrock & 30.0 & 88.4 \\
\hline \multirow[t]{5}{*}{ Type } & - & Unconsolidated & 69.8 & 10.4 \\
\hline & & Measured Extents ** & & \\
\hline & & Snowpack and Ice & & 8.3 \\
\hline & & Consolidated Bedrock & & 52.7 \\
\hline & & Unconsolidated & & 39.0 \\
\hline
\end{tabular}

* data from WaDNR, 2010.

** data from measured extents on 2009 ortho imagery (USDA-FSA, 2009). 


\section{JUNE LAKE DRAINAGE BASIN}

\section{Introduction}

The June Lake Drainage Basin is located in the southern quadrant of Mount St. Helens between Worm Flows to the east and Swift Creek to the west (Figure 15, Figure 38). The upper basin is defined by a lava flow ridge to the west and a ridge to the east that together form a wide $(300 \mathrm{~m})$ depression below the crater rim. This depression hosts a long, narrow glacier about $850 \mathrm{~m}$ long according to measurements taken from 2009 orthophotographs (USDA-FSA, 2009). At the lower end of the valley, it narrows into a corridor for the main channel that ends with a waterfall at 1,835 $\mathrm{m}$ elevation (UTM 10N563731E 5114152N) (Figure 39). Just above the waterfall is a zone of complex fluvial channels and deposits which indicate that the dominant runoff channel has previously switched channels between the lower June Lake Drainage and the Worm Flows Drainage.

Below the waterfall, the defined boundary of the total basin widens to include the surrounding lava flows and ravines which are part of the larger June Lake Drainage Basin. The glacial runoff that flows through the 2006 debris flow channel, actually bypasses June Lake because of a built-up sequence of lahar and debris flow levees and deposits. However, June Lake is fed by at least two waterfalls on the eastern side that emerge from the foot of the lava flows near UTM 10565230E 5111601N. Stream flow out of June Lake merges with the glacial runoff in the main channel downslope from the lake. 


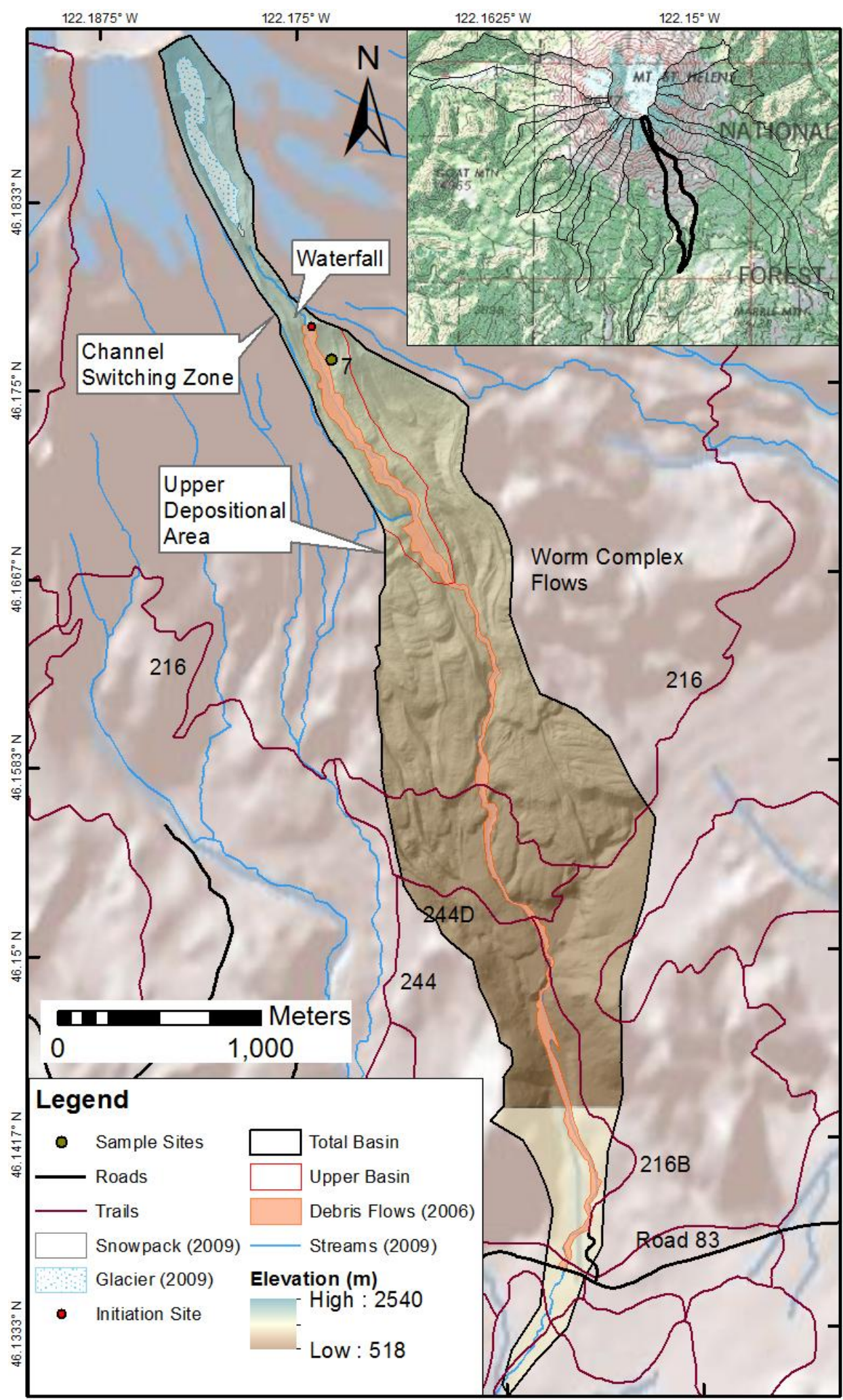

Figure 38: Map of June Lake Drainage located in the southern quadrant of Mount St. Helens between the Worm Flows and Swift Creek drainages. This drainage did experience a debris flow in 2006. The yellow area is beyond the range of LiDAR data. 


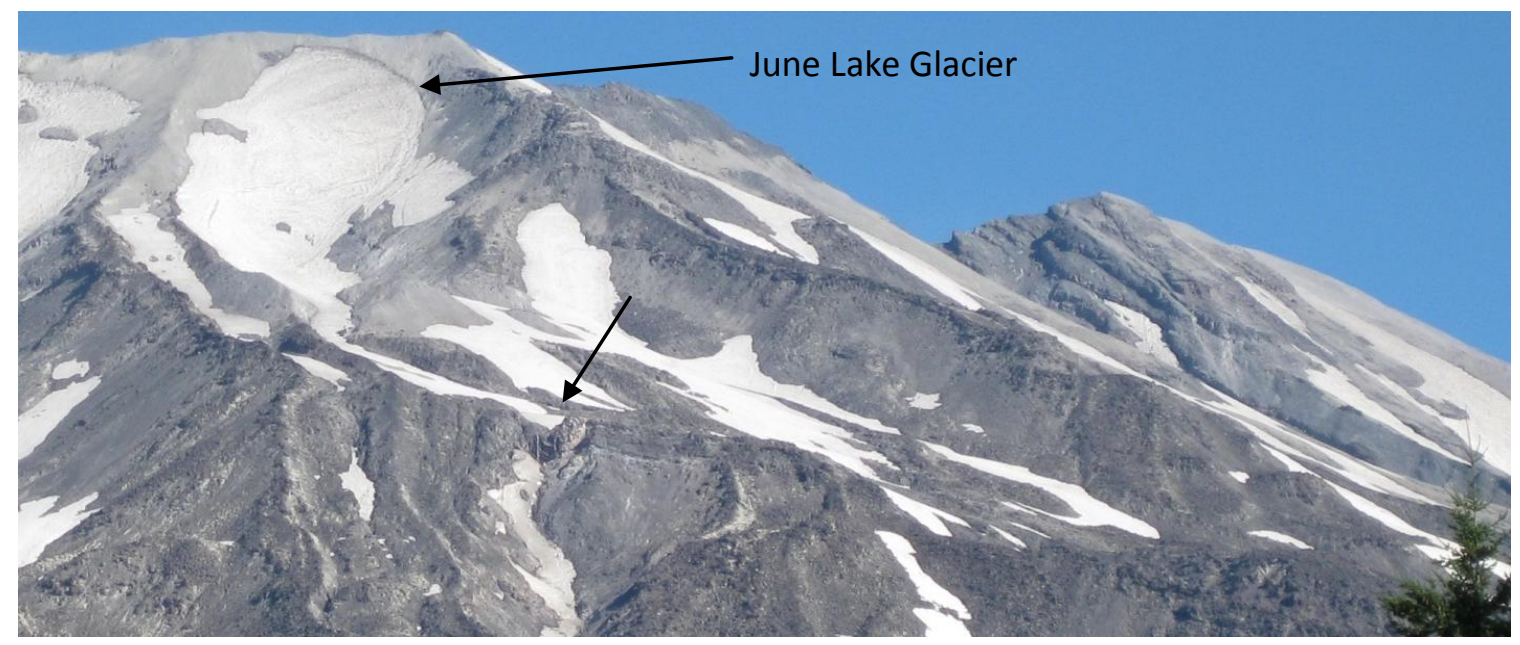

Figure 39: View of a portion of the June Lake upper basin. The ridge on the left defines the western boundary, while the right boundary is more complex. The waterfall (arrowed) marks the lower extent of the channel switching zone. Soil samples were taken in the hollow below the ridge on the right flank of the waterfall.

The lowest extent of the total basin ends about $700 \mathrm{~m}$ below Road 83, where streams from a wetland area north of Marble Mountain merge with the flow from the June Lake Drainage Basin. The main stream continues about three kilometers around the west side of Marble Mountain before merging into Swift Creek, which flows three more kilometers before emptying into the west end of Swift Reservoir near the dam.

\section{Determination of Initiation Zone}

Field observations found prodigious evidence of unstable slopes and landslide scarps along the channel banks in the upper basin. Determining the specific initiation source of the 2006 debris flow was difficult. Comparison of 2006 and 2009 ortho imagery was inconclusive because of poor resolution and sun shadows on the western bank; however, the area around and below the waterfall at 1,830 m elevation show possible changes due to channel wall erosion and landslides (Figure 40). Therefore, it 

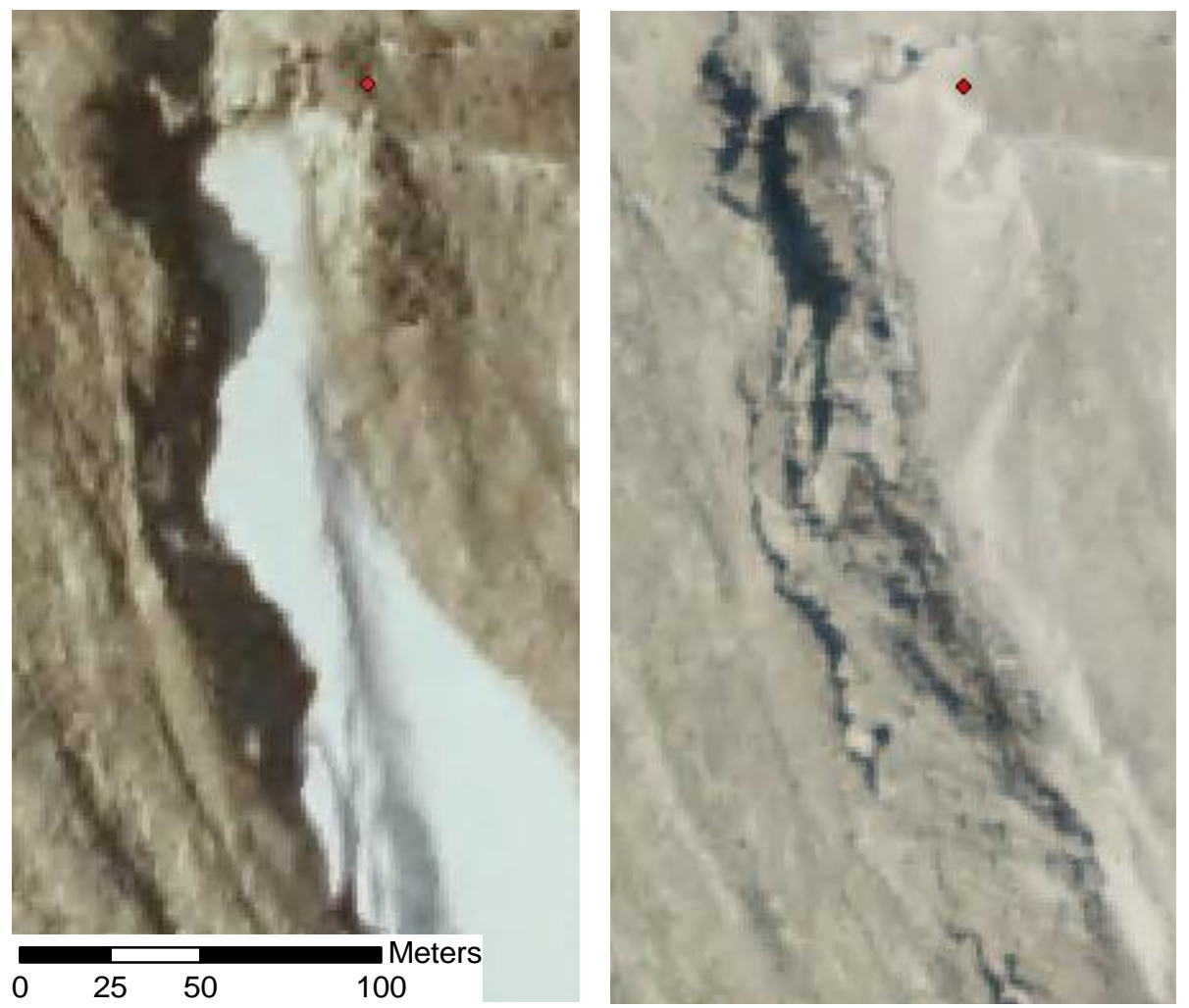

Figure 40: Comparison of 2006 (left) and 2009 (right) ortho imagery showing the initiation zone of the 2006 June Lake Debris Flow (USDA-FSA, 2006; USDAFSA, 2009). There is some indication of a landslide on the east side of the channel below the waterfall (below the red dot). Snow cover on the western channel bank prevents age verification of landslide scarps found there during field observations. The dots are in the same spatial location in both images (UTM 10N563735E 5114126N). North is up.

was determined that a landslide on the channel wall above $1,620 \mathrm{~m}$ and below $1,830 \mathrm{~m}$ elevation is the most-likely initiation site of the 2006 June Lake Debris Flow.

\section{Data Processing}

\section{Sieve Results}

Sieve results of the soil samples from the June Lake Drainage Basin are shown in Table 11 along with average values and standard deviation. The average bulk density 
Table 11: Sieve analysis for the soil samples taken in the June Lake Drainage. The sample is over half sand of coarse and fine sized grains.

\begin{tabular}{|c|c|c|c|c|c|c|c|}
\hline \multirow[t]{2}{*}{ Sample \# } & \multirow{2}{*}{$\begin{array}{l}\text { Bulk } \\
\text { Density } \\
\left(\mathrm{g} / \mathrm{cm}^{3}\right)\end{array}$} & \multirow{2}{*}{$\begin{array}{c}\text { Gravel } \\
(>2.0 \\
\mathrm{mm})\end{array}$} & \multirow{2}{*}{$\begin{array}{c}\text { Sand } \\
(2.0 \text { to } \\
0.063 \\
\mathrm{~mm})\end{array}$} & \multirow{2}{*}{$\begin{array}{c}\text { Silt \& Clay } \\
\text { (<0.063 } \\
\text { mm })\end{array}$} & \multicolumn{3}{|c|}{ Sand } \\
\hline & & & & & $\begin{array}{c}\text { Coarse } \\
\text { (2.0 to } \\
0.42 \\
\mathrm{~mm})\end{array}$ & $\begin{array}{c}\text { Medium } \\
\text { (0.42 to } \\
0.149 \\
\mathrm{~mm} \text { ) }\end{array}$ & $\begin{array}{c}\text { Fine } \\
(0.149 \text { to } \\
0.063 \\
\mathrm{~mm})\end{array}$ \\
\hline 7.1 & 2.1 & $28.7 \%$ & $67.2 \%$ & $4.1 \%$ & $39.6 \%$ & $31.3 \%$ & $29.1 \%$ \\
\hline 7.2 & 2.1 & $37.4 \%$ & $58.4 \%$ & $4.4 \%$ & $37.9 \%$ & $37.7 \%$ & $24.4 \%$ \\
\hline 7.3 & 2.2 & $40.7 \%$ & $64.1 \%$ & $4.3 \%$ & $35.9 \%$ & $17.1 \%$ & $47.0 \%$ \\
\hline Average & 2.2 & $35.6 \%$ & $63.2 \%$ & $4.3 \%$ & $37.8 \%$ & $28.7 \%$ & $33.5 \%$ \\
\hline Std. Dev. & 0.05 & $6.2 \%$ & $4.5 \%$ & $0.1 \%$ & $1.9 \%$ & $10.5 \%$ & $11.9 \%$ \\
\hline
\end{tabular}

was measured at $2.2 \mathrm{~g} / \mathrm{cm}^{3}$, and the average sample consisted of $36 \%$ gravel, $63 \%$ sand, and $4 \%$ silt and clay.

\section{$\underline{\text { Basin Attributes }}$}

The initiation zone was found in the June Lake Drainage at an elevation of 1,830 m, within an area mapped as andesite flows (Qva) (WaDNR, 2010). The geologic units of the upper basin were mapped as $46 \%$ bedrock (volcanics, andesite, and basalt), $30 \%$ unconsolidated (volcaniclastics, alluvium, and colluvium), and $25 \%$ ice according to the geologic map (WaDNR, 2010). The measured extents of the upper basin geology are $42 \%$ consolidated bedrock exposures, $46 \%$ unconsolidated deposits, and $12 \%$ snowpack and ice. A full summary of the basin attributes is listed in Table 12.

As measured on the 2009 orthophotographs, the June Lake Glacier covered an area of $72,910 \mathrm{~m}^{2}$, or $12 \%$, of the upper basin (USDA-FSA, 2009). Between 1998 and 2009 the glacier decreased in surface area by 39\%, and retreated upslope by $71 \mathrm{~m}$ (USGS, 2002; USDA-FSA, 2009). 
Table 12: June Lake Drainage Basin attributes.

\begin{tabular}{|c|c|c|c|c|}
\hline \multirow{2}{*}{$\begin{array}{l}\text { Basin Attributes } \\
\underline{\text { Total Basin }}\end{array}$} & & \multirow[t]{2}{*}{ Geologic Units* } & \multicolumn{2}{|c|}{$\%$ Basin } \\
\hline & & & Total & Upper \\
\hline Area $\left(m^{2}\right)$ & $3,702,330$ & Water & & \\
\hline Comparative size rank & $10^{\text {th }}$ & ice & 4.2 & 25.0 \\
\hline Highest elevation (m) & 2,491 & $\underline{\text { Volcanics }}$ & & \\
\hline Lowest elevation (m) & 780 & Qv(sh) & 0.0 & 0.2 \\
\hline Height (m) & 1,711 & Andesite & & \\
\hline Length ( $\mathrm{m})$ & 7,710 & MOian & & \\
\hline Gradient & 0.22 & MOva(2) & & \\
\hline \multirow[t]{2}{*}{ MRN } & 0.89 & Qiad(1) & & \\
\hline & & Qiad(2) & & \\
\hline$\underline{\text { Upper Basin }}$ & & QPLiad(g) & & \\
\hline Area $\left(m^{2}\right)$ & 625,321 & Qva(1sh) & & \\
\hline Comparative size rank & $13^{\text {th }}$ & Qva(2sh) & 61.2 & 45.3 \\
\hline Highest elevation (m) & 2,491 & Basalt & & \\
\hline Lowest elevation (m) & 1,287 & Qvb(2sh) & & \\
\hline Height (m) & 1,204 & $\underline{\text { Volcaniclastics }}$ & & \\
\hline Length $(\mathrm{m})$ & 3,130 & $\operatorname{MOvc}(2)$ & 12.5 & \\
\hline Gradient & 0.38 & OEvc & & \\
\hline MRN & 1.52 & Qvc(1sh) & 0.2 & \\
\hline Percent vegetation (\%) & 0.0 & Qvc(2sh) & 16.3 & 2.9 \\
\hline Percent steep slope (\%) & 43 & Qvc(sh) & & \\
\hline \multirow[t]{2}{*}{ Avg. annual precip. (m) } & 4.0 & Qvp(3sh) & & \\
\hline & & Ovt(1) & & \\
\hline$\underline{\text { Glacier }}$ & & $\underline{\text { Alluvium }}$ & & \\
\hline Area $\left(m^{2}\right)$ & 72,910 & Qa & & \\
\hline Retreat distance $(\mathrm{m})$ & 71 & Qgu & & \\
\hline \multirow[t]{2}{*}{ Percent change in area (\%) } & -40 & $\underline{\text { Colluvium }}$ & & \\
\hline & & Qvl(3sh) & 5.8 & 26.7 \\
\hline \multicolumn{5}{|l|}{ Initiation } \\
\hline Elevation (m) & 1,830 & Summary & & \\
\hline Direct connection to glacier & Yes & Ice & 4.2 & 25.0 \\
\hline Distance from glacier (m) & 622 & Bedrock & 61.2 & 45.5 \\
\hline \multirow[t]{5}{*}{ Type } & Landslide & Unconsolidated & 34.6 & 29.6 \\
\hline & & Measured Extents ** & & \\
\hline & & Snowpack and Ice & & 11.8 \\
\hline & & Consolidated Bedrock & & 42.0 \\
\hline & & Unconsolidated & & 46.2 \\
\hline
\end{tabular}

* data from WaDNR, 2010.

** data from measured extents on 2009 ortho imagery (USDA-FSA, 2009). 


\section{SWIFT CREEK DRAINAGE BASIN}

\section{Introduction}

The Swift Creek Drainage Basin is located in the southern quadrant of Mount St. Helens between June Lake to the east and Snowfield to the west (Figure 15, Figure 41). The Monitor Ridge Lava Flow forms part of the western boundary. The upper basin contains one glacier and multiple large snowpacks located in andesitic lava flow terrain similar to the neighboring June Lake, Worm Flows, and Pine Creek drainages (Figure 42). The lower boundary of the upper basin extends down to 1,230 m elevation at the lowest and includes two branches of Swift Creek. The eastern and western branches cross the upper basin boundary at an elevation of about 1,240 m, but separated by $315 \mathrm{~m}$. These two branches finally merge near 930 m elevation and individually have poorly defined drainage basins, therefore were joined together. Along these two main channels are mapped zones of lahar deposits (Qvl) (WaDNR, 2010). The total basin boundary extends about $3.4 \mathrm{~km}$ beyond the Road 83 where the channel merges with streams draining the June Lake and Marble Mountain area. Water from this drainage continues about three more kilometers southward before emptying into the west end of Swift Reservoir near the dam.

Although no 2006 debris flow was observed for this drainage basin, field observations found much evidence of past debris flow activity on the eastern branch of Swift Creek. The western branches were observed to have overgrown banks. Landsat image comparison found definitive evidence of two large debris flow depositional fans 


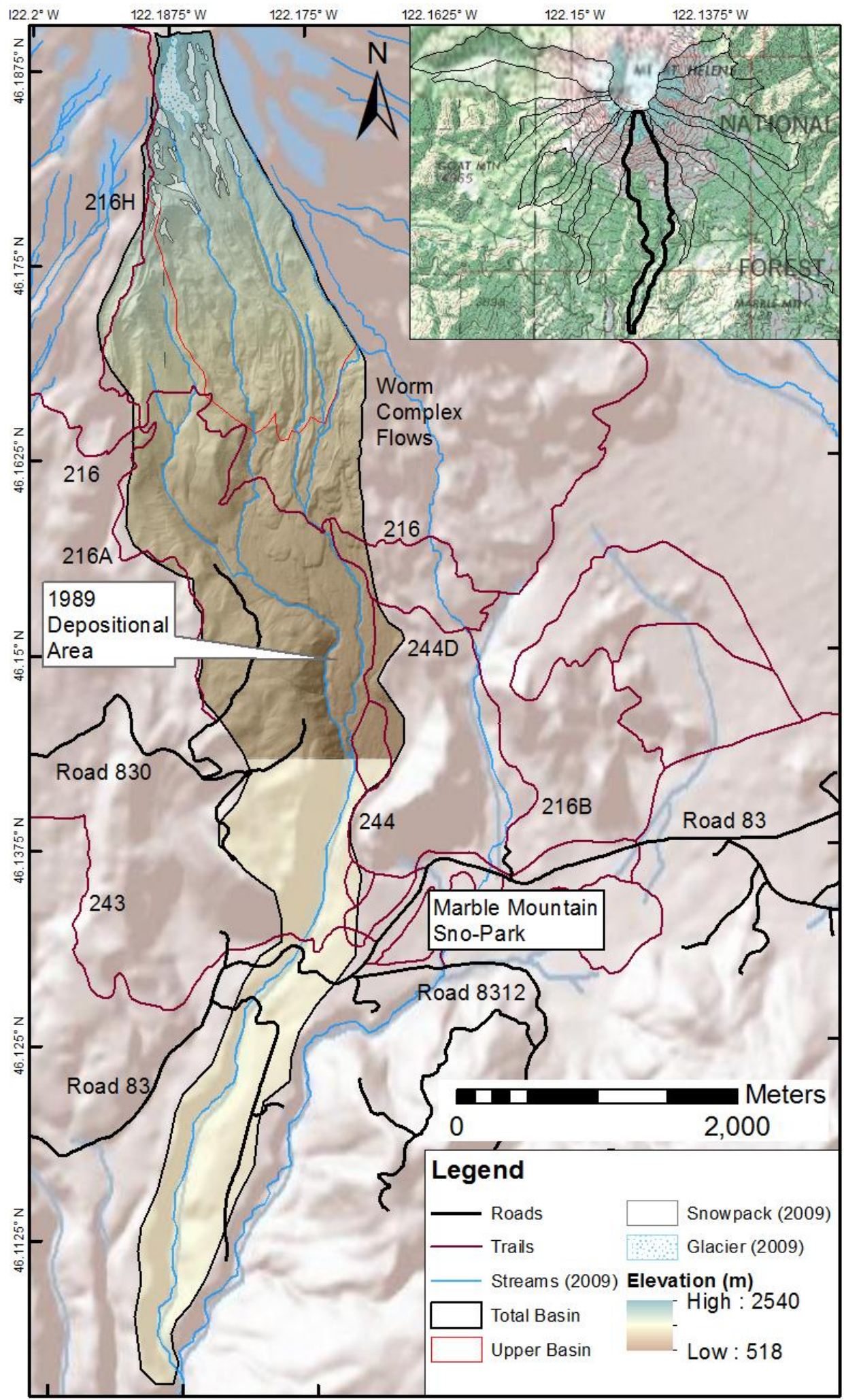

Figure 41: Map of the Swift Creek Drainage located in the southern quadrant of Mount St. Helens between the June Lake and Snowfield drainages. This drainage did not experience a debris flow in 2006. The yellow area is beyond the range of LiDAR data. 


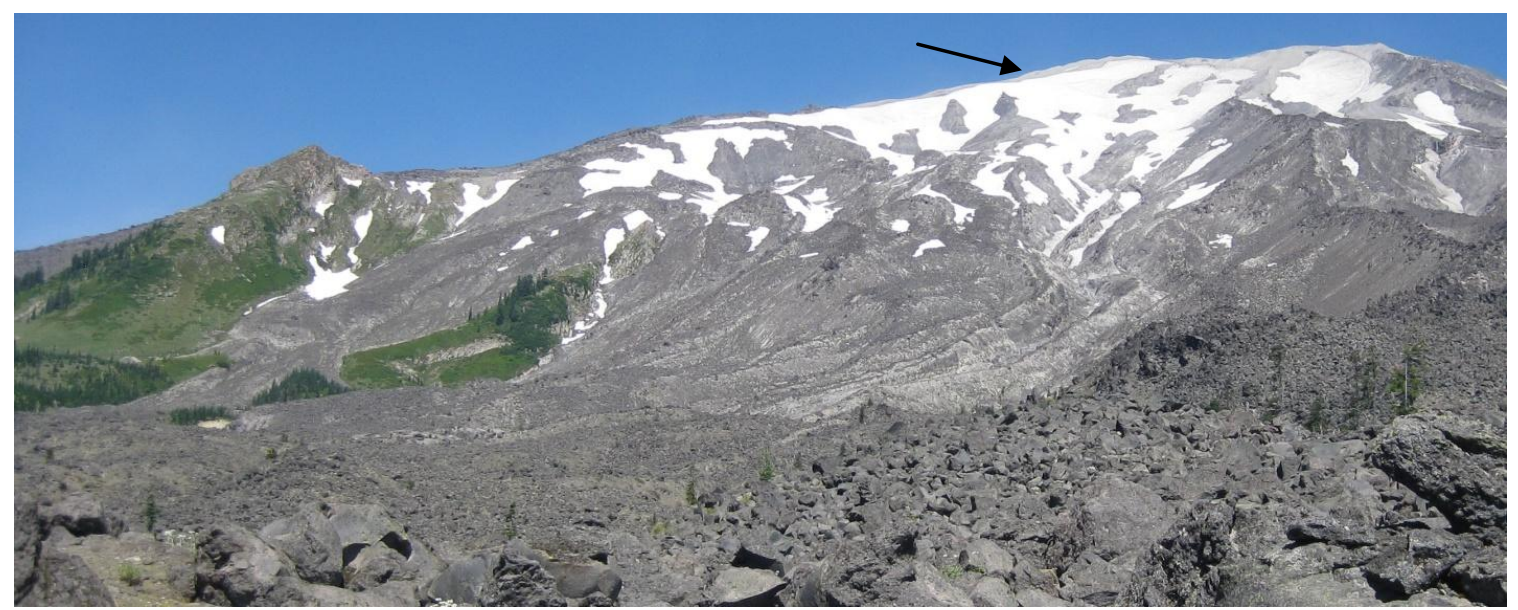

Figure 42: View of the Swift Creek upper basin from Trail 216 in an area of andesite flows. View is northward. The Swift Glacier (arrowed) is not visible as a distinct feature. The Monitor Ridge lava flow forms the boundary on the left horizon. The 1,823 $\mathrm{m}$ dome visible on the far left is unnamed on all maps.

on Swift Creek near 1,100 m elevation that were deposited between images taken in 1989 and 1990 (NASA Landsat Program, 1984-2009). One depositional area of approximately $65,500 \mathrm{~m}^{2}$ is centered at UTM $10 \mathrm{~N} 562985 \mathrm{E} 5112720 \mathrm{~N}$, while the other of about $60,000 \mathrm{~m}^{2}$ is centered at UTM 10N563294E 5111924N.

\section{Determination of Initiation Zone}

Although there is evidence of past debris flow deposits in the Swift Creek Drainage Basin and along the upper channel, there is no fresh evidence of recent levees or fan deposits. Also, comparison of 2006 and 2009 ortho imagery did not reveal evidence of a recent debris flow initiation site or depositional fan. Therefore, it was determined that this drainage did not have a debris flow in 2006. 


\section{Data Processing}

\section{Sieve Results}

No soil samples were taken from the Swift Creek Drainage.

\section{$\underline{\text { Basin Attributes }}$}

There was no initiation zone found in the Swift Creek Drainage for a 2006 debris flow, therefore no data related to debris flows were recorded. A full summary of the basin attributes is listed in Table 13. In summary, the geologic units of the upper basin are $20 \%$ unconsolidated (volcaniclastics, alluvium, and colluvium), 66\% bedrock (volcanics, andesite, and basalt), and 14\% ice according to the geologic map (WaDNR, 2010). The measured extents of the upper basin geology are $9 \%$ snowpack and ice, $49 \%$ consolidated bedrock exposures, and $42 \%$ unconsolidated deposits.

As of 2009 , the Swift Glacier covered an area of $104,425 \mathrm{~m}^{2}$, or $4 \%$, of the upper basin (USDA-FSA, 2009). Between 1998 and 2009 the glacier decreased in surface area by $65 \%$, and retreated upslope by 403 m (USGS, 2002; USDA-FSA, 2009). The 2009 orthophotographs also revealed that the glacier had separated into fragments with only the largest showing a bergschrund (USDA-FSA, 2009).

\section{SNOWFIELD DRAINAGE BASIN}

\section{Introduction}

The Snowfield Drainage Basin (Figure 15, Figure 43) is located in the southern quadrant of Mount St. Helens between Swift Creek to the east and Dryer Glacier to the 
Table 13: Swift Creek Drainage Basin attributes.

\begin{tabular}{|c|c|c|c|c|}
\hline \multirow{2}{*}{$\begin{array}{l}\text { Basin Attributes } \\
\text { Total Basin }\end{array}$} & & \multirow[t]{2}{*}{ Geologic Units * } & \multicolumn{2}{|c|}{$\%$ Basin } \\
\hline & & & Total & Upper \\
\hline Area $\left(m^{2}\right)$ & $9,326,490$ & $\underline{\text { Water }}$ & & \\
\hline Comparative size rank & $2^{\text {nd }}$ & ice & 3.5 & 13.6 \\
\hline Highest elevation (m) & 2,512 & $\underline{\text { Volcanics }}$ & & \\
\hline Lowest elevation (m) & 512 & Qv(sh) & 0.1 & 0.3 \\
\hline Height (m) & 2,000 & Andesite & & \\
\hline Length (m) & 10,603 & MOian & & \\
\hline Gradient & 0.19 & MOva(2) & & \\
\hline \multirow[t]{2}{*}{ MRN } & 0.65 & Qiad(1) & & \\
\hline & & Qiad(2) & & \\
\hline Upper Basin & & QPLiad(g) & & \\
\hline Area $\left(m^{2}\right)$ & $2,392,670$ & Qva(1sh) & 30.5 & 0.2 \\
\hline Comparative size rank & $2^{\text {nd }}$ & Qva(2sh) & 28.6 & 65.8 \\
\hline Highest elevation (m) & 2,512 & Basalt & & \\
\hline Lowest elevation (m) & 1,226 & Qvb(2sh) & & \\
\hline Height (m) & 1,286 & $\underline{\text { Volcaniclastics }}$ & & \\
\hline Length (m) & 3,045 & MOvc(2) & 0.0 & \\
\hline Gradient & 0.42 & OEvc & & \\
\hline MRN & 0.83 & Qvc(1sh) & 18.0 & \\
\hline Percent vegetation (\%) & 3.2 & Qvc(2sh) & 9.6 & 9.6 \\
\hline Percent steep slope (\%) & 36 & Qvc(sh) & & \\
\hline \multirow[t]{2}{*}{ Avg. annual precip. (m) } & 4.0 & Qvp(3sh) & & \\
\hline & & Ovt(1) & & \\
\hline Glacier & & Alluvium & & \\
\hline Area $\left(m^{2}\right)$ & 104,425 & Qa & & \\
\hline Retreat distance $(\mathrm{m})$ & 403 & Qgu & & \\
\hline \multirow[t]{2}{*}{ Percent change in area (\%) } & -65 & Colluvium & & \\
\hline & & Qvl(3sh) & 9.8 & 10.6 \\
\hline \multicolumn{5}{|l|}{ Initiation } \\
\hline Elevation (m) & - & Summary & & \\
\hline Direct connection to glacier & - & Ice & 3.5 & 13.6 \\
\hline Distance from glacier $(\mathrm{m})$ & - & Bedrock & 59.2 & 66.3 \\
\hline \multirow[t]{5}{*}{ Type } & - & Unconsolidated & 37.4 & 20.2 \\
\hline & & Measured Extents ** & & \\
\hline & & Snowpack and Ice & & 9.0 \\
\hline & & Consolidated Bedrock & & 48.9 \\
\hline & & Unconsolidated & & 42.1 \\
\hline
\end{tabular}

* data from WaDNR, 2010.

** data from measured extents on 2009 ortho imagery (USDA-FSA, 2009). 


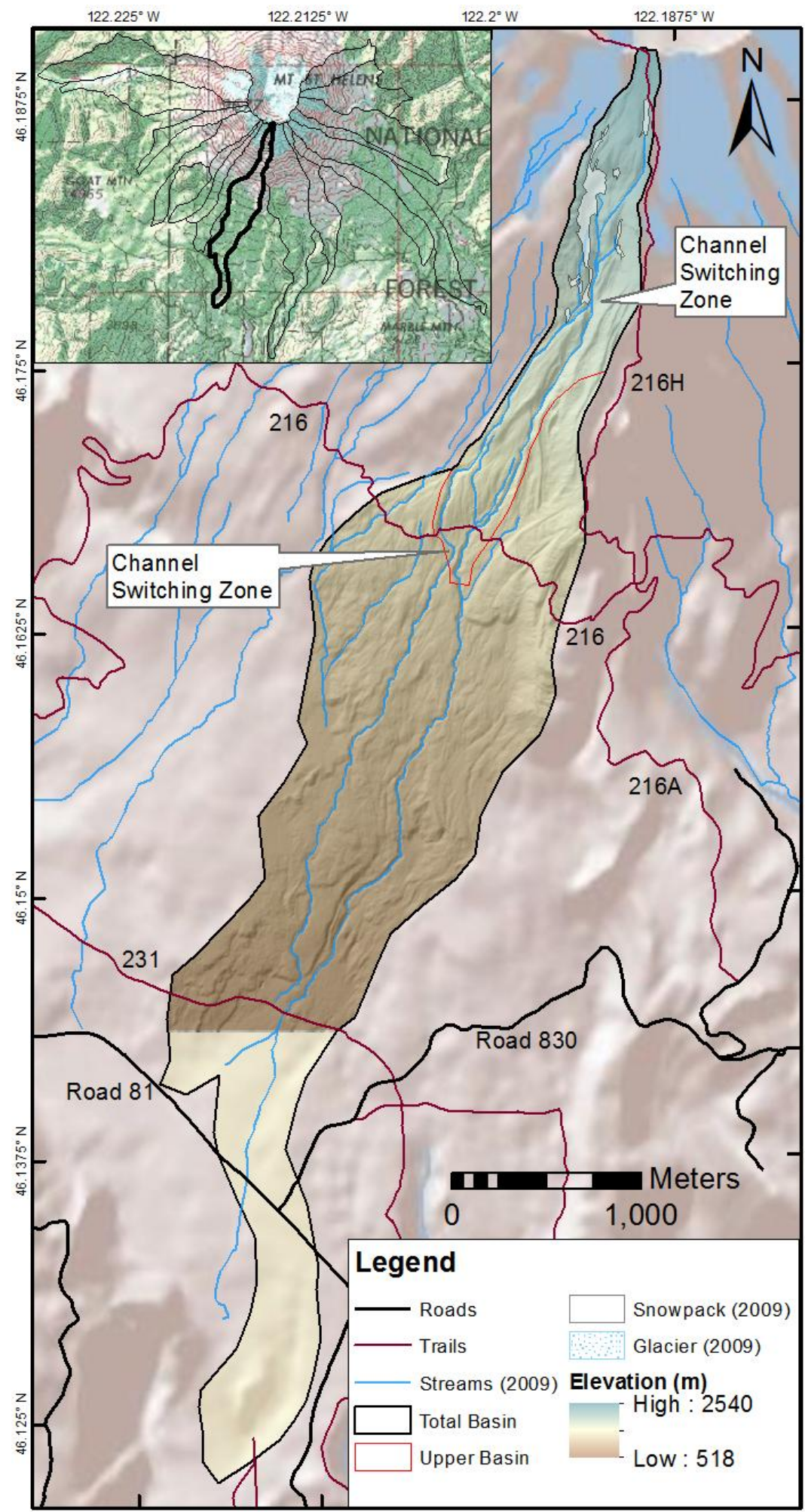

Figure 43: Map of the Snowfield Drainage located in the southern quadrant of Mount St. Helens between the Swift Creek and Dryer Glacier drainages. This drainage did not experience a debris flow in 2006. The yellow area is beyond the range of LiDAR data. 
west. The slopes between Monitor Ridge and Butte Camp Dome host many small rivulets and ravines; it was difficult to determine basin boundaries for this quadrant of Mount St. Helens.

The upper basin of Snowfield does not currently host a glacier, but does feature a hollow with a permanent snow pack. This drainage hugs the western edge of the Monitor Ridge lava flow and contains two main channels that have in the past switched hosting the dominant runoff (Figure 44). The switching points were observed to be at 1,896 m (UTM 10N562255E 5114115N) and 1,368 m elevation (UTM 10N561577E 5112823N). The upper basin includes both switching zones and extends about $300 \mathrm{~m}$ downslope from the Trail 316 crossing of the eastern channel. Both channels currently host ephemeral streams and feature deeply eroded ravines, which are about 5 to $10 \mathrm{~m}$ deep at the junction with Trail 216. However, the eastern channel was determined to

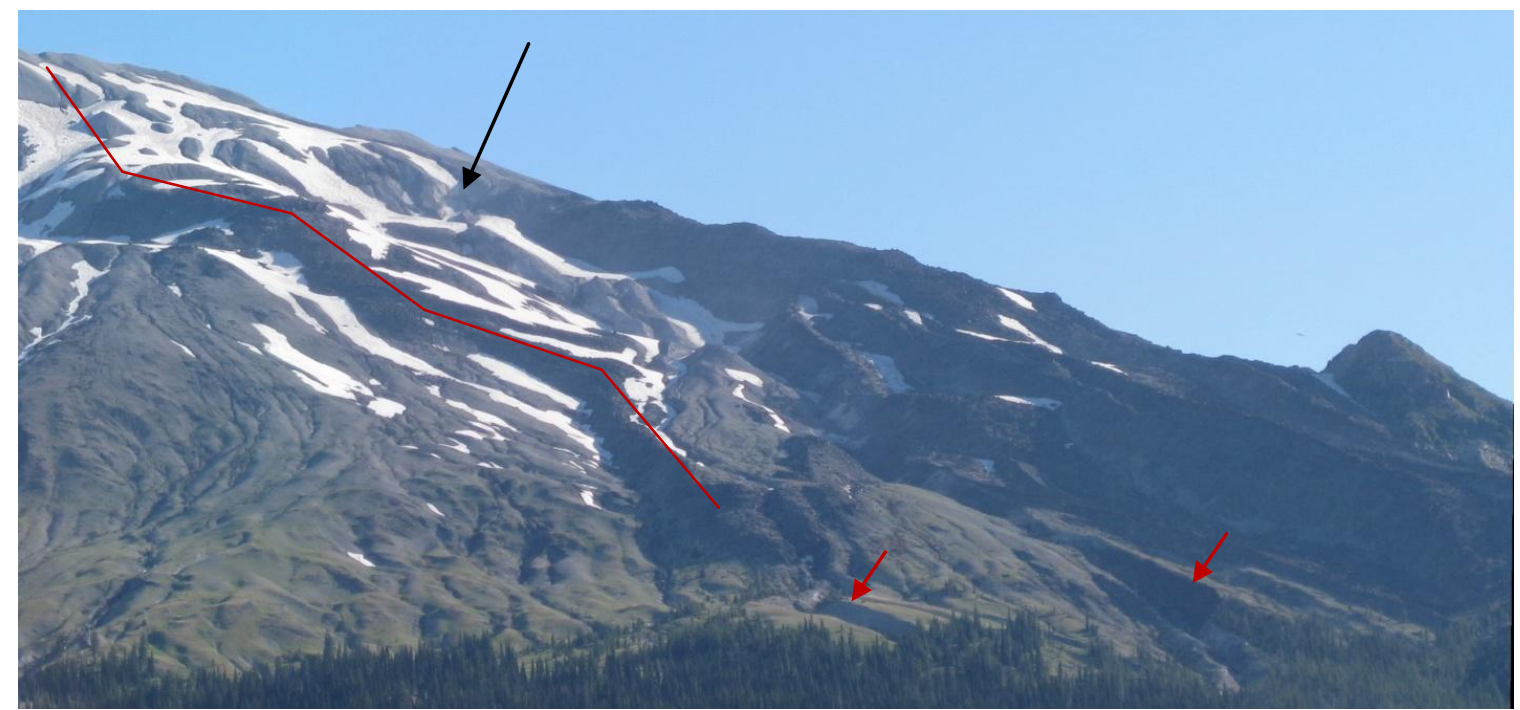

Figure 44: View of the Snowfield upper basin taken in early August 2010 with snow remaining on the upper slopes. The Snowfield hollow is indicated by the large black arrow and the red line roughly defines the western boundary. The Monitor Ridge lava flow that dominates the horizon on the right defines the eastern boundary. The two channels can best be seen near the treeline (red arrows). View is to the northeast from Redrock Pass. 
be more recently affected by debris flow activity, as it exhibited less vegetation and increased channel erosion. Therefore it was designated the dominant channel of the drainage basin.

The Snowfield total basin extends down to Road 81 and includes the junction with Road 81-830 which accesses the Climber's Bivouac. During the winter of 2006, the segment of Road 81 between Redrock Pass and the junction with Road 81-830 was closed due to flood damage (USDA-FS, 2007). The total basin boundary extends a further $1.7 \mathrm{~km}$ beyond Road 81 to near the upper entrance to Ape Cape. In this area the geology is mapped as basalt flows which can be traced through the Ape Cave area and down $8.5 \mathrm{~km}$ to the region between Swift Reservoir and Yale Lake. Northwest of Ape Cave, the stream from the Snowfield Drainage Basin merges with runoff from the Cinnamon Peak region. Water from this drainage continues to flow southward on the surface but disappears underground after about two kilometers, before flowing far enough south to reach the main Ape Cave entrance. Groundwater in this area likely joins the West Fork of the Swift Creek and enters the west end of Swift Reservoir.

\section{Determination of Initiation Zone}

Although evidence of past debris flows were observed along Trail 216 in the Snowfield Drainage Basin, there is no fresh evidence of recent levees or fan deposits. Also, comparison of 2006 and 2009 ortho imagery did not reveal evidence of a recent debris flow initiation site or depositional fan. Therefore, it was determined that this drainage did not experience a debris flow in 2006. 


\section{Data Processing}

\section{Sieve Results}

No soil samples were taken from the Snowfield Drainage.

\section{$\underline{\text { Basin Attributes }}$}

There was no initiation zone found in the Snowfield Drainage for a 2006 debris flow, therefore no data related to debris flows were recorded. A full summary of the basin attributes is listed in Table 14. In summary, the geologic units of the upper basin were mapped as $14 \%$ bedrock (volcanics, andesite, and basalt), 69\% unconsolidated (volcaniclastics, alluvium, and colluvium), and $17 \%$ ice according to the geologic map (WaDNR, 2010). The measured extents of the upper basin geology are $18 \%$ consolidated bedrock exposures, $76 \%$ unconsolidated deposits, and 6\% snowpack and ice.

As measured on the 2009 orthophotographs, the Snowfield Glacier covered an area of 43,699 $\mathrm{m}^{2}$, or 5\%, of the upper basin (USDA-FSA, 2009). Between 1998 and 2009 the glacier decreased in surface area by $76 \%$, but did not retreat upslope (USGS, 2002; USDA-FSA, 2009). The 2009 orthophotographs also revealed that the glacier had broken into fragments, none of which showed a bergschrund (USDA-FSA, 2009). Therefore, this drainage basin was classified as not hosting a glacier, but a permanent snowpack. 
Table 14: Snowfield Drainage Basin attributes.

\begin{tabular}{|c|c|c|c|c|}
\hline \multirow{2}{*}{$\begin{array}{l}\text { Basin Attributes } \\
\underline{\text { Total Basin }}\end{array}$} & & \multirow[t]{2}{*}{ Geologic Units* } & \multicolumn{2}{|c|}{$\%$ Basin } \\
\hline & & & Total & Upper \\
\hline Area $\left(m^{2}\right)$ & $5,304,460$ & Water & & \\
\hline Comparative size rank & $6^{\text {th }}$ & ice & 3.0 & 17.3 \\
\hline Highest elevation (m) & 2,520 & $\underline{\text { Volcanics }}$ & & \\
\hline Lowest elevation (m) & 735 & Qv(sh) & 0.1 & 0.4 \\
\hline Height (m) & 1,785 & Andesite & & \\
\hline Length ( $\mathrm{m})$ & 8,652 & MOian & & \\
\hline Gradient & 0.21 & MOva(2) & & \\
\hline \multirow[t]{2}{*}{ MRN } & 0.77 & Qiad(1) & & \\
\hline & & Qiad(2) & & \\
\hline$\underline{\text { Upper Basin }}$ & & QPLiad(g) & & \\
\hline Area $\left(m^{2}\right)$ & 926,223 & Qva(1sh) & & \\
\hline Comparative size rank & $9^{\text {th }}$ & Qva(2sh) & 7.9 & 5.7 \\
\hline Highest elevation (m) & 2,520 & Basalt & & \\
\hline Lowest elevation (m) & 1,332 & Qvb(2sh) & 18.2 & 7.9 \\
\hline Height (m) & 1,188 & $\underline{\text { Volcaniclastics }}$ & & \\
\hline Length $(\mathrm{m})$ & 3,162 & $\operatorname{MOvc}(2)$ & 0.0 & \\
\hline Gradient & 0.38 & OEvc & & \\
\hline MRN & 1.23 & Qvc(1sh) & 4.4 & \\
\hline Percent vegetation (\%) & 7.4 & Qvc(2sh) & 66.4 & 68.8 \\
\hline Percent steep slope (\%) & 27 & Qvc(sh) & & \\
\hline \multirow[t]{2}{*}{ Avg. annual precip. (m) } & 4.0 & Qvp(3sh) & & \\
\hline & & Ovt(1) & & \\
\hline$\underline{\text { Glacier }}$ & & Alluvium & & \\
\hline Area $\left(m^{2}\right)$ & 43,699 & Qa & & \\
\hline Retreat distance $(\mathrm{m})$ & - & Qgu & & \\
\hline \multirow[t]{2}{*}{ Percent change in area (\%) } & -76 & $\underline{\text { Colluvium }}$ & & \\
\hline & & Qvl(3sh) & & \\
\hline \multicolumn{5}{|l|}{ Initiation } \\
\hline Elevation (m) & - & Summary & & \\
\hline Direct connection to glacier & - & Ice & 3.0 & 17.3 \\
\hline Distance from glacier (m) & - & Bedrock & 26.2 & 13.9 \\
\hline \multirow[t]{5}{*}{ Type } & - & Unconsolidated & 70.8 & 68.8 \\
\hline & & Measured Extents ** & & \\
\hline & & Snowpack and Ice & & 6.4 \\
\hline & & Consolidated Bedrock & & 17.6 \\
\hline & & Unconsolidated & & 76.1 \\
\hline
\end{tabular}

* data from WaDNR, 2010.

** data from measured extents on 2009 ortho imagery (USDA-FSA, 2009). 


\section{DRYER GLACIER DRAINAGE BASIN}

Introduction

The Dryer Glacier Drainage Basin is located in the southwestern quadrant of Mount St. Helens between Snowfield to the southeast and Little Kalama to the northwest (Figure 15, Figure 45). The slopes between Monitor Ridge and Butte Camp Dome host many small rivulets and ravines; it was difficult to determine basin boundaries for this quadrant of Mount St. Helens.

The upper basin of Dryer Glacier does not currently host a glacier, but does feature permanent snowpacks drained by a single large channel (Figure 46). The basin also includes unconsolidated deposits of probable glacial origin which are mapped as volcaniclastic deposits or rocks (Qvc) (WaDNR, 2010). The central and eastern sides of the upper basin contain two regions of basalt flows with a total area of about 300,000 $\mathrm{m}^{2}$. Basalt flows are unusual on the upper slopes, but are found lower on the southwestern flanks. A long andesite flow dominates the western boundary of the upper basin. Between these flows the main channel passes through mostly unconsolidated volcaniclastic deposits, however a large bedrock exposure and waterfall can be seen at 1,777 m elevation. The lower boundary of the upper basin ends about $380 \mathrm{~m}$ below the Trail 216 crossing of the main channel. The lower boundary of the total basin extends roughly to Road 81 . This drainage basin may have been associated with the flood damage to the road reported during the 2006 storm event (USDA-FS, 2007). 


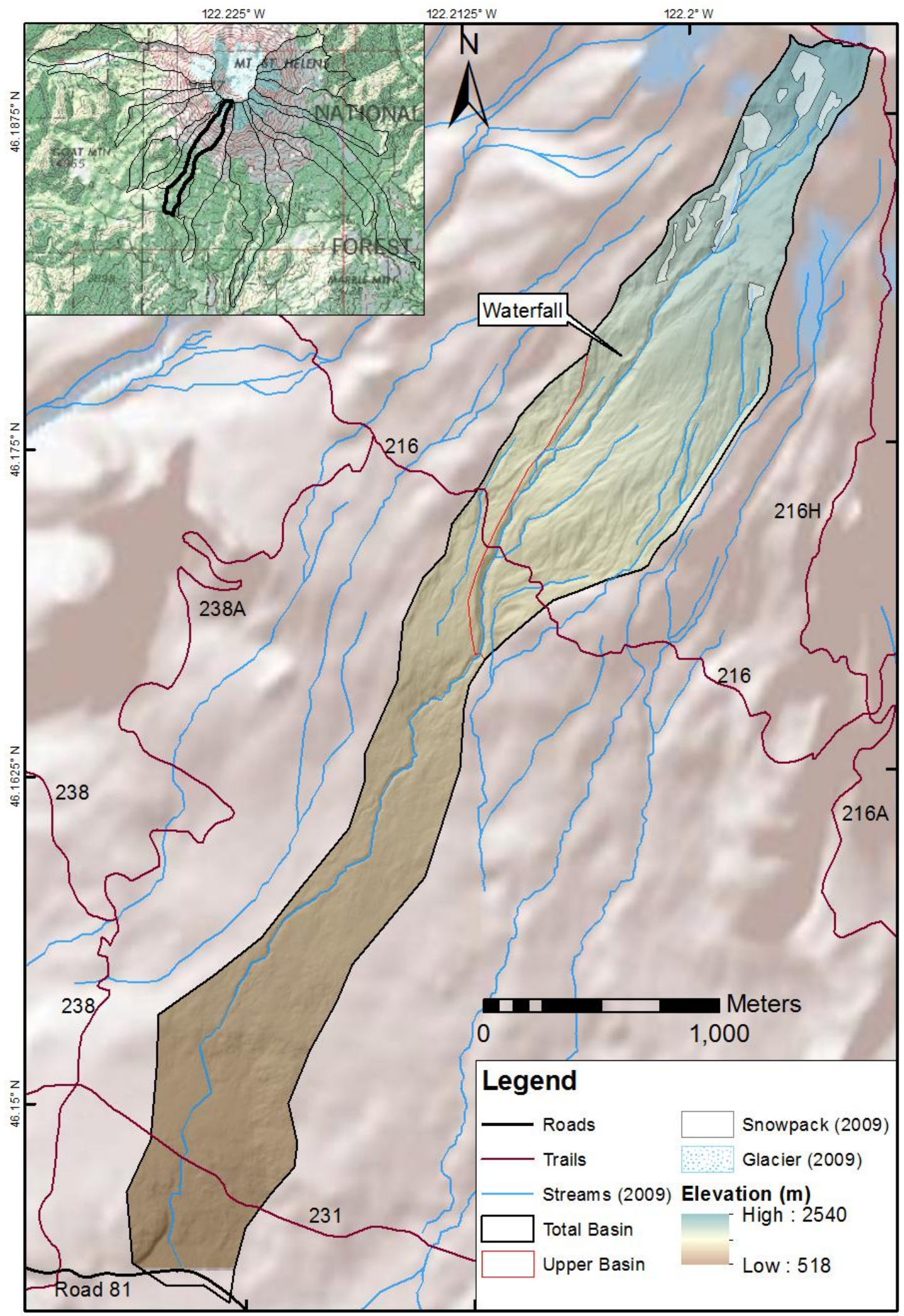

Figure 45: Map of Dryer Glacier Drainage located in the southwestern quadrant of Mount St. Helens between Snowfield and the Little Kalama Drainage. 


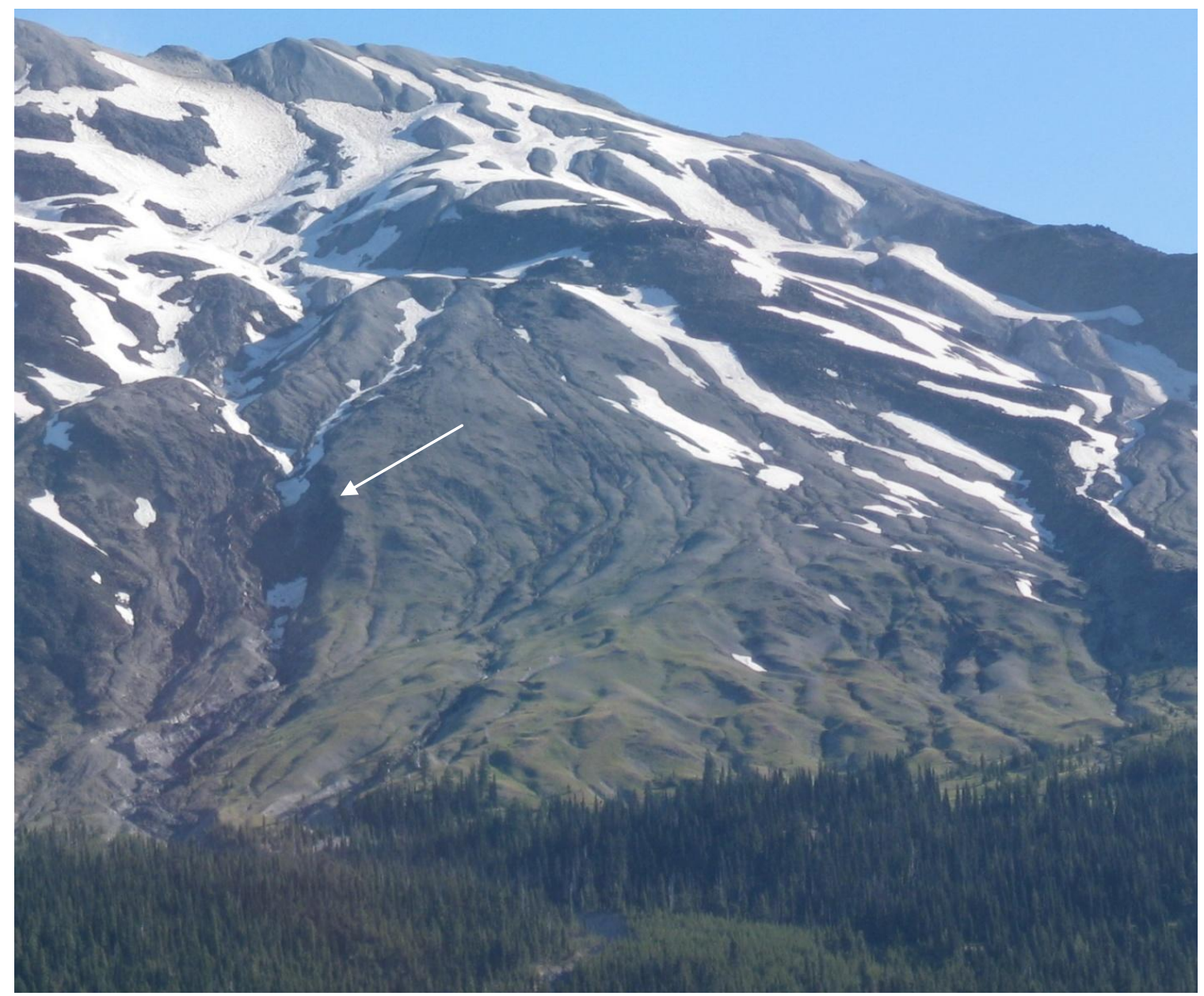

Figure 46: View of the Dryer Glacier upper basin taken in early August 2010 with snow remaining on the upper slopes. The main channel is seen on the left side of the image and extends upward through the snow packs. A large waterfall and erosional feature in the main channel is indicated by the arrow. The ridge on the right side of the image forms the southern boundary with the Snowfield Drainage Basin. View is to the northeast from Redrock Pass.

The main channel is between 5 to 15 meters deep in the upper basin and is welldefined until near the bottom of the upper basin at 1,296 m elevation where it shallows. By 1,175 m elevation the channel becomes difficult to follow on LiDAR although a channel can be traced down to the bottom of the total basin. However, divergent or vestal channels can be seen branching at that elevation. One of these channels connects to the neighboring Little Kalama Drainage, which is how the USGS digital water 
layer defined the course of this basin in 1998 and 2003 (USDA-FS, 1998; USDA-FS, 2003).

Following the LiDAR derived course, water from this drainage crosses Road 81 near

Redrock Pass where the stream bed is lost. Ground water in this area likely joins with streams flowing past the Ape Cave area.

Determination of Initiation Zone

Although evidence of past debris flows were observed along Trail 216 in the Dryer Glacier Drainage Basin, there is no fresh evidence of recent levee or fan deposits.

Also, comparison of 2006 and 2009 ortho imagery did not reveal evidence of a recent debris flow initiation site or depositional fan. Therefore, it was determined that this drainage did not experience a debris flow in 2006.

Data Processing

$\underline{\text { Sieve Results }}$

No soil samples were taken from the Dryer Glacier Drainage.

\section{$\underline{\text { Basin Attributes }}$}

There was no initiation zone found in the Dryer Glacier Drainage for a 2006 debris flow, therefore no data related to debris flows were recorded. A full summary of the basin attributes is listed in Table 15. In summary, the geologic units of the upper basin are $64 \%$ unconsolidated (volcaniclastics, alluvium, and colluvium), 29\% bedrock (volcanics, andesite, and basalt), and $8 \%$ ice according to the geologic map (WaDNR, 
Table 15: Dryer Glacier Drainage Basin attributes.

\begin{tabular}{|c|c|c|c|c|}
\hline \multirow{2}{*}{$\begin{array}{l}\text { Basin Attributes } \\
\text { Total Basin }\end{array}$} & & \multirow[t]{2}{*}{ Geologic Units* } & \multicolumn{2}{|c|}{$\%$ Basin } \\
\hline & & & Total & Upper \\
\hline Area $\left(m^{2}\right)$ & $3,077,600$ & Water & & \\
\hline Comparative size rank & $11^{\text {th }}$ & ice & 3.7 & 7.7 \\
\hline Highest elevation (m) & 2,523 & $\underline{\text { Volcanics }}$ & & \\
\hline Lowest elevation (m) & 926 & Qv(sh) & 0.3 & 0.7 \\
\hline Height (m) & 1,597 & $\underline{\text { Andesite }}$ & & \\
\hline Length $(\mathrm{m})$ & 6,737 & MOian & & \\
\hline Gradient & 0.24 & MOva(2) & & \\
\hline \multirow[t]{2}{*}{ MRN } & 0.91 & Qiad(1) & & \\
\hline & & Qiad(2) & & \\
\hline$\underline{\text { Upper Basin }}$ & & QPLiad(g) & & \\
\hline Area $\left(m^{2}\right)$ & $1,489,140$ & Qva(1sh) & & \\
\hline Comparative size rank & $6^{\text {th }}$ & Qva(2sh) & 11.0 & 9.3 \\
\hline Highest elevation (m) & 2,523 & Basalt & & \\
\hline Lowest elevation (m) & 1,317 & Qvb(2sh) & 10.6 & 18.6 \\
\hline Height (m) & 1,206 & $\underline{\text { Volcaniclastics }}$ & & \\
\hline Length $(\mathrm{m})$ & 3,161 & $\operatorname{MOvc}(2)$ & & \\
\hline Gradient & 0.38 & OEvc & & \\
\hline MRN & 0.99 & Qvc(1sh) & & \\
\hline Percent vegetation (\%) & 6.5 & Qvc(2sh) & 65.4 & 59.6 \\
\hline Percent steep slope (\%) & 16 & Qvc(sh) & & \\
\hline \multirow[t]{2}{*}{ Avg. annual precip. (m) } & 4.0 & Qvp(3sh) & & \\
\hline & & Ovt(1) & & \\
\hline Glacier & & $\underline{\text { Alluvium }}$ & & \\
\hline Area $\left(m^{2}\right)$ & 25,777 & Qa & & \\
\hline Retreat distance $(\mathrm{m})$ & 310 & Qgu & & \\
\hline \multirow[t]{2}{*}{ Percent change in area (\%) } & -73 & $\underline{\text { Colluvium }}$ & & \\
\hline & & Qvl(3sh) & 9.0 & 4.1 \\
\hline \multicolumn{5}{|l|}{ Initiation } \\
\hline Elevation (m) & - & Summary & & \\
\hline Direct connection to glacier & - & Ice & 3.7 & 7.7 \\
\hline Distance from glacier (m) & - & Bedrock & 21.9 & 28.6 \\
\hline \multirow[t]{5}{*}{ Type } & - & Unconsolidated & 74.4 & 63.7 \\
\hline & & Measured Extents ** & & \\
\hline & & Snowpack and Ice & & 6.1 \\
\hline & & Consolidated Bedrock & & 7.1 \\
\hline & & Unconsolidated & & 86.8 \\
\hline
\end{tabular}

* data from WaDNR, 2010.

** data from measured extents on 2009 ortho imagery (USDA-FSA, 2009). 
2010). The measured extents of the upper basin geology are $6 \%$ snowpack and ice, $7 \%$ consolidated bedrock exposures, and $87 \%$ unconsolidated deposits.

As of 2009 , the Dryer "Glacier" covered an area of $25,777 \mathrm{~m}^{2}$, or $2 \%$, of the upper basin (USDA-FSA, 2009). Between 1998 and 2009 the ice field decreased in surface area by 73\%, and retreated upslope by 310 m (USGS, 2002; USDA-FSA, 2009). The 2009 orthophotographs also revealed that the ice field had broken into fragments with none showing a bergschrund (USDA-FSA, 2009). Therefore, this drainage basin was classified as not hosting a glacier, but a permanent snowpack.

\section{LITTLE KALAMA DRAINAGE BASIN}

\section{Introduction}

The Little Kalama Drainage Basin is located in the southwestern quadrant of Mount St. Helens between Dryer Glacier to the southeast and Kalama to the northwest (Figure 15, Figure 47). The slopes between Monitor Ridge and Butte Camp Dome host many small rivulets and ravines; it was difficult to determine basin boundaries for this quadrant of Mount St. Helens.

The upper basin of Little Kalama extends to the 1980 crater rim and does not host a glacier, but does contain two small, possibly permanent, snowpacks. A single channel runs from the upper slopes, through mapped rocky andesite flows (Qva) in the upper basin (Figure 48) and down to the lower slopes of the volcano below the intrusive Butte Camp Dome (WaDNR, 2010). The upper basin ends at Trail 216 near 1,435 m elevation, while the total basin extends down to 975 m elevation. The lower total basin 


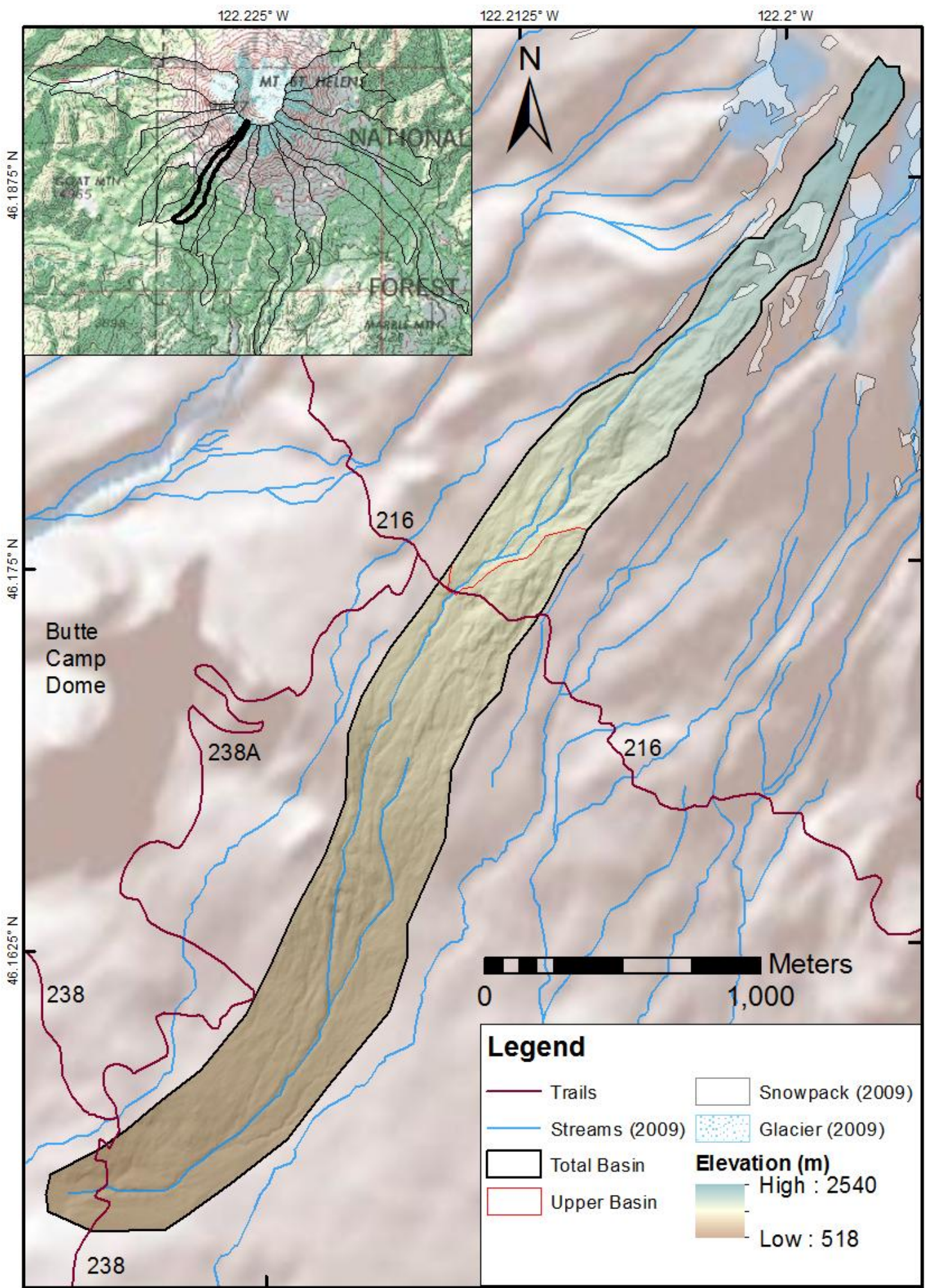

Figure 47: Map of the Little Kalama Drainage neighboring Kalama and Dryer Glacier in the southwestern quadrant of Mount St. Helens. The upper basin does not host a glacier, although a distinct channel was observed with past debris flow evidence. This drainage did not experience a debris flow in 2006. 


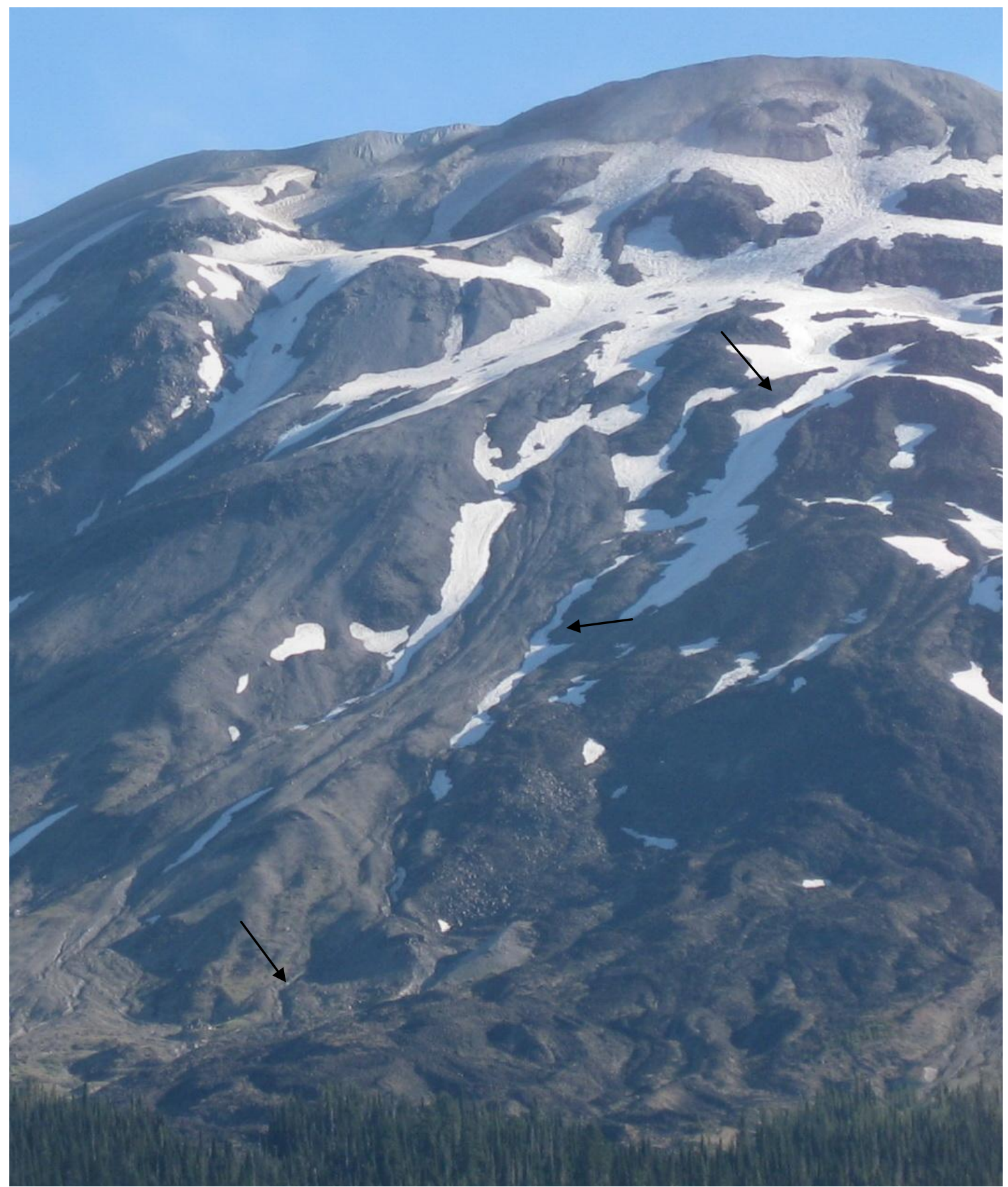

Figure 48: View of the Little Kalama upper basin taken in early August 2010 with snow remaining on the upper slopes. The main channel for this basin is arrowed at approximate elevations: $1,400 \mathrm{~m}, 1,600 \mathrm{~m}$, and $2,200 \mathrm{~m}$. This is a relatively minor drainage with few large features observed. Much of the middle slope is a Quaternary andesite lava flow. The drainage boundary generally conforms to the channel. View is to the northeast from Redrock Pass. 
includes a portion of a basalt flow (Qvb) that apparently originated from near the southeast corner of the intrusive Butte Camp Dome (WaDNR, 2010).

Near the terminus of the total basin, the channel crosses Trail 238 about one kilometer north of Redrock Pass. At this location, the dry stream bed consists of woody debris and sandy deposits that emerge from forest onto a fan about $50 \mathrm{~m}$ by $100 \mathrm{~m}$ in area covered in two meter high trees. Water from this drainage basin merges with the neighboring Kalama Drainage Basin and eventually joins the Kalama River which empties into the Columbia River.

\section{Determination of Initiation Zone}

Although evidence of a past lahar was observed along Trail 238 in the Little Kalama Drainage Basin, there is no definite evidence of recent debris flow activity. Also, comparison of 2006 and 2009 ortho imagery did not reveal evidence of a recent debris flow initiation site or depositional fan. Therefore, it was determined that this drainage did not experience a debris flow in 2006.

\section{Data Processing}

\section{$\underline{\text { Sieve Results }}$}

No soil samples were taken from the Little Kalama Drainage.

\section{$\underline{\text { Basin Attributes }}$}

There was no initiation zone found in the Little Kalama Drainage for a 2006 debris flow, therefore no data related to debris flows were recorded. A full summary of 
the basin attributes is listed in Table 16. In summary, the geologic units of the upper basin were mapped as $52 \%$ bedrock (volcanics, andesite, and basalt), $48 \%$ unconsolidated (volcaniclastics, alluvium, and colluvium), and $0 \%$ ice according to the geologic map (WaDNR, 2010). The measured extents of the upper basin geology are $33 \%$ consolidated bedrock exposures, $62 \%$ unconsolidated deposits, and $4 \%$ snowpack and ice.

\section{KALAMA DRAINAGE BASIN}

\section{Introduction}

The Kalama Drainage Basin is located in the southwestern quadrant of Mount St. Helens between Little Kalama to the southeast and the Butte Camp Dome Drainage to the northwest (Figure 15, Figure 49). This drainage has both the smallest total and upper basin areas, at 1,772,190 $\mathrm{m}^{2}$ and $348,560 \mathrm{~m}^{2}$, respectively. The slopes between Monitor Ridge and Butte Camp Dome host many small rivulets and ravines; it was difficult to determine basin boundaries for this quadrant of Mount St. Helens.

The Kalama upper basin does not extend to the 1980 crater rim, but does include a small ravine with a possibly permanent snowpack. Like the Little Kalama Drainage; a single, small channel runs from the upper slopes, through a rocky andesite lava flow (Qva) formation (WaDNR, 2010) (Figure 50). The upper basin ends some $220 \mathrm{~m}$ above the Trail 216 crossing at an elevation of 1,500 m, but the channel continues downslope to be diverted southward around an unusual outcrop. This outcrop forms a debris barrier to the southeast of the Butte Camp Dome intrusion and has a composition of 
Table 16: Little Kalama Drainage Basin attributes.

\begin{tabular}{|c|c|c|c|c|}
\hline \multirow{2}{*}{$\begin{array}{l}\text { Basin Attributes } \\
\text { Total Basin }\end{array}$} & & \multirow[t]{2}{*}{ Geologic Units * } & \multicolumn{2}{|c|}{$\%$ Basin } \\
\hline & & & Total & Upper \\
\hline Area $\left(m^{2}\right)$ & $1,698,690$ & $\underline{\text { Water }}$ & & \\
\hline Comparative size rank & $15^{\text {th }}$ & ice & & \\
\hline Highest elevation (m) & 2,537 & $\underline{\text { Volcanics }}$ & & \\
\hline Lowest elevation (m) & 974 & Qv(sh) & 0.3 & 0.9 \\
\hline Height (m) & 1,563 & Andesite & & \\
\hline Length (m) & 5,565 & MOian & & \\
\hline Gradient & 0.28 & MOva(2) & & \\
\hline \multirow[t]{2}{*}{ MRN } & 1.20 & Qiad(1) & & \\
\hline & & Qiad(2) & & \\
\hline$\underline{\text { Upper Basin }}$ & & QPLiad(g) & & \\
\hline Area $\left(m^{2}\right)$ & 534,629 & Qva(1sh) & & \\
\hline Comparative size rank & $14^{\text {th }}$ & Qva(2sh) & 25.6 & 50.7 \\
\hline Highest elevation (m) & 2,537 & $\underline{\text { Basalt }}$ & & \\
\hline Lowest elevation (m) & 1,435 & Qvb(2sh) & 16.0 & \\
\hline Height (m) & 1,102 & $\underline{\text { Volcaniclastics }}$ & & \\
\hline Length (m) & 2,582 & $\operatorname{MOvc}(2)$ & & \\
\hline Gradient & 0.43 & OEvc & & \\
\hline MRN & 1.51 & Qvc(1sh) & & \\
\hline Percent vegetation (\%) & 0.0 & Qvc(2sh) & 57.1 & 48.4 \\
\hline Percent steep slope (\%) & 23 & Qvc(sh) & & \\
\hline \multirow[t]{2}{*}{ Avg. annual precip. (m) } & 4.0 & Qvp(3sh) & & \\
\hline & & Ovt(1) & & \\
\hline$\underline{\text { Glacier }}$ & & $\underline{\text { Alluvium }}$ & & \\
\hline Area $\left(m^{2}\right)$ & - & Qa & & \\
\hline Retreat distance $(\mathrm{m})$ & - & Qgu & & \\
\hline \multirow[t]{2}{*}{ Percent change in area (\%) } & - & $\underline{\text { Colluvium }}$ & & \\
\hline & & Qvl(3sh) & 1.0 & \\
\hline \multicolumn{5}{|l|}{ Initiation } \\
\hline Elevation (m) & - & Summary & & \\
\hline Direct connection to glacier & - & Ice & 0.0 & 0.0 \\
\hline Distance from glacier $(\mathrm{m})$ & - & Bedrock & 41.9 & 51.7 \\
\hline \multirow[t]{5}{*}{ Type } & - & Unconsolidated & 58.1 & 48.4 \\
\hline & & Measured Extents ** & & \\
\hline & & Snowpack and Ice & & 4.3 \\
\hline & & Consolidated Bedrock & & 33.3 \\
\hline & & Unconsolidated & & 62.4 \\
\hline
\end{tabular}

* data from WaDNR, 2010.

** data from measured extents on 2009 ortho imagery (USDA-FSA, 2009). 


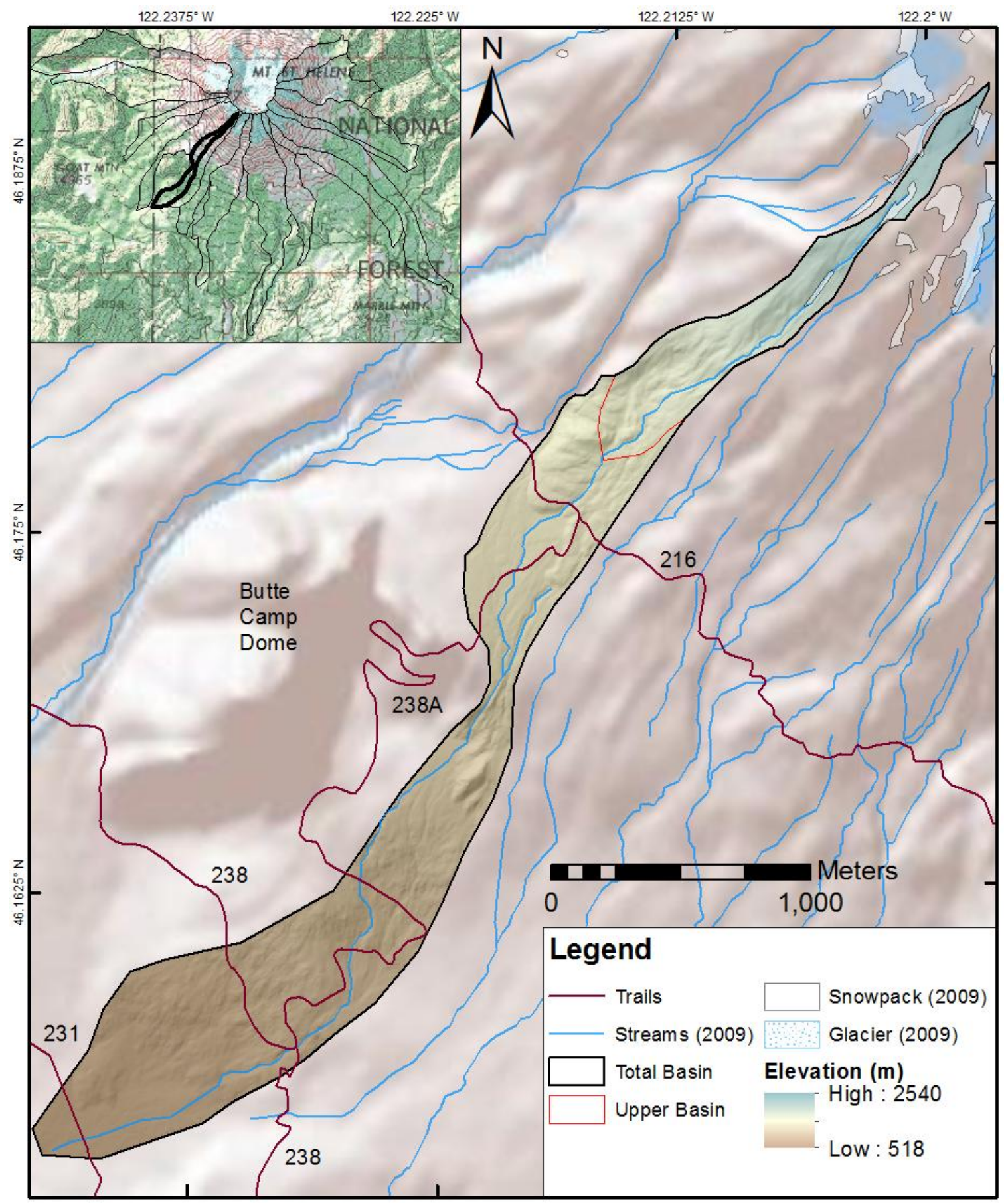

Figure 49: Map of the Kalama Drainage neighboring Butte Camp Dome and Little Kalama in the southwestern quadrant of Mount St. Helens. The upper basin does not host a glacier or extend to the crater rim, however a small channel was observed with past debris flow evidence. This drainage did not experience a debris flow in 2006. 


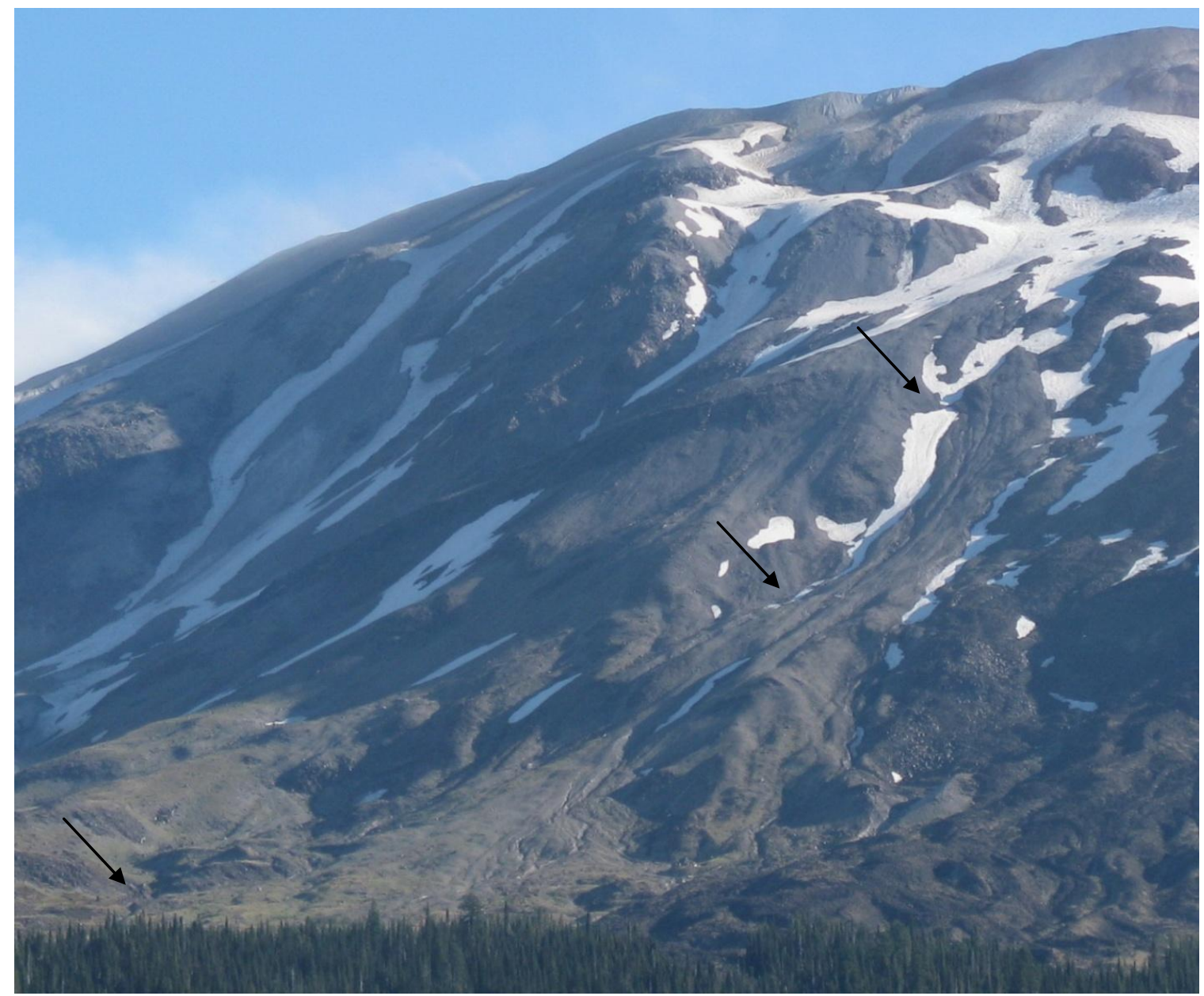

Figure 50: View of the Kalama upper basin taken in early August 2010 with snow remaining on the upper slopes. The main channel for this basin is arrowed at approximate elevations: 1,450 $\mathrm{m}, 1,830 \mathrm{~m}$, and $2,100 \mathrm{~m}$. This is a minor drainage with no large features observed. Much of the middle slope is a Quaternary andesite lava flow. The drainage boundary generally conforms to the channel. View is to the northeast from Redrock Pass.

Oligocene-Eocene volcaniclastic deposits (OEvc) with a core of Pleistocene-Pliocene intrusive andesite and dacite (QPLiad) that is related to the Goat Mountain dacite porphyry (WaDNR, 2010). This barrier has retained upper slope debris from the volcano deposited by this drainage and the Butte Camp Dome Drainage. Through time these deposits have filled in the paleo-topography above the Butte Camp Dome intrusion to an unknown depth forming a relatively flat plain of about $350,000 \mathrm{~m}^{2}$ at an elevation of 
roughly $1,400 \mathrm{~m}$. South of this barrier a basalt flow, that apparently originates from the near the Oligocene-Eocene unit, flows southwest and dominates the surface geology of the lower total basin. The total basin extends past Trail 238 and $175 \mathrm{~m}$ beyond Trail 231 to an elevation of 930 m southwest of the Butte Camp Dome intrusion. Water from this drainage basin continues to flow southwestward to the Kalama Spring and joins the Kalama River near McBride Lake south of Road 81. The Kalama River eventually empties into the Columbia River.

\section{Determination of Initiation Zone}

Of the sixteen drainage basins defined on Mount St. Helens, this is the first observed to have no evidence of debris flow activity in the past or during the 2006 event.

\section{Data Processing}

\section{$\underline{\text { Sieve Results }}$}

No soil samples were taken from the Kalama Drainage.

\section{$\underline{\text { Basin Attributes }}$}

There was no initiation zone found in the Kalama Drainage for a 2006 debris flow, therefore no data related to debris flows were recorded. A full summary of the basin attributes is listed in Table 17. In summary, the geologic units of the upper basin are $48 \%$ unconsolidated (volcaniclastics, alluvium, and colluvium), 52\% bedrock (volcanics, andesite, and basalt), and $0 \%$ ice according to the geologic map (WaDNR, 
Table 17: Kalama Drainage Basin attributes.

\begin{tabular}{|c|c|c|c|c|}
\hline \multirow{2}{*}{$\begin{array}{l}\text { Basin Attributes } \\
\text { Total Basin }\end{array}$} & & \multirow[t]{2}{*}{ Geologic Units * } & \multicolumn{2}{|c|}{$\%$ Basin } \\
\hline & & & Total & Upper \\
\hline Area $\left(m^{2}\right)$ & $1,772,190$ & $\underline{\text { Water }}$ & & \\
\hline Comparative size rank & $16^{\text {th }}$ & ice & & \\
\hline Highest elevation (m) & 2,449 & $\underline{\text { Volcanics }}$ & & \\
\hline Lowest elevation (m) & 927 & Qv(sh) & & \\
\hline Height (m) & 1,522 & Andesite & & \\
\hline Length (m) & 6,088 & MOian & & \\
\hline Gradient & 0.25 & MOva(2) & & \\
\hline \multirow[t]{2}{*}{ MRN } & 1.14 & Qiad(1) & & \\
\hline & & Qiad(2) & & \\
\hline$\underline{\text { Upper Basin }}$ & & QPLiad(g) & & \\
\hline Area $\left(m^{2}\right)$ & 348,562 & Qva(1sh) & & \\
\hline Comparative size rank & $16^{\text {th }}$ & Qva(2sh) & 15.7 & 63.3 \\
\hline Highest elevation (m) & 2,453 & $\underline{\text { Basalt }}$ & & \\
\hline Lowest elevation (m) & 1,502 & Qvb(2sh) & 46.6 & \\
\hline Height (m) & 950 & $\underline{\text { Volcaniclastics }}$ & & \\
\hline Length (m) & 2,139 & $\operatorname{MOvc}(2)$ & & \\
\hline Gradient & 0.44 & OEvc & & \\
\hline MRN & 1.61 & Qvc(1sh) & & \\
\hline Percent vegetation (\%) & 0.0 & Qvc(2sh) & 37.7 & 36.7 \\
\hline Percent steep slope (\%) & 15 & Qvc(sh) & & \\
\hline \multirow[t]{2}{*}{ Avg. annual precip. (m) } & 4.0 & Qvp(3sh) & & \\
\hline & & Ovt(1) & & \\
\hline$\underline{\text { Glacier }}$ & & $\underline{\text { Alluvium }}$ & & \\
\hline Area $\left(m^{2}\right)$ & - & Qa & & \\
\hline Retreat distance $(\mathrm{m})$ & - & Qgu & & \\
\hline \multirow[t]{2}{*}{ Percent change in area (\%) } & - & $\underline{\text { Colluvium }}$ & & \\
\hline & & Qvl(3sh) & & \\
\hline \multicolumn{5}{|l|}{ Initiation } \\
\hline Elevation (m) & - & Summary & & \\
\hline Direct connection to glacier & - & Ice & 0.0 & 0.0 \\
\hline Distance from glacier $(\mathrm{m})$ & - & Bedrock & 62.4 & 63.3 \\
\hline \multirow[t]{5}{*}{ Type } & - & Unconsolidated & 37.7 & 36.7 \\
\hline & & Measured Extents ** & & \\
\hline & & Snowpack and Ice & & 2.8 \\
\hline & & Consolidated Bedrock & & 4.2 \\
\hline & & Unconsolidated & & 93.0 \\
\hline
\end{tabular}

* data from WaDNR, 2010.

** data from measured extents on 2009 ortho imagery (USDA-FSA, 2009). 
2010). The measured extents of the upper basin geology are $4 \%$ snowpack and ice, $33 \%$ consolidated bedrock exposures, and 62\% unconsolidated deposits.

\section{BUTTE CAMP DOME DRAINAGE BASIN}

\section{Introduction}

The Butte Camp Dome Drainage Basin is located in the southwestern quadrant of Mount St. Helens between Kalama to the southeast and Blue Lake to the northwest (Figure 15, Figure 51). The upper basin is a very complex region defined by three channels, separated by rocky Holocene andesite lava flows (Qvc) and a Pleistocene intrusive andesite and dacite plug (Qiad) (WaDNR, 2010) (Figure 52). The upper basin does not host a glacier, but does contain permanent snowpacks above about 2,000 m elevation as seen in 2009 ortho imagery (USDS-FSA, 2009). The total basin boundary extends down to 890 m elevation below the intrusive Butte Camp Dome at the confluence with the Kalama Drainage Basin.

The three channels of the upper basin are the North Butte Camp Dome (BCD) Channel, Central BCD Channel, and South BCD Channel. These ravines merge into two channels in the lower portion of the upper basin and finally form one channel at 1,230 m elevation below the northern flank of the Butte Camp Dome intrusion. The middle zone channels, referred to as the North and South BCD Channels, are separated by a ridge mapped as a Holocene andesite lava flow (Qvc) (WaDNR, 2010) that is buried under prodigious unconsolidated deposits with only sporadic lava boulder outcrops. All channels in this region were observed to have evidence of debris flow activity. 


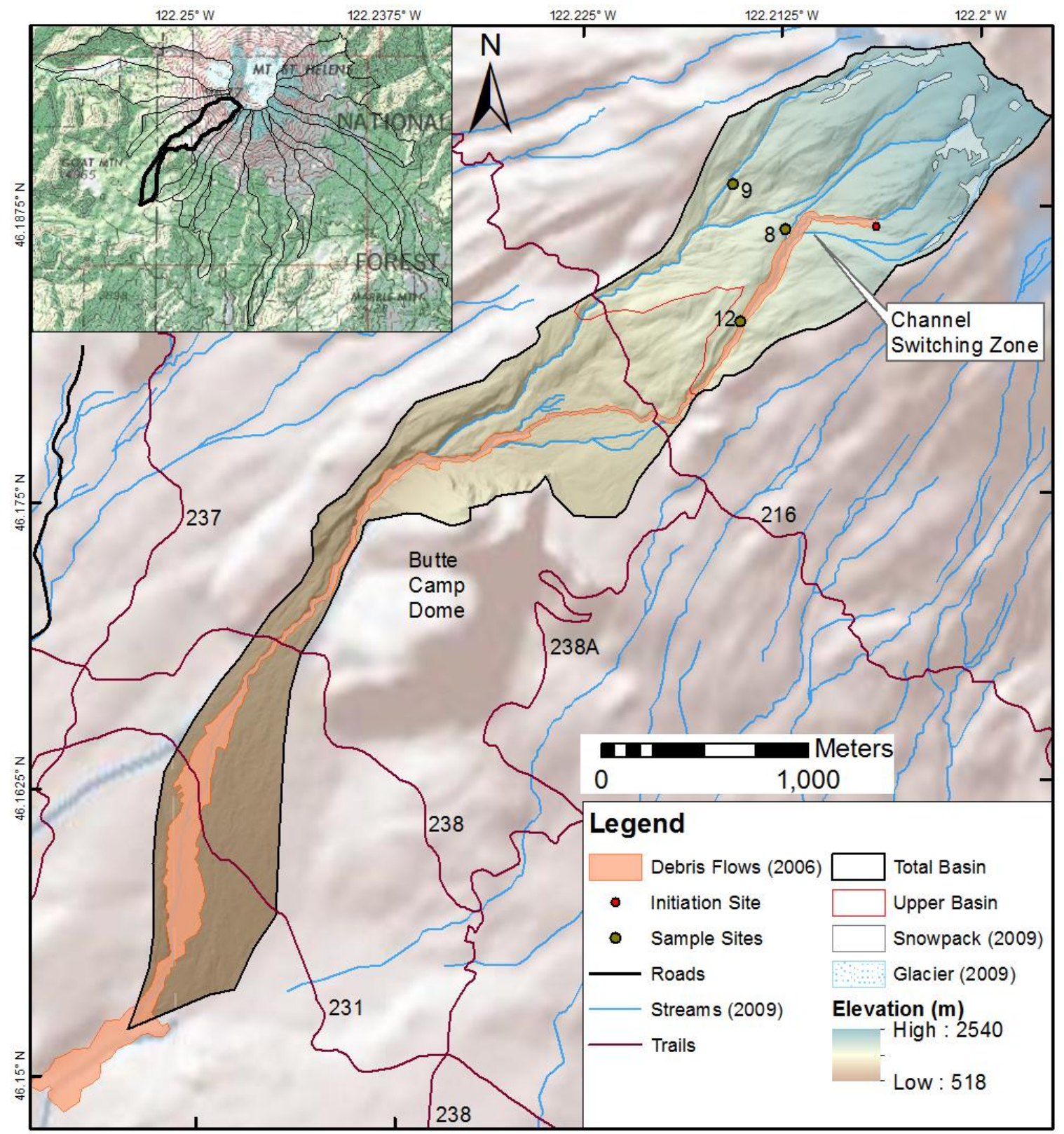

Figure 51: Map of Butte Camp Dome Drainage located in the southwestern quadrant of Mount St. Helens between the Kalama and Blue Lake drainages. The upper basin does not host a glacier, but contains multiple converging and diverging channels and evidence of channel switching and past debris flows. The southern branch of this drainage did experience a debris flow in 2006.

A channel switching zone was observed in the upper basin at 1,800 m elevation, below the intrusive andesite and dacite plug, which could divert the upper Central BCD and South BCD Channels into either of the middle zone channels. Currently, debris flow 


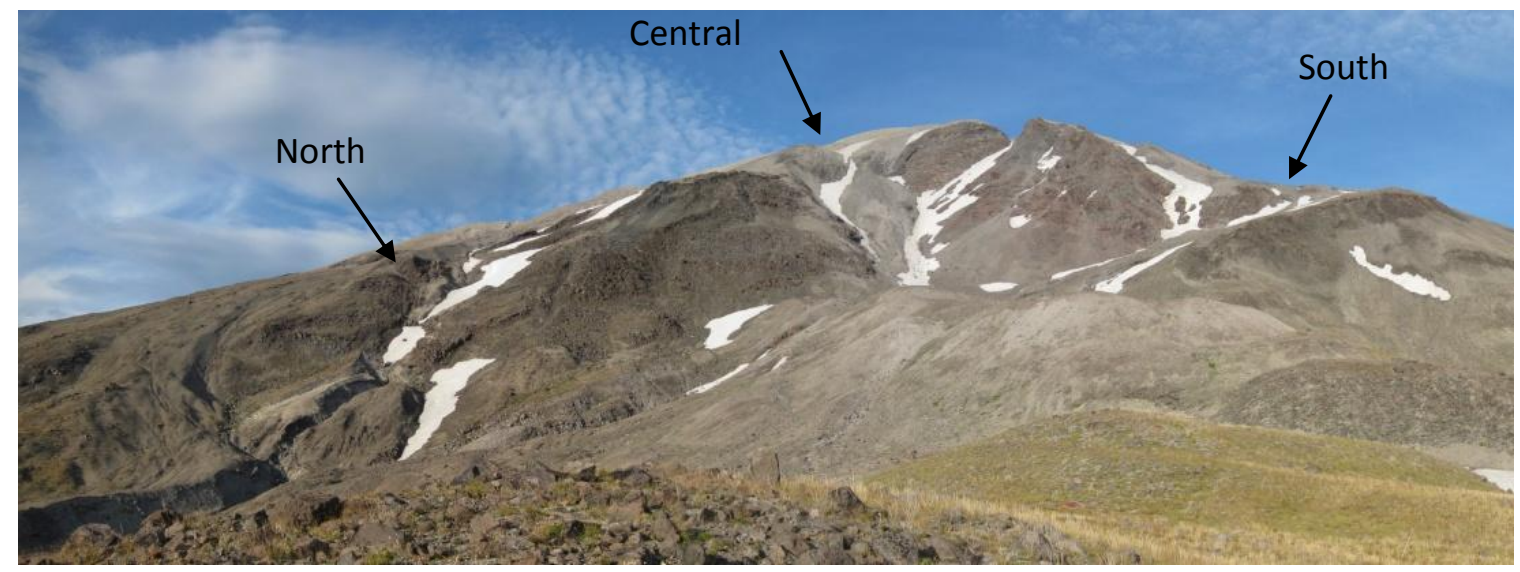

Figure 52: View of the Butte Camp Dome upper basin area from the ridge separating the middle zone channels. The arrows designate the North, Central, and South Channels. The andesite and dacite intrusion is visible as the false peak. View is to the northeast.

levees in this switching zone divert the southern and half the central upper basin channels down the South BCD ravine in the lower upper basin. The northern channel is very steep and passes north around a rocky outcrop mapped as an andesite lava flow (Qvc) (WaDNR, 2010). This channel merges with the northern half of the split Central BCD Channel at around 1,645 m elevation. Because of this division the upper basin has two lower extents: the southern terminates at 1,510 m elevation (about $280 \mathrm{~m}$ above Trail 216), while the northern ends about $125 \mathrm{~m}$ below Trail 216 at 1,440 m elevation.

The Butte Camp Dome itself is a 1,450 m high Pleistocene intrusion of andesite and dacite (Qiad) that forms a debris barrier on the side facing Mount St. Helens (WaDNR, 2010). This barrier has retained debris from the upper slopes of the volcano deposited by the South Butte Camp Dome Channel and Kalama Drainage (Figure 53). Since emplacement during the Ape Canyon Stage, deposits have filled in the paleo topography above Butte Camp Dome to an unknown depth forming a relatively flat 


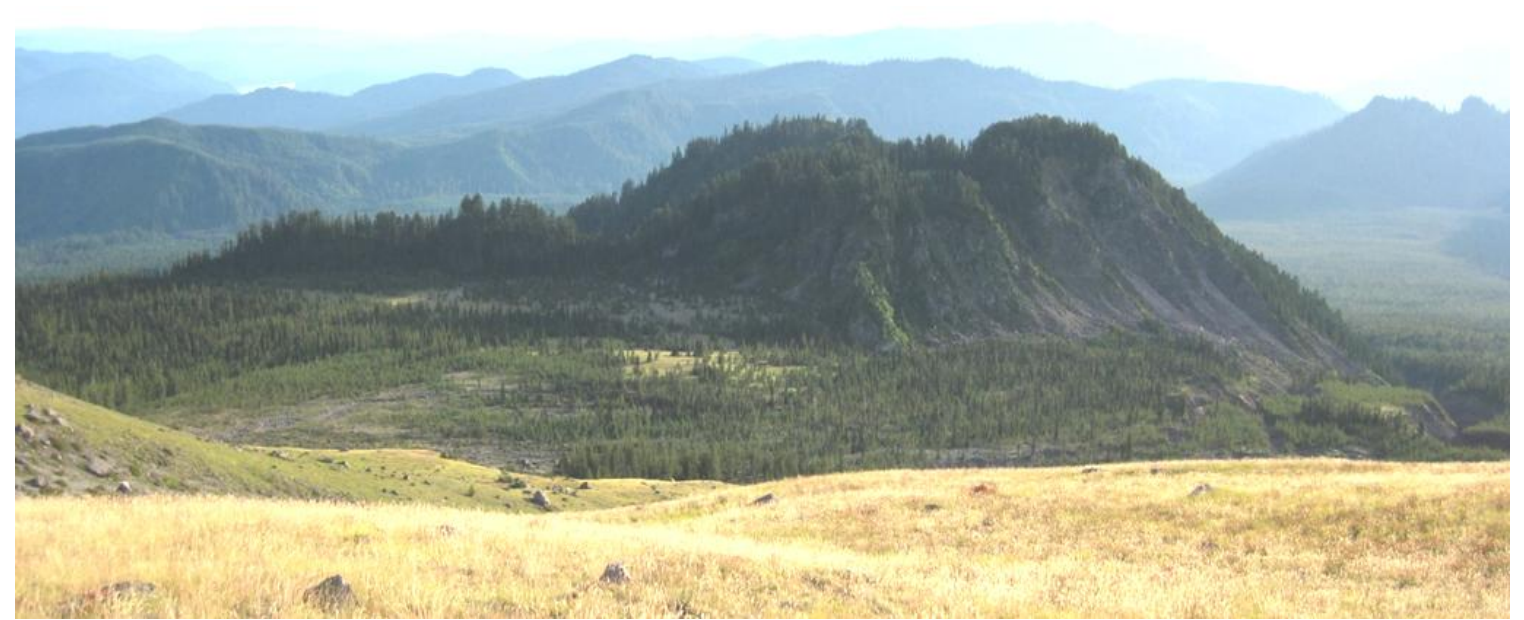

Figure 53: View of the Butte Camp Dome intrusion and debris fan. An area of active erosion on the north side of Butte Camp Dome is visible, as is the North BCD channel at the extreme right. View is to the southwest, from the same location as in Figure 52.

terrace with an area of about $350,000 \mathrm{~m}^{2}$ that is covered by dozens of debris flow fans and channels bounded by levees. Channels across this plain merge together at the northwestern corner and pass the landslide scarred northeastern flank of the dome to merge with the North BCD Channel forming a single channel.

The lower total basin extends around the north side of the Butte Camp Dome intrusion narrowly constricting the combined channel by an andesite lava flow to the north. Southwest of the dome, at 1,040 m elevation, the channel opens into a depositional area exhibiting successive debris flow lobes. The most recent deposit formed in 2006 and covers about $300,000 \mathrm{~m}^{2}$, but is the smallest measured for that storm event. This deposit also covers about $250 \mathrm{~m}$ of Trail 231 around $990 \mathrm{~m}$ elevation. Waters from this drainage continue to the south-southwest and join with the Kalama River and eventually the Columbia River. 


\section{Determination of Initiation Zone}

Field observations found evidence of recent debris flow deposits on the fan southwest of Butte Camp Dome including: lack of vegetation, run-up damage on trees, multiple lobes of debris deposition, and boulder dams that redirect flow. Some areas of soft sediment were also observed between boulders that had not undergone fluvial reworking. Further upslope a section of Trail 238 was scoured away and a new channel carved across the debris fan above the Butte Camp Dome intrusion by the South BCD Channel. This channel can be followed on ortho imagery upslope to the southern most of the three channels in the upper basin. A landslide scarp was measured in the switching zone at 1,800 m elevation, but debris flow evidence can be seen at higher elevations. Comparison of 2006 and 2009 ortho imagery (USDA-FSA, 2006; USDA-FSA, 2009) found evidence of channel wall erosion or a landslide scarp at $1,970 \mathrm{~m}$ elevation. Because of an obscuring snowpack during fieldwork and in the 2006 and 2009 ortho imagery, this was determined to be the highest evidence of debris flow activity. Therefore, it was determined that a landslide on the channel wall at 1,986 m elevation was the most likely initiation site of the 2006 Butte Camp Dome Debris Flow.

\section{Data Processing}

\section{Sieve Results}

Sieve results of the soil samples from the Butte Camp Dome Drainage Basin are shown in Table 18 and Table 19 along with average values and standard deviation. Total and site average values are also shown for the multiple samples taken in the southern 
Table 18: Sieve analysis for the soil samples taken on the South Channel in the Butte Camp Dome Drainage. The sample is half coarse to medium sized sand.

\begin{tabular}{|c|c|c|c|c|c|c|c|}
\hline \multirow[t]{2}{*}{ Sample \# } & \multirow{2}{*}{$\begin{array}{l}\text { Bulk } \\
\text { Density } \\
\left(\mathrm{g} / \mathrm{cm}^{3}\right)\end{array}$} & \multirow{2}{*}{$\begin{array}{c}\text { Gravel } \\
(>2.0 \\
\mathrm{mm})\end{array}$} & \multirow{2}{*}{$\begin{array}{c}\text { Sand } \\
(2.0 \text { to } \\
0.063 \\
\mathrm{~mm})\end{array}$} & \multirow{2}{*}{$\begin{array}{c}\text { Silt \& Clay } \\
\text { (<0.063 } \\
\text { mm })\end{array}$} & \multicolumn{3}{|c|}{ Sand } \\
\hline & & & & & $\begin{array}{c}\text { Coarse } \\
\text { (2.0 to } \\
0.42 \\
\mathrm{~mm})\end{array}$ & $\begin{array}{c}\text { Medium } \\
\text { (0.42 to } \\
0.149 \\
\mathrm{~mm})\end{array}$ & $\begin{array}{c}\text { Fine } \\
(0.149 \text { to } \\
0.063 \\
\mathrm{~mm})\end{array}$ \\
\hline 8.1 & 1.9 & $32.3 \%$ & $64.2 \%$ & $4.0 \%$ & $38.9 \%$ & $41.1 \%$ & $20.0 \%$ \\
\hline 8.2 & 2.1 & $48.2 \%$ & $48.3 \%$ & $3.9 \%$ & $39.4 \%$ & $37.1 \%$ & $23.5 \%$ \\
\hline 8.3 & 2.0 & $47.2 \%$ & $48.4 \%$ & $4.6 \%$ & $37.5 \%$ & $37.5 \%$ & $24.9 \%$ \\
\hline Site Avg. & 2.0 & $42.5 \%$ & $53.6 \%$ & $4.2 \%$ & $38.6 \%$ & $38.6 \%$ & $22.8 \%$ \\
\hline 12.1 & 1.5 & $39.4 \%$ & $55.3 \%$ & $5.2 \%$ & $36.9 \%$ & $38.8 \%$ & $24.3 \%$ \\
\hline 12.2 & 2.3 & $50.4 \%$ & $42.7 \%$ & $6.7 \%$ & $38.1 \%$ & $31.7 \%$ & $30.2 \%$ \\
\hline 12.3 & 2.0 & $28.4 \%$ & $64.2 \%$ & $7.4 \%$ & $36.0 \%$ & $36.7 \%$ & $27.2 \%$ \\
\hline Site Avg. & 1.9 & $39.4 \%$ & $54.1 \%$ & $6.4 \%$ & $37.0 \%$ & $35.7 \%$ & $27.2 \%$ \\
\hline Average & 2.0 & $41.0 \%$ & $53.8 \%$ & $5.3 \%$ & $37.8 \%$ & $37.2 \%$ & $25.0 \%$ \\
\hline Std. Dev. & 0.26 & $9.1 \%$ & $8.9 \%$ & $1.4 \%$ & $1.3 \%$ & $3.1 \%$ & $3.5 \%$ \\
\hline
\end{tabular}

Table 19: Sieve analysis for the soil samples taken on the North Channel in the Butte Camp Dome Drainage. The sample is half sand of coarse to medium sized grains.

\begin{tabular}{|c|c|c|c|c|c|c|c|}
\hline \multirow[t]{2}{*}{ Sample \# } & \multirow{2}{*}{$\begin{array}{l}\text { Bulk } \\
\text { Density } \\
\left(\mathrm{g} / \mathrm{cm}^{3}\right)\end{array}$} & \multirow{2}{*}{$\begin{array}{c}\text { Gravel } \\
(>2.0 \\
\mathrm{mm})\end{array}$} & \multirow{2}{*}{$\begin{array}{l}\text { Sand } \\
(2.0 \text { to } \\
0.063 \\
\mathrm{~mm})\end{array}$} & \multirow{2}{*}{$\begin{array}{c}\text { Silt \& Clay } \\
\qquad<0.063 \\
\mathrm{~mm})\end{array}$} & \multicolumn{3}{|c|}{ Sand } \\
\hline & & & & & $\begin{array}{c}\text { Coarse } \\
(2.0 \text { to } \\
0.42 \\
\mathrm{~mm})\end{array}$ & $\begin{array}{c}\text { Medium } \\
\text { (0.42 to } \\
0.149 \\
\mathrm{~mm})\end{array}$ & $\begin{array}{c}\text { Fine } \\
(0.149 \text { to } \\
0.063 \\
\mathrm{~mm})\end{array}$ \\
\hline 9.1 & 2.3 & $36.3 \%$ & $56.3 \%$ & $7.6 \%$ & $37.4 \%$ & $33.8 \%$ & $28.8 \%$ \\
\hline 9.2 & 1.9 & $44.8 \%$ & $51.1 \%$ & $4.2 \%$ & $46.5 \%$ & $36.4 \%$ & $17.1 \%$ \\
\hline 9.3 & 1.8 & $44.4 \%$ & $50.8 \%$ & $4.9 \%$ & $40.6 \%$ & $40.5 \%$ & $18.9 \%$ \\
\hline Average & 2.0 & $41.8 \%$ & $52.7 \%$ & $5.6 \%$ & $41.5 \%$ & $36.9 \%$ & $21.6 \%$ \\
\hline Std. Dev. & 0.29 & $4.8 \%$ & $3.1 \%$ & $1.8 \%$ & $4.6 \%$ & $3.4 \%$ & $6.3 \%$ \\
\hline
\end{tabular}

channel. Three samples were taken because of the multiple channels in the upper basin which merge and switch ravines periodically. In 2006, the southern channel experienced a major debris flow while the northern channel did not. For the southern drainage, the average bulk density was measured at $2.0 \mathrm{~g} / \mathrm{cm}^{3}$, and the average sample consisted of $41 \%$ gravel, $54 \%$ sand, and $5 \%$ silt and clay. In the northern drainage, the 
average bulk density was measured at $2.0 \mathrm{~g} / \mathrm{cm}^{3}$, and the average sample consisted of $42 \%$ gravel, $53 \%$ sand, and $6 \%$ silt and clay.

\section{Basin Attributes}

The initiation zone for the Butte Camp Dome Drainage was found at an elevation of 1,986 m, within an area mapped as volcaniclastic deposits and rocks (Qvc) (WaDNR, 2010). The geologic units of the upper basin were mapped as $38 \%$ bedrock (volcanics, andesite, and basalt), 62\% unconsolidated (volcaniclastics, alluvium, and colluvium), and $0 \%$ ice according to the geologic map (WaDNR, 2010). The measured extents of the upper basin geology are $17 \%$ consolidated bedrock exposures, $78 \%$ unconsolidated deposits, and $5 \%$ snowpack and ice. A full summary of the basin attributes is listed in Table 20.

\section{BLUE LAKE DRAINAGE BASIN}

\section{Introduction}

The Blue Lake Drainage Basin is located in the western quadrant of Mount St. Helens between Butte Camp Dome to the south and Sheep Creek to the north (Figure 15, Figure 54). The upper basin contains two large channels and extends upward to the 1980 crater rim, but does not host a glacier (Figure 55). The upper basin is mapped as 78\% volcaniclastic deposits (Qvc) that form unconsolidated slopes from the rim down to about 1,815 m elevation in the South Channel and 1,635 m elevation on the North Channel (WaDNR, 2010). At those elevations a competent layer of andesite flows (Qva) is exposed forming large waterfall features in both channels (WaDNR, 2010). Below the 
Table 20: Butte Camp Dome Drainage Basin attributes.

\begin{tabular}{|c|c|c|c|c|}
\hline \multirow{2}{*}{$\begin{array}{l}\text { Basin Attributes } \\
\text { Total Basin }\end{array}$} & & \multirow[t]{2}{*}{ Geologic Units * } & \multicolumn{2}{|c|}{ \% Basin } \\
\hline & & & Total & Upper \\
\hline Area $\left(m^{2}\right)$ & $3,956,070$ & Water & & \\
\hline Comparative size rank & $9^{\text {th }}$ & ice & & \\
\hline Highest elevation (m) & 2,539 & Volcanics & & \\
\hline Lowest elevation (m) & 889 & Qv(sh) & 0.1 & 0.2 \\
\hline Height (m) & 1,651 & Andesite & & \\
\hline Length $(\mathrm{m})$ & 7,199 & MOian & & \\
\hline Gradient & 0.23 & MOva(2) & & \\
\hline \multirow[t]{2}{*}{ MRN } & 0.83 & Qiad(1) & 5.0 & 5.0 \\
\hline & & $\operatorname{Qiad}(2)$ & & \\
\hline Upper Basin & & QPLiad(g) & & \\
\hline Area $\left(m^{2}\right)$ & $1,750,980$ & Qva(1sh) & & \\
\hline Comparative size rank & $4^{\text {th }}$ & Qva(2sh) & 23.4 & 32.7 \\
\hline Highest elevation (m) & 2,539 & Basalt & & \\
\hline Lowest elevation (m) & 1,442 & Qvb(2sh) & & \\
\hline Height (m) & 1,098 & $\underline{\text { Volcaniclastics }}$ & & \\
\hline Length (m) & 2,333 & MOvc(2) & & \\
\hline Gradient & 0.47 & OEvc & & \\
\hline MRN & 0.83 & Qvc(1sh) & & \\
\hline Percent vegetation (\%) & 0.0 & Qvc(2sh) & 58.5 & 60.2 \\
\hline Percent steep slope (\%) & 36 & Qvc(sh) & & \\
\hline \multirow[t]{2}{*}{ Avg. annual precip. (m) } & 4.0 & Qvp(3sh) & & \\
\hline & & Ovt(1) & & \\
\hline Glacier & & Alluvium & & \\
\hline Area $\left(\mathrm{m}^{2}\right)$ & - & Qa & & \\
\hline Retreat distance $(\mathrm{m})$ & - & Qgu & & \\
\hline \multirow[t]{2}{*}{ Percent change in area (\%) } & - & Colluvium & & \\
\hline & & Qvl(3sh) & 13.1 & 1.9 \\
\hline \multicolumn{5}{|l|}{ Initiation } \\
\hline Elevation (m) & 1,986 & Summary & & \\
\hline Direct connection to glacier & - & Ice & 0.0 & 0.0 \\
\hline Distance from glacier $(\mathrm{m})$ & - & Bedrock & 28.5 & 37.9 \\
\hline \multirow[t]{5}{*}{ Type } & Headless & Unconsolidated & 71.6 & 62.1 \\
\hline & & Measured Extents $* *$ & & \\
\hline & & Snowpack and Ice & & 4.8 \\
\hline & & Consolidated Bedrock & & 16.9 \\
\hline & & Unconsolidated & & 78.3 \\
\hline
\end{tabular}

* data from WaDNR, 2010.

** data from measured extents on 2009 ortho imagery (USDA-FSA, 2009). 


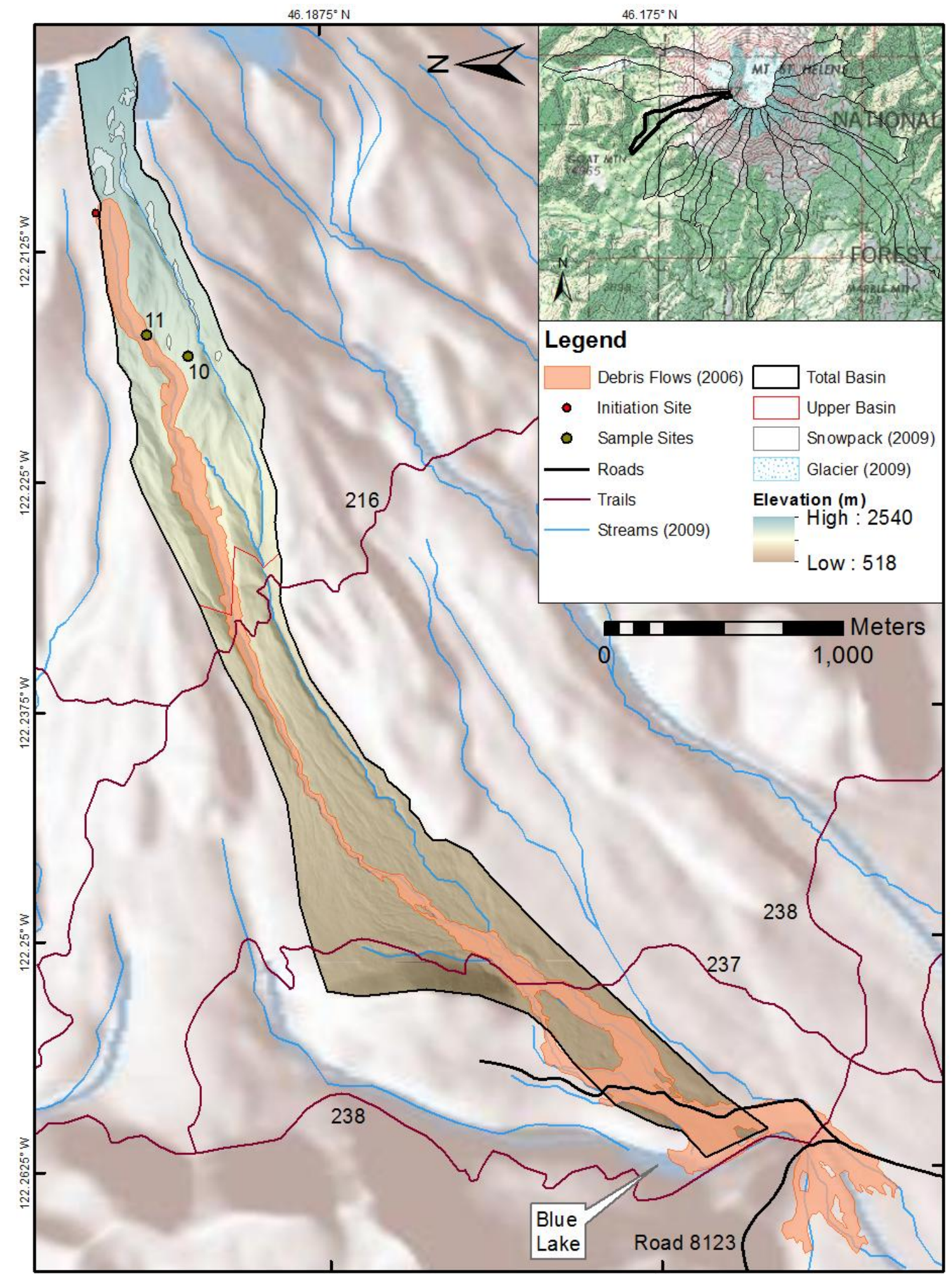

Figure 54: Map of Blue Lake Drainage located in the western quadrant of Mount St. Helens between the Butte Camp Dome and Sheep Creek drainages. The upper basin does not host a glacier, although the basin features two large channels and possible glacial deposits. North is to the left. 


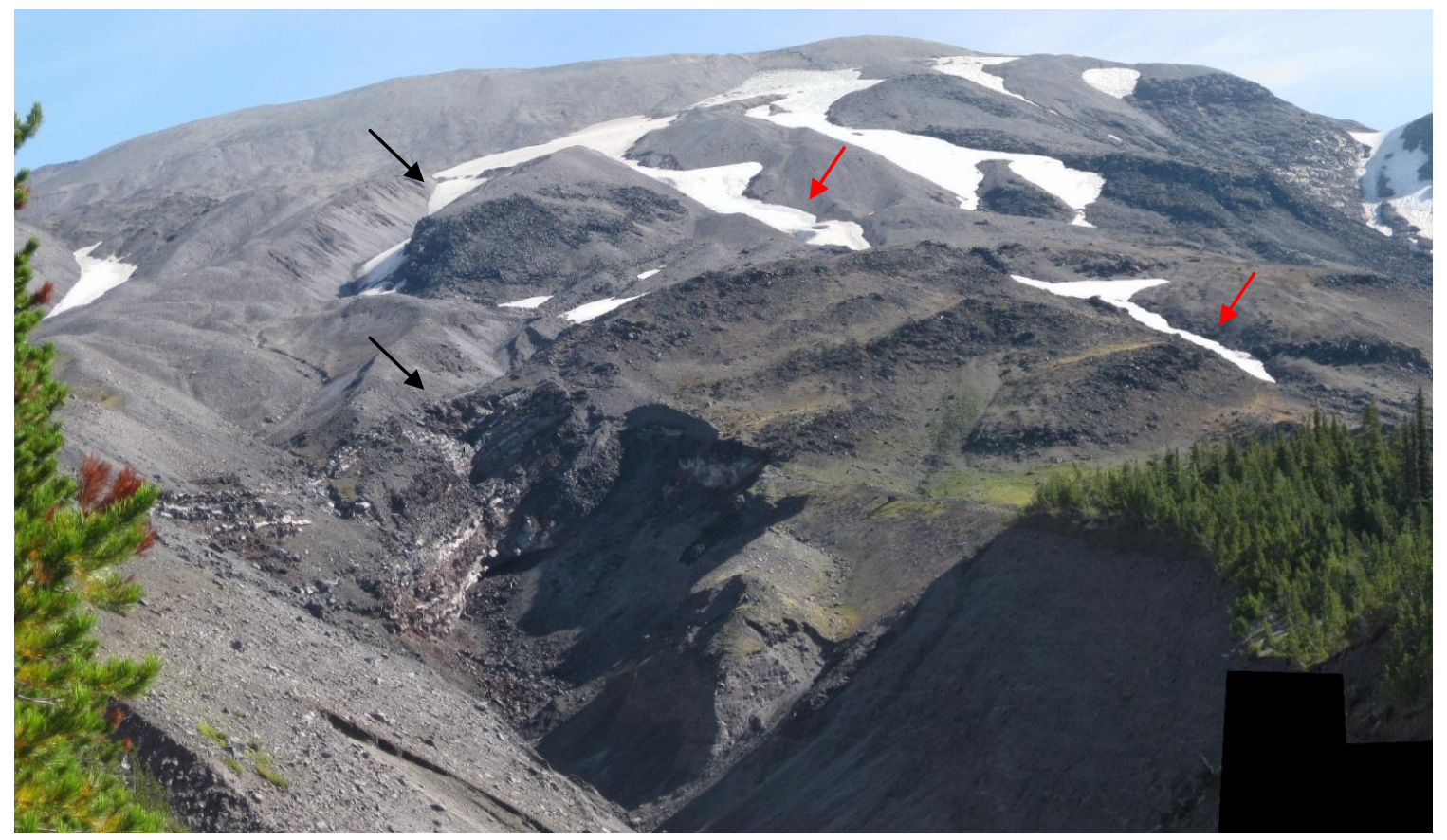

Figure 55: View of the Blue Lake upper basin from Trail 216 on the northern rim of the North Channel. The rocky area in the center of the image is an exposed andesite flow which is more resistant to erosion and forms waterfalls on both channels. The black arrows indicate the North Channel, while the red arrows designate the South Channel. View is to the east.

waterfalls, both channels feature deep, steep-sided ravines with active (and dangerous) erosion in the larger North Channel. The lowest extent of the upper basin is at $1,410 \mathrm{~m}$ elevation in the North Channel and 1,445 m elevation in the South Channel. Both extents of the upper basin end 40 to 50 meters upslope of the Trail 216 crossings.

The two channels converge in the lower total basin at roughly 1,190 m elevation (UTM 10N 558132E 5114762N). The exact location was not determined by field observations or remote sensing and is likely to be variable over time. The lower area is dominated by mapped lahar deposits (Qvl) which cover $35 \%$ of the total basin (WaDNR, 2010). Water from this drainage actually bypasses Blue Lake but merges with Coldspring Creek which drains from the south end of the lake (actually sourced from a 
spring to the north of the lake) and flows into Goat Marsh on the eastern side of Goat Mountain. The marsh drains northward and merges with Sheep Creek and South Fork Toutle River.

The lower total basin bends southward around a 1,280 m high ridge, just east of where the channel opens into an area of successive debris flow depositional lobes. The most recent deposit formed in 2006 and covers about $420,000 \mathrm{~m}^{2}$, which is the second largest measured for that storm event. The 2006 deposition zone begins in the North Channel at about 1,015 m elevation and extends southward about $2.7 \mathrm{~km}$. The deposit damaged or destroyed portions of Trails 237 and 238, buried $350 \mathrm{~m}$ of Road 8123, and completely buried the Blue Lake trailhead (Figure 56).

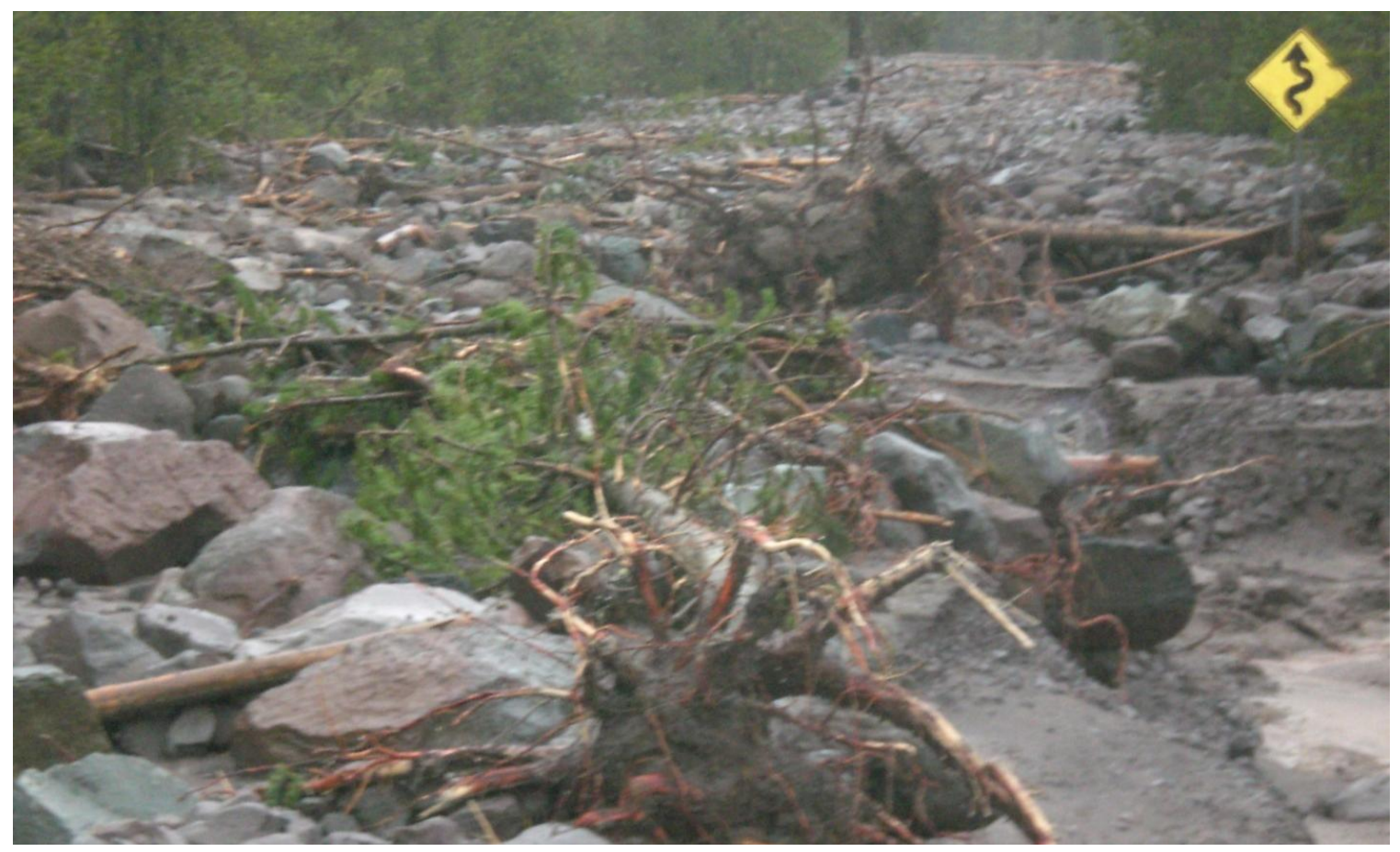

Figure 56: View of the Blue Lake Debris Flow deposit (USDA-FS, 2007) covering about 350 meters of Road 8123 and all of the Blue Lake trailhead parking area by deposits of up to three meters thick. 


\section{Determination of Initiation Zone}

Field observations found prodigious evidence of unstable slopes and landslide scarps along the North Channel banks in the upper basin. The debris flow deposition area shows evidence of multiple lobes or surges of deposits, indicating multiple initiation sources. Comparison of 2006 and 2009 ortho imagery confirmed that all of the landslide scarps and channel erosion sites observed in the field occurred during or subsequent to the 2006 event (USDA-FSA, 2006; USDA-FSA, 2009) (Figure 57, Figure 58, and Figure 59). Therefore, it was determined that multiple landslides including those at $1,565 \mathrm{~m}, 1,720 \mathrm{~m}$, and $2,100 \mathrm{~m}$ elevation as well as channel erosion are the initiation sources of the Blue Lake Debris Flow in 2006. There is also evidence of a pre-2006 debris flow in the South Channel, although no initiation site or debris flow deposits were observed in the upper basin.

\section{Data Processing}

\section{Sieve Results}

Sieve results of the soil samples from the Blue Lake Drainage Basin are shown in Table 21 along with average values and standard deviation. Total and site average values are also shown. The average bulk density was measured at $2.2 \mathrm{~g} / \mathrm{cm}^{3}$, and the average sample consisted of $41 \%$ gravel, $58 \%$ sand, and $5 \%$ silt and clay.

\section{$\underline{\text { Basin Attributes }}$}

The highest initiation site was found in the Blue Lake Drainage at an elevation of 2,100 m, within an area mapped as volcaniclastic deposits and rocks (Qvc) (WaDNR, 


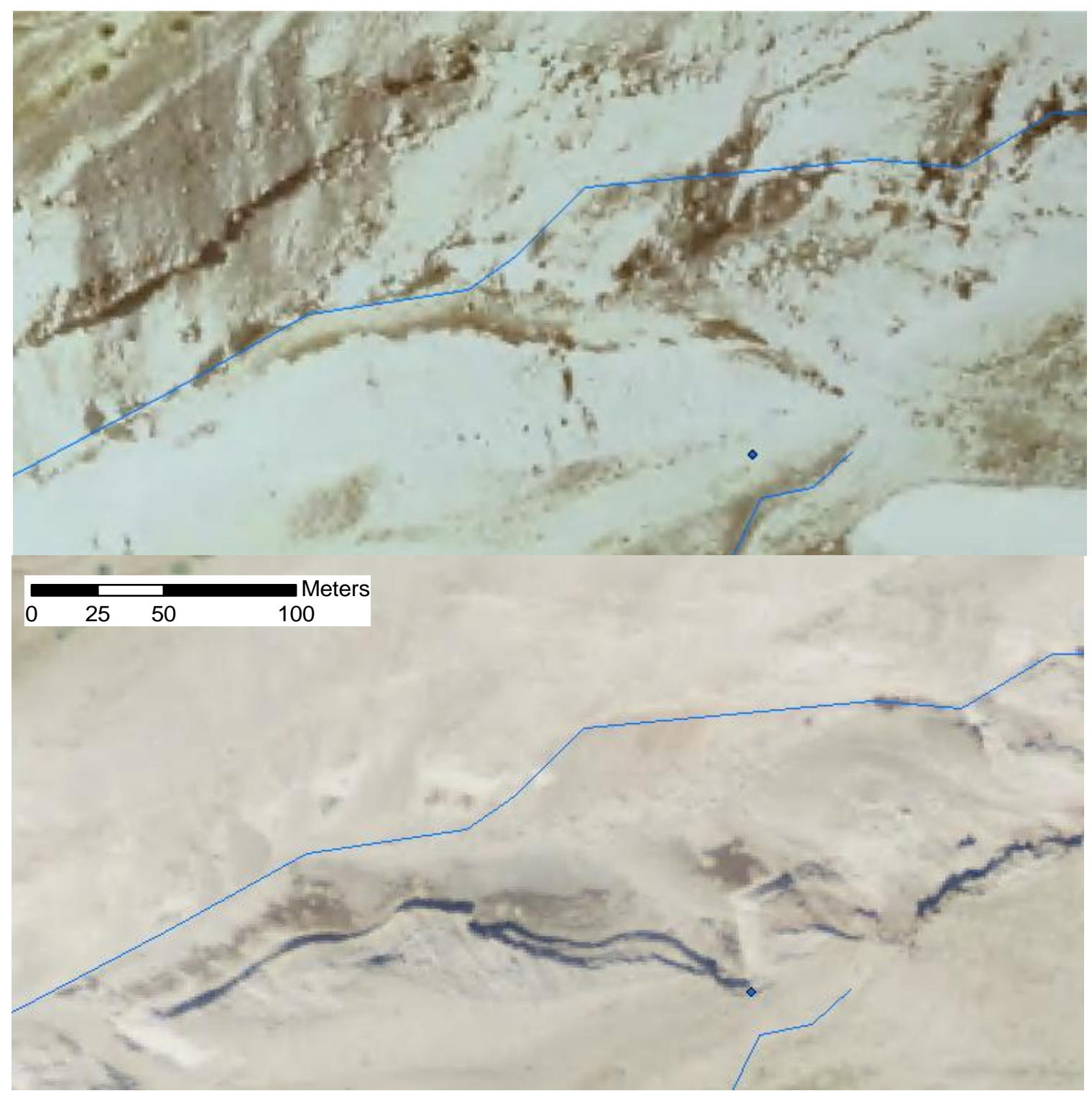

Figure 57: Comparison of 2006 (top) with 2009 (bottom) ortho imagery showing a channel wall landslide at 1,565 m elevation that is one possible initiation site of the 2006 Blue Lake Debris Flow. The waterfall is to the right in the image. The contrast on the 2006 image is poor, but there is a definite change in the southern channel wall at the location of the blue dot. The dots are in the same spatial location in both images (UTM 10N 559843E 51155741N). North is up.

2010). The geologic units of the upper basin are $85 \%$ unconsolidated (volcaniclastics, alluvium, and colluvium), 15\% bedrock (volcanics, andesite, and basalt), and $0 \%$ ice according to the geologic map (WaDNR, 2010). The measured extents of the upper 


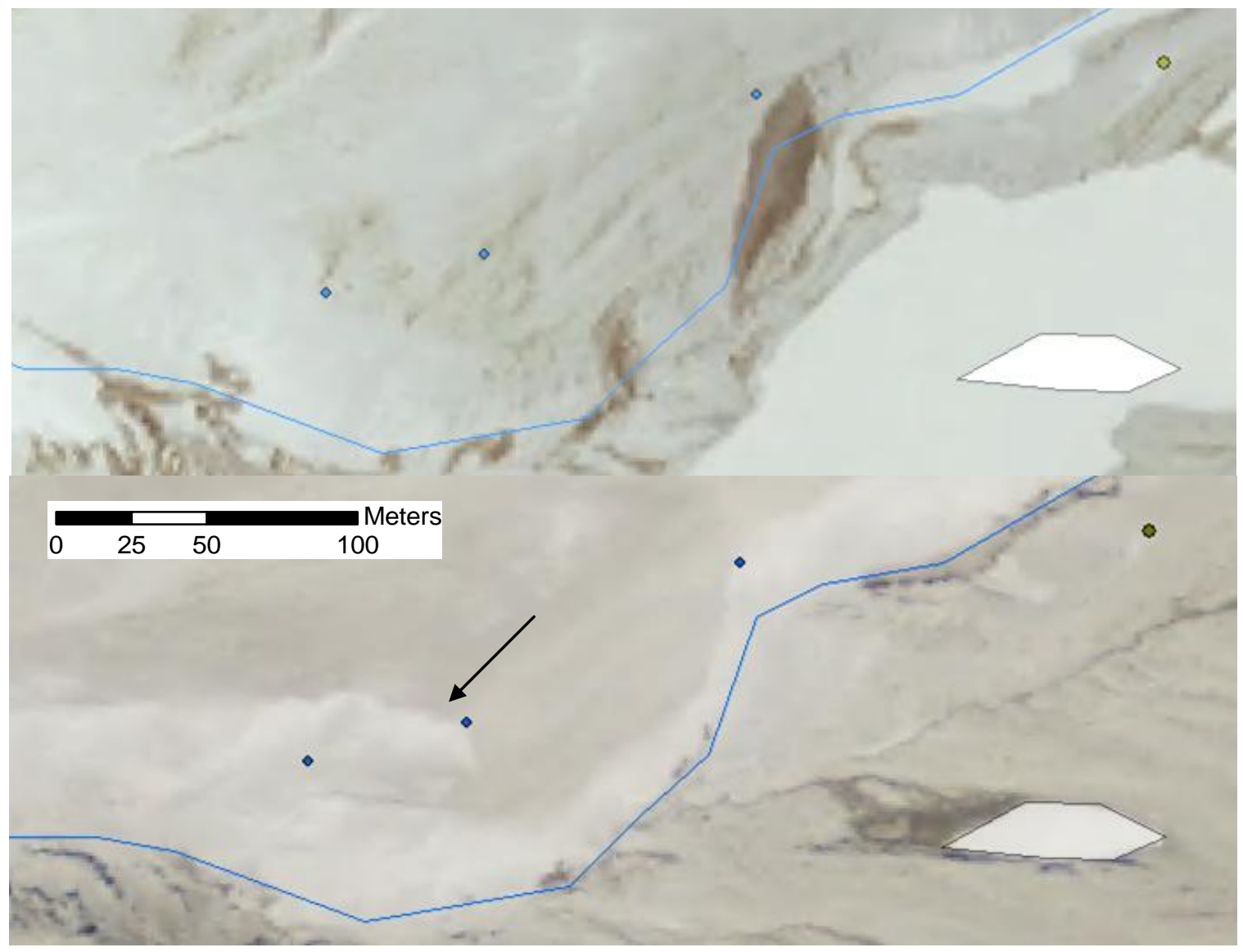

Figure 58: Comparison of 2006 (top) with 2009 (bottom) ortho imagery showing channel wall erosion (right) and a landslide (arrowed) at 1,720 m elevation that is one possible initiation site of the 2006 Blue Lake Debris Flow. The waterfall is to the left in the image. The dots are in the same spatial location in both images (UTM 10N 560207E 5115852N). North is up.

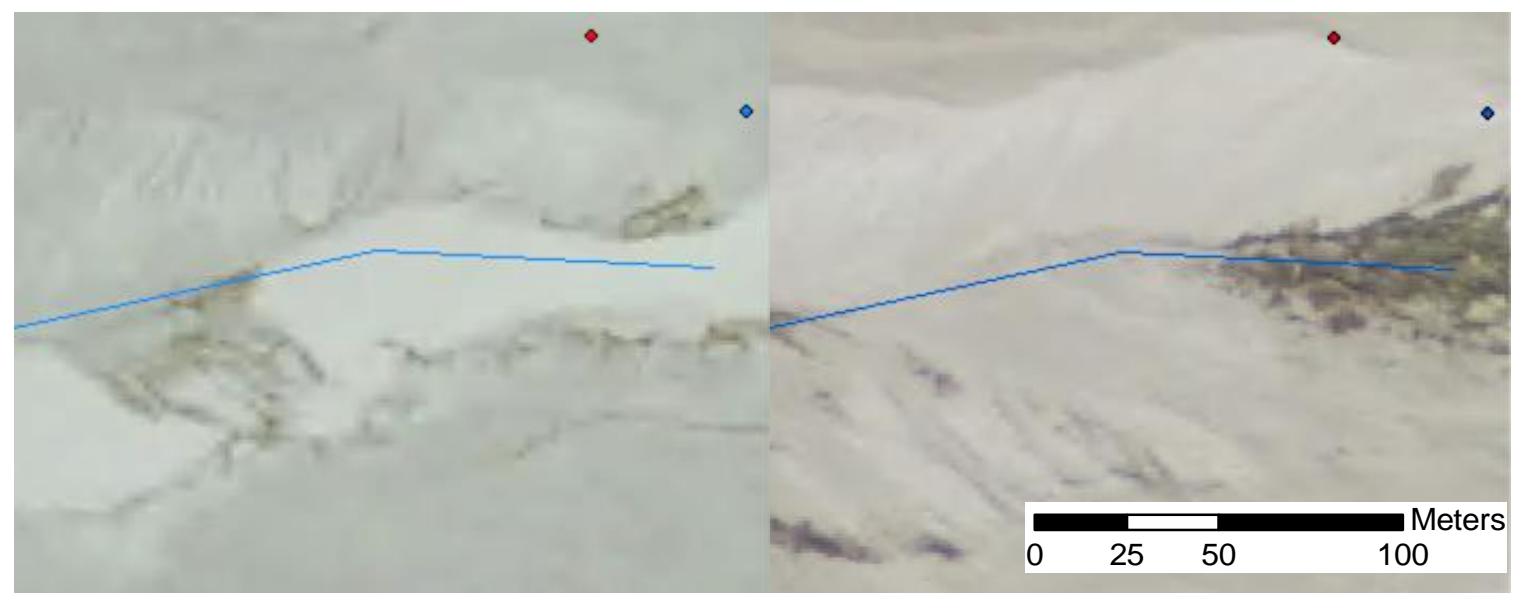

Figure 59: Comparison of 2006 (left) with 2009 (right) ortho imagery showing a channel wall landslide at 2,100 m elevation (red dot) that is one possible initiation site of the 2006 Blue Lake Debris Flow. The waterfall is to the distant left off the image. The dots are in the same spatial location in both images (UTM 10N 560917E 5116075N). North is up. 
Table 21: Sieve analysis for the soil samples taken in the Blue Lake Drainage. The sample is over half sand of predominately coarse-sized grains.

\begin{tabular}{|c|c|c|c|c|c|c|c|}
\hline \multirow[t]{2}{*}{ Sample \# } & \multirow{2}{*}{$\begin{array}{l}\text { Bulk } \\
\text { Density } \\
\left(\mathrm{g} / \mathrm{cm}^{3}\right)\end{array}$} & \multirow{2}{*}{$\begin{array}{c}\text { Gravel } \\
(>2.0 \\
\mathrm{mm})\end{array}$} & \multirow{2}{*}{$\begin{array}{l}\text { Sand } \\
(2.0 \text { to } \\
0.063 \\
\mathrm{~mm})\end{array}$} & \multirow{2}{*}{$\begin{array}{c}\text { Silt \& Clay } \\
\text { (< } 0.063 \\
\mathrm{~mm})\end{array}$} & \multicolumn{3}{|c|}{ Sand } \\
\hline & & & & & $\begin{array}{c}\text { Coarse } \\
\text { (2.0 to } \\
0.42 \\
\mathrm{~mm})\end{array}$ & $\begin{array}{c}\text { Medium } \\
\text { (0.42 to } \\
0.149 \\
\mathrm{~mm})\end{array}$ & $\begin{array}{c}\text { Fine } \\
(0.149 \text { to } \\
0.063 \\
\mathrm{~mm})\end{array}$ \\
\hline 10.1 & 2.2 & $40.6 \%$ & $59.6 \%$ & $3.4 \%$ & $41.0 \%$ & $36.4 \%$ & $22.7 \%$ \\
\hline 10.2 & 2.4 & $35.2 \%$ & $62.2 \%$ & $2.3 \%$ & $52.9 \%$ & $33.9 \%$ & $13.1 \%$ \\
\hline 10.3 & 2.3 & $26.7 \%$ & $67.4 \%$ & $5.9 \%$ & $32.4 \%$ & $36.1 \%$ & $31.5 \%$ \\
\hline Site Avg. & 2.3 & $34.2 \%$ & $63.1 \%$ & $3.8 \%$ & $42.1 \%$ & $35.5 \%$ & $22.4 \%$ \\
\hline 11.1 & 2.0 & $49.6 \%$ & $44.7 \%$ & $5.7 \%$ & $28.9 \%$ & $33.6 \%$ & $37.6 \%$ \\
\hline 11.2 & 2.3 & $42.7 \%$ & $51.2 \%$ & $6.1 \%$ & $35.9 \%$ & $32.2 \%$ & $32.0 \%$ \\
\hline 11.3 & 2.1 & $29.4 \%$ & $62.1 \%$ & $8.1 \%$ & $40.9 \%$ & $30.7 \%$ & $28.4 \%$ \\
\hline Site Avg. & 2.1 & $40.6 \%$ & $52.7 \%$ & $6.6 \%$ & $35.2 \%$ & $32.1 \%$ & $32.6 \%$ \\
\hline Average & 2.2 & $37.4 \%$ & $57.9 \%$ & $5.2 \%$ & $38.7 \%$ & $33.8 \%$ & $27.5 \%$ \\
\hline Std. Dev. & 0.15 & $8.6 \%$ & $8.4 \%$ & $2.1 \%$ & $8.4 \%$ & $2.2 \%$ & $8.6 \%$ \\
\hline
\end{tabular}

basin geology are $4 \%$ snowpack and ice, $3 \%$ consolidated bedrock exposures, and $94 \%$

unconsolidated deposits. A full summary of the basin attributes is listed in Table 22.

\section{SHEEP CREEK DRAINAGE BASIN}

\section{Introduction}

The Sheep Creek Drainage Basin is located in the western quadrant of Mount St.

Helens between Blue Lake to the south and South Fork Toutle River to the north (Figure 15, Figure 60). The upper basin is defined by a single channel that drains the southern flank of Crescent Dome, but does not host a glacier or permanent snowfield (Figure 61). The upper basin is mapped as $80 \%$ volcaniclastic deposits (Qvc) that form unconsolidated slopes throughout the upper basin (WaDNR, 2010). The loose rocky slopes of Crescent Dome, a Pleistocene intrusive andesite and dacite dome, are mapped 
Table 22: Blue Lake Drainage Basin attributes.

\begin{tabular}{|c|c|c|c|c|}
\hline \multirow{2}{*}{$\begin{array}{l}\text { Basin Attributes } \\
\underline{\text { Total Basin }}\end{array}$} & & \multirow[t]{2}{*}{ Geologic Units * } & \multicolumn{2}{|c|}{$\%$ Basin } \\
\hline & & & Total & Upper \\
\hline Area $\left(m^{2}\right)$ & $2,205,160$ & Water & & \\
\hline Comparative size rank & $13^{\text {th }}$ & ice & & \\
\hline Highest elevation (m) & 2,463 & $\underline{\text { Volcanics }}$ & & \\
\hline Lowest elevation (m) & 1,006 & Qv(sh) & & \\
\hline Height (m) & 1,457 & $\underline{\text { Andesite }}$ & & \\
\hline Length ( $\mathrm{m})$ & 5,741 & MOian & & \\
\hline Gradient & 0.25 & MOva(2) & & \\
\hline \multirow[t]{2}{*}{ MRN } & 0.98 & Qiad(1) & & \\
\hline & & Qiad(2) & & \\
\hline$\underline{\text { Upper Basin }}$ & & QPLiad(g) & 3.3 & \\
\hline Area $\left(m^{2}\right)$ & 876,409 & Qva(1sh) & & \\
\hline Comparative size rank & $10^{\text {th }}$ & Qva(2sh) & 6.1 & 15.3 \\
\hline Highest elevation (m) & 2,463 & Basalt & & \\
\hline Lowest elevation (m) & 1,404 & Qvb(2sh) & & \\
\hline Height (m) & 1,060 & $\underline{\text { Volcaniclastics }}$ & & \\
\hline Length $(\mathrm{m})$ & 2,490 & $\operatorname{MOvc}(2)$ & & \\
\hline Gradient & 0.43 & OEvc & & \\
\hline MRN & 1.13 & Qvc(1sh) & 10.6 & \\
\hline Percent vegetation (\%) & 2.2 & Qvc(2sh) & 42.3 & 77.5 \\
\hline Percent steep slope (\%) & 34 & Qvc(sh) & & \\
\hline \multirow[t]{2}{*}{ Avg. annual precip. (m) } & 4.0 & Qvp(3sh) & & \\
\hline & & Ovt(1) & & \\
\hline$\underline{\text { Glacier }}$ & & $\underline{\text { Alluvium }}$ & & \\
\hline Area $\left(m^{2}\right)$ & - & Qa & & \\
\hline Retreat distance $(\mathrm{m})$ & - & Qgu & 2.4 & \\
\hline \multirow[t]{2}{*}{ Percent change in area (\%) } & - & $\underline{\text { Colluvium }}$ & & \\
\hline & & Qvl(3sh) & 35.4 & 7.2 \\
\hline \multicolumn{5}{|l|}{ Initiation } \\
\hline Elevation (m) & 2,124 & Summary & & \\
\hline Direct connection to glacier & - & Ice & 0.0 & 0.0 \\
\hline Distance from glacier (m) & - & Bedrock & 9.4 & 15.3 \\
\hline \multirow[t]{5}{*}{ Type } & Landslide & Unconsolidated & 90.7 & 84.7 \\
\hline & & Measured Extents ** & & \\
\hline & & Snowpack and Ice & & 3.7 \\
\hline & & Consolidated Bedrock & & 2.8 \\
\hline & & Unconsolidated & & 93.5 \\
\hline
\end{tabular}

* data from WaDNR, 2010.

** data from measured extents on 2009 ortho imagery (USDA-FSA, 2009). 


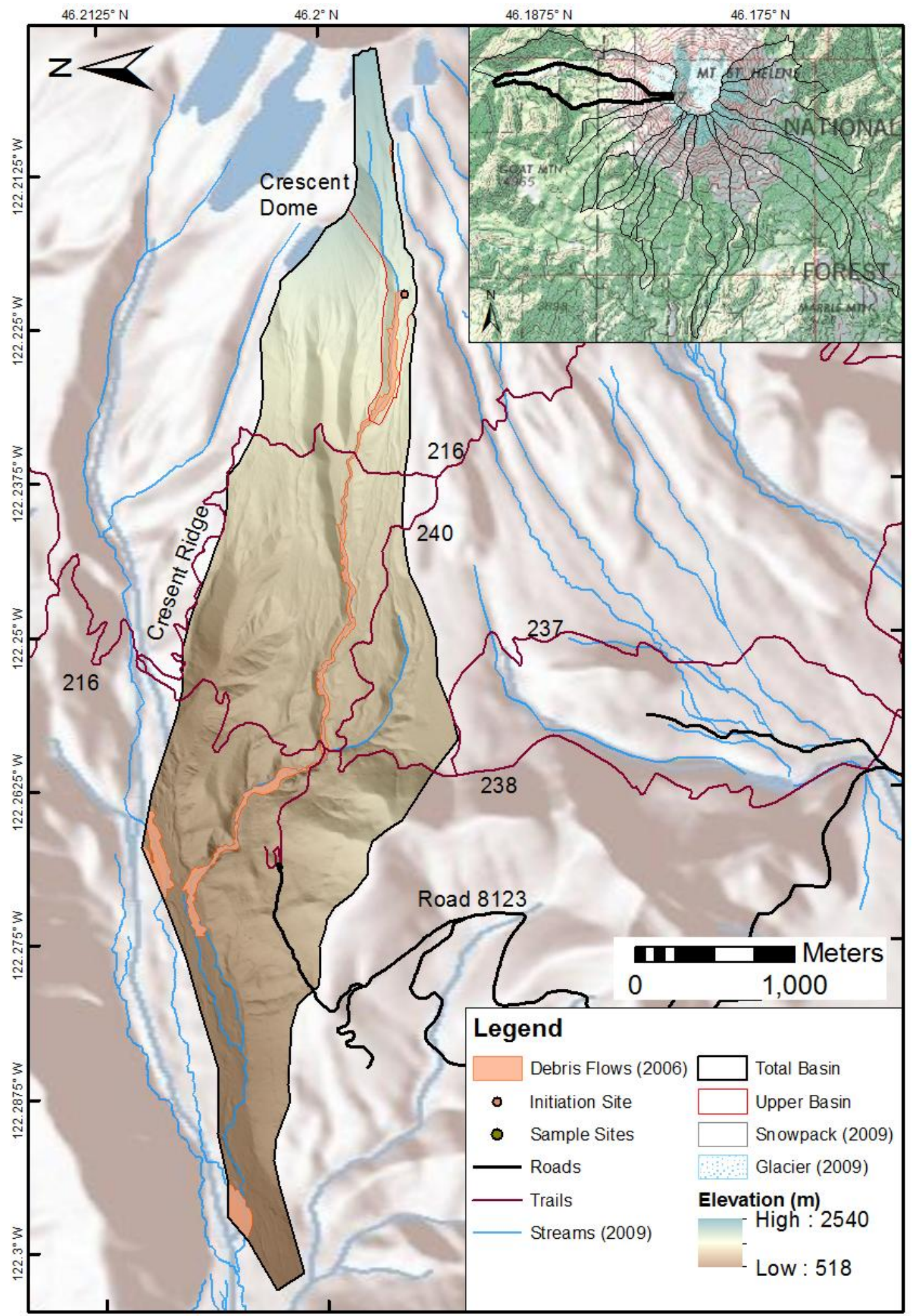

Figure 60: Map of Sheep Creek Drainage located in the western quadrant of Mount St. Helens between the Blue Lake and South Fork Toutle drainages. The upper basin no longer hosts a glacier, but the upper regions of the drainage contain large unconsolidated deposits. North is to the left. 


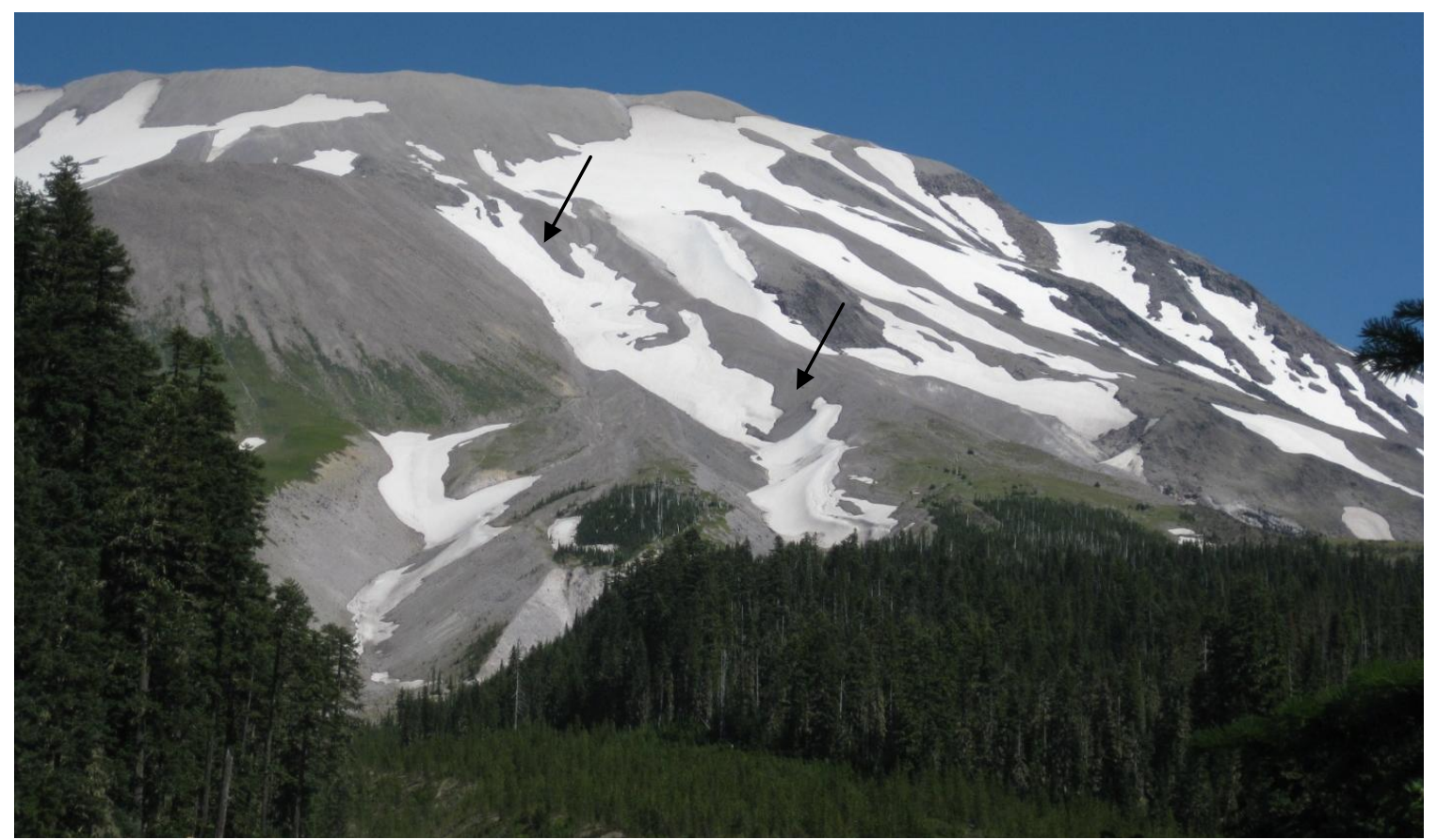

Figure 61: View of the Sheep Creek upper basin area from Trail 240 on the south side of Sheep Canyon. The arrows designate the active channel. The bare feature to the left is Crescent Dome a Pleistocene andesite and dacite intrusion. Considerable snow was present on the upper slopes of the mountain when this picture was taken in mid-August 2011. View is to the east.

over $10 \%$ of the upper basin and appear as a small segment of the northern wall of the channel (WaDNR, 2010). The lowest extent of the upper basin is about $1,420 \mathrm{~m}$ elevation or roughly $230 \mathrm{~m}$ above Trail 216.

Below the upper basin, Sheep Creek flows westward through Sheep Canyon. At about 1,100 m elevation the stream meets the junction of Trail 238 with 240 and makes a northward turn into a narrow canyon. In the $1.3 \mathrm{~km}$ between that junction and the opening of the canyon into the South Fork Toutle River Valley the stream loses $240 \mathrm{~m}$ of elevation. Possibly because of the narrow canyon there was no well-defined depositional fan as observed in other drainages. Waters from Sheep Creek Drainage Basin flow about $2.5 \mathrm{~km}$ along the south side of the valley bottom though a region of 
channel migration before merging with the South Fork Toutle River at about $700 \mathrm{~m}$ elevation.

\section{Determination of Initiation Zone}

Field observations found evidence of recent debris flow activity in the lower Sheep Creek Channel. However, mid-August snowpack in the active channel hid initiation sites from field observation. Comparison of 2006 and 2009 ortho imagery revealed channel migration and erosion at the lower end of the southern-most ravine and areas of possible channel erosion above 1,600 m elevation near the features observed in the field (USDA-FSA, 2006; USDA-FSA, 2009). Therefore, it was determined that a landslide in the channel bank or bank erosion near 1,600 m elevation was the most likely initiation site of the 2006 Sheep Creek Debris Flow.

\section{Data Processing}

\section{Sieve Results}

No soil samples were taken from the Sheep Creek Drainage.

\section{$\underline{\text { Basin Attributes }}$}

The initiation zone for the Sheep Creek Drainage was found at an elevation of $1,670 \mathrm{~m}$, within an area mapped as andesite flows (Qva) but nearby an area of volcaniclastic deposits and rocks (Qvc) (WaDNR, 2010). The geologic units of the upper basin were mapped as $17 \%$ bedrock (volcanics, andesite, and basalt), $83 \%$ unconsolidated (volcaniclastics, alluvium, and colluvium), and $0 \%$ ice according to the 
geologic map (WaDNR, 2010). The measured extents of the upper basin geology are $0 \%$ consolidated bedrock exposures, $100 \%$ unconsolidated deposits, and $0 \%$ snowpack and ice. A full summary of the basin attributes is listed in Table 23.

\section{SOUTH FORK TOUTLE RIVER DRAINAGE BASIN}

\section{Introduction}

The South Fork Toutle River Drainage Basin is located in the western quadrant of Mount St. Helens between Sheep Creek to the south and the 1980 debris avalanche zone to the north (Figure 15, Figure 62). This drainage has both the largest total and upper basin areas, at 9,872,990 $\mathrm{m}^{2}$ and 3,767,130 $\mathrm{m}^{2}$, respectively. The upper basin hosts two former glaciers which are now demoted to snowfields, and two large and deeply incised ravines (Figure 63). The northern channel branches at 1,430 m elevation into two upper channel basins which both host former glaciers. At 1,700 m elevation both of these channels have exposed a competent rock layer (unmapped) relatively resistant to erosion which has formed waterfalls with drops around $50 \mathrm{~m}$. The southern channel converges with the main South Fork Toutle River Channel at 1, 070 m elevation, which also defines the lower extent of the upper basin. The southern boundary is defined by Crescent Ridge, while the northern boundary follows the rim of the South Fork Toutle River valley. The geology of the upper basin is predominately mapped as $83 \%$ volcaniclastics (WaDNR, 2010).

Below the confluence, the combined channel continues in a narrow ravine about $800 \mathrm{~m}$ further downslope before opening onto a valley floor composed of debris flow 
Table 23: Sheep Creek Drainage Basin attributes.

\begin{tabular}{|c|c|c|c|c|}
\hline \multirow{2}{*}{$\begin{array}{l}\text { Basin Attributes } \\
\text { Total Basin }\end{array}$} & & \multirow[t]{2}{*}{ Geologic Units * } & \multicolumn{2}{|c|}{$\%$ Basin } \\
\hline & & & Total & Upper \\
\hline Area $\left(m^{2}\right)$ & $6,746,770$ & Water & & \\
\hline Comparative size rank & $5^{\text {th }}$ & ice & & \\
\hline Highest elevation (m) & 2,438 & $\underline{\text { Volcanics }}$ & & \\
\hline Lowest elevation (m) & 690 & Qv(sh) & & \\
\hline Height (m) & 1,749 & Andesite & & \\
\hline Length $(\mathrm{m})$ & 9,004 & MOian & & \\
\hline Gradient & 0.19 & MOva(2) & & \\
\hline \multirow[t]{2}{*}{ MRN } & 0.67 & Qiad(1) & 1.5 & 9.6 \\
\hline & & Qiad(2) & & \\
\hline$\underline{\text { Upper Basin }}$ & & QPLiad(g) & & \\
\hline Area $\left(m^{2}\right)$ & 433,877 & Qva(1sh) & & \\
\hline Comparative size rank & $15^{\text {th }}$ & Qva(2sh) & 1.0 & 7.3 \\
\hline Highest elevation (m) & 2,438 & $\underline{\text { Basalt }}$ & & \\
\hline Lowest elevation (m) & 1,418 & Qvb(2sh) & & \\
\hline Height (m) & 1,021 & $\underline{\text { Volcaniclastics }}$ & & \\
\hline Length $(\mathrm{m})$ & 2,406 & $\operatorname{MOvc}(2)$ & 8.4 & \\
\hline Gradient & 0.42 & OEvc & 1.7 & \\
\hline MRN & 1.55 & Qvc(1sh) & 50.2 & 2.4 \\
\hline Percent vegetation (\%) & 0.6 & Qvc(2sh) & 13.5 & 79.7 \\
\hline Percent steep slope (\%) & 36 & Qvc(sh) & & \\
\hline \multirow[t]{2}{*}{ Avg. annual precip. (m) } & 3.9 & Qvp(3sh) & & \\
\hline & & Ovt(1) & & \\
\hline$\underline{\text { Glacier }}$ & & Alluvium & & \\
\hline Area $\left(m^{2}\right)$ & - & Qa & 0.8 & \\
\hline Retreat distance $(\mathrm{m})$ & - & Qgu & & \\
\hline \multirow[t]{2}{*}{ Percent change in area (\%) } & - & Colluvium & & \\
\hline & & Qvl(3sh) & 23.1 & 1.0 \\
\hline \multicolumn{5}{|l|}{ Initiation } \\
\hline Elevation (m) & 1,670 & Summary & & \\
\hline Direct connection to glacier & - & Ice & 0.0 & 0.0 \\
\hline Distance from glacier (m) & - & Bedrock & 2.5 & 16.9 \\
\hline \multirow[t]{5}{*}{ Type } & Headless & Unconsolidated & 97.6 & 83.1 \\
\hline & & Measured Extents ** & & \\
\hline & & Snowpack and Ice & & 0.0 \\
\hline & & Consolidated Bedrock & & 0.0 \\
\hline & & Unconsolidated & & 100.0 \\
\hline
\end{tabular}

* data from WaDNR, 2010.

** data from measured extents on 2009 ortho imagery (USDA-FSA, 2009). 


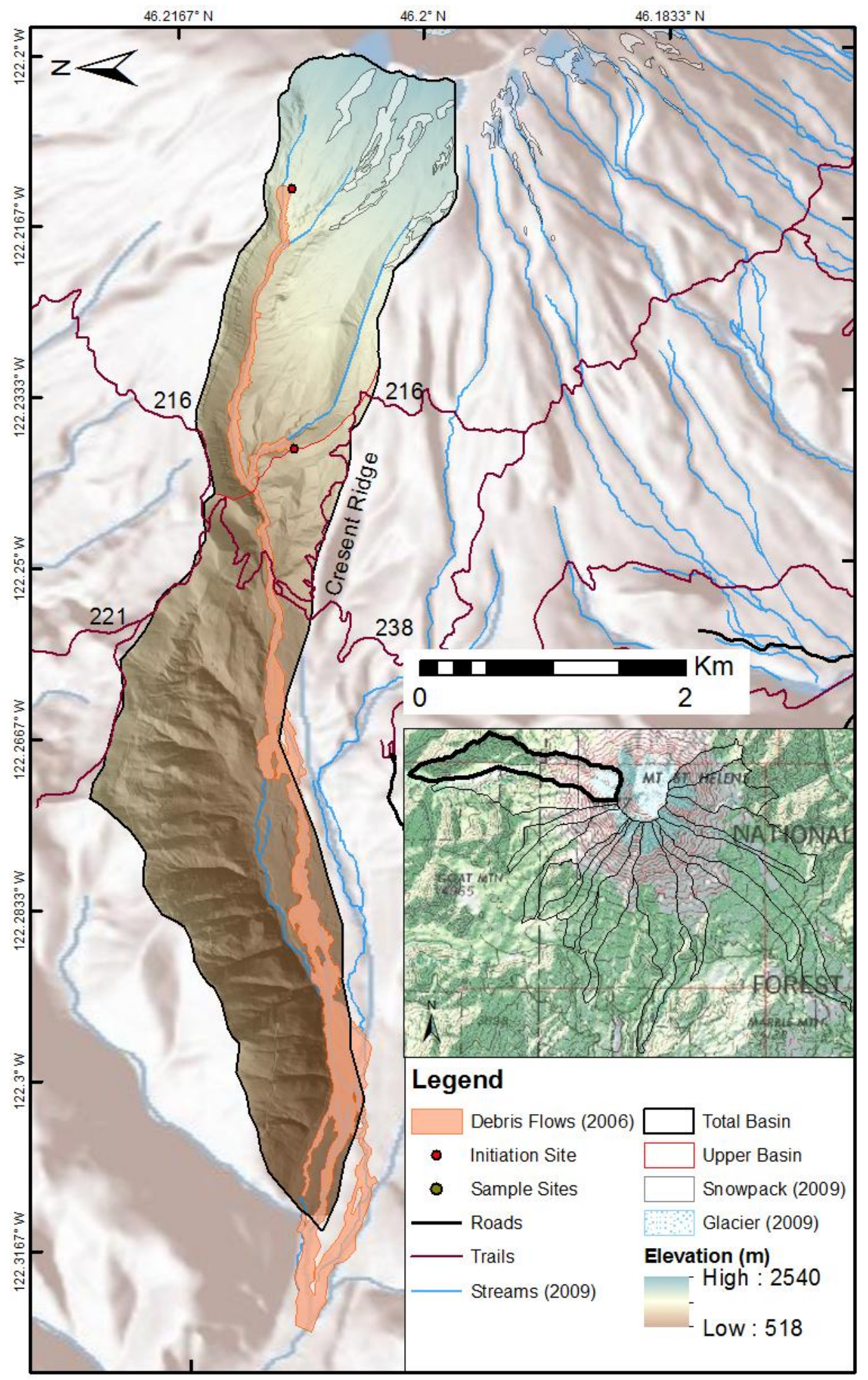

Figure 62: Map of South Fork Toutle River Drainage located in the western quadrant of Mount St. Helens between the Sheep Creek Drainage and the 1980 debris avalanche zone. The upper basin includes the Toutle and Talus Glaciers which did not exhibit bergschrunds in 2009 orthophotos (USDA-FSA, 2009). North is to the left. 


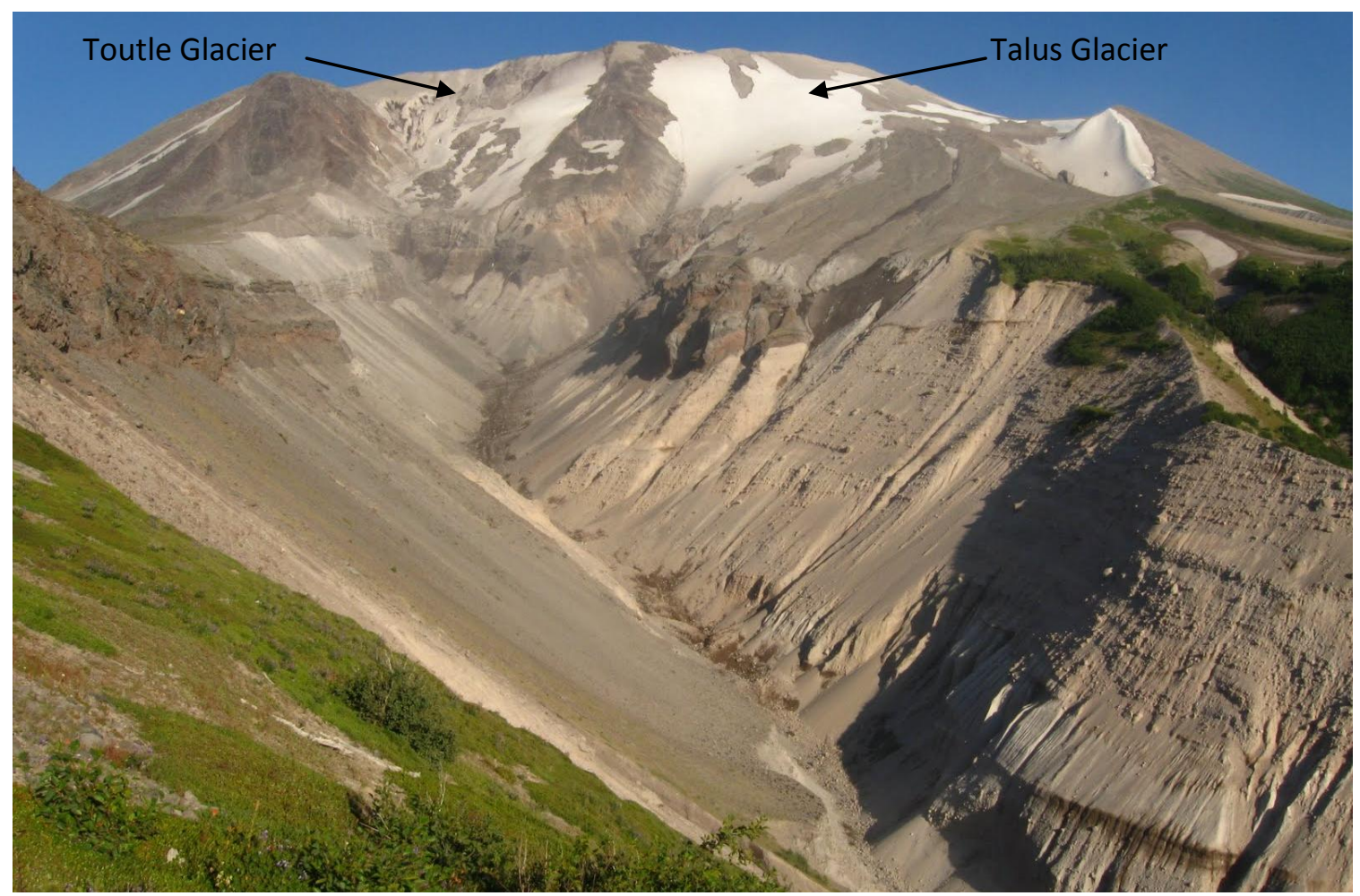

Figure 63: View of the northern channel of the South Fork Toutle River upper basin in August 2011. The southern channel is not visible, but is to the right of this image. The peak to the left is West Dome. The area to the right of that is the Toutle Glacier separated by a ridge from the Talus Glacier. View is the east from Trail 216. Photo credit to patskros.blogspot.com.

and lahar deposits (Qvl) (WaDNR, 2010). The most recent debris flow deposit, formed in 2006 , has been eroded and reworked by the stream, but is estimated to cover about $975,000 \mathrm{~m}^{2}$ and is therefore the largest depositional area measured for this storm event. Within the total basin, the widest extent of this valley is about $700 \mathrm{~m}$ near the stream elevation of $800 \mathrm{~m}$. The northern boundary of the total basin is defined by a 1,386 m high ridge mapped as Lower Oligocene tuffs and tuff breccias (Ovt) (WaDNR, 2010). The southern boundary is located near the middle of the valley and separates the South Fork Toutle River from channels of the Sheep Creek Drainage. The total basin extends westward about $5.5 \mathrm{~km}$ from the terminus of the upper basin. Water from this 
drainage basin continues westward to converge with the North Fork Toutle River, which joins the Cowlitz River, and eventually the Columbia River.

\section{Determination of Initiation Zone}

Field observations found some evidence of unstable slopes and recent debris flow activity along the main channel of the South Fork Toutle River. However, comparison of 2006 and 2009 ortho imagery was vital in examining such a large and rugged drainage basin. The comparison found three landslides in the upper basin: two in the northern channel near the waterfall below Toutle Glacier and one in the southern channel below the headward erosion notch. The landslide in the southern channel wall at 1,140 m elevation has a measured area of $95 \mathrm{~m}$ wide by $60 \mathrm{~m}$ high and an estimated depth of $40 \mathrm{~m}$ (Figure 64). These dimensions give an estimated volume of $222,000 \mathrm{~m}^{3}$.

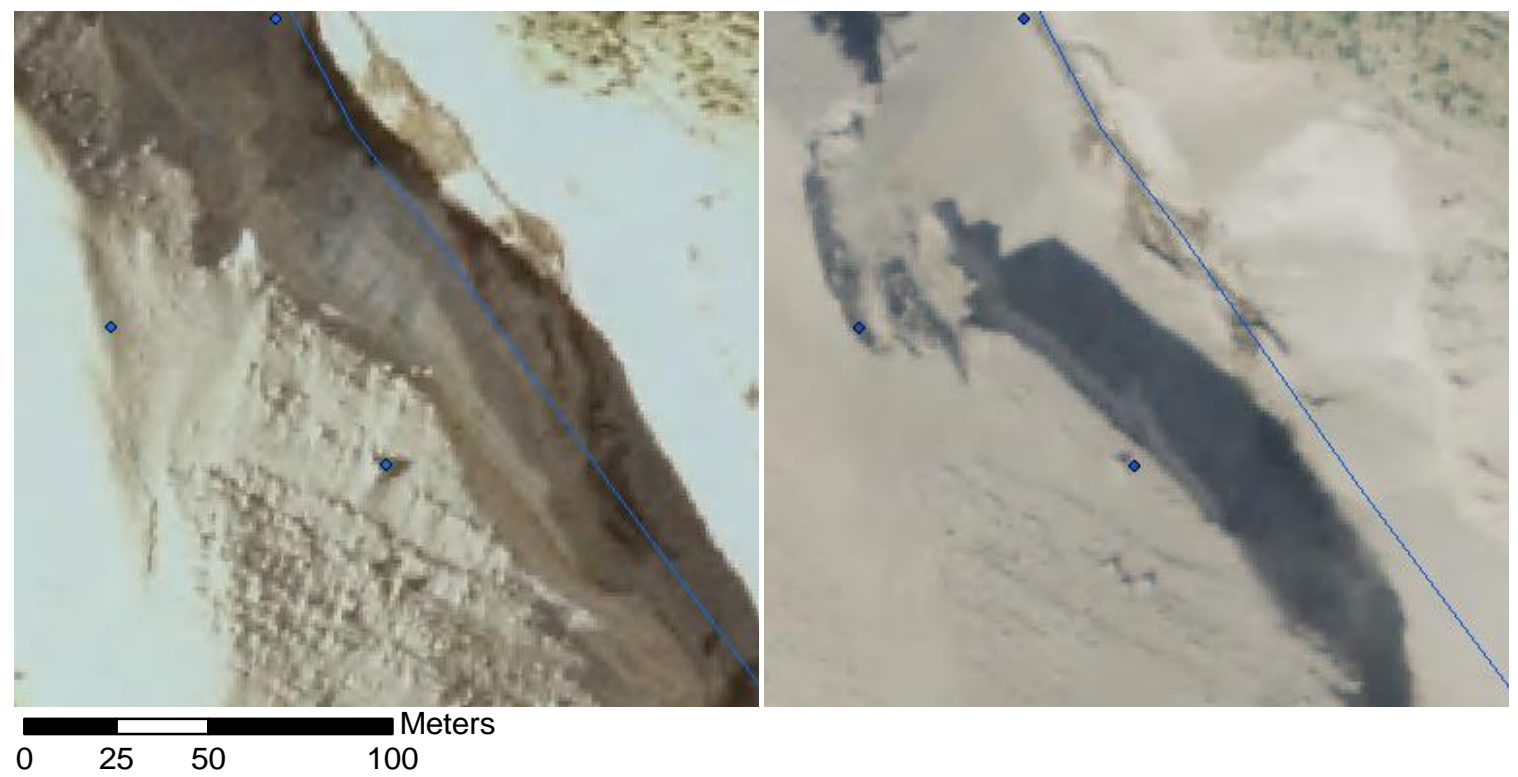

Figure 64: Comparison of 2006 (left) and 2009 (right) ortho imagery showing an initiation site of the 2006 South Fork Toutle River Debris Flow (USDA-FSA, 2006; USDA-FSA, 2009). The landslide scarp and toe are indicated by blue dots. A zone of channel wall erosion upslope from the landslide is also indicated. The dots (and stream line) are in the same spatial location in both images (the top of the landslide is at UTM 10N558740E 5117558N). North is up 
In the northern channel, the rock wall to the south of the waterfall below Toutle Glacier apparently retreated by about $30 \mathrm{~m}$ over some $80 \mathrm{~m}$ of cliff face. Estimating the height of the cliff face to be $40 \mathrm{~m}$, this equates to a rockfall volume of about $60,000 \mathrm{~m}^{3}$ (Figure 65). A landslide near 1,700 m elevation in unconsolidated deposits on the opposite side this waterfall has a measured area of $35 \mathrm{~m}$ wide by $40 \mathrm{~m}$ high, with an estimated depth of $50 \mathrm{~m}$, resulting in an estimated volume of $70,000 \mathrm{~m}^{3}$. The extent of the debris flow deposits were also mapped down-valley by changes in surface color caused by the removal of vegetation and the resurfacing of the valley floor. From ortho imagery comparisons, it was determined that multiple landslides were the initiation sources for the 2006 South Fork Toutle River Debris Flow.

\section{Data Processing}

\section{Sieve Results}

No soil samples were taken from the South Fork Toutle River Drainage.

\section{$\underline{\text { Basin Attributes }}$}

The primary initiation zone was found in the South Fork Toutle River Drainage at an elevation of $1,706 \mathrm{~m}$, within an area mapped as volcaniclastic deposits and rocks (Qvc) (WaDNR, 2010). The geologic units of the upper basin are $88 \%$ unconsolidated (volcaniclastics, alluvium, and colluvium), less than $1 \%$ bedrock (volcanics, andesite, and basalt), and $12 \%$ ice according to the geologic map (WaDNR, 2010). The measured extents of the upper basin geology are $7 \%$ snowpack and ice, $9 \%$ consolidated bedrock 

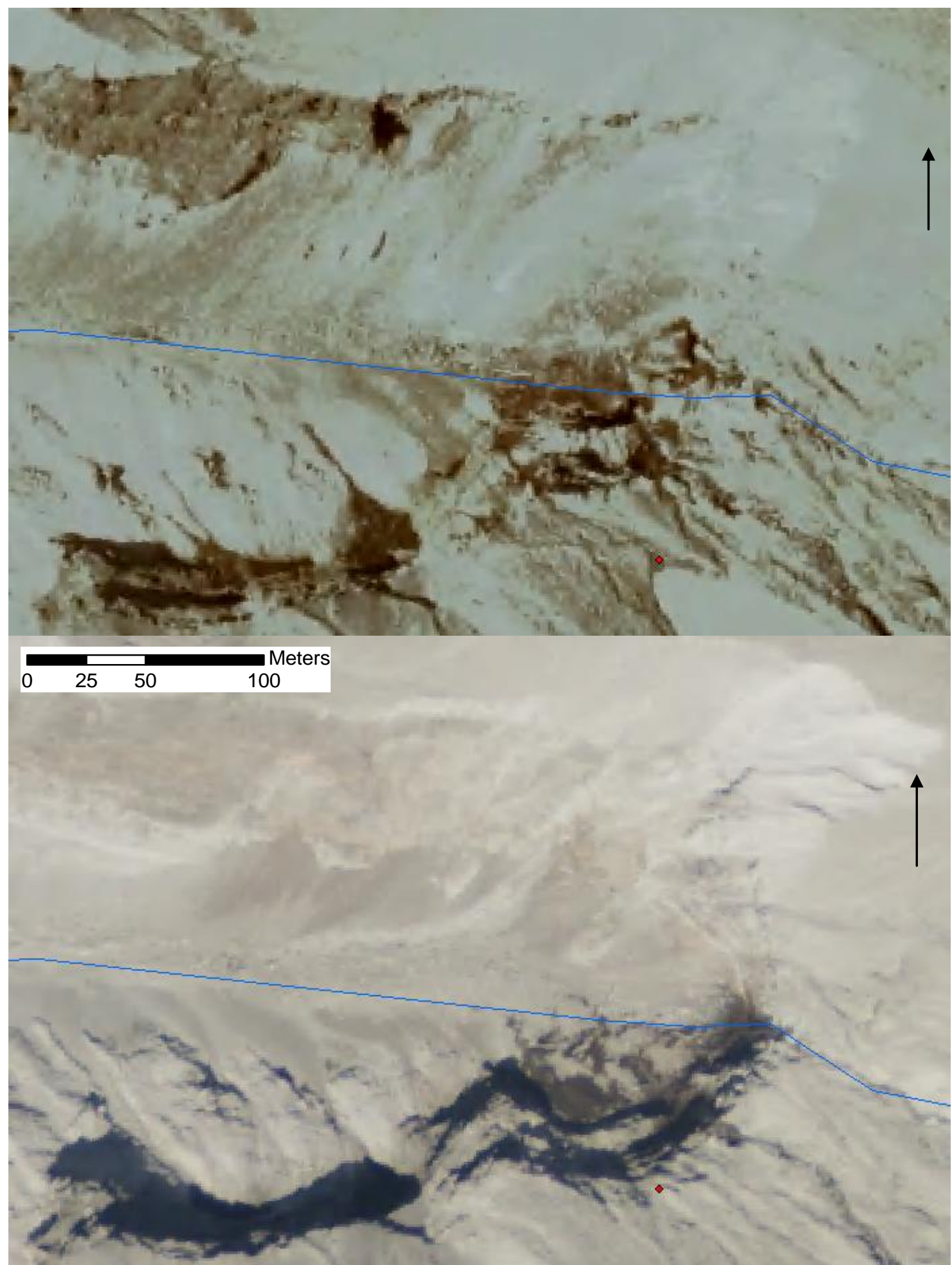

Figure 65: Comparison of 2006 (top) and 2009 (bottom) ortho imagery showing the initiation zone of the 2006 South Fork Toutle River Debris Flow (USDA-FSA, 2006; USDA-FSA, 2009). The cliff face on the right has apparently retreated (red dot) about $30 \mathrm{~m}$. A landslide is also visible in the upper right corner (arrow). The dots (and stream line) are in the same spatial location in both images (UTM 10N560693E 5117576N). North is up. 
exposures, and $85 \%$ unconsolidated deposits. A full summary of the basin attributes is listed in Table 24.

As measured on the 2009 orthophotographs, the Toutle and Talus Glaciers covered a combined area of $128,625 \mathrm{~m}^{2}$, or $3 \%$, of the upper basin (USDA-FSA, 2009). Of this amount, Toutle Glacier covered an area of $203,774 \mathrm{~m}^{2}$ and Talus Glacier an area of $267,766 \mathrm{~m}^{2}$. Between 1998 and 2009 the glaciers decreased in combined surface area by $147 \%$, or $77 \%$ by the Toutle Glacier and $69 \%$ by the Talus Glacier. During this interval the Toutle Glacier retreated upslope by 466 m (USGS, 2002; USDA-FSA, 2009), while the Talus Glacier apparently did not retreat. However, the 2009 orthophotographs reveal that both glaciers broke into fragments, with only the Toutle Glacier retaining one larger field which did not exhibit a bergschrund (USDA-FSA, 2009). Therefore, this drainage basin was classified as not hosting a glacier, but a two permanent snowpacks.

\section{DEBRIS FLOW SUMMARY}

During the heavy precipitation event of November 2006 those drainage basins that experienced debris flows on Mount St. Helens were the Muddy River, Shoestring Glacier, Pine Creek, June Lake, Butte Camp Dome, Blue Lake, Sheep Creek, and the South Fork Toutle River. All sixteen drainages except the Kalama had evidence of pre2006 debris flows. In some drainage basins the last debris flow activity may have been from lahars generated during the May 18, 1980 eruption. However, that each drainage has a Melton's Ruggedness Number greater than 0.3, suggests that they are all capable 
Table 24: South Fork Toutle River Drainage Basin attributes.

\begin{tabular}{|c|c|c|c|c|}
\hline \multirow{2}{*}{$\begin{array}{l}\text { Basin Attributes } \\
\text { Total Basin }\end{array}$} & & \multirow[t]{2}{*}{ Geologic Units * } & \multicolumn{2}{|c|}{$\%$ Basin } \\
\hline & & & Total & Upper \\
\hline Area $\left(m^{2}\right)$ & $9,872,990$ & Water & & \\
\hline Comparative size rank & $1^{\text {st }}$ & ice & 4.6 & 12.2 \\
\hline Highest elevation (m) & 2,424 & Volcanics & & \\
\hline Lowest elevation (m) & 640 & Qv(sh) & & \\
\hline Height (m) & 1,784 & Andesite & & \\
\hline Length (m) & 9,603 & MOian & 0.3 & \\
\hline Gradient & 0.19 & MOva(2) & 5.3 & \\
\hline \multirow[t]{2}{*}{ MRN } & 0.57 & Qiad(1) & 0.2 & 0.4 \\
\hline & & Qiad(2) & & \\
\hline$\underline{\text { Upper Basin }}$ & & QPLiad(g) & & \\
\hline Area $\left(\mathrm{m}^{2}\right)$ & $3,767,130$ & Qva(1sh) & & \\
\hline Comparative size rank & $1^{\text {st }}$ & Qva(2sh) & & \\
\hline Highest elevation (m) & 2,424 & Basalt & & \\
\hline Lowest elevation (m) & 1,058 & Qvb(2sh) & & \\
\hline Height (m) & 1,366 & $\underline{\text { Volcaniclastics }}$ & & \\
\hline Length (m) & 3,490 & $\operatorname{MOvc}(2)$ & & \\
\hline Gradient & 0.39 & OEvc & & \\
\hline MRN & 0.70 & Qvc(1sh) & 26.0 & 37.2 \\
\hline Percent vegetation (\%) & 9.3 & Qvc(2sh) & 15.0 & 38.8 \\
\hline Percent steep slope (\%) & 50 & Qvc(sh) & 0.3 & \\
\hline \multirow[t]{2}{*}{ Avg. annual precip. (m) } & 3.8 & Qvp(3sh) & 2.6 & 6.9 \\
\hline & & Ovt(1) & 29.5 & 0.0 \\
\hline$\underline{\text { Glacier }}$ & & $\underline{\text { Alluvium }}$ & & \\
\hline Area $\left(m^{2}\right)$ & 128,625 & Qa & 0.0 & \\
\hline Retreat distance $(\mathrm{m})$ & 466 & Qgu & & \\
\hline \multirow[t]{2}{*}{ Percent change in area (\%) } & -147 & $\underline{\text { Colluvium }}$ & & \\
\hline & & Qvl(3sh) & 16.2 & 4.5 \\
\hline \multicolumn{5}{|l|}{ Initiation } \\
\hline Elevation $(\mathrm{m})$ & 1,706 & Summary & & \\
\hline Direct connection to glacier & - & Ice & 4.6 & 12.2 \\
\hline Distance from glacier (m) & - & Bedrock & 5.8 & 0.4 \\
\hline \multirow[t]{5}{*}{ Type } & Landslide & Unconsolidated & 89.6 & 87.5 \\
\hline & & Measured Extents ** & & \\
\hline & & Snowpack and Ice & & 6.8 \\
\hline & & Consolidated Bedrock & & 8.6 \\
\hline & & Unconsolidated & & 84.6 \\
\hline
\end{tabular}

* data from WaDNR, 2010.

** data from measured extents on 2009 ortho imagery (USDA-FSA, 2009). 
of producing a debris flow as opposed to being predominantly driven by fluvial processes (Jackson et al., 1987)

The following is a summary of important cumulative statistics on the drainage basins in the studied quadrants of Mount St. Helens. The associated error in measurement for each value is reported in standard deviations.

- Of the eight debris flows, three were initiated by a landslide, five were initiated by channel side-wall or head-ward erosion during high flow in the stream, and none were initiated by combined surface flow and mobilized sediment from rilling or headless debris flows.

- In those drainages with debris flows, the initiation elevation ranged from 1,403 to $2,124 \mathrm{~m}$ with an average of $1,753 \pm 225 \mathrm{~m}$. Two initiation clusters were noted around elevations $1,700 \mathrm{~m}$ and $2,000 \mathrm{~m}$.

- Measured debris flow lengths ranged from 3,760 to 8,900 $\mathrm{m}$ with an average of $6,045 \pm 1,529 \mathrm{~m}$

- Measured depositional zones from ortho imagery ranged from 300,000 to $975,000 \mathrm{~m}^{2}$ with an average of 565,000 $\pm 360,104 \mathrm{~m}^{2}$.

- Six of the debris flows initiated in units mapped as Holocene volcaniclastic deposits (Qvc), while two were mapped as andesite flows (Qva) observed to be covered by 1980 lahar and/or pyroclastic deposits.

- The Melton's Ruggedness Number calculated for the upper basins with debris flows ranged from 0.70 and 1.55 , with an average of $1.08 \pm 0.32$. For 
upper basins without debris flows the value ranged from 0.83 to 1.61 , with an average of $1.18 \pm 0.27$

- Percent steep slopes above 33 degrees in the upper basin of each drainage with debris flows ranged from 34 to $51 \%$, with an average of $41 \pm 7 \%$. For upper basins without debris flows the value ranged from 15 to $39 \%$, with an average of $28 \pm 9 \%$.

- Percent vegetation in the upper basin of each drainage with a debris flow ranged from 0.0 to $9.3 \%$, with an average of $1.8 \pm 3.1 \%$. For upper basins without debris flows the value ranged from 0.0 to $7.4 \%$, with an average of

\section{$2.2 \pm 3.1 \%$}

- Categorizing geology by area from ortho imagery measurements into three groups found that for upper basins with debris flows: snowpack and ice averaged $6 \pm 3 \%$, consolidated bedrock averaged $21 \pm 16 \%$, and unconsolidated deposits averaged $74 \pm 19 \%$. For upper basins without debris flows the snowpack and ice averaged $7 \pm 3 \%$, consolidated bedrock averaged $27 \pm 18 \%$, and unconsolidated deposits averaged $67 \pm 19 \%$.

- Upper basin gradient ranged from 0.37 to 0.47 with an average of $0.41 \pm 0.03$ for basins with debris flows. For upper basins without debris flows the value ranged from 0.34 to 0.52 with an average of $0.43 \pm 0.06$.

- The upper basin lengths ranged from 2,333 to 3,490 $\mathrm{m}$ with an average of $2,867 \pm 439 \mathrm{~m}$ for basins with debris flows. For upper basins without debris 
flows the value ranged from 1,922 to $3,162 \mathrm{~m}$ with an average of $2,635 \pm 521$

m.

- The upper basin heights ranged from 1,020 to $1,366 \mathrm{~m}$ with an average of $1,171 \pm 111 \mathrm{~m}$ for basins with debris flows. For upper basins without debris flows the value ranged from 950 to $1,286 \mathrm{~m}$ with an average of 1,098 \pm 118 m.

- The upper basin highest elevation ranged from 2,424 to $2,539 \mathrm{~m}$ with an average of $2,475 \pm 35 \mathrm{~m}$ for basins with debris flows. For upper basins without debris flows the value ranged from 2,303 to $2,537 \mathrm{~m}$ with an average of $2,468 \pm 77 \mathrm{~m}$.

- The upper basin lowest elevation ranged from 1,058 to $1,442 \mathrm{~m}$ with an average of $1,304 \pm 124 \mathrm{~m}$ for basins with debris flows. For upper basins without debris flows the value ranged from 1,226 to 1,502 $\mathrm{m}$ with an average of $1,370 \pm 91 \mathrm{~m}$.

- The area of upper basins with debris flows ranged from 433,877 to 3,767,130 $\mathrm{m}^{2}$ with an average of $1,523,040 \pm 1,060,374 \mathrm{~m}^{2}$. For upper basins without debris flows the value ranged from 348,562 to $2,392,670 \mathrm{~m}^{2}$ with an average of $1,044,560 \pm 646,267 \mathrm{~m}^{2}$.

- Categorizing geology by area from geologic mapping into three groups found that for upper basins with debris flows: ice averaged $7 \pm 10 \%$, bedrock (volcanics, andesite, and basalt) averaged $36 \pm 26 \%$, and unconsolidated (volcaniclastics, alluvium, and colluvium) averaged $57 \pm 27 \%$ (WaDNR, 2010). 
For upper basins without debris flows the ice averaged $12 \pm 13 \%$, bedrock averaged $47 \pm 26 \%$, and unconsolidated averaged $41 \pm 24 \%$.

- The most common geologic area mapped within the upper basins was volcaniclastics which averaged $40 \pm 29 \%$, with andesite following with an average of $33 \pm 29 \%$, then ice with an average of $15 \pm 11 \%$, and finally basalt with an average of $13 \pm 8 \%$. Of the remaining geologic units in the upper basin: colluvium averaged $5 \pm 7 \%$, volcanics averaged $1 \pm 1 \%$, and alluvium averaged $0 \%$.

- Average annual rainfall ranged from 3.7 to $4.0 \mathrm{~m}$ with an average of $3.9 \pm 0.1$ $m$ in upper basins with debris flows. In upper basins without debris flows this value ranged from 3.5 to $4.0 \mathrm{~m}$ with an average of $3.9 \pm 0.2 \mathrm{~m}$

- The total basin area ranged from $1,975,140$ to $9,872,990 \mathrm{~m}^{2}$ with an average of $5,840,036 \pm 2,949,520 \mathrm{~m}^{2}$ for basins with debris flows. For total basins without debris flows the value ranged from $1,698,690$ to $9,326,490 \mathrm{~m}^{2}$ with an average of 4,202,193 $\pm 2,521,949 \mathrm{~m}^{2}$.

- The total basin length ranged from 5,741 to $12,661 \mathrm{~m}$ with an average of $8,283 \pm 2,136 \mathrm{~m}$ for basins with debris flows. For total basins without debris flows the value ranged from 3,874 to $10,603 \mathrm{~m}$ with an average of $6,993 \pm$ $2,345 \mathrm{~m}$.

- The total basin height ranged from 1,457 to $1,841 \mathrm{~m}$ with an average of 1,663 $\pm 131 \mathrm{~m}$ for basins with debris flows. For total basins without debris flows the value ranged from 1,253 to $1,999 \mathrm{~m}$ with an average of 1,624 $\pm 224 \mathrm{~m}$. 152 
- The total basin highest elevation values are the same as for the upper basin.

- The total basin lowest elevation ranged from 640 to $1,006 \mathrm{~m}$ with an average of $812 \pm 142 \mathrm{~m}$ for basins with debris flows. For total basins without debris flows the value ranged from 512 to $1,173 \mathrm{~m}$ with an average of $844 \pm 201 \mathrm{~m}$.

- Sieve analysis of soil samples collected in drainage basin with debris flows had an average bulk density of $2.0 \pm 0.1$ and an average composition of $36 \pm$ $5 \%$ gravel, $57 \pm 4 \%$ sand, and $7 \pm 3 \%$ silt and clay. Drainage basins without debris flows had an average bulk density of $1.8 \pm 0.2$ and an average composition of $38 \pm 3 \%$ gravel, $54 \pm 2 \%$ sand, and $8 \pm 2 \%$ silt and clay.

- Glacier area ranged from 25,780 to $128,625 \mathrm{~m}^{2}$ with an average of $71,490 \pm$ $32,870 \mathrm{~m}^{2}$.

- Glacier area lost from 1998 to 2009 ranged from 47,173 to $250,583 \mathrm{~m}^{2}$ with an average of $141,859 \pm 65,295 \mathrm{~m}^{2}$, or an average percent change of $-67 \pm$ $13 \%$.

- Only one initiation site was directly connected to a glacier. 


\section{CHAPTER 5 - STATISTICS}

\section{ANOVA AND MULTIPLE REGRESSION}

An analysis of variance (ANOVA) was performed to compare drainage basin attribute data between those that experienced a debris flow in 2006 and those drainage basins that did not experience a debris flow. Those drainage basins with evidence of a 2006 debris flow are Muddy River, Shoestring Glacier, Pine Creek, June Lake, Butte Camp Dome, Blue Lake, Sheep Creek, and South Fork Toutle River. Those without evidence for a 2006 debris flow are Nelson Glacier, Ape Glacier, Worm Flows, Swift Creek, Snowfield, Dryer Glacier, Little Kalama, and Kalama. This test determined that of all the basin attributes, only percent steep slopes has a significantly different mean between the two groups (Table 25). The full results of these ANOVA tests are listed in Table C.1.

Another ANOVA test was performed on the results of the sieve analysis of soil samples to compare between drainage basins that experienced a 2006 debris flow and those that did not experience a debris flow. The results of this test determined that none of the soil samples have significantly different means between the two groups. The bulk density between drainage basins with and without a 2006 debris flow was also tested with the same result. The full results of these ANOVA tests are listed in Table C.2.

A multiple logistic regression was conducted to determine which basin attributes are significant factors in predicting if a debris flow will occur. First, the basin attributes to be used as predictor variables were selected. To achieve this, each variable had to be 
correlated across all drainages, only relate to the upper basin, and not be represented within other attributes. For example, Melton's Ruggedness Number includes basin area and height, so those individual attributes could not be used separately. Also, the percent bedrock is inversely related to percent unconsolidated sediment and so only one was used. From the 24 possible basin attributes listed in Table 25, only 14 were selected (Table 26). Using these 14 variables, a total of 17 basin attribute combinations were generated for multiple logistic regressions tests. Of these 17 logistic regressions

Table 25: Summarized results from the ANOVA test between basin attributes in drainages with and without a 2006 debris flow. Percent steep slopes was the only factor determined to be significantly different. Units are also given for comparison.

\begin{tabular}{l|c|c}
\hline Basin Attribute & p-value & FOS \\
\hline Connection to Glacier & 0.33 & 0.05 \\
Total Basin Area $\left(\mathrm{m}^{2}\right)$ & 0.37 & 0.05 \\
Total Basin Highest Elevation (m) & 0.81 & 0.05 \\
Total Basin Lowest Elevation (m) & 0.72 & 0.05 \\
Total Basin Height (m) & 0.67 & 0.05 \\
Total Basin Length (m) & 0.27 & 0.05 \\
Total Basin Gradient & 0.13 & 0.05 \\
Total Basin Melton's Ruggedness Number & 0.42 & 0.05 \\
Upper Basin Area (m²) & 0.29 & 0.05 \\
Upper Basin Highest Elevation (m) & 0.82 & 0.05 \\
Upper Basin Lowest Elevation (m) & 0.25 & 0.05 \\
Upper Basin Height (m) & 0.23 & 0.05 \\
Upper Basin Length (m) & 0.35 & 0.05 \\
Upper Basin Gradient & 0.57 & 0.05 \\
Upper Basin Melton's Ruggedness Number & 0.52 & 0.05 \\
Upper Basin WaDNR Geology - Ice (\%) & 0.43 & 0.05 \\
Upper Basin WaDNR Geology - Bedrock (\%) & 0.42 & 0.05 \\
Upper Basin WaDNR Geology - Unconsolidated (\%) & 0.24 & 0.05 \\
Upper Basin Snowpack \& Ice (\%) & 0.43 & 0.05 \\
Upper Basin Consolidated Bedrock (\%) & 0.50 & 0.05 \\
Upper Basin Unconsolidated (\%) & 0.46 & 0.05 \\
Upper Basin Percent Vegetation (\%) & 0.82 & 0.05 \\
Upper Basin Percent Steep Slopes (\%) & 0.01 & 0.05 \\
Upper Basin Average Annual Precipitation (m) & 0.89 & 0.05 \\
\hline
\end{tabular}


Table 26: Selected basin attributes to be used in multiple logistic regression tests along with the variable name. All variables relate to upper basin attributes.

\begin{tabular}{l|c}
\hline Basin Attribute & Variable \\
\hline Gradient & $\mathrm{X}_{1}$ \\
Percent WaDNR Ice & $\mathrm{X}_{2}$ \\
Percent WaDNR Bedrock & $\mathrm{X}_{3}$ \\
Percent Steep Slopes & $\mathrm{X}_{4}$ \\
Percent Vegetation & $\mathrm{X}_{5}$ \\
Average Annual Rainfall & $\mathrm{X}_{6}$ \\
Melton's Ruggedness Number & $\mathrm{X}_{7}$ \\
Connection to a Glacier & $\mathrm{X}_{8}$ \\
Height & $\mathrm{X}_{9}$ \\
Area & $\mathrm{X}_{10}$ \\
Percent Snowpack \& Ice & $\mathrm{X}_{11}$ \\
Percent Consolidated Bedrock & $\mathrm{X}_{12}$ \\
Percent Unconsolidated & $\mathrm{X}_{13}$ \\
Percent WaDNR Unconsolidated & $\mathrm{X}_{14}$ \\
\hline
\end{tabular}

the most accurate model $(\# 6 C)$ is described here. The raw basin attribute data for model \# 6C are listed in Table D.1.

Next, the raw basin attribute data for these selected variables were normalized using Equation 5. The normalized data are presented in Table D.2. Then the logistic regression was performed to determine the first set of coefficients for each variable. The results of the first iteration of the multiple logistic regression are shown in Table D.3. Performing the Wald Test on the regression coefficients (Equation 6) indicated that variable $X_{11}$, percent snowpack \& ice, was the least significant. The next iterations removed variables as follows, from least significant to most: gradient $\left(X_{1}\right)$, Melton's Ruggedness Number $\left(X_{7}\right)$, and percent vegetation $\left(X_{5}\right)$. The final most significant variables are percent steep slopes $\left(X_{4}\right)$ with a coefficient of 0.75 , percent unconsolidated $\left(X_{13}\right)$ with a coefficient of 0.38 , and average annual rainfall $\left(X_{6}\right)$ with a coefficient of 0.40 
(Table D.4). Inserting these coefficients and variables into the probability model equation (Equation 4) gives,

$$
Y=\frac{e^{\left(0+0.75 X_{4}+0.38 X_{13}+0.4 X_{6}\right)}}{1+e^{\left(0+0.75 X_{4}+0.38 X_{13}+0.4 X_{6}\right)}}
$$

where $Y$ is the predicted outcome of the model and attribute variables are $X$ (Pirot, 2010).

To test the accuracy of the model in predicting 2006 debris flows $(Y)$, the normalized variable data for $X_{4}, X_{13}$, and $X_{6}$ are inserted into the equation for each drainage basin. The results of this predictive model are shown in Table 27 . This model correctly predicted 7 of 8 debris flows. Only the debris flow in Pine Creek Drainage was predicted to not occur.

Multiple combinations of basin attributes were combined and tested using this logistic regression model. Criteria for model acceptability included accuracy at correctly predicting occurrence or non-occurrence of a debris flows, and ability to avoid false positives or false negatives. Another consideration was the ranking of wrongly predicted debris flows, specifically false negatives. If a major 2006 debris flow, such as South Fork Toutle River, Blue Lake, or Muddy River was not predicted to occur, then that model was ranked lower than others with the same accuracy. The final consideration involved ranking the selection of most significant basin attributes by the logistic regression. For example, a model that found the connection to a glacier $\left(X_{8}\right)$ to be the most significant attribute for determining a debris flow in a drainage basin was ranked lower than other models with the same accuracy. 
Table 27: Results of the predictive model described by Equation 7. Drainages in bold have $Y$ values $>0.50$. This model has $94 \%$ accuracy with no false positives and one false negative.

\begin{tabular}{l|cc}
\hline & & $\begin{array}{c}\text { Debris Flow } \\
\text { Drainage }\end{array}$ \\
\hline South Toutle & $\mathbf{0 . 7 7}$ & $\mathbf{1}$ \\
Shoestring Glacier & $\mathbf{0 . 7 4}$ & $\mathbf{1}$ \\
Sheep Creek & $\mathbf{0 . 7 1}$ & $\mathbf{1}$ \\
Blue Lake & $\mathbf{0 . 6 4}$ & $\mathbf{1}$ \\
Butte Camp Dome & $\mathbf{0 . 6 3}$ & $\mathbf{1}$ \\
June Lake & $\mathbf{0 . 6 1}$ & $\mathbf{1}$ \\
Muddy River & $\mathbf{0 . 5 3}$ & $\mathbf{1}$ \\
Swift Creek & 0.46 & 0 \\
Snowfield & 0.46 & 0 \\
Pine Creek & 0.44 & 1 \\
Worm Flows & 0.39 & 0 \\
Ape Canyon & 0.35 & 0 \\
Unnamed 1 & 0.34 & 0 \\
Unnamed 2 & 0.34 & 0 \\
Dryer Glacier & 0.33 & 0 \\
Nelson Glacier & 0.25 & 0 \\
\hline
\end{tabular}

\section{MULTIPLE REGRESSION USING COMBINED DATA}

To further redefine the predictive model used by Pirot (2010), the drainage basin attribute data from both Mount St. Helens and Mt. Adams, Washington (Williams, 2011) were combined with those from Mt. Hood, Oregon. Pirot and Williams performed logistic regressions using similar basin attributes to predict debris flows on their respective volcanoes. However, only basin attributes that are correlated across all drainage basins can be combined in a multiple logistic regression. Pirot (2010) used rainfall amount, percent bedrock, percent vegetation, percent steep slopes, gradient, connection to a glacier, glacier area, and Melton's Ruggedness Number. Williams used 
percent ice, percent bedrock, percent steep slopes, percent vegetation, average annual rainfall, gradient, Melton's Ruggedness Number, percent glacier lost, and connection to a glacier. Since Pirot used actual storm rainfall measurements these cannot be compared with average annual rainfall used here and by Williams. Also, Williams did not have access to LiDAR data from Mt. Adams and so did not digitize consolidated bedrock and unconsolidated sediment; therefore, geology cannot be combined. Most glacier related basin attributes do not apply to Mount St. Helens and so cannot be combined. The remaining six variables that are correlated between all three studies are gradient, percent steep slopes, percent vegetation, Melton's Ruggedness Number, connection to a glacier, and percent WaDNR ice (Table 28).

Table 28: Basin attributes to be used in multiple logistic regression model combining Mt. Hood (Pirot, 2010), Mt. Adams (Williams, 2011), and Mount St. Helens data. Variable name is also given. All variables relate to upper basin attributes.

\begin{tabular}{l|c}
\hline Basin Attribute & Variable \\
\hline Gradient & $\mathrm{X}_{1}$ \\
Percent Steep Slopes & $\mathrm{X}_{2}$ \\
Percent Vegetation & $\mathrm{X}_{3}$ \\
Melton's Ruggedness Number & $\mathrm{X}_{4}$ \\
Connection to a Glacier & $\mathrm{X}_{5}$ \\
Percent WaDNR Ice & $\mathrm{X}_{6}$ \\
\hline
\end{tabular}

The raw basin attribute data to be compared are listed in Table E.1. The same procedure used for Mount St. Helens data was followed to calculate the multiple logistic regression for these data. The normalized data are presented in Table E.2. The results of the first iteration of the multiple logistic regression are shown in Table E.3. The iterations removed variables as follows, from least significant to most: gradient $\left(X_{1}\right)$, 
percent steep slopes $\left(X_{2}\right)$, percent ice $\left(X_{6}\right)$, and Melton's Ruggedness Number $\left(X_{4}\right)$. The final most significant variables are connection to a glacier $\left(X_{5}\right)$ with a coefficient of 0.46 and percent vegetation $\left(X_{3}\right)$ with a coefficient of -0.32 (Table E.4). The negative value for percent vegetation indicates an inverse relationship. Inserting these variables into the probability model equation (Equation 4) gives,

$$
Y=\frac{e^{\left(0+0.46 X_{5}-0.32 X_{3}\right)}}{1+e^{\left(0+0.46 X_{5}-0.32 X_{3}\right)}}
$$

where $Y$ is the predicted outcome of the model and attribute variables are $X$ (Pirot, 2010).

To test the accuracy of the combined model in predicting 2006 debris flows ( $Y$ ), the normalized variable data for $X_{5}$ and $X_{3}$ are inserted into the equation for each drainage basin. The results of this predictive model are shown in Table 29. This model correctly predicted only 14 of 22 debris flows, but failed to predict seven from Mount St. Helens and one from Mt. Adams. This version of the Pirot (2010) model has a 69\% accuracy rate with six false positives and eight false negatives. However, of the Mt. Hood and Mt. Adams drainage basins, all but one debris flow in the Little Muddy Drainage Basin on Mt. Adams was correctly predicted.

\section{LIMITATIONS, ASSUMPTIONS, AND SOURCES OF ERROR}

The Mount St. Helens drainage basin attribute data acquired for the analysis of 2006 debris flows involved various assumptions, limitations, and sources of error. All of these affect the results of the statistical analysis of variance (ANOVA) and multiple 
Table 29: Results for the combined predictive model described by Equation 8. Drainages in bold have $Y$ values $>0.50$. Drainages in red are from Mount St. Helens with $Y$ values $>0.50$. This model has $69 \%$ accuracy with six false positives and eight false negatives.

\begin{tabular}{|c|c|c|c|c|c|}
\hline Drainages & Model & $\begin{array}{l}\text { Debris Flow } \\
\text { Occurrence }\end{array}$ & Drainages & Model & $\begin{array}{l}\text { Debris Flow } \\
\text { Occurrence }\end{array}$ \\
\hline June Lake & 0.68 & 1 & Kalama & 0.46 & 0 \\
\hline Muddy Fork & 0.68 & 1 & Butte Camp Dome & 0.46 & 1 \\
\hline Salt Creek & 0.68 & 1 & Horeshoe & 0.46 & 0 \\
\hline Big Muddy & 0.67 & 1 & Worm Flows & 0.45 & 0 \\
\hline White & 0.67 & 1 & Sheep Creek & 0.45 & 1 \\
\hline Eliot & 0.66 & 1 & Muddy River & 0.45 & 1 \\
\hline Salmon & 0.66 & 1 & Shoestring Glacier & 0.45 & 1 \\
\hline Adams Creek & 0.65 & 1 & Pine Creek & 0.45 & 1 \\
\hline Cascade Creek & 0.65 & 0 & Little Muddy & 0.45 & 1 \\
\hline Sandy & 0.64 & 1 & Blue Lake & 0.44 & 1 \\
\hline Lewis Creek & 0.63 & 1 & Swift Creek & 0.44 & 0 \\
\hline Rusk Creek & 0.63 & 1 & East Fork & 0.42 & 0 \\
\hline Crofton Creek & 0.61 & 0 & Morrison Creek & 0.42 & 0 \\
\hline Ladd & 0.61 & 1 & Dryer Glacier & 0.42 & 0 \\
\hline Newton & 0.56 & 1 & Snowfield & 0.42 & 0 \\
\hline Coe & 0.55 & 0 & Gotchen Creek & 0.41 & 0 \\
\hline Clark & 0.54 & 1 & South Toutle & 0.41 & 1 \\
\hline Riley Creek & 0.53 & 0 & Zig Zag & 0.37 & 0 \\
\hline Hellroaring Creek & 0.53 & 0 & Killen Creek & 0.36 & 0 \\
\hline Muddy & 0.51 & 0 & Bird Creek & 0.27 & 0 \\
\hline Nelson Glacier & 0.46 & 0 & Trappers Creek & 0.24 & 0 \\
\hline Ape Canyon & 0.46 & 0 & Polallie & 0.17 & 0 \\
\hline Little Kalama & 0.46 & 0 & & & \\
\hline
\end{tabular}

logistic regression.

A central assumption in the analysis is the interpretation of the drainage

hydrologic boundaries for each basin using a DEM. The specification of upper basin drainage boundaries used in this study is just one interpretation. Other researchers would likely make other choices which would affect most of the resulting basin attribute data used in the analysis. Similarly, the digitizing of vegetation and bedrock outcrops from ortho imagery suffers from the same interpretation issue. 
On the other hand, digital data acquired from outside sources is affected by unknown production and quality control errors. Alternatively, co-opting data for an entirely different use than the original purpose may not translate well. For example, the geology layer produced by Washington DNR (2010) describes bedrock geology and the genetic origin of surficial deposits. The information actually of interest in this analysis was whether the surface deposits were competent rock outcrops or unconsolidated sediments.

This study used the distribution of average annual rainfall over the slopes of Mount St. Helens, while a more accurate estimation of actual storm precipitation would have better constrained the climatic conditions necessary to trigger debris flows. Pirot (2010) used National Weather Service NEXRAD (Next-Generation Radar) storm data which was also available for Mount St. Helens, but only accessible in a raw, unprocessed format which was too difficult to manipulate under thesis time constrains into a useable data layer.

Field observations and sampling may inadvertently cause errors in the analysis and conclusions. Observations made to determine whether a debris flow deposit occurred during 2006 were highly interpretative and based on discovered evidence. Different discoveries, interpretations, and conclusions could be reached by other researchers.

The small number of soil samples used in the statistical analysis lowers the reliability of the results (Davis, 2002). Sample size relates to both soil samples and number of drainages. The soil samples were limited to three replicates per sample site 
due to weight and limited resources, although five would have given more reliable statistical results (Ken Cruikshank, personal communication, October 2010). The small number of soil replicates and sample sites mean that the parent populations cannot be determined to be normally distributed; therefore the statistical results may not be accurate (Davis, 2002). The small number of drainage basins designated on the southern slopes of Mount St. Helens is, for the same reason, also a limiting factor in the logistic regression. To counter this, incorporating basin attribute data from other Cascade volcanoes into the logistic regression increases the accuracy of the resulting model.

The one-way analysis of variance test uses a significance level of 0.05 which results in a 5\% chance of a type 1 error. A type 1 error occurs when erroneously rejecting the hypothesis that the two groups being tested are similar (Davis, 2002). The ANOVA test assumes that each set of replicates in a sample group represents a random sample from different populations, that each group is part of a normally distributed population, and that each group has the same variance (Davis, 2002). The test can determine if two groups are from different parent populations, but not if they are from the same population.

Pirot (2010) used the Wald Test because of the difficulty performing calculations using the alternative likelihood ratio test, although the Wald Test can produce inconsistent results. The Wald Test also requires that the data be in normalized form (Davis, 2002). Therefore, the predictive model can only be used with normalized data. 
The multiple logistic regression statistical test is used to determine a relationship between variables, but does not say anything about causation (Lewicki and Hill, 2007). Many alternative hypotheses must be considered to determine the true relationship between correlated variables (Lewicki and Hill, 2007). Other limitations of multiple regression include an assumed linear relationship between tested variables and the recommendation that there are at least ten times more samples than variables (Lewicki and Hill, 2007). However, to prevent the model from becoming unstable and less generalized, it is recommended that the number of variables be minimized (Hosmer and Lemshow, 1989).

\section{SUMMARY}

The results of the analysis of variance test complement the results of the multiple logistic regression. The analysis of variance test found that only basin attribute percent steep slopes significantly differs between the two groups of drainage basins. Correspondingly, the multiple logistic regression found that some basin attributes are more significant than others, with percent steep slopes, percent unconsolidated, and average annual rainfall being statistically important. When a combined multiple logistic regression was calculated using basin attribute data from Mt. Hood, Mt. Adams, and Mount St. Helens the significant basin attributes were found to be connection to a glacier and percent vegetation (inverse relationship). The accuracy of this combined model was calculated to be $69 \%$. This is reduced from the $83 \%$ accuracy of the model using combined Mt. Adams and Mt. Hood data demonstrated by Williams (2010). That 
logistic regression found percent glacial coverage and average annual rainfall (inverse relationship) to be the most statistically important basin attributes (Williams, 2011). In comparison, the original Pirot model had $90 \%$ accuracy for the statistically important basin attributes: gradient (inverse relationship), percent vegetation (inverse relationship), and connection to a glacier (Pirot, 2010). 


\section{CHAPTER 6 - DISCUSSION}

\section{STORM EVENT}

The heavy precipitation event of November 3-8, 2006 brought over $60 \mathrm{~cm}$ of rainfall to the bare slopes of Mount St. Helens. Of the six SNOTEL snow depth sensors stationed around the mountain, only Spenser Meadow had a trace of snow before the storm. The key stations in the Swift Creek and June Lake drainages indicate that the lower slopes were not snow covered. A layer of snow at least half a meter deep on the slopes before a Pineapple Express type event would protect the bare slopes and prevent a debris flow (Marks et al., 1998). However, the hypothetical snowpack would still lose about $300 \mathrm{~mm}$ of snow water equivalent (SWE) during a five day storm and increase the amount of runoff (Marks et al., 1998). If the snowpack is not of sufficient thickness, however, the warm rains would completely melt it and increase runoff into streams, increase erosion from overland flow, and increase the possibility of debris flow activity. On Mount St. Helens in 2006, the warm, heavy storm rainfall melted any thin layers of snow that existed on the upper slopes and mobilized unprotected sediment on the bare slopes into multiple debris flows.

An examination of the inventory of debris flows that occurred in 2006 on Mount St. Helens reveals a few patterns (Figure 66). Debris flows were clustered in the western and southwestern quadrants, with another cluster in the southeastern quadrant. Normal Cascade rainfall patterns produce the highest precipitation on the western side of the mountain and a rain shadow on the eastern side. The result of this normal 


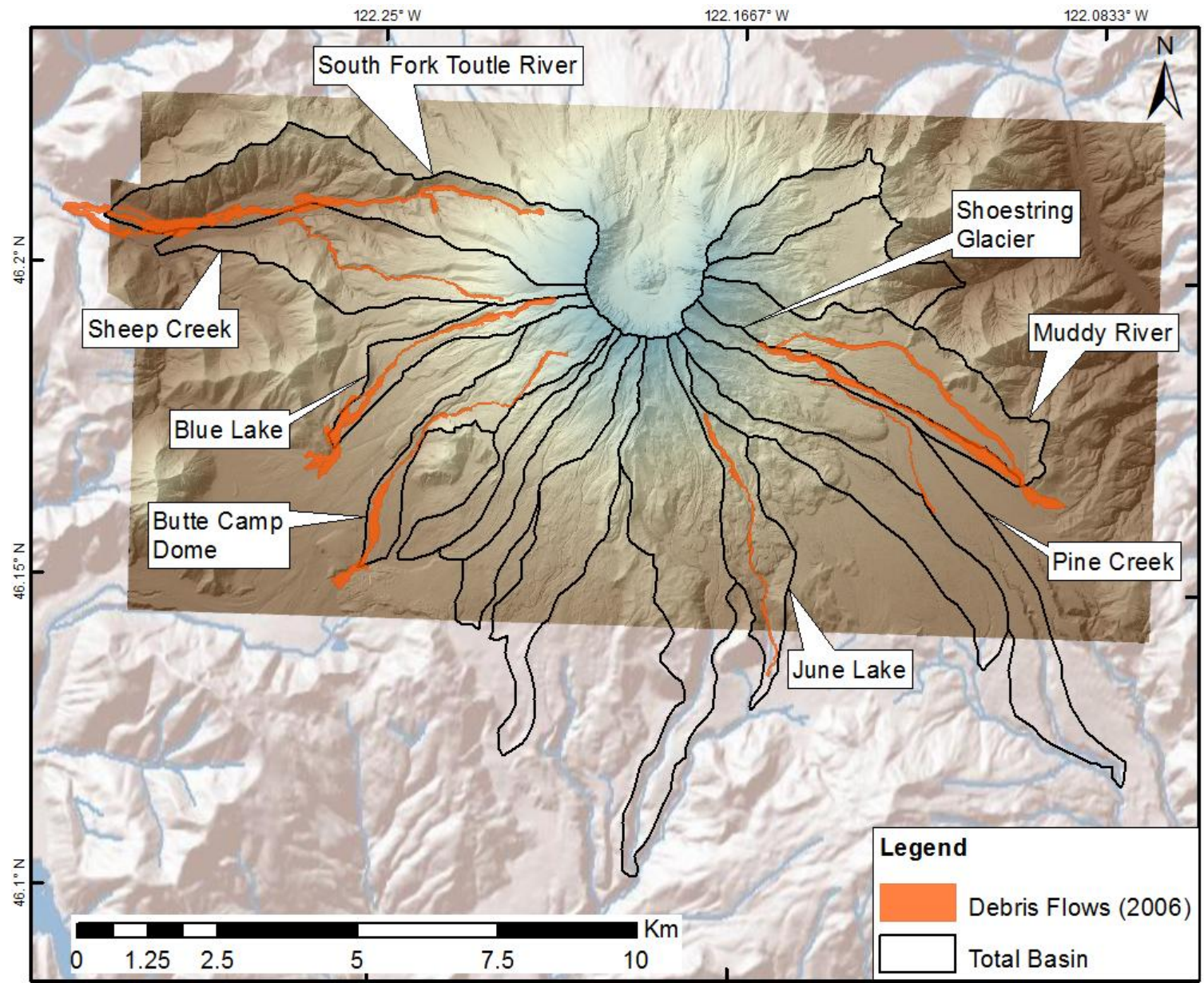

Figure 66: Debris flow inventory map showing defined drainage outlines and 2006 event flow paths. Drainages with a 2006 debris flow are named. The largest and longest debris flow occurred in the South Fork Toutle River Drainage in the western quadrant.

pattern is an increased rate of slope failures on the western flanks (Pirot, 2010).

However, rainfall measurements from PRISM data and SNOTEL sites in 2006 (Figure 10)

showed the areas of highest storm precipitation to be on the south and southeast flanks of the mountain. The June Lake SNOTEL station recorded $37 \mathrm{~cm}$ on November 7 , while the western side of the mountain received $27 \mathrm{~cm}$ on the same date at the Sheep Canyon SNOTEL station. This zone of the heaviest rainfall roughly corresponds with debris flow occurrence around the mountain. And the storm rain shadow to the northeast corresponds to the lack of debris flow occurrence on that side of the volcano. 
The SNOTEL sites nearest the mountain indicate little rainfall in the 10 days before the storm, but $12 \mathrm{~cm}$ of accumulated rainfall between October 15 and 20 . The heavy rainfall starting on November 3 quickly saturated the permeable soils. The upper slope channels, already filled with cobbles, boulders, and smaller debris that had tumbled off the steep channel walls, were becoming torrents of heavy runoff with suspended sand and gravel-sized particles. Soon the heavy stream runoff was transporting larger cobbles and causing additional erosional undercutting of the banks leading to fresh landslides. Scars of these channel wall failures are noted along most of the channels that experienced debris flows.

\section{SOIL SAMPLES}

The analysis of soil samples taken from initiation zones in most drainage basins found no statistical differences between drainages with debris flows and those without debris flows in 2006 (Figure 67). In summary, soil samples had an average of between 4 and $12 \%$ silt and clay sized particles, with June Lake at the low end and Muddy River at the high end of the scale. All samples were dominantly sand sized particles with averages that ranged from $52 \%$ at Shoestring Glacier to $63 \%$ at June Lake. The gravel sized particle component ranged from $28 \%$ at Muddy River to $42 \%$ at Butte Camp Dome. Although the Shoestring Glacier and neighboring basins should be dominantly finegrained glacial deposits, all flanks of the mountain are mantled in sand and gravel-sized pyroclastic deposits to varying depths. Drainage basins with debris flows had an average bulk density of $2.0 \pm 0.1$ and an average composition of $36 \pm 5 \%$ gravel, $57 \pm 4 \%$ 

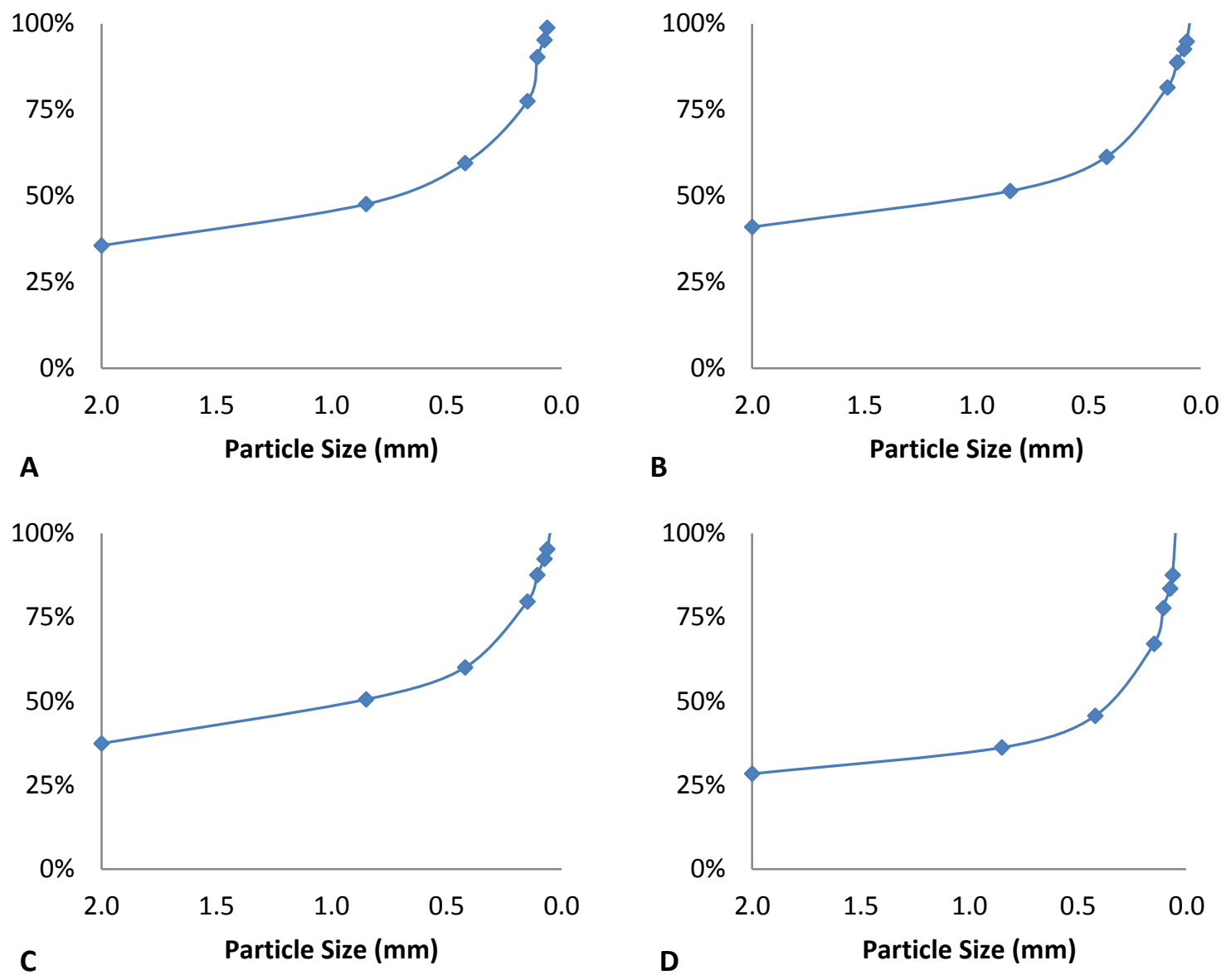

Figure 67: Selection of particle size distribution graphs for active channels in the June Lake (A), Butte Camp Dome (B), Muddy River (C), and Blue Lake (D) Drainage Basins. All graphs have a similar curve in the sand-sized fraction, but Blue Lake has less larger particles.

sand, and $7 \pm 3 \%$ silt and clay. Similarly, drainages without debris flows had an average bulk density of $1.8 \pm 0.2$ and an average composition of $38 \pm 3 \%$ gravel, $54 \pm 2 \%$ sand, and $8 \pm 2 \%$ silt and clay (Table 30$)$.

Table 30: Average soil sample properties for eight sampled drainage basins on Mount St. Helens with and without a 2006 debris flow.

\begin{tabular}{l|cc}
\hline Averages & $\begin{array}{c}\text { Drainages } \\
\text { w/ Debris Flow }\end{array}$ & $\begin{array}{c}\text { Drainages } \\
\text { w/o Debris Flow }\end{array}$ \\
\hline Bulk Density & 2.0 & 1.8 \\
\% Gravel & 36 & 38 \\
\% Sand & 57 & 54 \\
\% Silt and Clay & 7 & 8 \\
\hline \multicolumn{2}{c}{}
\end{tabular}




\section{MELTON'S RUGGEDNESS NUMBER}

Applying Melton's Ruggedness Number to the drainage basins of Mount St. Helens found that all basins have values above 0.3 , which suggests that all are capable of producing a debris flow (Jackson et al., 1987). Records indicate recent, pre-2006, debris flows in the Shoestring Glacier, Swift Creek, Blue Lake, and possibly Butte Camp Dome drainages (USDA-FS, 1997; NASA Landsat Program, 1984-2009). Only the minor Kalama Drainage Basin was observed not to have evidence of pre-2006 debris flows. However, distinguishing debris flow levees and deposits tens of years after the event can be difficult because of fluvial reworking and the re-growth of underbrush and trees. In general, debris flow deposits older than 1980 are buried under generally finer-grained lahar deposits unless exposed in channel walls through recent fluvial erosion (Pierson, 1985).

\section{STATISTICAL ANALYSIS}

The analysis of variance test determined that only one basin attribute (percent steep slopes) significantly differs between those drainage basins with a 2006 debris flow and those without. The multiple logistic regression was then used to develop a probability model to determine the relative significance of basin attributes. The selected probability model found that percent steep slopes, percent unconsolidated deposits in the upper basin, and average annual rainfall were the most significant basin attributes in predicting debris flows. 
The selection of these significant basin attributes is not surprising. The steep slopes above 33 degrees in an upper drainage basin are possibly more unstable and likely to fail as a landslide or rockfall and initiate a debris flow. Related to steepness is the basin gradient which was found to not be significantly different between basin groups. This may be because gradient is a linear measurement based on the highest and lowest basin elevations, while percent steepness is a two-dimensional value based on higher resolution gradient measurements taken over the entire area of the basin. Also related to steepness is the ruggedness of a drainage basin, through Melton's Ruggedness Number, which suggests a basin is capable of producing debris flows (Melton, 1965; Jackson et al, 1987; Willford et al, 2004). However, this attribute was also found to not be significantly different between basin groups. This may be because the upper basins are all similar in area and height (Equation 2). Neither attribute was significantly different between basin groups.

The amount of unconsolidated material in an upper drainage basin, is an indicator of the amount of material available to be mobilized into a debris flow once the climatic conditions are met in transportation-limited basins (Bovis and Jakob, 1999). That most basins on Mount St. Helens are transport-limited is understandable since most upper basin slopes are covered by a blanket of loose 1980 pyroclastic deposits. A few basins, such as Swift Creek, June Lake, and Worm Flows may be weathering-limited because they are largely located within the Holocene andesite Worm Complex Flows terrain. However, the situation is more complex at Swift Creek and June Lake since both basins host a glacier. 
Rainfall is probably the most important factor involved in debris flow initiation. However, the average annual rainfall data used in this analysis does not fully represent the intensity and short duration of this precipitation event. The heterogeneous distribution of rainfall across the mountain is probably the reason this basin attribute was selected for significance by the model (Figure 10).

Other combinations of basin attributes from Table 26 were modeled and tested for how well they predicted the 2006 debris flow pattern. Models related to the final model (\#6C) determined similar basin attributes to be the most significant. The first eight logistic regression models did not include Pine Creek and so used an incomplete data set. These were all re-calculated with Pine Creek included. One of these recalculated models (\#7C) used the three most significant basin attributes in the model to receive a $100 \%$ accuracy rating. However, this model found percent ice and bedrock digitized from the 2002 geologic map to be the second and third most significant basin attributes. This data set is not considered very accurate for this analysis since the geologic data is out-of-date and in 1:100,000 scale. Two other re-calculated models received the same highest accuracy rating of $94 \%$ with no bad predictions, while also using the three most-significant attributes in the model. One model (\#9C) found the same top three drainage basin attributes with the same coefficients. The difference between this and model \#6C is that Melton's Ruggedness Number was not used, but replaced with height and area of upper basin. Model \#9C was constructed from the best attributes after tabulating and analyzing performance of all basin attributes. The other model with $94 \%$ accuracy determined an inverse relationship to consolidated bedrock 
digitized from 2009 ortho imagery to be the second most significant basin attribute. In this model, percent steep slopes is the most significant attribute and average annual rainfall the third significant. Basically the same results as the accepted model (\#6C).

The most significant basin attributes found by logistic regression for Mount St. Helens do not agree with those found by Pirot or Williams. Both found that the presence of a glacier in the drainage basin was an important characteristic in determining the occurrence of a debris flow (Pirot, 2010; Williams, 2011). However, the lack of glacier coverage on Mount St. Helens is one of many differences it has from the other High Cascade volcanoes. Other differences: it is the youngest at about 300,000 years old, has the lowest elevation by at least $300 \mathrm{~m}$, and is the most recently active. Because of these differences, combining Mount St. Helens basin attribute data with those of Mt. Adams and Mt. Hood decreased the accuracy of the combined model in predicting 2006 debris flows.

\section{GLACIERS}

Mount St. Helens is geologically a very young member of the Cascade Range, with eruptive activity beginning about 300,000 years ago and the pre-1980 edifice developing over the last 3,000 years (Pringle, 2002; Clynne et al., 2008). Much of the deposits include large volumes of pumice-rich dacite fallout tephra, pyroclastic flows, and lahars (Pringle, 2002). Prior to the 1980 eruption the volcano was well glaciated, however as of 2009, this study has determined that only the Nelson, Ape, June Lake, Swift, and possibly the Shoestring Glaciers exist outside the crater (Figure 8, Table 31). 
The retreat and disappearance of glaciers uncovers more unconsolidated glacial sediment on the upper slopes where it can be mobilized by these heavy rainfall events into debris flows. The recent pyroclastic eruptions also supply loose sediment to the upper basins.

Despite lack of statistical significance in this study, the existence of glaciers and permanent snowpack in a drainage basin do contribute to stream runoff by channeling and concentrating rainfall. Ice acts as an impermeable surface that will speed up runoff; thick snow is more permeable and can absorb and slow down runoff. However, snow less than half a meter thick will not present a sufficient buffer and will provide additional surface water during rapid snowmelt such as occurred during the warm, heavy rainfall of November 2006 (Marks et al., 1998). It is this surface water that entrains debris, erodes channels, and undercuts banks causing landslides which can

Table 31: Comparison of 1998 and 2009 glacier coverage on Mount St. Helens. Glaciers listed in red did not present a bergschrund in 2009 ortho imagery and therefore were not considered to be glaciers. Of the ten glaciers on the exterior slopes of Mount St. Helens in 1998, only five remained in 2009. PC is percent change.

\begin{tabular}{|c|c|c|c|c|c|c|c|}
\hline \multirow[b]{2}{*}{ Glacier } & \multicolumn{3}{|c|}{ Area $\left(m^{2}\right)$} & \multicolumn{3}{|c|}{ Length (m) } & \multirow{2}{*}{$\begin{array}{c}\text { Retreat } \\
\text { (m) }\end{array}$} \\
\hline & 1998 & 2009 & PC & 1998 & 2009 & PC & \\
\hline Toutle & 203,774 & 46,373 & -77 & 876 & 666 & -24 & 466 \\
\hline Talus & 267,766 & 82,252 & -69 & 970 & 723 & -25 & 95 \\
\hline Dryer & 95,049 & 25,777 & -73 & 572 & 265 & -54 & 310 \\
\hline Snowfield & 180,018 & 43,699 & -76 & 938 & 517 & -45 & 260 \\
\hline Swift & 299,771 & 104,425 & -65 & 1031 & 672 & -35 & 403 \\
\hline June Lake & 120,083 & 72,910 & -39 & 1046 & 878 & -16 & 71 \\
\hline Shoestring & 306,832 & 56,249 & -82 & 2263 & 902 & -60 & 1,340 \\
\hline Ape & 225,496 & 77,661 & -66 & 830 & 646 & -22 & 236 \\
\hline Nelson & 149,855 & 62,565 & -58 & 694 & 392 & -44 & 330 \\
\hline Forsyth & ND & ND & ND & ND & ND & ND & ND \\
\hline Average & 188,977 & 56,817 & -68 & 1,170 & 809 & -35 & 398 \\
\hline Total & $1,848,643$ & 571,911 & & 9,220 & 5,661 & & \\
\hline
\end{tabular}


transform into debris flows. The 2006 ortho imagery does show extensive ice and snowpack cover in the early summer. However, the actual extent of the snowpack just prior to the November 2006 event is not known.

Also important to debris flow occurrence are the exposed unconsolidated sediments left behind by glaciers receding either because of volcanic eruptions or climate change. If caused by climate change, the decreased or altered snowfall patterns could also result in less early fall snow cover and more intense rainstorms. Together this is the recipe for an increased frequency of debris flows on Cascade volcanoes (Burns et al., 2009). That it is difficult to correlate historical glacier locations (Figure 8) to 2006 debris flow occurrence (Figure 66), is a strong argument that it is not climate change, but recent volcanic activity that is the primary influence. The Blue Lake and Butte Camp Dome drainages experienced two of the larger debris flows, yet neither has ever hosted a glacier, nonetheless both contain unconsolidated sediments on over $75 \%$ of their upper basins.

\section{INITIATION SITES}

Debris flow initiation site elevations fall within two groups. One is clustered around 1,700 $\mathrm{m}$ and the other around 2,000 m elevation. The lower cluster is associated with drainage basins that host modern or historic glaciers. The higher cluster includes the previously mentioned Blue Lake and Butte Camp Dome, but also June Lake. The June Lake Drainage Basin does contain a small glacier, but the basin largely consists of a geologically recent andesite lava flow complex. Possibly the debris flows in these 
three drainage basins are sourced primarily in the recent pyroclastic debris that mantle the upper slopes. The initiation method in two of these drainage basins (Blue Lake and June Lake) was interpreted to be by landslide. The only other debris flow with a landslide initiation method was located in the South Fork Toutle River Drainage Basin. All other drainage basins had debris flows interpreted to have been initiated by channel wall erosion, which could also be considered small landslides in some cases. Pine Creek and Muddy River were initiated by headward erosion in existing ravines.

\section{SUSCEPTIBILITY MAP}

The northern slopes and approaches of Mount St. Helens are located within a National Monument with limits on land use. The southern slopes above even Road 83 lie outside this boundary, although within the larger Gifford Pinchot National Forest. This area includes Marble Mountain Snow Park, numerous privately owned cabins and homes, and the recreational and power production infrastructure of Swift Reservoir. Debris flows in these drainage basin channels therefore may threaten loss of infrastructure, property, and lives.

Applying the model derived for Mount St. Helens allows for the creation of a map describing the susceptibility of each drainage basin to future debris flows (Figure 68). The map was generated by color-coding each basin based on the score resulting from the probability model equation (Equation 7), according to four hazard groups: less than 0.35 is very low (green), 0.35 to 0.50 is low (light green), 0.51 to 0.65 is moderate (yellow), and greater than 0.65 is high (orange) (Williams, 2011). According to this 


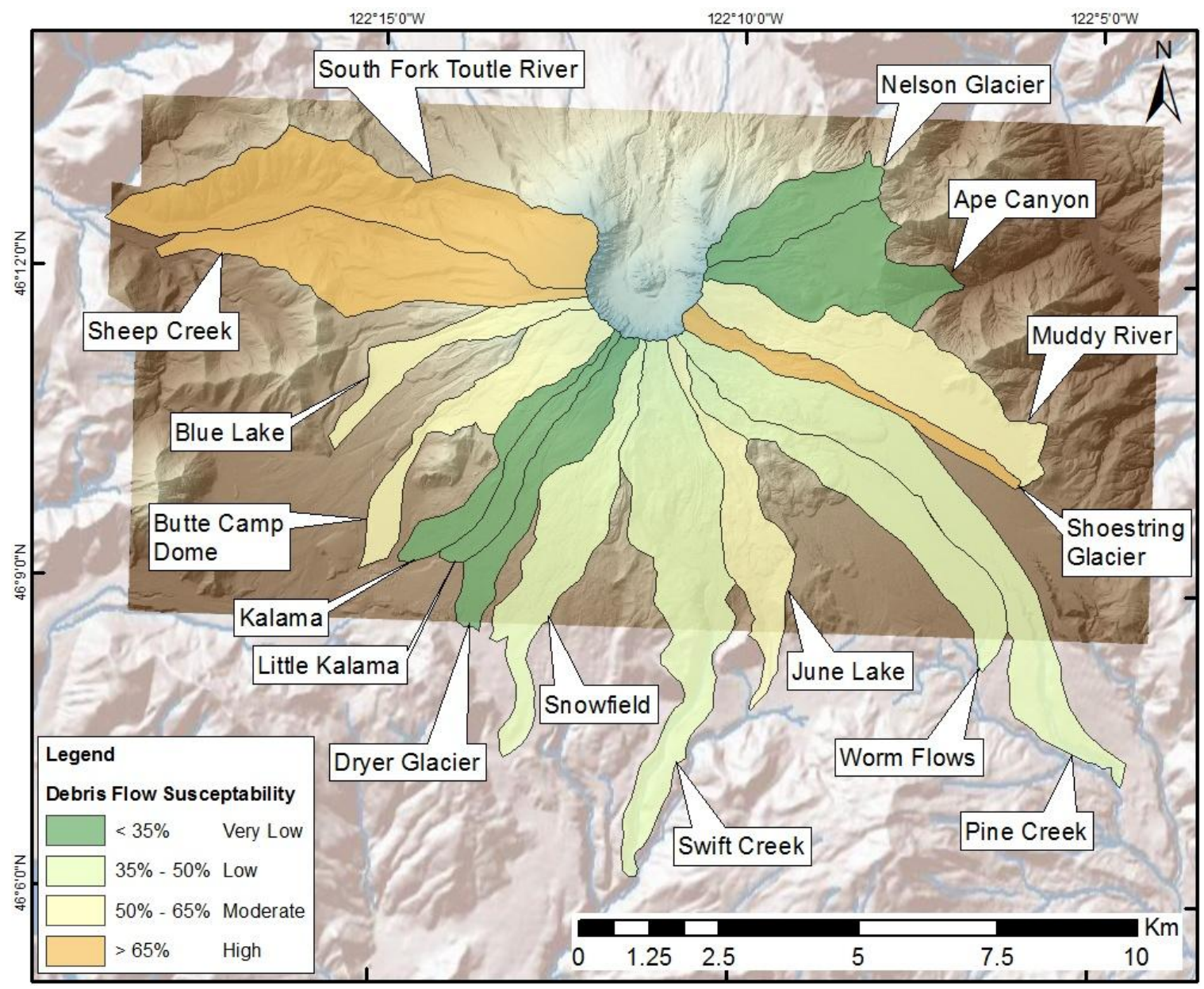

Figure 68: Debris flow susceptibility map for the non-blast zone drainages of Mount St. Helens developed using the basin attributes determined most significant by multiple logistic regression analysis. In this model there are three drainages of high probability.

model three drainage basins have high debris flow hazard, including Shoestring Glacier,

Sheep Creek, and South Fork Toutle River. Moderate hazard drainages include Blue

Lake, Butte Camp Dome, June Lake, and Muddy River. Low hazard drainages include

Snowfield, Swift Creek, Worm Flows, and Pine Creek. Very low hazard drainages include

Kalama, Little Kalama, Dryer Glacier, Ape Canyon, and Nelson Glacier (Table 32). 
Table 32: Comparison of the debris flow hazard level on the susceptibility map with the occurrence of a 2006 debris flow.

\begin{tabular}{l|cc}
\hline Hazard Level & $\begin{array}{c}\text { Drainages } \\
\text { w/ Debris Flow }\end{array}$ & $\begin{array}{c}\text { Drainages } \\
\text { w/o Debris Flow }\end{array}$ \\
\hline High & 3 & 0 \\
Moderate & 4 & 0 \\
Low & 1 & 3 \\
Very Low & 0 & 5 \\
\hline
\end{tabular}




\section{CHAPTER 7 - CONCLUSIONS}

The "Pineapple Express" precipitation event of November 3-8, 2006 dropped over $60 \mathrm{~cm}$ of rain onto the bare slopes of Mount St. Helens and generated debris flows in 8 of the 16 drainages on the southern flanks of the volcano (Figure 15). These debris flows occurred in two clusters on the mountain: the western to southwestern quadrant and the southeastern quadrant. Those drainages that experienced debris flows include the Muddy River, Shoestring Glacier, Pine Creek, June Lake, Butte Camp Dome, Blue Lake, Sheep Creek, and the South Fork Toutle River drainages. Of those eight debris flows, three were initiated by landslides, while five were initiated by side-wall or headward channel erosion. Specifically, June Lake, Blue Lake, and South Fork Toutle River had landslide initiated debris flows; and Muddy River, Shoestring Glacier, Pine Creek, Butte Camp Dome, and Sheep Creek had channel erosion initiated debris flows.

The debris flow with the longest estimated run-out distance was 8,900 $\mathrm{m}$ in the South Fork Toutle River Drainage. The next longest was the Butte Camp Dome Debris Flow at 6,700 m. Those with similar lengths are the Muddy River and Shoestring Glacier Debris Flows at 6,600 $\mathrm{m}$ and 6,400 $\mathrm{m}$, respectively. Medium length debris flows included Blue Lake at 5,900 m, June Lake at 5,300 m, and Sheep Creek at 4,800 m. The shortest debris flow, at 3,760 m, was observed on a side-channel of the Pine Creek Drainage.

The debris flow with the largest measureable depositional area was the South Fork Toutle River Debris Flow which comprised about $975,000 \mathrm{~m}^{2}$. The next largest debris flow deposit, at $420,000 \mathrm{~m}^{2}$, was from the Blue Lake Basin. The smallest of 
$300,000 \mathrm{~m}^{2}$ occurred in the Butte Camp Dome Basin. The depositional areas of the Muddy River and Shoestring Glacier Basins were roughly measured at $340,000 \mathrm{~m}^{2}$ and $460,000 \mathrm{~m}^{2}$ respectively; however, these measurements are inaccurate because of the overlapping lower depositional areas. The debris flows in the Sheep Creek, June Lake, and Pine Creek drainages were not observed to have well-defined depositional zones. Instead these drainages emptied into large channels, as in the case of Pine Creek, or had multiple side-channel depositional areas along the transport zone, as in the case of June Lake and Sheep Creek.

Geomorphologic evidence of debris flows prior to 2006 was observed in almost all drainages. Older debris flow levees and depositional fans were observed in the drainages of Snowfield, Dryer Glacier, Butte Camp Dome, Blue Lake, Swift Creek, Worm Flows, Pine Creek, and Shoestring Glacier. None or less definite evidence was observed in the Nelson Glacier and Ape Canyon drainages. U. S. Forest Service records indicate two debris flows occurred in the Blue Lake area in September 1997. And ten small debris flows were observed in the Shoestring Glacier drainage during late fall/early summer of 1981, 1982, and 1983 (Pierson, 1986).

A search for prior debris flow occurrences was conducted using Aster (2000 to 2010) and Landsat (1984 to 2009) data (LP DAAC, 2011; NASA Landsat Program, 2011). Although much evidence of past debris flows were observed in the field, only one prior debris flow could be confidently identified on Landsat data. This debris flow occurred between 1989 and 1990 in the Swift Creek Drainage and emplaced a large deposit 
around 1,100 m elevation. The initiation source and type of this debris flow could not be determined.

Of the sixteen drainages on the southern flanks of Mount St. Helens excluding the 1980 debris avalanche zone, all had a calculated Melton's Ruggedness Number of over 0.3 for both the total and upper basins. A value of over 0.3 suggests a basin is capable of producing a debris flow (Jackson et al., 1987).

Of the eight drainages with debris flows, six were initiated in deposits mapped as Holocene volcaniclastics deposits (Qvc) (WaDNR, 2010). Those observed at June Lake and Sheep Creek were in andesite flows (Qva). Also, the three initiation sites for South Fork Toutle River, Butte Camp Dome, and June Lake were mapped in or adjacent to consolidated bedrock units, while the rest were found deep within unconsolidated units.

The initiation site elevation for the drainages with debris flows was observed to range from $1,400 \mathrm{~m}$ at Pine Creek to $2,120 \mathrm{~m}$ at Blue Lake, with an average value of $1,750 \mathrm{~m}$. Although Pine Creek is a smaller debris flow on a side-channel, the initiation sites for Shoestring Glacier and Muddy River drainages were also located on sidechannels. Two initiation clusters were noted around elevations 1,700 m and 2,000 m. The lower cluster is associated with drainage basins that host modern or historic glaciers, while the upper is possibly associated with recent pyroclastic deposits.

The upper basins of drainages with debris flows were found to average $7 \pm 10 \%$ ice, $36 \pm 26 \%$ bedrock, and $57 \pm 27 \%$ unconsolidated deposits according to the geologic map (WaDNR, 2010). Measurements from 2009 ortho imagery data found an average of $6 \pm 3 \%$ snow and ice cover, $21 \pm 16 \%$ consolidated bedrock, and $74 \pm 19 \%$ 
unconsolidated deposits (USDA-FSA, 2009). Drainage basins without debris flows were found to average $12 \pm 13 \%$ ice, $47 \pm 26 \%$ bedrock, and $41 \pm 24 \%$ unconsolidated deposits according to the geologic map (WaDNR, 2010). Measurements from 2009 ortho imagery data found an average of $7 \pm 3 \%$ snow and ice cover, $27 \pm 18 \%$ consolidated bedrock, and $67 \pm 19 \%$ unconsolidated deposits (USDA-FSA, 2009).

Area of upper basins with debris flows ranged from $433,877 \mathrm{~m}^{2}$ at Sheep Creek to $3,767,130 \mathrm{~m}^{2}$ at South Fork Toutle River, with an average area of 1,523,040 \pm $1,060,374 \mathrm{~m}^{2}$. Those drainages without debris flows ranged in area from $348,562 \mathrm{~m}^{2}$ at Kalama to $2,392,670 \mathrm{~m}^{2}$ at Swift Creek, with an average area of 1,044,560 $\pm 646,267 \mathrm{~m}^{2}$.

Of the ten glaciers that existed in 1998, only five remain on the south and east slopes of Mount St. Helens in 2009. All glaciers experienced a reduction in size. The average decrease in glacier area was $67 \%$, while the glacier length decreased by $37 \%$. The average glacier terminus retreat was $471 \mathrm{~m}$. Only the debris flow initiation site in the June Lake Drainage Basin was found to have a direct connection to a glacier. Of the remaining drainage basins, those with glaciers included Nelson Glacier, Ape Canyon, Swift Glacier, and Shoestring Glacier. The Shoestring Glacier Basin did have a debris flow, but the initiation site was on a side-channel and not directly connected to the glacier.

Drainage basins with debris flows were found to have an average area of $41 \pm 4 \%$ steep slopes, an average area of $2 \pm 3 \%$ vegetation coverage, an average gradient of 0.4 \pm 0.03 , an average MRN of $1.1 \pm 0.3$, an average annual rainfall of $3.9 \pm 0.1 \mathrm{~m}$, and an average change in glacier coverage of $-89 \pm 54 \%$. Those drainage basins without debris 
flows had an average area of $28 \pm 9 \%$ steep slopes, an average area of $2 \pm 3 \%$ vegetation coverage, an average gradient of $0.4 \pm 0.1$, an average MRN of $1.2 \pm 0.3$, an average annual rainfall of $3.9 \pm 0.2 \mathrm{~m}$, and an average change in glacier coverage of $-68 \pm 7 \%$.

Although sediment samples were not taken from every drainage basin with a debris flow (South Fork Toutle River was not sampled), an analysis of variance compared the sieve analysis for drainages with and without debris flows. The group of drainages with debris flows had an average bulk density of $2.0 \pm 0.1$ and an average composition of $36 \pm 5 \%$ gravel, $57 \pm 4 \%$ sand, and $7 \pm 3 \%$ silt and clay; while, drainages without debris flows had an average bulk density of $1.8 \pm 0.2$ and an average composition of $38 \pm 3 \%$ gravel, $54 \pm 2 \%$ sand, and $8 \pm 2 \%$ silt and clay. The ANOVA test determined that none of the three sediment sizes had significantly different means between groups. Bulk density also did not have a significantly different mean between groups.

Analysis of variance of drainages with and without debris flows, determined that only percent steep slopes of all the factors has a significantly different mean. The factors tested for the upper basin include height, area, gradient, percent ice, percent bedrock, percent unconsolidated deposits, percent steep slopes (over 33 degrees), percent vegetation, average annual precipitation, the Melton's Ruggedness Number, and connection to a glacier. Separate measurements of percent ice, percent bedrock, and percent unconsolidated deposits were taken from the local geology map (WaDNR, 2010) and ortho imagery (USDA-FSA, 2009).

A series of multiple logistic regression analyses revealed that certain factors are significant in determining the occurrence of a debris flow during the 2006 rainfall event. 
The result of this analysis is the debris flow model in Equation 7. The significant factors are listed in order of decreasing significance:

1. Percent steep slopes in the upper basin $\left(X_{4}\right)$,

2. Percent unconsolidated deposits in upper basin $\left(X_{13}\right)$, and

3. Average annual rainfall $\left(X_{6}\right)$.

The analysis found that all factors are directly proportional to debris flow occurrence.

Those factors that were eliminated by the multiple logistic regression analysis of the best model are listed in order of decreasing significance:

4. Percent vegetation in the upper basin $\left(X_{5}\right)$,

5. Melton's Ruggedness Number $\left(X_{7}\right)$,

6. Gradient of the upper basin $\left(X_{1}\right)$, and

7. Percent ice and snowpack in the upper basin $\left(X_{11}\right)$.

where percent vegetation, gradient in the upper basin, and Melton's Ruggedness Number are inversely proportional to debris flow occurrence.

The debris flow hazard map for Mount St. Helens (Figure 68) was produced by color-coding each drainage basin based on the score resulting from the probability model equation (Equation 7). The resulting scores are categorized into four hazard levels of $<0.35$ very low, 0.35 to 0.50 low, 0.51 to 0.65 moderate, and $>0.65$ high. Three drainage basins had scores that assigned them to the high hazard level. The very low hazard drainage basins according to this model were found to be Kalama, Little Kalama, Dryer Glacier, Nelson Glacier, and Ape Canyon. The low hazard drainages are Snowfield, Swift Creek, Worm Flows, and Pine Creek. While the remaining drainage 
basins were designated as a moderate hazard, including: Blue Lake, Butte Camp Dome, June Lake, and Muddy River.

When factor data for Mount St. Helens drainages were combined with those of Mt. Adams (Williams, 2011) and Mt. Hood (Pirot, 2010) into a combined multiple logistic regression analysis, the most significant factors were found to be:

\section{Connection to glacier, and}

2. Percent vegetation in the upper basin (inverse relationship).

This does agree with the significant factors found by Pirot, but not with those found by Williams. Williams (2011) found for Mt. Adams that the two most significant basin attribute factors are percent glacial coverage in the upper basin and average annual rainfall (inverse relationship). Pirot (2010) found that the three most significant basin attributes determining debris flow occurrence on Mt. Hood are percent vegetation coverage in the upper basin (inverse relationship), gradient of the upper basin (inverse relationship), and connection to a glacier. Furthermore, the accuracy of this combined model decreased to $69 \%$ from the $83 \%$ accuracy of combined analysis performed by Williams for Mt. Adams and Mt. Hood data (Williams, 2011).

The reasons for this decrease can be found in the differences between Mount St. Helens and the other volcanoes. Mount St. Helens is the youngest at about 300,000 years old, has the lowest elevation by at least $300 \mathrm{~m}$, and is the most recently active. It also has less glacial area $\left(570,000 \mathrm{~m}^{2}\right)$ and very little vegetation $(<2 \%)$ on the upper slopes compared to the other mountains. Mt. Adams has a total glacial area of about $22,600,000 \mathrm{~m}^{2}$ and an average of $15 \%$ vegetation coverage in the upper basins 
(Williams, 2011). Mt. Hood has a total glacial area of about $13,500,000 \mathrm{~m}^{2}$ (Lillquist and Walker, 2006) and an average of $24 \%$ vegetation coverage in the upper basins (Pirot, 2010). 


\section{CHAPTER 8 - FUTURE WORK}

This project successfully produced an inventory of debris flows that occurred on Mount St. Helens after a "Pineapple Express" storm event in November 2006, characterized the initiation sites and methods, and produced a susceptibility map for future events. However, it also raised questions that could be addressed with future work.

Large scale debris flow initiation seems to occur only during extreme rainfall events that occur between the end of summer and before the first strong snowfalls. Although older debris flows were found at Blue Lake and Swift Creek, there was much evidence of older events in almost all drainages. The application of new discovery methods on existing data, new data sets (from orthophoto, LiDAR, or in-situ sensors), or the release of data sets covering older time periods may allow for the more accurate determination of debris flows during future extreme rainfall events.

More work could also be done to determine a single most accurate multiple logistic regression model. Although the models used on Mt. Hood (Pirot, 2010), Mt. Adams (Williams, 2011) and Mount St. Helens accurately predicted debris flow occurrences on those mountains, different significant factors were found for each. It would also be more accurate to use factors measured in three-dimensional units instead of the two-dimensional percent coverage units used in this study; i.e. using volume instead of area.

Rainfall is probably the most important factor involved in debris flow initiation, yet it was usually one of the first factors to be discarded in the multiple logistic 
regressions. This fact should negate the effectiveness of using multiple logistic regressions for modeling these phenomena. Either a method must be discovered of incorporating the extreme rainfall into this model or a more accurate modeling technique must be used.

More work is necessary to fully determine how the most significant factors revealed in the multiple logistic regression models are important in initiating debris flows. The mechanics of how roughness or connection to a glacier increases the likelihood of a debris flow is not fully understood.

More work could be done to analyze the large debris flows, especially at South Fork Toutle River, Blue Lake, and Muddy River. The initiation zones have been mapped and characterized, but a better understanding of the number of debris pulses involved, their volumes, and individual extents would be scientifically interesting and useful. In the South Fork Toutle River Drainage Basin, the initiation zone was not observed or sampled during field work. This drainage could be better characterized and further analyzed by incorporating other sources of data. For example, Cascade Volcano Observatory maintains seismic debris flow sensors in the South Fork Toutle River Valley (Adam Mosbrucker, USGS-CVO, personal communication, April 11, 2011).

Continued periodic observations of the erosional evolution of the drainage basins on Mount St. Helens should be conducted. This includes the acquisition of orthophoto or LiDAR data at periodic intervals, no more than five years apart. Currently, the only regular observations related to debris flows on the southern slopes of the mountain are of general road and trail conditions. 
Finally, this multiple logistic regression analysis method could be applied to other Cascade volcanoes in the Pacific Northwest to generate further debris flow susceptibility maps. This would help raise awareness of the geologic hazard to life and property in the region from debris flows. 


\section{REFERENCES}

Agresti, A., 1996, An introduction to categorical data analysis: New York, John Wiley and Sons, Inc., p. 290.

Alaback, P., Antos, J., Goward, T., Lertzman, K., MacKinnon, A., Pojar, J., Pojar, R., Reed, A., Turner, N., and Vitt, D., 1994, Plants of the Pacific Northwest Coast: Washington, Oregon, British Columbia and Alaska: Lone Pine Publishing, Vancouver B. C., CA, pp. 528.

American Society for Testing and Materials (ASTM), 2007, D422-63: Standard test method for particle-size analysis of soils: ASTM International, West Conshohocken, PA, DOI: 10.1520/D0422-63R07.

Benn, D., and Evans, D., 2010, Glaciers \& Glaciation, 2nd edition: Hodder Education, London, UK, pp. 802.

Bovis, M. J., and Jakob, M., 1999, The role of debris supply conditions in predicting debris flow activity: Earth Surface Processes and Landforms, vol. 24, p. 10391054.

Brugman, M.M., and Post, A., 1981, Effects of volcanism on the glaciers of Mount St. Helens: U.S. Geological Survey Circular 850-D, 11 p.

Burns, S., Pirot, R., Sobieszczyk, S., and Williams, K., 2009, Massive debris flow event on Pacific Northwest volcanoes, November 2006: More to come as the climate changes: Geological Society of America annual meeting Portland, Abstracts With Programs, vol. 41, No. 7, 716 p. 
Cannon, S. H., Gartner, J. E., Rupert, M. G., and Michael, J. A., 2007, Methods for the emergency assessment of debris-flow hazards from basins burned by the fires of 2007, Southern California: U.S. Department of the Interior, U.S. Geological Survey, Open-File Report 2007-1384, 10 p.

Carey, S. N., Gardner, J. E., Sigurdsson, H., 1995, The intensity and magnitude of Holocene plinian eruptions from Mount St. Helens volcano: Journal of Volcanology and Geothermal Research, v. 66, no. 1-4, p. 185-202.

Chapin, D. M., 1995, Physiological and morphological attributes of two colonizing plant species on Mount St. Helens: American Midland Naturalist, vol. 133, no. 1, p. 7687.

Clynne, M., Ramsey, D., Wolfe E., Hendley, J., II (ed), Stauffer, P. (ed), 2005, Pre-1980 Eruptive History of Mount St. Helens, Washington, USGS Fact Sheet 2005-3045: U.S. Geological Survey, Cascade Volcano Observatory, Vancouver, WA, 4 p. Clynne, M., Calvert, A., Wolfe, E., Evarts, R., Fleck, R., Lanphere, M., 2008, The Pleistocene Eruptive History Of Mount St. Helens, Washington, from 300,000 to 12,800 Years Before Present, in Sherrod, D. R., Scott, W. E., and Stauffer, P. H., eds., A Volcano Rekindled: the Renewed Eruption of Mount St. Helens, 20042006, U. S. Geological Survey Professional Paper 1750, p. 593-627.

Copeland, E. A., 2009, Recent periglacial debris flows from Mount Rainier, Washington: Oregon State University, Master's thesis.

Cornforth, D. H., 2005, Landslides in Practice: Investigation, Analysis, and Remedial/Preventative Options in Soils: Wiley, NJ, p. 20-22. 
Crandell, D.R., 1987, Deposits of Pre-1980 pyroclastic flows and lahars from Mount St. Helens volcano, Washington: U.S. Geological Survey Professional Paper 1444, 91 p.

Crandell, D. R. and Mullineaux, D. R. 1978, Potential hazards from future eruptions of Mount St. Helens Volcano, Washington: U.S. Geological Survey Bulletin 1383-C, $26 \mathrm{p}$.

Davis, J. C., 2002, Statistics and Data Analysis in Geology, $3^{\text {rd }}$ edition: New York, NY, pp. 638.

Godt, J. W., \& Coe, J. A., 2007, Alpine debris flows triggered by a 28 July 1999 thunderstorm in the central Front Range, Colorado: Geomorphology, vol. 84, p. 80-97.

Hatton, R. R., 2005, Portland, Oregon Weather and Climate: A Historical Perspective: Geographical Books, Bend, OR, pp. 382.

Hopson, Clifford A., 2008, Geologic map of Mount St. Helens, Washington prior to the 1980 eruption: U.S. Geological Survey Open-File Report 02-468, 2 sheets, scale 1:31,250 [http://pubs.usgs.gov/of/2002/of02-468/].

Hopson, C. A., Melson, W. G., 1990, Compositional trends and eruptive cycles at Mount St. Helens: Geoscience Canada, v. 17, no. 3, p. 131-141.

Hosmer, D. W., and Lemshow, S., 1989, Applied Logistic Regression: John Wiley \& Sons, Inc., New York, NY, pp. 307.

Iverson, R. M., 1997, The physics of debris flows: Reviews of Geophysics, p. 245-296. 
Jackson, L. E., Kostaschuk, R. A., and MacDonald, G. M., 1987, Identification of debris flow hazard on alluvial fans in the Canadian Rocky Mountains: In J. E. Costa, and G. F. Wieczorek (eds.), Debris Flows/Avalanches: Process, Recognition and Mitigation: Reviews in Engineering Geology, vol. 7: Geological Society of America, p. 115-124.

Janda, R.J., Scott, K.M., Nolan, K.M., and Martinson, H.A., 1981, Lahar movement, effects, and deposits, in Lipman, P.W., and Mullineaux, D. R., eds., The 1980 Eruptions of Mount St. Helens, Washington: U.S. Geological Survey Professional Paper 1250, p. 461-478.

Lillquist, K., and Walker, K., 2006, Historical glacier and climate fluctuations at Mount Hood, Oregon: Arctic, Antarctic, and Alpine Research, vol. 38, no. 3, p. 399-412. Lewicki, P., and Hill, T., 2007, Statistics: Methods and Applications: Statsoft, Inc., pp. 719.

Madden, R. A., Julian, P. R., 1971, Detection of a 40-50 day oscillation in the zonal wind in the tropical Pacific: Journal of the Atmospheric Sciences, vol. 28, p. 702-708.

Major, J., and Voight, B., 1986, Sedimentology and clast orientations of the 18 May 1980 southwest-flank lahars, Mount St. Helens, Washington: Journal of Sedimentary Petrology, vol. 56, no. 5, p. 691-705.

Marks, D., Kimball, J., Tingey, D., and Link, T., 1998, The sensitivity of snowmelt processes to climate conditions and forest cover during rain-on-snow: a case study of the 1996 Pacific Northwest flood: Hydrological Processes, vol. 12, p. 1569-1587. 
McKee, A., Means, J. E., Moir, W. H., and Franklin, J. F., 1987, First-year recovery of upland and riparian vegetation in the devastated area around Mount St. Helens. In: Bilderback, D. E. (ed.), Mount St. Helens 1980: Botanical Consequences of the Explosive Eruptions: University of California Press, Berkeley, CA, p. 168-187.

Melton, M. A., 1965, The geomorphic and paleoclimatic significance of alluvial deposits in southern Arizona: Journal of Geology, vol. 73, p. 1-38.

Moral, R. D., 1983, Initial recovery of subalpine vegetation on Mount St. Helens, Washington: American Midland Naturalist, vol. 109, no. 1, p. 72-80.

Moral, R. D., Clampitt, C. A., 1985, Growth of native plant species on recent volcanic substrates from Mount St. Helens: American Midland Naturalist, vol. 114, no. 2, p. 374-383.

Mullineaux, D. R., 1986, Summary of pre-1980 tephra-fall deposits erupted from Mount St. Helens, Washington State, USA: Bulletin of Volcanology (0258-8900), vol. 48, no. $1,17 \mathrm{p}$.

NASA Land Processes Distributed Active Archive Center (LP DAAC), 2000-2010, ASTER Level 2 Surface Radiance SWIR + VNIR, USGS/Earth Resources Observation and Science (EROS) Center, Sioux Falls, South Dakota, 2011.

NASA Landsat Program, 1984-2009, Landsat TM scene, L5046028_028<year><month><day>, L1T, USGS, Sioux Falls, South Dakota, 2011. National Oceanic and Atmospheric Administration (NOAA), National Weather Service (NWS), Climate Prediction Center, 2002, Monitoring Intraseasonal Oscillations, Frequently Asked Questions, from 
http://www.cpc.ncep.noaa.gov/products/intraseasonal/intraseasonal faq.html, accessed on May 13, 2012.

Office of the Washington State Climatologist (OWSC), 2006, 2006 record November rainfall, from http://www.climage.washington.edu/events/2006NovRain.html, accessed on May 13, 2012.

Orr, W. N., and Orr, E. L., 2002, Geology of the Pacific Northwest, $2^{\text {nd }}$ edition: Waveland Press, p. 74, 103.

Pierson, T. C., 1985, Initiation and flow behavior of the 1980 Pine Creek and Muddy River lahars, Mount St. Helens, Washington: Geological Society of America Bulletin, v. 96, p. 1056-1069.

Pierson, T. C., 2005, Distinguishing between debris flows and floods from field evidence in small watersheds: U.S. Geological Survey, USGS Fact Sheet 2004-3142, 4 p.

Pierson, T. C., and Scott, K. M., 1985, Downstream dilution of a lahar: transition from debris flow to hyperconcentrated streamflow: Water Resources Research, vol. 21, p. 1511-1524.

Pierson, T., 1986, Flow behavior of channelized debris flows, Mount St. Helens, Washington, in Abrahams, A. D., ed., Hillslope Processes: Boston, Allen and Unwin, p. 269-296.

Pierson, T. C., Janda R. J., Thouret J-C., and Borrero, C. A.,1990, Perturbation and melting of snow and ice by the 13 November 1985 eruption of Nevado del Ruiz, Colombia, and consequent mobilization, flow and deposition of lahars: Journal of Volcanology and Geothermal Research, vol. 41, p. 17-66. 
Pirot, R., 2010, Initiation zone characterization of debris flows in November, 2006 on Mount Hood, Oregon: Portland State University, Master's thesis.

Pringle, P. T., 2002, Roadside Geology of Mount St. Helens National Volcanic Monument and Vicinity: Washington Department of Natural Resources, Olympia, WA, pp. 124.

PRISM Climate Group, Oregon State University (OSU), 2007, Average annual 2006 precipitation gridded data for continental United States, downloaded from http://prism.oregonstate.edu, accessed in May 17, 2010.

Ritter, D. F., Kochel, R. C., and Miller, J. R., 2011, Process Geomorphology, $5^{\text {th }}$ edition: McGraw Hill, Boston, pp. 113.

Schilling, S. P., Carrara, P. E., Thompson, R. A., and Iwatsubo, E. Y., 2004, Posteruption glacier development within the crater of Mount St. Helens, Washington, USA: Quaternary Research, vol. 61, p. 325-329.

Scott, K. M., 1988, Origins, behavior, and sedimentology of lahars and lahar-runout flows in the Toutle-Cowlitz River system: U.S. Geological Survey Professional Paper 1447-A, 76 p.

Scott, W. E., Sherrod, D. R., and Gardner, C. A., 2008, Overview of the 2004 to 2006, and continuing, eruption of Mount St. Helens, Washington, in Sherrod, D. R., Scott, W. E., and Stauffer, P. H., eds., A Volcano Rekindled: the Renewed Eruption of Mount St. Helens, 2004-2006, U. S. Geological Survey Professional Paper 1750, p. 3-22. 
Shane, S., 1985, Discovering Mount St. Helens: A guide to the National Volcanic Monument: University of Washington Press, Seattle, pp. 166.

St. John, H., 1976, The flora of Mount St. Helens, Washington: The Mountaineers, vol. 70 , no. 6 , p. $65-77$.

Sobieszczyk, S., Ulrich, M. A., Piatt, D. R., and Bragg, H. M., 2008, Analysis of geomorphic and hydrologic characteristics of Mount Jefferson debris flow, Oregon, November 6, 2006: U. S. Geological Survey Scientific Investigations Report 20085204, 19 p.

U. S. Department of Agriculture (USDA) Farm Service Agency (FSA), Aerial Photography Field Office, October 2006, digital mosaic ortho imagery of Cowlitz and Skamania Counties, Washington (-123.254258 west, -121.5000 east, 46.5000 north, 45.5000 south), Version 20061016.

U. S. Department of Agriculture (USDA) Farm Service Agency (FSA), Aerial Photography Field Office, October 2009, digital mosaic ortho imagery of Cowlitz and Skamania Counties, Washington (-123.2500 west, -121.47 east, 46.5000 north, 45.5000 south), Version 20091007.

U. S. Department of Agriculture (USDA) Forest Service (FS), 1997, Gifford Pinchot National Forest News \& Events: Debris avalanche/flows occur on Mount St. Helens: http://www.fs.fed.us/gpnf/press/1997/pr77.htm, accessed May 14, 2012 (copy available from author). 
U. S. Department of Agriculture (USDA) Forest Service (FS), 1998, Gifford Pinchot National Forest, stream vector digital data (-122.75 west, -121.34 east, 46.88 north, 45.58 south), version 20071030.

U. S. Department of Agriculture (USDA) Forest Service (FS), 2003, Map of Mount St. Helens National Volcanic Monument \& Administrative Area, Gifford Pinchot National Forest, Washington.

U. S. Department of Agriculture (USDA) Forest Service (FS), 2006, Gifford Pinchot National Forest News \& Events: Forest Sno-Parks hit hard by recent record rains - winter conditions close forest roads:

http://www.fs.usda.gov/detail/giffordpinchot/newsevents/?cid=FSBDEV3 005979, accessed April 2011 (copy available from author).

U. S. Department of Agriculture (USDA) Forest Service (FS), 2007, Gifford Pinchot National Forest News \& Events: Storm damage affects visitor access to forest: downloaded from http://www.fs.usda.gov/detail/giffordpinchot/newsevents/?cid=FSBDEV3 006011, accessed April 2011 (copy available from author).

U. S. Department of Agriculture (USDA) Forest Service (FS), 2008a, Gifford Pinchot National Forest News \& Events: Forest Road 83 will reopen on Friday October 3, 2008: http://www.fs.usda.gov/detail/giffordpinchot/newsevents/?cid=FSBDEV3 005988, accessed April 2011 (copy available from author). U. S. Department of Agriculture (USDA) Forest Service (FS), 2008b, Gifford Pinchot National Forest, existing vegetation stands and non-forest areas (-122.52 west, 121.33 east, 46.84 north, 45.67 south), version 20080410. 
U. S. Department of Agriculture (USDA) Natural Resources Conservation Service (NRCS), 2007, Daily precipitation data tables, downloaded from http://www.wcc.nrcs.usda.gov/snow/, accessed on May 17, 2010.

U. S. Department of Agriculture (USDA) Natural Resources Conservation Service (NRCS), 2009, SNOTEL and snow survey \& water supply forecasting: National Weather and Climate Center, $2 \mathrm{p}$.

U. S. Geologic Survey (USGS), 2004, LiDAR Mapping of the Toutle River, Washington river basin (5 meter resolution), Version 20040315, downloaded from http://wagda.lib.washington.edu/data/type/elevation/lidar/st_helens/.

U. S. Geologic Survey (USGS), 2002, DRG of Mount Saint Helens Quadrangle topographic map at 1:24,000 Scale, 1998.

U.S. Geological Survey (USGS), Washington Water Science Center, 2006, USGS flood update for western Washington, Nov. 8, 2006, from http://wa.water.usgs.gov/news/2006/news.newhiflo.Nov06.htm, accessed May 13, 2012.

Walder, J. S., and Driedger, C. L., 1994, Geomorphic change caused by outburst floods and debris flows at Mount Rainier, Washington, with emphasis on Tahoma Creek Valley: U.S. Geological Survey, Open-File Report 93-4093, p. 3.

Walder, J.S, Schilling, S.P., Sherrod, D.R., and Vallance, J.W., 2010, Evolution of Crater Glacier, Mount St. Helens, Washington, September 2006-November 2009: U.S. Geological Survey Open-File Report 2010-1141, 34 p. 
Washington State Department of Natural Resources (WaDNR), Division of Geology and Earth Resources, June 2010, Digital Geology of Washington State at 1:100,000 Scale, Version 3.0.

Williams, K. J., 2011, Analysis and characterization of debris flows in November, 2006, Mount Adams, Washington: Portland State University, Master's thesis.

Willford, D. J., Sakals, M. E., Innes, J. L., Sidle, R. C., and Bergerud, W.A., 2004, Recognition of debris flow, debris flood and flood hazard through watershed morphometrics: Landslides, vol. 1, p. 61-66.

Zapffe, C., 1912, The geology of the St. Helens mining district of Washington: Economic Geology, vol. 7, no. 4, p. 340-350. 
APPENDIX A - RECONNAISSANCE AND SAMPLING 


\section{NELSON GLACIER DRAINAGE BASIN}

\section{Reconnaissance}

Field reconnaissance took place at the end of August 2010 along Trail 216D through the Plains of Abraham (Figure 16). A wide, fluvial channel ( $\sim 50 \mathrm{~m}$ where crossed) covered with sparse boulder to cobble deposits was observed on the Plain (Figure A.1) where the stream channel passes over the edge of the Plain and drops some $600 \mathrm{~m}$ over a short distance into the Smith Creek Valley. The deposits have interspersed vegetation and appear to have been uncovered by past fluvial activity since the surrounding plain is at least one meter higher than the floor of the channel.

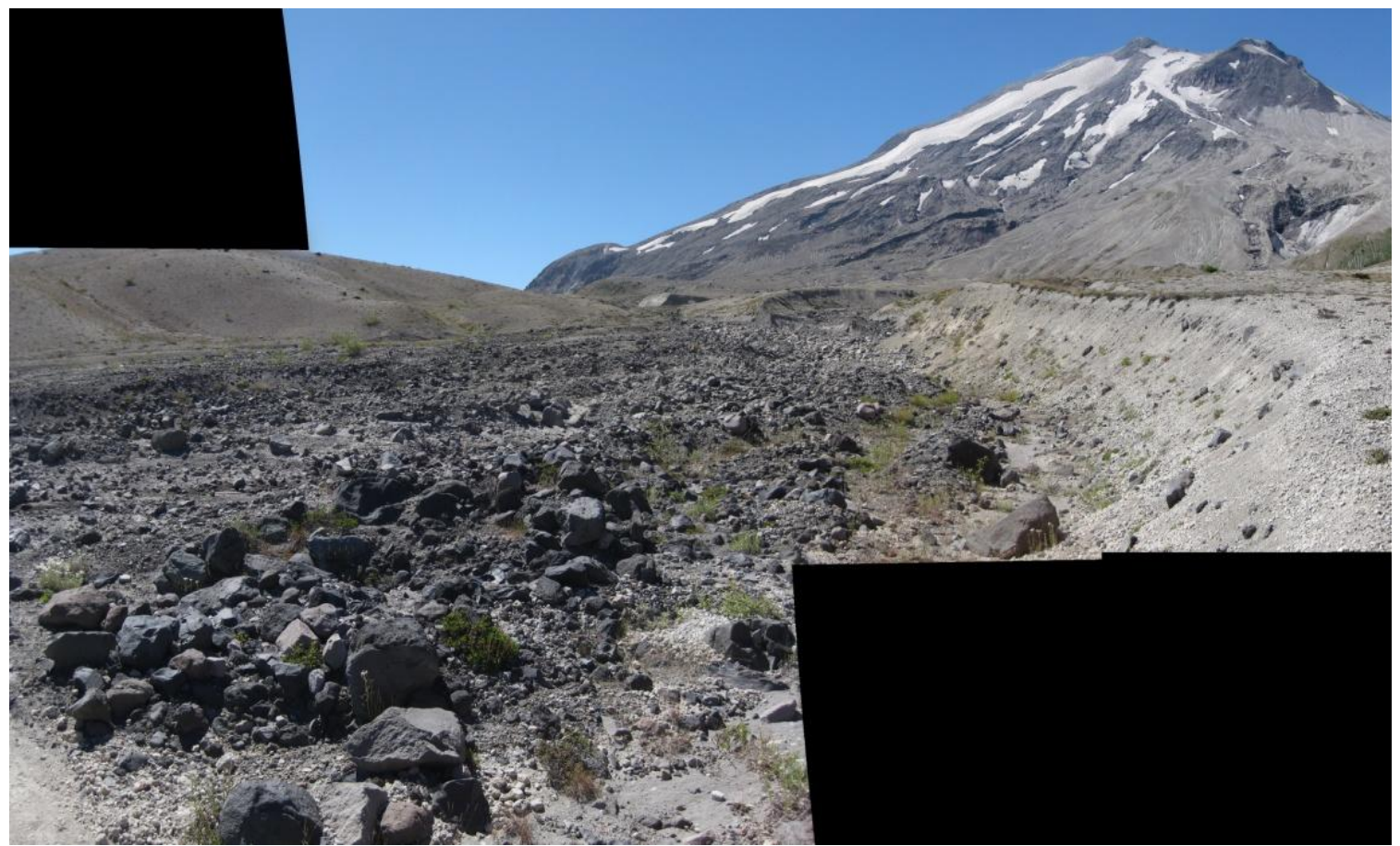

Figure A.1: Photographic mosaic of a channel in the lower Nelson Glacier Drainage Basin. Note the sparse vegetation and banks of lighter pumice. The channel is interpreted as old debris flow deposits uncovered by the fluvial removal of overlying 1980s pumice and ash layers. 
Field observations made in September 2011 approached from Windy Pass on Trail 216 and up the northern-most ravine toward Dogs Head. Some possible debris flow levees were observed (Figure A.2) in the ravine just south of the shallow northernmost ravine, but the prodigious snow prevented reliable identification. An alternative origin to these deposits is their exposure by fluvial removal of the overlying pumice layer as occurred on the Plains of Abraham. The multiple channels between this ravine and those in the southern portion of the upper basin were only observed from a distance as the terrain was too rough to permit closer inspection from this elevation.

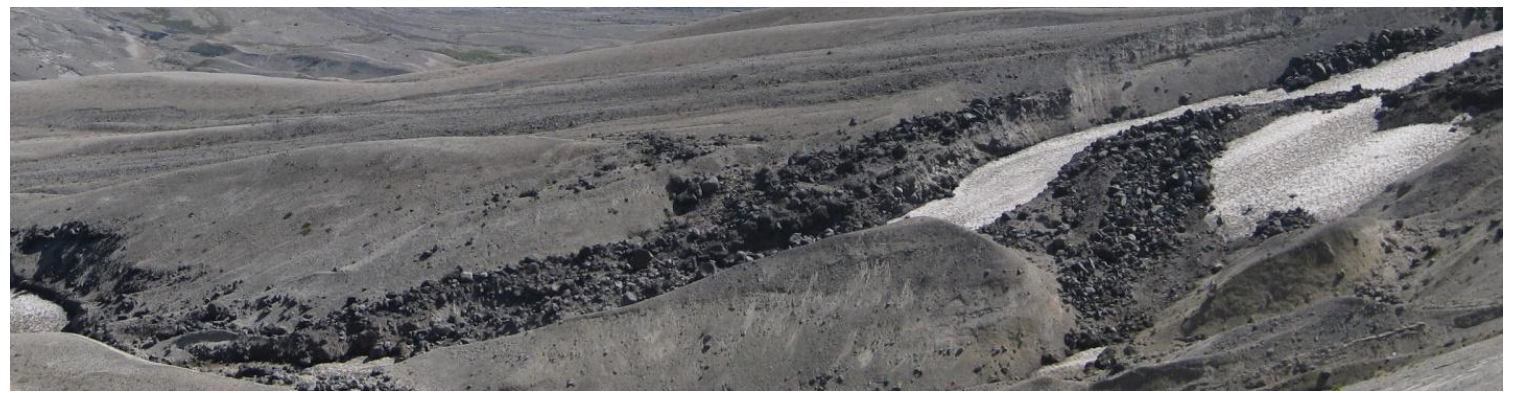

Figure A.2: Photographic mosaic of the lower area of the sampled channel in Nelson Glacier upper basin. A possible debris flow levee is visible on the right. Snow covers the channel floor the entire length to below the sample elevation. View is looking east-southeast.

\section{Soil Sample Collection}

One set of three soil samples were taken from the Nelson Glacier Drainage (Figure 16). The sample group was taken from the wall of the channel just south of the northern-most ravine in the Nelson Glacier Drainage Basin (Figure A.3) at an elevation of 1,735 m (UTM 10N 564654E 5117788N). This location was not at a landslide or erosional scarp but was chosen because the site was below the covering pumice layer and similar to deposits seen in the channel. The geology is mapped as pyroclastic flows 


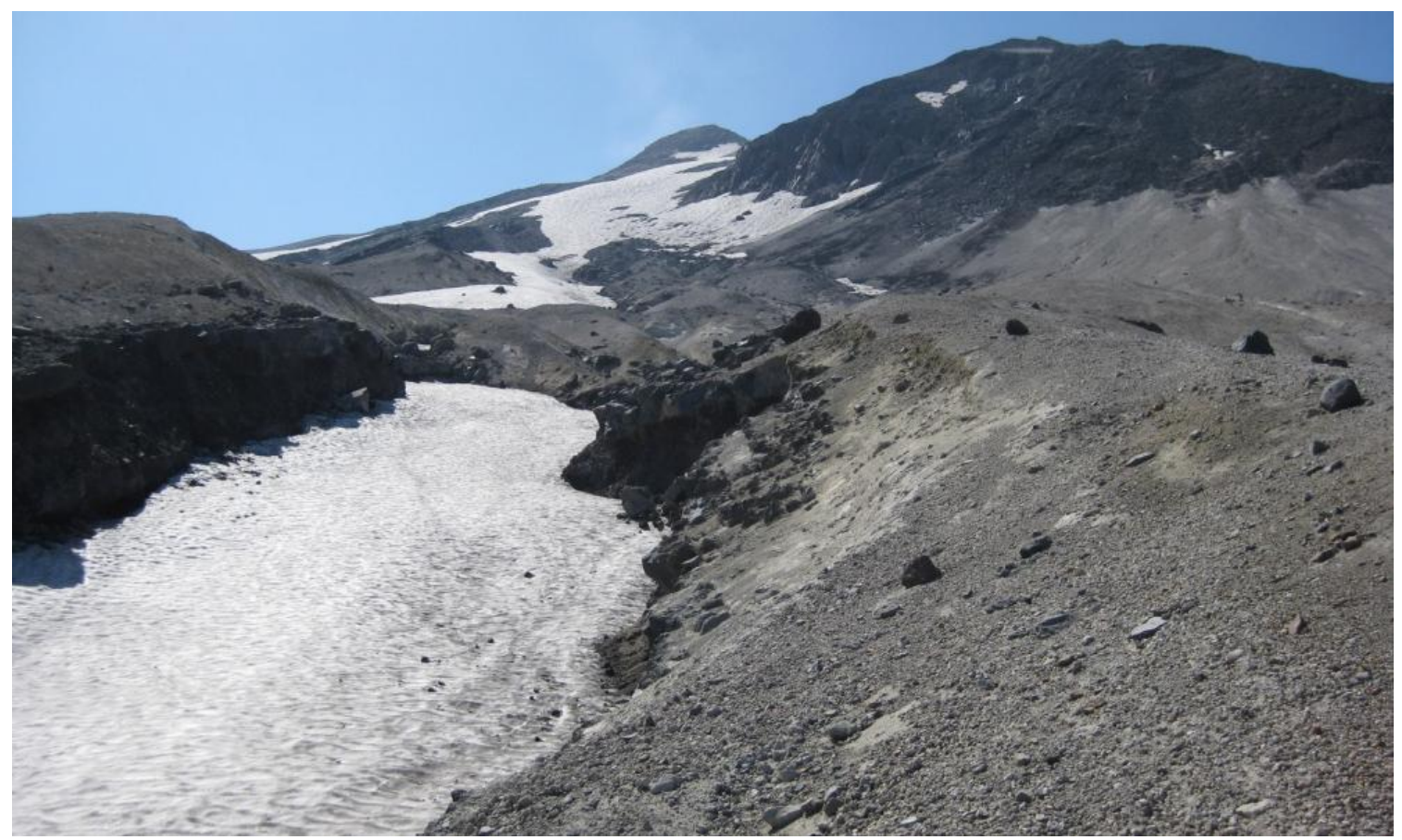

Figure A.3: View up from the sample site in the right foreground. Nelson Glacier is in the distance with the dark, rocky Dogs Head dome to the right. View is to the southwest.

(Qvp) related to the pumice plain deposits found to the north of the central crater (WaDNR, 2010).

\section{APE GLACIER DRAINAGE BASIN}

\section{Reconnaissance}

Field reconnaissance took place at the end of August 2010 along Trail 216 through the Plains of Abraham (Figure 20). A narrow, flat, fluvial channel ( $20 \mathrm{~m}$ wide) was crossed north of Pumice Butte (Figure 23) which widened and branched toward the base of the mountain. This channel contained cobble-sized debris and evidence of low debris levees that had been reworked by fluvial processes. Sparse vegetation was also observed within the channel. In late afternoon an ephemeral stream appeared that was 
not present earlier in the day.

During the reconnaissance, field observations were also made of two channels that empty into the lower plain from the upper Ape Canyon Drainage Basin (Figure A.4, Figure A.5). Both contained boulders and cobbles of possible past debris flows, but no levees were observed. Both channels also contained minor sparse vegetation.
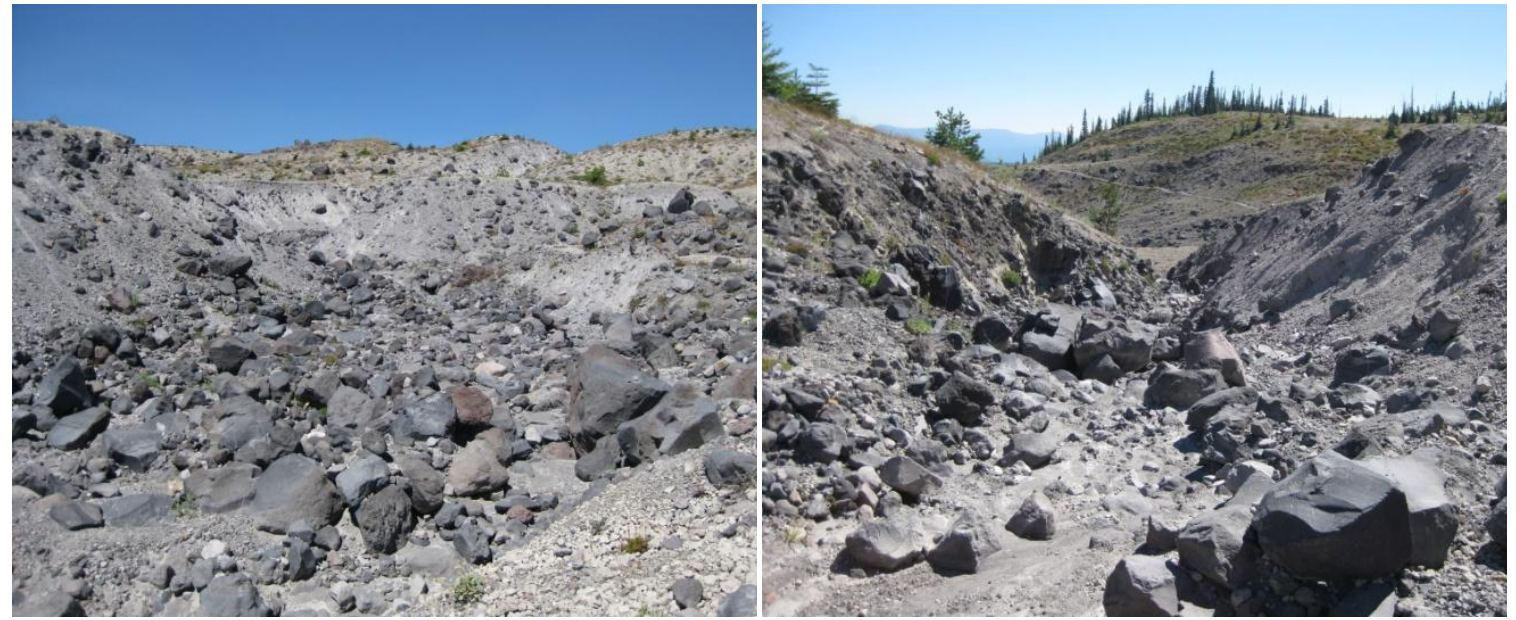

Figure A.4: The view up (right) and down (left) flow of the Ape Canyon channel that bends south around Pumice Butte. Vegetation including partridgefoot and pussy paws was observed within the channel between the boulder and cobble-sized material of a possible debris flow deposit. No levees were observed.
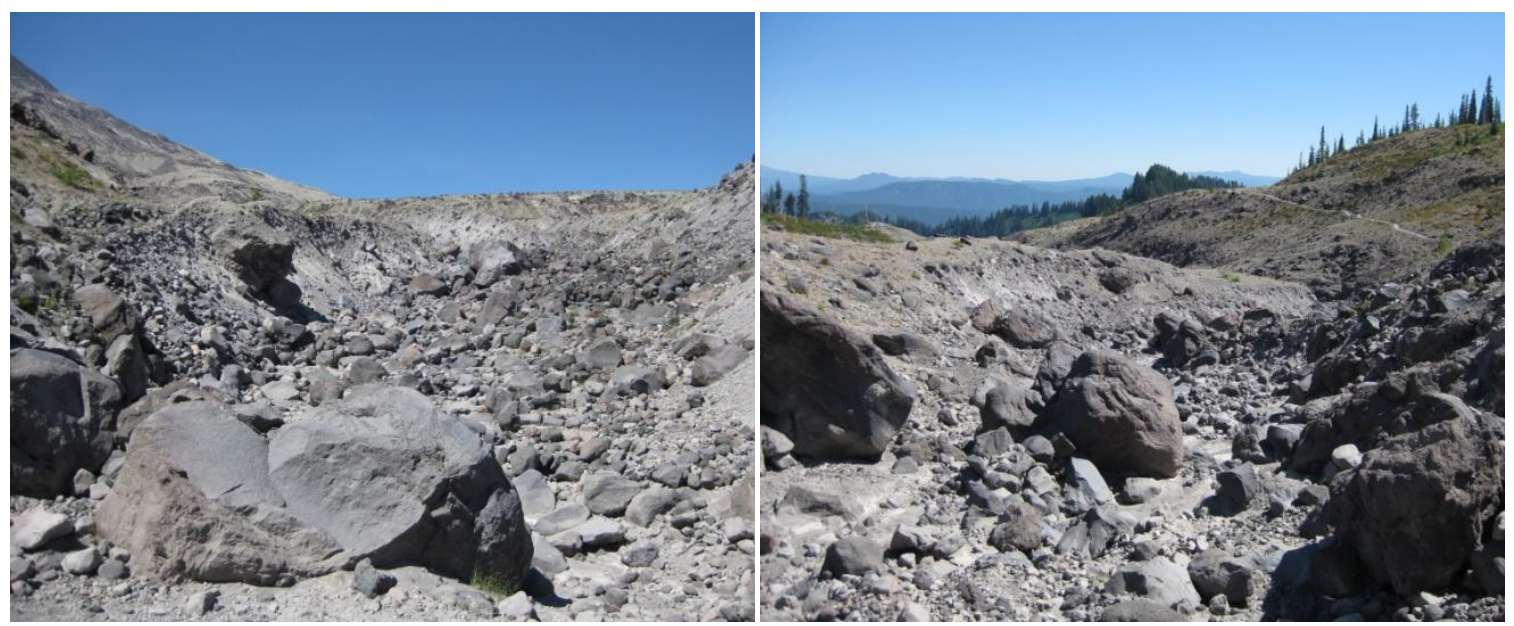

Figure A.5: The view up (right) and down (left) flow of the Ape Canyon channel that empties the area south and around East Dome. Vegetation was observed within the channel between boulders and cobbles of a possible debris flow deposit. No levees were observed along the channel. 
Field observations made in September 2011 approached the basin from the ridge south of East Dome. The route passed up and over East Dome, and then continued diagonally upslope beneath Ape Glacier and the snowpack. Many minor runoff channels were observed south of East Dome and under the southern extent of Ape Glacier. The large southern and central ravine channels were explored in the upper basin, but no debris flow evidence was observed (Figure A.6).

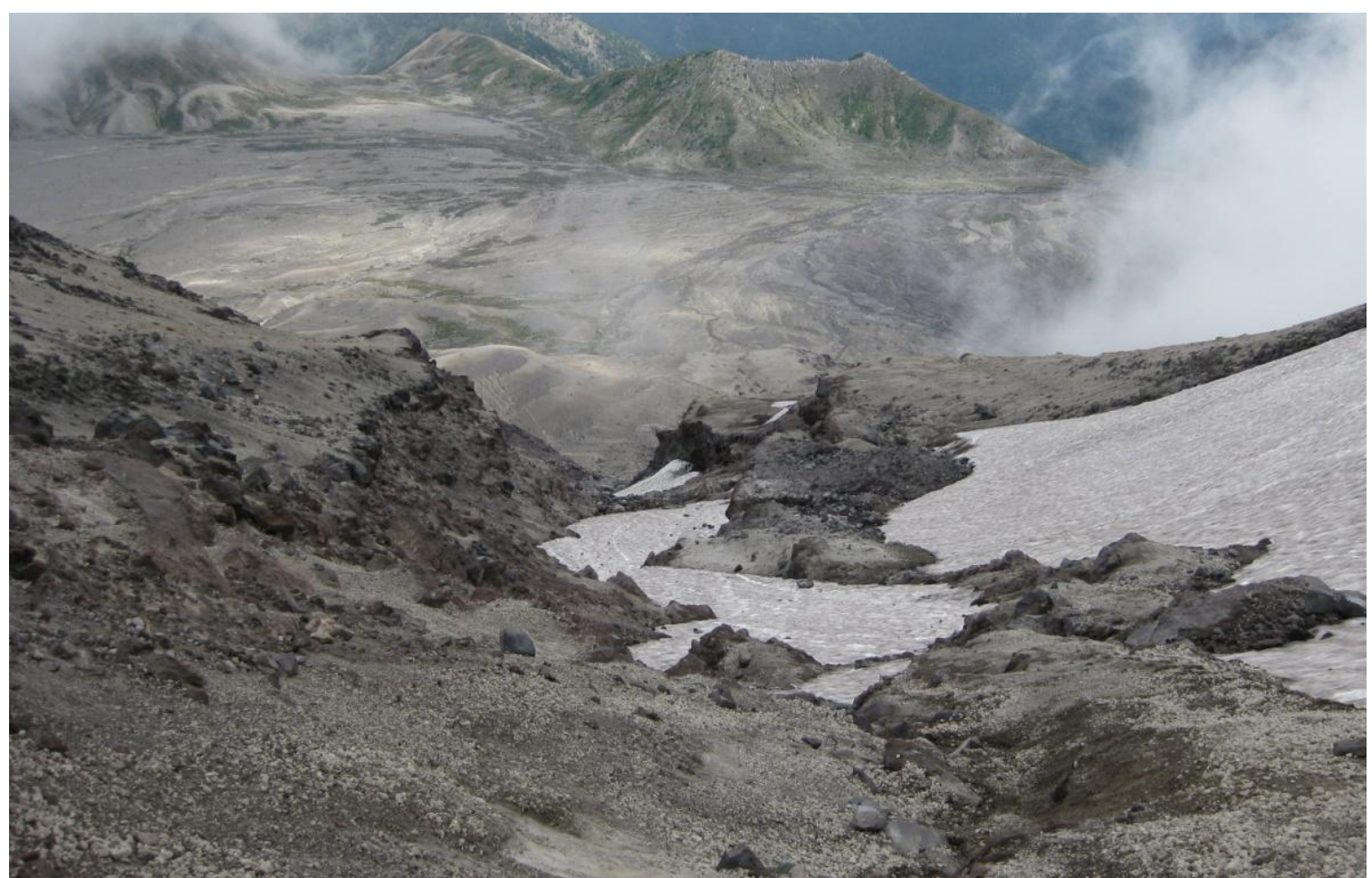

Figure A.6: View down the central major channel of the Ape Canyon upper basin. No debris flow evidence was observed.

\section{Soil Sample Collection}

Two sets of three soil samples each were taken from the Ape Canyon Drainage Basin (Figure 20). One sample group was taken below the southern extent of the snowpack associated with Ape Glacier, in a zone of runoff channels at an elevation of 1,672 m (UTM 10N 564747E 5116817N). The second was taken between the central 
and northern channels at an elevation of 1,796 m (UTM 10N 565149E 5116559N).

Neither site was located at a landslide or erosional scarp, but was chosen because of the relationship to surrounding topography and the exposure of soil through the covering pumice layer. The geology of both sample sites is mapped as andesite flows (Qva) which covers about $47 \%$ of the upper basin (WaDNR, 2010), although both sites were locally covered by unconsolidated sediments.

\section{MUDDY RIVER DRAINAGE BASIN}

\section{Reconnaissance}

Field reconnaissance occurred in this basin over multiple visits during August and September 2010, and again in August 2011 (Figure 25). Exploration was conducted from Trails 216 and 234 (Figure A.7), but also from hiking off-trail down the lahar plain and up the main channel to an elevation of $1,820 \mathrm{~m}$. Access above this point was restricted for safety reasons by the surrounding steep and rocky ravine walls. Field observations made in late August 2011 approached the main channel from south of East Dome and then progressed upslope to a waterfall at 1,820 m elevation (UTM 10N 564704E $5116154 N)$. No evidence of debris flow activity was observed between snow patches in the main channel between 1,600 m and the upper elevation (Figure A.8). However, where Trail 216 crosses the channel at 1,360 m, boulders and cobble sized debris were observed in the channel as well as small levees and steeply cut banks (Figure A.9).

Hiking down the lahar plain, observations were made into the Muddy River Channel at intervals. Between the break in slope at the mountain base (around 1,280 


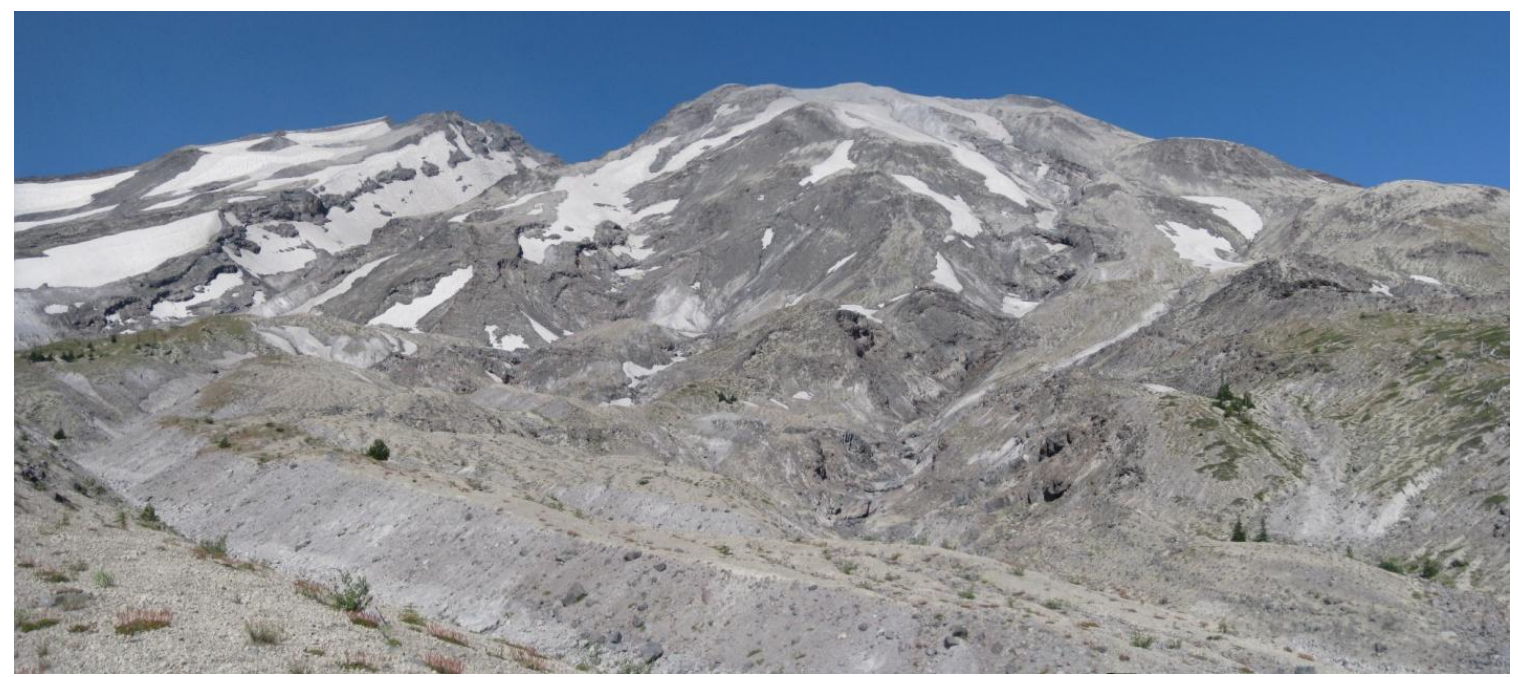

Figure A.7: Upper Muddy River Drainage Basin from Trail 216 on the lahar plain. View to the northwest. The main channel progresses down slope right of center and passes out of frame on the right. The foreground channel is a minor ravine that defines the bottom boundary of the upper basin.

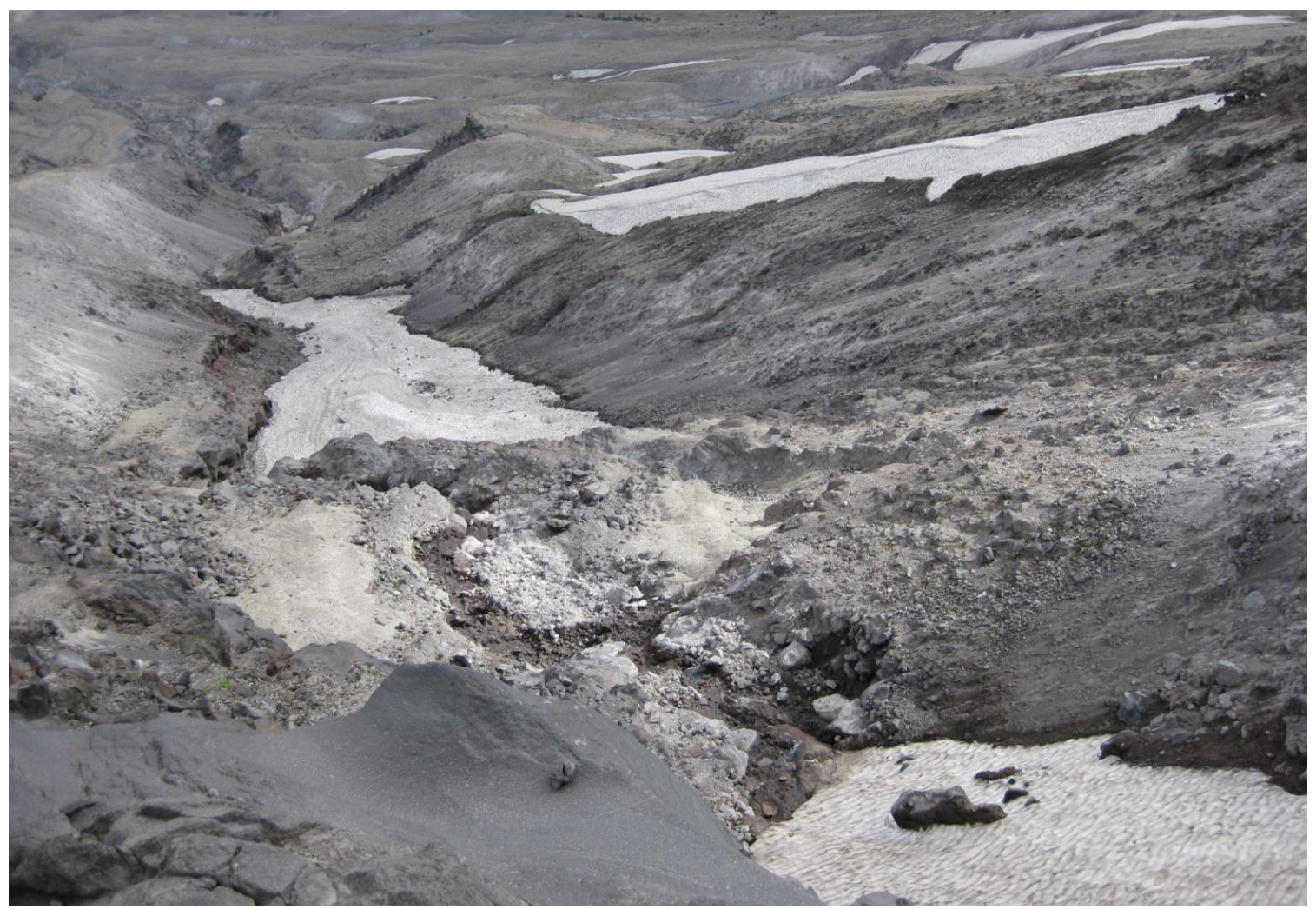

Figure A.8: View down the main channel of the Muddy River Drainage from the waterfall at 1,820 m elevation. No evidence of debris flow activity is observed between snow patches. 


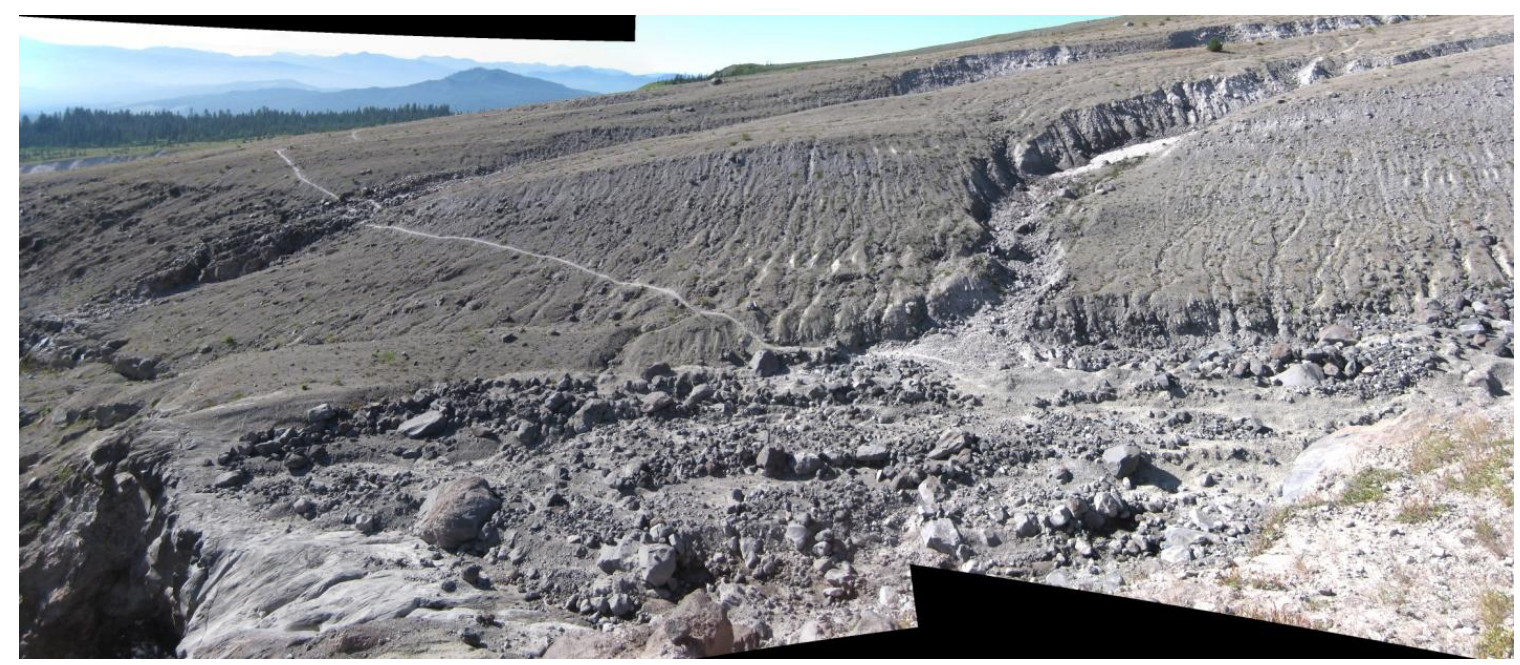

Figure A.9: Photographic mosaic of the Muddy River Channel at the Trail 216 crossing. Evidence of debris flows passing this point is seen from the amount of boulder and cobble debris and small levees. Upslope, steeply cut walls of the channel were observed.

m elevation) and 1,100 m elevation, the channel is about $60 \mathrm{~m}$ wide and $20 \mathrm{~m}$ deep with steep banks. Around the 1,050 m elevation (UTM 10N 567189E 5115412N), a large debris flow deposit filled and partially overflowed the channel (Figure A.10). This deposit is recent with no vegetation and areas without fluvial reworking. Below this point the channel widens to $120 \mathrm{~m}$ before narrowing the last $800 \mathrm{~m}$ to the confluence with the Shoestring channel. The confluence is also choked with recent boulder to sandsized debris that has filled the channel to within two meters of the rim. Deposits continue down to the Road 83 bridge, but it is difficult to distinguish how much of this material originated from the Muddy River Channel.

\section{Soil Sample Collection}

One set of three soil samples was collected from near the waterfall on the main Muddy River Channel at 1,774 m elevation (UTM 10N 564803E 5116186N, Figure 25). This was taken from a sloped area near the channel as access to the channel itself was 


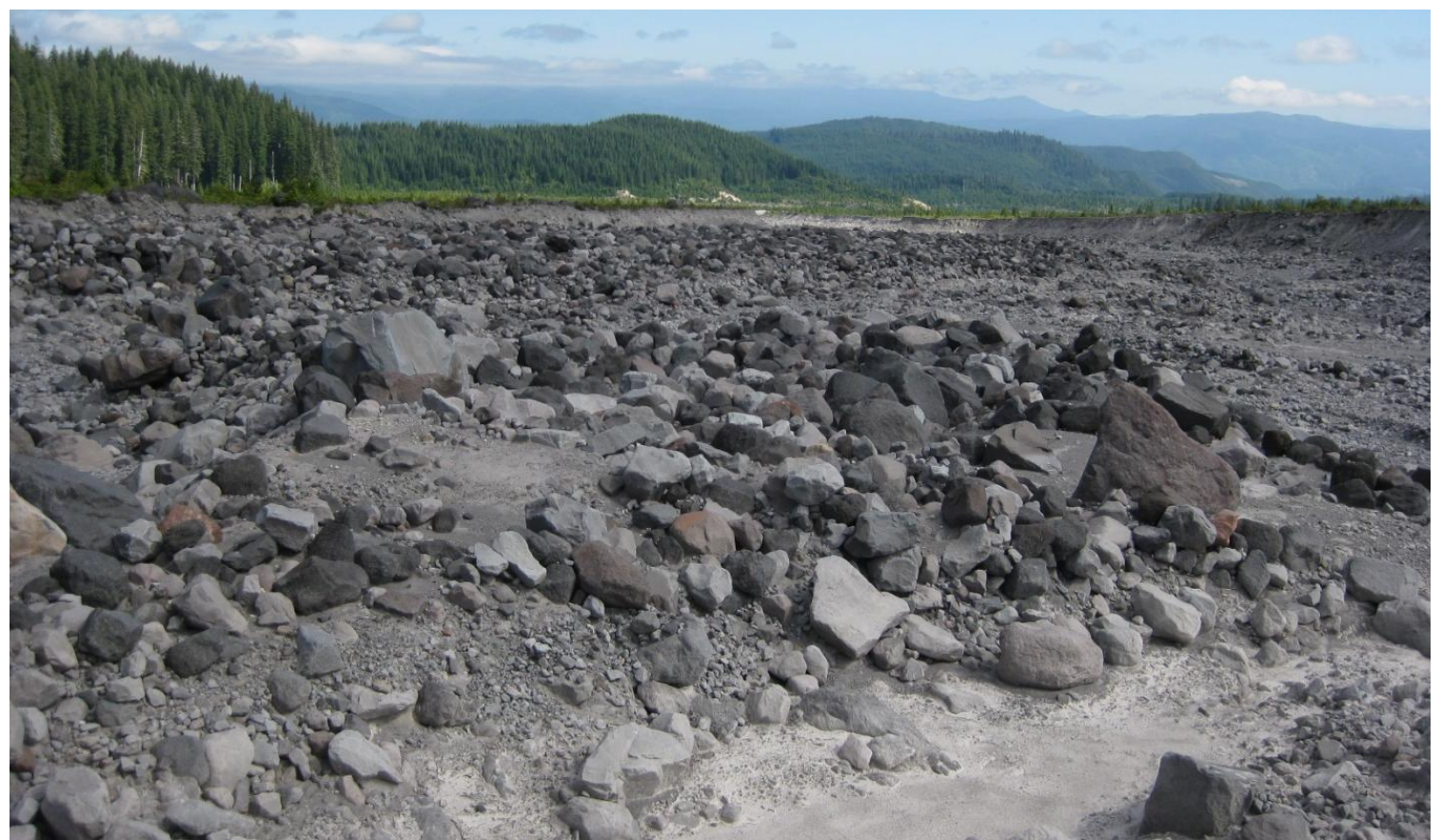

Figure A.10: View down flow from the center of the Muddy River Channel at the debris flow deposit around 1,050 m elevation. The current fluvial channel is to the right.

dangerous. No debris flow evidence was observed nearby; however, this sample is representative of the soils in the upper basin. The geology of the sample site is mapped as andesite flows (Qva) which covers about 56\% of the upper basin (WaDNR, 2010).

Two soil samples were taken from the Shoestring Glacier Drainage Basin near the Muddy River initiation zone. Although these samples have been categorized as belonging to the Shoestring Glacier Drainage, they were taken from similar deposits at sample sites only 150 and 255 m away.

\section{SHOESTRING GLACIER DRAINAGE BASIN}

\section{Reconnaissance}

Field reconnaissance into the Shoestring Glacier Drainage Basin (Figure 29) occurred during mid-August 2010 along Trail 216 northward from the June Lake 
trailhead. Multiple older ravines in this drainage basin without recent activity were crossed before reaching a wide deep channel about $250 \mathrm{~m}$ across and at least $35 \mathrm{~m}$ deep. This is the largest of many channels that join the main canyon along the south bank. The channel walls consisted of unconsolidated cobble to sand sized debris with apparent sub-horizontal bedding observable from a distant perspective (Figure A.11). Although the upper slope was unstable and unraveling, this side-channel showed no evidence of recent debris flow or fluvial activity as the ravine bottom was filled with debris from the canyon wall. Further northward, however, the main channel was filled with recent boulder, cobble and smaller sized debris where it crossed Trail 216 at 1,350 m elevation (Figure A.12).

Field observations made in late August 2011 approached the main channel from the north along Trail 216 and then progressed up the north rim of the channel to 1,644

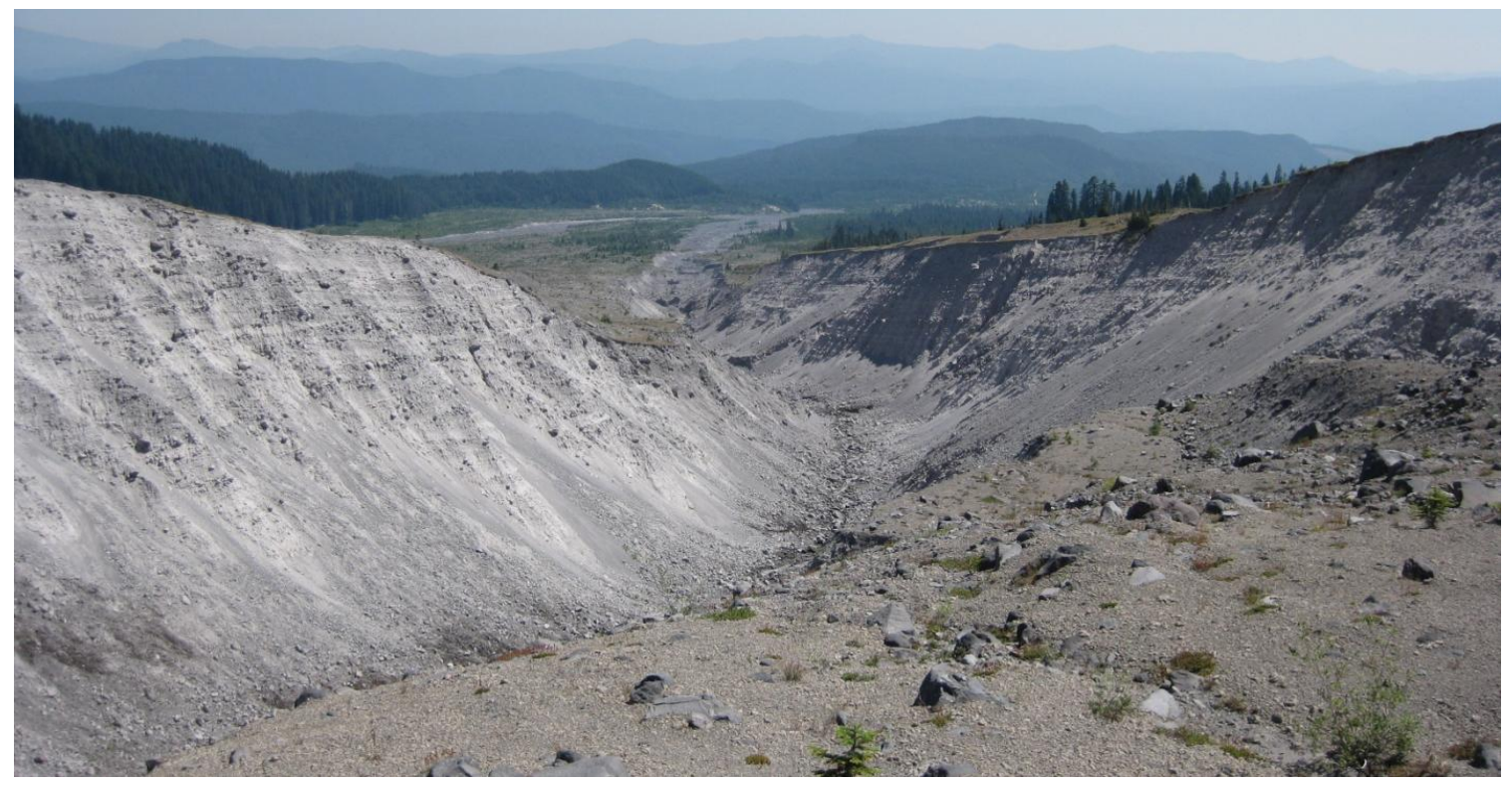

Figure A.11: View down the Shoestring Glacier Drainage from below Trail 216 and near the confluence of the main channel and the large side-channel on the southern bank. Note the subhorizontal layer in the canyon walls. The canyon is about $40 \mathrm{~m}$ deep at this point. 


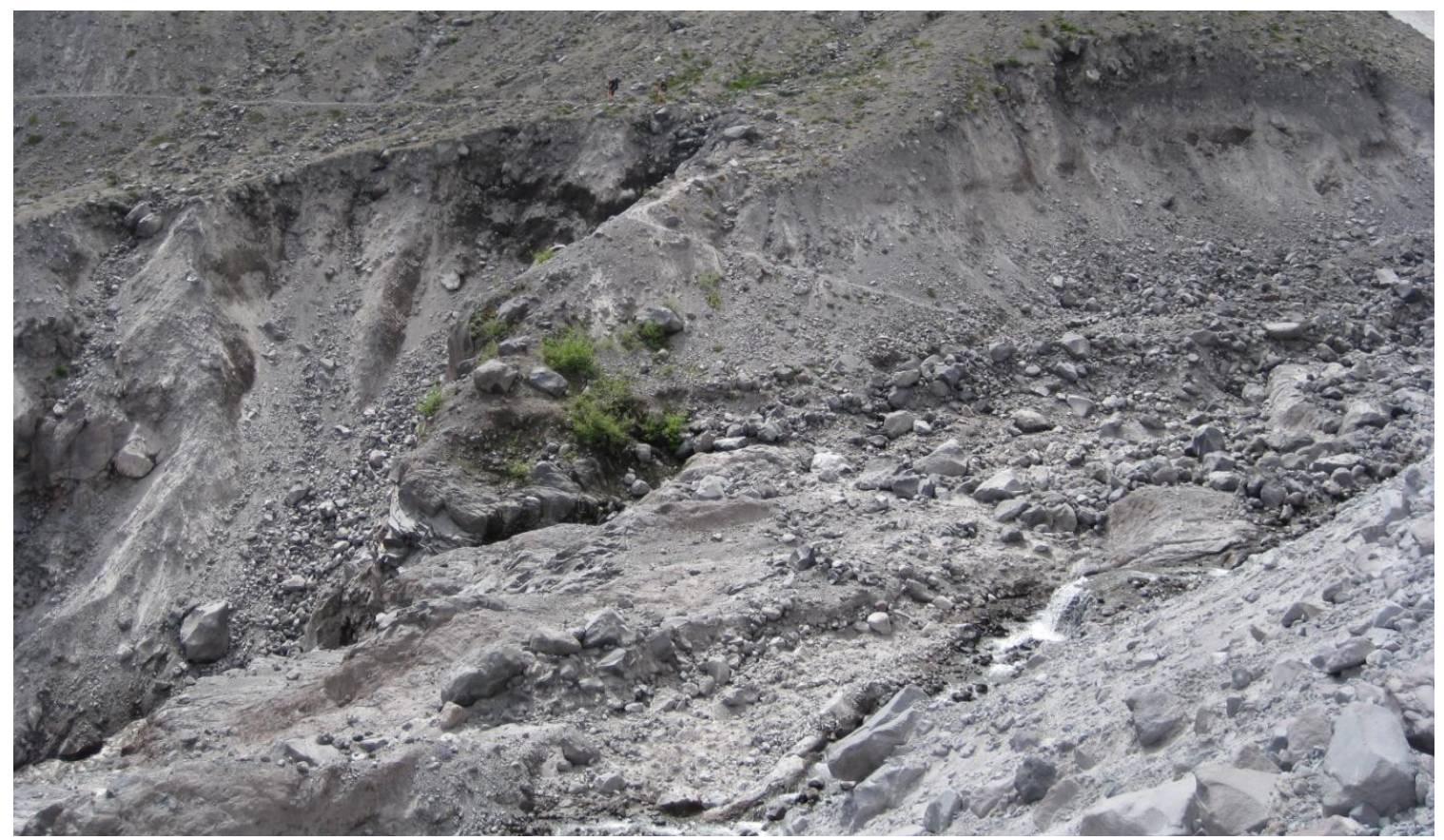

Figure A.12: View across the main Shoestring Glacier Channel at the Trail 216 crossing. Evidence of debris flows passing this point was observed from the amount of boulder and cobble-sized debris and small levees. An old landslide scarp is visible on the left.

m elevation (UTM 10N 564787E 5115380N). It was observed that from 1,525 m elevation upwards, the near channel wall showed evidence of recent failures, with bare unstable slopes and a lack of vegetation (Figure A.13). A stream bed was partially visible at the base through gaps in the snowpack. Within the channel, multiple mounds and ridges of unconsolidated deposits were observed, many displaying evidence of recent slope failures. The floor debris obstructed clear observations of a deeper ravine located near the opposite wall of the channel. At the upper extent of observations, a sidechannel continued upward into the steep, rocky formation and presented the same evidence of unstable slopes (Figure A.14). From ortho imagery comparison it was determined that major erosion in this side-channel was a possible initiation source of the 2006 Shoestring Glacier Debris Flow. 


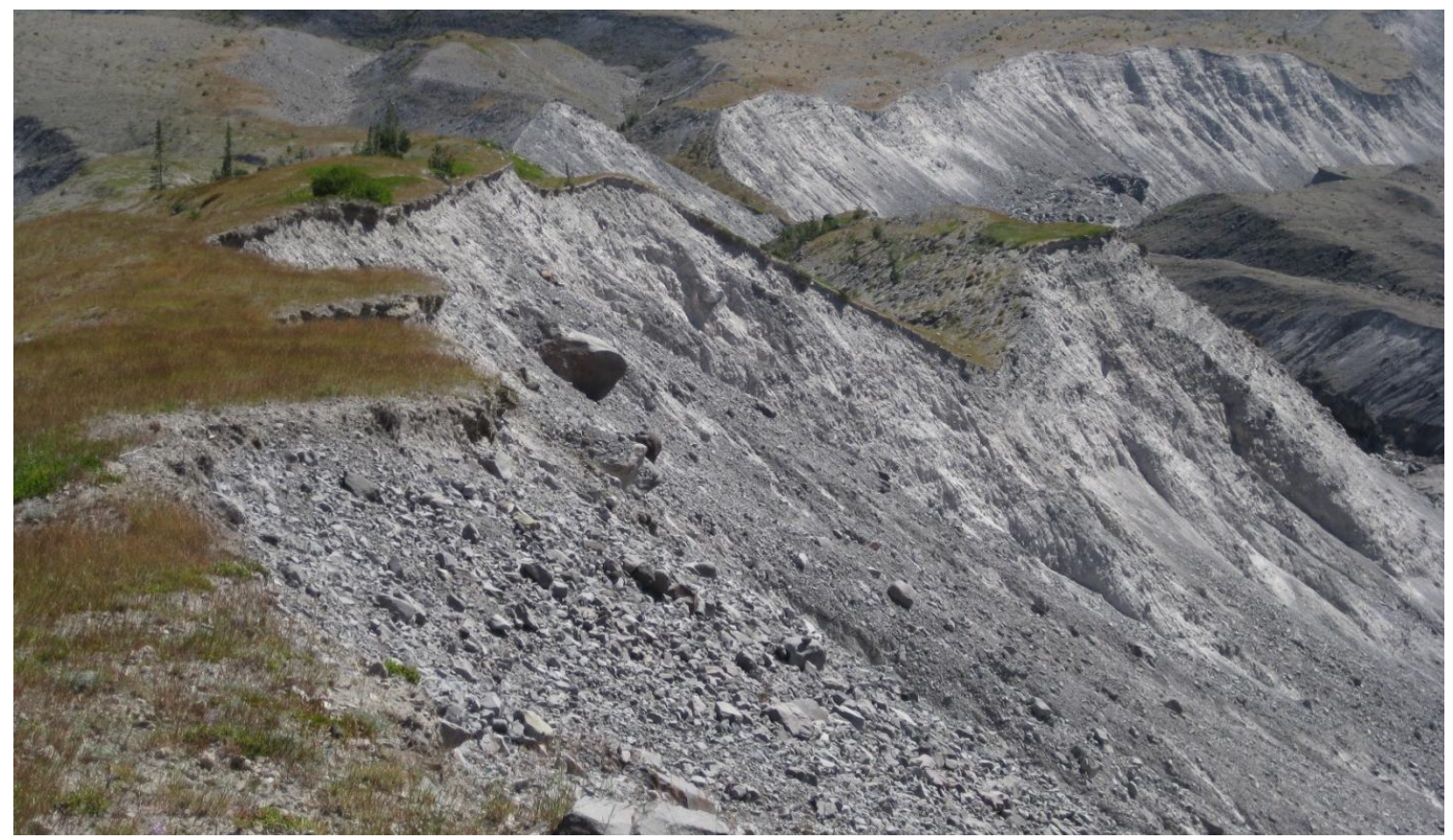

Figure A.13: The northern channel wall of the Shoestring Glacier Canyon showing active erosion and past landslide scars. Two samples were taken from along this ridge. View to the east.

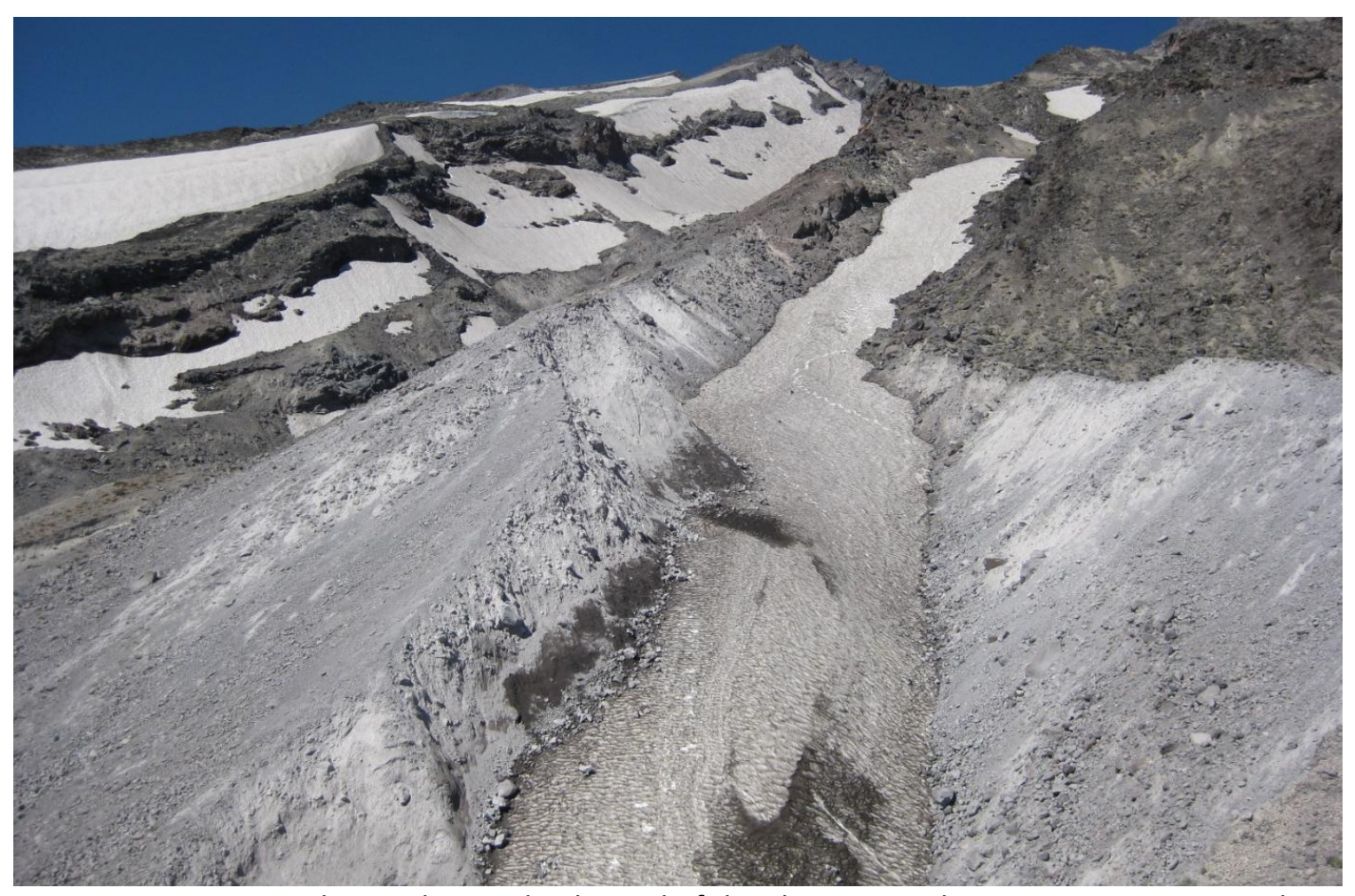

Figure A.14: View up the northern side-channel of the Shoestring Glacier Drainage Basin with freshly eroded walls visible in the foreground. The main channel is to the left beyond the light gray ridge. 
Hiking down the lahar plain, periodic observations were made into the Shoestring Glacier Channel. The channel maintains steep walls and a width of between 45 and $60 \mathrm{~m}$ down to about 1,020 m elevation. Beyond that point a debris flow deposit covering about $460,000 \mathrm{~m}^{2}$ raises the channel floor until the deposit overflows onto the surrounding lahar plain (Figure A.15). At 980 m elevation (UTM 10N 568649E $5113641 \mathrm{~N})$, the channel has overflowed to a width of about $200 \mathrm{~m}$. At the confluence with the Muddy River, the channel is constricted, but then widens again to about $200 \mathrm{~m}$ and forms a final debris flow deposit that fills the channel and surroundings down to the Road 83 bridge (Figure A.16). This deposit was recent with no vegetation and areas with no fluvial reworking observed.

\section{Soil Sample Collection}

Two sets of three soil samples each were taken from the Shoestring Glacier Drainage Basin (Figure 29). One sample group was taken along the northern channel rim at an elevation of 1,525 m (UTM 10N 565198E 5115318N, Figure A.13). Although this channel bank did not change between the 2006 and 2009 ortho imagery, it was observed in the field to consist of unconsolidated deposits and form steep, unstable slopes. The second sample was taken at the lower edge of the confluence between the main channel and a small northern side-channel at an elevation of $1,644 \mathrm{~m}$ (UTM 10N 564787E 5115380N). Both sites were located along the rim of the steep channel wall, which showed evidence of past landslide failures possibly by fluvial erosion of the slope base. The geology of both sample sites is mapped as volcaniclastics deposits and rocks 


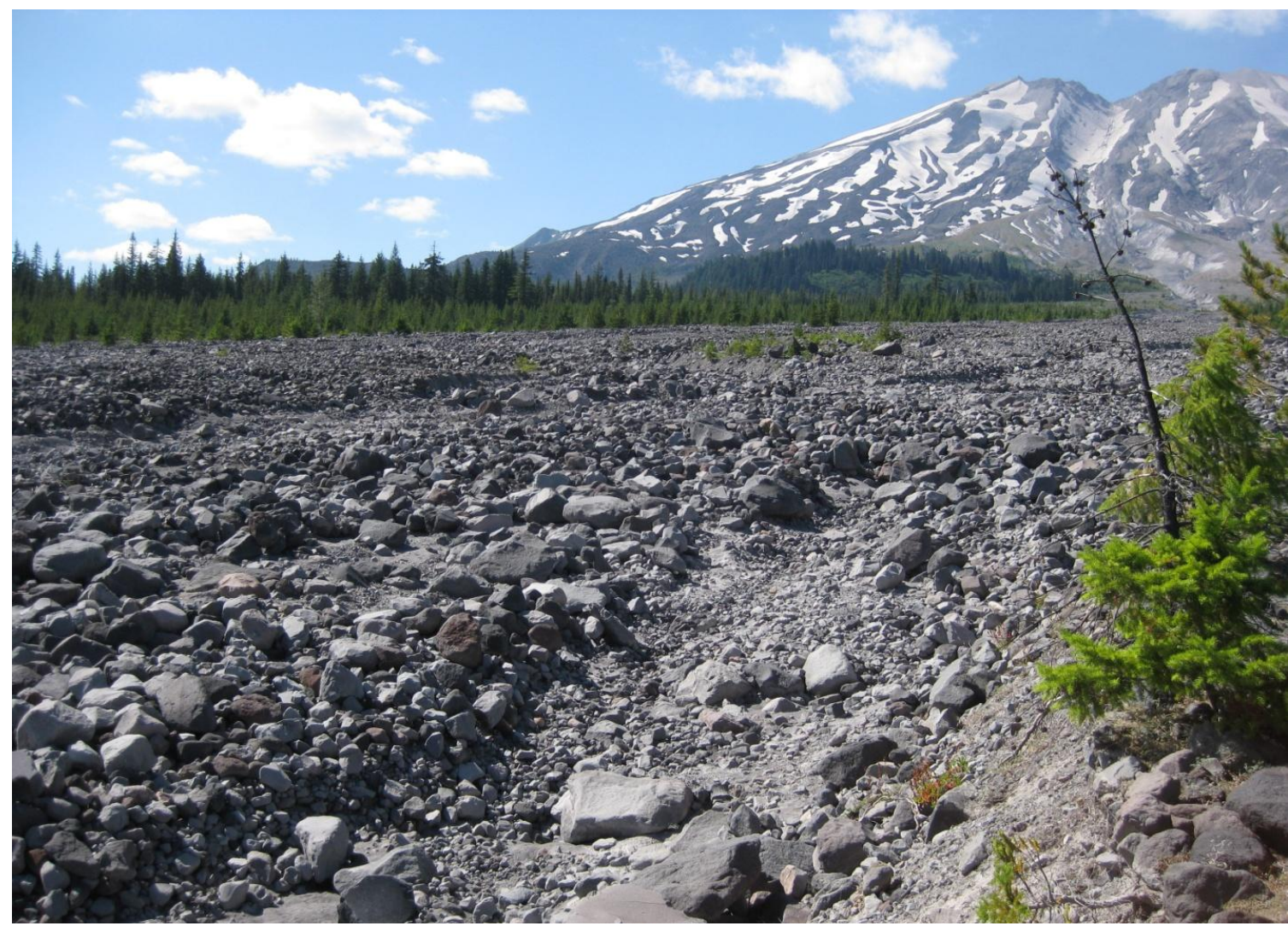

Figure A.15: View up flow of the Shoestring Glacier Debris Flow deposit. The picture was taken from the tree 'island' visible right of center in Figure 26.

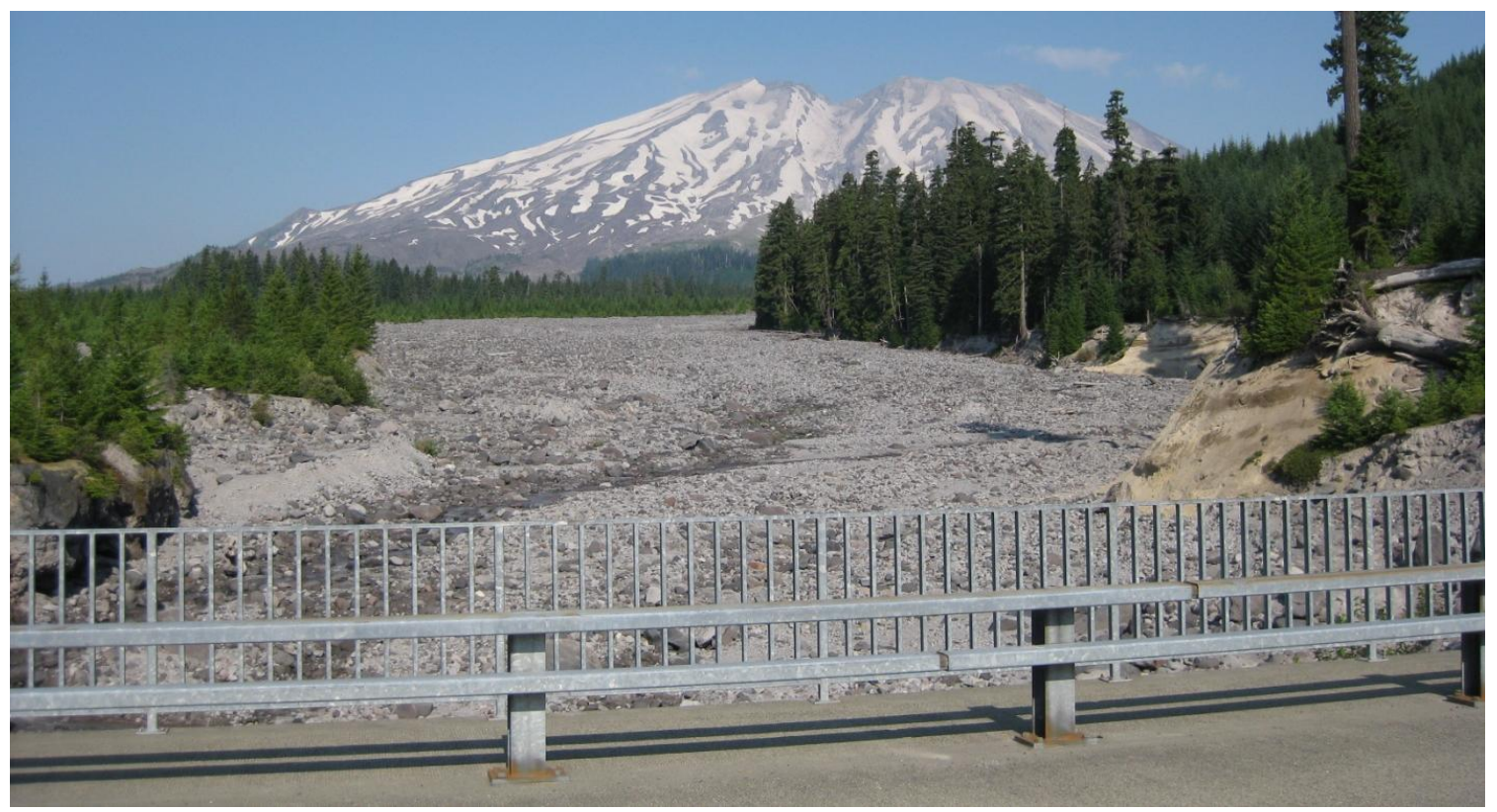

Figure A.16: View upslope of the combined Shoestring Glacier/Muddy River Debris Flow deposit from the Road 83 bridge. The Shoestring Glacier Canyon notch is visible in the mountain's profile. 
(Qvc) which covers about $42 \%$ of the upper basin. The upper site is on the boundary with another unit, andesite flows (Qva), which makes up 33\% of the upper basin (WaDNR, 2010).

\section{PINE CREEK DRAINAGE BASIN}

\section{Reconnaissance}

Field reconnaissance occurred in the basin during mid-August 2010 along Trail 216 through the Worm Complex Flows (Figure 32). Where the trail crossed the main channel, it is a narrow ravine less than $20 \mathrm{~m}$ in width that contains cobble and sand debris reworked by ongoing stream processes (Figure A.17). There was also substantial vegetation on the banks indicating no recent debris flow activity. Further observations were made by hiking up the drainage a short distance to the junction of two sidechannels with the main ravine. The channel floor was covered by dark colored, loose boulders and cobbles. At this junction a large ravine to the right, cut through deposits from neighboring Shoestring Glacier, but exhibited shallow angle slopes with rocky walls and a debris covered floor hiding any stream bed. The main channel also displayed shallow angled walls with sparse vegetation cover, but with a distinguishable stream bed. At the junction, the left-most channel contained the light-gray deposits indicating active erosion of the steep channel walls and loose, light colored debris on the channel floor. This channel (arrowed, Figure A.17) showed the most promising evidence of recent debris flow activity, yet ortho imagery and LiDAR indicate this is a short channel with a length of about $150 \mathrm{~m}$. 


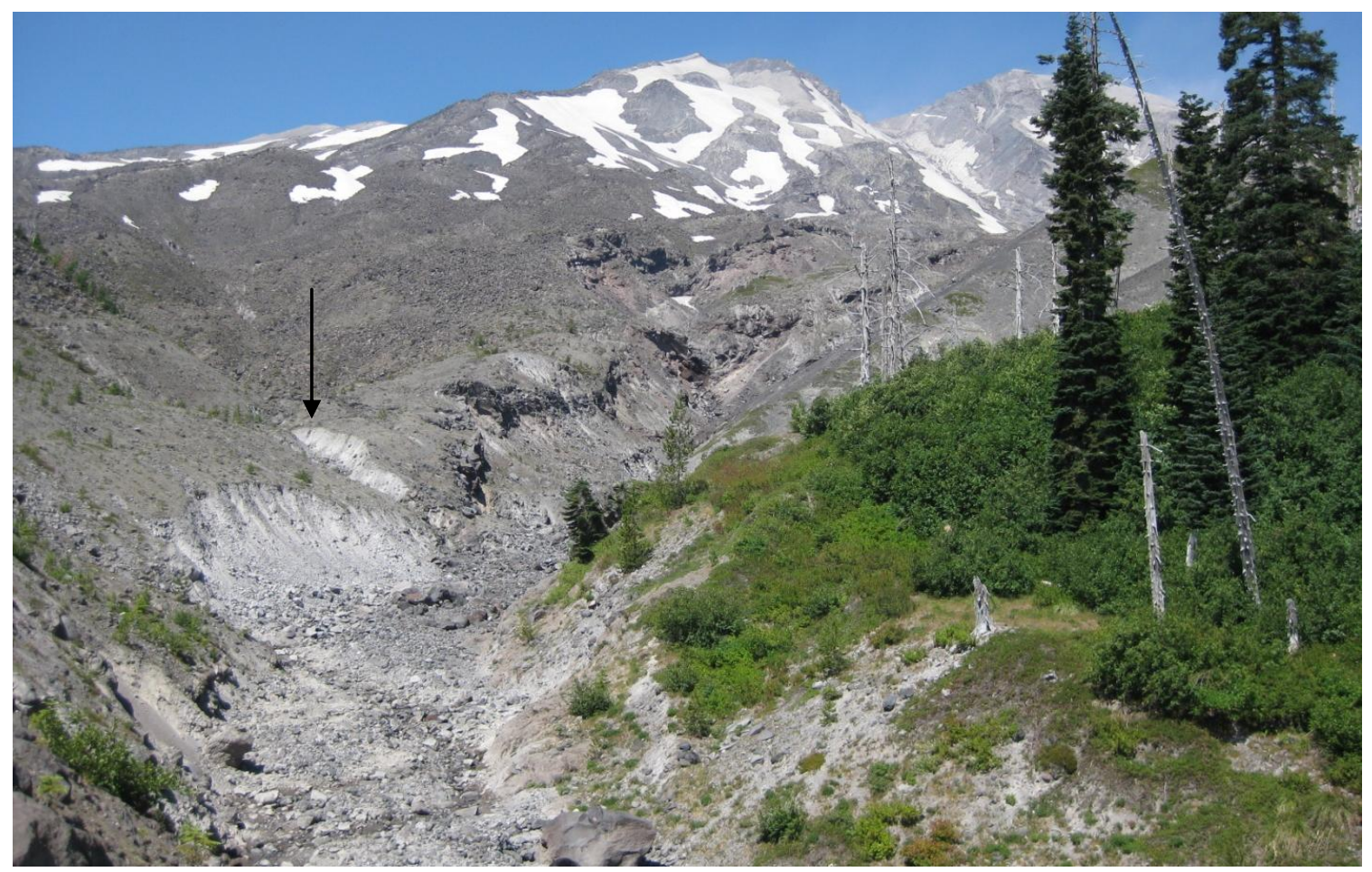

Figure A.17: View up the Pine Creek Channel near the Trail 216 crossing. Channel contains fluvially reworked boulders and cobbles and some evidence of past debris flow activity. Arrowed is the location of a side-channel with fresh, steep walls.

\section{Soil Sample Collection}

No soil samples were taken from the Pine Creek Drainage Basin. However, two sets of samples were taken from the Shoestring Glacier Drainage in deposits similar to those of the side-channel initiation zone.

\section{WORM FLOWS DRAINAGE BASIN}

\section{Reconnaissance}

Field reconnaissance took place in mid-August 2010 along Trail 216 from the June Lake access trail and through the Worms Complex Flows area (Figure 36). Where the trail crosses a bend in the main channel, a three meter deep ravine containing cobble and sand-sized debris was observed. The channel exhibits some steep sides, but 
also unraveling slopes and minor vegetation (Figure A.18). Up slope from the trail, the channel was visible for only a short distance as a steep ravine along the edge of a lava flow. Down slope from the trail, the channel was visible for some distance (Figure A.19) with the same unraveling slopes and minor vegetation observed. From Road 83, only a

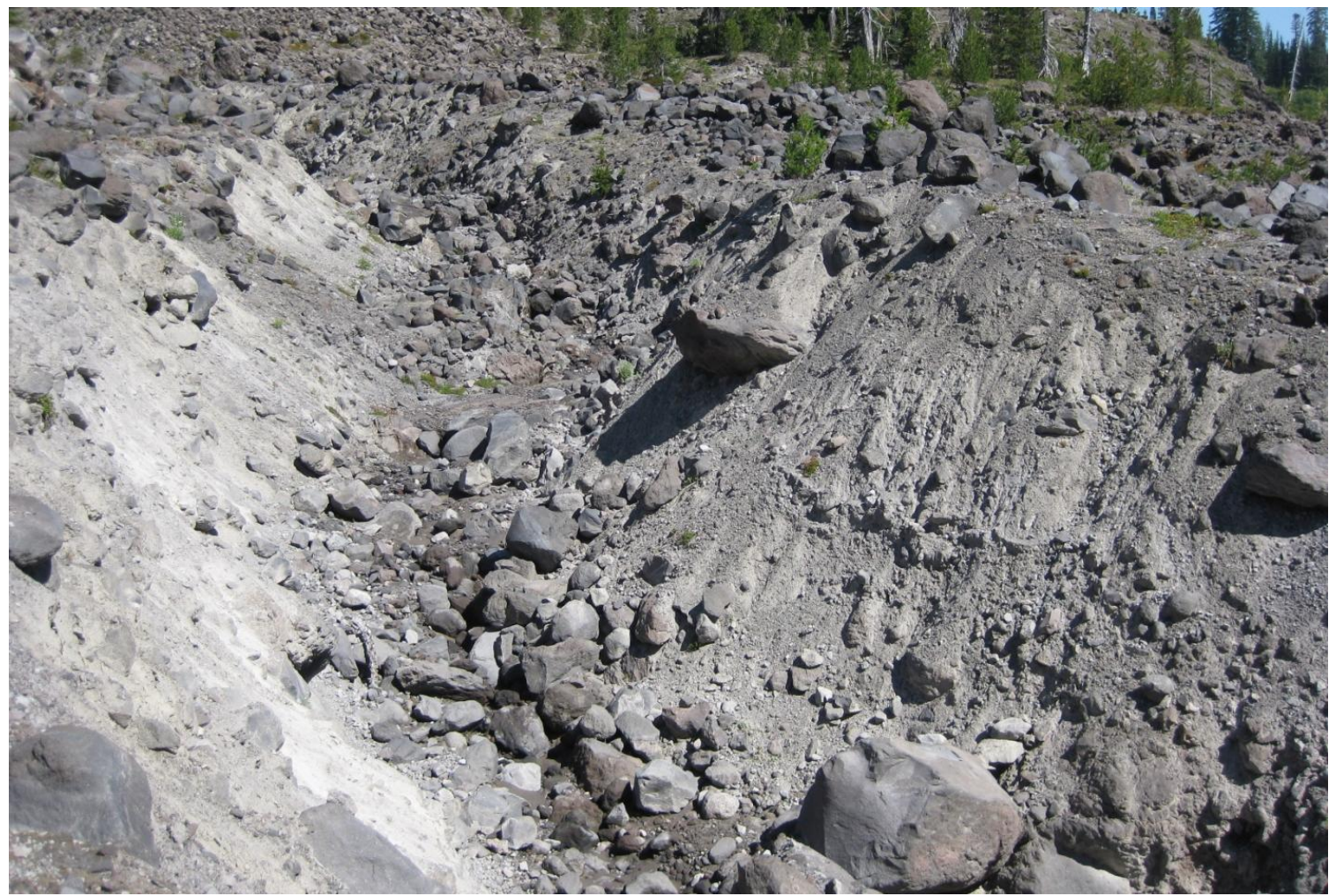

Figure A.18: Worm Flows Channel near the Trail 216 crossing. The debris flow cut channel contains steep slopes and boulder levees; however, it exhibits unraveling slopes with minor vegetation and trees on the walls of the channel. View is looking up-channel.

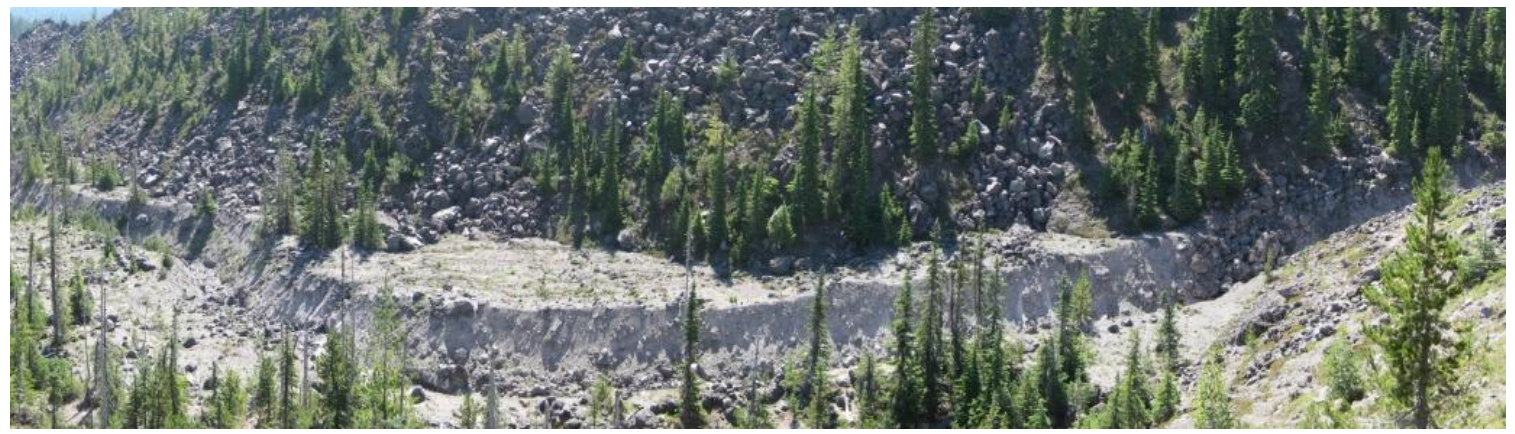

Figure A.19: Photographic mosaic of view down the main Worm Flows Channel from Trail 216 as it follows the edge of an andesite lava flow. 
small stream bed is observed with no evidence of having experienced a past debris flow. LiDAR observations show the banks of the main channel continue to decrease in height until disappearing completely at around 970 m elevation (UTM 10N567700E 5112386N), about $1.6 \mathrm{~km}$ above Road 83 .

\section{Soil Sample Collection}

No soil samples were taken from the Worms Flows Drainage Basin. However, one set of samples was taken from the June Lake Drainage on the opposite side of a ridge bounding the two drainages. The two sites are geographically and geologically related.

\section{JUNE LAKE DRAINAGE BASIN}

\section{Reconnaissance}

Field reconnaissance in the June Lake Drainage Basin occurred during midAugust 2010 along Trail 216B from the June Lake trailhead (Figure 38). Debris flow deposits from 2006 were observed along the channel from Road 83 upward to about 900 m elevation below June Lake (Figure A.20). There was no well-defined depositional fan as seen in other drainages. The deposits ended at Road 83 (Figure A.21), where the road and culvert needed clearing and replacement after the 2006 storm, but was delayed by weather until late 2008 (USDA-FS, 2008a). There was no damage to Trail 216B reported or observed, primarily because the trail keeps to the valley slopes above the stream. Trail 216 at the stream crossing was damaged by scour and covered by boulder and cobble debris. Since the stream gradient at this location is lower, lobes of 


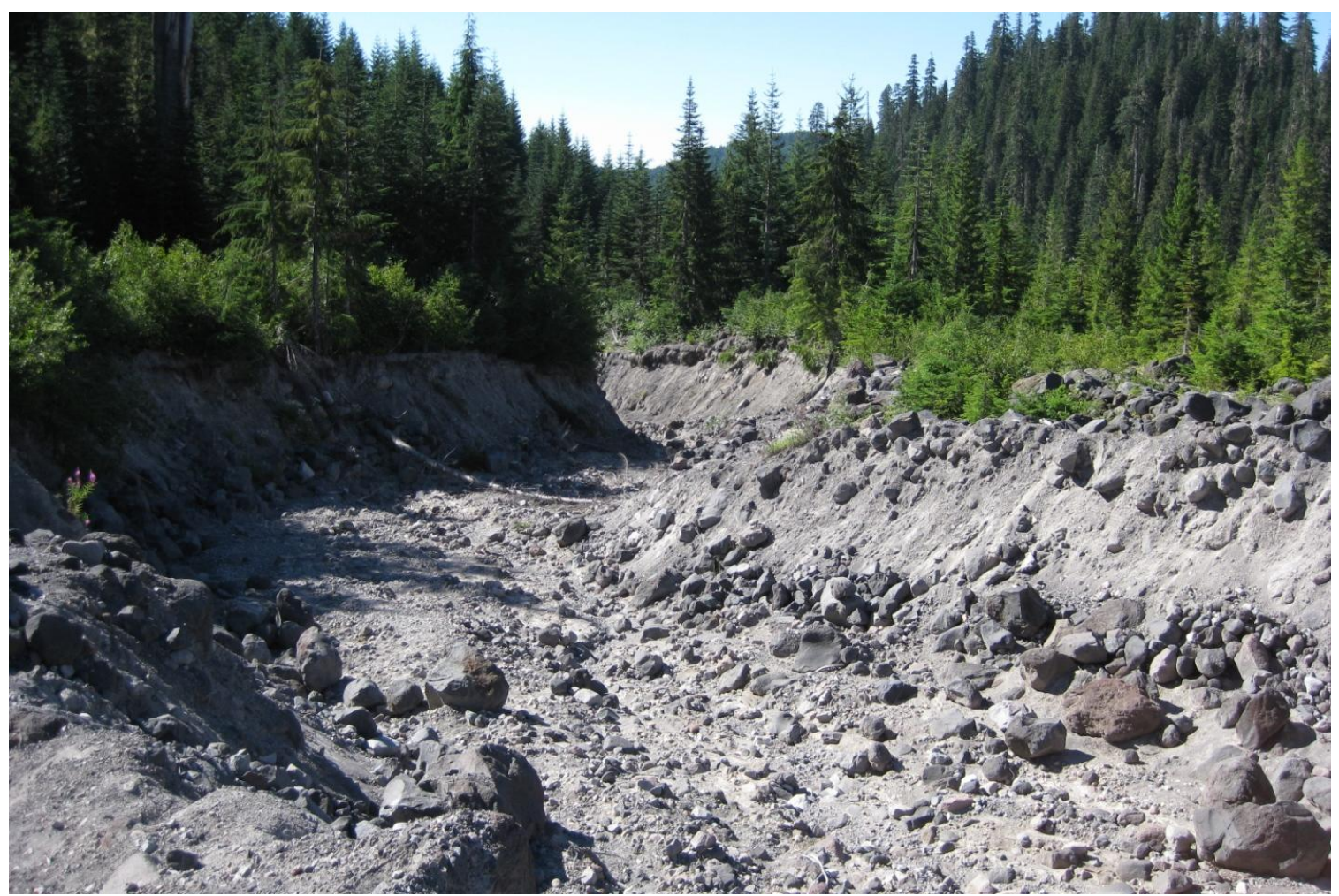

Figure A.20: The June Lake Debris Flow channel near June Lake. Levees are visible all down the opposite bank. Lack of vegetation was observed in the channel.

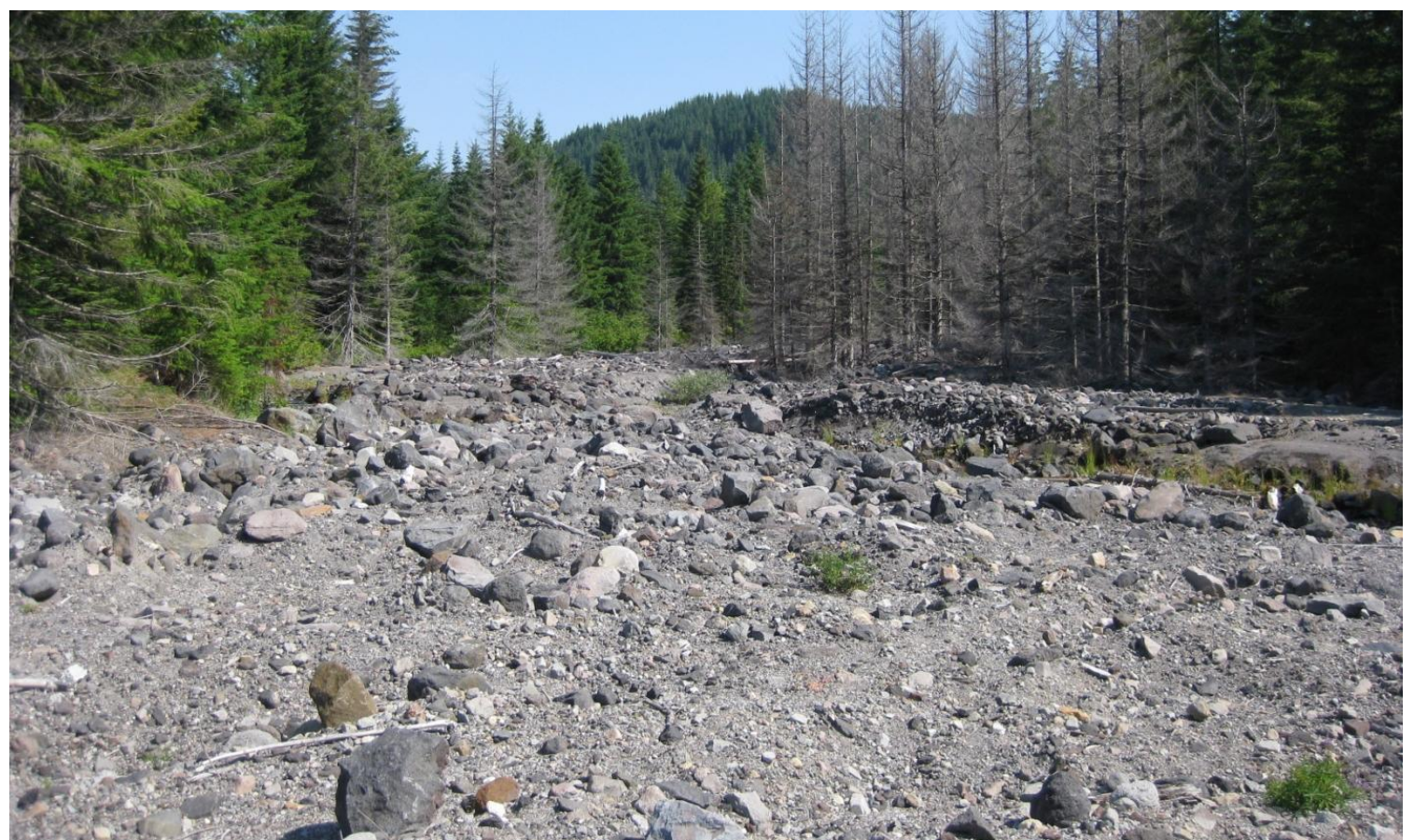

Figure A.21: View of June Lake Debris Flow deposit up-flow from where Road 83 crosses the June Lake Drainage. The 2006 debris flow deposit ends at the road, although the road was damaged by flood water and debris (USDA-FS, 2006, 2007, 2008a). 
debris deposits were observed up-stream on either side of the main channel (Figure A.22).

Upper basin field observations were made in September 2011 by climbing from Trail 216 up the lava flow ridge bordering the western side of the debris flow channel. At 1,225 m elevation a depositional area of about $26,500 \mathrm{~m}^{2}$ was observed with multiple past levees and channels exhibiting varying amounts of vegetation growth (Figure A.23). The main channel follows the east bank of this valley in a ravine ranging between 5 and 15 meters deep. Some possibly recent levees and deposits were observed along the main channel. Above the valley, observations were made from the east bank up to 1,710 m elevation where a soil sample was taken. Steep banks and possible landslide scarps were observed on the opposite bank at 1,460 m, 1,520 m, and 1,620 m elevation (Figure A.24). Below this zone of landslide scarps, well-defined debris flow levees are visible along the channel (Figure A.25). Attempts to get above the waterfall failed due

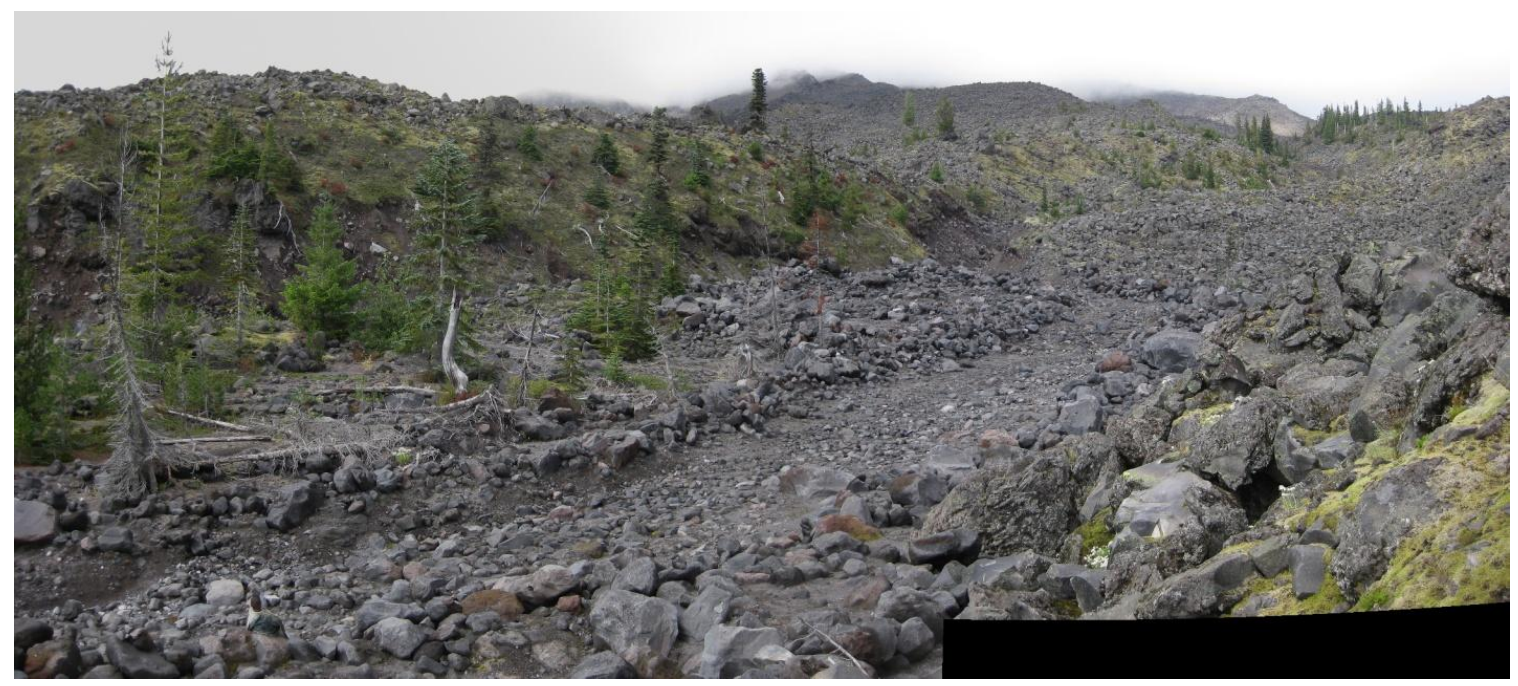

Figure A.22: June Lake Debris Flow levees and overflow lobes at the Trail 216 crossing. View is up-flow to the north-west. The rocky area in the far right foreground and background is an andesite lava flow. 


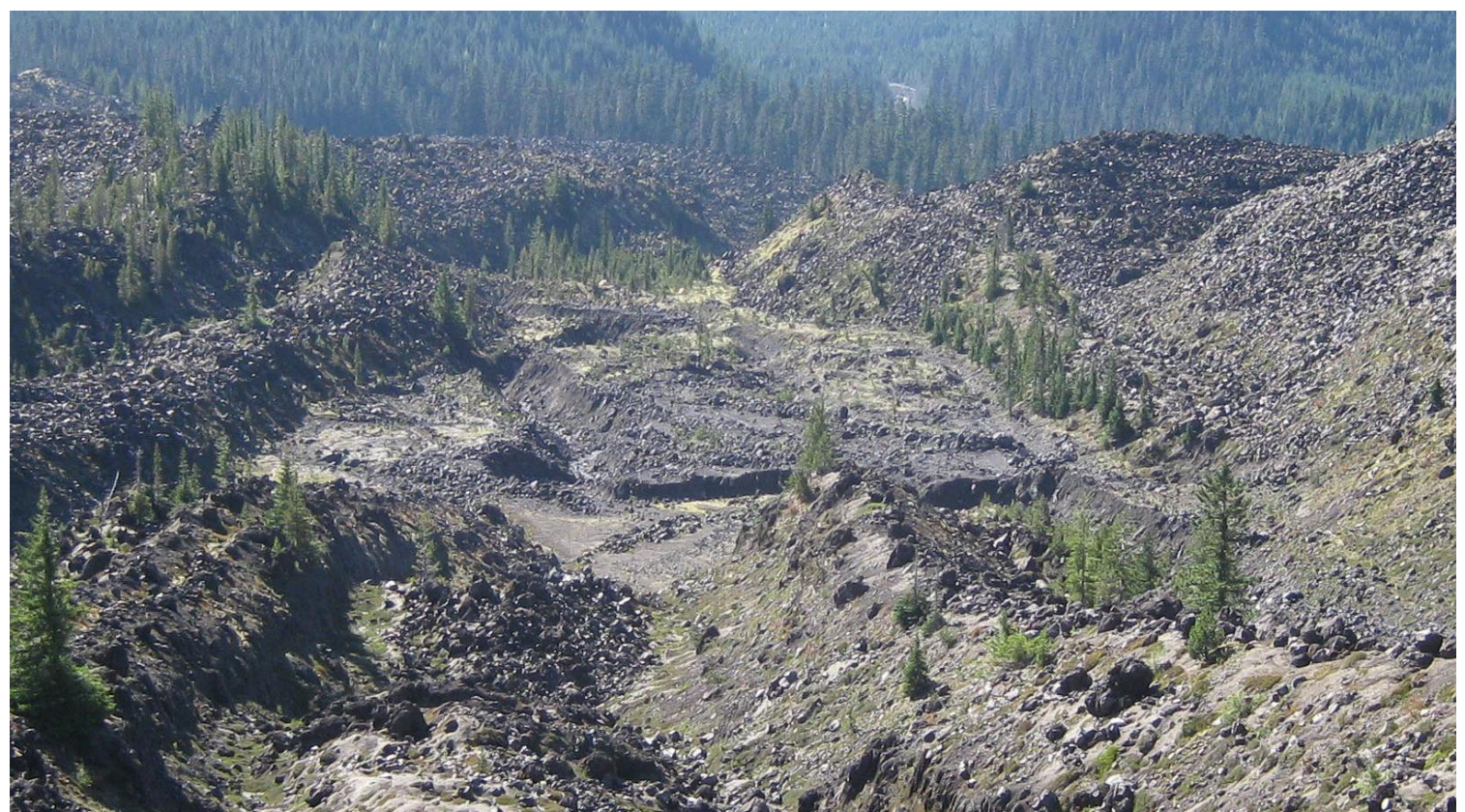

Figure A.23: Depositional area of about $26,500 \mathrm{~m}^{2}$ at $1,225 \mathrm{~m}$ elevation in the June Lake Drainage just below the upper basin. View is downslope to the south from about 1,500 $\mathrm{m}$ elevation.

to steepness of the ridge and dangerous conditions on the chosen climbing route. From ortho imagery comparison it was determined that a possible rockfall on the east side of the waterfall and landslides caused by channel wall erosion were the initiation sources of the June Lake Debris Flow.

\section{Soil Sample Collection}

One set of three soil samples were taken from the slope above the east bank of the channel and below the large waterfall in the June Lake upper basin at an elevation of 1,725 m (UTM 10N563829E 5113968N, Figure 38). The sample site is near the bottom of Figure 40, but off to the right side of the image. This location was not at an observed landslide or erosional scarp but was chosen because of accessibility and similarity of the surficial deposits to the surroundings. The geology of the sample site is 


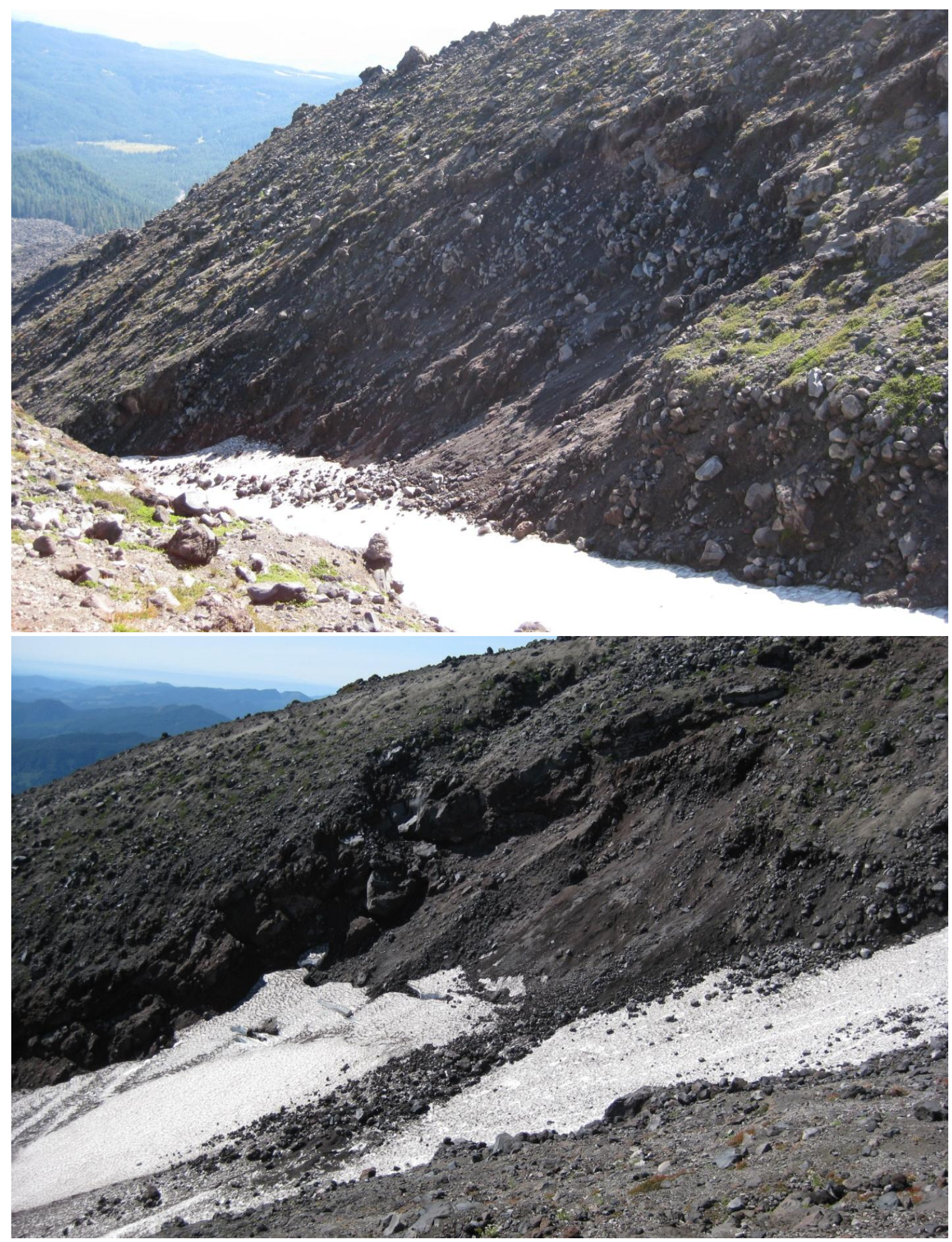

Figure A.24: Erosional scars of two possible landslide scarps on the west bank of the June Lake Channel. The upper image is of a feature at $1,460 \mathrm{~m}$ elevation (base) (UTM 10N563963E $5113552 \mathrm{~N}$ ). The lower image is from about 1,620 m elevation (base) (UTM 10N563821E $5113797 \mathrm{~N})$. Both show fresh landslide deposits onto the snowpack, which hides the channel bed. 


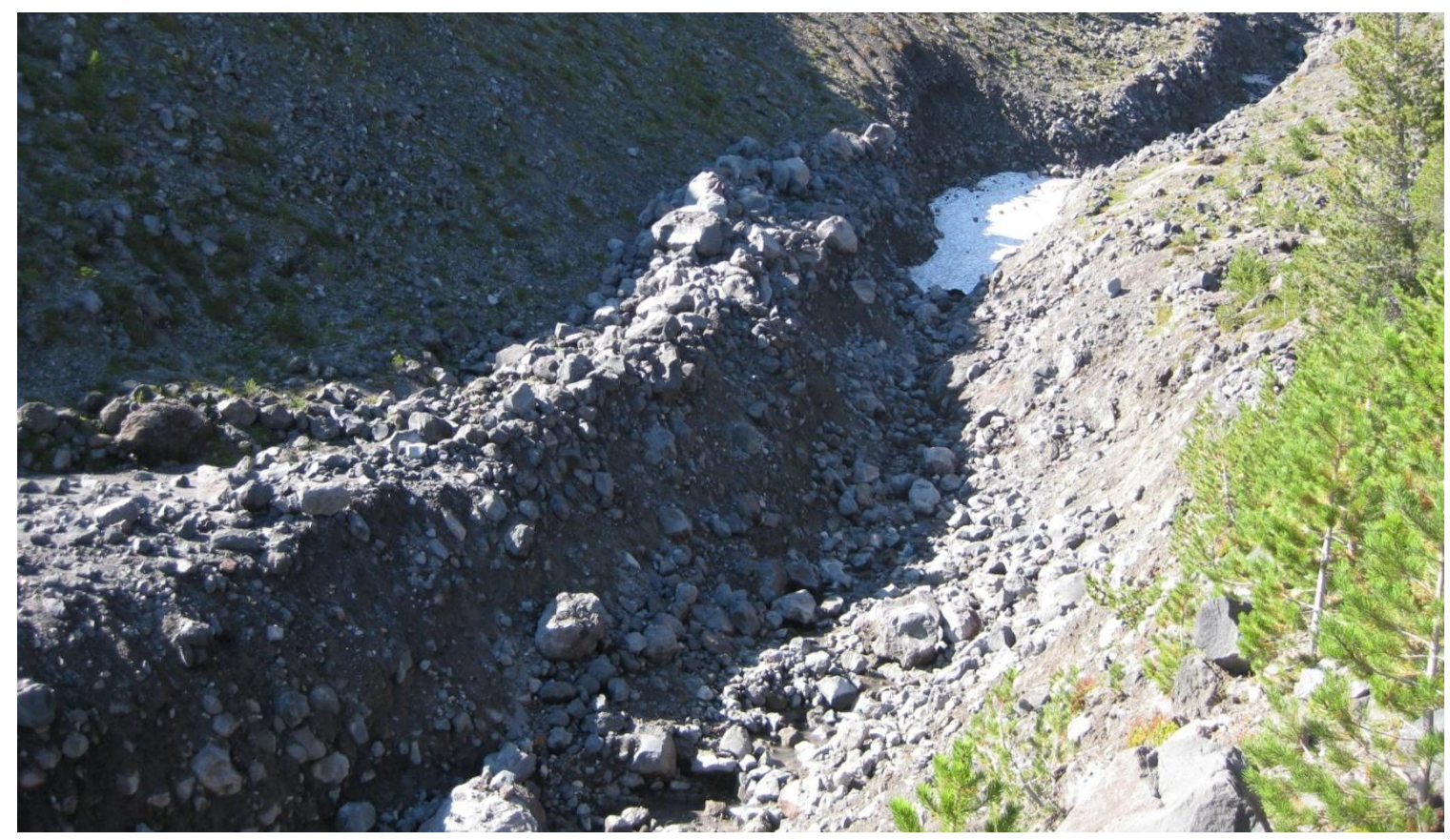

Figure A.25: Non-vegetated, well-defined levees appear on the banks of the channel just below the lowest landslide scarp. Largest boulders visible in this image are about three meters in diameter. This image was taken near 1,300 m elevation at UTM 10N564364E 5112979N.

mapped as andesite flows (Qva), but is probably related to a nearby mapped unit of unconsolidated lahar deposits (Qvl) (WaDNR, 2010).

\section{SWIFT CREEK DRAINAGE BASIN}

\section{Reconnaissance}

Field reconnaissance in this basin took place in mid-August 2010 along Trail 216 and a portion of Trail 244 from the June Lake trailhead (Figure 41). Much of this basin consists of andesite lava flows. Where Trail 216 crosses the eastern-most channel, a waterfall plummets off a solid bedrock ledge (lava flow) into a $15 \mathrm{~m}$ deep ravine which exhibits evidence of past debris flow activity including an incised channel, steeply eroded walls, boulder levees, and boulder and cobble debris on the bed (Figure A.26). 
There is also a channel overflow deposit to the east of the waterfall with rounded mossy boulders and moss partially covering the intervening sediment (Figure A.27). The channel was observed to have some vegetation, and tree seedlings about a one meter tall. Above this point, the stream flows over bare bedrock in a narrow channel for some distance upslope. Within the channel there is less evidence of debris flows, likely due to high flow rates. However, there are sparse areas with rounded boulder and cobble deposits.

The western-most channel was also observed from the Trail 216 crossing at $1,175 \mathrm{~m}$ elevation. At this location the stream is overgrown with brush and overhung by trees and does not have a deeply eroded channel (Figure A.28). Ortho imagery comparison between 2006 and 2009 did not reveal any recent debris flow evidence. Therefore, this drainage basin was determined to have not experienced a debris flow in 2006.

\section{Soil Sample Collection}

No soil samples were taken from the Swift Creek Drainage Basin. However one set of samples was taken from the neighboring June Lake Drainage in related geology.

\section{SNOWFIELD DRAINAGE BASIN}

\section{Reconnaissance}

Field reconnaissance in this area occurred in early and late August 2010 from Trail 216, accessed from the south by Trail 216A and the Climber's Bivouac (Figure 43). 


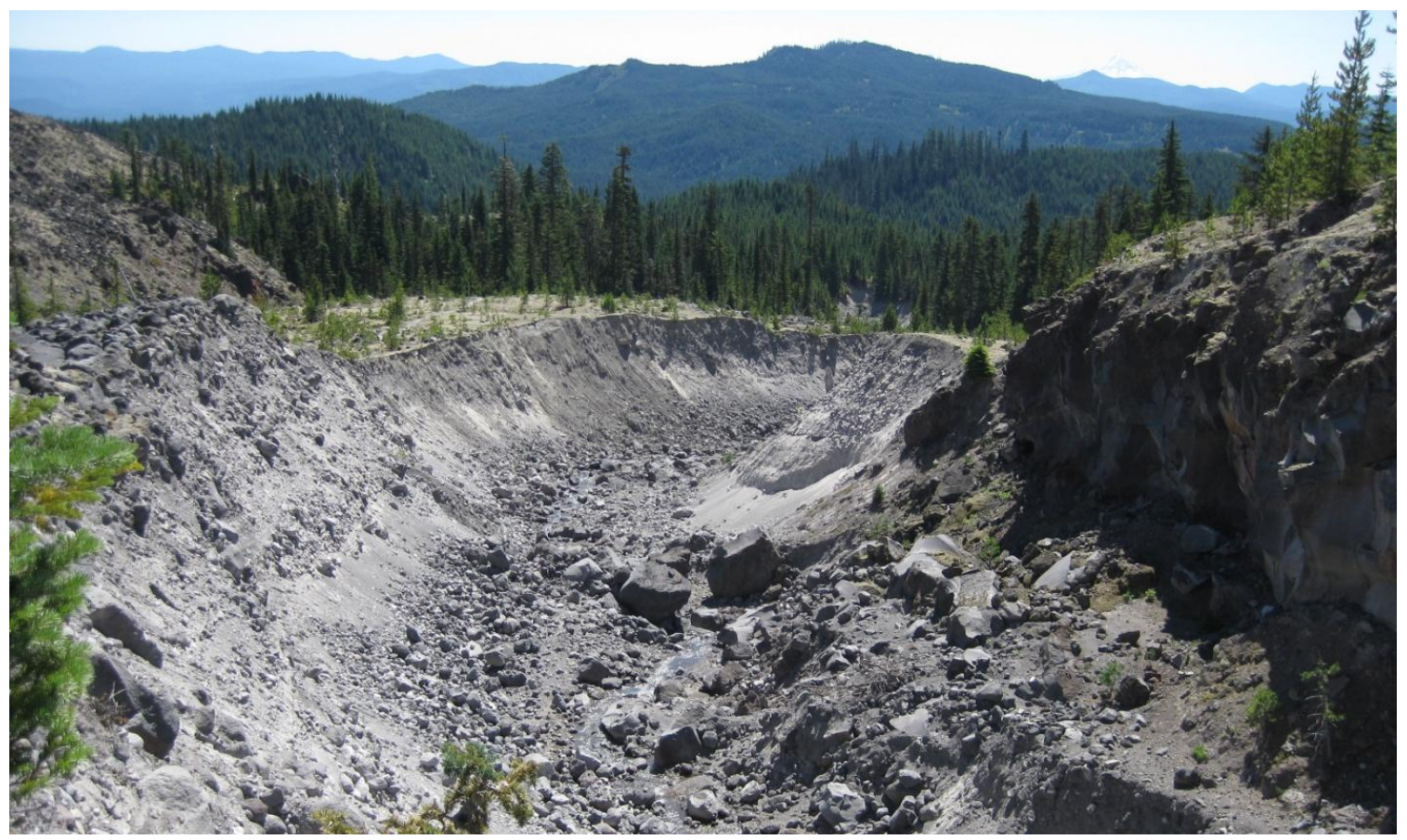

Figure A.26: View down-channel of the eastern Swift Creek Channel from the waterfall at the Trail 216 crossing. Note the large boulders in the channel and mini-terrace with small trees on the left. View is east of due south.

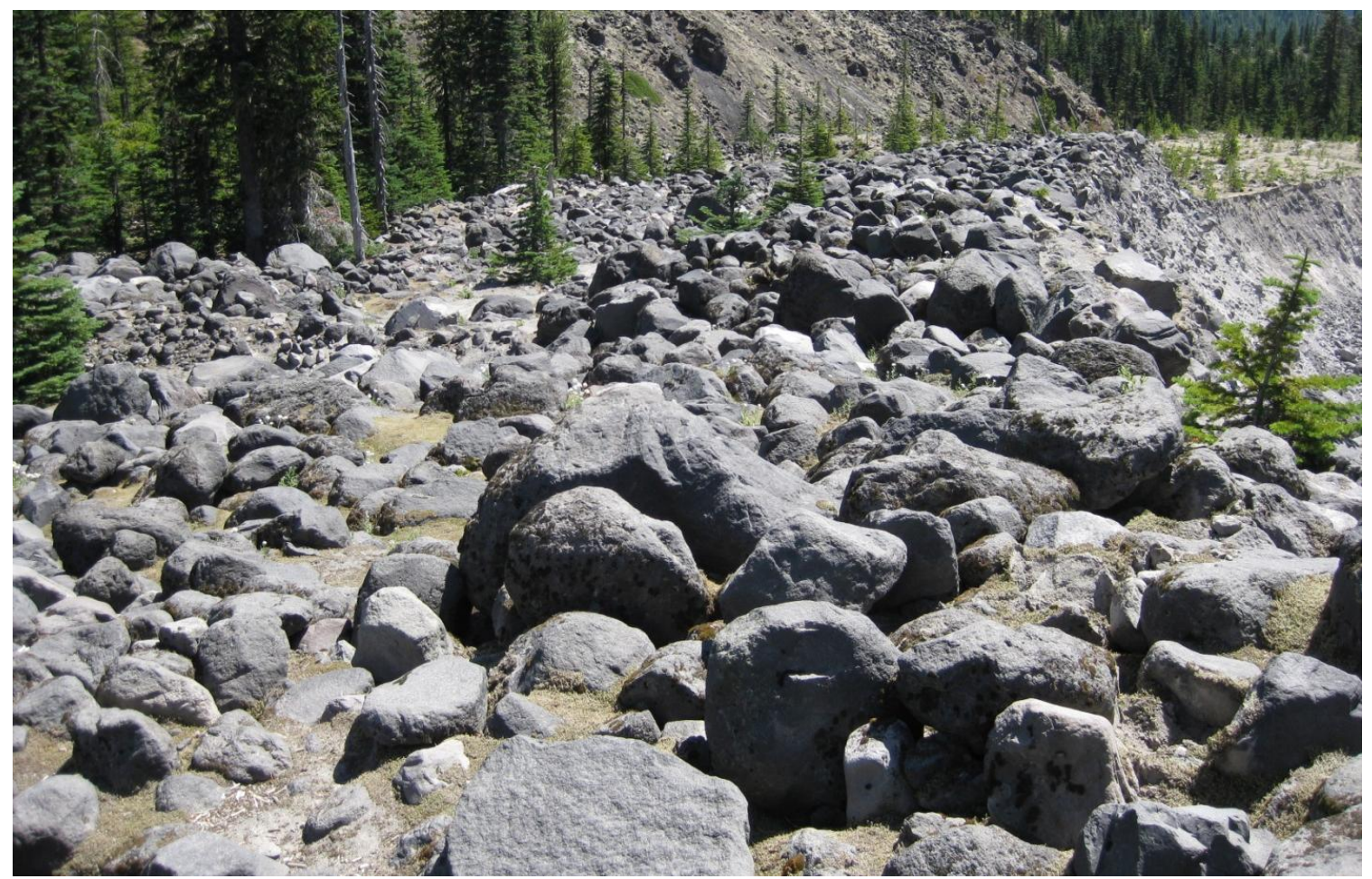

Figure A.27: Overflow deposit to the east of the waterfall (to the left in Figure A.26) above the channel bank. Sediment between boulders hosts moss with occasional plants and trees. 


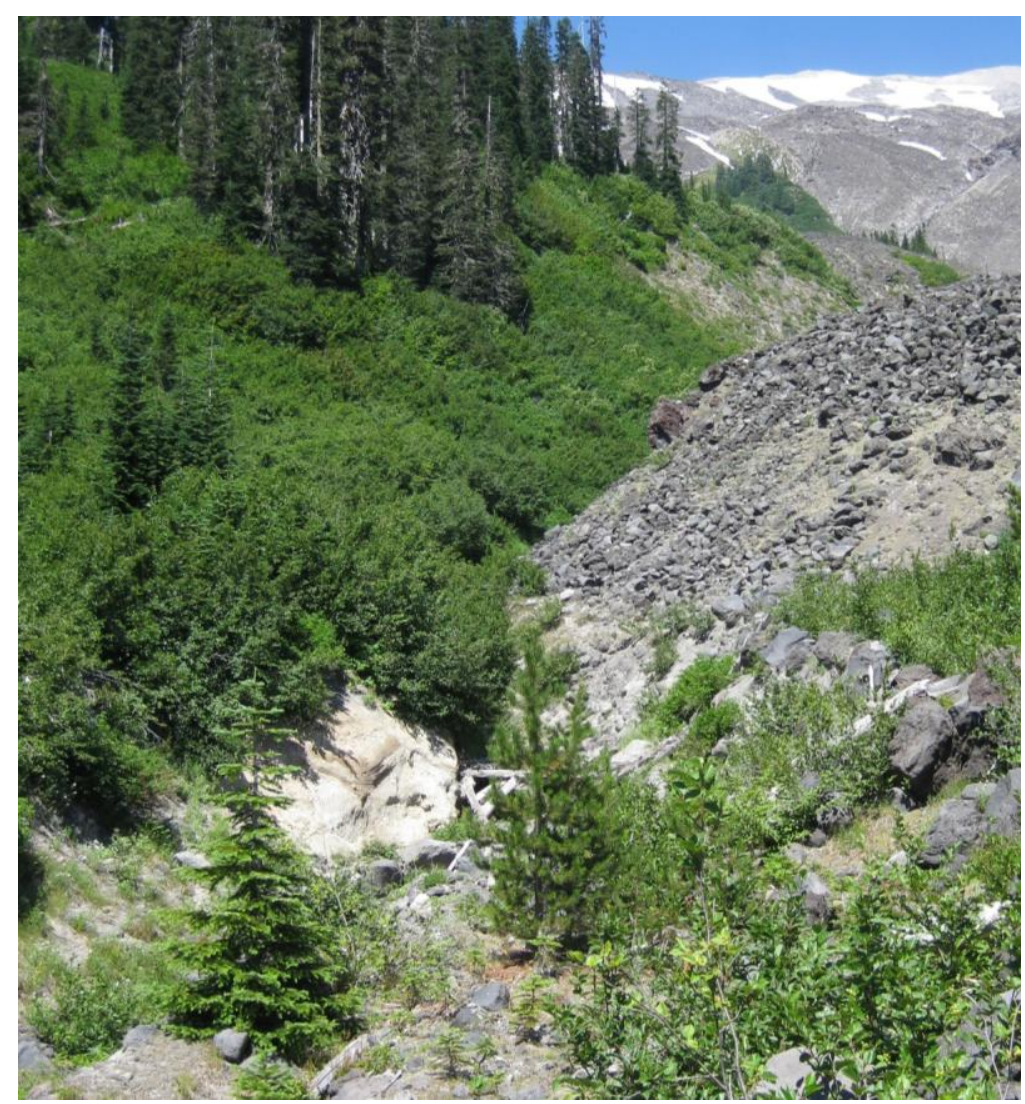

Figure A.28: View upslope of the western Swift Creek Channel showing no evidence of past debris flow activity.

When heading northward, the trail crosses the first channel, at 1,412 m elevation

(Figure A.29 and Figure A.30). This is the dominant eastern-most of two channels, which exhibits a more eroded bed, exposed bedrock in the streambed, and banks with less vegetation. However, compared to channels with recent debris flows, it has eroded Vshaped slopes and not the steep unraveling slopes and prodigious scattered debris with occasional deposits or levees.

About 180 m further along Trail 216, the second channel is crossed at about 1,400 m elevation. The $\mathrm{V}$-shape of this ravine indicates an even older debris flow 


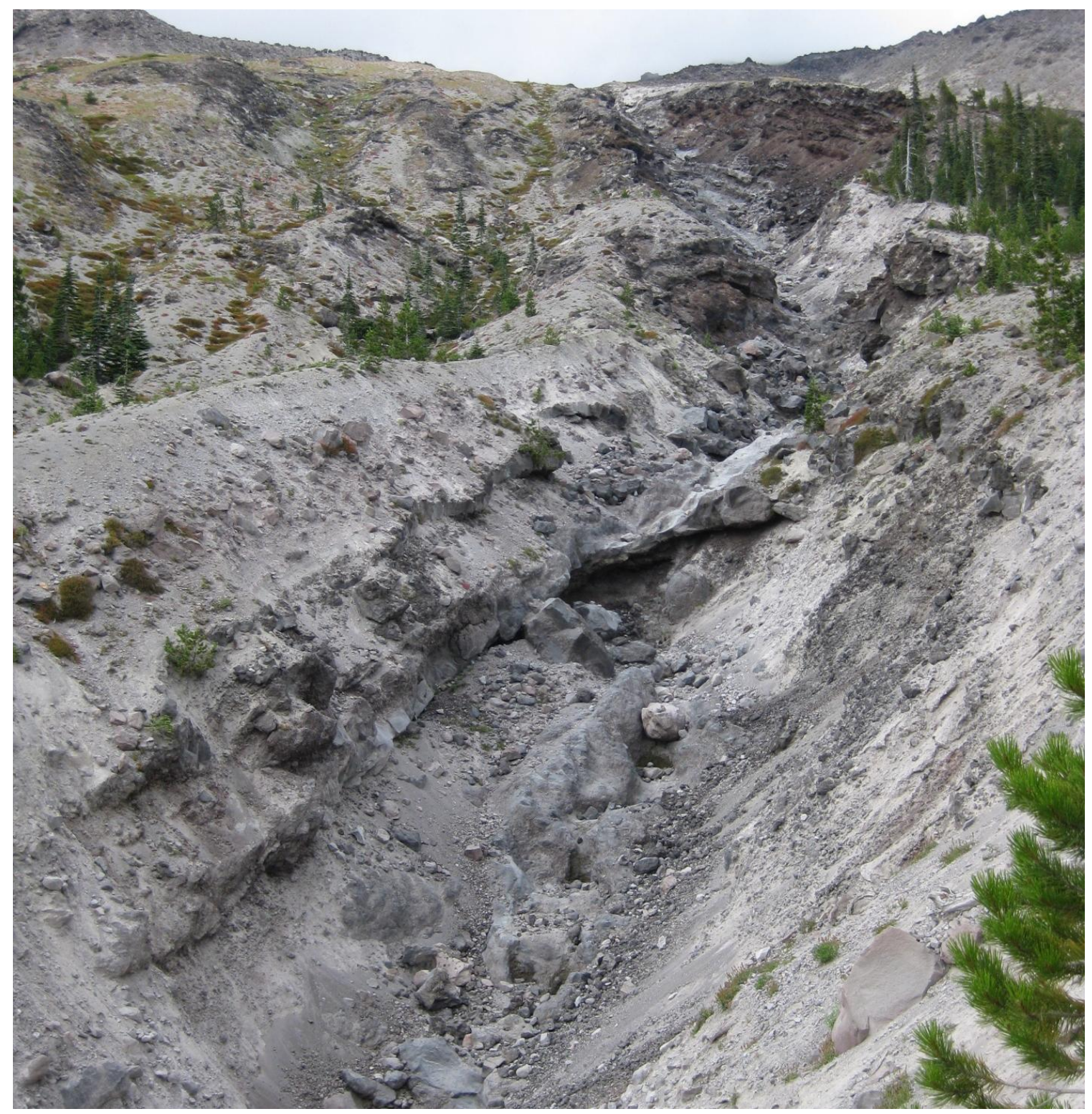

Figure A.29: View up the first (dominant) channel of the Snowfield Drainage Basin from above the Trail 216 crossing. The channel displays unraveled slopes with sparse vegetation indicating some time has elapsed since the last debris flow.

history. The channel is well vegetated with small alpine brush and trees. However, this channel does have a well-defined levee along the top of the channel wall (Figure A.31).

During field observations in early August, ephemeral flow was observed in both 


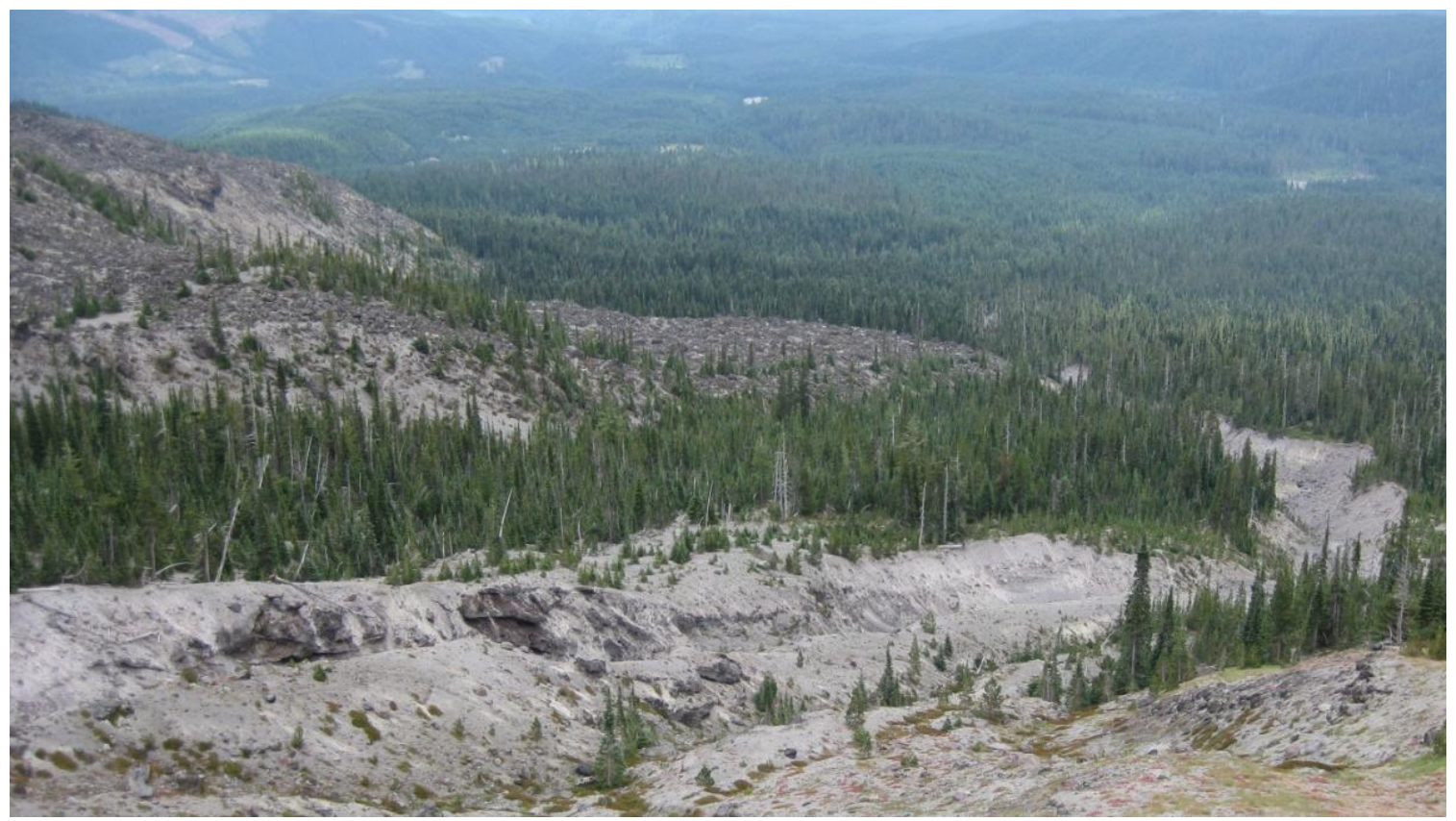

Figure A.30: View down slope of the eastern-most (dominant) channel in the Snowfield Drainage. The $\mathrm{V}$-shaped slopes are apparent at the bend (right side of image). This view is looking west of due south. A glimpse of Swift Reservoir is visible in the distance. The terminus of the Monitor Ridge lava flow can be seen in the middle distance.

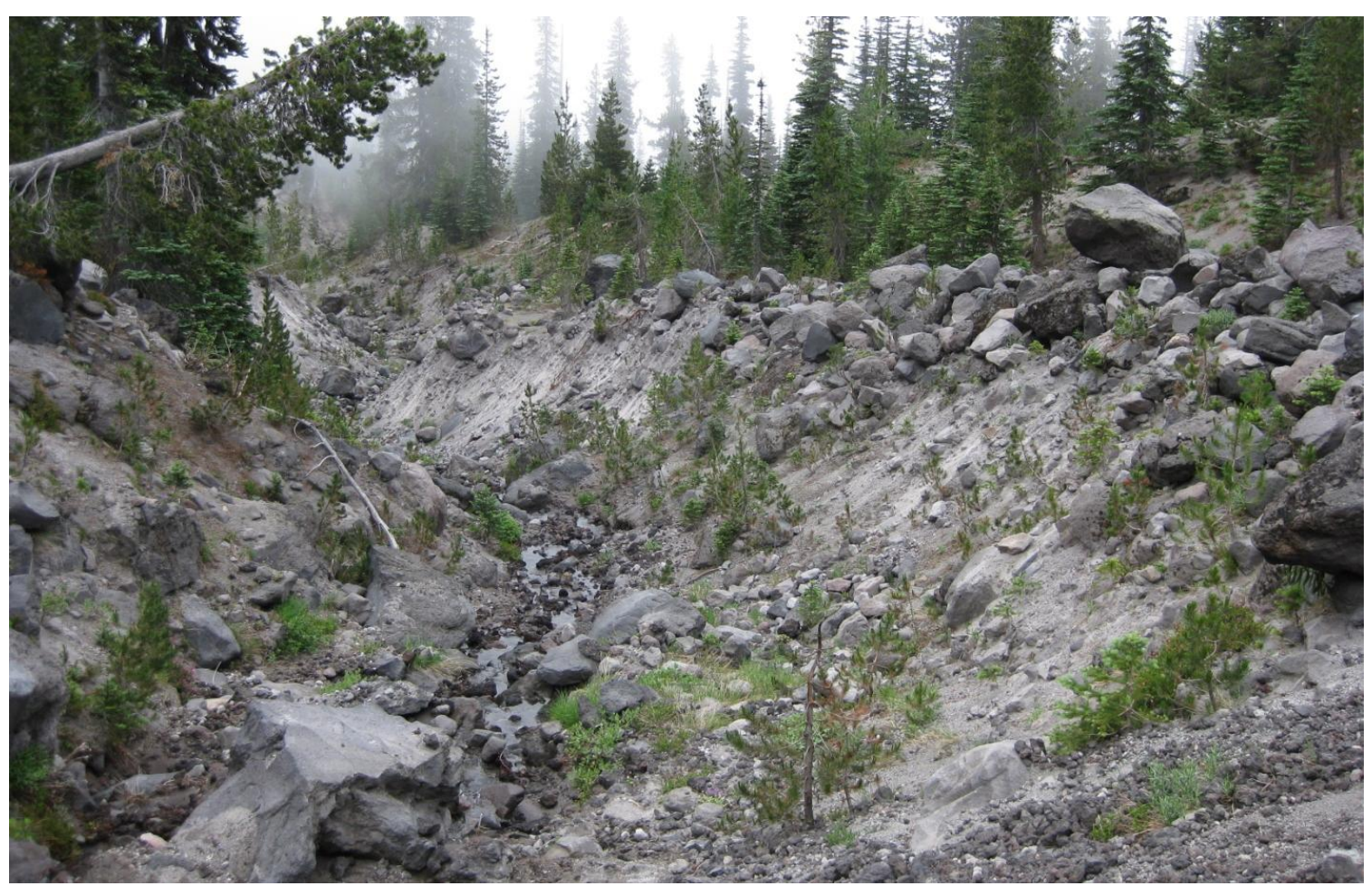

Figure A.31: View down slope in the western channel of the Snowfield Drainage Basin from Trail 216. This channel contains more alpine vegetation and young trees, but also has a well-defined debris flow levee. Water was observed in the stream bed at this time. 
channels from melting snow on the upper slopes. During observations conducted further upslope later in August, these ephemeral streams were not witnessed.

\section{Soil Sample Collection}

No soil samples were taken from the Snowfield Drainage Basin. However, samples were taken from the nearby Butte Camp Dome Drainage in similar deposits.

\section{DRYER GLACIER DRAINAGE BASIN}

\section{Reconnaissance}

Field reconnaissance in this basin occurred in early and late August 2010 from Trail 216, accessed from the south by Trail 216A and the Climber's Bivouac (Figure 45). Multiple small ravines in unconsolidated sand and gravel-sized debris were crossed on the southern side of the drainage basin before reaching the main channel. At the Trail 216 crossing, the channel is about $15 \mathrm{~m}$ deep and exposes at least three lava flows which would form small waterfalls in the channel during high flows. However, during field observations water was not present in this channel. On the south bank, both up and down slope from the trail, multiple segments of a boulder and cobble levees indicate the flow height of a past debris flow (Figure A.32, Figure A.33). However, the eroded V-shaped slopes hosting subalpine vegetation and small trees indicate a lack of recent debris flows in this channel. 


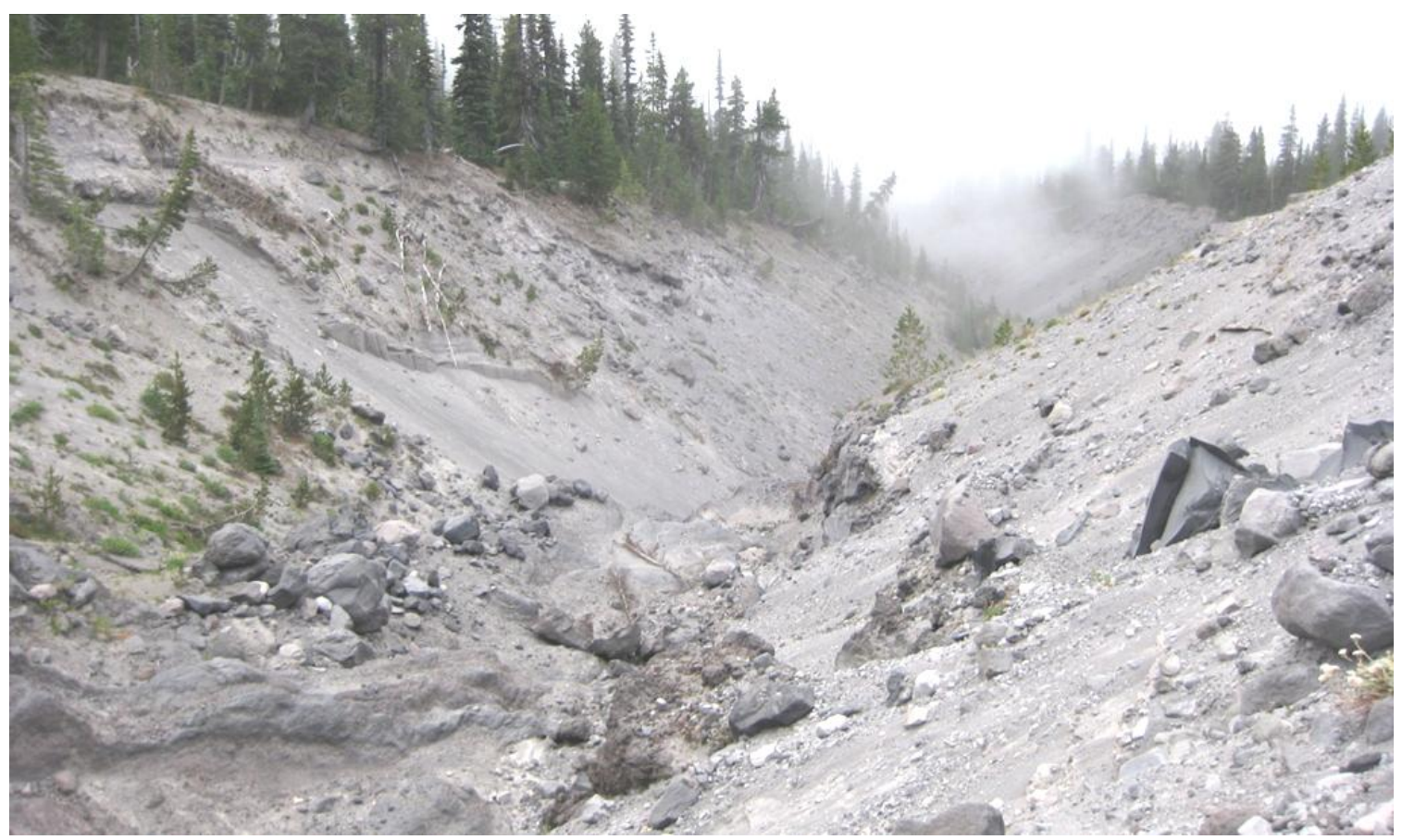

Figure A.32: View downslope of the Dryer Glacier Channel. The V-shaped channel and subalpine vegetation are visible. A line of levee boulders can be seen on the south wall (opposite) just above the stream bed. Erosional scarps in the unconsolidated sandy deposits are also visible on the south wall below the large trees.

\section{Soil Sample Collection}

No soil samples were taken from the Dryer Glacier Drainage Basin. However, samples were taken from the nearby Butte Camp Dome Drainage in similar volcaniclastic deposits.

\section{LITTLE KALAMA DRAINAGE BASIN}

\section{Reconnaissance}

Field reconnaissance in this basin occurred in early and late August 2010 from Trail 216, accessed via Trail 216A from the Climber's Bivouac (Figure 47). After crossing a wide andesite lava flow while hiking north, the trail drops into a small channel about 


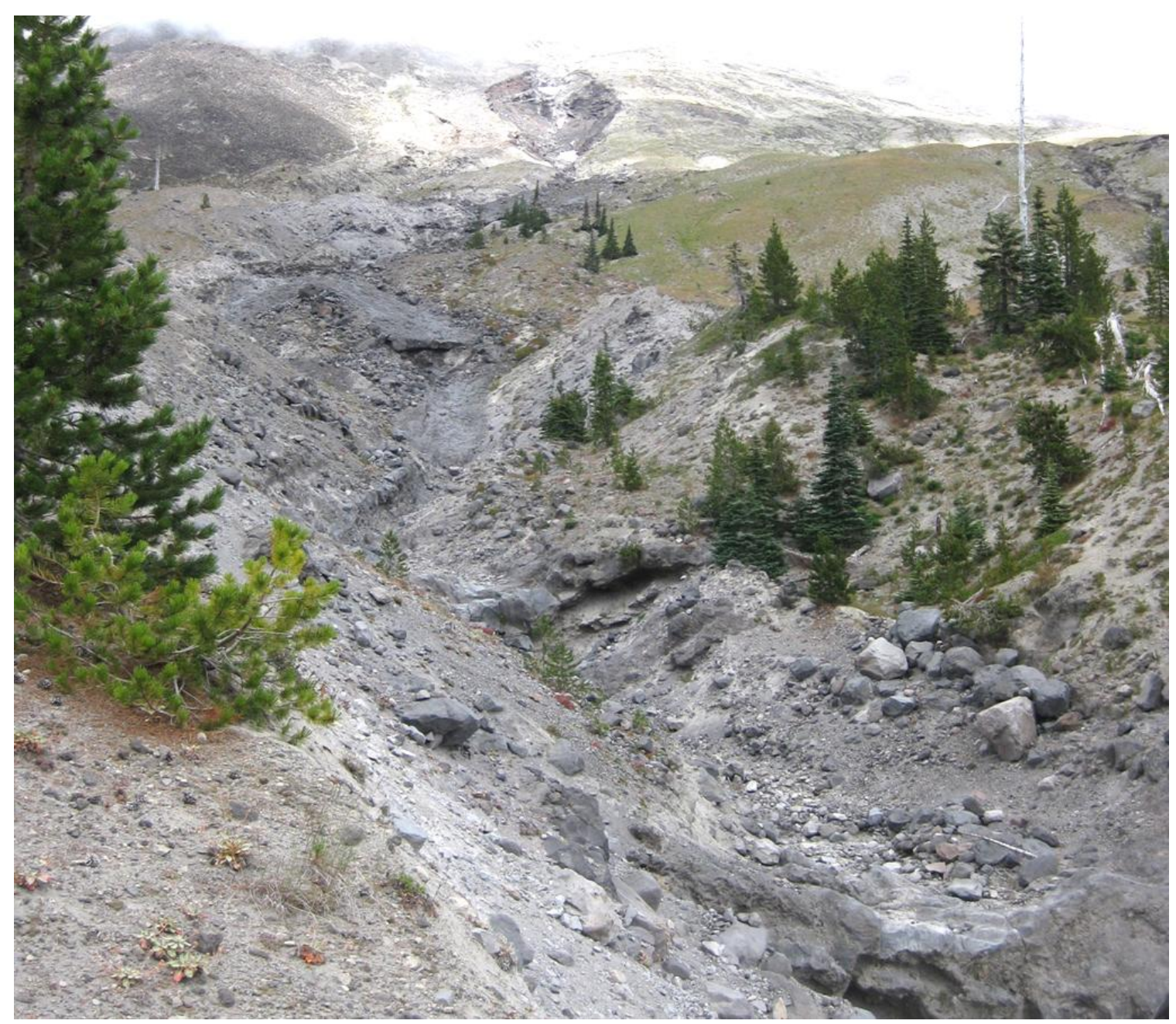

Figure A.33: View up the Dryer Glacier Drainage Basin channel from the Trail 216 crossing. The channel displays unraveled slopes with alpine vegetation and small trees indicating lack of recent debris flow activity. However, a levee indicated by a line of boulders in the bottom right corner of the image reveals the existence of a past debris flow.

five meters deep with rounded boulder and cobble-sized debris and a well-defined levee along the channel rim (Figure A.34). Sparse vegetation was found along the upper channel walls and near the bottom where the gradient decreased. Just above the trail the channel shows relatively steep, bare sides that have experienced some erosion and are nearly V-shaped. Downslope from the trail, the channel rim is covered in small trees about two meters tall that grow between levee boulders and the ravine deepens to 


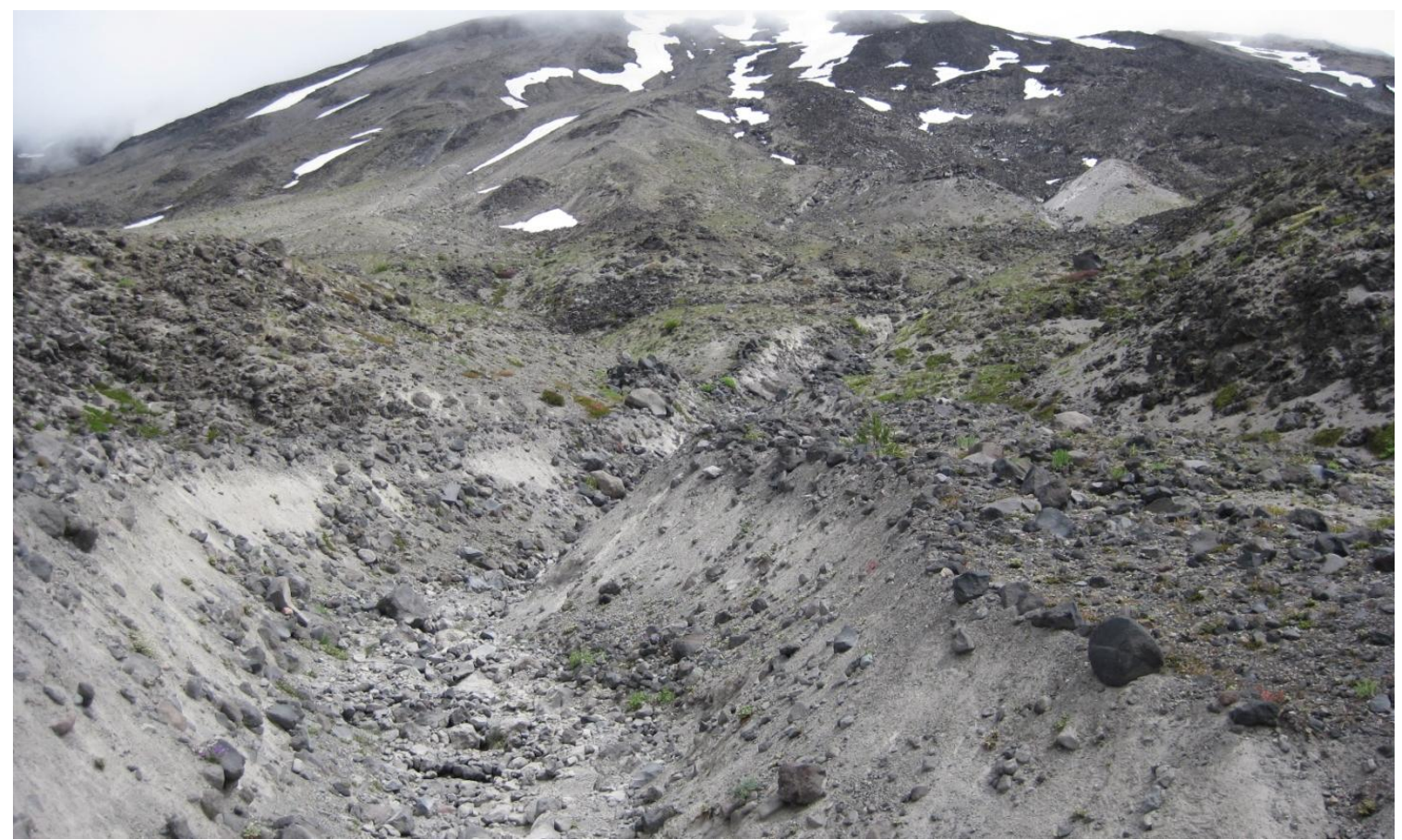

Figure A.34: View upslope from within Little Kalama Channel at the Trail 216 crossing. The alpine vegetation observed within the $U$-shaped channel walls is not as abundant as outside the channel. A well-defined debris flow levee with sparsely intergrown vegetation is visible in the foreground.

about ten meters (Figure A.35). The channel bed sediments at the trail crossing had experienced fluvial reworking, but an ephemeral stream was not observed during field observations.

Observations of the lower Little Kalama Channel were also made along Trail 238 about one kilometer north of Redrock Pass as determined by USGS maps (USDA-FS, 1998; USDA-FS, 2003). Where the trail crossed the channel, a dry stream bed of sandy debris was observed that opened out onto a fan about $50 \mathrm{~m}$ by $100 \mathrm{~m}$ in area. This fan was covered in small trees between two and three meters tall with a small half-meter channel incised by recent fluvial activity. Although not mapped by Washington DNR as such, these deposits are likely from a lahar during the 1980-1986 eruptive period. 


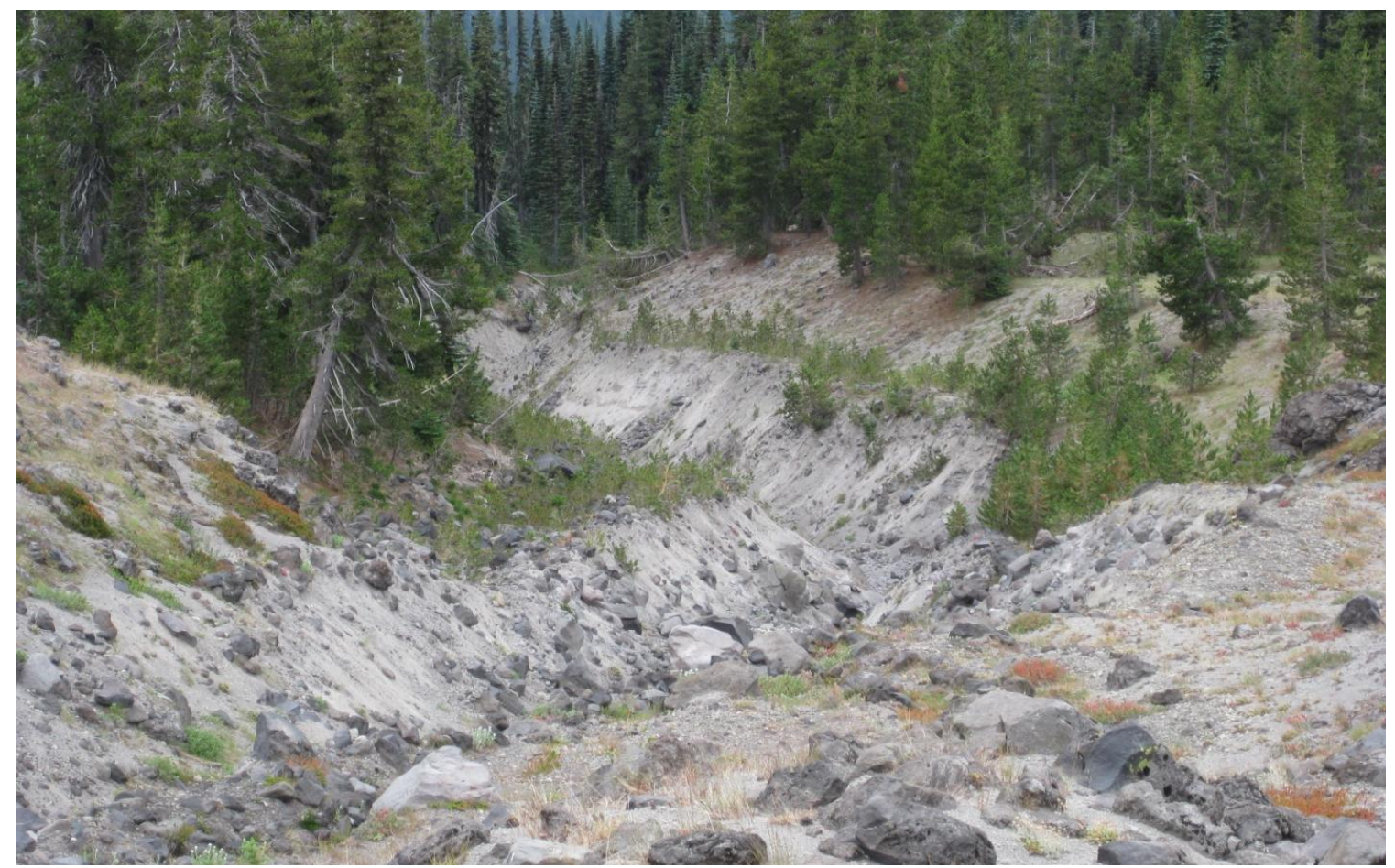

Figure A.35: View down-slope of the Little Kalama Channel from near the Trail 216 crossing. Debris flow levee deposits are obscured by two meter tall trees growing along the channel rim.

\section{Soil Sample Collection}

No soil samples were taken from the Little Kalama Drainage Basin. However, samples were taken from the nearby Butte Camp Dome Drainage in similar volcaniclastic and andesitic deposits.

\section{KALAMA DRAINAGE BASIN}

\section{Reconnaissance}

Field reconnaissance in this basin occurred in early and late August 2010 from Trail 216, accessed via Trail 216A from the Climber's Bivouac (Figure 49). North of the Little Kalama Drainage the trail passes through multiple small hollows and ravines of a debris fan, mapped as volcaniclastic deposits. Finally, the trail drops into a small 
channel about three meters deep surrounded by rocky debris and hosting much alpine vegetation. The dry stream bed was observed to be filled with rounded cobble-sized rocks of possible debris flow origin; however no levees were observed (Figure A.36).

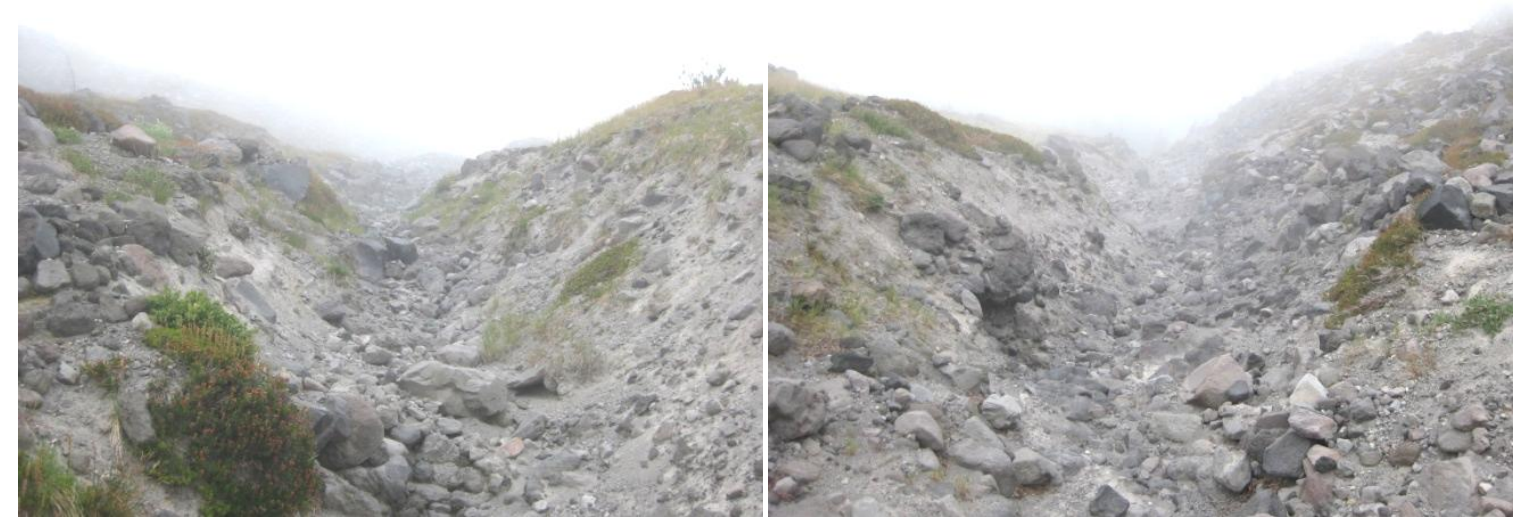

Figure A.36: View up (left) and down (right) slope of the Kalama Channel at the Trail 216 crossing. The alpine vegetation observed on the channel walls is not as abundant as on the surrounding slopes. The channel is filled with rounded cobbles that indicate subglacial, debris flow, or fluvial origin.

Observations of the Kalama Channel were also made along Trail 238 about 1.5 km north of Redrock Pass (at the junction with Trail 238A) according to USGS maps (USDA-FS, 1998; USDA-FS, 2003). Where the trail crossed the channel in heavy forest, the dry stream bed is shallow and narrow with a sandy bed, sparse cobble bars, and much woody debris.

\section{Soil Sample Collection}

No soil samples were taken from the Kalama Drainage Basin. However, samples were taken from the neighboring Butte Camp Dome Drainage in similar volcaniclastic and andesitic deposits. 


\section{BUTTE CAMP DOME DRAINAGE BASIN}

\section{Reconnaissance}

Field reconnaissance in the Butte Camp Dome Drainage Basin occurred during August 2010 by way of Trail 216 from the Climber's Bivouac (Figure 51). Approaching from the south, the trail enters a debris field above the Butte Camp Dome intrusion that is covered in boulder and cobble-sized blocks and crossed with dozens of old debris flow levees (Figure A.37). These older debris flow deposits are covered by small hemlock and pine trees and ground-hugging flowering plants including alpine buckwheat, Tolmie's saxifrage, Newberry's knotweed, pussy paws, and partidgefoot (St. Johns, 1976; Alaback et al., 1994). The new debris flow deposits are bare, with only occasional small alpine

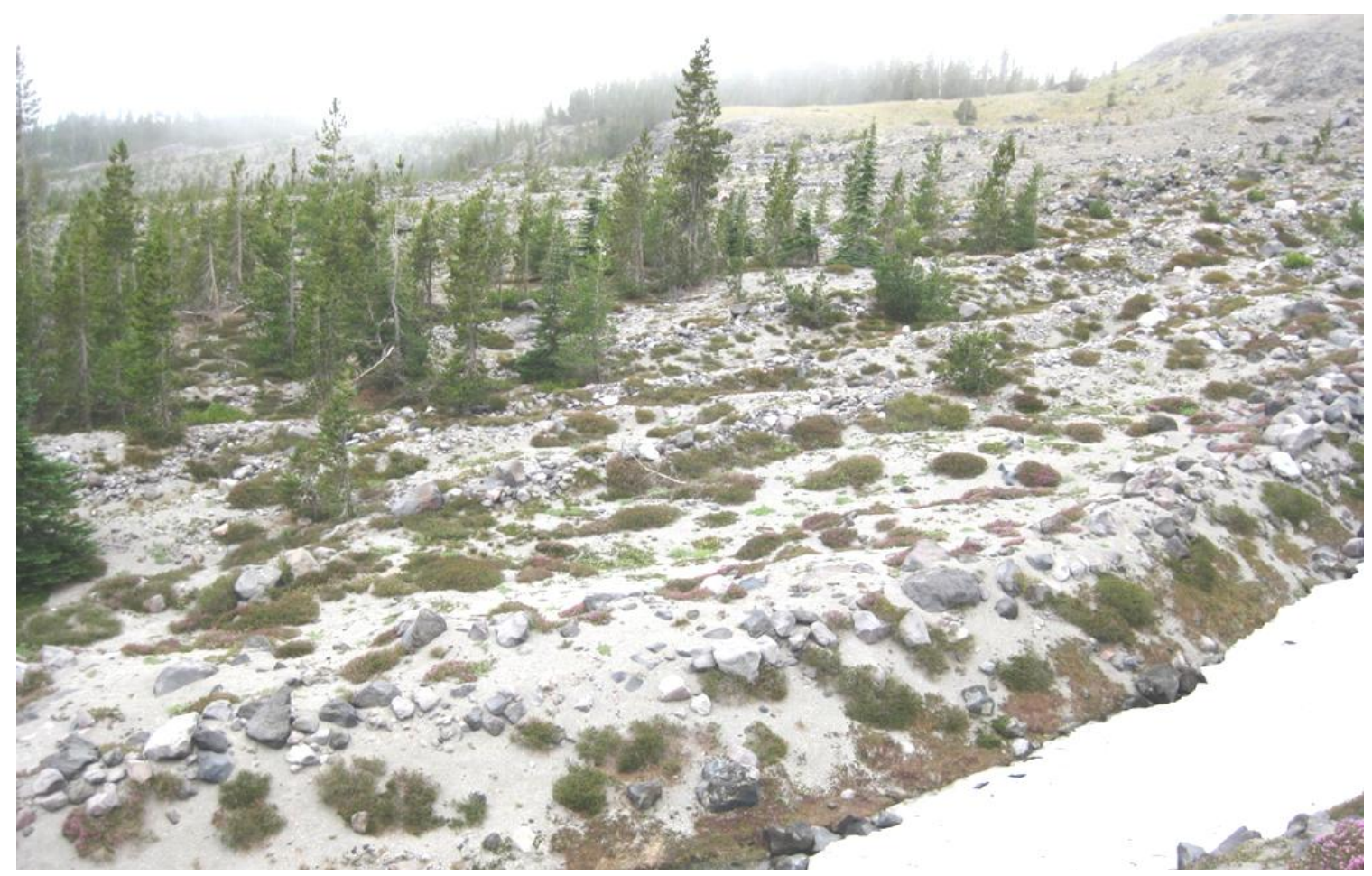

Figure A.37: View of the Butte Camp Dome Debris Fan near the mouth of the South BCD Channel (to the right). Dozens of linear boulder and cobble features are visible marking the location of old debris flow levees and deposits. The dominant ground hugging alpine vegetation of the area is visible. View is to the northwest. 
plants. The trail ends at the 2006 debris flow channel on the north side of this fan. At this location the channel is about four meters deep with steep walls and loose boulders and cobbles scattered along and partially exposed within the walls (Figure A.38).

The North Butte Camp Dome Channel is about $650 \mathrm{~m}$ further north from the South Channel along Trail 216. The appearance and geomorphology of this channel is very different from that of the South Channel (Figure A.39); it lacks evidence of recent debris flow activity such as levees and a steep U-shaped channel. Although, near the site imaged in Figure A.39, Trail 216 was slightly diverted because of a small landslide scarp that developed at the rim of channel. This channel has partially unraveled with large boulder and cobble -sized debris at the bottom and steep slopes beginning midway to the rim of the channel.

Field reconnaissance was also conducted in the lower total basin from Trail 238 and Trail 231 during early August 2010. The Trail 238 crossing of the Butte Camp Dome Channel was removed by intense debris flow scouring of the channel bed (Figure A.40) to the west of the dome. Here the channel shows a definite U-shaped profile, but also exhibits debris filling the bed of the channel. The depositional fan begins about $260 \mathrm{~m}$ downslope from this location and extends about $2.5 \mathrm{~km}$ beyond. Trail 231 crosses the debris fan about 750 m downslope from Trail 238 (Figure A.41), where evidence of multiple lobes of debris deposition, boulder dams that redirected flow, and angled mud run-up lines were observed on trees.

Upper basin field observations occurred during late September 2011 by climbing from Trail 216 near the South BCD Channel to the switching zone at elevation at 1,800 

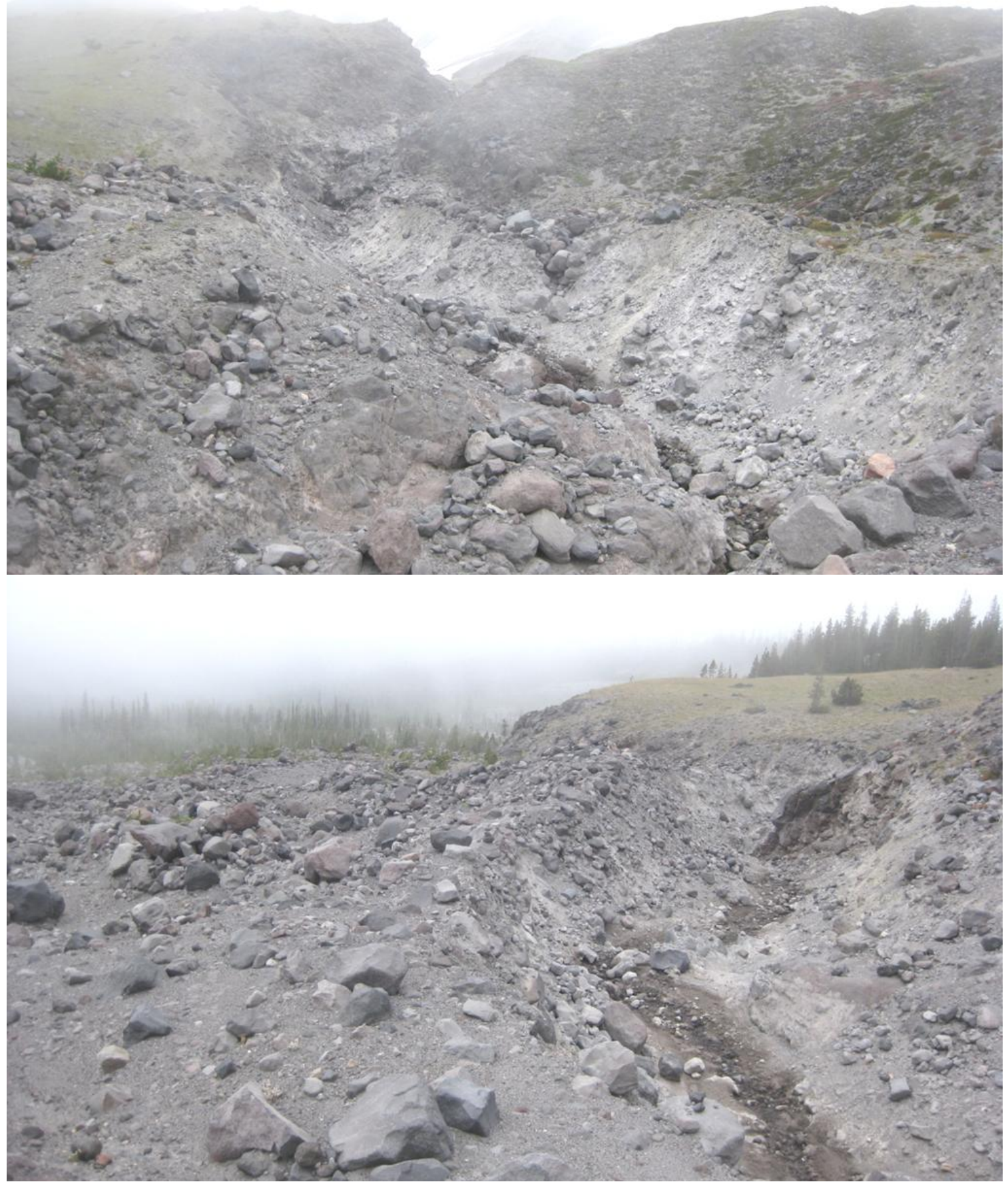

Figure A.38: View upslope (top) and downslope (bottom) where Trail 216 intersects the south channel of the 2006 Butte Camp Dome Debris Flow. Boulder and cobble levees extend outward from the steep channel walls onto the fan (to the left on the bottom image). The top view is to the northeast, and the bottom view is to the northwest. There was zero to sparse vegetation observed on the 2006 debris flow deposits. 


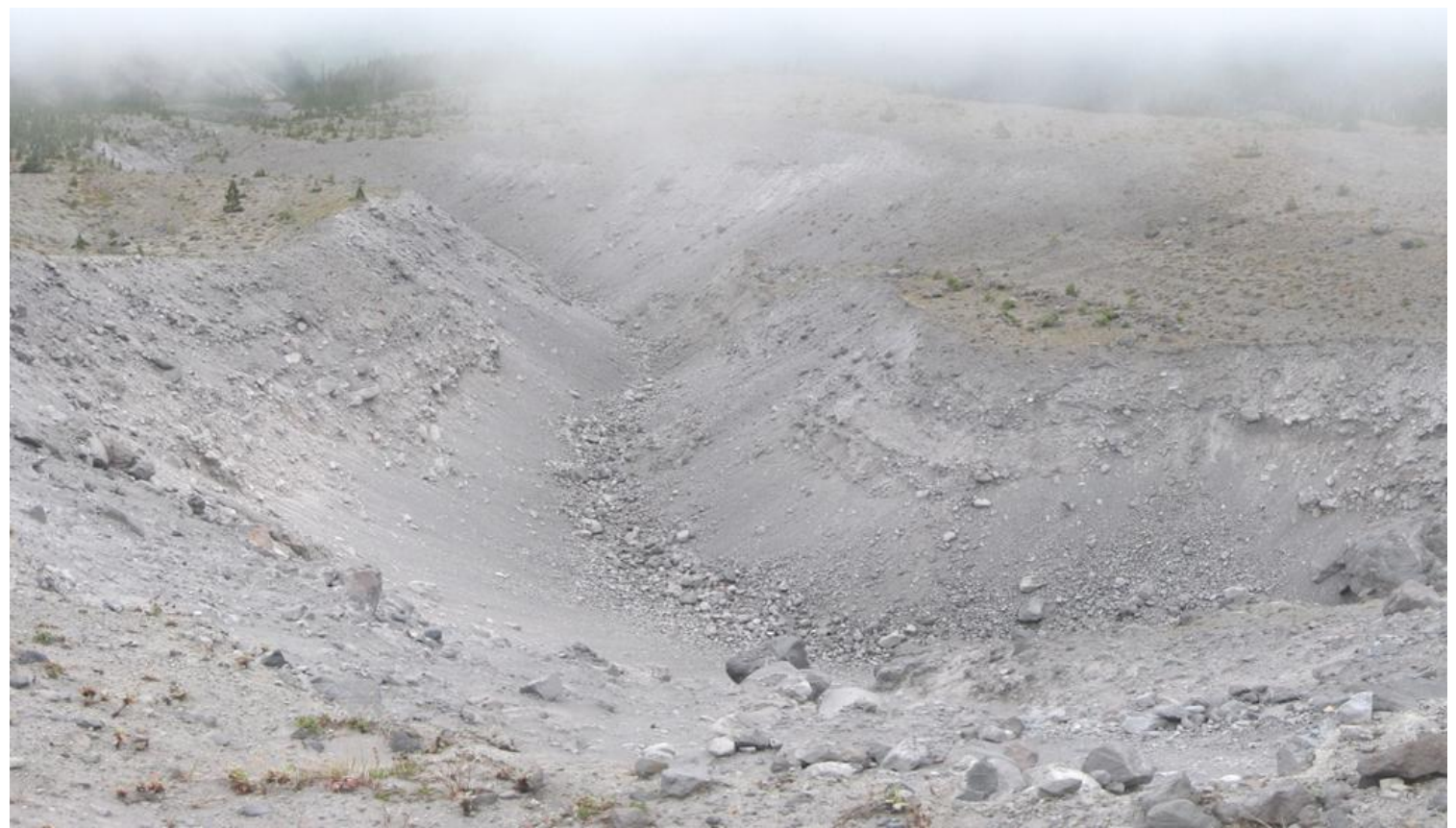

Figure A.39: View downslope of the North Butte Camp Dome Channel from near the Trail 216 crossing. Geomorphology of this channel presents a V-shape with large debris collecting at the bottom as the upper slopes collapse.

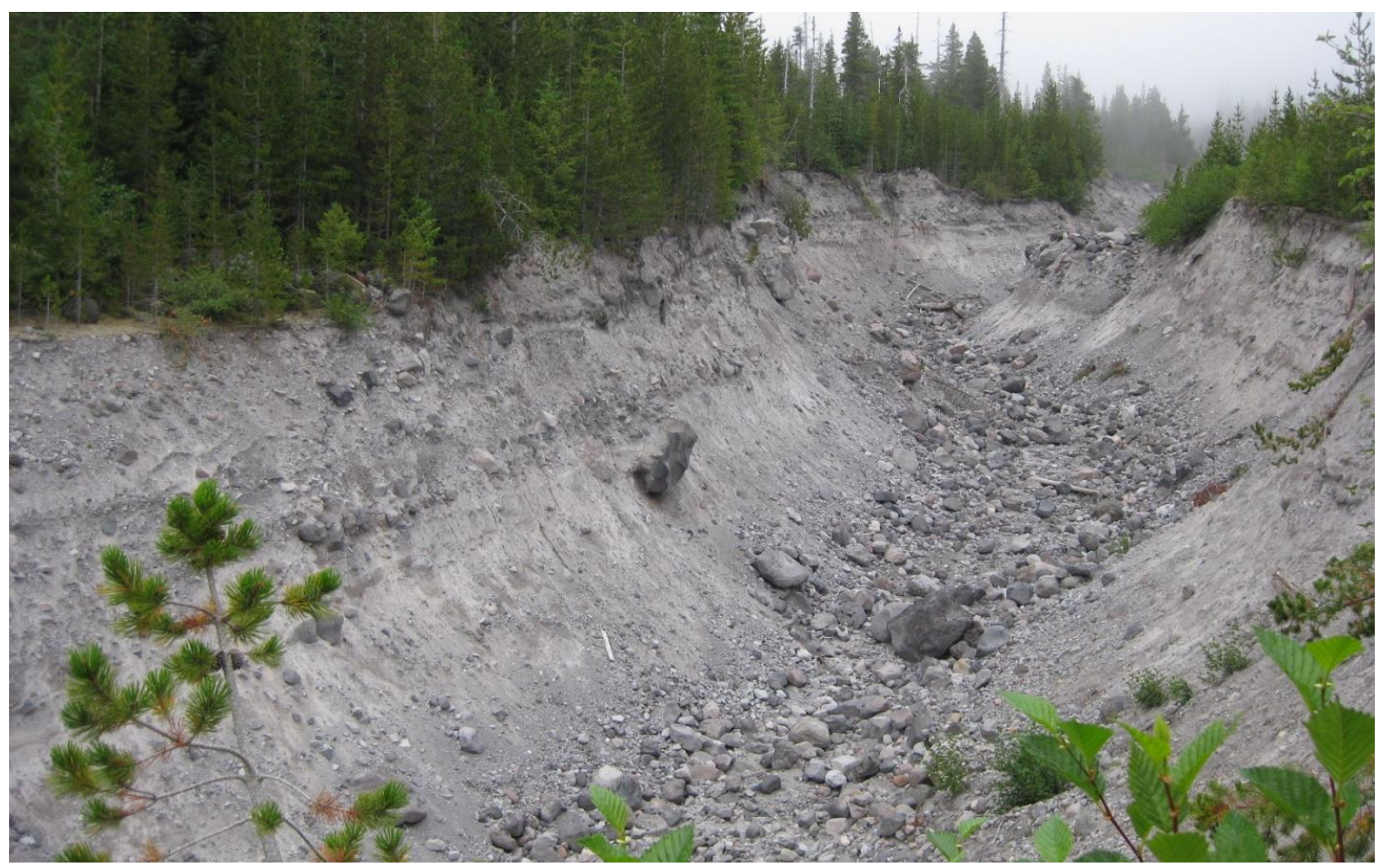

Figure A.40: View up channel at the old Trail 238 crossing of the Butte Came Dome Channel. Geomorphology of this channel exhibits a U-shape with active slope unraveling. Channel bed debris is probably not all from the slopes, but also from the last debris flow pulse. 


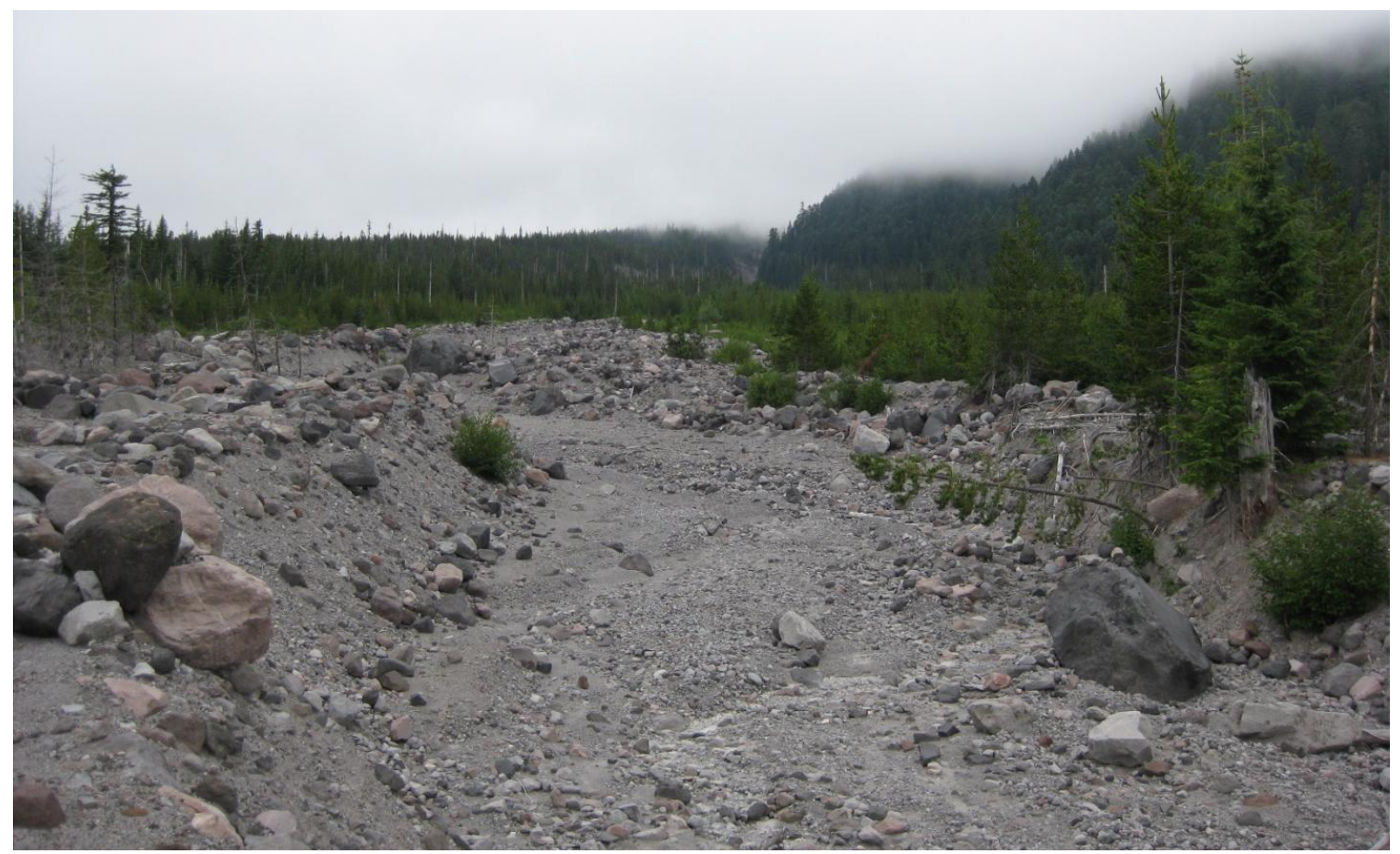

Figure A.41: View upslope of a portion of the Butte Camp Dome Debris Flow deposition zone near the old Trail 231 crossing. Fluvial reworking has created a new channel visible in the foreground.

m. No levees were noted along the upper South BCD Channel, but the walls were actively eroding (Figure A.42). Just below the switching zone a large landslide scarp in the channel wall at $1,760 \mathrm{~m}$ elevation was measured to be about $25 \mathrm{~m}$ wide by $12 \mathrm{~m}$ high and about 6 meters deep. The estimated volume of the slide is about $1,800 \mathrm{~m}^{3}$ (Figure A.43). Further upslope the channel switching zone was observed to contain multiple ridges separated by partially snow-filled ravines. Some well-defined and recent debris flow deposits were observed in these ravines possibly spilled over from the South Channel (Figure A.44). 


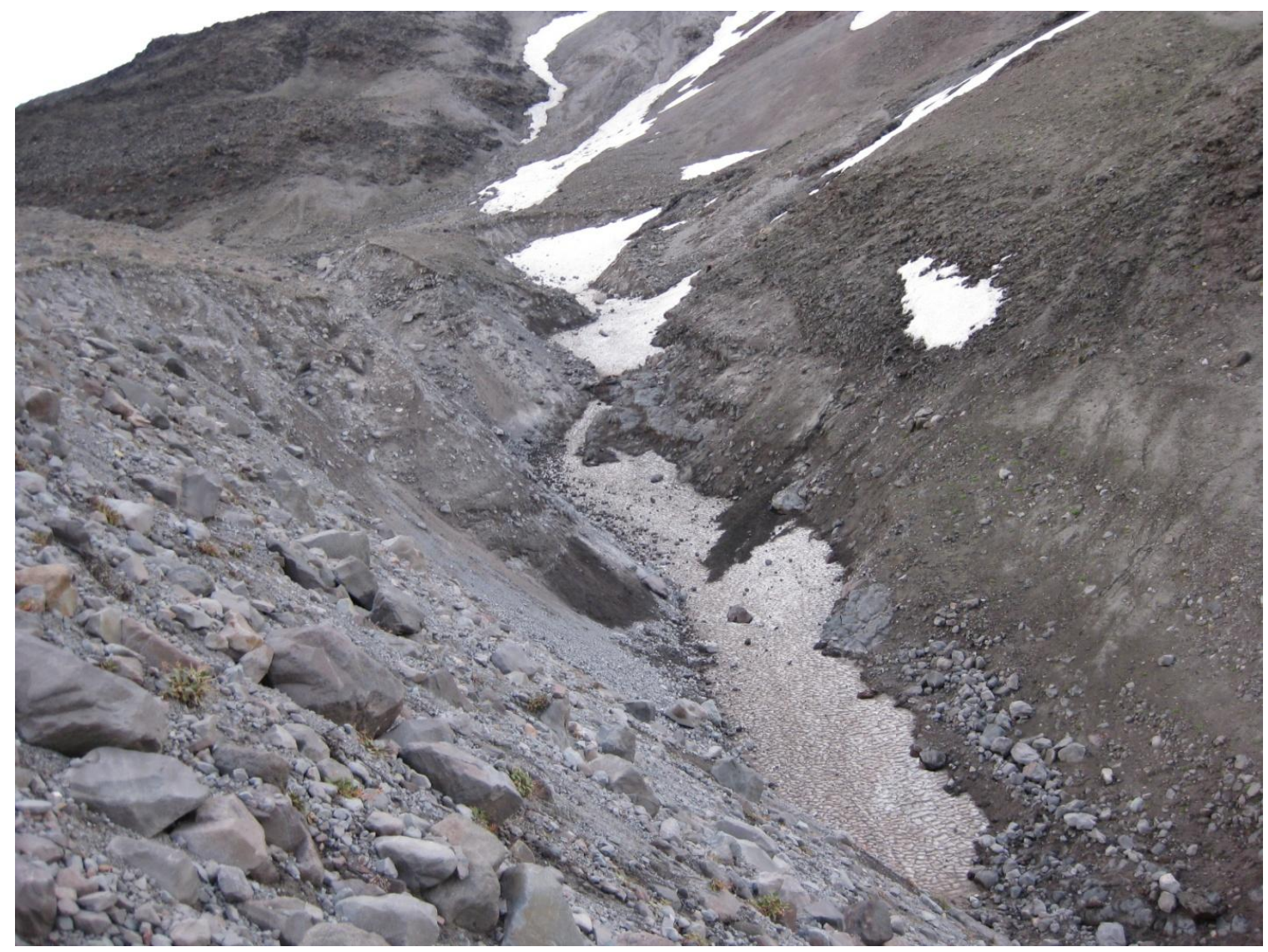

Figure A.42: View upslope of the South Butte Camp Dome Channel from near the lower boundary of the landslide scarp. The switching zone is directly ahead, while the debris flow channel follows the thin line of snow down from the right. View is to the northeast.

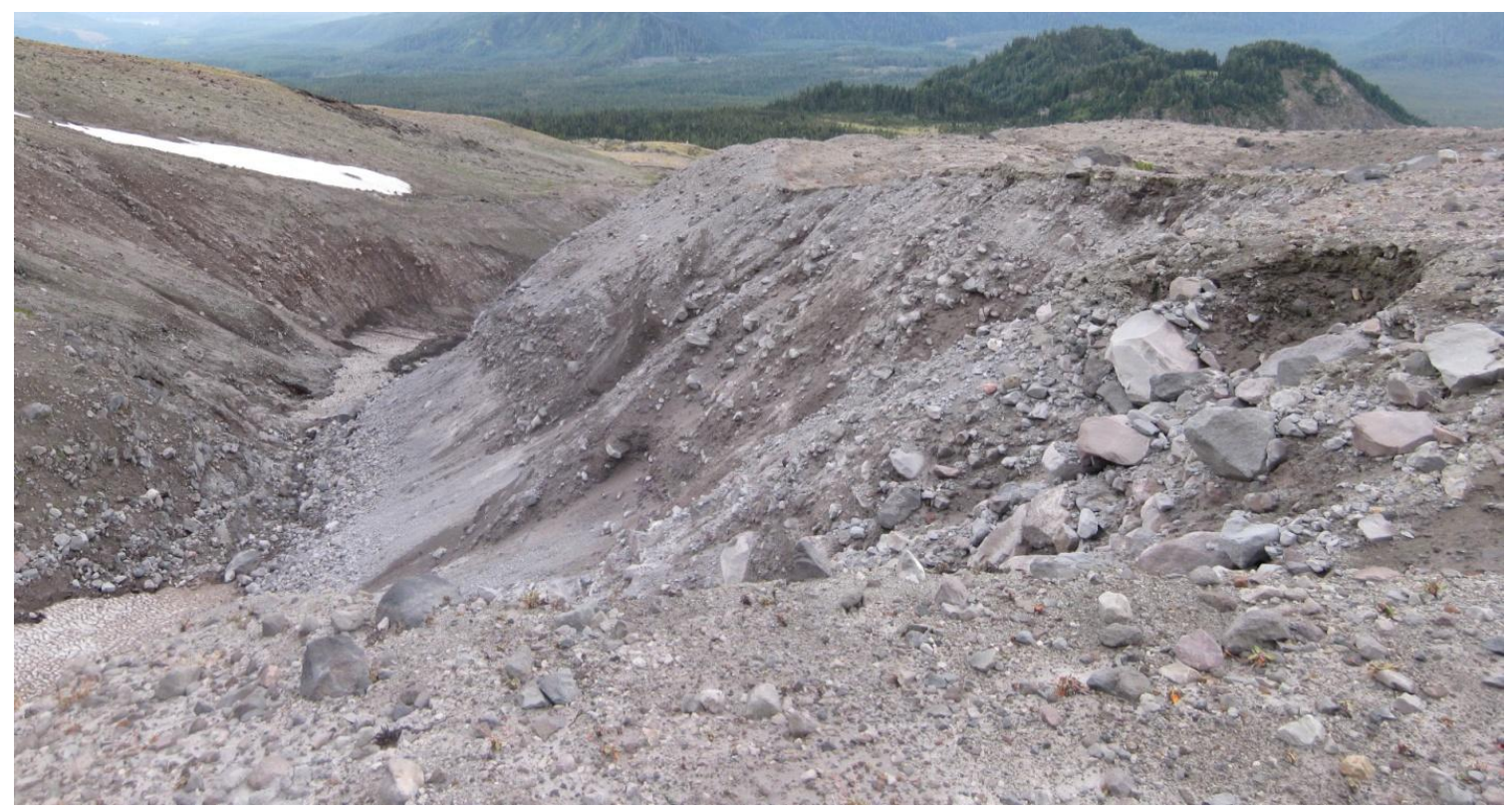

Figure A.43: View downslope of the South Butte Camp Dome Channel from the upper edge of the measured landslide scarp. View is to the southwest. 


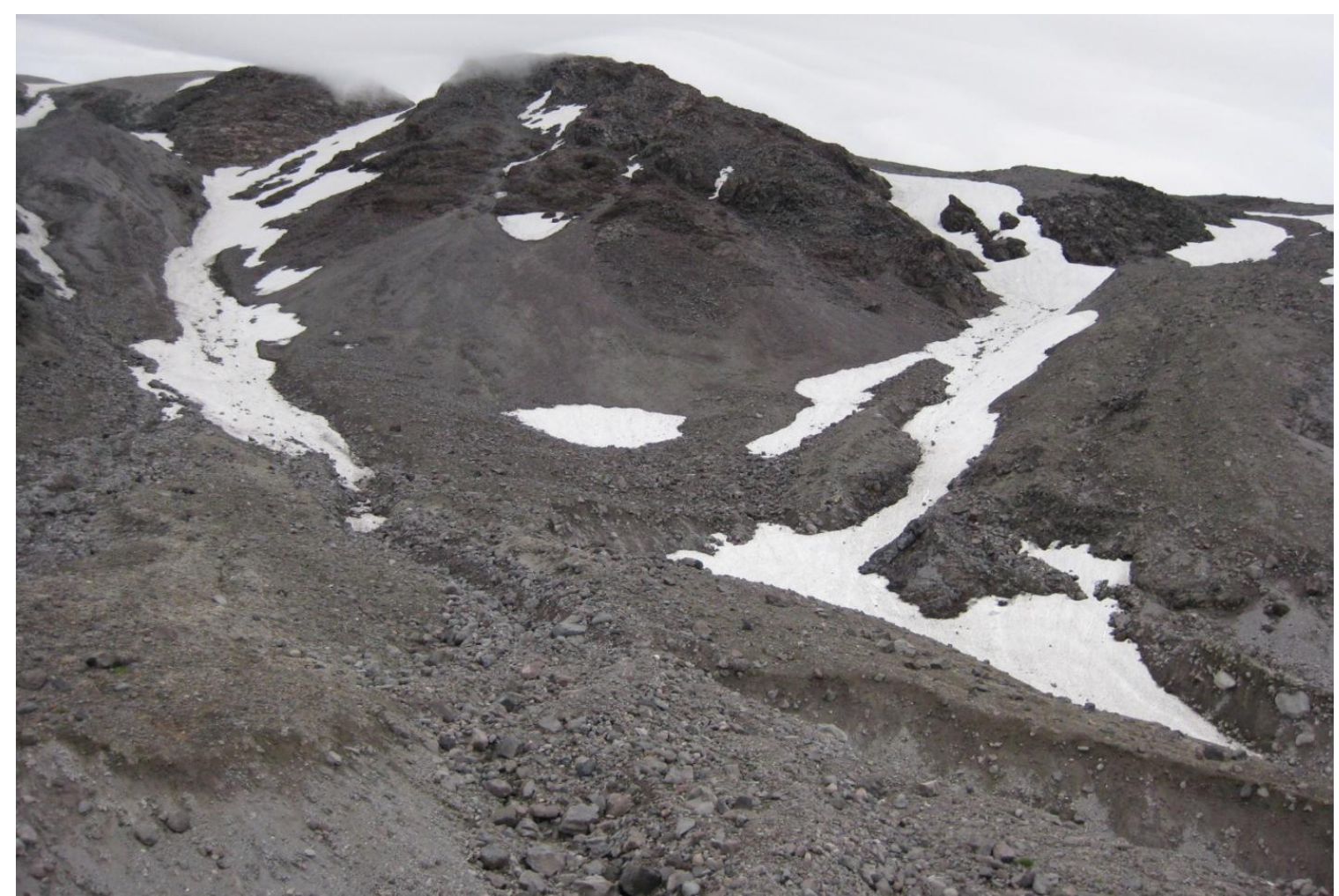

Figure A.44: View of the channel switching zone in the Butte Camp Dome Drainage. The large rocky outcrop is mapped as a Pleistocene intrusive andesite and dacite plug. The South BCD Channel underlies the snowpack to the right, while the central channel is under the snowpack on the left. View is to the east.

The upper North Butte Camp Dome Channel was observed by hiking across the ravines of the switching zone, just below the andesite outcrop on the north side of the upper basin. The channels in this area are shallower, but also deeply buried by snow. Sparse alpine vegetation was observed on the older exposed surfaces, but generally the upper basin contains very little vegetation. The connecting channel between the switching zone and the North BCD Channel was observed to contain debris flow deposits, but were less evident below about 1,750 m elevation. The North BCD Channel was crossed where the steep upper section through the andesite flows meets the shallower debris fan and has formed a five meter deep ravine with active wall erosion. 
No debris flow deposits or other evidence was observed. However, some well-defined debris flow levees were observed in this channel at a lower elevation around 1,590 m.

\section{Soil Sample Collection}

Three sets of three soil samples were taken from the upper channels of the Butte Camp Dome Drainage (Figure 51). Two were taken from the South BCD Channel near the landslide imaged in Figure A.43. One sample group was taken from the north rim of the channel wall below the landslide scarp at 1,640 m elevation (UTM 10N560552E $5114640 N$ ) in geology mapped as Holocene andesite flows (Qva) (WaDNR, 2010). The second sample group, taken in the debris flow deposits of the channel switching zone at 1,790 m elevation (UTM 10N560778E 5115086N), is in geology mapped as Holocene volcaniclastic deposits or rocks (Qvc) (WaDNR, 2010). The last group of three samples was taken from the North BCD Channel at the head of a ravine below the steep andesite lava flow (1,730 m elevation, UTM 10N560517E 5115307N), in geology mapped as Holocene volcaniclastic deposits (Qvc) (WaDNR, 2010).

\section{BLUE LAKE DRAINAGE BASIN}

\section{Reconnaissance}

Field observations of the 2006 debris flow deposits around the Blue Lake trailhead began in early August 2010 (Figure 54). Observations were made from the new trailhead to access the extent and thickness of the deposit (Figure A.45). Debris flow run-up lines and damaged bark on trees were observed. From field observations and 2009 ortho imagery it was noted that multiple lobes were deposited during the 


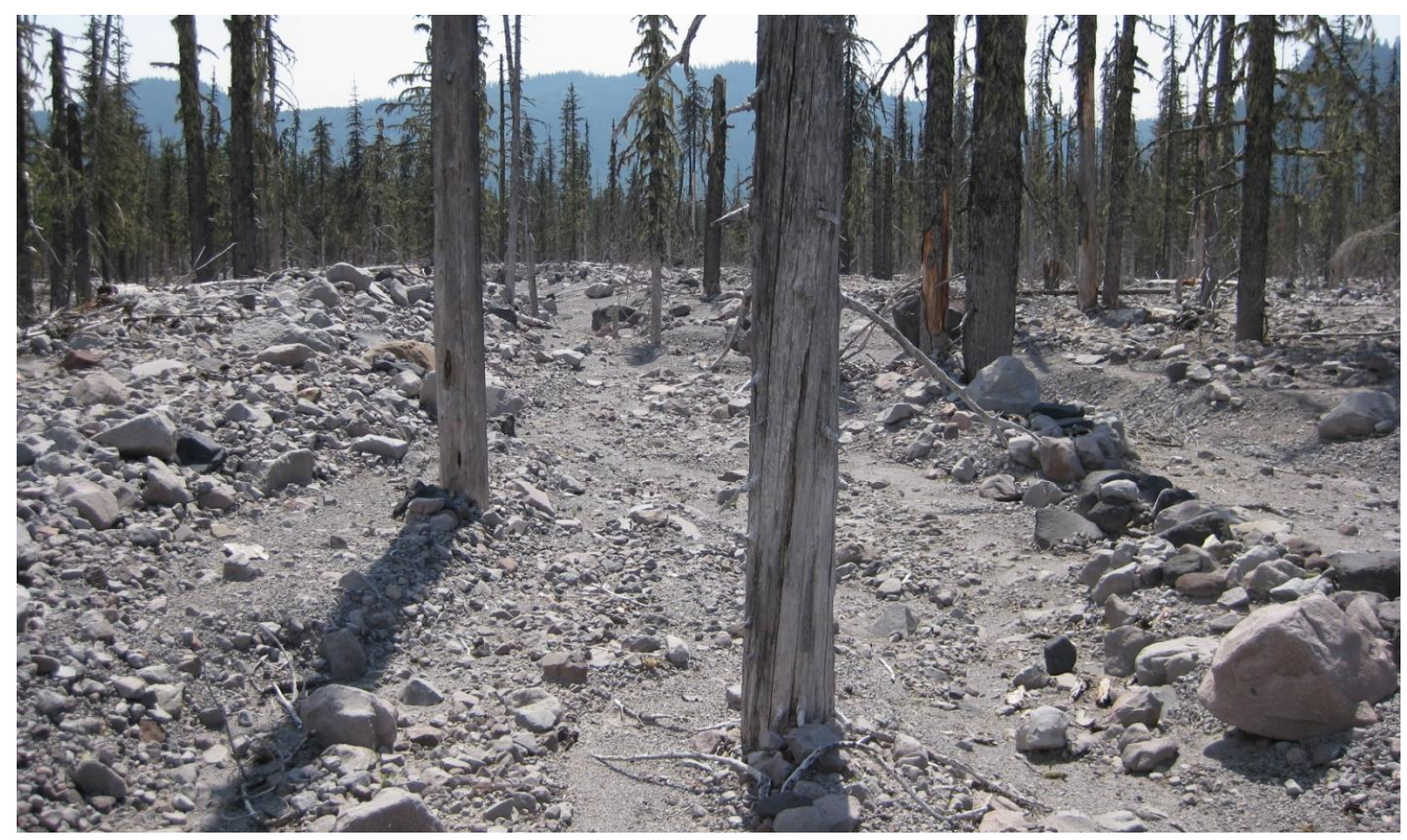

Figure A.45: View southward across a small portion of the 2006 Blue Lake Debris Flow deposit. Run-up lines and damage bark can still be seen on some trees.

2006 event. During multiple field visits three separate streams were observed flowing through the debris flow deposit.

Field reconnaissance began in earnest in late August 2010 by way of Trail 216 from the Climber's Bivouac. The trail crosses the South Channel at an elevation of 1,430 $\mathrm{m}$ and about $1.1 \mathrm{~km}$ north of the North Butte Camp Dome Channel. The South Channel at this location is steep and deeply incised into unconsolidated material mapped as lahar (Qvl) deposits (WaDNR, 2010). The channel geomorphology is confusing, with both V-shaped and U-shaped slopes observed (Figure A.46). The channel crossing is apparently undamaged; however there is evidence above and below that there has been recent debris flow activity older than 2006 since the channel walls have partially collapsed. Above the Trail 216 crossing, small levees were observed on a terrace above 


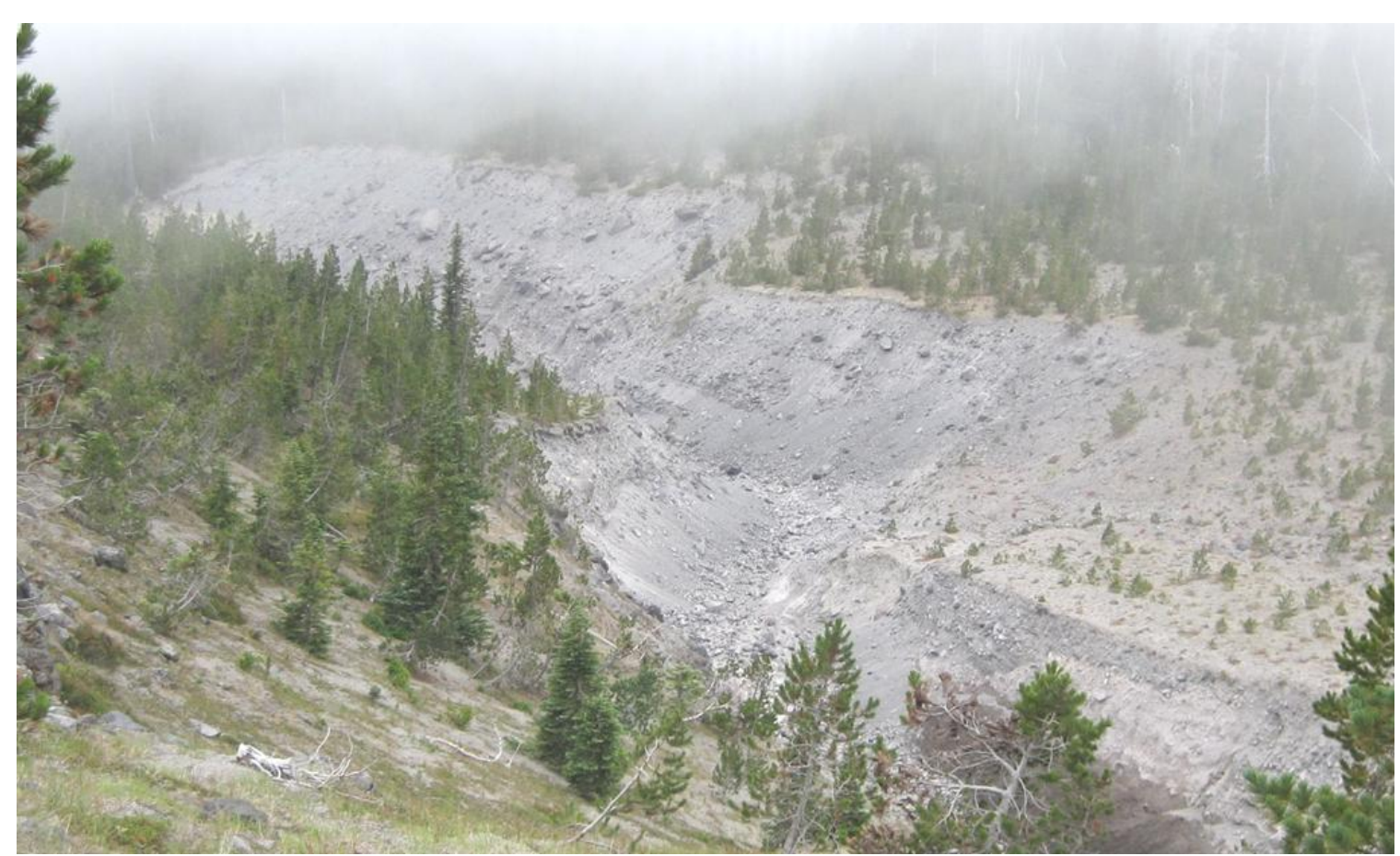

Figure A.46: View down the South Channel of the Blue Lake Drainage Basin from south of the Trail 216 crossing. The channel shows steep, eroding channel walls along this reach, but also segments with failed slopes free of large boulders. View is to the west.

the channel rim (Figure A.47). During this expedition bad weather curtailed detailed reconnaissance along Trail 216 of the North Channel, however quick observations noted an actively eroding channel about $30 \mathrm{~m}$ wide and $15 \mathrm{~m}$ deep at the trail crossing. The Trail 216 crossing itself however was scoured away and the steep slopes were completely un-passable.

Field observations in the upper drainage occurred during two expeditions, the first in mid-August 2011 and the second in mid-September 2011. The first expedition hiked from the Blue Lake trailhead up Trail 237 and 240, and finally reached Trail 216. The geomorphology of the North Channel at the old Trail 216 crossing indicates a recent debris flow that has left the walls unstable and actively eroding (Figure A.48, Figure A.49). 


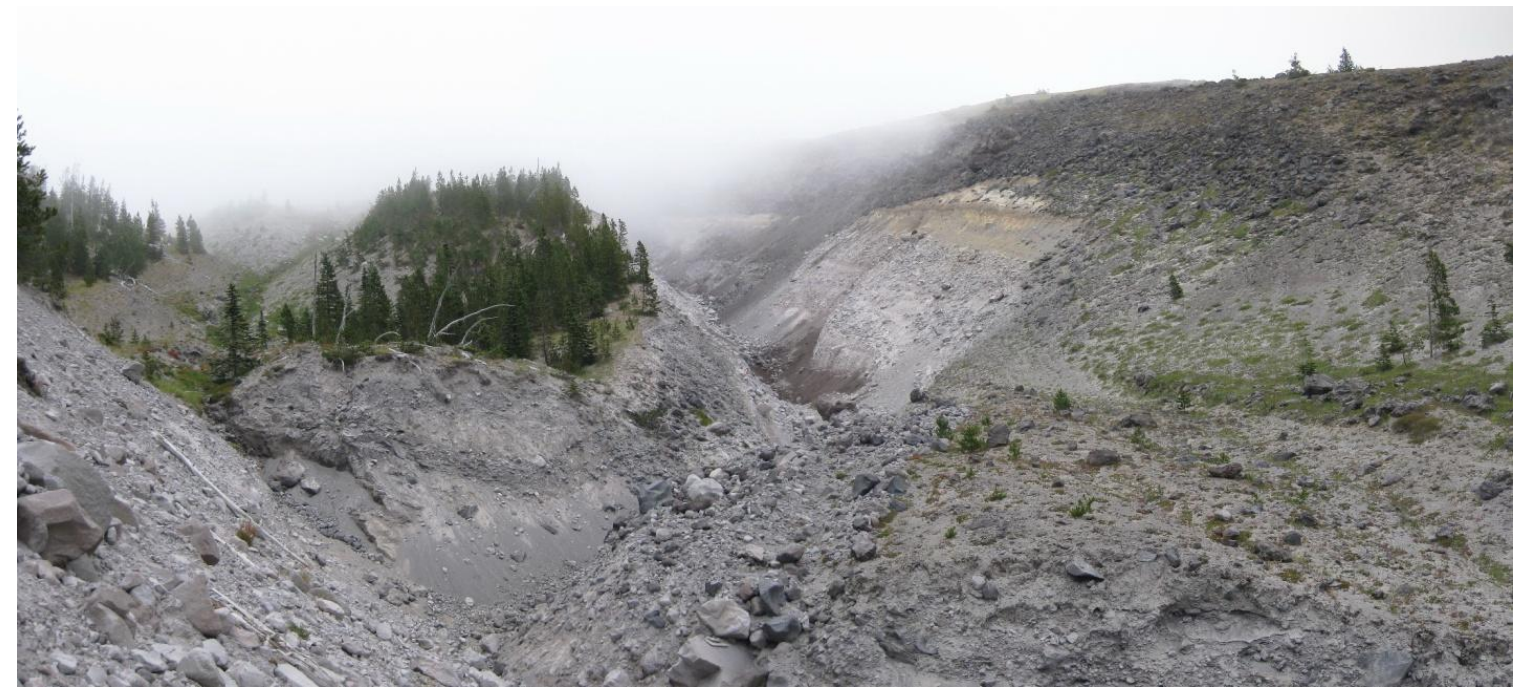

Figure A.47: View up the South Channel of the Blue Lake Drainage Basin. A small debris flow levee is visible in the central foreground at the terrace edge. The ravine to the right has incised deeper than the one on the left, which has caused it to become a hanging ravine. Raw slopes are visible up the right channel.

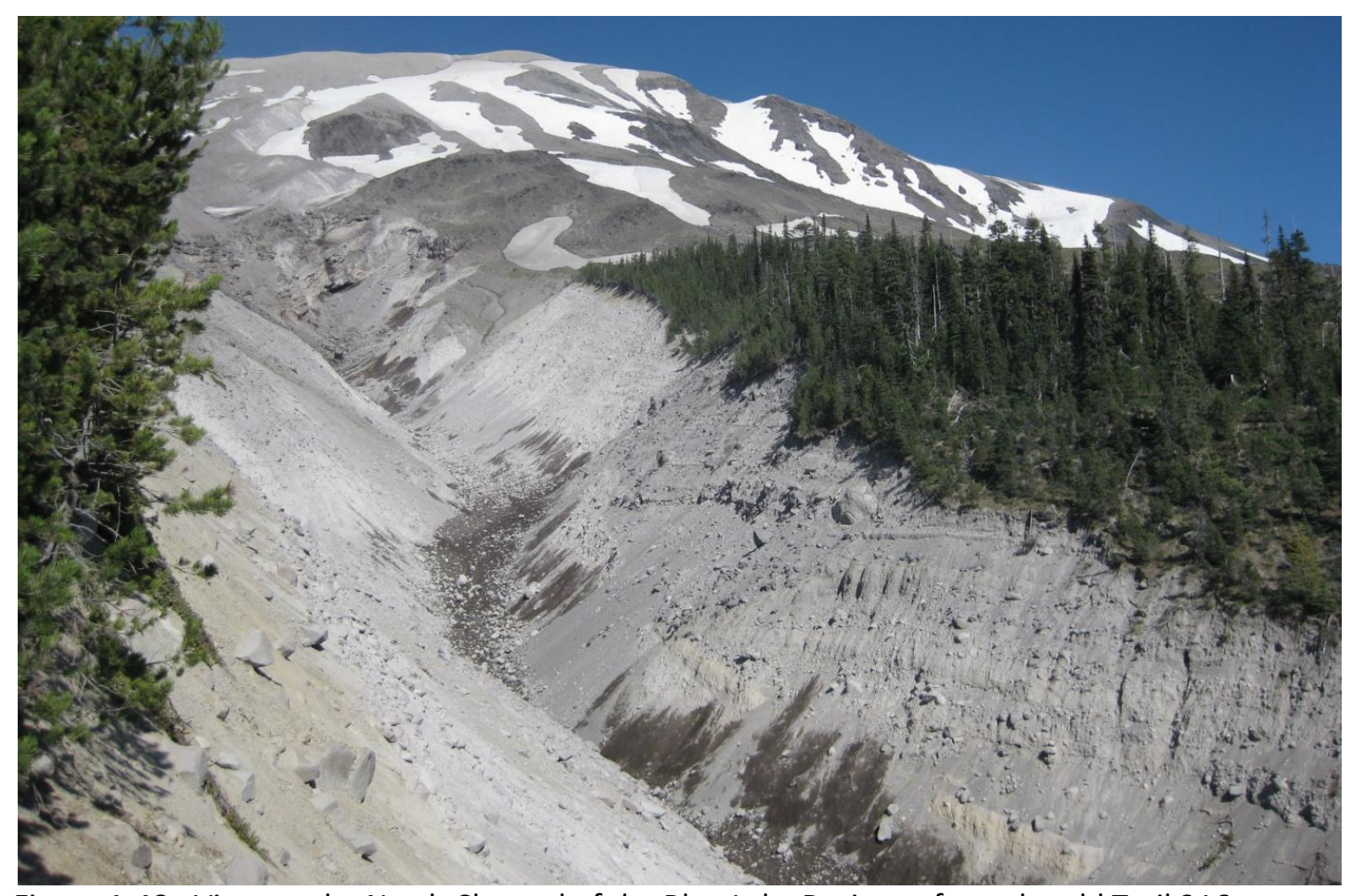

Figure A.48: View up the North Channel of the Blue Lake Drainage from the old Trail 216 crossing location. The steep, actively eroding walls are visible with the exposed andesite flow at the head of the deep ravine. View is to the east. 


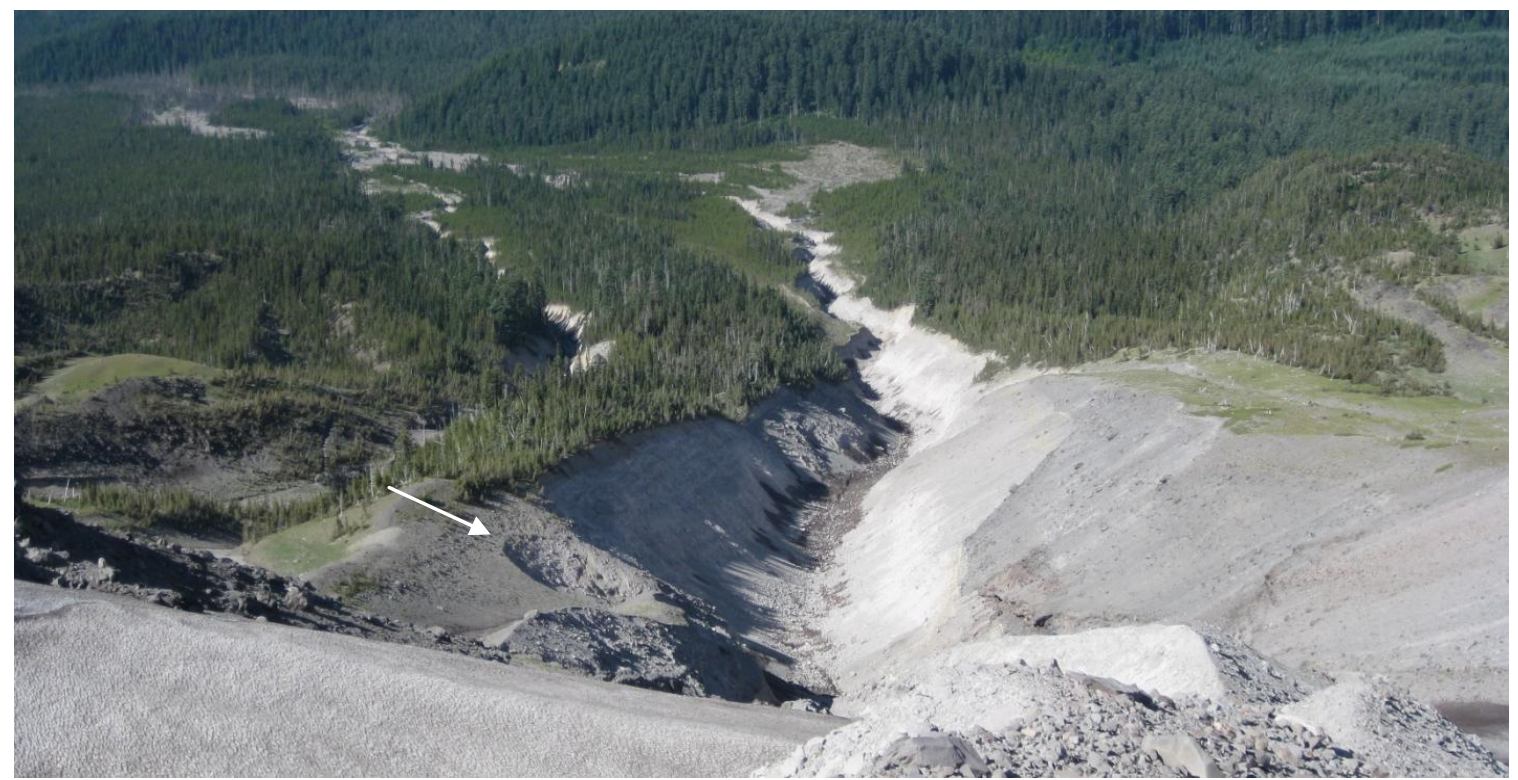

Figure A.49: View down the North Channel of the Blue Lake Drainage Basin from about 1,750 m elevation. The South Channel is visible to the left. The transport and deposition zones are visible in the distance (upper left). The landslide at 1,565 $\mathrm{m}$ elevation is arrowed. The U-shaped channel profile is more obvious from this angle. View is to the west.

Observations were conducted up the northern side of the North Channel to an elevation of 1,850 m. Multiple landslide scarps were observed at elevations: 1,565 m (UTM 10N 559843E 51155741N), 1,720 m (10N 560207E 5115852N), and 2,100 m (10N $560917 \mathrm{E} 5116075 \mathrm{~N})$. The extensive scarp at 1,565 $\mathrm{m}$ elevation is located on the south wall of the channel below the waterfall with dimensions of about $100 \mathrm{~m}$ wide by $35 \mathrm{~m}$ high and $45 \mathrm{~m}$ deep. The landslide at 1,720 m elevation is located on the north side of the channel above the waterfall and has dimensions of $30 \mathrm{~m}$ wide by $50 \mathrm{~m}$ high and 50 $m$ deep with an estimated volume of $75,000 \mathrm{~m}^{3}$ removed (Figure A.50). Extensive channel erosion occurred on the northern wall above this location (Figure A.51), with the largest zone located at 2,100 m elevation had dimensions of about $150 \mathrm{~m}$ wide by $20 \mathrm{~m}$ high and $15 \mathrm{~m}$ deep with an estimated volume of $22,500 \mathrm{~m}^{3}$ removed. 


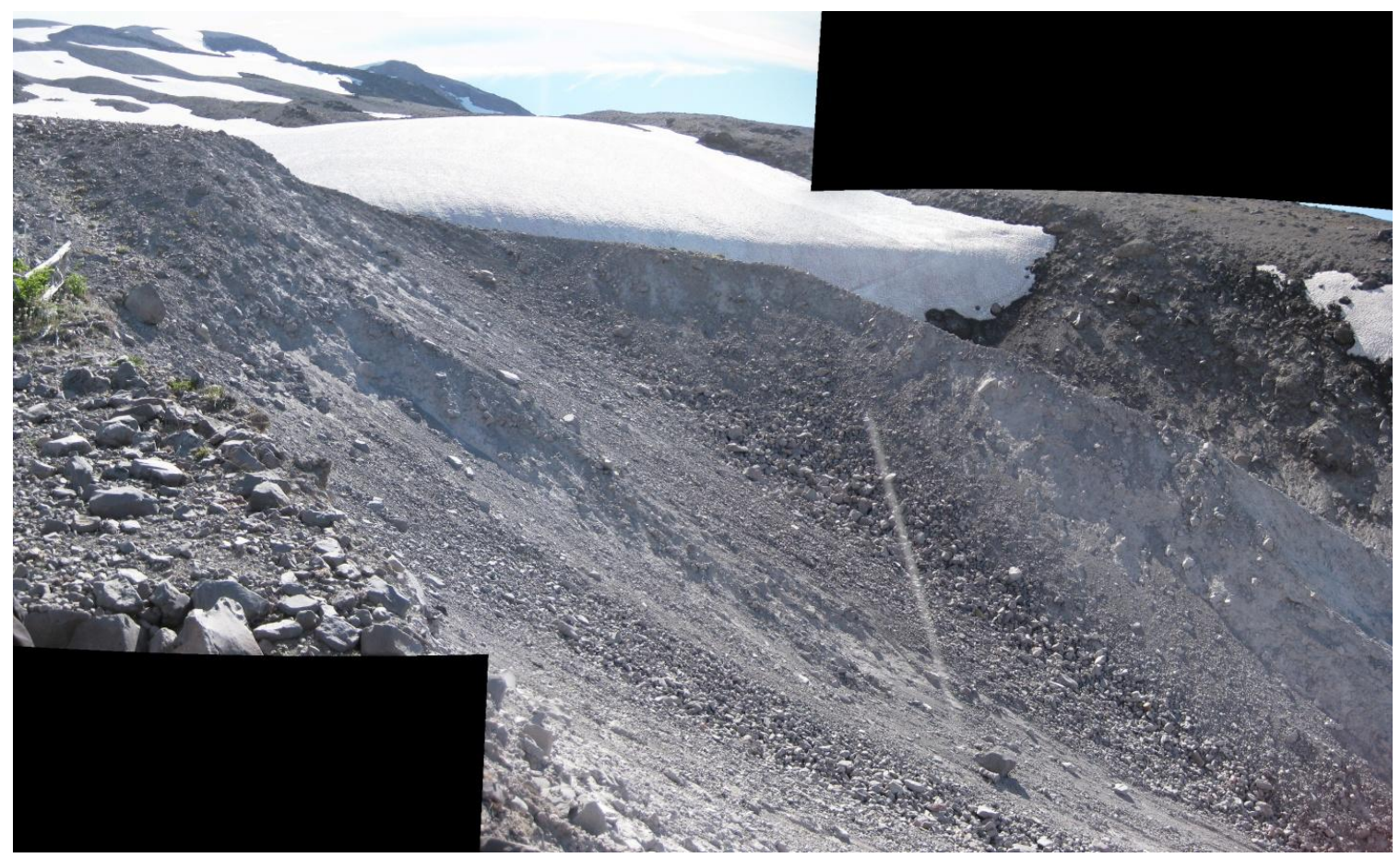

Figure A.50: The landslide at 1,730 m elevation near the North Channel of the Blue Lake Drainage Basin. The drainage channel is beyond the far side of the landslide scarp below the snowpack; the bottom of the landslide is open to the channel. Dimensions are roughly $30 \mathrm{~m}$ wide by $50 \mathrm{~m}$ wide and $50 \mathrm{~m}$ deep. View is to the southeast.

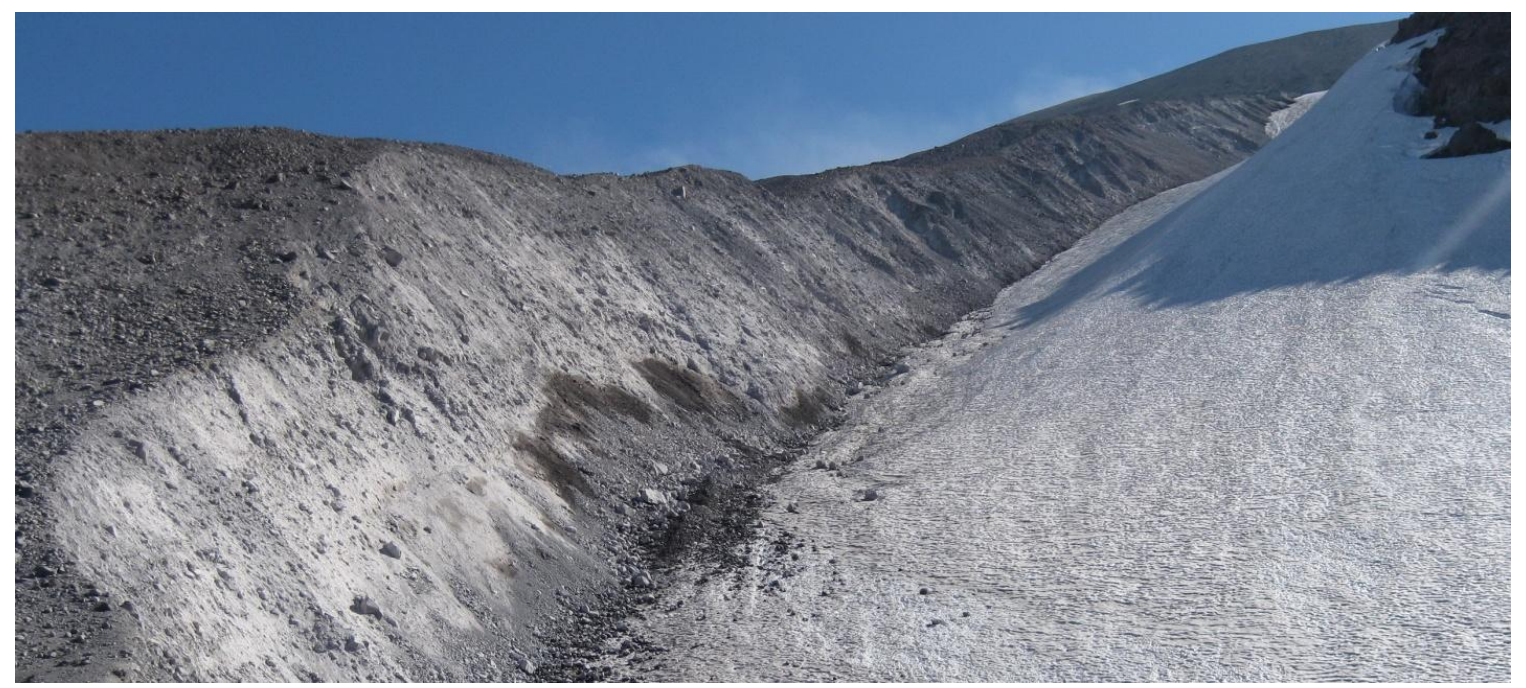

Figure A.51: View up the North Channel of the Blue Lake Drainage from about 1,860 m elevation. The channel bed and southern wall are hidden by snowpack. Extensive channel wall erosion occurred along the entire length with the greatest being in the foreground to the left and at the highest elevation of 2,100 $\mathrm{m}$ visible in the distance at the right. View to the east. 
The second expedition hiked from the Redrock Pass trailhead up Trail 238 and 238A to Trail 216. After observing the Butte Camp Dome Drainage, the South Blue Lake Channel was approached from the south at about 1,750 m elevation. At the channel crossing and below, the channel was shallow and the bed hidden by snowpack. From 2009 ortho imagery (USDA-FSA, 2009), any past debris flow activity must have initiated below 1,600 m, which was the highest elevation of obvious channel erosion. At this time soil samples were taken in the basin, but bad weather curtailed further observations.

\section{Soil Sample Collection}

Two sets of three soil samples each were taken from the Blue Lake Drainage Basin (Figure 54). One sample group was taken at the upper edge of a large snowfield between the North and South Channels at an elevation of 1,810 m (UTM 10N 560321E 5115739N). From ortho photographs this site was identified as the upper edge of a large arcuate ridge that forms the southern wall of the North Channel and is a possible

old landslide scarp. The second sample group was taken after crossing the snowfield to an exposed ridge of the southern wall of the North Channel at an elevation of $1,840 \mathrm{~m}$ (UTM 10N 560411E 5115912N). Both sites were located along walls within the North Channel, although the exact geomorphic significance of each could not be determined due to the extensive snowpack. The geology of both samples sites is mapped as volcaniclastic deposits and rocks (Qvc) which covers 78\% of the upper basin. 


\section{SHEEP CREEK DRAINAGE BASIN}

\section{Reconnaissance}

Field reconnaissance in the Sheep Creek Drainage Basin occurred mid-August 2010 by hiking Trail 238 from the Blue Lake trailhead (Figure 60). Debris flow deposits were first seen at the junction of Trail 238 and 240 where the stream is crossed by a bridge. Cobble-sized rocks visible from the trail are interspersed with quarter-meter high flowering plants and grasses indicating an older age deposit. However, other rocky deposits without vegetation were visible in the distance along bends in the channel (Figure A.52).

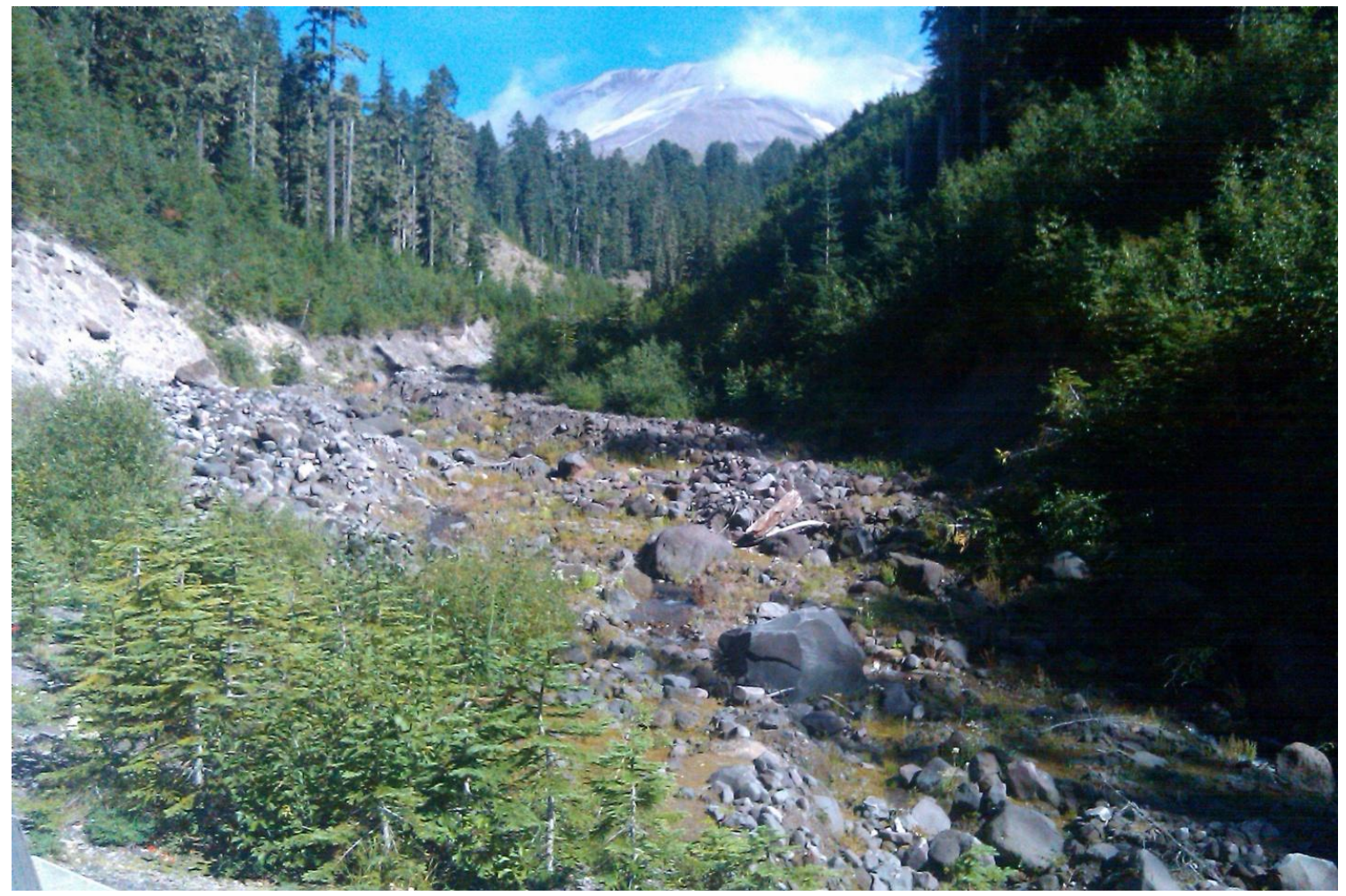

Figure A.52: View up the Sheep Creek Drainage from the Trail 238 bridge crossing. Visible are older stream deposits intergrown with vegetation and recent debris flow deposits in the middle distance to the left and right with no vegetation. View to the east. 
Hiking up Trail 240 to Trail 216 provided occasional observations into the steepsided channel with actively eroding walls with a U-shape indicating recent debris flow activity. The valley floor exhibits at least two terraces. The upper terrace hosts young pine trees about five meters tall and so probably formed during the 1980 eruption. The next lowest terrace contains younger trees about two meters tall. Cut into this terrace is the current active channel (Figure A.53). Trail 216 crosses this valley at a wide, flat zone just below three ravines that originate at the base of Crescent Dome. From the southern-most (and possibly middle) ravine extends a well-defined debris flow channel

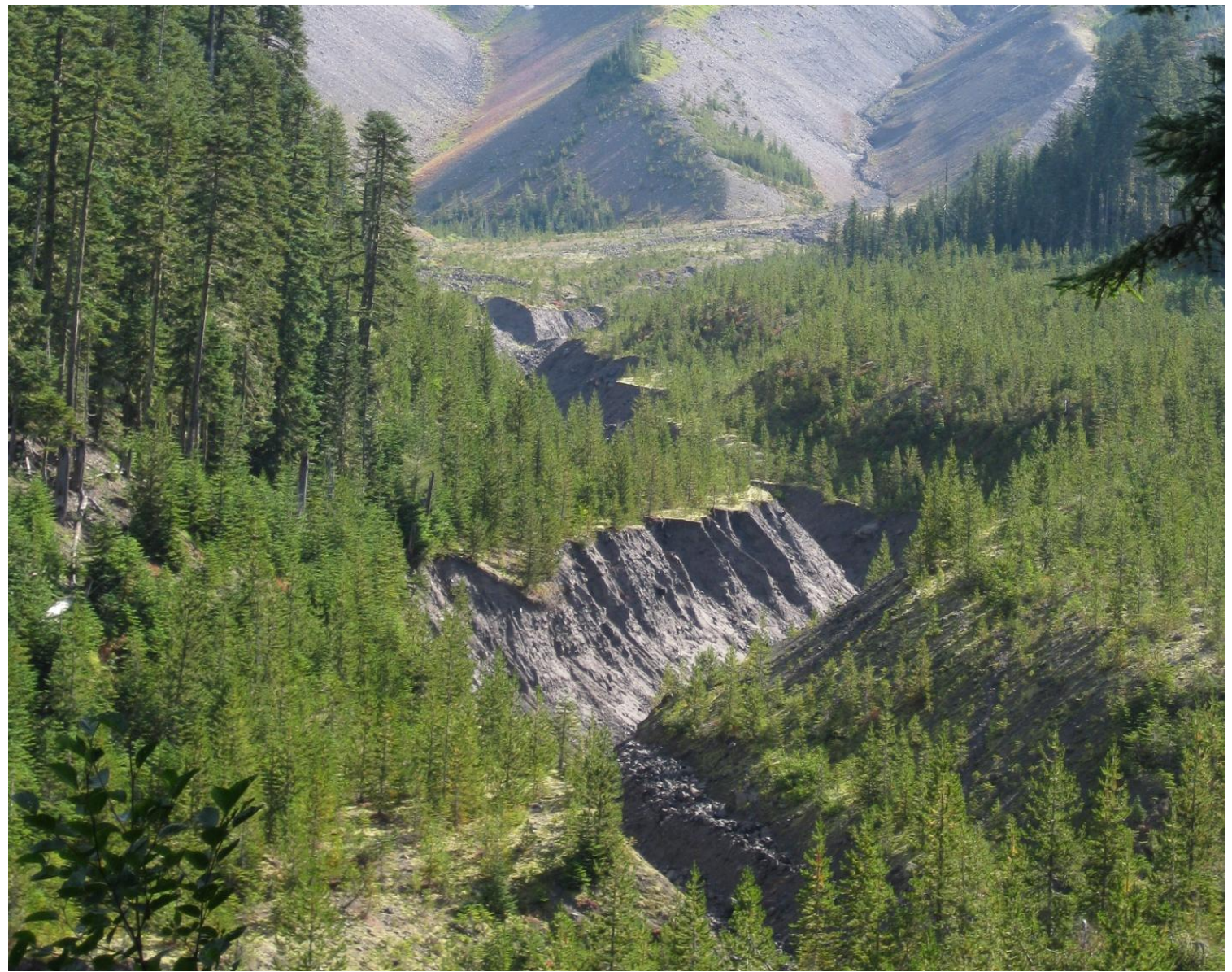

Figure A.53: View up the Sheep Creek Drainage from an overlook off Trail 240. Visible are two terraces with trees of different age populations. The channel shows deep incision and steep sides. View to the east. 
about five meters wide and two meters deep with boulder and cobble levees (Figure A.54).

Upper basin field observations occurred a year later in mid-August 2011 by hiking from the Blue Lake trailhead up Trail 237 and 240 to finally reach Trail 216.

During observations of the North Channel of the Blue Lake Drainage, the upper channel of Sheep Creek was also examined. Like the Blue Lake Channel, a late snowpack covered much of the southern slope and floor of the Sheep Creek Channel. The exposed north wall of the channel was observed to be primarily at the angle of repose indicating lack of recent erosion or debris flow activity (Figure A.55). However, some areas with steeper slopes were observed above the snowpack near 1,670 m elevation.

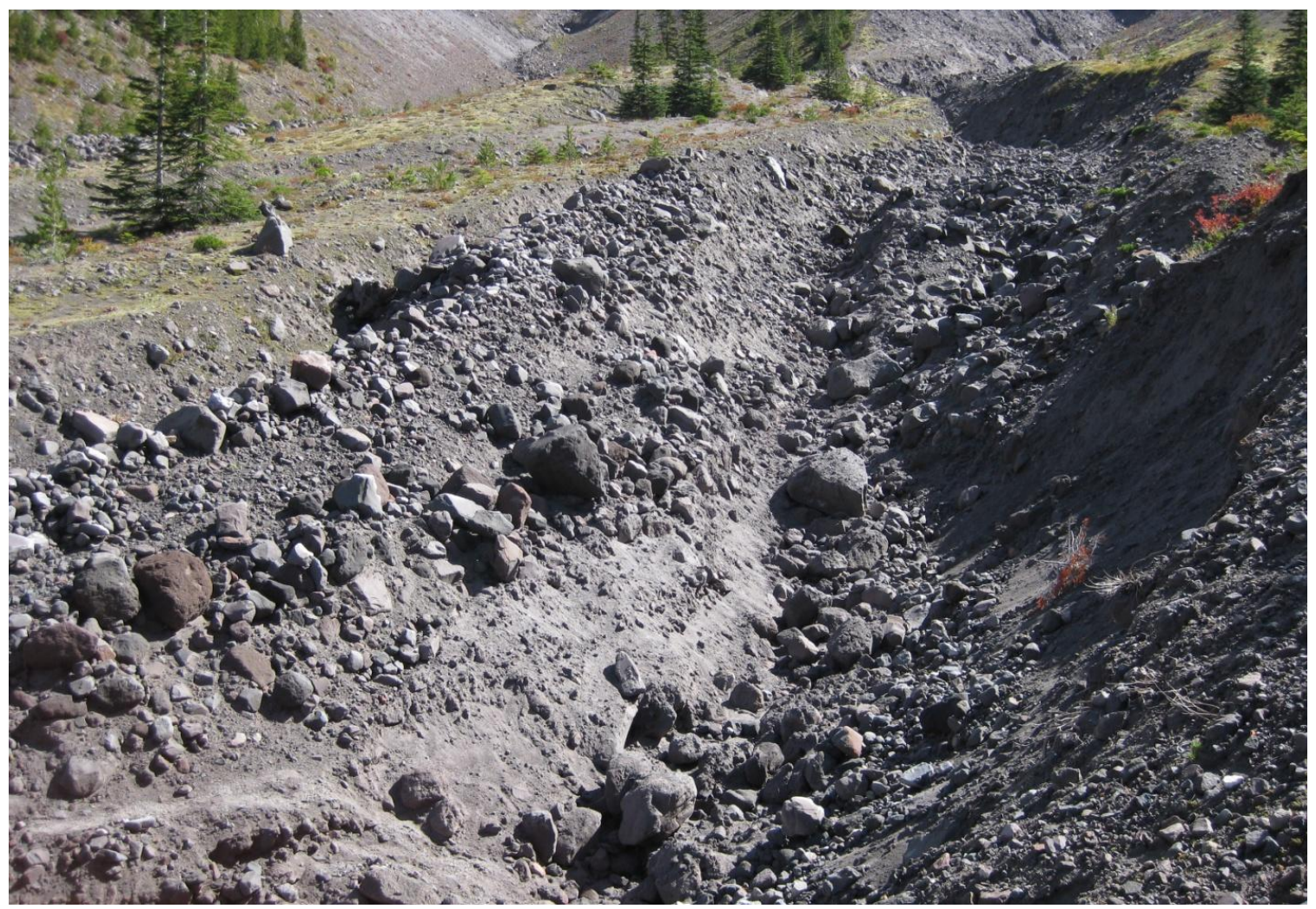

Figure A.54: Debris flow path from the southern-most Sheep Creek Channel. The channel was observed to be about five meters wide and two meters deep with boulder and cobble levees. 


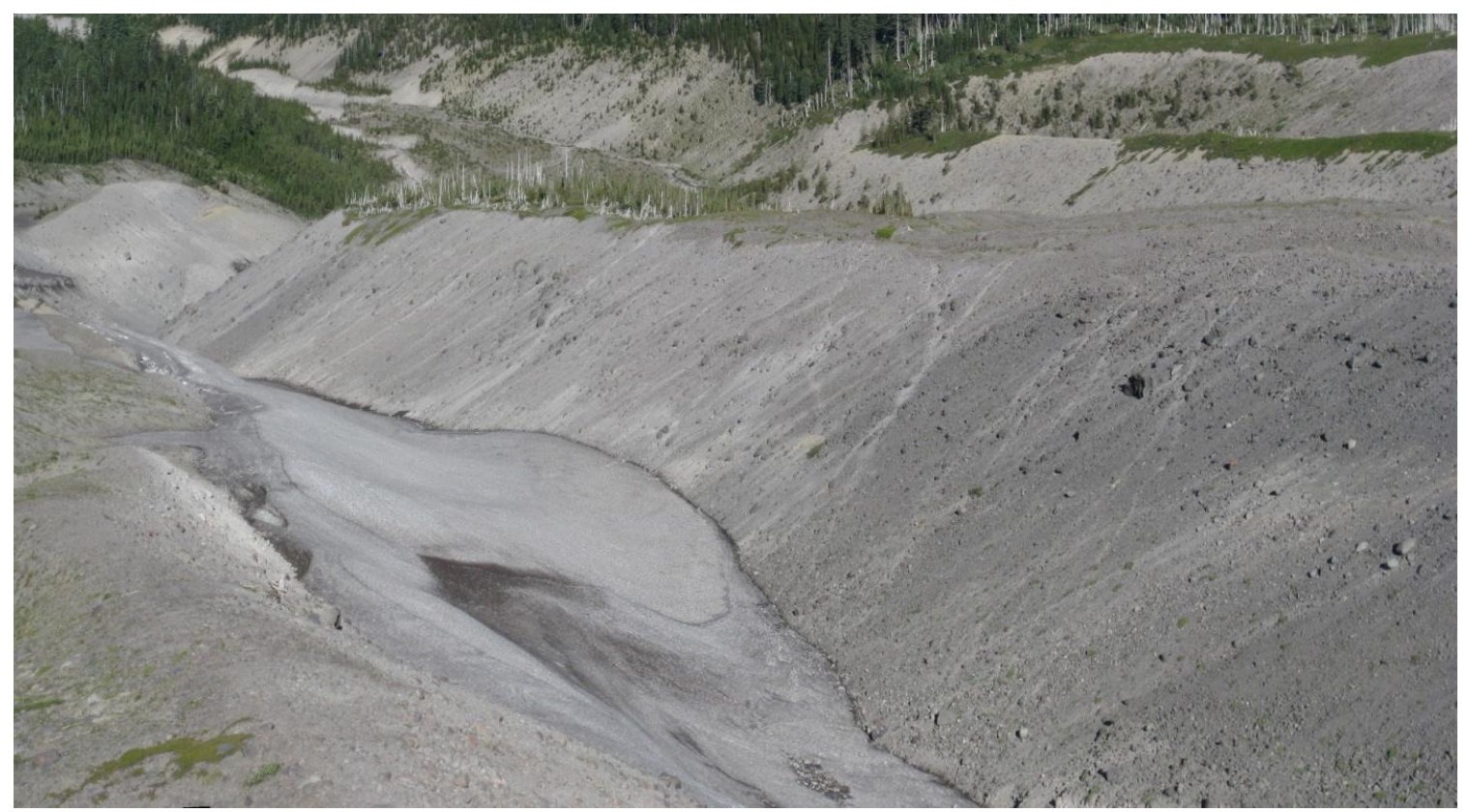

Figure A.55: View down the southern-most Sheep Creek Channel from near 1,600 m elevation. Snowpack obscures the south wall, but the north wall exhibits a V-shaped slope. Although not evident here, this channel did experience a debris flow in 2006. View to the northwest.

\section{Soil Sample Collection}

No soil samples were taken from the Sheep Creek Drainage Basin. However, samples were taken about $150 \mathrm{~m}$ away in similar volcaniclastic deposits of the neighboring Blue Lake Drainage.

\section{SOUTH FORK TOUTLE RIVER DRAINAGE BASIN}

\section{Reconnaissance}

Field reconnaissance in the South Fork Toutle River occurred during midSeptember 2011 along Trail 216, which was accessed via Trail 238 from the Blue Lake trailhead (Figure 62). Observations of the upper southern ravine were made from Trail 216 along Crescent Ridge at 1,420 m elevation. The walls of the ravine above this location primarily exhibits V-shaped slopes with debris filling the bed (Figure A.56). 


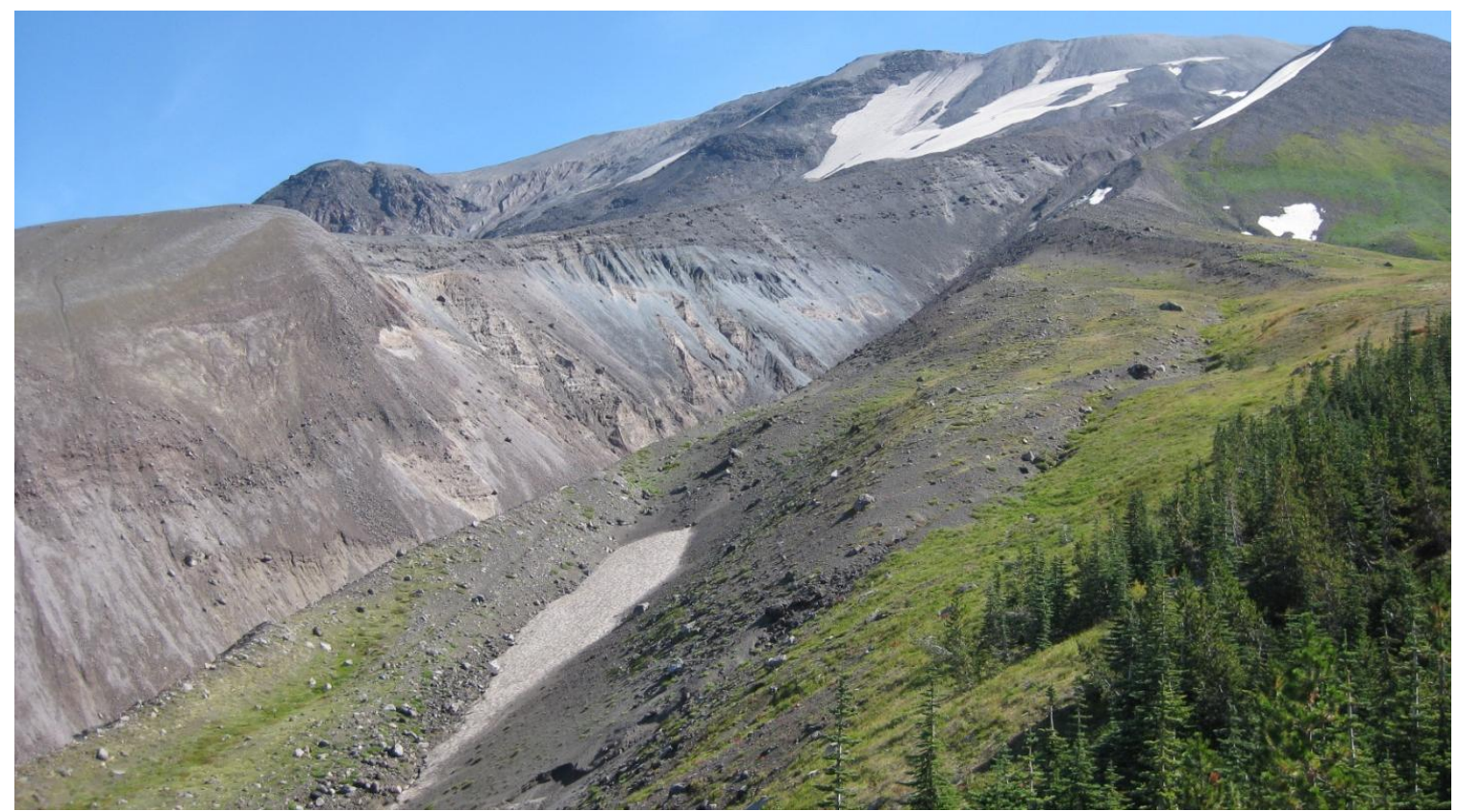

Figure A.56: View upslope of the southern South Fork Toutle River Channel from Trail 216 on Crescent Ridge. Channel walls are generally V-shaped and evidence of a recent debris flow is absent. View to the east.

Below this location a notch of headward channel erosion was observed at 1,250 m elevation, below which the channel walls became very steep and unstable.

Observations of the South Fork Toutle River Channel were made at the confluence with the southern channel. The channel at this location is about $30 \mathrm{~m}$ deep with walls cut near vertical in a well-defined U-shaped profile. Active stream erosion was occurring along the base, with a meandering channel flowing between cobble and boulder-sized debris. At least three terraces were observed along the channel (Figure A.57). The upper terrace hosts pine trees about five meters tall and possibly formed during the 1980 eruption. The next terrace is about $10 \mathrm{~m}$ lower and covered with little vegetation. The current channel bed is another $12 \mathrm{~m}$ lower and shows evidence of recent debris flow levees on the upper banks. 


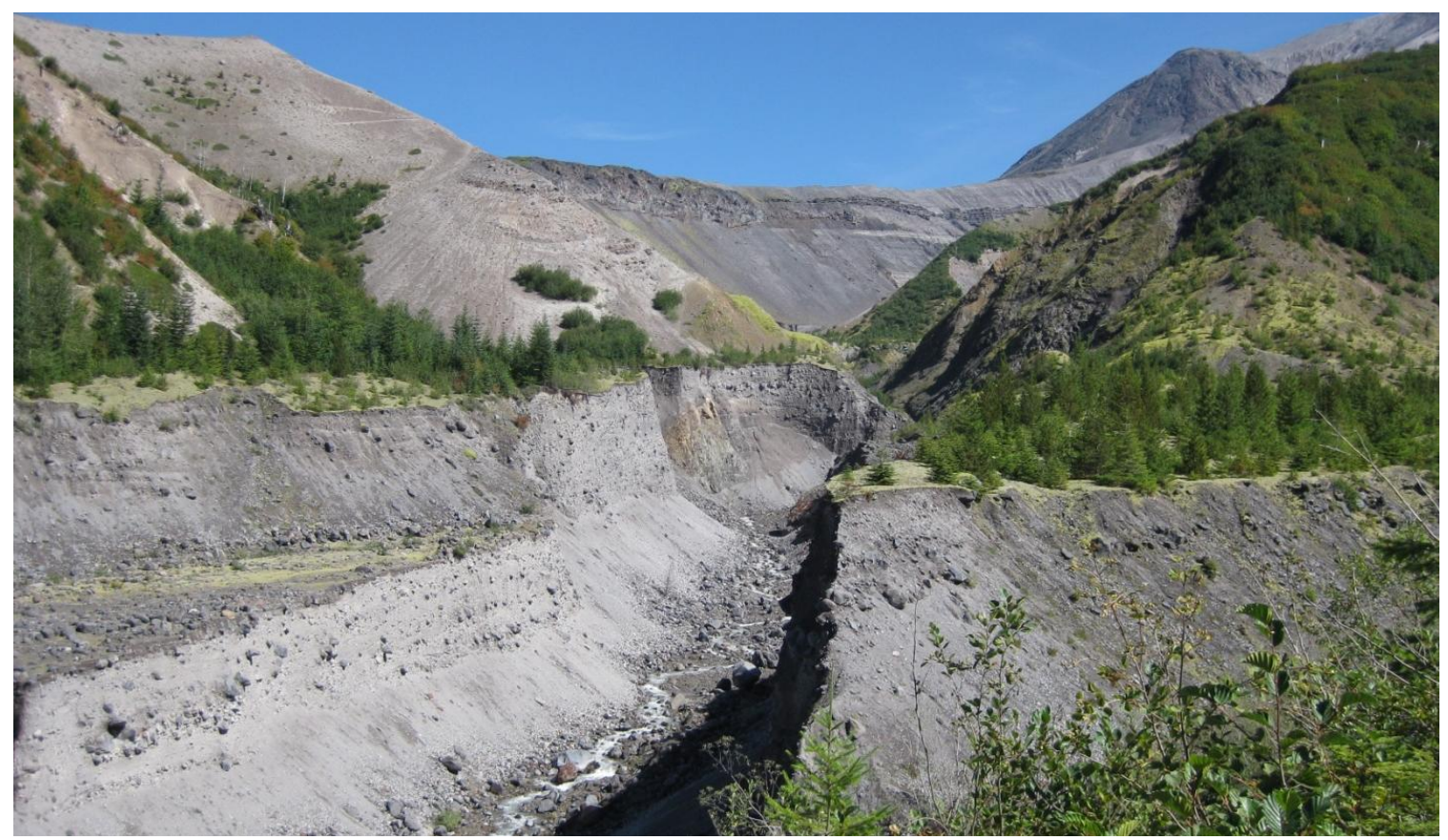

Figure A.57: View of the South Fork Toutle River Channel from Trail 216, near the confluence with the southern channel. The incised channel has a U-shaped profile and multiple terraces are visible from this location.

\section{Soil Sample Collection}

No soil samples were taken from the South Fork Toutle River Drainage Basin.

However, samples were taken from the nearby Blue Lake Drainage in similar volcaniclastic deposits and andesite lava flows. 
APPENDIX B - SNOTEL DATA 
Table B.1: SNOTEL precipitation data (in $\mathrm{cm}$ ) from sites around Mount St. Helens for November 2006 (USDA-NRCS, 2009).

\begin{tabular}{|c|c|c|c|c|c|c|}
\hline Day & $\begin{array}{l}\text { June } \\
\text { Lake }\end{array}$ & $\begin{array}{l}\text { Sheep } \\
\text { Canyon }\end{array}$ & $\begin{array}{l}\text { Lone } \\
\text { Pine }\end{array}$ & $\begin{array}{l}\text { Spencer } \\
\text { Meadow }\end{array}$ & $\begin{array}{l}\text { Spirit } \\
\text { Lake }\end{array}$ & $\begin{array}{l}\text { Swift } \\
\text { Creek }\end{array}$ \\
\hline 1 & 11.7 & 14.5 & 8.1 & 7.4 & 13.2 & 14.7 \\
\hline 2 & 0.5 & 0.0 & 0.3 & 0.0 & 0.0 & 0.0 \\
\hline 3 & 8.6 & 5.3 & 6.4 & 6.4 & 4.6 & 7.4 \\
\hline 4 & 13.7 & 9.7 & 7.9 & 4.3 & 4.8 & 15.0 \\
\hline 5 & 10.4 & 8.4 & 6.6 & 5.8 & 6.6 & 10.4 \\
\hline 6 & 10.2 & 6.1 & 4.8 & 5.6 & 5.1 & 8.6 \\
\hline 7 & 37.1 & 27.2 & 14.5 & 18.3 & 19.1 & 35.3 \\
\hline 8 & 14.7 & 11.9 & 5.8 & 7.9 & 7.6 & 13.2 \\
\hline 9 & 2.3 & 2.0 & 1.8 & 1.8 & 1.3 & 2.0 \\
\hline 10 & 2.0 & 2.0 & 1.0 & 1.5 & 0.8 & 2.8 \\
\hline 11 & 5.6 & 3.0 & 5.3 & 4.6 & 3.8 & 6.9 \\
\hline 12 & 3.6 & 3.0 & 1.8 & 1.8 & 2.5 & 2.8 \\
\hline 13 & 6.4 & 4.6 & 4.3 & 5.6 & 2.8 & 7.4 \\
\hline 14 & 3.3 & 2.8 & 1.8 & 1.5 & 2.3 & 2.0 \\
\hline 15 & 0.3 & 0.5 & 0.0 & 0.3 & 1.0 & 1.0 \\
\hline 16 & 6.9 & 4.6 & 4.3 & 5.6 & 3.3 & 6.9 \\
\hline 17 & 0.0 & 0.0 & 0.0 & 0.3 & 0.0 & 0.0 \\
\hline 18 & 0.0 & 0.0 & 0.3 & 0.0 & 0.3 & 0.0 \\
\hline 19 & 0.3 & 0.0 & 0.0 & 0.0 & 2.3 & 0.0 \\
\hline 20 & 4.1 & 3.3 & 2.3 & 2.5 & 2.3 & 3.6 \\
\hline 21 & 2.3 & 1.8 & 1.0 & 0.5 & 1.0 & 1.8 \\
\hline 22 & 6.1 & 4.1 & 4.1 & 4.6 & 3.3 & 5.3 \\
\hline 23 & 4.8 & 1.8 & 4.1 & 3.8 & 2.8 & 6.9 \\
\hline 24 & 7.9 & 1.5 & 4.1 & 3.6 & 3.0 & 3.6 \\
\hline 25 & 2.8 & 6.9 & 0.5 & 0.3 & 1.8 & 2.5 \\
\hline 26 & 0.5 & 1.0 & 1.8 & 0.5 & 0.8 & 0.8 \\
\hline 27 & 4.1 & 1.0 & 4.1 & 4.1 & 2.5 & 2.0 \\
\hline 28 & 2.3 & 1.8 & 0.3 & 1.0 & 1.0 & 1.5 \\
\hline 29 & 2.3 & 2.8 & 0.0 & 0.8 & 1.0 & 1.3 \\
\hline 30 & 1.3 & 0.0 & 0.3 & 0.5 & 0.3 & 0.0 \\
\hline
\end{tabular}


APPENDIX C - ANOVA RESULTS 
Table C.1: Full one-way ANOVA results of comparison between the attributes of drainage basins that experienced 2006 debris flows and those drainage basins that did not experience a 2006 debris flow.

\begin{tabular}{|c|c|c|c|c|c|c|}
\hline Groups & Count & Sum & Average & Variance & & \\
\hline Debris Flow & 8 & 1 & 0.13 & 0.13 & & \\
\hline No Debris Flow & 8 & 0 & 0.00 & 0.00 & & \\
\hline \multicolumn{7}{|l|}{ ANOVA } \\
\hline Source of Variation & SS & $d f$ & MS & $F$ & P-value & F crit \\
\hline Between Groups & 0.06 & 1 & 0.06 & 1 & 0.33 & 4.60 \\
\hline Within Groups & 0.88 & 14 & 0.06 & & & \\
\hline Total & 0.94 & 15 & & & NO & \\
\hline \multicolumn{7}{|l|}{ TOTAL BASIN AREA } \\
\hline Groups & Count & Sum & Average & Variance & & \\
\hline Debris Flow & 8 & $43,840,290.00$ & $5,480,036.25$ & $8.70 \mathrm{E}+12$ & & \\
\hline No Debris Flow & 8 & $33,617,540.00$ & $4,202,192.50$ & $6.36 \mathrm{E}+12$ & & \\
\hline \multicolumn{7}{|l|}{ ANOVA } \\
\hline Source of Variation & SS & $d f$ & MS & $F$ & $P$-value & F crit \\
\hline Between Groups & $6.53 \mathrm{E}+12$ & 1 & $6.53 E+12$ & 0.87 & 0.37 & 4.60 \\
\hline Within Groups & $1.05 \mathrm{E}+14$ & 14 & $7.53 E+12$ & & & \\
\hline Total & $1.12 \mathrm{E}+14$ & 15 & & & NO & \\
\hline
\end{tabular}




\begin{tabular}{|c|c|c|c|c|c|c|}
\hline \multicolumn{7}{|c|}{ TOTAL BASIN HIGHEST ELEVATION } \\
\hline Groups & Count & Sum & Average & Variance & & \\
\hline Debris Flow & 8 & $19,800.52$ & $2,475.07$ & $1,238.47$ & & \\
\hline No Debris Flow & 8 & $19,740.67$ & $2,467.58$ & $5,954.55$ & & \\
\hline \multicolumn{7}{|l|}{ ANOVA } \\
\hline Source of Variation & SS & $d f$ & MS & $F$ & P-value & F crit \\
\hline Between Groups & 223.88 & 1 & 223.88 & 0.06 & 0.81 & 4.60 \\
\hline Within Groups & $50,351.09$ & 14 & $3,596.51$ & & & \\
\hline Total & $50,574.96$ & 15 & & & NO & \\
\hline \multicolumn{7}{|c|}{ TOTAL BASIN LOWEST ELEVATION } \\
\hline Groups & Count & Sum & Average & Variance & & \\
\hline Debris Flow & 8 & $6,492.83$ & 811.60 & $20,085.49$ & & \\
\hline No Debris Flow & 8 & $6,748.47$ & 843.56 & $40,294.04$ & & \\
\hline \multicolumn{7}{|l|}{ ANOVA } \\
\hline Source of Variation & SS & $d f$ & $M S$ & $F$ & P-value & F crit \\
\hline Between Groups & $4,084.65$ & 1 & $4,084.65$ & 0.14 & 0.72 & 4.60 \\
\hline Within Groups & $422,656.67$ & 14 & $30,189.76$ & & & \\
\hline Total & $426,741.31$ & 15 & & & NO & \\
\hline \multicolumn{7}{|l|}{ TOTAL BASIN HEIGHT } \\
\hline Groups & Count & Sum & Average & Variance & & \\
\hline Debris Flow & 8 & $13,307.69$ & $1,663.46$ & $17,231.66$ & & \\
\hline No Debris Flow & 8 & $12,992.20$ & $1,624.02$ & $50,393.73$ & & \\
\hline \multicolumn{7}{|l|}{ ANOVA } \\
\hline Source of Variation & SS & $d f$ & $M S$ & $F$ & P-value & F crit \\
\hline Between Groups & $6,221.07$ & 1 & $6,221.07$ & 0.18 & 0.67 & 4.60 \\
\hline Within Groups & $473,377.74$ & 14 & $33,812.70$ & & & \\
\hline Total & $479,598.81$ & 15 & & & NO & \\
\hline
\end{tabular}




\begin{tabular}{|c|c|c|c|c|c|c|}
\hline \multicolumn{7}{|l|}{ TOTAL BASIN LENGTH } \\
\hline Groups & Count & Sum & Average & Variance & & \\
\hline Debris Flow & 8 & $66,265.72$ & $8,283.22$ & $4,561,879.92$ & & \\
\hline No Debris Flow & 8 & $55,947.17$ & $6,993.40$ & $5,500,241.05$ & & \\
\hline \multicolumn{7}{|l|}{ ANOVA } \\
\hline Source of Variation & SS & $d f$ & $M S$ & $F$ & $P$-value & F crit \\
\hline Between Groups & $6,654,536.14$ & 1 & $6,654,536.14$ & 1.32 & 0.27 & 4.60 \\
\hline Within Groups & $70,434,846.79$ & 14 & $5,031,060.48$ & & & \\
\hline Total & $77,089,382.93$ & 15 & & & NO & \\
\hline \multicolumn{7}{|l|}{ TOTAL BASIN GRADIENT } \\
\hline Groups & Count & Sum & Average & Variance & & \\
\hline Debris Flow & 8 & 1.66 & 0.21 & 0.00 & & \\
\hline No Debris Flow & 8 & 2.00 & 0.25 & 0.00 & & \\
\hline \multicolumn{7}{|l|}{ ANOVA } \\
\hline Source of Variation & SS & $d f$ & $M S$ & $F$ & P-value & F crit \\
\hline Between Groups & 0.007 & 1 & 0.007 & 2.53 & 0.13 & 4.60 \\
\hline Within Groups & 0.039 & 14 & 0.003 & & & \\
\hline Total & 0.046 & 15 & & & NO & \\
\hline \multicolumn{7}{|c|}{ TOTAL BASIN MELTON'S RUGGEDNESS NUMBER } \\
\hline Groups & Count & Sum & Average & Variance & & \\
\hline Debris Flow & 8 & 6.28 & 0.78 & 0.04 & & \\
\hline No Debris Flow & 8 & 6.94 & 0.87 & 0.04 & & \\
\hline \multicolumn{7}{|l|}{ ANOVA } \\
\hline Source of Variation & SS & $d f$ & MS & $F$ & $P$-value & F crit \\
\hline Between Groups & 0.03 & 1 & 0.03 & 0.68 & 0.42 & 4.60 \\
\hline Within Groups & 0.56 & 14 & 0.04 & & & \\
\hline Total & 0.59 & 15 & & & NO & \\
\hline
\end{tabular}




\begin{tabular}{|c|c|c|c|c|c|c|}
\hline \multicolumn{7}{|l|}{ UPPER BASIN AREA } \\
\hline Groups & Count & Sum & Average & Variance & & \\
\hline Debris Flow & 8 & $12,184,317.00$ & $1,523,039.63$ & $1.12 \mathrm{E}+12$ & & \\
\hline No Debris Flow & 8 & $8,356,479.00$ & $1,044,559.88$ & $4.18 \mathrm{E}+11$ & & \\
\hline \multicolumn{7}{|l|}{ ANOVA } \\
\hline Source of Variation & SS & $d f$ & MS & $F$ & $P$-value & F crit \\
\hline Between Groups & $9.16 \mathrm{E}+11$ & 1 & $9.16 \mathrm{E}+11$ & 1.19 & 0.29 & 4.60 \\
\hline Within Groups & $1.08 \mathrm{E}+13$ & 14 & $7.71 E+11$ & & & \\
\hline Total & $1.17 \mathrm{E}+13$ & 15 & & & NO & \\
\hline \multicolumn{7}{|c|}{ UPPER BASIN HIGHEST ELEVATION } \\
\hline Groups & Count & Sum & Average & Variance & & \\
\hline Debris Flow & 8 & $19,800.52$ & $2,475.07$ & $1,238.47$ & & \\
\hline No Debris Flow & 8 & $19,744.74$ & $2,468.09$ & $5,938.89$ & & \\
\hline \multicolumn{7}{|l|}{ ANOVA } \\
\hline Source of Variation & SS & $d f$ & MS & $F$ & P-value & F crit \\
\hline Between Groups & 194.46 & 1 & 194.46 & 0.05 & 0.82 & 4.60 \\
\hline Within Groups & $50,241.49$ & 14 & $3,588.68$ & & & \\
\hline Total & $50,435.95$ & 15 & & & NO & \\
\hline \multicolumn{7}{|c|}{ UPPER BASIN LOWEST ELEVATION } \\
\hline Groups & Count & Sum & Average & Variance & & \\
\hline Debris Flow & 8 & $10,435.50$ & $1,304.44$ & $15,373.04$ & & \\
\hline No Debris Flow & 8 & $10,961.98$ & $1,370.25$ & $8,252.93$ & & \\
\hline \multicolumn{7}{|l|}{ ANOVA } \\
\hline Source of Variation & SS & $d f$ & MS & $F$ & P-value & F crit \\
\hline Between Groups & $17,323.82$ & 1 & $17,323.82$ & 1.47 & 0.25 & 4.60 \\
\hline Within Groups & $165,381.79$ & 14 & $11,812.99$ & & & \\
\hline Total & $182,705.62$ & 15 & & & NO & \\
\hline
\end{tabular}




\begin{tabular}{|c|c|c|c|c|c|c|}
\hline \multicolumn{7}{|l|}{ UPPER BASIN HEIGHT } \\
\hline Groups & Count & Sum & Average & Variance & & \\
\hline Debris Flow & 8 & $9,365.02$ & $1,170.63$ & $12,287.44$ & & \\
\hline No Debris Flow & 8 & $8,782.76$ & $1,097.85$ & $14,017.44$ & & \\
\hline \multicolumn{7}{|l|}{ ANOVA } \\
\hline Source of Variation & SS & $d f$ & $M S$ & $F$ & P-value & F crit \\
\hline Between Groups & $21,189.17$ & 1 & $21,189.17$ & 1.61 & 0.23 & 4.60 \\
\hline Within Groups & $184,134.16$ & 14 & $13,152.44$ & & & \\
\hline Total & $205,323.33$ & 15 & & & NO & \\
\hline \multicolumn{7}{|l|}{ UPPER BASIN LENGTH } \\
\hline Groups & Count & Sum & Average & Variance & & \\
\hline Debris Flow & 8 & $22,937.10$ & $2,867.14$ & $192,418.94$ & & \\
\hline No Debris Flow & 8 & $21,078.56$ & $2,634.82$ & $271,030.87$ & & \\
\hline \multicolumn{7}{|l|}{ ANOVA } \\
\hline Source of Variation & SS & $d f$ & $M S$ & $F$ & P-value & F crit \\
\hline Between Groups & $215,885.64$ & 1 & $215,885.64$ & 0.93 & 0.35 & 4.60 \\
\hline Within Groups & $3,244,148.66$ & 14 & $231,724.90$ & & & \\
\hline Total & $3,460,034.30$ & 15 & & & NO & \\
\hline \multicolumn{7}{|l|}{ UPPER BASIN GRADIENT } \\
\hline Groups & Count & Sum & Average & Variance & & \\
\hline Debris Flow & 8 & 3.30 & 0.41 & 0.001 & & \\
\hline No Debris Flow & 8 & 3.41 & 0.43 & 0.004 & & \\
\hline \multicolumn{7}{|l|}{ ANOVA } \\
\hline Source of Variation & SS & $d f$ & MS & $F$ & P-value & F crit \\
\hline Between Groups & 0.001 & 1 & 0.001 & 0.33 & 0.57 & 4.60 \\
\hline Within Groups & 0.034 & 14 & 0.002 & & & \\
\hline Total & 0.035 & 15 & & & NO & \\
\hline
\end{tabular}




\begin{tabular}{|c|c|c|c|c|c|c|}
\hline \multicolumn{5}{|c|}{ UPPER BASIN MELTON'S RUGGEDNESS NUMBER } & & \\
\hline Groups & Count & Sum & Average & Variance & & \\
\hline Debris Flow & 8 & 8.68 & 1.08 & 0.10 & & \\
\hline No Debris Flow & 8 & 9.45 & 1.18 & 0.07 & & \\
\hline \multicolumn{7}{|l|}{ ANOVA } \\
\hline Source of Variation & SS & $d f$ & $M S$ & $F$ & P-value & F crit \\
\hline Between Groups & 0.04 & 1 & 0.04 & 0.43 & 0.52 & 4.60 \\
\hline Within Groups & 1.22 & 14 & 0.09 & & & \\
\hline Total & 1.26 & 15 & & & NO & \\
\hline \multicolumn{7}{|c|}{ UPPER BASIN WADNR GEOLOGY - ICE } \\
\hline Groups & Count & Sum & Average & Variance & & \\
\hline Debris Flow & 8 & 55.80 & 6.98 & 103.84 & & \\
\hline No Debris Flow & 8 & 93.93 & 11.74 & 168.13 & & \\
\hline \multicolumn{7}{|l|}{ ANOVA } \\
\hline Source of Variation & SS & $d f$ & $M S$ & $F$ & $P$-value & F crit \\
\hline Between Groups & 90.86 & 1 & 90.86 & 0.67 & 0.43 & 4.60 \\
\hline Within Groups & $1,903.84$ & 14 & 135.99 & & & \\
\hline Total & $1,994.70$ & 15 & & & NO & \\
\hline \multicolumn{7}{|c|}{ UPPER BASIN WADNR GEOLOGY - BEDROCK } \\
\hline Groups & Count & Sum & Average & Variance & & \\
\hline Debris Flow & 8 & 291.06 & 36.38 & 682.67 & & \\
\hline No Debris Flow & 8 & 378.02 & 47.25 & 661.92 & & \\
\hline \multicolumn{7}{|l|}{ ANOVA } \\
\hline Source of Variation & SS & $d f$ & MS & $F$ & P-value & F crit \\
\hline Between Groups & 472.67 & 1 & 472.67 & 0.70 & 0.42 & 4.60 \\
\hline Within Groups & $9,412.10$ & 14 & 672.29 & & & \\
\hline Total & $9,884.77$ & 15 & & & NO & \\
\hline
\end{tabular}




\begin{tabular}{|c|c|c|c|c|c|c|}
\hline \multicolumn{7}{|c|}{ UPPER BASIN WADNR GEOLOGY - UNCONSOLIDATED } \\
\hline Groups & Count & Sum & Average & Variance & & \\
\hline Debris Flow & 8 & 453.60 & 56.70 & 723.87 & & \\
\hline No Debris Flow & 8 & 328.51 & 41.06 & 590.04 & & \\
\hline \multicolumn{7}{|l|}{ ANOVA } \\
\hline Source of Variation & SS & $d f$ & MS & $F$ & P-value & F crit \\
\hline Between Groups & 978.01 & 1 & 978.01 & 1.49 & 0.24 & 4.60 \\
\hline Within Groups & $9,197.35$ & 14 & 656.95 & & & \\
\hline Total & $10,175.36$ & 15 & & & NO & \\
\hline \multicolumn{7}{|c|}{ UPPER BASIN GEOLOGY - ICE AND SNOWPACK } \\
\hline Groups & Count & Sum & Average & Variance & & \\
\hline Debris Flow & 8 & 44.21 & 5.53 & 11.05 & & \\
\hline No Debris Flow & 8 & 54.08 & 6.76 & 7.62 & & \\
\hline \multicolumn{7}{|l|}{ ANOVA } \\
\hline Source of Variation & SS & $d f$ & $M S$ & $F$ & P-value & F crit \\
\hline Between Groups & 6.08 & 1 & 6.08 & 0.65 & 0.43 & 4.60 \\
\hline Within Groups & 130.73 & 14 & 9.34 & & & \\
\hline Total & 136.81 & 15 & & & NO & \\
\hline \multicolumn{7}{|c|}{ UPPER BASIN GEOLOGY - CONSOLIDATED BEDROCK } \\
\hline Groups & Count & Sum & Average & Variance & & \\
\hline Debris Flow & 8 & 164.42 & 20.55 & 260.17 & & \\
\hline No Debris Flow & 8 & 211.97 & 26.50 & 316.00 & & \\
\hline \multicolumn{7}{|l|}{ ANOVA } \\
\hline Source of Variation & SS & $d f$ & $M S$ & $F$ & $P$-value & F crit \\
\hline Between Groups & 141.33 & 1 & 141.33 & 0.49 & 0.50 & 4.60 \\
\hline Within Groups & $4,033.18$ & 14 & 288.08 & & & \\
\hline Total & $4,174.51$ & 15 & & & NO & \\
\hline
\end{tabular}




\begin{tabular}{|c|c|c|c|c|c|c|}
\hline \multicolumn{7}{|c|}{ UPPER BASIN GEOLOGY - UNCONSOLIDATED } \\
\hline Groups & Count & Sum & Average & Variance & & \\
\hline Debris Flow & 8 & 591.37 & 73.92 & 353.19 & & \\
\hline No Debris Flow & 8 & 533.95 & 66.74 & 367.48 & & \\
\hline \multicolumn{7}{|l|}{ ANOVA } \\
\hline Source of Variation & SS & $d f$ & MS & $F$ & P-value & F crit \\
\hline Between Groups & 206.06 & 1 & 206.06 & 0.57 & 0.46 & 4.60 \\
\hline Within Groups & $5,044.69$ & 14 & 360.33 & & & \\
\hline Total & $5,250.75$ & 15 & & & NO & \\
\hline \multicolumn{7}{|c|}{ UPPER BASIN PERCENT VEGETATION } \\
\hline Groups & Count & Sum & Average & Variance & & \\
\hline Debris Flow & 8 & 14.57 & 1.82 & 9.57 & & \\
\hline No Debris Flow & 8 & 17.51 & 2.19 & 9.81 & & \\
\hline \multicolumn{7}{|l|}{ ANOVA } \\
\hline Source of Variation & SS & $d f$ & $M S$ & $F$ & $P$-value & F crit \\
\hline Between Groups & 0.54 & 1 & 0.54 & 0.06 & 0.82 & 4.60 \\
\hline Within Groups & 135.63 & 14 & 9.69 & & & \\
\hline Total & 136.17 & 15 & & & NO & \\
\hline \multicolumn{7}{|c|}{ UPPER BASIN PERCENT STEEP SLOPES } \\
\hline Groups & Count & Sum & Average & Variance & & \\
\hline Debris Flow & 8 & 328.11 & 41.01 & 53.10 & & \\
\hline No Debris Flow & 8 & 220.95 & 27.62 & 79.09 & & \\
\hline \multicolumn{7}{|l|}{ ANOVA } \\
\hline Source of Variation & SS & $d f$ & $M S$ & $F$ & P-value & F crit \\
\hline Between Groups & 717.66 & 1 & 717.66 & 10.86 & 0.005 & 4.60 \\
\hline Within Groups & 925.35 & 14 & 66.10 & & & \\
\hline Total & $1,643.01$ & 15 & & & YES & \\
\hline
\end{tabular}




\begin{tabular}{|c|c|c|c|c|c|c|}
\hline \multicolumn{7}{|c|}{ UPPER BASIN AVERAGE ANNUAL PRECIPITATION } \\
\hline Groups & Count & Sum & Average & Variance & & \\
\hline Debris Flow & 8 & 31.11 & 3.89 & 0.01 & & \\
\hline No Debris Flow & 8 & 31.01 & 3.88 & 0.05 & & \\
\hline \multicolumn{7}{|l|}{ ANOVA } \\
\hline Source of Variation & SS & $d f$ & $M S$ & $F$ & P-value & F crit \\
\hline Between Groups & 0.001 & 1 & 0.001 & 0.02 & 0.89 & 4.60 \\
\hline Within Groups & 0.47 & 14 & 0.03 & & & \\
\hline Total & 0.47 & 15 & & & NO & \\
\hline
\end{tabular}

กั 
Table C.2: Full one-way ANOVA results of comparison between the bulk density and sieve analysis of soil samples taken from drainage basins that experienced 2006 debris flows and samples taken from drainage basins that did not experience a 2006 debris flow.

\begin{tabular}{|c|c|c|c|c|c|c|}
\hline \multicolumn{7}{|l|}{ BULK DENSITY } \\
\hline Groups & Count & Sum & Average & Variance & & \\
\hline Debris Flow & 5 & 10.30 & 2.06 & 0.02 & & \\
\hline No Debris Flow & 3 & 5.50 & 1.83 & 0.04 & & \\
\hline \multicolumn{7}{|l|}{ ANOVA } \\
\hline Source of Variation & SS & $d f$ & $M S$ & $F$ & $P$-value & F crit \\
\hline Between Groups & 0.10 & 1 & 0.10 & 3.64 & 0.10 & 5.99 \\
\hline Within Groups & 0.16 & 6 & 0.03 & & & \\
\hline Total & 0.26 & 7 & & & NO & \\
\hline \multicolumn{7}{|l|}{ GRAVEL } \\
\hline Groups & Count & Sum & Average & Variance & & \\
\hline Debris Flow & 5 & 1.82 & 0.36 & $2.41 \mathrm{E}-03$ & & \\
\hline No Debris Flow & 3 & 1.15 & 0.38 & $9.96 \mathrm{E}-04$ & & \\
\hline \multicolumn{7}{|l|}{ ANOVA } \\
\hline Source of Variation & SS & $d f$ & $M S$ & $F$ & $P$-value & F crit \\
\hline Between Groups & $6.68 \mathrm{E}-04$ & 1 & 0.001 & 0.34 & 0.58 & 5.99 \\
\hline Within Groups & $1.16 \mathrm{E}-02$ & 6 & 0.002 & & & \\
\hline Total & $1.23 \mathrm{E}-02$ & 7 & & & NO & \\
\hline \multicolumn{7}{|l|}{ SAND } \\
\hline Groups & Count & Sum & Average & Variance & & \\
\hline Debris Flow & 5 & 2.87 & 0.57 & $1.86 \mathrm{E}-03$ & & \\
\hline No Debris Flow & 3 & 1.63 & 0.54 & $4.44 \mathrm{E}-04$ & & \\
\hline \multicolumn{7}{|l|}{ ANOVA } \\
\hline Source of Variation & SS & $d f$ & $M S$ & $F$ & $P$-value & F crit \\
\hline Between Groups & $1.83 \mathrm{E}-03$ & 1 & $1.83 \mathrm{E}-03$ & 1.32 & 0.29 & 5.99 \\
\hline Within Groups & $8.34 \mathrm{E}-03$ & 6 & $1.39 \mathrm{E}-03$ & & & \\
\hline Total & $1.02 \mathrm{E}-02$ & 7 & & & NO & \\
\hline
\end{tabular}




\begin{tabular}{|c|c|c|c|c|c|c|}
\hline \multicolumn{7}{|l|}{ SILT \& CLAY } \\
\hline Groups & Count & Sum & Average & Variance & & \\
\hline Debris Flow & 5 & 0.36 & 0.07 & $1.18 \mathrm{E}-03$ & & \\
\hline No Debris Flow & 3 & 0.23 & 0.08 & 4.10E-04 & & \\
\hline \multicolumn{7}{|l|}{ ANOVA } \\
\hline Source of Variation & SS & $d f$ & $M S$ & $F$ & $P$-value & F crit \\
\hline Between Groups & 4.37E-05 & 1 & 4.37E-05 & 0.05 & 0.84 & 5.99 \\
\hline Within Groups & $5.54 \mathrm{E}-03$ & 6 & $9.23 \mathrm{E}-04$ & & & \\
\hline Total & $5.58 \mathrm{E}-03$ & 7 & & & NO & \\
\hline
\end{tabular}


APPENDIX D - MULTIPLE REGRESSION FOR MOUNT ST. HELENS 
Table D.1: Raw basin attribute data used for multiple logistic regression test \# 6C.

\begin{tabular}{|c|c|c|c|c|c|c|c|c|}
\hline Drainage & 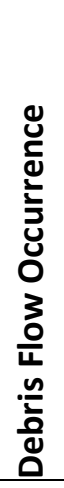 & $\begin{array}{l}\text { 坖 } \\
\frac{.0}{0} \\
\frac{\pi}{0}\end{array}$ & 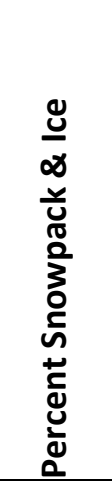 & 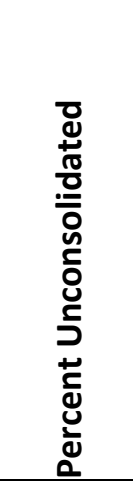 & 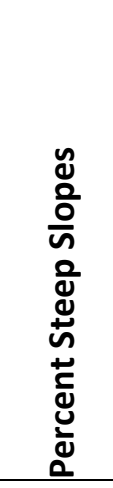 & 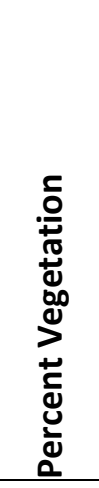 & 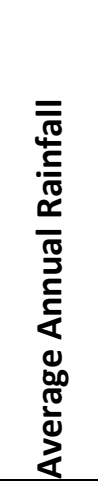 & 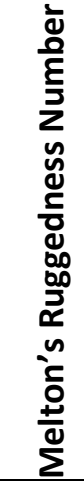 \\
\hline & $Y$ & $x_{1}$ & $X_{11}$ & $X_{13}$ & $X_{4}$ & $x_{5}$ & $x_{6}$ & $x_{7}$ \\
\hline Nelson Glacier & 0 & 0.52 & 5.69 & 67.68 & 31.84 & 0.00 & 3.50 & 0.95 \\
\hline Ape Canyon & 0 & 0.50 & 11.54 & 66.87 & 38.67 & 0.00 & 3.50 & 1.24 \\
\hline Muddy River & 1 & 0.42 & 5.25 & 62.79 & 43.93 & 0.65 & 3.70 & 0.92 \\
\hline Shoestring Glacier & 1 & 0.37 & 5.11 & 71.48 & 51.39 & 0.70 & 3.80 & 1.16 \\
\hline Pine Creek & 1 & 0.40 & 6.78 & 54.51 & 33.55 & 1.20 & 3.93 & 0.87 \\
\hline Worm Flows & 0 & 0.34 & 8.25 & 39.04 & 33.13 & 0.44 & 4.00 & 1.09 \\
\hline June Lake & 1 & 0.38 & 11.82 & 46.18 & 43.38 & 0.00 & 4.00 & 1.52 \\
\hline Swift Creek & 0 & 0.42 & 8.99 & 42.12 & 36.16 & 3.20 & 4.00 & 0.83 \\
\hline Snowfield & 0 & 0.38 & 6.35 & 76.09 & 26.61 & 7.35 & 4.00 & 1.23 \\
\hline Dryer Glacier & 0 & 0.38 & 6.11 & 86.79 & 16.07 & 6.51 & 4.00 & 0.99 \\
\hline Little Kalama & 0 & 0.43 & 4.34 & 62.37 & 23.44 & 0.00 & 4.00 & 1.51 \\
\hline Kalama & 0 & 0.44 & 2.80 & 93.00 & 15.03 & 0.00 & 4.00 & 1.61 \\
\hline Butte Camp Dome & 1 & 0.47 & 4.75 & 78.31 & 35.53 & 0.00 & 4.00 & 0.83 \\
\hline Blue Lake & 1 & 0.43 & 3.73 & 93.48 & 33.53 & 2.18 & 3.96 & 1.13 \\
\hline Sheep Creek & 1 & 0.42 & 0.00 & 100.00 & 36.45 & 0.57 & 3.94 & 1.55 \\
\hline South Toutle & 1 & 0.39 & 6.77 & 84.62 & 50.36 & 9.28 & 3.77 & 0.70 \\
\hline
\end{tabular}


Table D.2: Normalized basin attribute data used in multiple logistic regression test \# 6C.

\begin{tabular}{|c|c|c|c|c|c|c|c|c|}
\hline Drainage & 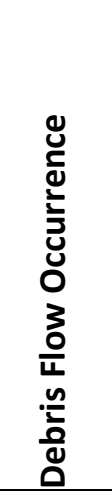 & 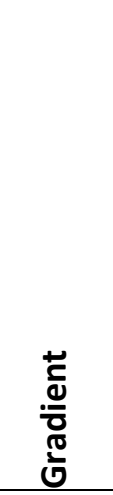 & 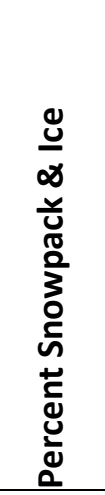 & 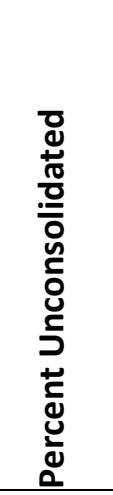 & 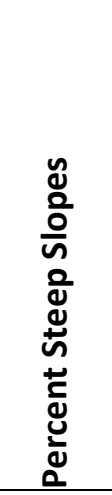 & 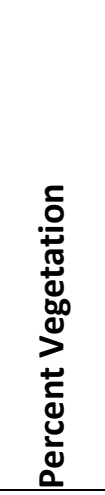 & 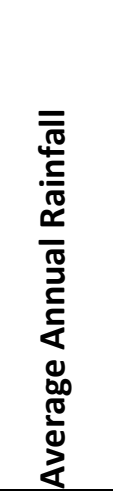 & 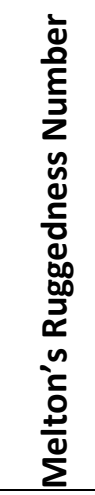 \\
\hline & $Y$ & $x_{1}$ & $X_{11}$ & $X_{13}$ & $X_{4}$ & $X_{5}$ & $x_{6}$ & $x_{7}$ \\
\hline Nelson Glacier & -0.97 & 2.07 & -0.15 & -0.14 & -0.24 & -0.67 & -2.17 & -0.63 \\
\hline Ape Canyon & -0.97 & 1.73 & 1.79 & -0.18 & 0.42 & -0.67 & -2.16 & 0.38 \\
\hline Muddy River & 0.97 & 0.12 & -0.29 & -0.40 & 0.92 & -0.45 & -1.01 & -0.74 \\
\hline Shoestring Glacier & 0.97 & -0.99 & -0.34 & 0.06 & 1.63 & -0.43 & -0.49 & 0.08 \\
\hline Pine Creek & 0.97 & -0.33 & 0.21 & -0.85 & -0.07 & -0.27 & 0.29 & -0.92 \\
\hline Worm Flows & -0.97 & -1.70 & 0.70 & -1.67 & -0.11 & -0.52 & 0.68 & -0.16 \\
\hline June Lake & 0.97 & -0.71 & 1.88 & -1.29 & 0.87 & -0.67 & 0.68 & 1.35 \\
\hline Swift Creek & -0.97 & 0.07 & 0.94 & -1.51 & 0.18 & 0.40 & 0.68 & -1.04 \\
\hline Snowfield & -0.97 & -0.90 & 0.07 & 0.31 & -0.74 & 1.78 & 0.68 & 0.35 \\
\hline Dryer Glacier & -0.97 & -0.77 & -0.01 & 0.88 & -1.74 & 1.50 & 0.68 & -0.50 \\
\hline Little Kalama & -0.97 & 0.16 & -0.60 & -0.43 & -1.04 & -0.67 & 0.68 & 1.29 \\
\hline Kalama & -0.97 & 0.52 & -1.11 & 1.21 & -1.84 & -0.67 & 0.65 & 1.65 \\
\hline Butte Camp Dome & 0.97 & 1.07 & -0.46 & 0.43 & 0.12 & -0.67 & 0.67 & -1.05 \\
\hline Blue Lake & 0.97 & 0.13 & -0.80 & 1.24 & -0.08 & 0.06 & 0.44 & 0.00 \\
\hline Sheep Creek & 0.97 & 0.11 & -2.03 & 1.59 & 0.20 & -0.48 & 0.33 & 1.44 \\
\hline South Toutle & 0.97 & -0.57 & 0.21 & 0.76 & 1.53 & 2.41 & -0.63 & -1.48 \\
\hline
\end{tabular}


Table D.3: Results of the first iteration of the multiple logistic regression. The results of the Wald's Test are also shown in the last column with the least significant regression coefficient indicated in red.

\begin{tabular}{|c|c|c|c|c|c|c|c|c|c|}
\hline \multicolumn{2}{|c|}{ Regression Statistics } & & & & & & & & \\
\hline Multiple R & 0.90 & & & & & & & & \\
\hline R Square & 0.81 & & & & & & & & \\
\hline Adjusted R Square & 0.64 & & & & & & & & \\
\hline Standard Error & 0.60 & & & & & & & & \\
\hline Observations & 16 & & & & & & & & \\
\hline \multicolumn{10}{|l|}{ ANOVA } \\
\hline & $d f$ & SS & MS & $F$ & Significance $F$ & & & & \\
\hline Regression & 7 & 12.08 & 1.73 & 4.73 & $2.21 \mathrm{E}-02$ & & & & \\
\hline Residual & 8 & 2.92 & 0.36 & & & & & & \\
\hline \multirow[t]{3}{*}{ Total } & 15 & 15 & & & & & & & \\
\hline & & Standard & & & & Upper & Lower & Upper & Wald's \\
\hline & Coefficients & Error & t Stat & $P$-value & Lower 95\% & $95 \%$ & $95.0 \%$ & $95.0 \%$ & Test \\
\hline Intercept & $1.17 \mathrm{E}-15$ & 0.15 & $7.78 \mathrm{E}-15$ & 1.00 & -0.35 & 0.35 & -0.35 & 0.35 & \\
\hline $\mathrm{X} 1$ & -0.12 & 0.29 & -0.40 & 0.70 & -0.78 & 0.55 & -0.78 & 0.55 & 0.16 \\
\hline $\mathrm{X} 11$ & 0.09 & 0.29 & 0.32 & 0.76 & -0.57 & 0.75 & -0.57 & 0.75 & 0.10 \\
\hline $\mathrm{X} 13$ & 0.68 & 0.34 & 2.02 & 0.08 & -0.10 & 1.46 & -0.10 & 1.46 & 4.07 \\
\hline X4 & 0.86 & 0.21 & 4.10 & $3.45 E-03$ & 0.38 & 1.35 & 0.38 & 1.35 & 16.80 \\
\hline X5 & -0.48 & 0.29 & -1.66 & 0.13 & -1.16 & 0.19 & -1.16 & 0.19 & 2.76 \\
\hline$x 6$ & 0.47 & 0.25 & 1.90 & 0.09 & -0.10 & 1.05 & -0.10 & 1.05 & 3.60 \\
\hline$x 7$ & -0.32 & 0.23 & -1.38 & 0.21 & -0.85 & 0.21 & -0.85 & 0.21 & 1.89 \\
\hline
\end{tabular}


Table D.4: Results of the last iteration of the multiple logistic regression. The results of the Wald's Test are also shown in the last column, designating $X_{4}$ as the most significant basin attribute factor.

\begin{tabular}{lr}
\hline \multicolumn{2}{c}{ Regression Statistics } \\
\hline Multiple R & 0.75 \\
R Square & 0.57 \\
Adjusted R Square & 0.50 \\
Standard Error & 0.70 \\
Observations & 16 \\
\hline
\end{tabular}

\begin{tabular}{lrrrrr} 
ANOVA & \multicolumn{6}{c}{ SS } & \multicolumn{1}{c}{ S } & Significance $F$ \\
\hline Regression & 2 & 8.55 & 4.27 & 8.61 & 0.004 \\
Residual & 13 & 6.45 & 0.50 & & \\
Total & 15 & 15 & & & \\
\hline
\end{tabular}

\begin{tabular}{|c|c|c|c|c|c|c|c|c|c|}
\hline & & Standard & & & & Upper & Lower & Upper & Wald's \\
\hline & Coefficients & Error & t Stat & P-value & Lower 95\% & $95 \%$ & $95.0 \%$ & $95.0 \%$ & Test \\
\hline Intercept & $1.73 \mathrm{E}-16$ & 0.18 & $9.80 \mathrm{E}-16$ & 1.00 & -0.38 & 0.38 & -0.38 & 0.38 & \\
\hline $\mathrm{X} 13$ & 0.38 & 0.19 & 2.00 & 0.07 & -0.03 & 0.78 & -0.03 & 0.78 & 4.02 \\
\hline$X 4$ & 0.75 & 0.19 & 4.00 & 0.002 & 0.35 & 1.15 & 0.35 & 1.15 & 16.03 \\
\hline
\end{tabular}


APPENDIX E - COMBINED MULTIPLE REGRESSION 
Table E.1: Raw basin attribute data used for combined multiple logistic regression.

\begin{tabular}{|c|c|c|c|c|c|c|c|c|}
\hline Mountain & Drainage & 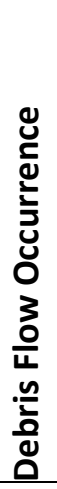 & 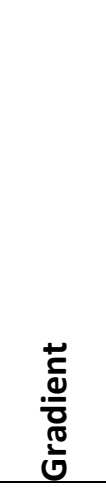 & 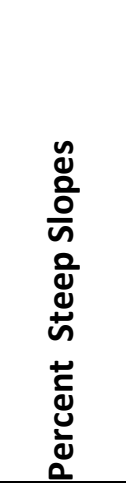 & 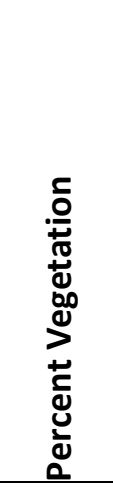 & 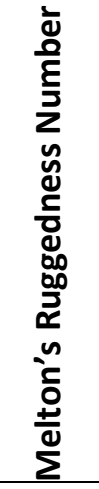 & 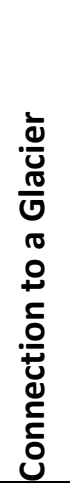 & 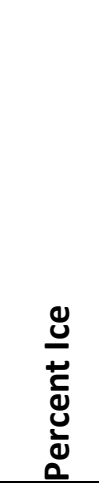 \\
\hline & & $Y$ & $X_{1}$ & $X_{2}$ & $X_{3}$ & $X_{4}$ & $X_{5}$ & $X_{6}$ \\
\hline Helens & Nelson Glacier & 0 & 0.52 & 31.84 & 0.00 & 0.95 & 0 & 15.25 \\
\hline Helens & Ape Canyon & 0 & 0.50 & 38.67 & 0.00 & 1.24 & 0 & 38.73 \\
\hline Helens & Muddy River & 1 & 0.42 & 43.93 & 0.65 & 0.92 & 0 & 0.00 \\
\hline Helens & Shoestring Glacier & 1 & 0.37 & 51.39 & 0.70 & 1.16 & 0 & 18.57 \\
\hline Helens & Pine Creek & 1 & 0.40 & 33.55 & 1.20 & 0.87 & 0 & 0.10 \\
\hline Helens & Worm Flows & 0 & 0.34 & 33.13 & 0.44 & 1.09 & 0 & 1.28 \\
\hline Helens & June Lake & 1 & 0.38 & 43.38 & 0.00 & 1.52 & 1 & 24.97 \\
\hline Helens & Swift Creek & 0 & 0.42 & 36.16 & 3.20 & 0.83 & 0 & 13.59 \\
\hline Helens & Snowfield & 0 & 0.38 & 26.61 & 7.35 & 1.23 & 0 & 17.35 \\
\hline Helens & Dryer Glacier & 0 & 0.38 & 16.07 & 6.51 & 0.99 & 0 & 7.74 \\
\hline Helens & Little Kalama & 0 & 0.43 & 23.44 & 0.00 & 1.51 & 0 & 0.00 \\
\hline Helens & Kalama & 0 & 0.44 & 15.03 & 0.00 & 1.61 & 0 & 0.00 \\
\hline Helens & Butte Camp Dome & 1 & 0.47 & 35.53 & 0.00 & 0.83 & 0 & 0.00 \\
\hline Helens & Blue Lake & 1 & 0.43 & 33.53 & 2.18 & 1.13 & 0 & 0.00 \\
\hline Helens & Sheep Creek & 1 & 0.42 & 36.45 & 0.57 & 1.55 & 0 & 0.00 \\
\hline Helens & South Toutle & 1 & 0.39 & 50.36 & 9.28 & 0.70 & 0 & 12.17 \\
\hline Adams & Adams Creek & 1 & 0.30 & 11.00 & 6.00 & 0.67 & 1 & 52.00 \\
\hline Adams & Big Muddy & 1 & 0.36 & 31.00 & 2.00 & 0.60 & 1 & 44.00 \\
\hline Adams & Bird Creek & 0 & 0.19 & 1.00 & 38.00 & 0.31 & 0 & 0.00 \\
\hline Adams & Cascade Creek & 0 & 0.37 & 11.00 & 6.00 & 0.78 & 1 & 19.00 \\
\hline Adams & Crofton Creek & 0 & 0.40 & 24.00 & 14.00 & 0.72 & 1 & 10.00 \\
\hline Adams & East Fork & 0 & 0.47 & 30.00 & 6.00 & 0.86 & 0 & 29.00 \\
\hline Adams & Gotchen Creek & 0 & 0.25 & 7.00 & 9.00 & 0.35 & 0 & 8.00 \\
\hline Adams & Hellroaring Creek & 0 & 0.29 & 16.00 & 29.00 & 0.49 & 1 & 22.00 \\
\hline Adams & Horeshoe & 0 & 0.36 & 8.00 & 0.00 & 0.80 & 0 & 6.00 \\
\hline Adams & Killen Creek & 0 & 0.23 & 3.00 & 18.00 & 0.43 & 0 & 11.00 \\
\hline Adams & Lewis Creek & 1 & 0.29 & 8.00 & 9.00 & 0.61 & 1 & 31.00 \\
\hline Adams & Little Muddy & 1 & 0.30 & 8.00 & 44.00 & 0.47 & 1 & 18.00 \\
\hline Adams & Morrison Creek & 0 & 0.36 & 9.00 & 6.00 & 0.70 & 0 & 11.00 \\
\hline Adams & Muddy Fork & 1 & 0.62 & 20.00 & 0.00 & 0.42 & 1 & 49.00 \\
\hline
\end{tabular}




\begin{tabular}{ll|rrrrrrr} 
Adams & Riley Creek & 0 & 0.34 & 10.00 & 28.00 & 0.63 & 1 & 17.00 \\
Adams & Rusk Creek & 1 & 0.40 & 25.00 & 9.00 & 0.75 & 1 & 26.00 \\
Adams & Salt Creek & 1 & 0.38 & 22.00 & 0.00 & 0.79 & 1 & 39.00 \\
Adams & Trappers Creek & 0 & 0.18 & 0.00 & 44.00 & 0.34 & 0 & 0.00 \\
Hood & Clark & 1 & 16.00 & 27.00 & 27.00 & 0.68 & 1 & 27.00 \\
Hood & Coe & 0 & 25.00 & 10.00 & 25.00 & 0.53 & 1 & 40.00 \\
Hood & Eliot & 1 & 23.00 & 18.00 & 4.00 & 0.85 & 1 & 38.00 \\
Hood & Ladd & 1 & 19.00 & 11.00 & 14.00 & 0.33 & 1 & 30.00 \\
Hood & Muddy & 0 & 30.00 & 12.00 & 32.00 & 0.70 & 1 & 34.00 \\
Hood & Newton & 1 & 15.00 & 23.00 & 24.00 & 0.72 & 1 & 37.00 \\
Hood & Polallie & 0 & 17.00 & 6.00 & 66.00 & 0.46 & 0 & 13.00 \\
Hood & Salmon & 1 & 23.00 & 9.00 & 4.00 & 0.43 & 1 & 33.00 \\
Hood & Sandy & 1 & 27.00 & 30.00 & 8.00 & 0.44 & 1 & 38.00 \\
Hood & White & 1 & 18.00 & 42.00 & 2.00 & 0.75 & 1 & 24.00 \\
Hood & Zig Zag & 0 & 25.00 & 46.00 & 16.00 & 0.40 & 0 & 25.00 \\
\hline
\end{tabular}


Table E.2: Normalized basin attribute data used in combined multiple logistic regression.

\begin{tabular}{|c|c|c|c|c|c|c|c|}
\hline Drainage & 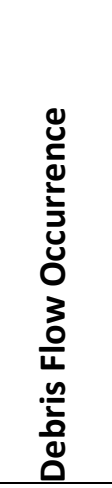 & 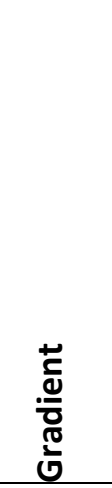 & 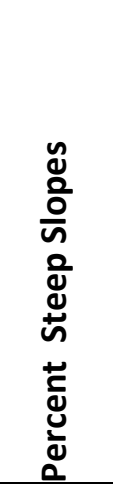 & 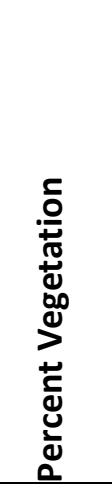 & 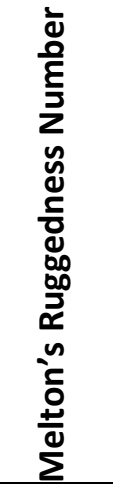 & 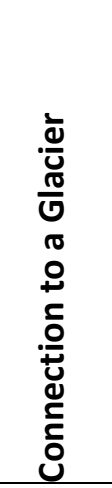 & 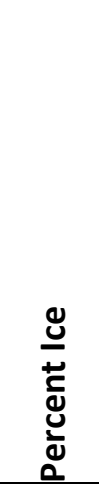 \\
\hline & $Y$ & $x_{1}$ & $x_{2}$ & $x_{3}$ & $x_{4}$ & $X_{5}$ & $x_{6}$ \\
\hline Nelson Glacier & -0.97 & -0.53 & 0.64 & -0.78 & 0.50 & -0.92 & -0.28 \\
\hline Ape Canyon & -0.97 & -0.53 & 1.12 & -0.78 & 1.35 & -0.92 & 1.26 \\
\hline Muddy River & 1.01 & -0.54 & 1.50 & -0.73 & 0.40 & -0.92 & -1.29 \\
\hline Shoestring Glacier & 1.01 & -0.55 & 2.02 & -0.73 & 1.09 & -0.92 & -0.07 \\
\hline Pine Creek & 1.01 & -0.54 & 0.76 & -0.70 & 0.25 & -0.92 & -1.28 \\
\hline Worm Flows & -0.97 & -0.55 & 0.73 & -0.75 & 0.89 & -0.92 & -1.20 \\
\hline June Lake & 1.01 & -0.54 & 1.46 & -0.78 & 2.16 & 1.06 & 0.35 \\
\hline Swift Creek & -0.97 & -0.54 & 0.94 & -0.56 & 0.15 & -0.92 & -0.39 \\
\hline Snowfield & -0.97 & -0.55 & 0.27 & -0.28 & 1.32 & -0.92 & -0.15 \\
\hline Dryer Glacier & -0.97 & -0.54 & -0.48 & -0.34 & 0.61 & -0.92 & -0.78 \\
\hline Little Kalama & -0.97 & -0.54 & 0.04 & -0.78 & 2.12 & -0.92 & -1.29 \\
\hline Kalama & -0.97 & -0.54 & -0.55 & -0.78 & 2.42 & -0.92 & -1.29 \\
\hline Butte Camp Dome & 1.01 & -0.54 & 0.90 & -0.78 & 0.14 & -0.92 & -1.29 \\
\hline Blue Lake & 1.01 & -0.54 & 0.76 & -0.63 & 1.02 & -0.92 & -1.29 \\
\hline Sheep Creek & 1.01 & -0.54 & 0.97 & -0.74 & 2.24 & -0.92 & -1.29 \\
\hline South Toutle & 1.01 & -0.54 & 1.95 & -0.16 & -0.22 & -0.92 & -0.49 \\
\hline Adams Creek & 1.01 & -0.55 & -0.84 & -0.37 & -0.32 & 1.06 & 2.13 \\
\hline Big Muddy & 1.01 & -0.55 & 0.58 & -0.64 & -0.53 & 1.06 & 1.60 \\
\hline Bird Creek & -0.97 & -0.56 & -1.55 & 1.76 & -1.37 & -0.92 & -1.29 \\
\hline Cascade Creek & -0.97 & -0.55 & -0.84 & -0.37 & 0.00 & 1.06 & -0.04 \\
\hline Crofton Creek & -0.97 & -0.54 & 0.08 & 0.16 & -0.18 & 1.06 & -0.63 \\
\hline East Fork & -0.97 & -0.54 & 0.51 & -0.37 & 0.23 & -0.92 & 0.62 \\
\hline Gotchen Creek & -0.97 & -0.56 & -1.12 & -0.17 & -1.26 & -0.92 & -0.76 \\
\hline Hellroaring Creek & -0.97 & -0.55 & -0.48 & 1.16 & -0.85 & 1.06 & 0.16 \\
\hline Horeshoe & -0.97 & -0.55 & -1.05 & -0.78 & 0.06 & -0.92 & -0.89 \\
\hline Killen Creek & -0.97 & -0.56 & -1.40 & 0.43 & -1.02 & -0.92 & -0.56 \\
\hline Lewis Creek & 1.01 & -0.55 & -1.05 & -0.17 & -0.50 & 1.06 & 0.75 \\
\hline Little Muddy & 1.01 & -0.55 & -1.05 & 2.16 & -0.91 & 1.06 & -0.10 \\
\hline Morrison Creek & -0.97 & -0.55 & -0.98 & -0.37 & -0.24 & -0.92 & -0.56 \\
\hline Muddy Fork & 1.01 & -0.52 & -0.20 & -0.78 & -1.05 & 1.06 & 1.93 \\
\hline
\end{tabular}




Riley Creek
Rusk Creek
Salt Creek
Trappers Creek
Clark
Coe
Eliot
Ladd
Muddy
Newton
Polallie
Salmon
Sandy
White
Zig Zag

\begin{tabular}{|rrrrrrr}
-0.97 & -0.55 & -0.91 & 1.10 & -0.44 & 1.06 & -0.17 \\
1.01 & -0.54 & 0.15 & -0.17 & -0.09 & 1.06 & 0.42 \\
1.01 & -0.54 & -0.06 & -0.78 & 0.03 & 1.06 & 1.28 \\
-0.97 & -0.57 & -1.62 & 2.16 & -1.29 & -0.92 & -1.29 \\
1.01 & 1.09 & 0.30 & 1.03 & -0.29 & 1.06 & 0.49 \\
-0.97 & 2.04 & -0.91 & 0.90 & -0.73 & 1.06 & 1.34 \\
1.01 & 1.83 & -0.34 & -0.51 & 0.20 & 1.06 & 1.21 \\
1.01 & 1.41 & -0.84 & 0.16 & -1.32 & 1.06 & 0.68 \\
-0.97 & 2.56 & -0.77 & 1.36 & -0.24 & 1.06 & 0.95 \\
1.01 & 0.99 & 0.01 & 0.83 & -0.18 & 1.06 & 1.14 \\
-0.97 & 1.20 & -1.19 & 3.63 & -0.94 & -0.92 & -0.43 \\
1.01 & 1.83 & -0.98 & -0.51 & -1.02 & 1.06 & 0.88 \\
1.01 & 2.25 & 0.51 & -0.24 & -0.99 & 1.06 & 1.21 \\
1.01 & 1.30 & 1.36 & -0.64 & -0.09 & 1.06 & 0.29 \\
-0.97 & 2.04 & 1.64 & 0.29 & -1.11 & -0.92 & 0.36
\end{tabular}


Table E.3: Results of the first iteration of the combined multiple logistic regression. The results of the Wald's Test are also shown in the last column with the least significant regression coefficient indicated in red.

\begin{tabular}{lr}
\hline \multicolumn{2}{c}{ Regression Statistics } \\
\hline Multiple R & 0.65 \\
R Square & 0.42 \\
Adjusted R Square & 0.33 \\
Standard Error & 0.82 \\
Observations & 45 \\
\hline
\end{tabular}

\begin{tabular}{|c|c|c|c|c|c|}
\hline & $d f$ & SS & $M S$ & $F$ & Significance $F$ \\
\hline Regression & 6 & 18.37 & 3.06 & 4.54 & 0.001 \\
\hline Residual & 38 & 25.63 & 0.67 & & \\
\hline Total & 44 & 44 & & & \\
\hline
\end{tabular}

\begin{tabular}{lrrrrrrrrr}
\hline & Coefficients & Standard Error & \multicolumn{1}{c}{ t Stat } & P-value & Lower 95\% & \multicolumn{1}{c}{ Upper } & $\begin{array}{c}\text { Lower } \\
\text { 95.0\% }\end{array}$ & $\begin{array}{c}\text { Upper } \\
95.0 \%\end{array}$ & $\begin{array}{c}\text { Wald's } \\
\text { Test }\end{array}$ \\
\hline Intercept & $7.11 \mathrm{E}-17$ & 0.12 & $5.81 \mathrm{E}-16$ & 1.00 & -0.25 & 0.25 & -0.25 & 0.25 & \\
X1 & -0.05 & 0.15 & -0.33 & 0.74 & -0.35 & 0.25 & -0.35 & 0.25 & 0.11 \\
X2 & 0.47 & 0.16 & 2.96 & 0.01 & 0.15 & 0.78 & 0.15 & 0.78 & 8.75 \\
X3 & -0.18 & 0.17 & -1.09 & 0.28 & -0.52 & 0.16 & -0.52 & 0.16 & 1.19 \\
X4 & -0.18 & 0.17 & -1.09 & 0.28 & -0.52 & 0.16 & -0.52 & 0.16 & 1.19 \\
X5 & 0.58 & 0.19 & 3.15 & 0.003 & 0.21 & 0.96 & 0.21 & 0.96 & 9.93 \\
X6 & -0.11 & 0.19 & -0.57 & 0.57 & -0.50 & 0.28 & -0.50 & 0.28 & 0.32 \\
\hline
\end{tabular}


Table E.4: Results of the last iteration of the combined multiple logistic regression. The results of the Wald's Test are also shown in the last column, designating $X_{5}$ as the most significant basin attribute factor.

\begin{tabular}{lr}
\hline \multicolumn{2}{c}{ Regression Statistics } \\
\hline Multiple R & 0.53 \\
R Square & 0.28 \\
Adjusted R Square & 0.25 \\
Standard Error & 0.87 \\
Observations & 45 \\
\hline
\end{tabular}

\begin{tabular}{|c|c|c|c|c|c|}
\hline & $d f$ & SS & $M S$ & $F$ & Significance $F$ \\
\hline Regression & 2 & 12.36 & 6.18 & 8.21 & 0.001 \\
\hline Residual & 42 & 31.64 & 0.75 & & \\
\hline Total & 44 & 44 & & & \\
\hline
\end{tabular}

\begin{tabular}{|c|c|c|c|c|c|c|c|c|c|}
\hline & Coefficients & Standard Error & t Stat & P-value & Lower 95\% & $\begin{array}{c}\text { Upper } \\
95 \%\end{array}$ & $\begin{array}{l}\text { Lower } \\
95.0 \%\end{array}$ & $\begin{array}{l}\text { Upper } \\
95.0 \%\end{array}$ & $\begin{array}{c}\text { Wald's } \\
\text { Test }\end{array}$ \\
\hline Intercept & $1.24 \mathrm{E}-16$ & 0.13 & $9.55 \mathrm{E}-16$ & 1.00 & -0.26 & 0.26 & -0.26 & 0.26 & \\
\hline X3 & -0.32 & 0.13 & -2.45 & 0.02 & -0.59 & -0.06 & -0.59 & -0.06 & 6.02 \\
\hline$\times 5$ & 0.46 & 0.13 & 3.52 & 0.001 & 0.20 & 0.73 & 0.20 & 0.73 & 12.37 \\
\hline
\end{tabular}

